

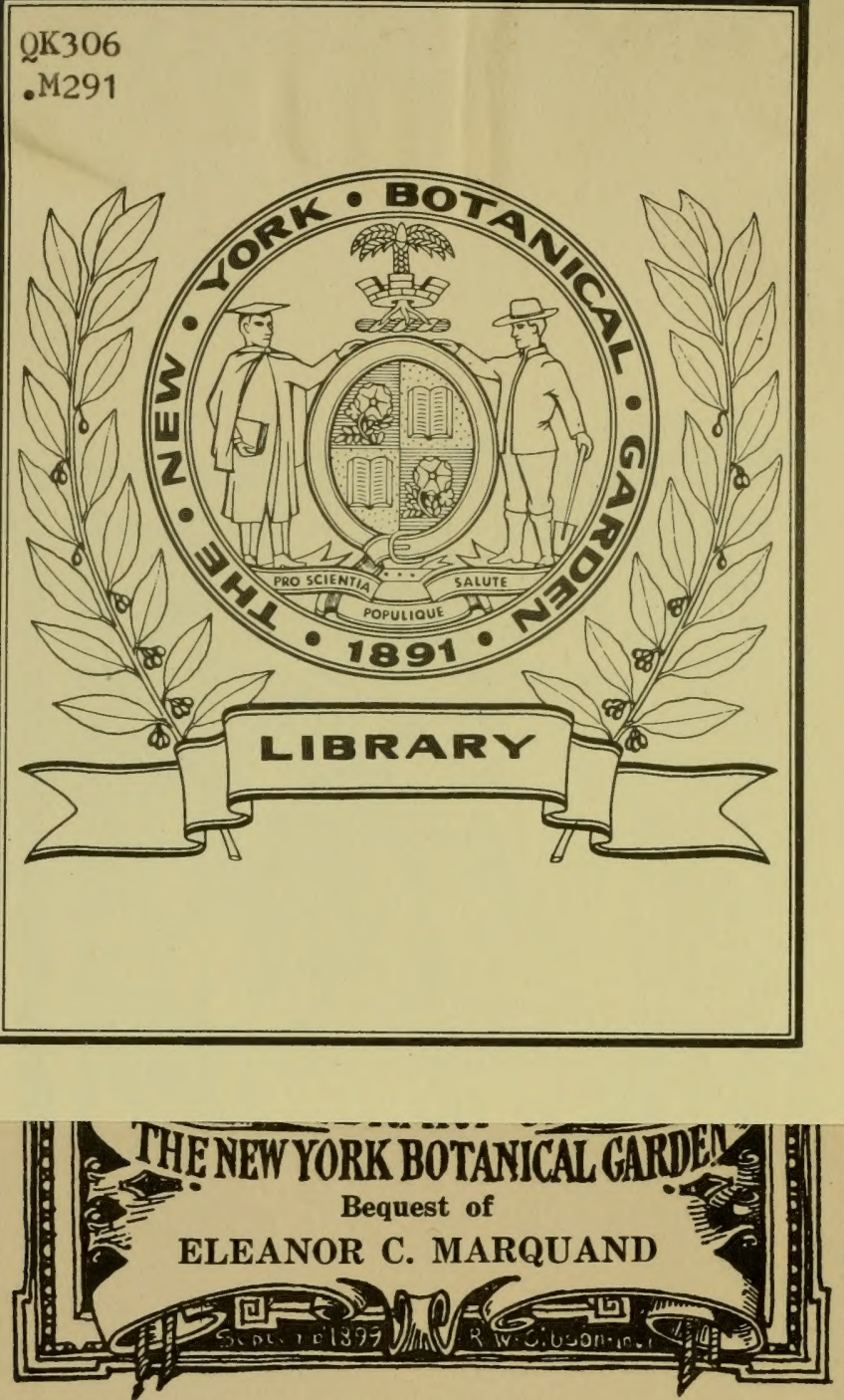



\section{FLORA OF GUERNSEY}

AND

THE LESSER CHANNEL ISLANDS. 



\title{
FLORA OF GUERNSEY ASD THE
}

\section{LESSER CHANNEL ISLANDS:}

\author{
NAMELY,
}

ALDERNEY, SARK, HERM, JETHOU, AND THE ADJACENT ISLETS.

BY

ERNEST DAVID MARQUAND,

Late President of the Guernsey Society of Nitural Science.

WITH FIVE MAPS.

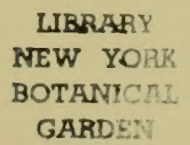

LONDON :

DULAU \& CO., 37 SOHO SQUARE, W.

I90I.

[PRICE IO/6 NET.] 
QK306

M291

Made in Great BritalN. 


\section{PREFACE.}

T T seems hardly necessary to offer an apology for bringing out the present volume, considering that more than sixty years have elapsed since the publication of the only work dealing systematically with the flora of the Channel Islands,-Professor C. C. Babington's Primitiae Florae Sarnicae. The researches of later botanists have filled in many details which were only faintly outlined in that useful little book; while the cryptogamic flora, about which practically nothing was known in those early days, has received a fair measure of attention during recent times.

The great bulk of the notes embodied in these pages were collected during my residence in Guernsey from I888 to 1895; and, although the record is by no means complete, it will serve as a fresh starting-point for future workers, by showing exactly what has been done up to the present time.

The plan adopted by Babington of enumerating under each plant all the different islands in which it is found, has not been followed on this occasion : because it seems to me that the botanical features of each island can be more clearly perceived when it is treated as an entirely separate area, possessing its own particular and distinctive flora. Botanists visiting this part of the kingdom will, I think, appreciate the advantage of the present arrangement.

From the summary which is given at the end of the general Introduction, it will be seen that the various islands have not all been worked up to the same level of thoroughness, more especially in the case of the lower cryptogams. No difficulty, however, will be experienced in comparing any section of the flora of one island with that of another, inasmuch as the botanical names and classification are the same throughout.

The notes on etymology and plant-lore which are given in the principal phanerogamic list will not be found to interfere with the strictly botanical portion of the work, and they may perchance interest those lovers of wild flowers who do not confine their studies merely to the dry bones of science. Some of the Norman plant. names still current among the peasantry of Guernsey are extremely curious, as well as ancient, and they certainly deserve to be rescued 
from oblivion: for, ere many decades have passed, the Sarnian patois will have to be numbered among extinct dialects.

Those who desire information on the Geology, Natural History, Antiquities, and Folk-lore of these islands should consult the Transactions of the Guernsey Society of Natural Science, - an institution which has done admirable work during the last twelve or fifteen years.

I have to express my grateful acknowledgments for much kindly help rendered during the preparation of this Flora. Among local workers from whom I have received valuable assistance I would specially mention Mrs. C. Lewis (then Miss M. Dawber), Mrs. C. Andrews (then Miss B. Agnew), Mr. G. T. Derrick, Mr. T. C. Royle, and Mr. Cecil R. P. Andrews, M.A. The last-named gentleman has studied the Flowering Plants of Guernsey with great care during the last three years, and has supplied me with a store of interesting notes. For the determination of a great many critical and perplexing forms, both phanerogamic and cryptogamic, I am indebted to Mr. J. G. Baker, F.R.S., Mr. Arthur Bennett, F.L.S., the late Mr. Henry Boswell, M.A., Dr. R. Braithwaite, F.L.S., Messrs. Henry and James Groves, F.L.S., Mr. E. M. Holmes, F.L.S., the Rev. E. F. Linton, M.A., and Mr. G. Massee, F.L.S. Many other persons, whose names will appear in the following pages, have also helped in various ways: and to them, as well as to all those who have in any degree contributed to render the present work more accurate and more complete than it would otherwise have been, I desire to return my most cordial thanks.

All published records which I have been able to discover have been utilised, but it is probable that others exist of which I have no knowledge. With a view to the issue at some future time of a revised and enlarged edition of the Flora of Guernsey, I shall be grateful to any one who will indicate these omissions, or supply additional information as well as critical notes on the flora of these islands. Finally, I shall esteem it a favour if those who use this book will point out to me any errors they may detect.

E. D. MARQUAND.

Alderney, 7 June, I9o1. 


\section{CONTENTS.}

GeNERAL INTRODUCTION

PLAN $\cap F$ THE FLORA . . . . . . . . . . 6

SUMMARY OF SPECIES RECORDED . . . . . . . 7

GUERNSEY :

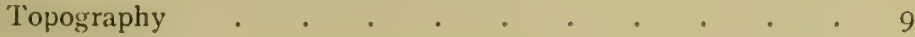

Climate . . . . . . . . . . I4

Geology . . . . . . . . . 20

History and Literature of Local Botany . . . . 22

Principal Botanical Features . . . . . . . 27

Grades of Plants and Types of Distribution . . . . 38

The Flora :

Flowering Plants . . . . . . . . 42

Ferns, Fern-allies, and Characeae . . . . . 207

Mosses . . . . . . . . 216

Hepaticae . . . . . . . . . 230

Fungi . . . . . . . . . . 234

Lichens . . . . . . . . . 278

Seaweeds . . . . . . . . . . 303

Fresh-water Algae . . . . . . . 32 I

Diatomaceae . . . . . . . 325

ALDERNEY :

Introduction . . . . . . . . . 345

The Flora . . . . . . . . . 350

SARK :

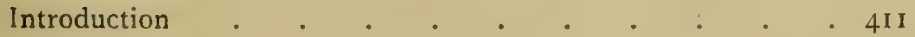

The Flora . . . . . . . . . 415

HERM :

Introduction . . . . . . . . . 447

The Flora . . . . . . . . . 449 
JETHOU :

Introduction

The Flora

LIHOU :

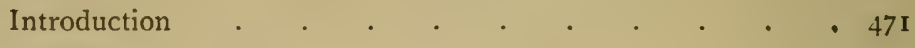

The Flora . . . . . . . . . . 472

CREVICHON :

Introduction . . . . . . . . . . 475

The Flora . . . . . . . . . 476

BURHOU :

Introduction . . . . . . . . . . 479

The Flora . . . . . . . . . . . $48 \mathrm{I}$

Plants peculiar to Jersey • • • . • • 483

INDEX . . . . . . . . . . 485 


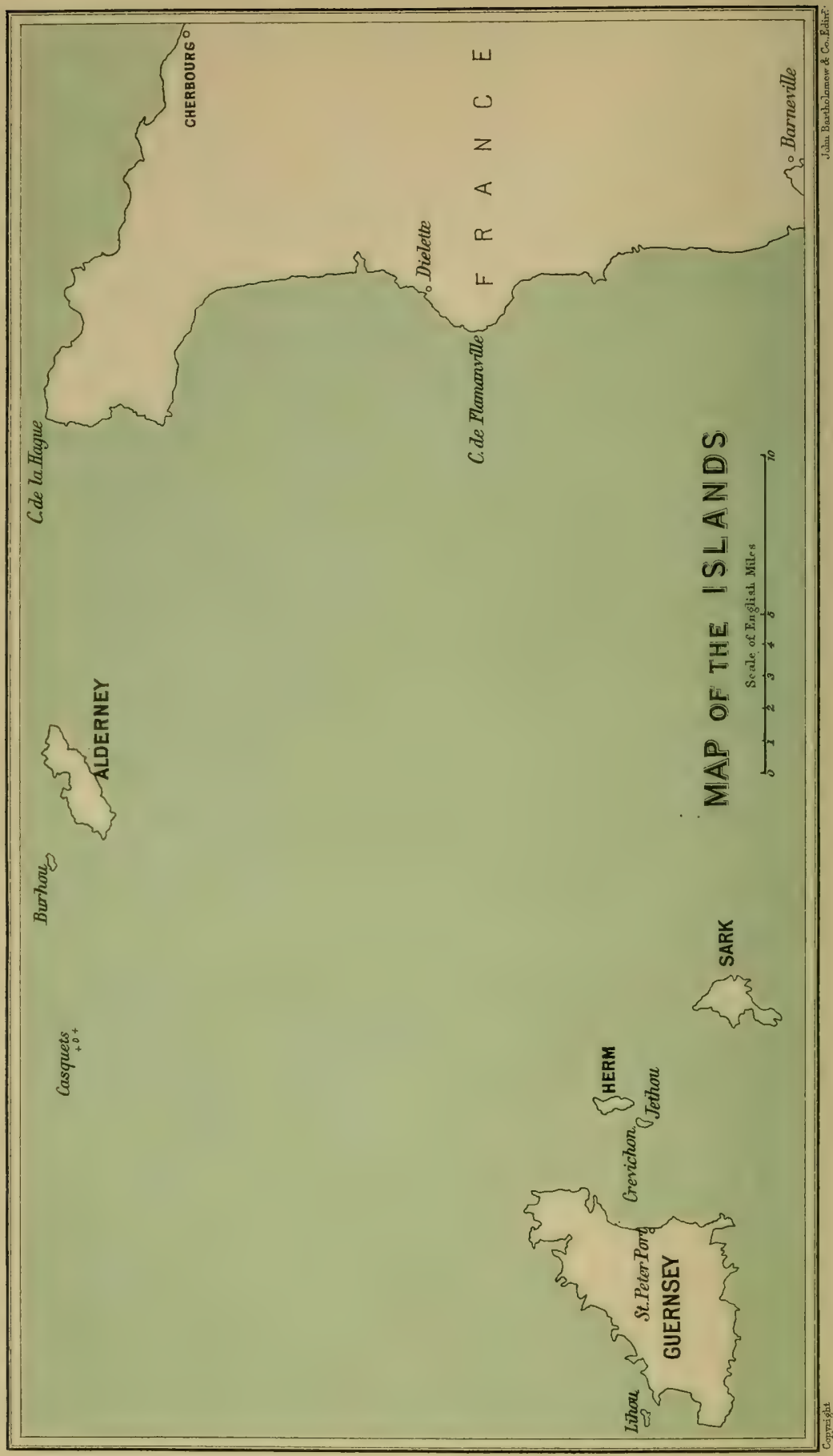




\section{INTRODUCTION.}

$\mathrm{O}^{\mathrm{N}}$

$\mathrm{N}$ the north-western coast of France, within what is called the Bay of Saint Michel, or the Gulf of Avranches, there is a group of small islands which, notwithstanding their proximity to the French mainland, have been British possessions for more than eight hundred years. They belonged to France from the earliest times down to the year 887 , when, on the cession of the province of Neustria, afterwards called Normandy, by Charles the Simple to Rollo, the first Duke, ancestor to William the Conqueror, these islands became part of the Duchy of Normandy. England lost all her other Norman possessions early in the thirteenth century, but King John managed to retain the Channel Islands, and they have ever since appertained to the British Crown. Our neighbours across the water speak of them as Les Iles Anglo-Normandes, or Les Iles de la Manche; but in the old French historians we find them designated Les Iles de Coutances, because up to the end of the sixteenth century they were comprised in the diocese of the Bishop of Coutances, on the opposite French coast.

Although proud of their Norman origin, and bearing Norman names, many of which are prominent in the history of the eleventh and twelfth centuries, the people are thoroughly English in their sympathies and interests, and, as a matter of fact, nowhere in the world can be found more loyal and devoted subjects of the English Sovereign than the inhabitants of the Channel Islands. As Norman subjects they enjoy the ancient privileges which they held under the first Dukes of Normandy, and to these they naturally cling with great tenacity. The ancient Customary Law of Normandy, compiled about the middle of the thirteenth century, still serves as the basis of the insular legislation; and no Act of Parliament is operative until it has been formally received and registered by the Royal Court. The local laws and regulations relating to land and real property in general are extremely curious, and very perplexing to an outsider.

English is spoken everywhere, and is the common language of conversation among the townspeople and educated classes, who are, as a general rule, also thoroughly versed in French. In the rural districts a peculiar patois is commonly employed colloquially 
by the inhabitants, but it is gradually dying out, and, in Guernsey at least, will probably be quite extinct in another couple of generations or so. This singular dialect (which differs considerably both in accent and in vocabulary in the various islands) is not a corrupt and distorted form of modern French, but a relic of the old Norman language which was introduced into England at the time of the Conquest, and which for some centuries afterwards continued to be the language of the English Court and the English nobility.

It has been truly said that there are few places so small that take so long to see as the Channel Islands, for each one is remarkable for exquisite beauty of natural scenery. The climate leaves nothing to be desired; few other spots in northern Europe are so mild and pleasant in the late autumn, all through November and December; there are no fogs, the winds are seldom cold, and at that season frosts are practically unknown.

The various islands composing this little archipelago differ considerably in magnitude as well as in general features. Six of them have a resident population; but there are besides several uninhabited islets, and a countless multitude of rocks dotted about in all directions, in some parts too numerous to be marked on the charts. The entire area, extending over many hundreds of square miles, is exceedingly dangerous to navigation, not only on account of sunken rocks, but also because of a complicated and peculiar set of currents, which are so strong that in foggy weather ships are sometimes drifted for miles out of their proper course.

Jersey, the largest of the group, has a population of about 55,000 inhabitants, and covers sixty-two square miles, or nearly double the area of all the remaining Channel Islands put together. From its nearest point Guernsey, which lies to the north-west, is seventeen miles away; but, the harbour of St. Helier's being situated on the south of the island, the distance from port to port is about twentyfive miles. Jersey is the most southerly of the islands.

Guernsey is more isolated, and lies to the westward at a distance of twenty-six miles from the nearest part of the French mainland, on the coast of Normandy. The shores of England are rather more than twice as far off, Portland Bill, in Dorsetshire, bearing nearly due north, being fifty-nine miles distant, and the Start Point, in Devon, to the north-west, a mile or two more. The population of Guernsey is about 36,000 , and its area a little over twenty-four square miles.

Alderney forms the northern outpost of the group, and is situated coinparatively near to France, less than nine miles of sea separating it from Cap La Hague, near Cherbourg. The extreme length of the island, from north-east to south-west, is three miles and a half, and its greatest width not much more than one mile. It lies to the north-east of Guernsey at a distance from point to point of eighteen miles, and twenty-one from port to port. The 
inhabitants number about 1500 , besides a garrison of 300 or 400 soldiers.

Sark, which is commonly termed the gem of the Channel Islands, is distant about seven miles east from Guernsey. It is a little smaller than Alderney, and its resident population hardly numbers more than 600 or 700 , but this figure is largely augmented during the summer by the influx of visitors.

Herm is a small island about a mile and a half long, situated midway between Guernsey and the northern extremity of Sark The census of I $89 \mathrm{I}$ gives the number of inhabitants as thirty-eight.

Jethou, pronounced Jetto, is only half the size of Herm, from which it is separated by a narrow channel. Only one or two families reside on the island throughout the year, and not more than about fifty acres of ground are available for cultivation.

On examining a chart it will be seen that all the islands, rocks, and shoals which collectively compose what are called the Channel Islands are naturally divided into four distinct groups separated by wide channels : I, a northern group, comprising Alderney, the island of Burhou, and the Casquet Rocks; 2, a western group, comprising Guernsey, Jethou, Herm, and Sark; 3, a south central group, comprising Jersey and several clusters of rocks towards France; and 4, a southern group, comprising the Minquier Rocks, the Chausey Islands, and some outlying reefs. The Chausey Islands, which belong to France, consist of a number of small islets situated about eight miles from Granville.

The ancient names of the islands. as known to the Romans, were Caesarea for Jersey, Sarnia for Guernsey, and Riduna for Alderney. The word Sarnia has sometimes been used by writers as though it applied to the whole of the Channel Islands collectively, but this is altogether a mistake; Sarnia signifies Guernsey exclusively. In French the name takes an intermediate $e$, which changes it into a word of three syllables-Guernesey. Sark also undergoes a change both in spelling and pronunciation, becoming Sercq in French, and Alderney assumes the Latinised form of Auregny or Aurigny. The names of the others are similar in both languages.

In a constitutional and ecclesiastical sense the smaller islands, Alderney, Sark, Herm, and Jethou, are dependencies of Guernsey, so that all of them together, or, in other words, the whole of the Channel Islands which lie to the north of Jersey, constitute what is termed in legal phraseology the Bailiwick of Guernsey. It is this area which forms the subject of the present volume.

There can be no doubt that the Channel Islands are the remaining vestiges of a territory which at some period in the remote past stretched away into the Atlantic Ocean,- - stony hill-tops which have managed to keep their summits above the encroaching sea, and so have become islands. Geologists tell us that the separation of 
these islands from the mainland of the continent did not take place simultaneously over the entire area; it was not the result of a rapid or even a uniformly slow universal subsidence. On the contrary, long periods of time must have elapsed, we are told, between the formation of the different groups of islands. And there seems to be strong evidence to prove that Guernsey. together with Herm and Jethou, and perhaps Sark also, was cut off from the continent at an epoch immensely anterior to the detachment of the Jersey and Alderney groups; in other terms, that Guernsey was an island for ages, while the others were still united to, and formed part of, the French mainland. This is a point of some importance, which it is well to bear in mind in studying and comparing the fauna and flora of the different islands inter se, and in noting the characteristics of each in relation to the opposite French and English coasts.

Strictly speaking, the indigenous animals and plants of these islands cannot be regarded as British in the sense in which the term is usually applied to the fauna and flora of Britain proper. If a line be drawn down the English Channel midway between the shores of England and France, the Channel Islands will be found to lie well within the French side of the line. Geographically, therefore, they belong to France beyond question, although politically they appertain to England, and, it is to be hoped, will always continue to do so. But, at the same time, their relationship zoologically and botanically to the continental mainland is not nearly so intimate as might be inferred from their geographical position; and, since the French naturalists regard them as foreign territory, and, indeed, practically ignore their existence altogether, it is only just and fair that the mother country should take them under her sheltering wing.

With considerably more than twice the land area of Guernsey, the sister island of Jersey naturally possesses a much more varied and extensive flora, but perhaps it is not really more rich in species in proportion to its size. In I $896 \mathrm{Mr}$. J. Piquet published a paper entitled 'The Phanerogamous Plants and Ferns of Jersey,' in which he gave a list of all the species he had himself collected during forty years' botanising in the island. In this list Mr. Piquet enumerates $72 \mathrm{I}$ plants, of which twenty-three are ferns and fern-allies; but it is obvious that it would admit of some extension, as, for example, in the genus Rubus, which is represented solely by the aggregate species $R$. fruticosus. Many of the woodland and marsh plants of Jersey are not to be found elsewhere in the Channel Islands, whilst, on the other hand, certain species which are undoubtedly indigenous to Guernsey and the smaller islands are unknown in Jersey. * If sufficient materials were at hand, it would be extremely

* In the concluding pages of this volume will be found a list of the Jersey plants recorded by $\mathrm{Mr}$. Piquet which are not known to occur in any of the other islands. 
interesting to compare and contrast Guernsey and Jersey as regards each of the different sections of their flora; but at present nothing of this kind can be attempted. With the important exception of the lichens, the cryptogamic vegetation of Jersey does not appear to have been systematically studied, and the lists published in the second edition of Ansted's Channel Islands are by no means to be relied upon.

For several reasons I have thought it best in the present work to treat all the islands under consideration as distinct and independent botanical areas, irrespective of size or geographical relationship, so that botanists visiting any particular one will be able to ascertain at a glance exactly how much or how little is known about its flora. Commencing with the mother island, Guernsey, about which most is known, the others will follow in the order of their importance from a botanical point of view, and a brief description of each island and islet will be given as an introduction to the lists, together with such notes as may be of interest to the visitor.

Insignificant as they appear on the map of the British Isles, these tiny fragments of land furnish a surprisingly large field for patient and painstaking research. When I left Guernsey in I 895 , after working assiduously for seven years at the flora of that island, I calculated that it would have required seven years more of steady work to accomplish what I aimed at, and to attain the standard of completeness which I had set before me at the outset.

It is hardly possible to over-estimate the value of carefully studying the fauna and flora of small islands, whether continental or oceanic. Viewed merely as so many square miles of land, they may be of very trifling account; but each of them has something to teach which cannot be learnt so well anywhere else, some apparently trivial facts to reveal which throw fresh light on the subject of the variability of species, or of their distribution from given centres. Hence it is that even diminutive and barren islets, regarded as the silent historians of past ages, assume an importance altogether out of proportion to their size. It has been well said: What we have to do is to work patiently in recording all we can in sincerity and truth, so that, when the pages shall be full, others may read them, and read them in fuller light.

'If we take the organic productions of a small island,' says Wallace, in his Island Life, 'or of any very limited tract of country, such as a moderate-sized country parish, we have in their relations and affinities - in the fact that they are there, and others are not there-a problem which involves all the migrations of these species and their ancestral forms; the whole series of actions and reactions which have determined the preservation of some forms and the extinction of others; in fact, the whole history of the earth, inorganic and organic, throughout a large portion of geological time.' 


\section{PLAN OF THE FLORA.}

The Flowering Plants and Ferns are arranged and named in accordance with the last (eighth) edition of Babington's Manual of British Botany. The English names are those most generally in use, but mere book names have often been omitted altogether.

Immediately after the name of the plant its grade of citizenship is denoted, and then follows the date of the earliest known published record, or of the first discovery of the plant in the island, with the name of the recorder or discoverer.

The author is in all cases responsible for details of distribution and other particulars, except where such notes are followed by a name in brackets, or otherwise distinguished. As similar local names of places occur in different parts of Guernsey, or may not be generally known, Roman numerals have occasionally been used (in brackets) to indicate the district, the ten parishes being numbered in the following order:-

I. St. Peter-Port.
II. St. Andrew's.
III. St. Martin's.
IV. Forest.
V. Torteval.

VI. St. Peter-in-the-IVood.

VII. St. Saviour's.

VIII. Catel.

IX. Vale.

X. St. Sarmpson's.

Information which may be found in all the text-bouks commonly in use has been omitted, such as synonymy, habitat, and time of flowering. As regards the last item, a reference to the list of winter flowers given under the head of Climate will show that the period is considerably lengthened in these islands.

Species doubtfully or erroneously recorded for Guernsey, as well as plants peculiar to the smaller islands, are mentioned in their proper place in the general enumeration, but the names are printed in smaller type and enclosed in brackets. Species known or believed to be extinct are distinguished by having a star $\left(^{*}\right)$ prefixed.

All remarks on local names, folk-lore, etymology, medicinal virtues, \&c., occupy a separate paragraph under each species.

At the head of each of the cryptogamic sections will be found mentioned the sources whence the information which follows has been derived, together with such other notes as may be necessary.

Each island and islet is treated as a separate area, and its flora is given in full, phaneroganic and cryptogamic, so far as at present known. The names and arrangement are the same throughout, so that the comparison of one list with another will present no difficulty. English names, notes, and other details already given in the Guernsey Flora, will not be repeated in the succeeding lists.

The Table of Contents at the beginning of the book shows the 
order of sequence of the different divisions of the work. The Index comprises all the English, foreign, and generic names mentioned in these pages. Separate indexes are given for Guernsey, Alderney, and Sark; the smaller islands require none.

The number of plants recorded in this volume for Guernsey and the lesser islands collectively is as follows:-

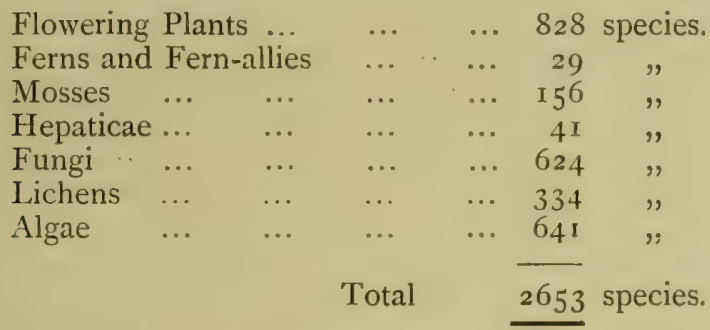

The following summary shows the number of species recorded in each section of the flora for the different islands within the area :-

Guernsey :

\begin{tabular}{|c|c|c|c|c|c|c|}
\hline Flowering $\mathrm{P}$ & Plants & $\cdot \cdot$ & $\cdots$ & & $\cdots$ & $78^{-}$ \\
\hline Equisetacea & & $\cdots$ & $\cdots$ & .. & $\ldots$ & 3 \\
\hline Ferns & & .. & $\ldots$ & .. & .. & I9 \\
\hline Lycopodiac & eae & ... & ... & .. & $\cdots$ & I \\
\hline Characeae & $\ldots$ & ... & $\ldots$ & & ... & 5 \\
\hline Mosses & .. & ... & ... & $\cdot$ & ?. & I 45 \\
\hline Hepaticae & ... & $\cdots$ & $\cdots$ & & $\cdots$ & 40 \\
\hline Fungi & ... & $\ldots$ & ... & .. & $\ldots$ & 6 × 2 \\
\hline Lichens & $\ldots$ & $\ldots$ & $\ldots$ & .. & $\ldots$ & $3 \circ 9$ \\
\hline Seaweeds & $\ldots$ & $\ldots$ & $\ldots$ & . & $\ldots$ & $25^{2}$ \\
\hline Fresh-water & Algae & $\ldots$ & $\ldots$ & & $\ldots$ & 53 \\
\hline Diatomaceas & & $\ldots$ & $\ldots$ & .. & . & $3^{23}$ \\
\hline
\end{tabular}

Alderney :

Flowering Plants $\quad \ldots \quad \ldots \quad \ldots \quad \ldots \quad \ldots \quad 503$

$\begin{array}{llllll}\text { Equisetaceae } & \ldots & \ldots & \ldots & \ldots & 3\end{array}$

$\begin{array}{lllllll}\text { Ferns } & \ldots & \ldots & \ldots & \ldots & \ldots & \text { I3 }\end{array}$

$\begin{array}{lllllll}\text { Mosses } & \ldots & \ldots & \ldots & \ldots & \ldots & \\ \end{array}$

$\begin{array}{lllllll}\text { Hepaticae } & \ldots & \ldots & \ldots & \ldots & \ldots & 2 \text { I }\end{array}$

$\begin{array}{lllllll}\text { Fungi } & \ldots & \ldots & \ldots & \ldots & \ldots & \text { 109 }\end{array}$

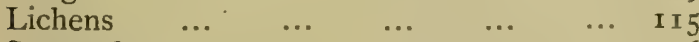

Seaweeds $\quad \ldots \quad \ldots \quad \ldots \quad \ldots \quad \ldots \quad \ldots \quad$ I 56 
SARK :

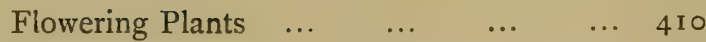

$\begin{array}{llllll}\text { Equisetaceae } & \ldots & \ldots & \ldots & \ldots & 3\end{array}$

$\begin{array}{lllllll}\text { Ferns } & \ldots & \ldots & \ldots & \ldots & \ldots & \text { I } 2\end{array}$

$\begin{array}{llllllr}\text { Mosses } & \ldots & \ldots & \ldots & \ldots & \ldots & \\ \text { Hepaticae } & \ldots & \ldots & \ldots & \ldots & \ldots & 8\end{array}$

$\begin{array}{lllllll}\text { Hepaticae } & \ldots & \ldots & \ldots & \ldots & \ldots & \text { I }\end{array}$

$\begin{array}{lllllll}\text { I. } i c h e n s & \ldots & \ldots & \ldots & \ldots & \ldots & 89\end{array}$

$\begin{array}{lllllll}\text { Seaweeds } & \ldots & \ldots & \ldots & \ldots & \ldots & 38\end{array}$

HERM :

$\begin{array}{lllllll}\text { Flowering Plants } & \ldots & \ldots & \ldots & \ldots & 248\end{array}$

$\begin{array}{llllll}\text { Equisetaceae } & \ldots & \ldots & \ldots & \ldots & \text { i }\end{array}$

$\begin{array}{lllllll}\text { Ferns } & \ldots & \ldots & \ldots & \ldots & \ldots & 6\end{array}$

$\begin{array}{lllllll}\text { Characeae } & \ldots & \ldots & \ldots & \ldots & \ldots & \text { I }\end{array}$

$\begin{array}{lllllll}\text { Lichens } & \ldots & \ldots & \ldots & \ldots & \ldots & 43\end{array}$

Jethou :

$\begin{array}{llllll}\text { Flowering Plants } & \ldots & \ldots & \ldots & \ldots & \text { I } 79\end{array}$

$\begin{array}{lllllll}\text { Ferns } & \ldots & \ldots & \ldots & \ldots & \ldots & 7\end{array}$

$\begin{array}{lllllll}\text { Lichens } & \ldots & \ldots & \ldots & \ldots & \ldots & 10\end{array}$

LiHou :

$\begin{array}{llllll}\text { Flowering Plants } & \ldots & \ldots & \ldots & \ldots & 95\end{array}$

$\begin{array}{lllllll}\text { Ferns } & \ldots & \ldots & \ldots & \ldots & \ldots & 4\end{array}$

$\begin{array}{lllllll}\text { Fungi } & \ldots & \ldots & \ldots & \ldots & \ldots & \text { I } 3\end{array}$

Crevichon :

$\begin{array}{llllll}\text { Flowering Plants } & \ldots & \ldots & \ldots & \ldots & 39\end{array}$

$\begin{array}{lllllll}\text { Ferns } & \ldots & \ldots & \ldots & \ldots & \ldots & 6\end{array}$

$\begin{array}{lllllll}\text { Lichens } & \ldots & \ldots & \ldots & \ldots & \ldots & 4\end{array}$

BURHOU :

$\begin{array}{llllll}\text { Flowering Plants } & \ldots & \ldots & \ldots & \ldots & \text { I } 6\end{array}$

$\begin{array}{lllllll}\text { Ferns } & \ldots & \ldots & \ldots & \ldots & \ldots & 2\end{array}$ 



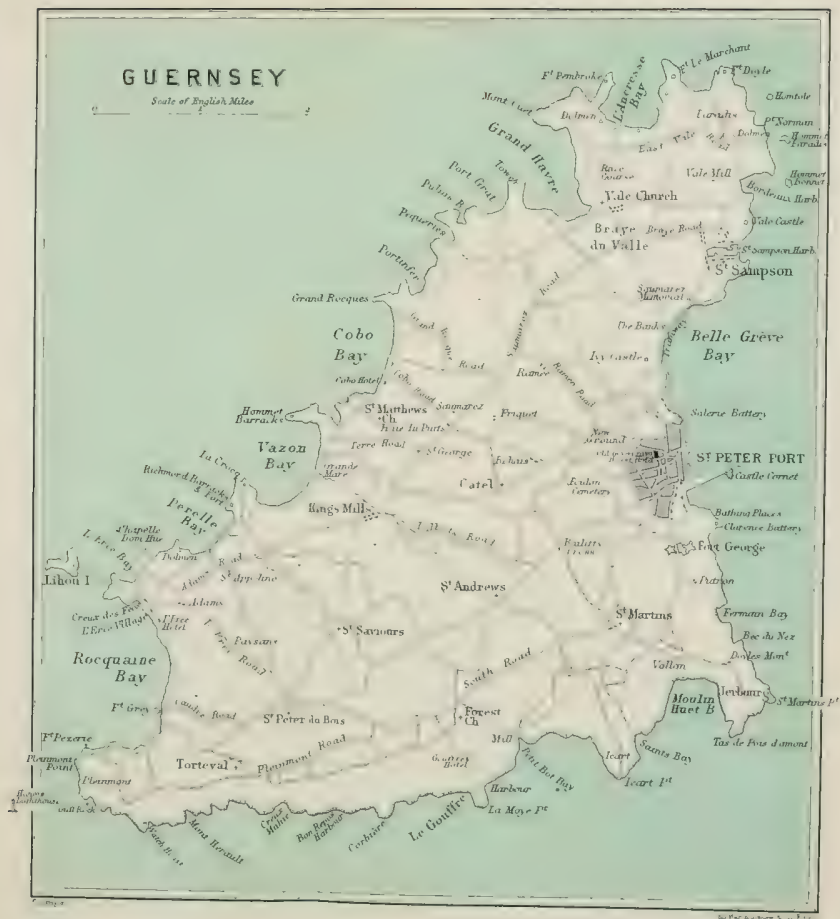




\section{GUERNSEY.}

\section{I.-DESCRIPTIVE.}

()

WING to its remoteness from the mainland, and consequently its greater isolation, Guernsey presents in several respects a more interesting field for scientific study than any of its sister islands.

In shape it more or less resembles a right-angled triangle, of which the longest side, which faces the north-west, measures between nine and ten miles. The land all along this part, as well as at the northern extremity, lies very low, in many places scarcely rising above sea level, and the coast is indented by a succession of sandy bays fringed with rocky reefs and ledges, which are laid bare for a great distance seawards at low tide. The southern portion of the island, extending about six miles from point to poirt, and forming as it were the base of the triangle, is of a totally different character. It consists of an elevated plateau, which abuts on the sea in precipitous rocky cliffs, here and there intersected by deep valleys that open out into little coves nestling between projecting headlands. The town of St. Peter-Port, with its spacious harbour, is situated on the eastern side of the island, and on the same side, two or three miles further north, lies the smaller town of St. Sampson's. 'The total area of land above high-water mark is not quite twenty-four and a half square miles, the commonly recognised measurement giving 15,560 English acres, and of these about I I,000 acres are under cultivation.

That Cuernsey was at one time well wooded seems perfectly certain, for not only do two of the pariches bear the expressive names of The Forest (La Forêt) and St. Peter-in-the-Wood (St. Pierre-du-Bois), but there exists under the sand on the shore at Vazon Bay a submerged forest of unknown extent, portions of which are occasionally uncovered after violent storms. At the present day, however, there are no longer either woods or copses, because land has become so valuable that it cannot be allowed to lie idle. Trees used to be fairly numerous in all parts even twenty or thirty years ago, but they have been ruthlessly felled and cleared away to make room for greenhouses, which are now by far the most striking feature of the island, though by no means the most pleasing one from an æsthetic point of view. 
Simall streams and rivulets are plentiful, ponds and pools very few ; and the salt marshes, which abounded in the lowlands early in the century, have vanished. The soil is very productive under skilful management, and the land being mostly owned by small farmers and market gardeners, who cultivate it themselves, every square foot of available ground is utilised. Happily for the naturalist there are still left unreclaimed the sand-hills which border the shore of the low-lying districts, the grand stretch of undulating sward called Lancresse Common, and the steep, stony cliff-sides, covered with heather, gorse, and bracken.

The island is traversed in all directions by fine broad roads, from which branch out at short intervals smaller roadways, lanes, and pathways in perplexing number and variety, all of them hedged in by banks loaded with ferns and wild flowers. In rambling through the country lanes, it is difficult to realise that Guernsey is actually the most densely populated island on the face of the earth; there is nowhere evidence of any overcrowding ; the houses are dotted about, and oiten lie in such out-of-the-way nooks that their proximity is hardly suspected. Many of the farm-houses are two or three centuries old, contrasting in their grey and sombre tones with the ornamental villas and pretty cottages which are springing up everywhere with mushroom-like rapidity. Each house has its little front garden, neatly kept and aglow with flowers, and there is everywhere a general appearance of contentment and prosperity which cannot fail to be noticed by the least observant.

There is much about Guernsey that reminds one of Comwallnot the wooded districts, nor that part which is disfigured by the dihris of tin mines - but the quiet agricultural region of the extreme south-west. On all sides are to be seen charming little bits of typical Cornısh scenery. The rugged coast line, the small sandy coves, sheltered by bold headlands and rocky reefs, the intense blue colour of the sea, the leafy lanes and diminutive fields, the ancient churches, massive and grey, the quaint, old-fashioned farm-houses and thatched cottages, the little flower gardens, the cliffs, the sandhills, the winding roads, and a hundred other points, constantly recall the scenery of West Cornwall, and especially the Land's End neighbourhood; only all on a reduced scale, smaller in every way, more compressed, and, as it were, more compact.

And, again, like Cornwall, Guernsey presents many evidences of having been the abode of prehistoric man, or, at least, of man in very early historic times. Five or six examples of those ancient monuments known as Dolmens, Cromlechs, or Druids' altars are still to be seen at the north and west of the island, but a great many have been destroyed. One superb specimen crowns the hill overlooking Lancresse Bay, and owes its preservation to the fortunate accident of lying for ages hidden from human sight, buried in the sand. Another very fine specimen, towards Bordeaux Harbour, 
composed of stones of stupendous size and weight, was, until very recently, almost concealed by brambles and rank herbage, but now it has been carefully cleared and railed in, so that it will be preserved for all future time. At St. Peter's, a huge monolith, eleven feet high, 'by lichens grey and scanty moss o'ergrown,' marks the burial-place of some famous warrior chief, perhaps, or commemorates his exploits. Rude pottery, stone implements, and other relics of human workmanship, have been disinterred from time to time, proving that the island was inhabited by man at a very remote period.

Guernsey is divided civilly and ecclesiastically into ten parishes, which are separated from each other by streamlets or main roads as a general rule, but sometimes by invisible lines, which bisect fields and gardens, or even houses, so that there are instances where a farm-house has certain rooms in one parish and the remainder in another. St. Andrew's, which occupies the centre of the island, is the only parish that has no seaboard.

The town of St. Peter-Port, which is comprised within the parish of that name, is situated on the eastern side of Guernsey, and numbers a population of about 17,000 souls. Built on the slope of a hill which rises rapidly from the sea, it presents a strikingly beautiful picture when approached from the water; and the rocky fortress of Castle Cornet, together with the magnificent harbour and breakwater, add considerably to the general effect. Judging from the old prints and drawings still extant, the lown must have presented an exceedingly quaint appearance a century ago, having narrow streets and leaning houses, such as we find in many an old French town at the present time. During the last few decades great altrations and improvements have been made, and the inhabitants hare gained largely in the matter of comfort and convenience, though unarridably at the cost of much that was picturesque.

The parish of St. Martin's, which forms the south-eastern angle of the island, has furnisherl more subjects for brush, pencil, and camera than any other part of Guernsey. Fermain Bay; Jerbourg Point, the Peastacks, Moulin Huet Bay and its famous water-lane, Saints Bay, and Icart Point are all within its boundaries; and in the adjoining parish of the Forest we have Petit Bot Bay, the prettiest of all, and the bold cliffs and black abyss of the Gouffre.

Very striking cliff scenery is to be found all along the south coast as far as the Land's End of Guernsey, Pleinmont Point, on which stands the lonely house immortalised by Victor Hugo in his thrilling novel, Les Travailleurs de la Mer. Rocquaine Bay opens out to the west, and presents a bristling array of rocks at all times of the tide. To the south are the Hanois Rocks and lighthouse, to the north the wind-swept islet of Lihou, on which are still to be seen the ruins of an ancient priory and chapel, dating from the beginning of the twelfth century. 
The Chapel of St. Apolline, at St. Saviour's, is the last remaining one of the chapels erected for Christian worship before the building of the parish churches. It is the oldest building in the island, belonging to some early period anterior to the Norman Conquest. Conjecture has variously assigned its erection to the eighth, ninth, or tenth century. This chapel is fairly well preserved, and bears traces of rude frescoes on some of its walls.

All along the coast of the lowlands, in suitable places, the interesting and picturesque custom of seaweed-gathering may be seen in full operation. This seaweed, or wrack (termed in the patois ira $i^{\prime}$ ), is largely used by the farmers for manuring the ground for certain crops, and they collect it in great quantities at various seasons. What may be called the harvest of the sea is secured by two methods : wrack-cutting, or detaching the Fucus from the rocks with billhooks, a process strictly regulated by law, and only permitted for certain weeks twice in the year ; and wrack-gathering, or the raking in of Laminaria and other seaweed washed ashore after a storm, and this is allowed from sunrise to sunset throughout the year.

The entire northern end of Guernsey falls within the parish of the Vale, which possesses the greatest extent of coast line, as well as the largest piece of unenclosed land in the island, viz., Lancresse Common, a fine expanse of undulating sandy ground a mile and a half long. The Vale is famous for its granite quarries, which are very numerous, and furnish the bulk of the stone exported from Guernsey. The Castle of St. Michael (better known as the Vale Castle, a very interesting and picturesque relic of the tenth century or a little later' is at the present moment seriously imperilled by the extension of a hideous granite quarry almost underneath its. foundations.

Two ancient structures still exist at St. Sampson's. First, the Parish Church, one of the three in the Channel Islands built, it is said, in the year I I I I (St. Brelade's in Jersey, and St Anne's in Alderney being the others) - it was complettly mantled with ivy until a few years ago, but now it is shorn of its glory; and, secondly; an ivy-covered ruin known as Ivy Castle, but properly named Le Chateau des Marais, or the Castle of the Marshes. Tradition says it was built by Robert, Duke of Normandy, the father of IVilliam the Conqueror. The town of St. Sampson's is a busy little place on account of the stone trade, most of the granite exported being shipped from there.

The parish of St. Andrew's, which occupies the entire central portion of the island, abounds in pretty lanes, but it does not border the sea, and consequently it lacks an element of charm and beauty which its sister parishes share in common.

I had intended to devote a page or two to the curious dialect which is still in use among the rural population of Guernsey, an 
unwritten Norman patois, full of interest to the philologist and the student of the early French language; but the idea had to be abandoned, as I found it practically impossible to compress within the necessary limits anything like an intelligible outline of its peculiarities of construction, idiom, and pronunciation. But one point may be mentioned. There are in the Guernsey dialect peculiar vowel-sounds, accents, and rombinations of consonants, which have no exact parallel in either English or French, and therefore cannot possibly be phonetically expressed in writing without constructing some special system of notation. As a matter of fact, though many attempts have been made, no one has yet succeeded in writing the patois in such a way that a total stranger may read it off and pronounce it correctly.

At the commencement of the nineteenth century the population of Guernsey did not amount to 20,000 ; now it must have nearly doubled, as the census of r $89 \mathrm{r}$ gave the number of inhabitants as 35,2 I 8 . Even that figure gives the very high average of over I 400 persons to the square mile, or more than treble that of England and Wales.

The exportation of granite has for very many years contributed in a large measure to the prosperity of the island, and millions of tons have found their way to nearly all parts of the kingdom. The stone is of excellent quality and very durable, and it is shipped off either in large rough blocks, as hewn from the quarry, or dressed into cubes for street-paving and building purposes. Large quantities are also exported after being broken up into small pieces suitable for macadamising roads, and it is said no stone in the world is equal to it for that purpose. Thirty years ago the quantity of granite exported averaged about 200,000 tons per annum; in $1 S 97$ it amounted to over 291,000 tons, and in 1898 the quintity shipped reached the unprecedented total of 300,639 tons.

But during the last twenty years the fruit-growing industry has advanced by such leaps and bounds that it has to a great extent eclipsed the stone trade. At the present day there are certainly scores, if not hundreds, of miles of greenhouses in the island, fitted up with all the very latest appliances and modern improvements, employing thousands of skilled workmen, and producing all through the year the finest fruit, vegetables, and flowers. Every week-day during the spring and summer months large shiploads of vegetable produce leave Guernsey for the English markets, as many as 28,000 baskets and crates having been dispatched in a single day. The official returns show that the export of this kind of produce is at present more than six times as large as it was about a dozen years ago. The quantity for the year i 899 surpassed all previous records, and attained the enormous total of $1,639,496$ packages, and during the three months ending June 30 th, 1900, the number of packages of Guernsey produce exported, viz., fruit, flowers, vegetables, bulbs, 
and plants, amounted to over half a million, the actual figures being 503,478 . This kind of market gardening has proved extremely lucrative when compared with the old-time farming of small holdings, and, as a natural consequence, greenhouses have sprung up on every side with magical rapidity. How long the business will continue remunerative time will show.

The entomology of Guernsey has been very carefully worked up during the last twenty years, and long lists of species belonging to nearly all the orders of insects have been published in the Transactions of the local Natural History Society. On studying these lists it will be perceived that in all the large orders, and in most of the smaller ones, insects occur which do not belong to Britain proper. This is only what might be expected; but what is far more curious and less easily accounted for is the entire absence of many species which are universally distributed, and as a rule quite common, throughout the south of England. Another interesting point is that each of the smaller islands possesses certain. forms or races peculiar to itself, and not found elsewhere in the Channel group.

In every department of marine zoology the Channel Islands in general, and Guernsey in particular, present an almost ideal huntingground, and one which is probably unrivalled on the British coasts. For not only is the marine fauna exceedingly rich and varied, but the study of it is facilitated by the great range of the tide, which, at low water, lays bare a vast expanse of rocky sea-bed, and renders accessible many outlying clusters of rocks, which, with the exercise of caution, may be investigated without inconvenience and almost dry-shod.

Climate. Meteorological observations have been very carefully registered in Guernsey for more than fifty years without a break. The following notes are extracted from the valuable papers and tables prepared by Mr. A. Collenette, and printed in the Transactions of the Guernsey Society of Natural Science :-

The average annual rainfall of the island, computed from a continuous series of readings taken twice daily from January Ist, I 843 , to December 3 Ist, I 892 , is $36^{\circ} 99$ inches, divided among the four seasons thus:-

$\begin{array}{lcccr}\text { March, April, May } & \ldots & \ldots & \ldots & 609 \\ \text { June, July, August } & \ldots & \ldots & \ldots & 6.72 \\ \text { September, October, November } & \ldots & \ldots & 12^{\circ} 67 \\ \text { December, January, February } & \ldots & \ldots & 10^{\circ} 61\end{array}$

The average number of wet days per annum is $180^{\circ} 3$. The driest month of the year is June, with a rainfall of 2.08 inches, and an average of I I' I wet days. The wettest month is October, with a rainfall of $5^{\circ} \circ 3$ inches, and an average of 18.8 wet days. The heaviest fall of rain 
in a single day during fifty years occurred on the rith of October, I865, when 2.87 inches of rain fell in the twenty-four hours. The two longest durations of absolute drought, or periods without any rain at all, occurred in 1869 and in 1893 ; in the former year it lasted from June 2 Ist to July $25^{\text {th }}$ inclusive, and in 1893 from March 18 th to April 2 Ist, in both cases, curiously enough, a similar period of thirty-five days. The average reading of the barometer, corrected and reduced to $32^{\circ}$ at mean sea-level, is $29^{\circ} 956$, with a mean range for the whole year of $I^{\circ} \circ 45$.

The mean annual temperature of the air in the shade is $50.6^{\circ}$, divided among the four quarters of the year as follows :-

$\begin{array}{lcccc}\text { March, April, May } & \ldots & \ldots & \ldots & 47^{\circ} 2^{\circ} \\ \text { June, July, August } & \ldots & \ldots & \ldots & 5^{\circ} 6^{\circ} \\ \text { September, October, November } & \ldots & \ldots & 53^{\circ} 0^{\circ} \\ \text { December, January, February } & \ldots & \ldots & 43^{\circ} 5^{\circ}\end{array}$

One of the most favourable peculiarities of this climate is the continuance of a mild autumn temperature to a very late period of the year. As a rule, the temperature of July and August continues with little change into September and October, the summer and autumn differing but slightly, and the latter extending into the months which in England are regarded as mid-winter. It may almost be said, therefore, that winter as a season is absent altogether; but, on the other hand, the spring is cold and late, and easterly winds prevail. The mean daily range of the thermometer in Guernsey is only $8 \cdot 5^{\circ}$, a quantity so small as to be quite exceptional in northern latitudes; and it is this uniformity which imparts to the climate of this and the other islands its peculiar feature, namely, that of equability.

Although the rainfall is considerable, though actually less than in the extreme south-west of England, the climate of Guernsey is certainly not unpleasant from excessive humidity. Even during the wettest months of the year a continuance of more than twelve hours' rain is very rare; indeed, it seldom happens that a wet morning is not succeeded by a fine evening. Except during unusually severe winters snow rarely falls, and generally disappears in the course of a day or two. Hail is much more frequent, and a smart hail-shower during the summer months is by no means an uncommon occurrence. Severe frosts are exceptional, and seldom prolonged, so that skating is practically unknown.

The Channel Islands may justly rank among the sunniest places in the kingdom; it is quite an unusual experience to be two whole days without seeing the sun or the clear sky. Mr. Collenette's records for Guernsey show that in 1896 there was a period of 146 days in succession without a sunless one, viz., from April 3 rd to August I8th; but even this long period had been exceeded the previous year, when not a single sunless day was registered between 
April 2nd and October 6th, a period of 186 consecutive days. Thunder-storms are of comparatively rare occurrence, and generally of short duration.

'The sunrises and sunsets of the Channel Islands, but especially the latter, involve at all seasons some of the grandest and most beautiful atmospheric effects obtainable on the west coast of Europe. These sunsets are equally remarkable for the form and colour of the clouds, and the rapidity with which they change in these respects; and also for the softened tints of the sky.' (Ansted, Channel Islands, p. I $5 \%$.)

A large variety of exotic trees and shrubs, rarely seen in England except under glass, grow freely and without shelter in the open air, and garden flowers continue to blossom nearly all through the winter unless checked by an early frost. A few years ago I made a catalogue of all the wild plants I could find in flower during the month of December, and they amounted to 187 species. About fifty were fairly common throughout the month, and about as many were only seen once, and in many cases consisted of a single flower only. On the $4^{\text {th }}$ of December, during a few hours' ramble, no less than 115 species, all well in flower, were collected-a really surprising number considering the season. Another day's walk produced 107 species; and on the very last day of the year, after a long spell of wet and stormy weather, eighty-six different kinds of wild flowers were gathered, of which three had not been met with before during the month, showing that even at the end of December something new was to be found.

I once noticed I Io wild plants in flower in Cornwall during Christmas week, and that was considered a large number; but the Guernsey list of December flowers so far surpasses this that it is worth preserving, so it is given here. Moreover, to many persons it will convey a better idea of the mildness of the climate than mere figures and tables of temperature.

\begin{tabular}{|c|c|c|c|}
\hline Ranunculus Flammula & & & Lesser Spearwort. \\
\hline repens & $\ldots$ & $\ldots$ & Creeping Crowfoot. \\
\hline bulbosus & ... & & Meadow Buttercup. \\
\hline Ficaria & $\ldots$ & $\ldots$ & Pilewort. \\
\hline Papaver Rhoeas... & $\ldots$ & $\ldots$ & Corn Poppy. \\
\hline Fumaria confusa & $\ldots$ & $\ldots$ & Fumitory. \\
\hline Cardamine hirsuta & $\cdot \cdot$ & .. & Common Bittercress. \\
\hline flexuosa & . & . & Wavy Bittercress. \\
\hline Alyssum maritimum & .. & . & Seaside Alyssum. \\
\hline Cochlearea danica & $\ldots$ & $\ldots$ & Scurvy Grãss. \\
\hline Sisymbrium thalianum & $\cdots$ & ‥ & Thale Cress. \\
\hline officinale & .. & .. & Hedge Mustard. \\
\hline apis arvensis ... & $\ldots$ & $\ldots$ & Charlock. \\
\hline ... & $\ldots$ & . & Hoary Mustard. \\
\hline
\end{tabular}


Diplotaxis tenuifolia

Capsella Bursa-pastoris

Senebiera didyna

Raphanus maritimus

Reseda luteola ...

Viola arvensis

Polygala vulgaris

Silene maritima ... anglica $\ldots .$.

Lychnis diurna

\section{Flos-cuculi}

Cerastium glomeratum

$$
\text { triviale }
$$

Stellaria media ...

$$
\text { uliginosa }
$$

Sagina procumbens

Spergula arvensis

Lepigonum rupestre

Polycarpon tetraphyllum

Tamarix gallica ...

Hypericum humifusum...

Lavatera arborea

sylvestris

Malva rotundifolia

$$
\text { sylvestris ... }
$$

Linum angustifolium

Geranium molle dissectum

Robertianum

Erodium cicutarium moschatum ...

Oxalis corniculata

Ilex Aquifolium

Ulex Gallii

Medicago lupulina

Melilotus arvensis officinalis

Trifolium pratense arvense repens incarnatum minus...

Lotus major hispidus
... Wall Rocket.

... Shepherd's Purse.

... Wart Cress.

... Sea Radish.

... Dyers' Weed.

... White Field Pansy.

... Milkwort.

... Sea Campion.

... English Catchfly.

... Red Spotted Catchfly.

... Red Campion.

... Ragged Robin.

... Broad-leaved Mouse-ear Chickweed.

Narrow-leaved Mouse-ear Chickweed.

Chickweed.

... Bog Stitchwort.

... Pearlwort.

... Corn Spurrey.

... Sandwort Spurrey.

... Allseed.

... Tamarisk.

... Trailing St. John's Wort.

... Tree Mallow.

... Lesser Tree Mallow.

... Dwarf Mallow.

... Common Mallow.

... Narrow-leaved Flax.

... Dove's-foot Cranesbill.

... Jagged-leaved Cranesbill.

. Herb Robert.

... Hemlock Storksbill.

... Musky Storksbill.

... Yellow Wood Sorrel.

... Holly.

... Furze.

... Black Medick.

... Field Melilot.

... Common Melilot.

... Purple Clover.

... Hare's-foot Trefoil.

... Dutch Clover.

... Crimson Clover.

... Yellow Trefoil.

... Greater Bird's-foot Trefoil.

... Hairy Bird's-foot Trefoil. 
Ornithopus perpusillus ... Arthrolobium ebracteatum Vicia angustifolia Rubus fruticosus

Geum urbanum ... Potentilla fragariastrum...

Tormentilla

Alchemilla arvensis

Cotyledon Umbilicus

Sedum anglicum

Conium maculatum

Smyrnium Olusatrum

Apium graveolens

Petroselinum sativum

Foeniculum officinale

Oenanthe crocata

Aethusa cynapium

Heracleum Sphondylium

Daucus gummifer

Hedera Helix

Lonicera Periclymenum

Galium Mollugo...

Sherardia arvensis

Centranthus ruber

Valerianella carinata olitoria

Bellis perennis ...

Erigeron mucronatum Achillaea Millefolium Anthemis Cotula nobilis

Chrysanthemum segetum

Matricaria inodora

\section{Leucanthemum}

Petasites fragrans

Senecio vulgaris

sylvaticus

Jacobaea

Carduus lanceolatus

palustris

arvensis

Centaurea nigra ...

Helminthia echioides

Crepis virens

Hieracium Pilosella

Hypochoeris radicata umbellatum

... $\quad \ldots$

... $\quad \ldots$ Fragrant Butterbur.

... $\quad \ldots$ Groundsel.

... $\quad \ldots$

..

... $\quad$.. Spear Thistle.

... Marsh Thistle.

.. Creeping Thistle.

... Black Knapweed.

... Ox-tongue.

... Hawksbeard.

... Mouse-ear Hawkweed.

... Narrow-leaved Hawkweed.

... Cat's Ear. 
Leontodon hirtus

Taraxacum officinale

Sonchus oleraceus asper ...

Jasione montana

Calluna vulgaris...

Erica cinerea

Armeria maritima

Primula vulgaris

Anagallis arvensis

Vinca major

Erythraea Centaurium

Borago officinalis

Lycopsis arvensis

Solanum nigrum

Linaria Cymbalaria

Elatine...

vulgaris

Antirrhinum Orontium

Veronica agrestis

Buxbaumii

arvensis

serpyllifolia

Chamaedrys

Pedicularis sylvatica

Orobanche Hederae

Thymus Serpyllum

Salvia Verbenaca

Prunella vulgaris

Stachys sylvatica

arvensis...

Lamium purpureum

Ballota nigra

Teucrium Scorodonia

Plantago major ...

lanceolata

Coronopus

Chenopodium murale

Beta maritima ...

Atriplex deltoidea

Polygonum aviculare

Persicaria

Rumex conglomeratus

crispus ...

obtusifolius

Acetosella

Euphorbia Helioscopia
... $\quad$.. Huwkbit.

... ... Dandelion.

... Common Sow 'Thistle.

... Rough Sow Thistle.

... Sheep's Bit.

... Heather.

... Heath.

... Thrift.

... Primrose.

.. Scarlet Pimpernel.

... Periwinkle.

... Centaury.

... Borage.

... Bugloss.

... Black Nightshade.

... Ivy-leaved Toadflax.

... Sharp-leaved Toadflax.

... Yellow Toadflax.

... Small Snapdragon.

... Field Speedwell.

... Buxbaum's Speedwell.

Wall Speedwell.

... Thyme-leaved Speedwell.

... Germander Speedwell.

... Lousewort.

... Broomrape.

... Thyme.

... Wild Sage.

... Self-heal.

... Hedge IVoundwort.

... Corn Woundwort.

... Dead Nettle.

... Black Horehound.

... Wood Sage.

... Great Plantain.

... Ribwort Plantain.

... Buck's-horn Plantain.

... Nettle-leaved Goosefoot.

... Sea Beet.

... Orache.

... Knotgrass.

... Spotted Persicaria.

... Sharp Dock.

... Curled Dock.

... Broad-leaved Dock.

... Sheep's Sorrel.

... Sun Spurge. 
Euphorbia portlandica ... Paralias

Peplus exigua

Mercurialis annua

Urtica urens

Parietaria officinalis

Ruscus aculeatus

Juncus bufonius...

Scirpus Savii

lamprocarpus

Carex vulpina

Phalaris canariensis

Anthoxanthum odoratum

Alopecurus pratensis

Phleum pratense

Agrostis alba

Gastridium lendigerum ...

Holcus mollis lanatus ...

Arrhenatherum avenaceum

Triodia decumbens

Cynosurus cristatus

Dactylis glomerata

Poa annua trivialis

Glyceria fluitans ...

Festuca sciuroides

Bromus sterilis ... mollis

Brachypodium sylvaticum Lolium perenne ..

Triticum junceum Hordeum murinum
.. Portland Spurge.

... Sea Spurge.

... Petty Spurge.

... Dwarf Spurgé.

... Mercury.

... Small Nettle.

. Wall Pellitory.

... Butcher's Broom.

... Toad Rush.

... Jointed Rush.

... Mud Rush.

... Great Sedge.

... Canary Grass.

... Sweet Vernal Grass.

... Fox tail Grass.

... Cat's-tail Grass.

... Marsh Bent Grass.

... Nit Grass

... Creeping Soft Grass.

... Meadow Soft Grass.

... False Oat Grass.

... Heath Grass.

... Dog's-tail Grass.

... Cock's-foot Grass.

... Annual Meadow Grass.

... Rough Meadow Grass.

... Floating Meadow Grass.

... Wall Fescue Grass.

... Barren Brome Grass.

... Soft Brome Grass.

... False Brome Grass.

... Rye Grass.

... Sea Wheat Grass.

... Wall Barley.

Ceology. Very nearly the whole of the rocks of Guernsey belong Ceology. to the most ancient of formations, that of the Archæan period, and consequently they are of immense antiquity. The northern portion of the island consists of diorite, sometimes approaching hornblende-rock with syenitic and granitic veins. The elevated portion is mainly composed of gneiss, which forms the cliffs and shore from Castle Cornet on the east, round the south and west as far as Vazon Bay: but diorite also occurs in many places. Some of the gneiss towards the west of the island is highly granitoid, while some of the syenite has a gneissic structure. To the east of Lancresse there is a rather fine-grained granite clearly intrusive in the diorite, which approaches gneiss in structure, apparently the 
resuit of compression, and veins of similar granite intrude in the gneiss.

The grey rocks, which are largely quarried all over the northern part of Guernsey, are locally termed granite: but, strictly speaking, they are diorites or syenites. They make excellent blocks for street paving, and very durable road metal. A rock known as hornblende gabbro, of a dirk colour, is also extensively quarried, and is locally called 'bird's eye.' 'True granite is found in the vicinity of Cobo and Grandes Rocques, as well as at l,ancresse and a few other places.

To the south of a line drawn from the town across the island the various gneissic rocks are traversed by intrusive veins of trap, porphyry, and greenstone. Quartz rock protrudes in picturesque masses on the cliffs at Jerbourg on the western side. The rock which prevails at the south-western extremity of the island is a granitoid gneiss, and along the cliffs eastward it acquires a coarse porphyritic character and an agreeable tint, owing to the presence in abundance of large red crystals of orthoclase felspar. Dykes of quartz felsite are abundant in Guernsey, and still more so in Alderney, but are rare or absent in Sark. Mica-traps, which are interesting on account of their extreme rarity in England, are frequent. They are composed chiefly of mica and felspar, and from their colour and roughness, and the glitter of the particles of mica, have probably given rise to the statement found in old books that emery was one of the products of these islands.

Notwithstanding the complete absence of limestone or calcareous rock in Guernsey, the average quantity of lime in drinking water is, by analysis, not less than seven grains per gallon, while from ten to fifteen grains is by no means an unusual quantity. Clays of various kinds exist in large quantities on the high ground, as well as in many of the lower levels, and in some places there are distinct traces of stratification. Some kinds are only found in veins, like the Kaolin clay, which does not occur as a superficial deposit in the island. The yellow clay, the unctuous blue clay, and others used in the manufacture of bricks, occur in deposits of variable thickness, and occasionally contain waterworn pebbles and flints.

Evidences of the ancient changes of sea-level are found in the ' raised beaches,' which exist nearly all round the coast, as well as in several places in the interior. Their height ranges from twenty-three feet to seventy-five feet above the present mean sea-level.

The existence of a kind of peat under the sea-beach has long been known. The beds extend along the low shores of the north and west coasts, but the richest deposit occurs beneath the sands at Vazon Bay, where it has been dug into to a depth of twenty feet. This peat, which is locally known by the patois name of gorban, is dried by the cottagers and used as fuel. Trunks of full-grown trees, still erect, occur in this peat bed, as well as acorns and hazel-nuts, and also the teeth of hogs and horses; but the presence of pottery 
and rude implements shows that the change in ievel must have taken place in comparatively recent times.

Excavations in the peat under the sands of Lancresse Bay in I 895 brought to light a quantity of bones and teeth, the former being, unfortunately, much broken. Enough remained, however, for identification, and they were found to belong to Bus longifrons, Cervus Elaphus, Sus scrnfa, Ovis sp., and Canis sp. Pieces of coarse pottery were dug up at the same time, together with a very interesting relic in the shape of a broken stone ring made of finegrained diorite, highly polished. From these discoveries it would appear that the submerged peat beds belong to the late Neolithic period, and that pre-historic man inhabited this region, or, at any rate, that he visited it, perhaps for the purpose of hunting bison and deer in the primeval forests which have lain for countless ages buried beneath the blue waters of the Atlantic.

\section{II.-BOTANICAL.}

THE literature relating to the botany of Guernsey is neither voluminous nor ancient. The earliest record of a plant indigenous to the island occurs in Symons' Synorsis Plantarum Insulis Britannicis, published in 1798 , where the minute Rush funcus capitatus was added to the British Flora on the authority of William Hudson, author of the Flora Angrica. The record is worded thus: 'Habitat in insulâ Sarnia sed rarissime in loco infra pagum Boret dictum, inter Fort George et Fermain Bay.' By a confusion of names Sarnia was supposed by subsequent writers to signify Jersey instead of Guernsey, and in Smith's English Flora, published in 1824, we read, under Juncus capitatus: 'In sandy ground : very rare. Found by Mr. Hudson below the village of Bovet, between Fort George and Fermain Bay, in the Isle of Jersey: Symons.' A trifling geographical error exists here, though it is practically of no consequence. There is no such place as Bovet in the locality mentioned. What was doubtless meant was the small hamlet known as $\mathrm{La}$ Bouvée, which is situated, not between Fermain Bay and Fort George, but some way further south, between Fermain Bay and Jerbourg. The plant still grows on the cliffs in that neighbourhood.

The earliest list of Guernsey plants is the lengthy and valuable one which is printed in the appendix to Berry's History of Guernsey, a rather scarce quarto volume, published in the year is 15 . This list, which gives the Latin names as well as their English equivalents, arranged in alphabetical order, bears the following title, ' Flora Sarniensis, or Genera of Guernsey Plants, arranged alphabetically after the Genera and Species of Hudson's Flora Anglica, by the late Joshua Gosselin, Esq., a native of the Island, I 788 : and 
presented to the History of Guernsey by his grandson, Thomas William Gosselin, Esq.'

It requires no very profound study of this catalogue of names to perceive that Joshua Gosselin was an acute and painstaking observer, and a botanist of no mean ability. That he was personally acquainted with Hudson seems almost certain : indeed, it is quite likely that he was the original discoverer of Juncus capitatus, although, as the plant does not figure in his list, we have no direc $i$ evidence of the fact. At this distance of time a few notes on the comparative frequency of the different plants would have added immensely to the value of the list, which consists merely of bare names; but, notwithstanding this deficiency, it is of the greatest interest.

A careful analysis of the curious obsolete names (occasionally the same plant is entered under two or three synonyms) shows that no less than 528 species are enumerated, consisting of--

$\begin{array}{lcccccr}\text { Flowering Plants } & \ldots & \ldots & \ldots & \ldots & 458 \\ \text { Ferns and Fern-allies } & \ldots & \ldots & \ldots & \text { I } 5 \\ \text { Mosses } & \ldots & \ldots & \ldots & \ldots & \ldots & 3 \text { I } \\ \text { Hepaticae } & \ldots & \ldots & \ldots & \ldots & \ldots & 6 \\ \text { Lichens } & \ldots & \ldots & \ldots & \ldots & \ldots & \text { I } 8\end{array}$

The proportion of non-vascular cryptogams appears small : but it must be remembered that comparatively little was known about them a century and a (puarter ago; in fact, the British Mosses described in Hudson's Flora Angliat only amount to about onesixth of the number now known, and the Lichens only about onetenth.

One point in connexion with this catalogue may be noticed. According to the title, it was compiled in 1788 , but it was only published twenty-seven years later, viz., in $18 \mathrm{I}_{5}$. What plants, if any, were added to the original list during the interval we have no means of knowing; nor is it of any importance, except that possibly Gosselin may be credited with recording species which were really discovered by some subsequent observer.

Out of a total of 458 phanerogams enumerated by Joshua Gosselin no less than 423 species, or ninety-two per cent., are known to have occurred in Guernsey during recent years; so that thus far the general accuracy and reliability of his list are placed beyond question. Seven other species were recorded independently by Babington in the Flora Sarnica, twenty-four years afterwards, thus leaving only twenty-eight species unconfirmed by other later botanists. Happily, a large portion of Gosselin's own herbarium still exists, and is at present in the possession of Mr. Edgar Dupuy. I am greatly indebted to Mr. Cecil Andrews for taking the pains to go through this valuable old collection, and for supplying me with copious notes upon it. The specimens are not dated, but most of them must have been collected some while before I788, and their 
excellent preservation at the present time shows that the collection has always been in good hands.

Evidence of the former occurrence in Guernsey of eleven species which are now certainly extinct is afforded by specimens preserved in this collection, and, as the localities where they were found are specified, there is no doubt about their belonging to this island. Six plants peculiar to Alderney are mentioned in the printed list, from which it would appear that Gosselin intended it to comprise as far as possible the flora of the entire Bailiwicl: of Guernsey, and not merely of the island of Guernsey alone. A few of the names are certainly erroneous, and some others are doubtful, but these form only a small percentage of the species recorded, and do not seriously impair the value of the list.

It is pleasant to be able to pay a well-deserved tribute to the memory of the old workers like Joshua Gosselin, and to rescue their names from oblivion. Too often they have met with scant recognition at the hands of their successors. In the preface to the Flora Samica, after alluding to one or two papers then lately printed describing botanical tours in the Channel Islands, Professor Babington goes on to say: 'A catalogue of Guernsey plants, drawn up in I 788 by Mr. Gosselin, has been recently published by his grandson in Berry's History of Guernsey, but without any correction or augmentation, and it is very imperfect.' And so it was cast aside and utterly ignored by the young botanist, whose own work in the same field, though admirable in its way, has proved by no means free from error and imperfection. So far as concerns Guernsey alone, we could better afford to-day to blot out every record in the Flora Sarnica than lose the Flora Samiensis of Joshua Gosselin.*

Very little was known about the distribution of the plants of these islands uritil the year 1839 , when Charles Cardale Babington brought out his little book entitled 'Primitice Flore Sarnicre, or an Outline of the Flora of the Channel Islands of Jersey; Guernsey, Alderney, and Sark.' A few lists and papers had appeared in the journals describing tours and visits, but no attempt had been made to deal with the subject systematically; so that Babington broke new ground, and his book did much towards directing the attention

* I am indebted to Miss Carey, of Le Vallon, for the following particulars of the life of this old Guernsey botanist, who was her great-great-grandfather. Joshua Gosselin, who was born in Guernsey on November 6th, I739, was lineally descended from the Bailiff of Guernsey, Hellier Gosselin, notorious in the reign of Queen Mary. He was the son of Joshua Gosselin and Anne Guille, of St. George. In I76r he married Martha Le Marchant, daughter of Thomas Le Marchant, of Le Bosq, by whom he had a large family. He died May 27th, 1813, at Bengeo Hall, Hertfordshire, the residence of his eldest surviving son who afterwards became Senior Admiral of the British Navy. Gosselin was a skilful artist, and was one of the first Guernseymen to take an intelligent interest in the Druidical remains of his native island, as shown by a paper, written and illustrated by himself in Archaeologia, vol, xviii. p. 254. He spent much of his time in England, and was personally acquainted with many of the celebrities of his day. 
of English botanists to this remote and neglected corner of the kingdom.

The materials for this work were personally collected by the author during two visits made to the islands in 1837 and 1838 . On the first occasion, we learn from his journals, he arrived in Jersey on the I6th of July, and spent nearly four weeks there, afterwards moving on to Guernsey, where he stayed from the I Ith to the 3 Ist of August. The following year, 1838 , he started earlier in the 'season, reaching Jersey on the Ist of June, limiting his stay there to three weeks, and then devoting the remainder of the time, from June .22 nd to August 8th, to Guernsey and the smaller islands.

The total number of flowering plants and ferns recorded in the Flora Sarnica amounts to 348 species for all the Channel Islands combined. Of this number 553 belong to Guernsey, viz., 536 phanerogams and seventeen ferns and fern-allies.

Considering the immense changes that have have taken place in this island during the sixty odd years that have elapsed since the day when young Babington and his friend, William Christy, 'found Euphorbia Peplis in great plenty on the sands of Grand Havre, at some distance beyond the Vale Church,' the wonder is that the number of wild plants which have totally disappeared is not far greater than it really is. Many, however, which are still bravely struggling against the steady advance of the builder and the market gardener are growing more and more scarce, and ere long they will have to be ranked among extinct species.

Out of the 536 flowering plants noted for Guernsey in the Flora Sarnica, fifteen species then recorded for the first time have not been met with during the last twenty years. A few of them being cornfield weeds, may reappear some day, but the majority have been lost through drainage and the cultivation of waste land. These fifteen plants are:-

Myosurus minimus.

Ranunculus Lingua.

Papaver Argemone.

Sium angustifolium.

Chaerophyllum temulum.

Rubia peregrina.

Scabiosa Columbaria

Verbascum Blattaria.
Linaria spuria.

Pedicularis palustris.

Stachys Betonica.

Typha angustifolia.

Phalaris arundinacea.

Aira flexuosa.

Sclerochloa procumbens.

Clearness and conciseness mark every page of the Flora Samica. The system of enumerating after each plant all the islands in which it occurs certainly ensures economy of space, but it likewise increases the possibility of error, as a name may easily drop out unnoticed in the course of transcription. Perhaps this accounts for the singular omission from particular islands of many common plants which Babington could not fail to have seen. With respect to Jersey I 
am not qualified to speak; but, as regards Guernsey, the number of untloubtedly erroneous records is very small, the principal ones being Viola odorata, Acer campestre, Senecio paludosus, Plantago media, and Betula allia. Among those who assisted in the compilation of the Guernsey list we find the name of an accomplished botanist and horticulturist, Mr. Hilary O. Carré, of Valnord, one of the Jurats of the Royal Court of Guernsey, and afterwards LieutenantBailiff of the island.

In that well-written and comprehensive work, Ansted's Channel Islands, the second edition of which was published in 1865 , long lists of species are given in almost every department of zoology and botany, and, although they are not all of equal merit, they serve to give a fair idea of the indigenous fauna and flora. These lists consist simply of scientific names, arranged in alphabetical order, to which letters are affixed denoting the different islands where each species has occurred. The list of flowering plants includes all the species in the Flora Samia, together with about fifty others added for Guernsey, 'thirty-two of them by Major Smith, R.M., formerly a resident, nine by MIr. Wolsey, an exceedingly intelligent nurseryman and excellent botanist in Guernsey, and the rest by Miss Le Lievre and other island botanists.' About two-thirds of the plants thus recorded for the first time have been found since, but the following species recuire confirmation before they can be admitted into the Flora:-

Elatine hexandra.

Silene noctiflora.

Pyrus communis.

Bupleurum tenuissimum.

Galium uliginosum.

Scabiosa succisa.

Wahlenbergia hederacea.
Ceratophylium demersum.

Allium Babingtonii.

Luzula Forsteri.

Polypogon littoralis.

Agrostis Spica-venti.

Elymus arenarius.

It is difficult to tell exactly what weight to attach to this list. The probability or improbability of the occurrence of certain species cannot be discussed now, but something will be said about each of them in its proper place. In a local flora every known record should be recognised in some way, and either confirmed, questioned, or refuted : none should be ignored; for, even if a record be manifestly erroneous, no better opportunity can possibly present itself for the correction of the error.

Through the kindness of Mr. W. A. Luff, I have had an opportunity of looking through an annotated copy of the Flora Sarnica which formerly belonged to Major H. Smith, one of the contributors to the list last mentioned. Besides sundry notes which are valuable as confirmatory evidence of plants found by Gosselin seventy or eighty years before, he gives particulars of the occurrence of two very interesting species which are not marked for Guernsey in Ansted's list, viz., Helianthemum inulgare and Drosera rotundifolia. 
The latter plant is said to have been found in two places at Grande Mare in the year I812, but it no longer grew there in Smith's time.

A leap of thirty years or so from the date of Ansted's Channel. Islands brings us down to the period when the Guernsey Society of Natural Science, which had sunk into a condition of lethargy, awoke to new life, and by the publication of annual Transactions gave a fresh impetus to the study of local natural history. One of the earliest papers was an exhaustive account of the Ferns of Guernsey, by Mr. G. T. Derrick, an observant resident botanist, who had been fortunate some time previously in discovering in this island the so-called Jersey Fern (Gymnogramme leptophylla). In r89i I read a paper before the Socieiy summarising my own botanical work during the preceding three years, and giving a list, with local distribution, of $6{ }_{3} 6$ phanerogams, eighteen ferns, and nine fern-allies found by myself in Guernsey; about one-fifth of these were previously unrecorded. Since then additions have been made to the list from time to time, most of which have been recorded in the annual Transactions of the Society.

Having disposed of the Flowering Plants, and brought the record up to date, an endeavour was made to treat the cryptogamic flora of Guernsey in the same manner. The only existing lists-those contained in Ansted's book on the Channel Islands-were mere names, giving no information at all about the local distribution; moreover, it was evident that the lists stood in need of some revision. Accordingly, in $1 S_{92}, 1$ commenced a series of papers for the Transactions on the Cryptogams of Guernsey, presenting as a first instalment lists of $I_{42}$ Mosses, 38 Hepaticae, and 243 Lichens. Then followed an enumeration of the Diatomaceae, amounting to 322 species. In I $S_{94}$ I contributed a paper on the Algae of Guernsey, giving a list of 236 Seaweeds, 43 Fresh-water Algae, and 9 llesmids. Lastly, the Fungi, amounting to 612 species, formed the subject of two papers read before the Society in 1897 and 1398 .

So much for what may be termed the historical side of the subject. Let us now rapidly glance at the principal features of interest in different sections of the Guernsey flora.

\section{Flowering Plants.}

The first thing that deserves to be mentioned, although it is certainly not the first thing that will attract the notice of a stranger, is the remarkable absence of quite a number of common plants which any one with a little knowledge of the botany of the south of England would expect to find here. The absence in sniall areas of species which are generally common is a matter which is often ignored; but it is one of considerable importance in the study of plant distribution. Here are some plants, for example, which have never been found in Guernsey; and yet all of them are common in Normandy, the 
nearest portion of the continental mainland, and at least half a dozen occur in the neighbouring island of Jersey:-

Anemone nemorosa.

Caltha palustris.

Stellaria Holostea.

Oxalis Acetosella.

Orobus tuberosus.

Angelica sylvestris.

Valeriana officinalis.

Solidago Virga-aurea.
Lactuca muralis.

Campanuła rotundifolia.

Vaccinium Myrtillus.

Erica tetralix.

Melampyrum pratense.

Lamium album.

Lysimachia vulgaris.

Mercurialis perennis.

And the list might easily be extended Some of these are woodland species, it is true, but it must be remembered that Guernsey was once well wooded, even within historic times.

In all descriptive works dealing with the flora of Britain, as well as in the various editions of the London Catalogue of British Plants, it has been customary to distinguish in some way those particular species which are confined to the Channel Islands; that is to say, continental plants indigenous to the group, but unknown on the north side of the English Channel. This is a convenient arrangement. since it recognises their existence within the limits of the United Kingdom, without including them in the flora of Britain proper. About twenty of these Channel Island plants are enumerated in the last (1895) edition of the London Catalugue: some of them are peculiar to Jessey, some to Guernsey, one or two to Alderney, and some occur in two or in all three of these islands. Out of the seventeen non-British species found in Guernsey, six are confined to that island exclusively Various attempts have been made from time to time by foolish persons to introduce into the other islands some of these local plants, but happily such attempts have for the most part proved abortive. The non-British Guernsey plants (omitting Casuals which are not permanent in their stations) are the following :-

Brassica Cheiranthus.

Sinapis incana.

Viola nana.

Silene quinquevulnera.

Gnaphalium luteo-album.

Centaurea aspera.

Cicendia pusilla

Orchis laxiflora.

Allium Ampeloprasum.
Phalaris minor.

Milium scabrum.

Lagurus ovatus.

Cynosurus echinatus:

Bromus maximus.

Gymnogramme leptophylla.

Ophioglossum lusitanicum.

Isoetes Hystrix.

Now it is well to notice that these seventeen plants are by no means common on the adjacent French coast. On the contrary, a reference to Corbiere's Nouvelle Flore de Normandic (1894) will show that not a single one occurs there plentifully; several are very 
rare, and five or six do not occur in Normandy at all. Ophioglossum lusitanicum and Isoetes Hystrix, for example, do not grow nearer than the coast of Finisterre and Côtes du Nord, and Milium scabrum is not known to occur anywhere within a radius of one hundred and fifty miles, its nearest station being on the shores of the Bay of Biscay.

Add to this the fact that no vestige can be found in Guernsey and the smaller islands of many continental plants which are more or less plentiful on the coast opposite, and it will be perfectly apparent that the flora of this little archipelago is much less closely related to that of Normandy than would at first sight be imagined. If we run through the Flore de Normandie and the Flore de l'Ouest de la France, and pick out the species noted as common or very common in those portions of Normandy and Brittany which lie nearest to Guernsey, we shall find quite a long list of plants of which no trace whatever occurs here, so that in comparison our seventeen continental species are a very small number indeed. And so the question suggests itself: Was Guernsey detached from the mainland before these plants had spread into the north-western corner of France? Difference of geological formation does not account for all the absentees.

Considering its small size, Guernsey possesses an unusually high percentage of British rarities. Taking merely those plants which have a comital census below ten (i.e., plants found in less than ro out of the II 2 counties and vice-counties into which England, Scotland, and Wales are divided) according to the last edition of the London Catalogue, it will be found that they comprise some of the very rarest wild flowers of south Britain, about half a dozen being confined each to a single locality on the English mainland :-

Matthiola sinuata.

Polycarpon tetraphyllum.

Hypericum linarifolium.

Lavatera sylvestris.

Ononis reclinata.

Arthrolobium ebracteatum.

Tillaea muscosa.

Callitriche truncata.

Lythrum hyssopifolium.

Eryngium campestre.

Bupleurum aristatum.

Cicendia filiformis.

Myosotis Balbisiana.

Echium plantagineum.

Scrophularia Scorodonia.

Sibthorpia europaea.

Orobanche amethystea.
Orobanche coerulea.

Herniaria glabra.

$$
\text { ciliata. }
$$

Polygonum maritimum.

Euphorbia Peplis.

Spiranthes aestivalis.

Romulea Columnae.

Allium triquetrum.

Juncus capitatus.

Arum italicum.

Cyperus longus.

Carex punctata.

Mibora minima.

Polypogon monspeliensis.

Cynodon Dactylon.

Briza minor.

Bromus rigidus. 
From a botanist's point of view, the most interesting portion of this island is unquestionably that part which lies north of a line drawn from Grand Havre to St. Sampson's Harbour. This imaginary line, scarcely more than a mile in length, traverses a belt of low-lying, marshy ground which, from the earliest times down to the beginning of the century, was inundated by the sea at high spring tides, so that the entire northern extremity of Guernsey became converted into an island. About the year $\mathrm{ISI}_{2}$ this periodically submerged tract was reclaimed, and although the 300 acres so recovered were, in the words of a contemporary writer, 'to all appearance little better than a bed of sand,' they became in course of time very good pasture land. This must have been a fine hunting-ground for the botanist, because brackish pools and salt marshes were scattered about on all sides. Gradually, however, these marshes have been drained, and the ground brought into cultivation and built upon; hence the disappearance of many plants which flourished when Babington visited the island sixty years ago, and which continued to exist there for probably a quarter of a century afterwards.

Further north, however, there is plenty to be found. One of the most conspicuous objects in the landscape is the Vale Windmill, which stands on an eminence. Within a radius of a mile or two from that spot a large proportion of the best flowering plants in the Sarnian flora are to be found. Indeed, the collector will have need of a capacious vasculum if he spends a summer's day in rambling over this charming country, with its network of winding lanes, its deeply indented coast, and the green, undulating sward and sand dunes of Lancresse Common. The following plants have their headquarters in this district:-

Brassica Cheiranthus.

Silene conica. quinquevulnera.

Ononis reclinata.

Arthrolobium ebracteatum.

Bupleurum aristatum.

Gnaphalium luteo-album.

Cicendia pusilla.

Herniaria glabra.

Cynosurus echinatus.

Bromus maximus.

Isoetes Hystrix.

The vicinity of Vazon Bay, about four miles westward of the town of St. Peter-Port, is another locality exceedingly rich in good flowering plants, perhaps hardly inferior to the one just described. Conchologists will be interested to see the rare Tenby snail (Helix pisana) in immense numbers on the sand-hills by the sea wall; they are not indigenous, however, and the shells are less handsomely marked than the Welsh specimens.

Half a mile inland from Vazon Bay lies the famous marsh known as Grande Mare, the sole remaining relic of what was once an extensive area of swampy, bogey ground. Quite a number of plants occur nowhere else in the island, so that, if the regrettable project 
of draining the marsh is carried into execution (and it has already commenced), the local flora will sustain an irreparable loss. In this neighbourhood may be seen in all its glory that most beautiful of orchids, Orchis laxiflora. It grows in profusion in the meadows all round, and about the second week in June some places are purple with the flowers. Besides this Orchis, and some of the plants already mentioned as found in the Vale district, the following rarities may be seen within a mile of Vazon Bay :-

Callitriche truncata.

Centaurea aspera.

Spiranthes aestivalis.

Cyperus longus.

Carex punctata.

\begin{abstract}
Mibora minima.
Lagurus ovatus.

Cynodon Dactylon.

Bromus rigidus.

Chara baltica.
\end{abstract}

A pretty little plant, Evigeron mucronatum, a native of Mexico, is thoronghly naturalised in Guernsey, and grows profusely on several old walls in the suburbs of St. Peter-Port. Although totally different in foliage and habit, the flowers bear a striking resemblance to those of the common daisy, and thereby it escapes notice. How and when this species was introduced is not known, but it has existed on the same old walls for very many years.

In the eyes of visitors, the greatest botanical curiosity in the island is Gunnera scabra, a gigantic plant locally known by the name of Wild Rhubarb, from the general resemblance of its enormous leaves, which measure five or six feet across, with leaf-stalks as thick as a man's wrist. It has long been grown here in private grounds, and during the last twenty or thirty years has become thoroughly established on the borders of pools and valley streams in the south. Above Moulin Huet Bay this magnificent plant, a native of South America, grows in great luxuriance, but it suffers severely in hard winters.

It is hardly necessary to state that the Guernsey Lily (Nerine sarniensis) is not indigenous; but its introduction into the island was rather remarkable. About two centuries ago, a Japanese vessel was wrecked on the coast of Guernsey, and some bulbs of this lily were washed ashore and got buried in the sand. Here they remained unobserved until the great beauty of the flower attracted the attention of the Hon. Charles Hatton, son of Lord Hatton, then Governor of the island, who cultivated the plant and distributed specimens. Dr. James Douglas published a treatise on the Guernsey Lily, or Lilium sarniense, in 1725 . The bulbs have been cultivated by flower-growers in the island ever since, and considerable quantities are sent to England every year.

Ferns. The profusion of ferns is one of the most striking characteristics of the native vegetation of Guernsey. Everywhere throughout the island, on hedge-banks and stream sides, 
they abound; but it is in the deep, shady water-lanes of the south that they are seen in their greatest luxuriance and beauty. With the exception of the Scale Fern or Rustyback (Ceterach officinarum) and the Wall Spleenwort (Asplenium Trichomanes), both of which are decidedly rare, most of the common English ferns are found here in plenty. The Hart's-tongue (Scolopendrium vulgare) is unusually abundant, and the fronds often attain a length of three feet or more. The Sea Fern (Asplenium marinum) is common on the coast, often abundant in caves and caverns moist with sea-spray, but generally in inaccessible places high up on the walls or roof, having been dug out wherever it could be reached.

The Royal Fern (Osmunda regalis), the noblest of thern all, has now entirely disappeared. It used to be plentiful in days gone by, but its reputed medicinal virtues created a demand for it, so that it was sought after by herbalists; and the remnant that escaped has since fallen a prey to the insatiable rapacity of senseless ferngrubbers. The Adder's-tongues (Ophioglossum) are well represented, for in no other spot in the kingdom can all the three British forms be found. The small one ( 0 . Iusitanicum) was discovered in 1854 , and for more than thirty years was supposed to be rare, but during the winter of $1889-90$ I proved it to be so widely distributed and abundant on the southern cliffs as to dispel all fear of possible extirpation.

The so-called Jersey Fern (Gymnogramme leptophylla), another non-British species, is exceedingly rare, and appears to be confined to the one spot where it was first detected by Mr. G. T. Derrick in I 877 . The secret of its habitat has been so jealously preserved that hardly half a dozen persons have ever seen this delicate and graceful little fern growing in Guernsey; so it continues to hold its ground, though I have observed that, being an annual, it is more plentiful in some seasons than in others. Mr. Derrick has informed me that on more than one occasion he has endeavoured to establish it elsewhere in this island, but without success.

One of the most remarkable of all indigenous plants - and interesting also from the fact that it is found nowhere in the United Kingdom except in Guernsey - is Isoetes Hystrix, a very curious species, with a spinous, subterranean bulb and a tuft of slender, dark green leaves. It occurs more or less plentifully in several parts of Lancresse Common, but it is an extremely difficult little thing to detect, necessitating much patient searching on hands and knees, and, until one knows it, the digging up of many plants which prove to be something else. Isoetes Hystrix was discovered here by Wolsey in $\mathrm{I} 860$, and it was a particularly interesting find of hisbetter even than Orhioglossum iusitanicum, because at that date the existence of a terrestrial Isoetes was hardly suspected, though several aquatic species were known. An exhaustive paper by Dr. D. H. Scott, F.R.S., on the structure and affinities of this singular plant, 
prepared from living Guernsey specimens, will be found in Annals of Botany, vol. xiv. (I900), p. 4I3.

The Characeae are not numerously represented in this island, and the only species worth noting here is the very rare Chara baltica var. affinis, which occurs, or, at any rate, used to occur in some quantity ten years ago, in the ditches at Grande Mare.

Mosses. In this warm, moist climate, so similar in many respects to that of the south-western extremity of England, mosses of course abound, and are to be met with almost every. where. Old walls, cliff sides, rocks, and boulders are very productive as a rule, but tree trunks present comparatively little variety. Hedge banks, disused quarries, and sandy commons are rich in species, as also sheltered valleys and stream-sides. Bryologists who are acquainted with the prolific sphagnum-bogs of Devon and Cornwall will be sorely disappointed with Grande Mare, the largest and finest piece of marshy waste land in the island, for it promises so much and yields so little: in fact, it is as poor in mosses and hepaticae as it is rich in flowering plants. Three or four species are abundant enough, but a host of mosses peculiar to peat bogs and wet heaths are absent; even the beautiful genus Sphagmum is very meagrely represented by a small patch or two of $S$. acutifolium, which will soon disappear if the marsh is drained.

The great bulk of the mosses are of course lowland forms, but there are a few which are strictly sub-alpine in their range, although the highest elevation barely exceeds 350 feet. Possibly this poirits back to a period when the altitude of the land above sea-level was very much greater than it is now. Besides a fair share of interesting species, Guernsey possesses one, Fissidens rivularis, which ranks among the very rarest in the British flora, as it has hitherto only been found at Hastings. Another great rarity will very likely be discovered on the cliffs if searched for, as I have found it in abundance in Alderney. This is Bartramia stricta, the only British locality for which is in Wales. It used to grow in one spot in Sussex, but it is believed to be extinct there now.

As in other sections of the flora, several mosses which are common in precisely similar localities in the south-west of England appear to be absent; but the western portion of the island has not been thoroughly investigated, and possibly in course of time some of these deficiencies will be filled up. At present the list comprises as nearly as possible one-fourth of the total number indigenous to the British Isles.

Hepaticae. 'Taking the Hepaticae as a whole, they are relatively far less plentiful in the island than mosses: they seldom grow luxuriantly, and many promising localities, like Grande Mare, are singularly barren of them. The Guernsey list is not a 
lengthy one, comprising only one-fifth of the British species, but it includes two which deserve notice, on account of their rarity. The first is Cephalozia Turneri (one of the most minute of all the Hepaticae) which grows at Fermain on a gravelly bank among small mosses; the second is Lophocolea spicata, an Irish species like the other, though it was found in England twenty years ago in one spot near the Land's End by my old friend, the late William Curnow, one of the best hepaticologists of his day.

The occurrence of Irish plants in Guernsey is peculiarly interesting, and should stimulate wider and more minute investigation. Zoologists say that the Channel Islands are included in overlapping zones of British and Mediterranean faunas, and that among the lower forms of animal life there is much to be found here that is peculiar both to the north-west of continental Europe and to Ireland and the extreme south-west of England. From a botanical standpoint it remains to be seen how far the Irish element is represented in the insular flora.

\section{Fungi.}

Until very recently nothing was known respecting the Fungi. have resulted in the compilation of a list of more than six hundred species for Guernsey alone. All the principal genera of the Agaricineae-i.e., Mushrooms and Toadstools - are represented. The occurrence of a number of species usually found in woods may be attributed to the circumstance that there existed formerly in the island stretches of forest and woodland of considerable extent. That Guernsey is exceptionally rich in this tribe of plants is proved by the fact that during four months in I 897 , August to November inclusive, more than 450 different species of fungi were collected here and identified at Kew. Even in mid-winter numbers of Agarics are to be found, for no less than fifty-three species were gathered, many of them from several different localities, during the month of January ( $\mathrm{I} 898$ ). As it serves to illustrate the mildness of the climate as well as the richness of the mycological flora, the list is worth preserving:

Tricholoma pumilum. exscissum. nudum. personatum.

Marasmius oreades. prasiosmus.

Collybia velutipes. atrata. confluens.

Mycena tenerrima. flavo-alba. galericulata.
Russula nitida. Laccaria laccata. Clitocybe flaccida. Omphalia umbellifera. belliae. rustica. integrella. Luffii.

Hygrophorus chlorophanus. puniceus. psittacinus. niveus. 
Hygrophorus russo-coriaceus. obrusseus. pratensis. aureus.

Entoloma prunuloides. costatum. sericeum.

Leptonia lampropoda. serrulata.

Galera spartea. ovalis. tenera.

Tubaria inquilina. furfuracea.

Cortinarius ochroleuca.

Agaricus sagatus.
Stropharia coronilla. stercoraria. melasperma. inuncta. Hypholoma fasciculare. capnoides. hydrophilus.

Psilocybe foenisecii. semilanceata.

Panaeolus sphinctrinus.

papilionaceus.

campanulatus.

Coprinus micaceus.

'Taking the Agaricineae as a whole, the most interesting genus is certainly Hygrophorus, of which twenty-four species are recorded. After examining all the Guernsey forms, Mr. George Massee favoured me with the following suggestive note:-

'The occurrence of so many species of Hy'grophomes within so limited an area is very remarkable, and careful study would almost certainly add to the number already observed, as several specimens received in a condition too imperfect for certain identification did not appear to belong to recorded species. Furthermore, the remarkable variation in form, colour, and size of such species as $H$. punicens, $H$. coccineus, and others, suggests a line of work which could not fail, if thoroughly investigated, to aid to a very material extent in solving the interesting problem bearing on the causes of variation in species. The examples from Lancresse Common proved exceedingly interesting from this standpoint. Perfectly typical specimens occurred mixed with such varied departures from the type that the extreme forms, if collected in localities apart from the typical form, and not connected by intermediate links, might reasonably have been considered as distinct species. Why is this? The question can only be answered by some person resident in the island; and the fascination certain to accrue from a study of this cause of variation, and the great benefit to science generally, should stimulate some one to undertake the task.'

Three fungi new to science were discovered in Guernsey Clitopilus samicus, Omphalia Luffi, and Verticillium Marquandii; and ten species were added to the British Flora, viz., Lepiota carneifolua, Marasmius globularis, Agaricus rubellus, Polystictus tomentosus, Lachnea pulcherrima, Bertia collapsa, Torula asperula, Volutella vitis, Fusarium argillaceum, and Phyllosticta hedericola. Besides these, there are several excessively rare British species in 
the list, some not found for a great many years past, and some which have only been met with once or twice. So that altogether the fungus-flora of Guernsey is an exceptionaliy fine one, the number of species recorded having rarely been equalled in any locality of the same size.

Lichens. It has been so long customary to regard the lichens as forming a perfectly natural and well-defined family of plants, that it is not easy to reconcile oneself to the idea that they are after all merely symbiotic fungi, and that the green gonidia, which used tc be looked upon as their essential differentiating character, do not belong to them physiologically, but are algae pure and simple, associated with these particular fungi in a lifelong partnership. To the field botanist, however, lichess will be lichens to the end of time, whatever their systematic position may be, and no finer field for the study of these interesting plants will he find anywhere than this little island of Guernsey, where some 300 species have been recorded-a number which, though large, is certainly not exhaustive.

Plenty of work for hammer and chisel will be found among the stupendous rock-masses and boulders which adj so much to the beauty of the coast scenery, for, generally speaking, it is impossible to lay one's hand upon the exposed face of a rock without corering a lichen. Some of the stones are excessively hard, and the temper of both the collector and his chisel will often be put to a severe test. Saxicolous forms largely predominate, especially those peculiar to maritime districts, whereas lichens which grow on wood, whether trees or dry timber, a:e much less plentiful. We do not find the treetrunks shaggy and bearded, or densely corered with lichen growth, as they are in the south of England; but it should be observed that many species which are normally lignicolous, find in this island a congenial habitat on stone.

The plant which was named after the island by Salwey Chioflecton sarnuense is one of the rarest of Guernsey lichens, but it still grows in the spot where he discovered it half a century ago. It does not appear to have been found anywhere outside of the Channel Islands.

It may not be out of place here to impress upon the young lichen-collector the imperative necessity of testing, chemically as well as microscopically, every specimen he gathers before placing it in his herbarium. It is sheer waste of time to try to identify a Lecidea, a Lecanora, or a Verrucaria by external characters alone. Even for a practised hand it is seldom safe, and lichenologists of high repute have been known to make most grievous blunders through this hasty and carelesi method of jumping at conclusions Some of the foliaceous lichens, like Parmelia Borreri and P. reddenda, are so exactly similar as to be absolutely indistinguishable, except by 
the employment of chemical reagents; whilst in an enormous and unwieldy genus like Lecidea, containing as it does some 400 British species, the very first step towards identification is an examination of the spores.

\section{Algae.}

That seaweeds were collected in this island a long time ago is attested by a fresh-looking specimen of Fucus zesi-mlosus preserved in the Herbarium of the Royal Botanic Gardens at Kew, which bears this label: 'Alga narina. Gather'd on the Isle of Guernesey.-T. Know, I 726.' And it may be worth noticing that the first indigenous plant to bear the name of the island was a seaweed, now called Rhodymenia palmata, var. samiensis. It was originally described by Mertens in 1806, under the name of Fucus sarmiensis, in Roth's Catalecta Botanica, with the note, 'Ex insula Sarnia misit amicus quidam Mertensio.' 'Two years later Dawson 'Turner adopted the name in his great work, and remarked. 'Professor Mertens received the plant from the Island of Guernsey.' Curiously enough, however, there is in the Kew Herbarium a specimen received by Dawson Turner from Mertens in 1807 , bearing a label in his (Mertens') own handwriting, as follows: 'Fucus sarniensis, mihi. Brought from the Isle of Jersey by a military friend in the Dutch service.' Here again we have a confusion of the names of the two islands, Guernsey and Jersey, precisely similar to what has already been alluded to in reference to Juncus capitatus (see p. 22).

In the matter of seaweeds Guernsey is particularly favoured by its southerly situation, and the possession of a magnificent rocky coast, so that not only is there an abundance and variety of these beautiful plants, but a large proportion of them attain a luxuriance of growth and development which is quite exceptional, if not unknown, on the Englis: shores. Several species that are plentiful here are of extreme rarity on the other side of the English Channel, and a few have not as yet been found there. It was my good fortune, during the year 1894, to discuver four species new to Britain, viz., Strebloncma Zanardinit, Polysiphonia opaca, Lichmannia Leveillii, and Lithophyllum expansum.

The very best localities for seaweed-collecting, as far as my experience goes, are, on the north of the island, Bordeaux Harbour and Cobo, the outlying reefs of rocks only accessible at the lowest spring tides; and, on the south, Moulin Huet Bay and the eastern side of Petit Bot. But on these splendid shores something interesting is sure to be found in every nook and corner that is carefully examined, and deep-water forms of great rarity are frequently washed up after violent autumnal storms.

There is not much to be said about the Fresh-water Algae, which are very poorly represented in Guernsey. The most promising localities yield but little, and the few species that occur here 
have an unhealthy look about them, and do not fructify at all freely. Desmids are remarkably scarce, and give one the impression that as a family they are dying out. Repeated gatherings made at different seasons at Grande Mare and elsewhere have failed to produce even a dozen different Desmids, whereas on the Cornish moors it is nothing unusual to find thirty or forty species in a pool a few yards square. A single gathering which I once made on Tremethick Moor, near Penzance, contained no less than sixtyeight species of Desmids alone, besides other unicellular Algae. Doubtless the salinity of the water in stagnant pools accounts in part for the paucity of Fresh-water Algae in general, and particularly of Desmids; but there must be some other cause besides. My own belief is that it is largely due to the natural drainage of highly manured land, and the pollution of cattle, and this view is supported by the generally feeble growth and unhealthy condition of the bulk of the specimens.

Although strictly a subdivision of the Algae, it is customary to keep the Diatomaceae apart, and they will be so treated in the systematic portion of this work. A great deal still remains to be done before an exhaustive list can be conpiled, but what has been done sufficiently shows how rich the island is in these nicroscop. ic forms of vegetable life. Mr. Thomas Rylands, an accomplished diatomist, who examined the material collerted in Guernsey by Dr. Wallich in $185^{8}$ and 1859 , and prepared a list of the species it contained, remarks: "It would be difficult to name a locality more likely to reward with success a diligent search for these things in their natural haunts than the shores of Guernsey, or in general to point to a more desirable field for the collection of Diatomaceae than the Channel Islands.'

No vestige of fossil Diatoms has ever been found in Guernsey. On several occasions I have prepared and carefully examined samples of various deposits selected for the purpose by geologists in the island, hoping to find traces of these organisms, but nothing of the kind has been detected.

The vegetation of an island such as Guernsey may be divided into two sections: first, the truly indigenous plants, the aboriginal possessors of the ground; and, secondly, the exotic contingent, or introduced plants, those which did not originally belong to the place, although at present they are perfectly wild, and form an important part of the local flora. By far the largest number belong to the former category; they are the old inhabitants of the soil, which have existed there for ages, long before the advent of man upon the scene. These alone, strictly speaking, constitute the natural flora of a district. But intermixed with these, and growing side by side with them, there are numbers of plants belonging to the second category, species not truly native, however much they 
appear so, but introduced into the district either directly or indirectly through the instrumentality of man. These, again, may be divided according to their various degrees of wildness, so that the whole vegetation of the place will fall into certain grades of citizenship, so to speak, which, following the arrangement of the late H. C. Watson, are commonly classed as follows :-

Natives. - The aboriginal occupants of the soil.

CoLonists.--Weeds of cultivated land in general, mostly found where the ground has been rendered favourable for their growth by the operations of man. If cultivation ceased, these would probably disappear altogether in course of time.

Denizens. - Plants having all the appearance of being really native, but which are either known or suspected of having been introduced into the locality by human agency. These would probably continue to hold their footing even if man became extinct.

Aliens.-Plants certainly known to be of foreign origin; less thoroughly established than Denizens, and in many cases fugitive in their stations.

CASUALS. - Chance stragglers from cultivation, not likely to become permanently established, garden outcasts, and foreign plants occasionally imported or sown with agricultural seeds, or introduced with ballast.

In almost every area certain species might be located equally well under one or other of these divisions, especially the last two, because no hard-and-fast line can be drawn between them; moreover, a plant which is unquestionably native in one part of the country may be no more than a mere Casual in another. The principal point, however, is to avoid placing on the same level as true Natives those plants which are properly merely Aliens or Casuals. It matters little how many of these foreign forms are recorded in a local flora (the information may be very useful some day) provided they are distinguished as such ; but, for all purposes of analysis and comparison, onlr the first three classes-Natives, Colonists, and Denizens--should be taken into account. And, again, plants known or believed to be extinct should be excluded from Tables and Summaries used in comparing local Floras, because our knowledge of extinct species must necessarily depend upon old records, whether printed or manuscript lists, or else collections of preserved specimens; and, where such evidences are wanting for a particular district, nothing can be known about the plants which used to exist there.

An analysis of the Guernsey flora, as recorded in these pages, 
will show that the flowering-plants, ferns, and fern-allies are divided as follows:-

$\begin{array}{ccccccc}\text { Natives... } & \ldots & \ldots & \ldots & \ldots & \ldots & 588 \\ \text { Colonists } & \ldots & \ldots & \ldots & \ldots & \ldots & 52 \\ \text { Denizens } & \ldots & \ldots & \ldots & \ldots & \ldots & 27 \\ & & & & & & 667 \\ \text { Aliens } & \ldots & \ldots & \ldots & 56 & \\ \text { Casuals } & \ldots & \ldots & \ldots & 64 & \\ \text { Extinct } & \ldots & \ldots & \ldots & 22 & \\ & & & & & - & \mathbf{1 4 2} \\ & & & & & \\ & & & & & & \end{array}$

Although the flora of Guernsey appears at first sight numerically large for so small an island, it probably does not exceed the average when all the circumstances of geographical position are taken into account. It must be remembered that the smaller the area the larger will be the flora relatively to the space, in all places presenting somewhat similar features. This relation of species to area has been admirably illustrated by Watson in the fourth volume of his great work, the Cybele Britannica, where he shows that a single square mile of diversified country in the north of Surrey produces nearly one-half of the wild plants found in the entire county, which has an area of 760 square miles. The whole of Britain, he calculated, only furnishes an average of one species to every sixty-one square miles of area.

At the time the Cybele Britannica was written, or rather the Comnindium, in 1872 , which expresses the author's later views, the number of plants admitted as British was reckoned at 1.425 These were classified by Watson under certain 'types of distribution,' which he defines as follows:-

I. British type: species widely spread throughout Britain.

2. English type: species chiefly seen in south or south-middle Britain.

3. Scottish type: chiefly seen in north or north-middle Britain.

Intermediate type : chiefly seen in middle Britain.

4. Highland type: chiefly seen about the mountains.

5. Germanic type: chiefly seen in east England.

6. Atlantic type : chiefly seen in west England.

Local species : restricted to single or few provinces.

After excluding the Rubi, the Characeae, and a number of Aliens, Casuals, and segregates not classified by IVatson, besides the seventeen non-British plants, it will be found that Guernsey possesses 636 out of these 1425 species. Although it is parva componere 
magnis, the two areas stand thus when their respective floras are divided into types:--

Types.

British

\begin{tabular}{|c|c|c|c|c|c|}
\hline British & ... & 532 & ... & $\ldots$ & 394 \\
\hline English & ... & 409 & $\ldots$ & $\ldots$ & I 79 \\
\hline Scottish & ... & 81 & ... & $\ldots$ & 2 \\
\hline Intermediate & ... & 37 & ... & $\cdots$ & $u$ \\
\hline Highland ... & $\ldots$ & 120 & $\ldots$ & $\ldots$ & $\circ$ \\
\hline Germanic ... & $\ldots$ & 1 27 & $\ldots$ & $\ldots$ & 18 \\
\hline Atlantic & ... & 70 & $\ldots$ & $\cdots$ & $3^{8}$ \\
\hline Local or doubtful .. & $\cdots$ & 49 & $\cdots$ & $\cdots$ & 5 \\
\hline Total & $\ldots$ & 1425 & ... & $\cdots$ & 636 \\
\hline
\end{tabular}

The Atlantic element, it will be seen, is proportionately very large, while the Germanic is small; and in these respects Guernsey resembles the south-western extremity of England. On the southern borders of Devon and Cornwall I6 Germanic and 36 Atlantic species are found (Briggs, Flore of Plymouth, Introd., p. xxvi.). Coming eastward, the proportion changes. There are in the Isle of Wight 37 Germanic and 26 Atlantic species, and on the mainland of the county of Hampshire 54 Germanic and 2.4 Atlantic plants ('Townsend, Flora of Hampshire, p 492).

Of the 120 plants which occur in every one of the 38 sub. provinces into which Watson has divided Great Britain, 7 are wanting in the Guernsey flora; of 54 which occur in 37 subprovinces 9 are wanting; of 44 which occur in $3^{6}$ sub-provinces 7 are wanting; of $4 \mathrm{I}$ which occur in 35 sub-provinces 7 are wanting; of 46 which occur in 34 sub-provinces II are wanting; and the number of absentees increases as we proceed. On the other hand, the island can show ro species which are found in only 5 subprovinces, 8 species which are found in only 4,6 species which are found in only 3,5 species which are found in only 2 , and 7 species which are restricted to a single sub-province. 


\section{RANUNCULACEAE.}

Clematis Vitalba, L. Traveller's Joy. Old Man's Beard.

Alien. First found: Dupuy, I 864 .

Rare: always a garden escape in these islands. Roadside hedge in Talbot's Valley in I889. Koadside near Le Jardin, Catel, covering a hedge for some forty yards (Andrews). In Mr. Edgar Dupuy's herbarsum there is a specimen which he gathered on the Forest road in 1864 .

The term Woodbine, commonly used by the later poets to signify the Honeysuckle, was formerly applied to various weak-stemmed climbers, including the present plant. In Midsummer Night's Dream, iv. I, we read :-

'Sleep thou, and I will wind thee in my arms :

So doth the woodbine the sweet honeysuckle

Gently entwist.'

Adonis autumnalis, L.

Pheasant's Eye.

Casual. First found: Dupuy, 1865.

A specimen of this plant was found in June, 1865 at the Vale by Mr. E. Dupuy, and is preserved in his herbarium. So far as I know, this is the first and only instance of its occurrence in these islands.

Myosurus minimus, L.

Mousetail.

Casual. First record: Babington, 1839.

This curious little plant is noted for Guernsey, without locality, in Fl. Sarn. on the authority of H. O. Carré. It has not been seen in the island of late years.

Ranunculus trichophyllus, Chaix.

Water Fennel.

Native. First found: Gosselin, I 788.

Frequent in pools about Grandes Rocques and Cobo. In Gosselin's herbarium there are specimens (named $R$. aquatilis) from Grandes Mielles and Grande Mare.

Ranunculus Drouetii, Schultz.

Native. First found: Royle, 189 I.

Rare. Quarry pool at the Vale (T. C. Royle). Pool in a field towards Grandes Rocques in I900 (Andrews).

Ranunculus heterophyllus, Fr.

Native. First found: Andrews, I900.

Pool by the coast road towards Portinfer, the var. submersus, Hiern. (Andrews). 
Ranunculus triphyllos, Wallr.

Native (?). First record : Babington (?).

This plant, which is now considered a variety of $R$. heteroplyyllus, holds the rank of a species in the last (I88I) edition of Babington's Manual, where it is described as confined to Guernsey. In the Report of the Bot. Loc. Rec. Club for I88I and I882, R. triphyllos is recorded as having been found in ditches near Coventry by Mr. J. E. Bagnall. I know nothing of the Guernsey plant.

\section{Ranunculus Baudotii, Godr.}

Native. First found: Groves, 1892.

In considerable quantity in a marshy field a little to the north of Ivy Castle. I am indebted to Mr. James Groves for pointing out this plant to me during the summer of 1892 .

(Ranunculus floribundus, Bab. has been recorded for Sark.)

\section{Ranunculus peltatus, Fries.}

Water Crowfoot.

Native. First found: Gosselin, 1788.

In several of the pools at Lancresse, mostly the var. trunicatus, Hiern. Specimens of this plant are preserved in Gosselin's herbarium mixed with $R$. trichophrllus.

Ranunculus hederaceus, $L$.

Native. First record: Gosselin, I8 15.

Ivy-leaved Cronifoot.

Not common, though found in most parts of the island by springs and rivulets, and on the borders of small pools and ditches. A large form, mostly floating, with sub-entire leaves (var. omiophyllus, Ten.) grows in the ditches behind Ivy Castle.

\section{Ranunculus sceleratus, L.}

Native. First found: Gosselin, I 788.

Celery-leaved Cronofoot.

Rare. A few plants in a field on the Vale Road. More plentiful in the marshes north of Ivy Castle. A specimen in Gosselin's herbarium is labelled 'Ditches in the Grande Mare,' but the plant no longer grows there.

The juice of this plant is so irritant that if applied to the skin it produces blisters which are difficult to heal, and are apt to pass into irritable ulcers.

Ranunculus Flammula, L. Lesser Spearciort.

Native. First record : Gosselin, I 815.

Very common in wet and swampy places. A form with regularly serrate leaves (var. serratus, Breb.) occurs in the moat at Ivy Castle, and in several other places. The var. pseudo-reptans, Syme, is found in Saints Bay Valley, the meadows at Grande Mare, at St. Saviours, at the Vale, and is probably not uncommon.

Known in Normandy by the name of Douve. The distilled water of this plant is said, on high medical authority, to be preferable to any other agent for producing instant vomiting in cases of poisoning. 
* Ranunculus Lingua, ${ }^{-} \mathrm{L}$.

Great Spiancort.

Extinct.

This fine species has long ceased to exist in the island, no trace of it having been found for over thirty years. No locality is specified in Fl. Sarn., but Babington saw the plant himself in 'wet places, Guernsey.' It occurs in Alderney.

Ranunculus Ficaria, L. Pilezert. Lesser Celandine.

Native. First record: Gosselin, 18 5 .

Very common in all parts. One of the earliest of spring flowers, being frequently found in blossom early in January. In $\mathrm{r} 89+\mathrm{I}$ saw a plant well in flower in Saints Bay Valley on the $24^{\text {th }}$ of November.

Called in the Guernsey patois Pissenliette (French, Pissenlit), the exact equivalent of an old name which is still used in many rural parts of England, but also shared, both in this country and in France, with the Dandelion. In Normandy it is known by the name of Jaunet. The Pilewort, although visited by insects, rarely ripens seed, but produces instead little bulbs in the axils of the leaves, and these, washed out after heavy rains and accumulated in quantities, have originated the myth of a rain of potatoes.

Ranunculus acris, $L$.

Native. First record: Gosselin, 1815 .

Very common in meadows and damp pastures.

Called in Normandy Piedbot, or Piépot. Very irritant, like most of the yellow-flowered Ranunculi. Both this species and $k$. bu hosus are called Guldcups in Devonshire, and they are the 'Cuckoo-buds of yeilow hue' referred to in the song in Lore's Labour's Lost, v. 2.

Ranunculus repens, L.

Native. First record: Gosselin, I8,5.

Creeping Buttercup.

Common in cultivated fields and gardens, and about ditches, roadsides, and waste spots.

Ranunculus bulbosus, $\mathrm{L}$.

Native. First record: Gosselin, I 8 I 5 .

Bulbous Buttercup.

Common in all parts. In 1889 I found in a lane by Richmond Hill a large plant bearing numerous flowers, every one of which was apetalous, In Journ. Bot., I×7 I, p. 198 , Dr. H. Trimen describes a singular variety which he found in a pasture field above Moulin Huet; but its strange appearance was ascertained to be due to the presence of a fungus In Alderney I have found a root bearing very double flowers, resembling the garden form called Bachelor's Buttons. It was growing in a perfectly wild spot, among multitudes of the ordinary plant.

According to Prior (Popular Names of British Plants, 1879) 
the syllable cup in the words Buttercup, Kingcup, and Goldcup does not refer to a drinking vessel, but is the old English word cup, a stud, or head of a button, as in French, Bouton d'or.

Ranunculus hirsutus, Curt.

Colonist. First record: Babington, I 839.

Hairy Butterup.

Frepuent ir cornfields and cultivated ground, but liable to be overlooked from its general resemblance to $R$. bulbosus. More common in the south of the island than in the north.

Ranunculus parviflorus, $\mathrm{L}$.

Native (?) First record: Babington, 1839

Rare. Abundant in 1891 in a cultivated field just under Noirmont Mill (IX.), but none seen there the following year or afterwards. In I899 and I900 Mr. Andrews found it in good (juantity growing in the turf of a field near the Caudré Mill (vi.) and also in a meadow in the neighbourhood: not a specimen being found in the ploughed land. In Alderney the plant is undoubtedly native, as it grows in several places where the ground has certainly never been cultivated. Babington records this species as found by H. O. Carré near Le Grognet (viII.).

\section{Ranunculus arvensis, $\mathrm{L}$.}

Casual. First record: Gosselin, 18 I 5 .

Corn Crowefoot.

Very rare. 'Two or three specimens sprang up in a garden at Mount Durand in $\mathrm{I} 898$, and were sent to me for identification. The plant is mentioned in Gosselin's list, but there is no specimen in his herbarium.

(Ranunculus auricomus is included in Gosselin's list, but as there is no specimen in his herbarium I regard it as a very questionable record.)

\section{Aquilegia vulgaris, $L$.}

Columbine

Alien. First found: Dupuy, I864.

Very rare, and always an escape from cultivation. Naturalised in a neglected piece of ground at Torteval, at some distance from a house, where many plants were flowering in 1895 . In June, 1864 , specimens were gathered in a field near Petit Bot by Mr. Edgar Dupuy, and are preserved in his herbarium.

Delphinium Ajacis, Reich.

Casual. First record: Marquand, I892.

Larkspur.

Very rare. Vale Castle quarry heap, one plant in I889. Another on Vazon Green in I89I. One plant on the sand-hills at Port Soif (Andrews) This plant is very rare in Normandy, and is not considered indigenous there. 


\section{PAPAVERACEAE.}

Papaver Argemone, L.

Long Prickly-headed Poppy.

Casual or Colonist. First record: Babington, I839.

Noted by Babington in the Fl. Sarn. as having been found by him at Lancresse Bay. Has not been seen in the island of late years.

Papaver hybridum, L. Ronnd Prickly'headed Poppy.

Colonist. First record : Babington, I 839 .

In cornfields and cultivated ground, very rare. Two plants near the Déhus Cromlech (Ix.) in I $\$ 89$. One or two near the Round Tower, Mont Saint. A few in a cornfield at Clos au Comte (viII.) in r89r, This plant is rather common in Alderney.

Papaver Rhoeas, L.

Colonist. First record: Gosselin, I8 15.

Corn Poppy.

Common throughout the island: especially so in the lowlands. One plant which I found in June, I89I, on the Vale Castle quarry heap, had narrow leaf-segments, and long, reddish-purple, bristly hairs on the sepals and upper part of the peduncles, giving the plant a very distinct appearance. This is the var. Pryorii, Druce (see Rep. Bot. Exch. Cl. I888, p. I99). In I894 I found the Corn Poppy still in flower in December. Var. strigosum, Boen. Rocquaine Bay, in lane coming down from Paysans Road, in good quantity. Etiennerie lane (viII.) a few plants. Sandy fields at Grandes Rocques, frequent. Portinfer (Andrews).

The common French name of the Corn Poppy is Coquelicot, but in the Guernsey patois it is called Rose de Tchen, literally Dog Rose. The belief is current in some parts of England that the fresh flowers, if placed too near the eyes, will cause blindness, and if applied to the ear a violent earache will ensue. The flowers of Poppies, like those of Roses, secrete no honey, and insects visit them for the sake of the pollen alone.

Papaver dubium, L.

Colonist. First record: Babington, 1839.

Common in the lowlands at the north and north-west, becoming more rare southwards. In sandy fields about Grandes Rocques growing in company with $P$. Rhoeas and its var. strigosum. Often dwarf, two or three inches high, in dry places. Babington did not recognise this plant in Guernsey, but records it on the authority of H. O. Carré, and questions whether $P$. Rhoeas var. strigosum may not have been mistaken for it.

Papaver somniferum, L.

Casual. First record: Marquand, I891.

Opium Poppy.

Very rare. Two or three plants in a cornfield near the Vale 
pond in 1889 . Several plants in a cornfield opposite Grandes Maisons (x.) in 1890 .

The large 'poppy-heads' of the druggists and herbalists belong to this species, and the juice obtained by wounding the unripe capsules, and afterwards dried, forms the Opium of commerce. It is curious that, although the seed-vessels contain opium juice in large quantities, the seeds themselves are innocuous, and have even been used for food in some places.

Glaucium luteum, Scop.

Native. First record: Gosselin, I8 15.

Yellowe Horn Poppy.

Locally common all along the shores of the north and northwestern coast: abundant on the shingle at Lerée. It is the Chelidonium glaucium of Gosselin's list.

This plant, known in the middle ages under the name of Ficus infernalis, used to be credited with very mysterious properties, and was commonly used by witches in their incantations.

\section{Chelidonium majus, L.}

Celandine.

Denizen. First record: Gosselin, I815.

Rather rare, and usually in small quantity in each locality: it occurs, however, in nearly all the parishes, always close to houses.

The name Chelidonium, derived from the Greek word for a swallow, was applied to this plant in very ancient times from its supposed efficacy in restoring the sight of young swallows. Lyte, in I578, calls it the Swallow-her-b, 'bycause (as Plinie writeth) it was first found out by Swallowes, and hath healed the eyes and restored sight to their young ones that have had harme in their eyes, or have bene blinde.' In France the Celandine is called Eclaire, suggesting the idea of clearing or enlightening (the eyes). The yellow juice of the plant is a violent acrid poison, and is a popular remedy for warts; hence another French name, Herbe aux verrues.

\section{FUMARIACEAE.}

Corydalis lutea, DC.

Yellowe Corydalis.

Alien. First found: Andrews, I 898.

Very rare. Observed on garden walls in Hauteville by Mr. C. Andrews; evidently escaped from cultivation. In many parts of England this plant is naturalised on old walls, but it is not so here, and therefore it is not properly entitled to a place in these pages.

\section{Fumaria pallidiflora, Jord.}

Colonist. First found: Dupuy, r 864 .

Generally distributed throughout the island, but rather rare. The earliest known specimen is in the herbarium of Mr. E. Dupuy, and was gathered by him in Fort Bay in April, I864. The plant 
has been noted during the last ten years in many parts of the interior, as well as on the coast. Mr. Andrews has found a pink form on a bank above Les Terres, and another with dark, red-purple flowers in a field near the Gouffre: these are probably var. speciosa, Jord.

Fumaria Boraei, Jord.

Colonist. First found : Gosselin, I 788 .

Generally distributed and quite as common as $F$. confusa, but until recently both species have been mixed up under the latter name. Thirty years ago Dr. Trimen expressed the opinion (Journ. Bot. 187 I, p. 198) that "the common Channel Island plant, which has large pink flowers, bears more resemblance to $F$. Boraci than to any other British variety.' In Gosselin's herbarium there is a specimen labelled $F$. officinalis.

Fumaria confusa, Jord.

Colonist. First record: Babington, I839.

Rampant Fumitory.

Common in cultivated ground in all parts of the island. It is the $F$. capreolata, L. of $F l$. Sarn. p. 4, which Babington afterwards referred to $F$. confusa, Jord.

The patois name is Feumeterre. The word Fumitory, or as Shakespeare writes it in King Lear, iv. 4, Fumiter, and the French Fumeterre, cone from the old Latin name of the plant, Fumnes terrae, or earth smoke, because it was supposed to be produced without seed from vapours rising out of the earth. Doubtless this originated in the singular property of the root, which, when freshly pulled up, emits a strong odour very like that of nitric acid.

Fumaria muralis, Sond.

Colonist. First found: Andrews, 1900.

Rare. On a bank above Les Terres, and at Casrouge (Iv.), Le Graie (VI.), and on a wall at Cobo (Andrews). Also found at the Gouffre by Miss B. Agnew.

Fumaria officinalis, L.

Colonist. . First record: Babington, I 839.

Frequent in gardens and cultivated ground, but less common than $F$. confusa and $F$. Boraei. In Alderney I have found an intermediate form with exactly the rampant habit of confusa, and the flowers and fruit of officinalis: prohably F. media, Loisel. Although the name appears in Gosselin's list, the specimen so labelled in his herbarium is $F$ Boraei. 


\section{CRUCIFERAE.}

Matthiola sinuata, R. Br.

Sea Stock.

Native. First found: Gosselin, I 788.

Rare: in sandy fields and on the sand-hills of the lowlands. Rousse Martello Tower. Portinfer. Rocquaine Bay, rather plentiful. Les Vardes, near Ronceval. This is the Cheiranthus tricuspidatus sive simuatus of Gosselin's list; a specimen from Vazon Bay is preserved in his herbarium.

Cheiranthus Cheiri, L.

Alien. First record: Babington, 1839 .

Wallflower.

On walls occasionally, especially in the outskirts of the town. This species is really not entitled to a place here, as the plants are merely garden specimens accidentally growing on walls. 'The true plant has the flowers of a uniform pale yellow, sometimes as pale as those of Diplotaxis, whereas the Guernsey form is the old favourite of cottage gardens: 'the yellow wallflower, stained with iron brown.'

Nasturtium officinale, $\mathrm{R}$. Br.

Water Cress.

Native. First record: Gosselin, 1815.

Very common by streamlets and in wet places. In a bushy place at Grande Mare I have seen luxuriant plants from two to three feet high, approaching var. siifolizm, Reich.

Called in the patois Kerson, the local form of the French Cresson, from which we get the English word Cress. Few native plants are better known than this excellent salad, which was highly valued by the old Greeks and Romans. The showy garden flowers commonly called Nasturtiums, or by corruption Sturtions (Tropacolum) were ranked by the old herbalists among the Cresses (Nasturtium) owing to the flavour of their leaves.

Nasturtium sylvestre, R. Br. Creeping Yellow Cress.

Native. First record: Babington, 1839.

Rare. Eraye Road, eastward from the Vale Road, very plentiful in 1892 and 1893 on the roadside, extending for 200 or 300 yards. Mr. Derrick afterwards found it in the Melrose Estate, "lower ground towards the well, several plants in a group.' In I899 Mr. Andrews saw it 'plentifully in waste ground by the Vale Road, north of the Braye Road.' Babington also found this plant at the Vale.

Barbarea vulgaris, $\mathrm{R}$. Br.

Yellow Rocket.

Colonist (?). First found : Gosselin, I 788.

Very rare. A single plant was gathered in 1892 at La Villette, St. Martin's, by Miss Dawber; and later I found a specimen 3 feet 6 inches high in a lane between Hougue Fouque and Les Buttes 
(viI.). A specimen (without locality) is preserved in Gosselin's herbarium.

This plant has long been used as an early salad: in Sweden it is boiled and eaten in the same way as cabbage. $B$. praeco.x, called by the French Cresson d'Amerique, and by the Germans Amerikanischer Kresse, is less bitter in salads than this species, and is preferred by many.

\section{Barbarea intermedia, Bor.}

Colonist. First found: Miss Agnew, 1899.

Rare. About twenty small plants in the corner of a meadow at Le Moulin (vi.), and about as many larger plants scattered over a cultivated field near Caudré Mill, in the same parish (Miss B. Agnew). One large plant in a field by Chemin le Roi (IV.) and another in a field near Le Jaonnet (III.) in I900 (Andrews).

Barbarea praecox, R. Br. Early Winter Cress.

Colonist or Casual. First found: Gosselin, 1788.

Rare: on roadsides, banks, and waste places. Very sparingly near Le Chêne (Iv.) and near Bordeaux (Ix.). Rather plentiful in the lane behind Morley Chapel, in several places. A specimen in Gosselin's herbarium is labelled 'Erysimum barbarea: grows oftentimes of its own accord in gardens.' This species may be distinguished from its allies by its agreeable watercress-like taste, the others being bitter.

Arabis hirsuta, R. Br.

Native. First found: Gosselin, I 788.

Hairy Wall Cress.

Local, and much less common than in Alderney. WTestern sille of Lancresse Common, scattered plants. Sandy field at Portinfer. Plentiful in a field at Grandes Rocques, and sparingly near Grandes Rocques Barracks. That this was the plant named by Gosselin Turritis glabra is proved by a specimen so labelled from Grandes Mielles (IX.) still preserved in his herbarium.

Cardamine flexuosa, With.

Native. First record: Marquand, ז891.

Usually grows in moister and more shady places than the next species, and though generally distributed is far less common. This may possibly be the Cardamine parriflora of Gosselin's list.

Cardamine hirsuta, L.

Native. First record: Gosselin, I8 I 5.

Hairy Bitter Cress.

Common on walls and dry banks. One of the earliest crucifers to blossom, often flowering in mild winters as early as December.

Cardamine pratensis, I.

Native. First found: Gosselin, т 788.

Common in wet meadows and marshy places everywhere. 
Some years ago Mr. Derrick informed me that the doubleflowered variety grew in the meadows between Le Villocq and Sausmarez. (viII.).

Called in Normandy Pentecote (Whitsuntide), a name applied in Guernsey to Orchis laxiflera. These flowers are the "ladysmocks all silver white' of Shakespeare, in Love's Labour's Lost, v. 2 ; and since they appear, as Gerarde says, "when the cuckoo doth begin to sing her pleasant notes without stammering,' they are also called Cuckoo Flowers.

Sisymbrium officinale. Scop.

Native. First record: Gosselin, 1815 .

Hedge Mustart.

Common, especially in the low-lying districts, in waste spots and roadsides, and also as a weed in cultivated land.

This plant was formerly held in high repute as an expectorant, and valued as a stimulant medicine. Even to this day it is considered a remedy for coughs, hoarseness, and asthma: hence the French popular name Herbe aux chantres.

Sisymbrium thalianum, Gand.

Thale Cress.

Native. First record: Gosselin, I8 I 5.

Very common in all parts, growing on dry banks, waste places, cultivated ground, and roadsides.

Alliaria officinalis, Andrz. Garlic Mustard. Sauce Alunr.

Native. First record : Gosselin, I8I 5.

Rather rare, though of general distribution. I have noted it, sometimes in three or four stations, in nearly every parish in the island. It is a handsome plant, though not a general favourite, owing to its very strong odour of garlic.

According to an old herbalist, this plant is called Sauce Alomi from being 'eaten in spring-time with meat, and so highly flavoured that it serves of itself for sauce, instead of many others.'

Erysimum cheiranthoides, L.

Treacle Musterd.

Casual. First record: Marquand, I89I.

Three plants sprang up as weeds in my garden at Fermain House in IS9I, and a few more in $\mathrm{I}_{922}$. I saw several specimens in the garden at St. George (VIII.) in 1894 , and was informed that the plant had been known there as a weed for ten years or more.

This species derives its name, Treacle Mustard, from being used among seventy-two ingredients in making 'Venice Treacle,' a famous vermifuge and antidote to all animal poisons much in vogue during the Middle Ages.

(Brassica orientalis of Gosselin's list is not Erysimum orientule. as proved by a specimen so labelled in his herbarium, which is a form of Brassica campestris.) 
Brassica oleracea, L.

Native. First record: Babington, I839.

Wild Cabbage.

Very rare: perhaps now extinct. Recorded in Fl. Sam. as found by S. H. Haslam on 'rocks by Clarence Bay,' where it is quite possible the plant still occurs, as that part of the coast is difficult of access owing to the fortifications. The name occurs in Gosselin's list, but the plant so called in his herbarium is Diplotaxis muralis.

Brassica campestris, L.

Casual. First found: Gosselin, I 788 .

Field Cabbage.

Rare, and always an escape from cultivation. Var. Rapa, L. Carrefour au Lievre, one plant in r889. Hubit Lanes, one plant in I899 (Miss B. Agnew). Many plants on the quarry-heap near Bordeaux, and in several places on borders of fields (Andrews). Var. Napus, L. One plant at Havelet in 1898 (Andrews). A form of this species (probably var. Rapa) in Gosselin's herbarium is labelled Brassica orientalis.

Brassica Cheiranthus, Vill.

Colonist (?). First record: Marquand, r89 I.

Very rare. A few plants on the large quarry-heap near the ValeCastle in 1889 and following years. On the shore at Bordeaux Harbour several plants in 1899. I have seen this plant more plentifully in Jersey.

Sinapis nigra, L.

Native. First record: Gosselin, I8I5.

Rare. Cliffs above Fort Bay in plenty. Mont Crevelt, sparingly. Table mustard is prepared from the seeds of this species. In Shake speare's time mustard was a customary adjunct to pancakes, as. witness the amusing scene with Touchstone in As You Like It, i. 2.

Sinapis arvensis, $\mathrm{L}$.

Colonist. First record: Gosselin, I8 I 5 .

Charlock.

A common and troublesome weed in cornfields and cultivated ground throughout the island, but less abundant than in Alderney. The form with hairy pods (var. villosa, Merat) occurs occasionally.

Sinapis alba, L.

Colonist or Casual. First record: Gosselin, I8r5.

White Mustard.

In 1889 I found a few plants on the quarry-heap by the Vale Castle, and afterwards a good number in a cornfield at Les Naftiaux (II.). Babington records it for Guernsey on the authorityof H. O. Carré.

Sinapis incana, $\mathrm{L}$.

Denizen (?). First record: Marquand, I89I.

Very rare. Western side of Lancresse Bay. Quarry-heap near the Vale Castle. A much commoner plant in Alderney. 
Diplotaxis tenuifolia, DC.

Denizen. First record: Babington, 1839.

Wall Rocket.

Frequent on the coast of the lowlands from Lerée to Belgrave Bay, but rather local, though usually abundant where it occurs, as on Vazon Green, about Pulias Barracks, and in parts of the Vale. In Alderney it is an abundant and troublesome weed. The flowers are sweet-smelling, but the foliage emits a disagreeable odour when rubbed.

Diplotaxis muralis, DC.

Colonist. First found: Gosselin, 1788.

Sand Rocket.

A rather common weed in cornfields and sandy cultivated ground in the low districts; less frequent in the interior; rare in the south. Var. Babingtonii, Syme. Roadside near Fort George. Albecq. Near St. Sampson's Bridge. This species is not mentioned in Gosselin's list, but there is a specimen in his herbarium labelled Brassica oleracea. In the third edition of English Botany and in Hooker's Student's Flora the sub-species, D. viminea, DC., is noted as occurring at St. Peter-Port, Guernsey, and plants gathered in the island within the last few years have, I believe, been referred to that form. It was first found here by the Rev. W. W. Newbould.

\section{Alyssum incanum, $\mathrm{L}$.}

Casual. First record: Marquand, r89r.

Very rare. In July. I889, I found a single plant near Bordeaux Harbour : and a second specimen was gathered by Mr. C. Andrews in 1899 in an old quarry at L'Islet.

Alyssum maritimum, L.

Szeeet Alyssum.

Alien. First record: Marquand, r $89 \mathrm{r}$.

A garden plant now established on walls in several places, and in dry rocky spots. On walls at Well Road, Doyle Road, Vauvert, and Fort George, above Clarence Battery; also at Le Préel (viri.) and near the Hermitage, Lancresse. Cliffs above Fort Bay. Near Bordeaux. Waste places at side of lane at Les Villets (IV.) in I 894 . Mr. Andrews reports it as abundant in sandy places near Grandes Rocques in 1897 and 1898 .

Draba verna, L.

Whitlow Grass.

Native. First record : Gosselin, I8I 5 .

Not uncommon on dry banks and sand-hills all round the north coast from Vazon to Lancresse and St. Sampson's; apparently rare elsewhere. Mr. Derrick has seen it on the roadside wall at Swissville, Rohais; and Mr. I. H. Burkill has shown me specimens collected by him at Icart Point.

The leaves were used by the old practitioners in the form of a poultice for the cure of whitlows, hence its English name. Gerarde 
says, 'It hath been taken to heale the disease of the nailes called a whitlowe.'

\section{Cochlearia danica, $L$.} Danish Scurvy Grass.

Native. First record: Babington, 1839.

Generally distributed throughout the island, and common on banks and seaside wastes, and in rocky places. In early blooming or starved plants the flowers are frequently rosy or purplish. In (iosselin's list two species of Cochlearia are mentioned: C. Groenlandica, Greenland Scurvy Grass, and C. angliat, English or Sea Scurvy Grass. Neither of these appears to have been found in the island since, and in all probability the former name was intended for C. danica. In ('osselin's herbarium the plant labelled Cochlearia anglica is really $C$. officinalis, a species which occurs in several places in Alderney, and as no locality is noted it seems likely that the specimen came from that island.

Armoracia rusticana, Rupp.

Horse Radish.

Alien. First record: Babington, I 839.

This plant grows in a great many places, but chiefly in the north. and north-west, becoming more rare in the interior and southern parts of the island. Frequently it is found in field corners, having perhaps been introduced there with manure: at any rate it is always an escape from cultivation. In its semi-wild state it seldom flowers here.

Horse radish would appear from Gerarde's account to have been used in his day as a condiment to roast beef as we use it now: he says it 'causeth better digestion than mustard.'

Thlaspi arvense, L.

Colonist. First record: Gosselin, I8 I 5.

Rare. In cultivated fields here and there in all parts of the island, but as a rule only very few plants occur in each spot.

In Normandy this plant is called Monnovire, from the old French word monnoie, coin, in allusion to the coin-like shape of the seedpods: its German name, Feld Pfonnigkrant, like our own, conveys the same meaning.

Teesdalia nudicaulıs, R. Br.

Native. First record: Gosselin, I8 15.

Field Penny Cress.

Frequent all along the southern cliffs from Jerbourg to Rocquaine, in some places abundant. Rare on dry banks inland. In mild winters it begins to flower as early as February.

Lepidium Draba, L.

Denizen. First record: Babington, I 839.

Whitloze Pepperwort.

Rare. North side of Burdeaux, plentiful. Hedge-bank in the Videclins Road above Moulin de Haut. Shore north of Richmond Hill. Lane near Les Hunguets (II.) and near St. Briocq (vi.). 
Abundant in 1893 in a cornfield between Les Prevosts and Grantez Mill. Field at Caudré (VI.) in I 894 . Lane above the Trinity Houses (v.) in r sos (Miss B. Agnew). Babington found this plant growing 'near the brick-kiln in the Rohais Road,' a locality which has long since been built upon.

Le, idium campestre, R. Br.

Mithridate Pepperitort.

Casual. First record: Royle, 1892.

A single specimen was found by Mr. 'T. C. Royle in 1892 at the Vale, on the roadside between Queen's Quarry and Bordeaux. According to Corbière (Nouv. Fl. Norm.), this plant is rare or altogrether absent 'sur les terrains purement silicieux' in Normandy, which seems to be the case also in Guernsey.

Lepidium Smithii, Hook.

Smooth Field Pepperiwort.

Native. First found: Gosselin, $x 788$.

Rather common in all parts of the island, growing in waste ground, dry banks, and field corners. In Gosselin's list it is given under the name of Thlaspi hirtum, and specimens so labelled are in his herbarium.

Lepidium sativum, $\mathrm{L}$.

Common Cress.

Casual. First record: Marquand, 1891.

About twenty plants in $189 \mathrm{I}$ on the shore at the south side of Grand Havre: undoubtedly escapes from cultivation. I his species, said to be a native of Persia, has no claim whatever to rank among indigenous plants, but, having long been grown as a salad in many parts of England, it has now become in some places semi-naturalised.

\section{Lepidium ruderale, L.}

Narrozeleaned Pepperzerort.

Denizen (?. First record: Babington, I 839.

Very rare. Several scattered plants on the quarry-heap near the Vale Castle in 188y, and for some years afterwards; also a few on the roadside near Rocques Barrées. Waste ground on the roadside by Bordeaux Harbour. fifteen or twenty plants in 1890 ; about as many there in 1899 . Babington records this species on the authority of H. O. Carré from 'roadside near Grande Marche.'

Lepidium latifolium, L.

Dittander.

Native. First found: Gosselin, I 788 .

Rare, but plentiful where it occurs. In a field on the left side of the road entering Cobo, where Babington found it sixty years ago. Les Goubais, between Noirmont Mill and Grandes Rocques, where it has existed for considerably over a century, as shown by a specimen preserved in Gosselin's herbarium labelled 'near Michel Le Pettevin's house at the Grandes Mielles.' On the green at the western end of Vazon Bay. In a sandy hollow near the sea at Portinfer. Close to a cottage at the Landes, near Fort Doyle; probably planted there. 
From its hot, pungent taste, this plant was much in request at one time as a condiment, being used at table in the same way as Horse radish. It was known under the name of Dittander or Poor Man's Pepper, and used to be cultivated in cottage gardens.

Capsella Bursa-pastoris, DC.

Shepherd's Purse.

Native. First record: Gosselin, I8 15.

Common everywhere in cultivated ground, waste places, and roadsides.

Once a famous remedy for wounds and bruises, and employed as an astringent against spitting of blood or bleeding at the nose. Hence it was called Poor Man's Parmaieti, a corruption of Spermaceti, which was in great request as a vulnerary in Shakespeare's time. The word occurs in Henry IV., First Part, iv. 1, where Parmaceti is said to be 'the sovereign'st thing on earth' for an inward bruise.

Senebiera Coronopus, Poir.

Common Wart Cress.

Native. First record: Gosselin, I8 I 5.

Rather rare. Of general distribution, but more often met with on the lower levels of the interior and the coast.

Senebiera didyma, Pers. Lesser Wart Creis.

Denizen. First record: Babington, 1839.

Generally distributed, and common in waste corners and by roadsides. Much more plentiful than the last species, from which it may be readily distinguished by its strong, rank odour. This plant is supposed to have come originally from America.

Bunias orientalis, L.

Casual. First found: Andrews, 1899.

Very rare. Three clumps of this plant were discovered by Mr. Cecil Andrews in July, I 899, in meadows near Ozanne's Tower, Cobo. This species is a native of south-eastern Europe, and has very seldom been seen in England.

Cakile maritima, Scop.

Native. First found: Gosselin, 1788.

Sea Rocket.

Scattered plants, occasionally numerous, occur all along the sandy shores of the lowlands from Rocquaine to Lancresse and Belgrave Bay. In $1900 \mathrm{Mr}$. Andrews found some extremely fine plants belonging to the var. interrifolia, Koch., in a cultivated field 100 feet above the sea, near the Caudré Mill (vi.).

Gerarde tells us that 'the root and seede stamped, and mixed with vinegar and the gall of an ox, taketh away freckles, lentiles, black and blewe spots, and all such deformities of the face.' 
Crambe maritima, L. Sea Kale.

Native. First record: Gosselin, I 8 I 5 .

Very rare. Among the shingle on the north side of Portinfer, extending for seven or eight yards. In $\mathrm{I} 892$ the plants were almost entirely buried in sand. A small clump on the shore at Les Pêqueries, near Portinfer. A few plants on the south-western side of Lihou Island. In Fl. Sarn. it is recorded from the last-named station on the authority of W. C. Lukis.

The precise date of the introduction of Sea Kale as an esculent vegetable is uncertain, but it was already cultivated for the table about the middle of the eighteenth century. As far as my experience goes, the wild plant is far superior in flavour to the cultivated one

Raphanus Raphanistrum, L.

Wild Radish.

Colonist. First record: Gosselin, I8 15.

Not uncommon in sandy fields about Cobo, Grandes Rocques, and Vazon, and in parts of the Vale.

The Roman physicians recommended Radishes to be eaten raw, with bread and salt, in the morning before any other food. According to Bentham, our garden Radish is unknown in a wild state.

Raphanus maritimus, Sm.

Sea Radish.

Native. First record: Babington, I 839 .

Common all round the coast: on the cliffs as well as in the lowlands. Occasionally the flowers are white.

\section{RESEDACEAE.}

Reseda lutea, I.

Wild Mignonette.

Casual. First found: Royle, I894.

Very rare. A single plant was detected in $\mathrm{I} 894$ on a ballast heap at Spur Point (x.) by Mr. T. C. Royle. In Normandy both this species and $R$. Luteola are equally common.

Reseda suffruticulosa, L.

Casual. First found: Marquand, I 893.

One large plant grew on the seashore at Grand Havre in 1893 , but not far from a spot where I noticed several garden outcasts: so that very probably it had originally been thrown out from a garden.

Reseda Luteola, L.

Dyer's Rocket.

Native. First record: Gosselin, 18 i 5 .

Rather common in the north and north-west, especially near the - sea : more local in the south, as at Fort George and on the cliffs. Occasionally plentiful in cultivated fields.

Under the name of Weld this plant has long been employed in dyeing silk, wool, cotton, and linen: hence its common French name, Herbe a jaunir. In Normandy it is called Gaude or Vaudre. 
Reseda odorati, the Mignonette of our gardens, is a native of Egypt, and found its way to us through France, where it was called Wigmonctte, or Little Darling. Cowper, in the Task, speaks of 'the fragrant weed, the Frenchman's darling.'

(Helianthemum guttatum, Mill., a plant unknown in Britain proper, occurs in profusion on the cliffs in Alderney.)

(Helianthemum vulgare, Gaert. Common Rock Rose. In Iajor H. Smith's annotated copy of the Flora Samica there is this note: "Mr. Field states that he saw it (Cistus Helionthemum) growing sparingly on Pleinmont, to the northward of the old house.' If this plint really occurred there fifty years ago, it should still be found, as no great alteration has taken place in that part of the island.)

\section{VIOLACEAE.}

Viola Riviniana. Reich.

Native. First record: Gosselin, 18 r 5 .

Dog Violet.

Very common in hedgebanks and on the cliffs. Both Gosselin and Babington record it under the old aggregate name of $V$. canina. IT. Reichenbachiana has not been found in these islands; the Moulin Huet plant, which I recorded as such in I89I, was merely an unusual form of the present species.

In Normandy this plant is called Martinets, and in the Guemsey patois it is known, according to Métivier, by the name of Coucou, or Pain d' Coucou, the latter term leing applied in France to the Wood fiorrel. Tradition says that the Violet sprang from the body of Io, and it is to this that Shakespeare alludes in Hamlet, v. I. :-

\section{'Lay her i' the earth ;}

And from her fair and unpolluted flesh

May violets spring !'

Viola tricolor, L.

Colonist First record: Gosselin, I815.

Very rare. Lane between Les Annevilles (vir.) and Mont Saint, about twenty plants at the foot of a hedge in a length of fity yards. In a field near Pulias (Andrews). Possibly the plant was more plentiful formerly, as Gosselin notes it, and so does Babington, though the latter does not mention having found the var. arrensis in Guernsey. Var. arvensis, Murr. Common in cultivated ground throughout the island.

The word Pansy comes, as every one knows, from the French Jenséc- 'There's pansies, that's for thoughts,' Hamlet, iv. 5-but it was written in various ways in Shakespeare's day, e.g., pawnce, panzie, and pancye. Lyte speaks of 'the pances or hartes ease,' which he says is also called 'love in idlenesse.' Shakespeare gives a poetical account of the origin of this pretty flower in some compli- 
mentary lines to Queen Elizabeth in Midsummer Night's Dream, ii. 2, and describes how Cupid's shaft fell

\section{'Upon a little western flower,- \\ Before, milk-white, now purple with love's wound,- And maidens call it love-in-idleness.'}

The name Heartsease was applied by the old writers to the Wallflower as well as to the Pansy. Turner, in his Names of Herbes [5+S), calls the former plant 'Hertes ease or wal Gelefloure.'

\section{Viola nana, Godr.}

Native. First record: Marquand, I89I.

Rare and local, but abundant where it occurs. Sandhills at Lancresse by the Great Cromlech. Also on the sandhills round Rousse Martello Tower. This minute Violet is usually in full flower at the middle of April, but after a mild winter it may be found in blossom early in March, and I have seen flowers as late as June $\mathbf{I}$ th. In dry seasons, however, as in 1892 , not a vestige of the plant can be detected so late. Some of the plants at Rousse had almost white flowers. $V$. nana occurs rather commonly on the north-west coast of Normandy, and has been found in Jersey.

(Viola odorata, L., is recorded in Fl. Sarn. as occurring in 'several parts of Guernsey,' but this is certainly an error. It has never been found since, and is not mentioned in (iosselin's old list.)

(Drosera rotundifolia, L. Common Sundew. In Major H. Smith's annotated copy of the flora sarrica the following note occurs among some carefully written entries on a blank page: - Drosera rotundifolia.-Mr. Butler informed me that in i $S$ I 2 he found it in the Grande Mare in two places. I am inclined to think it has now become extinct, as I have often looked for it, but without success.' As the Sundew is fairly common in Normandy, and also occurs in Jersey, it is not improbable that at one time it existed in Guernsey also; but there is no mention of it in Gosselin's list.)

\section{FRANKENIACEAE.}

\section{*Frankenia laevis, L.}

Smooth Sea Heath.

\section{Extinct.}

The name given in Gosselin's list is confirmed by a specimen still preserved in his herbarium; and the plant is also recorded in Fl. Sam. as found in St. Sampson's marshes by W. Christy. It is almost certain, however, that every trace of it has now disappeared owing to extensive draining and building-over of large tracts in the Braye du Vale and the surrounding districts. The latest evidel:ce 
of its occurrence in this island has been kindly furnished by $\mathrm{Mr}$. L. V. Lester, of Jersey, who, having seen a Guernsey specimen in Mr. J. Piquet's herbarium, wrote for particulars at my request, and received the following reply from Mr. Piquet: 'I gathered Frankenia laevis at the salt-pans in the north of Guernsey, either in the Vale parish or St. Sampson's, many years ago with Mr. Wolsey, a good local botanist. There was plenty of it.' 'The date would be about I 864 or $\mathbf{1} 865$.

\section{POLYGALACEAE.}

\section{Polygala vulgaris, L.}

Milkwort.

Native. First record: Gosselin, I 8 I 5 .

Including the var. oxyptera, this plant is of frequent occurrence throughout the island, but the type and the variety graduate into each other. Fairly typical eu-vulgaris occasionally occurs, but the great bulk of the forms can scarcely be assigned with. confidence to either. Babington found var. oxyptera at Jerbourg and on Lancresse Common: it is generally distributed and plentiful on the cliffs, but not quite typical, the capsule being usually shorter, though broader, than the wings. The fowers vary in colour, being either deep blue, light blue, pink, purple, or (often) white. At Lerée Point I have gathered oxyptera more nearly typical than elsewhere in the island.

Métivier, in his Dictionnaure Franro-Normand, gives the Guernsey patnis name for the Milkwort as Symnancie, 'parcecjue selon nos bonnes femmes, elle rend la parole à ceux qui sont affectés d'esquinancie, et aux paralytiques.' Squinancy was the old word for quinsy, and the only plant known in England as Squinancywort is Aspernia cynanchica, a species unknown in Guernsey, though found in Alderney and in Normandy, where it is called Herbe à l'esquinancie.

\section{Polygala depressa. Wend.}

Native. First record: Marquand, 1891.

This species occurs in different parts of the island, but I have not always been able to distinguish it clearly from forms of the preceding; in fact, the plants belonging to this genus found here require more critical study than they have yet received. In a paper on the Britısh species of Polygala in Journ. Bot., I877, p. 168, Mr. Alfred IV. Bennett finds it impossible to draw any sharp line between' the varieties and sub-species of this genus.

(Elatine hexandra is noted for Guernsey in Ansted's Channel Islands. As this minute plant occurs in many places on the opposite French coast, it is quite possible that it will be found here if searched for; but at present there is no reliable evidence of its existence.) 


\section{CARYOPHYLLACEAE.}

(Dianthus Armeria, L., the Deptford Pink, occurs in Alderney and Sark.)

(Saponaria officinalis, L. Soapwort. This species has been recorded for Sark, but it has no title to a place in the Guernsey list, as the plant I recorded in $189 \mathrm{r}$ as 'overrunning a low hedge in the lane from Cobo to Ozanne's Tower--probably an old garden escape,' subsequently proved to be simply the ordinary cultivated form, with double flowers.)

Saponaria Vaccaria, L.

Casual. First found: Miss Agnew, 1900.

Growing in company with several other rare Casuals in an old neglected garden in Hauteville in 1900 : found by Miss B. Agnew.

\section{Silene anglica, L.}

Colonist. First record: Gosselin, 18 I 5 .

English Catchfly.

Rather common in cultivated fields in all districts ; plentiful but dwarf, on the cliffs near Mont Herault (VI.). I have found the var. rosea near Miellette Bay (IX.) and also on the Vale Castle Hill intermixed with $S$. quinquevulnera. Probably $S$ gallica also occurs here: I have seen plants which perhaps belong to that form in Alderney. Mr. J. C. Melvill considers S. en-gallica, anglica, rosea, and quinquevulnera all forms of one protean species, as they cannot be distinguished except by the petals. See Journ. Bot., r880, p. I46.

\section{Silene quinquevulnera, L.}

Native (?). First record: Gosselin, I8 15 .

This plant is strictly a variety of the last, but it deserves separate notice on account of its being peculiar to the Channel Islands. Abundant on the east side of Vale Castle Hill. South side of Grand Havre. Coast west of the Vale Church. Dr. Boswell, in Engl. Bot., ed. 3, considers this plant truly wild in Guernsey, and I am inclined to agree with him, more particularly as it is included in the list of indigenous plants compiled by Gosselin as far back as I 788 .

Silene inflata. Sm.

Casual (?). First record: Gosselin, I8 5 .

Bladder Campion.

Very rare. A few plants on the Vale Castle quarry-heap in 1890. Shore by Mont Crevelt, one or two. One near Ozanne's Mill in 1893 , and a few more the following year in a lane close by. A small clump by the mill above Moulin Huet in I 899 (Andrews). The rarity of this species is somewhat remarkable, as it is common in Normandy and also in Alderney. It is the Cucubahus Behen of Gosselin's list. 
Silene maritima, IVith.

Native. First record : Gosselin, I 8 I 5 .

Common near the sea all round the island: occasionally on walls and dry banks inland, especially at St. Peter's and St. Saviour's. The flowers are frequently discoloured by a parasitic fungus (Ustilago vio'acea), which infests the anthers. In these islands $S$. maritima flowers at least three weeks earlier than $S$. inflata, and this is noticeable in Alderney, where the latter is fairly common.

The patois name is Eillet d'banque, which signifies literally Seashore Pink. This plant is one of the few British examples of a maritime species reappearing also as an alpine one: it grows on the Scotch mountains at an elevation of over 3000 feet.

Silene conica, L.

Native. First record: Gosselin, I 8 I 5 .

Sand Catchfly.

Locally common on the sandhills and sandy turf about Vazon Bay, Cobo, Grandes Rocques, and the Vale coast; also on many parts of Lancresse Common. All the plants are small, usually from one to three inches high, rarely more. In one place in Alderney this species attains an uncommon size, the plants growing to a height of twelve to fifteen inches.

(Silene noctiflora is noted for Guernsey in Ansted's Channel Islands. Certainly an error.)

(Silene nutans, L., Nottingham Catchfly, occurs in Alderney and in Herm. It is included in Gosselin's list, but the specimens in his herbarium are labelled 'Island of Erm.' As several other plants peculiar to Alderney or the smaller islands are enumerated in the old list, it would seem that Gosselin intended it rather as a Flora of the Bailiwick of Guernsey than as restricted to that island alone.)

Lychnis Flos-cuculi, L.

Native. First record: Gosselin, I8 I 5 .

Ragged Robin.

Common in marshes and wet meadows in all parts. With pure white flowers at the Vale towards Fort Le Marchant.

The French name is Fleur de Coucou, which, like Flos cuculi, signifies Cuckoo Flower; but in England this name is very rarely, if ever, applied to the present plant.

Lychnis vespertina, Sibth.

Colonist or Casual. First record: Babington, 1839.

Very rare. Two or three plants at the Vale, and one in a cornfield at Icart, were all I saw in three years. In $\mathrm{I} 892$ it occurred in plenty in a field at Rue Poudreuse, and also near Ozanne's VIill. Scattered plants have since been found close to the Vale Mill and on Rousse headland. In Alderney this is quite a common plant, and $L$. diurna is rare. The flowers are deliciously fragrant in the evening. 
Lychnis diurna, Sibth.

Native. First found: Gosselin, I 788.

Red Campion.

Very common: flowering throughout the year. There is a specimen in Gosselin's herbarium to which is appended this note: 'A white and a red sort, rather different in the leaf, grows at Frm.'

Called in the patois Violette Saurage or Violette de Fossai, Wild or Hedge Stock. A favourite flower in cottage gardens is the Red and White Stock, which goes by the name of Violette, the IVallfower being Jaune Violette.

Lychnis Githago, Scop.

Corn Cockle.

Colonist. First record: Gosselin, $181_{5}$.

Rare. Occurs most often in cornfields, but occasionally in other cultivated land, and in waste places. Noted in all parts of the island, but seldom more than a few plants at a time.

The seeds of this species are reputed to render corn unwholesume when ground into flour: and in Normandy the plant is known as Nile or Nielle des blis, a word signifying the rust or mildew of whent.

Sagina procumbens, L.

Procumbent Pearluort.

Native. First found: Gosselin, I 788.

Common everywhere on walls, footpaths, neglected garden wallis, and similar spots.

These plants are called l'earlworts from having been employed in olden times to cure a disease of the eye called pearl. The name Sagina (from saginc, to fatten or cram) appears to have beloned originally to some kind of corn, and etymologically scems ill-alpllied to these insignificant plants.

Sagina apetala, L.

Native. First record: Babington, 1839.

Common in all parts of the island on walls, foot-paths, and similar dry places.

Sagina ciliata, Fries.

Native. First record: Marquand, I891.

Sinall-flowered Pearlicort.

Not uncommon on all parts of the coast, on the sandy shores as well as on the cliffs from Jerbourg to Pleinmont. Two forms occur: var. patula, Jord., having a glandular pedicel and calyx; and viur. ambigua, Lloyd, with pedicel and calyx glabrous. The former is the commoner form in this island. In Alderney I have gathered specimens of var. ambigua seven inches high.

Sagina maritima, Don.

Sea Pearlicort.

Native. First record: Babington, 1839 .

Frequent near the sea in all parts, especially in the lowlunds. An inconspicuous little plant easily overlooked, and so perhaps much more plentiful than is supposed. 
Sagina subulata, Wimm.

Native. First record: Gosselin, I8I 5 .

Azul-leaved Pearluert.

Rather common in dry, sandy, or exposed places, chiefly near the sea. Occurs in a great many places on the cliffs from Jerbourg to Pleinmont, and on Lancresse Common. More rarely inland, as at Dosdanes (vIII.). In Gosselin's list this species is noted under the name of Spergula laricina.

Sagina nodosa, Meyer.

Native. First found: Gosselin, I 788.

Knotted Pearlwort.

Local on the sandy commons of the lowlands : generally plentiful where it occurs. Lancresse Common, Portinfer, Grandes Rocques, Houmet Point, Vazon Green. This species is the Speryula saginoides of Gosselin's list, as proved by specimens in his herbarium.

Honkeneja peploides, Ehrh.

Sea Purslane.

Native. First record: Gosselin, I8 I5.

A common seashore plant on the sandy coasts of the north and north-ivest. In some places very abundant.

In Yorkshire this plant is eaten as a pickle, and is said to have an agreeable, pungent flavour.

Arenaria serpyllifolia, L. Thy'me-leaved Sandzerort.

Native. First record: Gosselin, I8 I 5 .

Frequent, and occasionally abundant, in the low-lying, sandy districts. It is a very variable species, but the local forms have not been noted. In Alderney the varieties Lloydii, Jord., and leptoclados, Guss., occur.

(It is uncertain what plant Gosselin meant in his list by Arenaria laricifolia. The sheet so labelled in his herbarium consists of Sagina procumbens and Lepigonum nubrum.)

Stellaria media, Vill.

Chickweed.

Native. First record: Babington, I839.

A very common weed everywhere, flowering throughout the year. The var. Boraeana, Jord., has occurred near the King's Mills, and at Lancresse.

The patois name Moudron or Mourdron is a variation of the French Mouron, which, according to Métivier (Dict. Franc. Norm.): 'Vient de l'inusité mour, souris (lat. mus, muris), les anciens botanistes ayant comparé la feuille de cette plante à l'oreille d'une souris.'

Stellaria graminea, L.

Native (?). First record: Gosselin, I 8 I 5 .

Lesser Stitchwort.

Very rare. In $189^{2}$ Miss Dawber found this species growing sparingly on a small heath between Ruettes Brayes and Ozanne's Vill, and I afterwards found it in hedges quite close to the Mill, both stations being near together. Babington did not see the plant, 
but records it on the authority of $\mathrm{H}$. O. Carré. Gosselin notes it in his list dated I 788, and published in I 8 I 5. The extreme rarity and doubtfu: nativeness of this species in Guernsey, combined with the total absence of $S$. Holostea, are very remarkable, seeing that both are quite cnmmon in Normandy as well as in the south of England.

Stellaria uliginosa, Murr.

Bog Stitchuert.

Native First record: Gosselin, 18I5.

Common in wet meadows and by springs and streamsides in all parts of the island. Through some oversight this species is not recorded for Guernsey in Fl. Sarm.

Cerastium glomeratum, Thuil.

Broad-leaved Mouse-ear

Native. First found: Gosselin, I 788.

[Chickweed.

Frequent throughout the island in cultivated ground, and on banks and roadsides. A specimen in Gosselin's herbarium is labelled C. vulgatum.

Cerastium triviale, Link.

Narrozi-leaved Mouse-ear

Native. First found: Gosselin, I 788.

[Chickweed.

Very common in hedgebanks, pastures, walltops, and a variety of other situations. Specimens in Gosselin's herbarium are labelled C. semidecandrum.

Cerastium semidecandrum, L. Little Mouse-ear Chick-

Native. First record: Babington, 1839. [ureed.

Sandhills by Rousse Martello Tower, plentiful. Vazon Green, common in places. Sandy field at Cobo. Mr. Andrews has found it at Grandes Rocques, on Lancresse Common in several places, and on the cliffs near Les Thielles. This name is in Gosselin's list, but the plant so called in his herbarium is $C$. triviale.

Cerastium tetrandrum, Curt. Fonr-cleft Mouse-ear Chick-

Native. First found: Gosselin, I 788.

[reed.

Very common all round the coast, on the cliffs as well as on the sandhills. It is the Cerastium nova species of Gosselin's list, as proved by his herbarium specimens, which are labelled Cerastium nova.

Moenchia erecta, Sm.

Native. First record: Gosselin, I8 I 5 .

Locally common all round the coast: plentiful on the cliffs in some places. It occurs more rarely inland, as at Les Camps (VIII.) and Dosdanes (viri.).

Polycarpon tetraphyllum, L.

Four-leaved Allseed.

Native. First record: Gosselin, 1815.

Rather common on roadsides and in cultivated fields and waste ground all over the island. Frequent on the shingle in the north and north-west. Sometimes very fine in old quarries. 
Lepigonum rubrum, Fr.

Native. First found: Gosselin, 1788 .

Field Sanduert-Spurrey.

Rather common in all parts in dry, sandy, or gravelly spots, and in old quarries, especially near the sea.

Lepigonum rupestre, Kindb.

Native. First found: Gosselin, I 788 .

Rock Sandwort-Spurrey.

Common on rocks and banks all round the coast: also inland occasionally. In the Botan. Exch. Club Report for I870, p. Io, 1)r. Boswell says: 'Spergularia rupicola, Lebel (rupestris, Lon. Cat.) was first introduced into the British list in the London Catalogue of r 857 on my own authority, from specimens collected in Guernsey in 1853. In 1860 it was detected in Britain proper in the Isle of Wight by Mr. A. G. More.' In Townsend's Flora of Hampshire, p. 62, the latter date is wrongly printed 1840 . There can be no doubt that this was the plant intended by Babington in $F l$. Sarn. p. 16, under the name Arenaria marina, Oed, which he noted for 'Sea-coast: Jersey, Guernsey, Alderney, Sark, Herm, Jethou.' The present species is common throughout this area, whereas no suitable locality occurs in the four smaller islands for either L. marinum or L. salinum. The Arenaria marina of Gosselin's list is also this species.

Lepigonum salinum, Fr.

Native. First found: Gosselin, I 788.

Sea Sandwort-Spurrey.

Rare. Used to grow ten years ago in a small marsh on the north side of Bordeaux, but the marsh has been filled up with quarry rubbish. Plentiful in a marshy field by Ivy Castle. Brackish pool at Pulias. Wet corner of a field below the Vale Mill. In most cases the seeds are without a scarious wing. Mr. Andrews has found this plant in a marsh near Rousse (rx.), in the marshes by the Vale pond, and abundantly at Claire Mare, Perelle. In Gosselin's herbarium three species are mixed together: L. rubrum, L. salinum, and L. rupestre, and the sheets are labelled, 'Arenaria rubra and marina.'

Spergula arvensis, $\mathrm{L}$.

Native. First record: Gosselin, I8I5.

Corn Spurrey.

Common in all parts in cultivated fields and waste ground. A curious dwarf form occurs here and there all along the south cliff : it is only an inch or two in length, prostrate, and flowers as early as March or April, sometimes even in February. It is usually quite over before the type form commences to flower. The seeds are exactly similar to those of the large form, and are not winged, as in some of the Continental species. A dwarf form, similar to this in habit, but flowering in summer, occurs in dry places at Lancresse; and $\mathrm{Mr}$. Andrews has found intermediate decumbent forms at Paradis. 
Called in the patois Genoilliere, perhaps from the fancied resemblance of the deflexed pedicels to a knee (genou). The French name is Spargoutte. The Corn Spurrey is said to enrich the milk of cows and improve the butter, and even in Gerarde's day it was used ' of purpose to fatten cattel, and to cause them to give much milke.' In several parts of the Continent the plant is grown for fodder.

Scleranthus annuus, L.

Native. First found: Gosselin, I 788.

Knawel.

Very rare : not seen in this island for many years. It is recorded in Fl. Sarn. as found by Babington, and in Gosselin's herbarium there is a specimen gathered 'In a cornfield from which gravel has been dug out, joining La Planque des Rohais.' 'This plant occurs rarely in Alderney, more commonly in Sark.

\section{MALVACEAE.}

Malva moschata, L.

Musk Mallowe.

Native. First record : Marquand, I89I.

Rare. Hougue des Quartiers, north of the Rabbit Warren, two large patches. Roadside hedge above Villiaze Chapel. A large clump in a pasture field between Hougue Fouque and Bordages (vir.). A small patch in a field near Jerbourg. Mr. Andrews has found it in lucerne fields near Le Chêne, near La Fosse (III.), and to the east of Petit Bot.

Malva sylvestris, L.

Common Mallowe.

Native. First record: Gosselin, I8I 5 .

Common throughout the island, and variable; sometimes approaching $M$. rotundifolia in its prostrate habit and small round leaves.

The patois name, like the French, is Mauve, whence comes the name of the colour now in general use, from the hue of the flowers. The fruits taste something like nuts, and commonly go under the name of cheeses, fairy cheeses, or bread-and-cheese, and the same idea is expressed in the German name of the plant, Käsepappel. The Common Mallow is a favourite remedy among country people, being applied externally in the shape of poultices, and also administered as a decoction.

Malva rotundifolia, L.

Dwarf Mallowe.

Native. First record: Gosselin, 1815.

Frequent throughout the island in waste spots and on roadsides, but more commonly found in the northern districts.

Malva borealis, Wallm.

Casual. First record: Marquand, 1892.

I found a single plant at the Vale in 1892 in a field corner 
bordering the lane leading from Brookdale Nursery towards Noirmont. As Watson observes (Comp. Cyb. Brit., iii. p. 493) this species is 'more like parviflora than rotundifolia, although it is usually compared with the latter.'

*Althaea officinalis, L.

Marsh Mallow.

Extinct.

We have evidence of the former existence of this beautiful plant in Guernsey, by the preservation in Gosselin's herbarium of a specimen gathered more than a century ago, labelled, 'Near the house of the Abreuveurs, at St. Sampson's.' It may have been extinct in Babington's time, as there is no record of it in Fl. Sam.

Lavatera arborea, L.

Native (?). First record: Gosselin, I8 15.

Locally common on the shores of the north and north-west, as. far as Rocquaine. Plentiful and fine at Perelle and Lerée. Grows in most of the old disused quarries of the lowlands. Occasionally found on the south coast, but much more rarely than in the north.

\section{Lavatera sylvestris, Brot.}

Casual. First record: Marquand, I891.

Very rare. A few plants on the Vale Castle quarry heap, and also a few on the shingle on the Bordeaux side. The plant maintained its position in both these stations for several years, but did not increase in quantity. Plentiful in 1894 on a green patch at the end of St. Sampson's Bridge. This species is liable to be overlooked when past flowering, owing to its very close resemblance to some forms of Malva sylvestris, but the three large lobes of the calyx at once distinguish it.

\section{HYPERICACEAE.}

Hypericum Androsaemum, L.

Native. First found : Gosselin, 1788 .

Tutsan.

Very rare. Sparingly in a copse at Moulin de Haut, near King's Mills. Scattered plants here and there on the cliffs between Fermain Bay and St. Martin's Point. In these two stations this species is no doubt really wild. I have seen specimens in a few places at St. Saviour's and St. Peter's, where they were certainly escapes from cultivation. There is a specimen in Gosselin's herbarium from the cliffs on the western side of Saints' Bay.

This plant used to be called Balm of the Warrior's Wound and All-heal; the English name, Tutsan, is merely a corruption of its French name, Toute saine. Gerarde says: 'The leves, floures, and seedes, stamped and put into a glasse with oile olive, and set in the sunne for certain weekes, doth make an oile of the colour of blood, 
which is a most pretious remedie for deep wounds, and those that are thorow the body.'

(Hypericum calycinum, L., a species readily known by its very large flowers, is occasionally to be met with, but only in places where it has been intentionally planted. It is nowhere naturalised in these islands.)

Hypericum tetrapterum, Fr. Square-stemmed St. John's

Native. First record: Gosselin, I 8 I 5. Wort.

Common on stream-sides, and in wet, marshy places throughout the island. It is the $H$. quadrangulatum of Gosselin's list.

Hypericum perforatum, L. Dottcd-leaved St. John's Wort. Native. First record: Gosselin, I8 15 .

Rather common in all parts, but especially so in the interior, as at St. Andrew's, where it is quite plentiful in hedges.

The Guernsey patois name, Herbe a mille pertus, or plant with a thousand holes, is the same as that used in Normandy, alluding to the apparent perforations of the leaves. The name, St. John's Wort, refers to the custom, prevalent in most European countries, of gathering the plant on the eve of St. John's Day (June 24th) to hang up in windows as a preservative against lightning, and also against evil spirits : hence one of its old names was Fuga daemomum.

Hypericum humifusum, L.

Trailing St.John's Wort.

Native. First record: Gosselin, I8 I 5 .

Generally distributed and rather common on dry banks, commons and roadsides. A form with ciliated sepals, probably the var. decumbens, Peterman, is frequent throughout the island.

Hypericum linarifolium, Vahl. Narrou-leaved St. John's Native. First record: Marquand, I89 I. [Wort.

Very rare. In the hedge of a lane between Eperons and Blicqs (II.), a few plants in I889. On the cliffs at Sommeilleuse (IV.) in I 899 (Andrews). A hybrid between this species and $H$. humifusum occurs in several parts of St. Martin's cliffs, and without careful examination might be taken for the present plant. I have seen quite typical $H$. linarifolium in Alderney on a headland very similar to the spot where it grows at Cape Cornwall, near the Land's End.

Hypericum pulchrum, L. Small Upright St. John's Wort. Native. First record: Gosselin, 18 5 .

Frequent in hedges by the roadside in all parts of the island, but seldom found in any quantity.

Hypericum elodes, L. Marsh St. John's Wort.

Native. First found: Gosselin, $\mathbf{1} 788$.

Common in nearly all the cliff-streams along the south coast. 
Plentiful at Grande Mare. Marsh at the eastern end of Lancresse. There is a specimen in Gosselin's herbarium labelled, 'North side of ditch in Ivy Castle.'

\section{ACERACEAE}

\section{Acer Pseudo-platanus, L.}

Sycannore.

Alien. First record: Gosselin, I8 5 .

A common and beautiful tree, generally distributed throughout the island. It springs up freely from seeds, and in most parts of England has all the appearance of being truly native.

The patois name is the same as in French and English: Sycamore. The wood is said to surpass that of all other trees as fuel, being unequalled for the quantity of heat it throws out, and the time it continues to burn. A kind of wine used to be made in Scotland from the sap, which flows very copiously in the spring.

(There can be no doubt that Babington fell into error in recording the Maple (Acer campestre) for Guernsey. It is not mentioned in Gosselin's old list, and I have never been able to discover any evidence of the occurrence in the past of a wild Maple in these islands. At present it is found nowhere outside of plantations and gardens, and not commonly even there.)

\section{GERANIACEAE.}

Geranium striatum, L.

Pencilled Geranium.

Alien. First record: Marquand, 189I.

Well established in several places. Roadside descending to St. Andrew's Church, and also opposite St. Helena. Corner of lane between the cross-roads and Le Vauriouf (III.). Roadside at. Les Buttes (vII.). Valley below Casrouge (IV.).

(Geranium sanguineum, L., occurs in Alderney.)

Geranium molle, L.

Native. First found : Gosselin, 1788.

Soft Cranesbill.

Very common throughout the island. A specimen in Gosselin's herbarium shows that he named this species $G$. rotundifolium.

Geranium rotundifolium, L.

Round-leaved Cranesbill.

Alien. First record: Marquand, I 89I.

A few plants at the north side of the quarry-heap near the Vale Castle, persisting for several years from 1889 onwards. Certainly an Alien in Guernsey, although common, and probably native, in Normandy. Gosselin's plant was $G$. molle. 
Geranium dissectum, L.

Native. First record: Gosselin, 18 I 5 .

Common in all parts, but rather less so than $G$. mulle.

Geranium columbinum, $\mathrm{L}$.

Long-stalked Cranesbill.

Native. First record: Gosselin, 1815 .

Very rare. Plentiful, about the year 1890 , in a hedge at the junction of the roads above Ronceval, extending about a dozen yards. In I 894 Miss Dawber reported finding this plant 'near Foote's Lane, Lower Rohais,' and Mr. Collens 'about twenty plants in Pont Vaillant Lane,' both these records referring probably to the same station. In Fl. Sarn. it is recorded on the authority of H. O. Carré, but no locality is specified.

Geranium Robertianum, L. Herb Robert.

Native. First record: Gosselin, I8 I 5 .

Generally distributed throughout the island, and rather common. Var. purpureum, Vill. Plentiful in a lane a little beyond the King's Mills, in two localities. Grosse Hougue (x.). Spur Point.

In the Guernsey patois this pretty but ill-smelling plant is called Rouâge Gambe, literally red leg, from the colour of the stems; and, according to Britten and Holland (Dict. Engl. Pl. Names), the similar name, Red Shanks, is used for this plant in Lisle's Observations in Husbandry (1757). In the neighbourhood of Cherbourg Herb Robert is known by the name of Epingles à la Vierge.

Erodium cicutarium, Sm.

Common Storksbill.

Native. First record: Gosselin, 1815.

Common everywhere in dry turfy places and sandy commons, especially near the sea. I possess specimens collected in June, 1853 , on Lancresse Common by Dr. Boswell (Syme), labelled in his handwriting Erodium pimpinellifolium.

Erodium moscnatum, Sm.

Musk Storksbill.

Native. First record: Gosselin, I 815.

Frequent in all districts, but much less common than the last species. The musky odour is sometimes hardly noticeable.

Erodium maritimum, L'Her.

Native. First found: Gosselin, I 788.

Rare. Near Fort Doyle, and in two or three places between that and Fort Le Marchant. Western side of Lancresse Bay. Shore between Grandes Rocques and Portinfer. Lihou Island, plentiful on the east side. Icart Point (Rev. H. Gray, in 1894). Specimens in Gosselin's herbarium were gathered 'on the parapet of the south Pier,' but the plant is not likely to be found there now. 


\section{OXALIDACEAE.}

Oxalis corniculata, $\mathrm{L}$.

Yelloze Wood Sorrel.

Alien. First found : Gosselin, I 788 .

Rare: generally in small quantity. Hedgebank at Coutanchez. I ane behind St. Helena. Graie, St. Peter's. Sausmarez, Catel. Lune from Annevilles to Mont Saint. Near Ville ès Pies, Vale. Mr. Andrews has found it in a courtyard at Hauteville, in waste ground at Havelet, and on walls near Caudré Mill. Miss B. Agnew notes it for a lane near the Forest Church and the valley below St. Peter's Arsenal. Babington recorded the plant from Grandes Maisons (x.). In Gosselin's herbarium a specimen is misnamed O. Acetosella.

(Oxalis Acetosella, L. Wood Sorrel. This name occurs in Gosselin's printed list, but a specimen so named in his herbarium is $O$ corniculata. There is no evidence that the IVood Sorrel ever grew in Guernsey, even in the days when the island was well wooded.)

Oxalis cernua, Thunb.

Alien. First found: Andrews, I 900.

Established on a wall overhung by trees at Le Graie, St. Peter's, where it was detected by Mr. C. Andrews in the spring of 1900 . This plant is a native of the Cape of Good Hope, and is said to be establishing itself rapidly in southern Europe.

\section{LINACEAE.}

Linum angustifolium, Huds.

Narrozi-leared Flax.

Native. First found: Gosselin, 1788.

Frequent throughout the island. This species is the L. usitatissimum of Gosselin's list, as proved by a specinen so labelled in his herbarium.

The well-known Linseed Oil is obtained from the seeds of the Common Flax (Linum usitatissimum). The generic name is the Latinised form of the Celtic lin, thread, from which we derive our word linen. One of the good old proverbs associated with flax enjoins the necessity of faith in our actions: 'Get thy spindle and thy distaff ready, and God will send the flax.'

Linum catharticum, L.

Native. First record: Gosselin, I8 I 5 .

Purging Flax.

Abundant in sandy places in the neighbourhood of Grandes Rocques and Portinfer, and at the western end of Lancresse.

The whole of this little plant is cathartic, and was formerly 
extensively employed in medicine: even now, in some parts of the country, it is boiled in ale, and the decoction given as a remedy for rheumatism.

Radiola millegrana, Sm. Allseed.

Native. First record: Gosselin, I8 I 5.

Common all round the coast. It occurs in plenty on the cliffs and on Lancresse Common, but, from its minute size and inconspicuous appearance, is often overlooked.

\section{CELASTRACEAE.}

Euonymus europaeus, L.

Alien. First record: Marquand, $189 \mathrm{r}$.

Spindle Tree.

Very rare. Two or three bushes in a hedge bordering the lane at the back of Les Eperons, St. Andrew's. As no other station is known for this shrub, it can hardly be indigenous, although it is fairly common in Normandy and in the south of England.

\section{LEGUMINOSAE.}

Ulex europaeus, L.

Common Furze or Gorse.

Native. First record: Gosselin, i 815.

Very common, both in its natural habitat on cliffs and commons, anil also on the tops of hedges, where the seeds are sown, so that the Furze may afford a shelter for cattle in the fields in winter. It is then cut every third year, and used for heating ovens.

The patois word for Furze is Jan (usually written Jaon), which can hardly be a corruption of Ajonc, the French name of the plant. In the northern parts of Normandy it is commonly known by the name of Landes, Prquets, and Borsjan, and in the last word we perhaps get some connexion with the Guernsey vernacular name.

Ulex nanus, Forst.

Dwarf Furze.

Native. First record: Marquand, 1892.

One large clump in August, 1892, close to the lane leading from the Vale Nurseries to St. Sampson's Bridge. 'This is the only spot in the island where I have noticed this species, but probably it will be found elsewhere. It is much more distinct from the two other species than they are from each other. In $U$. nanus the flowers have the wings straight (not curved, as in Gallii) and distinctly shorter than the keel: and the bracts are narrower than the peduncles. All three species grow in Alderney.

Ulex Gallii, Planch.

Native. First record: Babington, 1839.

Generally distributed but less common than $U$. europaeus. This 
was the species noted in $F \%$. Sarn. under the name of $U$. nanus as being frequent in all the larger Channel Islands.

Sarothamnus scoparius, Koch.

Broom.

Native. First record: Gosselin, 18 15 .

Rather rare, though found in all districts; occasionally on the cliffs, frequently in old quarries, and often in waste, stony corners. Var. prostratus, Bail. Plentiful at the top of the cliffs at the Thielles, and to the north of Pleinmunt Point. Near Sommeilleuse IVatchhouse and at the Corbiere (Andrews).

The patois name is Genêt. a word which also means, like the English Broom, a long-handled brush. Before the introduction of hops, broomtops were often used to communicate a bitter flavour to beer, and in medicine the plant had a certain reputation. An old writer asserts that "that worthie prince of famous memorie, Henry VIII., King of England. was wont to drinke the distilled water of Brome floures against surfets, and diseases thereof arising.'

Ononis arvensis, L.

Native. First record: Gosselin, I 8 I 5 .

Very common on the coast, and also occasionally on dry banks and waste spots inland. I have found a form with terminal spines to the branches on the sandhills near Rousse Tower, but very sparingly.

The common French name of this plant is Bugrane, but in some parts, as about Cherbourg, it is known as Réglisse (liquorice). In the north of England the roots are dug up during the flowering season and eaten by children as a substitute for liquorice root, whence they call the herb Wild Liquorice. The old herbalists called it Arresta bovis and Remora aratri, and Gerarde refers to it as Rest Plough or Rest Harrow.

\section{Ononis reclinata, $L$.}

Native First found: Wolsey, 1867 (?).

Very rare. Lancresse Conmmon, near the Hermitage, scattered over a few acres of ground. Mrs. C. Lewis has informed me that formerly (about I886) she used to find this plant at Portinfer, but the locality has since been built over. It begins to fluwer at the end of May, and is mostly over by the time $O$. arvensis comes into blossom. O. reclinata was first discovered in Guernsey by $\mathrm{G}$. Wolsey, an acute resident botanist, and I possess specimens collected by him in 1867 . The headquarters of this plant appear to be in Alderney, where it uccurs in great profusion in several places: in Normandy it is unknown.

Medicago sativa, L.

Lucerne.

Alien. First record: Marquand, I89 I.

Frequent in pastures and field corners: always an escape 
from cultivation, as it is extensively grown in the island as fodder for cattle.

Lucerne has been so long and so generally grown as a fodderplant, even from early Greek and Roman times, that it is sairl no station is known where it may not have spread from cultivation. It was introduced into England in the year 1757 . Authorities are not agreed as to the origin of the name Lucerne.

\section{Medicago falcata, L.}

Sickle Medick.

Casual. First found : Collens, 1894.

Very rare. In I $894 \mathrm{Mr}$. J. S. Collens showed me a fresh specimen of this plant, which he had gathered near Bordeaux Harbour. It was the only one he saw.

\section{Medicago lupulina, L.}

Black Medick.

Native. First record: Gosselin, 18 I5.

Common in all parts of the island: perhaps rather more so in the low-lying districts.

This plant has often been regarded as the true Shamrock, and, in fact, it is often worn as such in Ireland on St. Patrick's Day. In the opinion of the best authorities, however, Trifolium repens and Trifolium minus are better entitled to the name.

Medicago maculata, Sibth.

Native. First record: Gosselin, I 8 r 5 .

Generally distributed and rather common, especially in the northern districts. It is the Medicago arabica sive polymorpha of Gosselin.

Medicago denticulata. Willd.

Reticulated Meaick.

Denizen. First record: Babington, 1839 .

Rather rare. I have noted a considerable number of localities for this species, and (with the exception of Moulin Huet) they are all in the lowlands. Miss Agnew found it in a meadow near Le Moulin (vi.). Var. apiculata, Willd. Rare. Cultivated field at Grosse Hougue (x.) sparingly in 1889. Vale Castle quarry heap, a plant or two. Abundant in cultivated fields at Lerée in 1890. Rue des Bergers (viri.), on the roadside, several plants in I89r.

Melilotus officinalis. Willd.

Common Melilot.

Casual. First record: Marquand, i891.

In 1890 , and for some years afterwards, this plant grew rather plentifully on the shore below the Vale Castle, having $M$. arvensis sparingly intermixed with it.

It is said that the peculiar flavour of Gruyère cheese is due to the seeds and flowers of Melilot, which are bruised and mixed with the milk. 
Melilotus arvensis, Willd.

Field Melilot.

Casual. First record: Marquand, I 891 .

Very rare. Field on the coast road near Rousse Tower, a good many plants in I889. Vale Castle quarry heap. Shore below the Vale Castle, intermixed with the last species. Waste place below Le Tertre (1x.) one plant in 1893 . In an old garden at Hauteville in r 900 (Miss Agnew).

Melilotus alba, Lam.

Casual. First record: Marquand, 1891.

White Melilot.

Very rare. One plant at Paradis, Vale, and another near Ozanne's Mill in 1890 . One on the quarry heap north of Bordeaux in 1893. Waste ground near Ivy Castle, one plant in 1899 (Andrews).

Melilotus parviflora, Desf.

Casual. First found : Marquand, I 894.

A single specimen, in good flower, occurred on the roadside near Doyle's Monument in 1894 .

Melilotus messanensis, Desf.

Casual. First found: Marquand, 1894.

In September, 1894, I found one large plant bearing plenty of ripe fruit growing on a rubbish heap at the Vale, not far from Brookdale Nursery. It is a south European species, seldom seen in this country, and is remarkable by its large strongly-ribbed pods.

Trifolium pratense, L.

Purple Clover.

Native. First record: Gosselin, I815.

Very common. Much grown for fodder. In 1895 Miss B. Agnew found on the north coast some plants of a curious variety, resembling the type generally, but having flower-heads shaped like those of $T$. intarnaum, and on very long peduncles. It was suggested that they were possibly hybrids, pratense $x$ incarnatum.

Called in the patois by its common French name, Trefte, in Normandy, Tremaine. In days of old, when there were witches abroad, a clover leaf was considered a potent charm against their evil machinations. Purple clover was first introduced into English agriculture about the year 1645 .

Trifolium medium, Huds.

Native (?). First found: Miss Agnew, I 899.

Very rare. A few plants were found in 1899 by Miss B. Agnew near the Rousse Martello Tower, Vale.

Trifolium incarnatum, L.

Crimison Clover.

Casual. First record: Royle, I894.

This clover being grown in the island for fodder, stray plants are frequently found on roadsides and in waste corners; but it is hardly 
entitled to a place in the Flora. The variety with cream-coloured flowers (not found in these islands) is, according to Bentham, the most common in a truly wild state on the Continent. In some parts of Normandy I have seen it in abundance, and near Coutances it forms the entire clover crop, red flowers being rare.

Trifolium arvense, $\mathrm{L}$.

Native. First record: Gosselin, I8 15

Hare's Foot Trefoil.

Rather common all round the coast ; more rare inland. Seldom occurs in any quantity: usually in single tufts or small patches. I have seen a very dwarf form on the Thielles cliffs; and $\mathrm{Mr}$. Andrews has shown me specimens gathered by him at the Vale in I 899 , having remarkably elongated cylindrical flower-heads, some of them two inches in length.

Trifolium striatum, $\mathrm{L}$.

Native. First record: Gosselin, 1815 .

Soft Knotted Trefoil.

Generally distributed and rather common, especially in the lowlands, and also on the cliffs. Var. erectum, Leight. Old quarry south of Ronceval. Cliffs by Sommeilleuse watch-house. Near Jerbourg Barracks.

Trifolium scabrum, $L$.

Native. First record: Babington, 1839 .

As widely distributed as the last species, and growing in similar situations; but rather more common. In the absence of perfect flowers these two little Trefoils may be distinguished by the venation of the leaves: in scabrum the lateral veins are arched or bent at the edge of the leaf : in striatum they are straight.

Trifolium maritimum, Huds.

Native (?). First record: Marquand, 189r.

Rare, but abundant where it occurs. Usually grows in meadows. Rue des Bergers, near Grande Mare Hougue du Pommier. Camp du Roi. Near Noirmont Mill. Formerly at the north end of the Vale Road, but the spot is now covered with houses. In all these localities this plant occurred in such profusion that it formed the most conspicuous portion of the vegetation.

Trifolium subterraneum, L.

Native. First record: Gosselin, 1815 .

Subterranean Trefoil.

Rather common in all districts, growing in dry, sandy, or turfy places all round the coast as well as in the interior.

Trifolium glomeratum, L.

Round-headed Trefoil.

Native. First record: Gosselin, I 8 15.

Frequent in dry, sandy, and gravelly places in all parts of the island. In Fl. Sarn. it is recorded on the authority of H. O. Carré. 
Trifolium suffocatum, $\mathrm{L}$.

Native. First record: Marquand, I89r.

Dense-flowered Trefoil.

Very rare apparently, but so inconspicuous a plant is very easily overlooked. In a damp hollow on the western side of Lancresse Common, a few plants in 1891 . Again found in 1900 on Lancresse Common by Miss B. Agnew, and by Mr. Andrews on the sand-hills close to Lancresse Bay.

Trifolium repens, $L$.

Native. First record : Gosselin, I 8I 5 .

White Clover.

Very common. Occasionally I have found a curious sport or frondescent form, in which the sepals and petals are transformed into small leaves, quite altering the appearance of the flower.

This plant is commonly called Dutch clover from the fact that at one time the seed was imported from Holland in very large quantities. It is pointed out by Dr. Prior (Pop. Names Brit. Pl.) that the word clover would be more correctly written claver, as it was by the old authors; the name being derived from the Latin clava, a club. The leaf is, in fact, the 'club' of our playing-cards, which in French is trèfle, a trefoil.

\section{Trifolium hybridum, L.}

Casual. First found: Marquand, 1894.

Very rare. Two or three plants in 1894 on the roadside by St. Sampson's Harbour. In 1899 Mr. Andrews found it growing at Grande Mare.

This speries takes its English name from being found abundantly in the parish of Alsike, near Upsal, in Sweden.

Trifolium fragiferum, L. Strazeberry-headed Trefoil.

Native. First record: Gosselin, I8 5 .

Rather rare. I have not met with this species in the south of the island, but in the north and north-west it occurs in a great many places in damp meadows and pastures, especially near the sea.

Trifolium resupinatum, $\mathrm{L}$.

Reversed Trefoil.

Alien. First record: Marquand, r89r.

Very rare. In 1890 I discovered a small patch of this plant about a yard square on the east side of the Vale Castle hill : the spot was conspicuous at a little distance by the bright rose-pink colour of the flowers. Two or three years later this station was destroyed by the cutting of a new pathway up the hill, to facilitate the quarrying operations.

Trifolium procumbens, L.

Native. First found: Gosselin, 7888 .

Hop Trefoil.

Common in all parts, especially near the sea. We have two forms in these islands: var. campestre, Schreb., and var. pseudo- 
procumbens, Gmel. This plant is the Trifolium agrarium of Hudson, and of Gosselin's list and herbarium, and the $T$. procumbens of Hudson is the $T$. minus of modern botanists.

(Trifolium agrarium, L., has been recorded for Sark.)

\section{Trifolium minus, $\mathrm{Sm}$.}

Native. First found: Gosselin, $\mathbf{7} 788$.

Lesser Yellow Trefoil.

Very common everywhere: probably the most abundant species of the genus. Specimens in Gosselin's herbarium are called by the old Hudsonian name, $T$. procumbens.

Much diversity of opinion has always existed, and probably will always continue to exist, on the question which particular plant should be regarded as the true Shamrock, the three principal claimants to the distinction being Medicago lupulina (Black Medick), Trifolium repens (Dutch Clover), and the present species. Moore and More, in their Contributions towards a Cyliele Hibernica (1866), adduce strong evidence in favour of the Dutch clover. Twenty years later Britten and Holland (Dict. Engl. Plant Names) assert that 'at the present day Trifolium minus is the plant most in repute as the true Shamrock.'

Trifolium filiforme, $\mathrm{L}$.

Native. First record: Gosselin, 1815 .

Slender Yellow Trefoil.

Frequent on sandy commons and dry, turfy spots, especially near the sea.

Falcatula ornithopodioides, Bab.

Native. First record: Marquand, 1891 .

Fenugreek.

Rare. On the Vale coast below Ronceval, and at Grand Havre; also in many parts of Lancresse Common. Cliffs between the Gouffre and the Corbiere (Miss B. Agnew).

The name Fenugreek is derived from that of an allied species called Faenum graecum, a plant cultivated by the Romans.

Lotus corniculatus. L.

Native. First record: Gosselin, 1815.

Very common throughout the island. Var. crassifolius, Pers. This is really the maritime form of the plant, and is abundant near the sea. Var. villosus, Ser. Occurs both near the sea and in the interior.

This species is called in the patois Arrête boeu, the ancient name Arresta bovis, under which the old herbalists knew the Rest Harrow (Ononis arvensis).

Lotus tenuis, Kit.

Native. First found: Andrews, 1900.

Found by Mr. Cecil Andrews growing among Juncus acutis at Albecq. Possibly less rare in the island than would appear from 
this single locality, but likely to be passed over from its general resemblance to $L$. corniculatus.

Lotus major, Scop.

Native. First record: Babington, 1839 .

Marsh Bird's-foot Trefoil.

Common throughout the island in wet places, and by damp roadsides and ditches.

Lotus angustissimus, L. Long-podded Bird's-foot Trefoil.

Native. First record: Babington, 1839.

Rather rare, though in some places plentiful. More frequently met with on the cliffs than in the low districts. This species flowers about a fortnight earlier than L. hispidus, with which it often grows. I have found the two species so interwoven in a tuft that they could not be separated without tearing them to pieces.

Lotus hispidus, Desf. Short-podded Bird's-foot Trefoil.

Native. First record: Babington, $\mathbf{1 8 3 9}$.

Frequent in all parts of the island: rather common on the cliffs; often found on banks inland. This is a much commoner plant than the last; the flowers are deeper orange-yellow, and the foliage and stems are more pubescent; otherwise they are much alike, except in the length of the seed-pods. In June, I894, I found a remarkably large and woody form of this species, with stems from two and a half to three feet high, growing plentifully on the roadside near the old Caudré Mill at St. Peter's.

Anthyllis vulneraria, L.

Kidney. Vetch.

Native. First record: Babington, 1839 .

Very rare. A sprinkling of plants in sandy fields between Cobo and Grandes Rocques. Two very small patches on the coast close to the Vale Castle. This plant is generally distributed and quite common in Alderney.

The application of the leaves to a fresh wound instantly checks the bleeding, so that in olden time the plant had a great repute as a vulnerary. According to Lyte, who wrote in 1578 , it is called Kidney Vetch because 'it shall .prevayle much against the payne of the reynes.'

Vicia hirsuta, Koch.

Native. First record: Gosselin, 1815.

Hairy Tare.

Generally distributed throughout the island, but not very common. It is the Ervum hirsutum of Gosselin's list.

Vicia tetrasperma, Moench.

Slender Tare.

Native. First record: Gosselin, 1815.

Rare. I have noted this species in nearly all the parishes, but it is a far rarer plant than the last. It occurs rather plentifully on the coast between Bordeaux and Fort Doyle. 
Vicia Cracca, L.

Native. First record: Gosselin, 1815.

Tifted Vetch.

Frequent in the low districts, both near the coast and inland: very rare in the higher parts of the island. Hedges on the Forest Road near Les Cornus.

Vicia bithynica, L.

Casual. First record: Marquand, I89r.

Very rare. One or two plants on the quarry heap near the Vale Castle in 1890 .

Vicia sepium, L.

Native. First found: Gosselin, 1788 .

Bush Vetch.

Very local. Cliffs from Fermain Bay to St. Martin's Point, frequent. Copse at Moulin de Haut (vili.), sparingly. A few plants in Rue des Bergers, near Grande Mare. In Gosselin's herbarium a specimen is labelled, 'North hedge of the lane of Havelet below the fountain.'

Vicia lutea, L.

Native. First record: Babington, 1839 .

Yellow Vetch.

Rare. On the shingle cast up on the roadside at Lerée, in fair quantity. This is evidently the station given in Fl. Sarn. "Shore near Lerée Barracks: Mr. Haslam.' Hillside near Rocquaine, in I 894 (Rev. W. Gray). Vale Castle quarry heap, one plant in I 894 (Miss Dawber). A patch eight or ten feet square in Rocquaine Bay in 1898 (Miss B. Agnew).

Vicia sativa, L.

Casual. First record: Gosselin, 1815 .

Cultivated Vetch.

A stray from cultivation, occasionally found in hedgebanks and borders of fields. Much grown in the island for fodder.

Vicia angustifolia, Roth.

Common Wild Vetch.

Native. First record: Marquand, $189 \mathrm{r}$.

Common throughout the island. Var. Bobartii, Koch. Roadside at the north end of Bordeaux in I890, very sparingly. Near Rousse Tower, one plant in 1899 : also on the western side of Lancresse, and at Rocquaine (Andrews). Var. uncinata, Desv. probably occurs here, as it has been found in Alderney and Sark, and is very common in Normandy.

Vicia lathyroides, L.

Native. First record: Gosselin, I815.

Spring Vetch.

Rare. Western side of Lancresse Common. Plentiful around Rousse Martello Tower. IVestern end of Vazon Green, plentiful. In a stony field at Pulias. Mr. Andrews has found it in two localities on the coast north of Bordeaux, and at Rocquaine. 
(Vicia varia, Host, a very beautiful purple-flowered Vetch, a native of Central Europe, has occurred as a Casual in Alderney.)

Lathyrus Aphaca, L.

Casual. First found : Collens, I894.

Yellow Vetchling.

Very rare. In $1894 \mathrm{Mr}$. J. S. Collens showed me two specimens of this plant, which he had found in a cornfield near Paradis, Vale.

The ripe seeds of this Vetch are narcotic, and produce excessive headache, but when green they may be eaten without any ill effects.

\section{Lathyrus pratensis, $\mathbf{L}$.}

Native. First found: Gosselin, 1788.

Meadowe Vetchling.

Very rare. Hedge of a lane between the Hougue du Pommier mainroad and Les Goubais. In Gosselin's herbarium there is a specimen labelled 'Roadside from Hougue du Pommier to the Pièce des Mielles,' which is probably the same station. This plant used to grow, I am told, in a hedge at the crossroads by the blacksmith's forge at St. Martin's, but it has not been seen there for many years.

\section{Lathyrus latifolius, L.}

Alien. First record: Marquand, I89r.

Everlasting Pea.

Grows in the middle of a thick hedge on the western side of Grande Mare-a marshy spot remote from houses, so that it is difficult to guess how it got there. The plant has been known in that station for over twenty years : it flowers every summer, but does not seem to increase.

This is the Everlasting Pea of cottage gardens, so called, not because it flowers for a longer period than others, but because it is a perennial plant, not an annual, like the Sweet Pea and the Common Pea.

Ornithopus perpusillus, L.

Native. First record: Gosselin, I8r5.

Common Bird's-foot.

Common on the cliffs and on the shore of the lowlands as well as in dry sandy waste spots and banks inland.

Arthrolobium ebracteatum, DC.

Yellow Bird's-foot.

Native. First record: Babington, 1839 .

Rare. Occurs in many parts of Lancresse Common, especially on the western side, but also about Fort Doyle; usually in small quantity in each spot. Occasionally very fine specimens are to be found in old quarries. This plant flowers in May and again in August, and in $1894 . I$ found specimens in good flower as late as December, in the hedge of a lane behind the Vale School. A. ebracteatum occurs much more plentifully in Alderney, but in France it is not found nearer than the island of Bréhat, about fifty miles southsouth-west from Guernsey.

(Onobrychis sativa, Lam., Sain-foin, occurs in Alderney.) 


\section{ROSACEAE.}

Prunus spinosa, L.

Native. First record: Gosselin, I8I5.

Blackthorn. Sloe.

Common throughout the island. In 1894 it was already beginning to flower on March 3 rd at Moulin Huet. I have noticed the var. fruticans at Moulin Huet, and here and there at the Vale and Catel: probably it is not uncommon.

The patois name is Nere Epeine, the local form of the French Epine noire. White, of Selborne, says the Blackthorn 'usually blossoms while cold north-east winds blow, so that the harsh, rugged weather obtaining at this season is called by the country people Blackthorn winter.'

Prunus insititia, L.

Native. First record: Marquand, I89 г.

Bullace.

Rare. Several trees above Divette Cove, below Doyle's Monument. Also several on the steep bank of the road leading down to Fermain Bay. Mr. Andrews has noted two small bushes by the roadside at Sausmarez, St. Martin's, and several in a hedge on the road to Doyle's Monument.

Prunus domestica, L.

Denizen. First found: Miss Dawber, 1887.

Wild Plum.

In the Report of the Watson Botanical Exchange Club for 1887-88, the following note occurs: 'Prunus domestica, L. Moulin Huet, Guernsey, May, I9, x 887 , M. Dawber. Mr. Baker thinks it may go under $P$. domestica, but shading off towards insititia. A. Bennett.' In I900 Mr. C. Andrews found this species growing abundantly on both sides of the path leading down to Moulin Huet, below the Vallon grounds: evidently the same station.

Prunus Cerasus, L.

Denizen. First record : Babington, I839.

Divarf Cherry.

Upper end of Talbot's Valley. Lane by St. Andrew's Rectory. Hedge opposite St. Andrew's brickfield. Near Ozanne's Tower. Near Les Fauxquets (viri.). This species is probably the Prumus Avium, Common Wild Cherry, of Gosselin's list. There is no evidence of the occurrence of the true $P$. Avinm in the Channel Islands.

Poterium Sanguisorba, L

Salad Burnet.

Native. First record: Gosselin, I8I 5.

Local. Plentiful on Lancresse Common on the western side, and towards Lancresse Bay; but the plants are somewhat scattered.

The leaves of this plant, which taste something like cucumber, were used formerly in the preparation of a beverage called 'cool tankard;' hence the name Poterium, which signifies a drinking-cup. 
Gerarde says that the plant 'being put into wine, it yieldeth a certaine grace in the drinking, making the heart merrie and glad.'

(Agrimonia Eupatoria, L., Common Agrimony, occurs in Alderney and Sark.)

Agrimonia odorata, Mill.

Native. First record: Marquand, I89I.

Scented Agrimony.

Rare. Saints Bay Valley and cliffs Cliffs below Calais. Petit Port cliffs. West end of Chemin le Roi (Iv.). Lane from Upper Catel Road to Lower Rohais. Near the Catel Hospital. Roadside at Les Marchais (VI.). Not quite typical, I think, but always lemonscented.

Agrimony was one of the favourite plants of the old herbalists, being employed by them in various ways for many ailments. Gerarde tells us that ' a decoction of the leaves is good for them that have naughty livers ;' and we still hear of Agrimony 'tea' in the rural districts.

Alchemilla arvensis, Scop.

Parsley Piert.

Native. First record: Gosselin, 1815.

Common throughout the island in dry places. It is the Aphanes arvensis of Gosselin's list.

The old English name was Percepier, from the French perce pierre, so called from its supposed lithotriptic properties. By corruption this word became Pursley-piert and subsequently Parsley Piert. Gerarde recommends this little plant for its 'many good vertues,' among others the removing of freckles, spots, pimples, and sunburning.

Potentilla anserina, L.

Native. First record: Gosselin, I8 5 .

Silverweed.

Generally distributed and rather common on damp roadsides and moist ground. A form with the upper side of the leaves densely silky and silvery (var. sericea, Koch) occurs at St. Andrew's. It is the prevailing form in Alderney.

The French name Argentine corresponds with our English Silverzeed. The roots, which are said to taste like parsnips, are often eaten in the Hebrides, being simply prepared by roasting or boiling.

Potentilla reptans, L.

Native. First record: Gosselin, I8 I5.

Creeping Cinquefoil.

Rather common at the north of the island: less so in the lowlying parts of St. Saviour's and the Catel. This species does not seem to occur, or only rarely, in the southern districts. 
Potentilla Tormentilla, Nesl.

Native. First found: Gosselin, 1788.

Tormentil.

Very common in heathy places, commons, and barren pastures. Abundant on the cliffs. Var. procumbens, Sibth. I have found this variety in hedgebanks in several places, all of them being, curiously enough, in St. Andrew's parish. There is a specimen of this form (mixed with two others belonging to the type) in Gosselin's herbarium, labelled 'edge of ditch south of Ivy Castle.'

Locally known in the rural districts of Guernsey as Herbe at paralysie, the belief being current that a 'tea' made of this plant will ward off paralysis. The specific name is derived from the Latin word tormen, dysentery ; and Gardiner, in his Flora of Forfar, says of this plant: 'In cases of dysentery I have known a decoction of the root used with great efficacy; but, being a very powerful astringent, caution must be exercised in its administration.' It is said to contain a larger proportion of tannin than any wood or bark.

Potentilla fragariastrum, Ehrh.

Barren Strawberry.

Native. First record: Gosselin, 1815 .

Common in all districts on dry banks and walls. Begins to flower very early, often in the opening days of the year. The receptacle does not swell or become succulent as the fruit ripens, as in the case of the Wild Strawberry: hence its old name Fragaria sterilis, under which it figures in Gosselin's list.

Comarum palustre, L.

Native. First record: Babington, I839.

Marsh Cinquefoil.

Local and rare. Found only at Grande Mare, where the plant occurs in a good many places, so that it is less likely than some other species to disappear when the marsh is drained.

The roots yield a dull orange or reddish dye, which imparts a yellow colour to woollen stuffs. In some parts of Ireland milkpails are stained with it, in order to give a richer appearance to the milk.

Fragaria vesca, L.

Native (?). First record: Babington, 1839 .

Wild Strazeberry.

Very rare. Hedge of the lane between Le Jardin and Woodlands, extending for about twenty yards, and when I saw it, bearing ripe fruit. Mr. Derrick (who showed me the spot) has known the plant there for a great many years, and never heard of its having been planted. No other station is known in Guernsey, but Babington notes it in $F l$. Sarn. as found by him sixty years ago at St. Andrew's. As $F$. vesca is common in Normandy, it may have occurred more plentifully in this island in ancient times: though in that case one would have expected to find it mentioned by Gosselin. 
(Rubus Idaeus, L., the Raspberry, oocurs in Alderney.)

Rubus affinis, Wh. and N. Var. Briggsianus, Rogers.

Native. First record: Rogers, 1898 .

In several places, especially at St. Sampson's, Cobo, Petit Bot Bay, and St Peter's. Exactly the British form described in Journ. Bot. 1894, p. 42.*

Rubus rhamnifolius, Wh. and N. (sp. coll.).

Native. First record: Rogers, 1898.

Fermain Bay. Petit Bot Bay. Very near the ordinary British form (R. cardiophyllhes, Lefv. and Muell.) if not identical with it.

Rubus pulcherrimus, Neum.

Native. First record: Rogers, 1898 .

Rather common. La Vallette. Lanes near Ville au Roi. Petit Bot Bay. St Peter's. Near Vale Castle.

\section{Rubus dumnoniensis, Bab.}

Native. First record: Rogers, 1898 .

Petit Bot Bay, in good quantity. Also at Rocquaine Bay and one or two other localities. Usually identical with our luxuriant British form. But a second form occurs in Sark, and also at Petit Bot Bay (unknown thus far in Britain) with terminal leaflet subrotund and strongly cordate.

Rubus rhombifolius, Weihe.

Native. First record: Rogers, 1898 .

Fermain Bay.

Rubus argentatus, P. J. Muell.

Native. First record: Rogers, $\mathbf{1} 898$.

Generally distributed, but variable: one of the most abundant brambles in the island. La Vallette. Lanes near Ville au Roi. Les Norgiots. Fermain Bay. Petit Bot Bay. St. Peter's. Near Vale Castle. Var. robustus, P. J. Muell. Here, rather than under the type, appear to belong forms that occur at Cobo, St. Sampson's, Fermain Bay, and near St Martin's Church: but the range of variation is considerable and somewhat bewildering.

* All the information contained in these pages respecting the brambles of Guernsey and the smaller islands is extracted from a valuable paper on 'The Rubi and Rosae of the Channel Islands,' contributed to the Journal of Botany for March, 1898 (p. 85), by the Rev. W. Moyle Rogers, F.L.S., to whom I return my grateful acknowledg. ments. Until Mr. Rogers visited these islands in 1897 , very little was known about the local forms of this difficult and perplexing genus. Only five species were recorded by Professor Babington in the Flora Sarnica in 1839, and, in Mr. Rogers's opinion, - it is probably quite impossible now to ascertain what plants he referred to under the names he gives.' Mr. Rogers states that 'in all the islands the vast majority of the brambles seen are practically identical with our British forms,' and 'no localities are given for the islands except those in which [Mr. Rogers] saw the plants in question growing.' 
Rubus rusticanus, Merc.

Native. First record : Rogers, $I 898$.

Very common, and at least as variable as in England.

Rubus laciniatus, Willd.

Native. First record: Rogers, I898.

Quarry near Petit Bot Bay: not quite the usual form. [Trans. Guern. Soc. Nat. Sc., I898, p. 296:]

Rubus macrophyllus, Wh. and N. Var. Schlechtendalii, Weihe.

Native. First record : Rogers, 1898 .

Rather frequent. St. Sampson's. St. Martin's. Fermain Bay. A very glandular form. [In Journ. Bot. loc. cut. Mr. Rogers recorded this bramble as 'var. microphylloides, very near Schlechtendalii ;' but in a subsequent list made out and published in Trans. Guernsey Soc. Nat. Sc.., 1898, p. 296, he names it without query as above.]

Rubus Sprengelii, Weihe.

Native. First record: Rogers, 1898 .

Fermain Bay : quite typical.

Rubus leucostachys, Schleich,

Native. First record : Rogers, 1898.

As an aggregate species abundant in Guernsey, though usually in an untypical form. Var. angustifolius, Rogers. Fermain Bay. Nearly allied to $R$. leucostachys, and considered by Dr. Focke to be also near $R$. argyranthus, Boul. and Luc. are plants which occur in some quantity at Les Norgiots, St. Andrews; but these demand further study.

Rubus Boraeanus, Genev.

Native. First record: Rogers, 1898 .

Lane above Glatney Esplanade, St. Peter Port : a form with very few pricklets on faces of stem, and an abnormally prickly panicle. St. Sampson's : a plant which also seems to go best under this species.

Rubus Borreri, Bell-Salt.

Native. First record: Rogers, 1898.

Abundant and characteristic near Vale Castle. In quarries between St. Sampson's and Lancresse (var. dentatifolius, or near it), and in lanes near Ville au Roi.

Rubus radula, Weihe. Var. anglicanus, Rogers.

Native. First record: Rogers, 1898 .

In Journ. Bot. loc. cit. this bramble is noted for Jersey only, but in a later list in Trans. Guernsey Soc. Nat. Sc., 1898, p. 296, Mr. Rogers records it as found at Fermain Bay. 
Rubus rudis, Wh. and N.

Native. First record : Rogers, I898.

Fermain Bay: typical, or nearly so.

Rubus Lejeunii, Wh. and N. Var, ericetorum, Lefv.

Native. First record: Rogers, I898.

This species is not mentioned in the original paper in Journ. Bot., but is included (without locality) in Mr. Rogers's list in Trans. Guernsey Soc. Nat. Sc. for 1898 .

Rubus Bloxamii, Lees.

Native. First record: Rogers, 1898.

Common: widely distributed and mostly quite characteristic. La Vallette. Petit Bot Bay. St. Martin's. Les Norgiots. St. Peter's. St. Sampson's.

Rubus dumetorum, Wh. and N. Var. ferox, Weihe.

Native. First record: Rogers, $\mathbf{1} 898$.

Generally distributed, but variable, as in Britain. La Vallette. Petit Bot Bay. St. Sampson's.

Rubus corylifolius, Sm. (sp. coll.).

Native. First record: Rogers, 1898.

Cobo. Near Vale Church. Var. cyclophyllus, Lindeb. Fairly frequent in Guernsey.

(Rubus Balfourianus, Blox., occurs in Sark.)

Rubus caesius, L.

Native. First record : Marquand, r89r.

Dewberry.

Near St. Peter's Church. Hedges towards Les Marais, Catel. Noted by Rev. W. Moyle Rogers as rather frequent in Guernsey.

(At the end of the list of Rubi, published in Trans. Guern. Soc. Nat. Sc., 1898, p. 296, Rubus Genevierii, Bor., is erroneously noted for Petit Bot Bay. Mr. Rogers informs me that it has no right to a place in the list, as this bramble has not so far been found in the Channel Islands. It is not a British species.)

Geum urbanum, L.

Native. First record: Gosselin, 18 55 .

Generally distributed, but not common, though often plentiful where it occurs. Mostly found in the interior of the island.

The name Herb Bennet (in French Benoite) is taken from the old Latin Herba benedicta, because the plant was supposed to ward off all evil spirits, venomous serpents, and wild beasts. 'Where the root is in the house,' says a writer at the end of the sixteenth century, 'the devil can do nothing, and flies from it ; wherefore it is. blessed above all other herbs.' 
Rosa spinosissima, L.

Native. First record: Gosselin, 1815.

Locally plentiful on the north coast. Sandy field near Grandes Rocques. Neighbourhood of L'Islet and Grand Havre. Lancresse Bay, and on several parts of the Common. It is curious how the habitats of this Rose vary in the different islands. In Guernsey it is confined to the sandy commons and sandhills of the lowlands; in Alderney it is never found in such localities, but always on the cliffs ; while in Sark, according to Mr. Derrick, it 'abounds in furzebrakes all over the plateau.'

(Rosa involuta, Sm., and R. tomentosa, Sm., occur in Alderney.)

Rosa rubiginosa, $\mathrm{L}$.

Native. First found: Rogers, 1897.

Szeetbriar.

Rare. One bush at Perelle Bay, found by Mr. F. A. Rogers in 1897. One near the White Tower at Fermain, and another near Les Pelleys (viII.) in I 900 (Andrews).

This is the Eglantine of Shakespeare and other poets, although Milton applies the term to the honeysuckle. The word is properly French, and is supposed to be derived from the Latin aculeus, a prickle, through aculentus, whence old French aiglent (covered with prickles), and aiglentier, which afterwards became églantier and. églantine.

Rosa micrantha, Sm.

Native. First record: Marquand, 1892.

I found one bush in 1892 at the bend of the road down to Fermain Bay, but two or three years later it disappeared when some new fencing was put up. Doubtless, however, this Rose will be found elsewhere, as it occurs in Alderney and Sark.

The tufty excrescences found on the stems and leaves of wild Roses, which children call 'Robin's pincushions,' are galls produced by the fly Cynips (Rhodites) Roscee. All sorts of medicinal qualities used to be attributed to these outgrowths by the practitioners of the olden time. They are also known as the Bedeguar of the Rose.

Rosa obtusifolia, Desv.

Native. First found: Andrews, I900.

Rare. The var. tomentella, Lem., was found by Mr. C. Andrews. on the border of a meadow near Fort Doyle in I900; a form much more pubescent than usual.

Rosa canina. L.

Dog Rose.

Native. First record: Gosselin, 1815.

Rare, though generally distributed in the central and southern districts. Nearly always found in single or small bushes, which are 
shy of flowering. The prevailing form, as far as my observation goes, is the var. dumalis, Bechst. (var. sarmentacea of Fl. Sarn.). Mr. C. Andrews has found in a hedge near Lilyvale (virr.) the var. biserrata, Merat (vinacea, Baker); and Babington records the var. surculosa, Woods, from 'near Moulin de Veschelle,' a place unknown to me, unless it be a printer's error for L'Echelle, a watermill in the Talbots Valley. The Roses of this island have not been properly studied and other varieties are certain to be found. The following additional varieties of $R$. canina have been collected in Alderney: lutetiana, Lem., sphaerica, Gren., verticillacantha, Merat, dumetorum, Thuill., and decipiens, Dum.

(Rosa stylosa, Desv., occurs in Alderney and Sark.)

Crataegus Oxyacantha, L.

Hawthorn. White Thorn. Native. First record: Gosselin, I8I5.

Very common. I have only seen the var. monogyna, Jacq., in this island.

The patois name, unlike the French Aubépine, is Bianche Epeine, and the fruits are called, as in Normandy, Hâgues, i.e., Haws. In the country parishes of Guernsey the belief prevails that sickness or death will ensue if the flowers are brought into a house, and the same superstition is current in some parts of Essex. In ancient Greece the bridal wreath was composed of hawthorn flowers, and in later days in merrie England a garland of these blossoms always surmounted the Maypole. Burns, in one of his songs (the one beginning 'Oh, love will venture in'), has very poetically described an old hawthorn-bush clothed with tufts of shaggy lichen (Ramalina) :-

'The hawthorn I will pu', wi' its locks o' siller grey,

Where, like an aged man, it stands at break o' day.'

\section{Mespilus germanica, $\mathrm{L}$.}

Wild Medlar.

Denizen. First record: Babington, I 839 .

Rare. Small spinous shrubs occur in the valley below Le Becquet (III.); in the lane between St. George and Les Mourants (viri.); between Les Cornus and La Pompe (III.); in hedges along the Forest Road, in two or three places; in the valley below Les Issues (vIr.); and on the cliffs near the Gouffre. Rather large trees with few spines occur in Fermain Lane, at Ville au Roi, and near La Fosse (III.). I have classed the Medlar as a Denizen, but it may be really native. Babington says (Fl. Sarn., p. 34) it is 'truly wild' in Jersey.

The patois name of this tree is Melier, the same as in Normandy, and the fruits are called Mêles. In modern French the fruits are Neffles and the tree Neffier. In a wild state the Medlar is more or less spinous, but it loses its spines in cultivation. 
(Pyrus communis, the Wild Pear, is noted for Guernsey in Ansted's Channel Islands, but there is no satisfactory evidence of its occurrence. It has been recorded for Sark.)

Pyrus Malus, L.

Native. First record: Babington, 1839 .

Wild Apple. Crab.

Frequent along the cliffs from Fort George to St. Martin's Point, but more commonly beyond Fermain Bay. Scattered trees all along the cliffs as far as the Corbiere. One or two at Rocquaine, one at the Hubits, and one on the Villiaze Road. I have only seen the var. mitis, Wallr., in this island.

This is the parent stock of all our cultivated apples. It seems that in former days apple-sauce was eaten with shellfish, which explains the punning couplet:-

'The crab of the wood is sauce very good for the crab that lives in the sea ;

But the wood of the crab is sauce for a drab that will not her husband obey.'

(Pyrus Aucuparia, the Mountain Ash, has been noted in some lists, but of course it has no claim whatever to a place among the indigenous plants of Guernsey.)

\section{LYTHRACEAE.}

Lythrum Salicaria, L.

Native. First record: Gosselin, I8I5.

Purple Loosestrife.

Rare. Hedges in Foote's Lane, Lower Rohais, and in the adjacent fields. In two or three places between Ivy Castle and Baubigny. Hedge of a marshy field near the Hermitage, Vale.

The name Loosestrife, which properly belongs to plants of another genus (Lysimachia) refers to an ancient belief, mentioned by Pliny, that if a tuft of it were laid upon the yoke of a pair of oxen when they were quarrelling, it would quiet them.

\section{Lythrum Hyssopifolia, L.}

Casual (?). First record: Marquand, 1892.

Hyssop-leaved Purple

In 182 I found about twe [Losestrife. entrance of a lane (called La Rue ès Chiens, I believe) branching off the Braye Road in the direction of Noirmont: but two or three years afterwards no vestige of the plant was to be seen there.

Peplis Portula, L.

Native. First record : Gasselin, 181 5.

Water Purslane.

Very rare. Rather plentiful in a small marsh on the coast between Fort Doyle and Fort Le Marchant. Pool near Fort Doyle. Babington found this plant at Grande Mare. 


\section{TAMARISCACEAE.}

Tamarix anglica, Webb.

Tamarisk.

Alien. First record: Gosselin, $x_{8} \mathrm{r}_{5}$.

Rather common in the maritime districts of the lowlands, where it often forms hedges between fields. Rare in the south of the island. Although this plant is usually described as a shrub, and is commonly met with as such, in some parts of Guernsey, as at the Vale and near the Mare de Carteret, it attains the dimensions of a large tree, with a trunk several feet in circumference. That the Tamarisk was introduced into the island a long time ago is evident, since it is included in Gosselin's list compiled in 1788 , and this list comprises no cultivated plants. It is sometimes described as an evergreen shrub, but it sheds all its leaves in winter.

Gerarde says: 'If ale or beere be continually drunke forth of a cup or dish made of the wood or timber of Tamariske, it is of great efficacie.'

\section{ONAGRACEAE.}

Epilobium hirsutum, L. Great Hairy Willowe-herb.

Native. First found: Gosselin, I 788.

Frequent by streamsides and wet corners of fields in the lowlying parts of the island, but rarely seen in the south. Valley below Calais (11I.). This species is the Epilobium ramosum of Gosselin, and a specimen still preserved in his herbarium was gathered ' in Mr. Charles Mauger's orchard at St. Martin's called the Maindoniaux.'

This plant is called Codlins and Cream and also Apple-pie, from the smell of the leaves when slightly bruised, and also from the fragrance of the flowers, which, however, is transitory, and lasts but a few minutes after gathering.

Epilobium parviflorum, Schreb.

Small flowered Hairy

Native. First found: Gosselin, 1788.

[ Willow-hcrb.

Common on streamsides in the cliff valleys, and in wet places in the south: much less frequent in the lowlands. This species figures in Gosseiin's list under two names, Epilobium hirsutum and E. molle, as proved by specimens in his herbarium.

Epilobium montanum, L.

Broad-leaved Willow-hert.

Native. First record: Gosselin, I8 I5.

A frequent roadside weed in the interior and southern parts of the island, occurring also in hedgebanks and waste places.

Epilobium lanceolatum, Seb. and Maur.

Native. First record: Marquand, $189 \mathrm{r}$.

Spear-leaved [ Willow-herb.

Frequent in the interior, but seldom found close to the sea. Grows freely on many of the walls in the outskirts of the town. 
Epilobium tetragonum, L.

Long-podded Square-stalked

Native. First record: Babington, I839.

Rare. In two places to the east of Ronceval. Field near Baubigny, fairly plentiful in I890. Near Pont Vaillant in two or three spots. Lane near Le Graie St. Peter's (Miss B. Agnew). In Fl. Sarn. it is noted for St. Peter-Port, but this would refer to the aggregate species, including $E$. obscurum.

Epilobium obscurum, Schreb.

Short-podded Square-

Native. First record: Marquand, I8gr. [stalked Willoze-herb.

Common throughout the island, being by far the most plentiful species of Epilobium found here.

Epilobium palustre, L.

Native. First record: Babington, 1839.

Very rare. In $\mathrm{I} 889 \mathrm{I}$ found a single specimen of this plant in a lane adjoining Grande Mare: but I have not met with it again. Babington found it at Long Port and at Paradis.

Oenothera biennis, L.

Common Evening Primrose.

Alien or Casual. First found: Andrews, I898.

Very rare. Several plants on the cliffs above Fort Bay, where they have very much the appearance of being wild (Andrews). More evident escapes from cultivation have been found in the Talbots Valley and near the Vale Castle. This is a North American plant, long cultivated in gardens, but now thoroughly naturalised in many parts of Normandy, especially in the valley of the Seine.

Oenothera odorata, Jacq.

Fragrant Evening Primrose.

Denizen. First record: Marquand, I89I.

On the sandhills on the south side of Rousse Martello Tower, plentiful, having all the appearance of being truly native. Abundant in small fields near Lancresse Lodge and near Les Mielles. A few plants in a waste corner between the Vale Church and Grand Havre. Close to Calais quarry (III.) a few plants, probably garden outcasts. Vale Castle quarry heap, I899, and in a quarry at Mont Cuet (Andrews).

Called Evening Primrose or Evening Star because the flowers open at sunset and continue expanded throughout the night until a little after sunrise : they are deliciously fragrant.

Circaea lutetiana, L.

Enchanter's Nightshade.

Native. First record: Gosselin, 18 15.

Most commonly met with as a troublesome weed in gardens, especially in the town; but also found on waste ground and borders of lanes in many parts of the island. Its creeping rootstock is very difficult to eradicate.

This pretty little plant derives its generic name from the circum- 
stance that, according to Dioscorides, 'Circe, an enchantress, expert in herbs, used it as a tempting powder in amorous concerns.' The French name, Herbe aux magiciennes, is very similar to our English one.

\section{HALORAGACEAE.}

Myriophyllum spicatum, L.

Native. First found: Gosselin, 1788 .

Spiked Water Milfoil.

This species is mixed with $M$. alterniflonum in two different packets in Gosselin's old herbarium, the whole being labelled Myriophyllum verticillatum: but no localities are specified. I have no other evidence of the occurrence of this plant in the island.

Myriophyllum alterniflorum, DC. Alternate-flowered

Native. First found: Gosselin, $\mathbf{x} 788$.

[ Water Milfoil.

Rare. Small pool between Coutanchez and Baubigny, and pool below a large quarry heap at Baubigny. Quarry pool towards Fort Le Marchant. In Fl. Sarn. it is recorded for ditches to the north of Ivy Castle, where very likely it is still to be found. Gosselin gives in his list $M$. verticillatum, but the specimens so labelled in his herbarium consist of the present species and $M$. spicatum intermixed.

*Hippuris vulgaris, $\mathrm{L}$.

Mare's-tail.

Extinct.

This is one of the plants that have long since ceased to exist in Guernsey owing to the drainage of marsh land. It is mentioned in Gosselin's list, and a specimen is preserved in his herbarium gathered in a 'marsh on the west of Pleinheaume.' At Longy Pond, in Alderney, this species grows in profusion. Babington does not mention it in Fl. Sarn.

\section{PORTULACEAE.}

Montia fontana, L.

Native. First record: Gosselin, I8r 5 .

Blinks.

Frequent on the southern cliffs, growing near springs and in damp spots. Scattered about Lancresse Common and near Fort Doyle. Roadside towards Torteval Church. Var. rivularis, Gmel. A form six or eight inches high occurs in a roadside streamlet at Les Marais, towards Richmond, and near the Trinity Houses, Rocquaine.

The origin of the name Blinks has not been satisfactorily explained, for we cannot seriously accept the derivation suggested by Prior (Pop. Names Brit. Pl.) that the plant is 'so called from its half-closed little white flowers peering from the axils of the upper leaves, as if afraid of the light.' 


\section{PARONYCHIACEAE.}

Herniaria glabra, L.

Native. First found: Gosselin, $\mathbf{1} 788$.

Rupturewort.

Local, but plentiful where it occurs on commons and dry, sandy ground all along the coast from Vazon Bay to Lancresse and Fort Doyle. Although this plant is not mentioned in Gosselin's list, there are specimens, without locality, in his herbarium. Var. subciliata, Bab. Pulias Point, and on several parts of Lancresse Common.

Recommended by the old practitioners for the cure of hernia, and Culpepper tells us that 'this herbe hath not his name in vayne.'

\section{Herniaria ciliata, Bab.}

Native. First record: Babington, 1839 .

Very rare. In I 891 , after much searching, I discovered a small patch of this species growing at the northern end of Port Soif, near Grandes Rocques. I have very little doubt that this is the station indicated for the plant in $F$. Sarn., viz., 'On the northern point bounding Port de Fer, Guernsey, but in small quantity.' There is no such place as Port de Fer, but one of the small bays near Grandes Rocques is called Portinfer, and is so close to Port Soif that the names might well be mistaken.

\section{CRASSULACEAE.}

Tillaea muscosa, L.

Native. First found: Gosselin, I 788 .

Plentiful on St. Martin's cliffs, and all along the south coast as. far as Pleinmont. Also in many places on Lancresse Common and on the coast to the westward. Inland I have found it at Hougue des Quartiers (x.). In Gosselin's list it figures as Tillaea muscosa, Mossy Redshanks, and specimens from Vazon Bay are preserved in his herbarium. In Fl. Sarn. it is recorded on the authority of H. O. Carré. This minute plant (easily overlooked, although conspicuous enough by its brilliant red colour) is only to be seen in early spring: in dry seasons it has completely disappeared by the end of May.

(Sedum Telephium, L., Orpine, has been found in Alderney.)

Sedum album, L.

Alien. First record: Marquand, r89r.

Very rare. Roadside wall at Cobo. Roadside wall at the Vale near La Turquie. 
Sedum anglicum, Huds.

Native. First record: Gosselin, I8I 5 .

English Stonecrop.

Very common on the cliffs and the shores of the lowlands, as well as inland on dry banks, walltops, and old thatched roofs.

Sedum acre, L.

Native. First record: Gosselin, I8I5.

Rather common generally, sometimes abundant, in sandy ground all round the coast of the low-lying districts. This species does not appear to grow on the cliffs here, as it does in Alderney.

The whole plant is hot and pungent when chewed, and when applied to the skin produces blisters. In the northern parts of Normandy, both this and $S$. anglicum are known under the name of Thym de Crapaud, or Toad's Thyme.

Sedum reflexum, L.

Alien. First record: Marquand, I89r.

Yellow Stonecrop.

Rare. Mostly on old walls. Plentiful on an old wall at Les Goubais (Ix.) and at foot of the hedge nearly opposite. Also in the same parish at Les Rouvets, and on a roof at St. Clair. Between Cobo Church and Castle. Les Bourgs (virr.). Planted on a hedge at Mauxmarquis (Ir.).

Sedum Forsterianum, Sm.

Alien. First record: Babington, I839.

Very rare. On banks on both sides of a lane above L'Echelle Mill, Talbots Valley. On walls at Naftiaux (II.) and nearly opposite Le Chêne (rv.). Recently planted on a roadside hedge at Mauxmarquis. This plant seems to have disappeared from Babington's old station: 'on a wall by the roadside leading from St. Peter's Port to Grand Cobo.'

Sempervivum tectorum, L.

Houseleek.

Alien. First record: Gosselin, I 8 × 5 .

Formerly common on the roofs of farm buildings, but now very rare and almost extinct. A few plants on the walltop above L'Echelle Mill, Talbots Valley. Walltop behind Richmond Hotel (viI.). One or two plants on a wall at La Villette (III.).

Locally known as Jaune barbe. The medirval name of the Houseleek was Jovis barba, or Jupiter's beard. From this came the French name Joubarbe, corrupted in Normandy into Jombarbe, and still further altered in the Guernsey patois into the more intelligible, if less correct, name of Jaune barbe, or yellow beard. Similarly the Houseleek is called in Germany Donnerbart, Jupiter being regarded there as the Thunderer. From this arose the belief that the buildings on which it grew were thereby protected from lightning. Charlemagne commanded that it should be planted 
on the roof of every house, a custom which still lingers in England and on the Continent.

Cotyledon Umbilicus, L.

Wall Pennyiort. Naveluvort.

Native. First record: Gosselin, I8I5.

Very common throughout the island on old walls, stony banks, and thatched roofs.

The patois name of this plant is Etriqueur or Etricaur, a singular word, of which the meaning is obscure. Métivier (Dict. Franco-Norm.) says: 'Etriqueur ou Stricheur vient du vieux français stricher, racler ou raser le boisseau. C'est une allusion à l'habitude -qu'ont les enfants de stricher ou de racler les épis de cette plante, et d'en jeter les semences à la nuque du cou de leurs camarades.' This is an extremely strained and very unlikely derivation. Bearing in mind that the spelling is purely phonetic, and that the word may be equally well written Etriceur, it would be easy to derive it from the patois verb etriller, to rend or tear, and cour, the heart, thus signifying the exact opposite of Heart's-ease: but I cannot discover that the Navelwort anywhere bears a name approaching this in meaning. Its common French name is Nombril de V'́nus, a translation of the old Umbilicus Veneris: and another old name was Herba coxendica, from the resemblance of the leaf to the hipsocket. In Normandy the plant is variously called Godets, Grasse Herbe, and Chandelles.

\section{SAXIFRAGACEAE.}

\section{Saxifraga tridactylites, L.}

Rue-leaved Saxifrage.

Native. First record: Gosselin, 18 I 5 .

Local and rare; usually abundant in the spots where it occurs. In several places on the coast about Grandes Rocques and Portinfer. Vazon Green. Near Rousse Tower. Lancresse Bay, and on the Common below the Great Cromlech. In the south of England as well as in these islands I have almost always found this plant growing in company with Draba verna.

An allied species, $S$. umbrosa, which abounds on some of the Irish mountains, is the London Pride or None-so-pretty of our gardens.

Chrysosplenium oppositifolium.

Native. First record: Gosselin, $18 \times 5$.

Common on the moist banks of shaded streamlets and springs everywhere in the middle and south of the island. I have not noticed it in the extreme north. 


\section{UMBELLIFERAE.}

Hydrocotyle vulgaris, L.

Marsh Pennyzerort.

Native. First record: Gosselin, I8 I 5 .

Common in marshes, wet places, and damp meadows in all parts of the island.

In Normandy this plant is known by the name of Ecuelle d'eau, from its saucer-like leaves. Like many other marsh plants, it is believed by farmers to cause disease in cattle, hence its names White-rot and Sheep's-bane.

Eryngium maritimum, L.

Native. First record: Gosselin, I8 I 5 .

Sea Holly.

Common on the sandy shores of the lowlands all round the north and north-west.

Called in the Guernsey patois Cardon d'banque, which means literally Seashore Thistle. In Normandy it is known as Panicant. The candied roots of this plant were a celebrated sweetmeat in the Elizabethan age, and are alluded to under the name of 'kissing comfits' and 'eringoes' in Merry Wizes of Windsor, v. 5.

\section{Eryngium campestre, L.}

Casual. First record: Marquand, 1892.

I found a single plant at Bordeaux Harbour in 1892 , growing on the shingle. It is the only specimen that has occurred in the island, so far as I know. This species is common in Normandy.

Apium graveolens, L.

Native. First record: Gosselin, I8 15 .

IVild Celery:

Rather common in marshy places in the low districts, especially those within the influence of the sea, where the water is more or less brackish. Hardly found at all in the south, the only place I know being Les Rebouquets (IV.).

Called in Normandy Ache. In its wild state the plant is acrid, and even poisonous; but in its cultivated form, as celery, it is mild and wholesome, and very pleasant to the taste.

Apium nodiflorum, Reich.

Procumbent Marshuert.

Native. First record: Gosselin, I8I5.

$V$ ery common on the borders of streams and ditches everywhere. The var. repens, Koch., which is noted in the Fl. Sarn. for Long Port, Braye du Vale, and Paradis, occurs in several parts of the island.

Called in the patois Bêle, a variation of the French Berle, a name applied, not to the present species, but to Sium angustifolium, which it much resembles. 
Apium inundatum, Reich.

Least Narshurort.

Native, First record: Babington, 1839 .

Rare. Pool by Fort Doyle Marsh on the coast between Fort Doyle and Fort Le Marchant.

Petroselinum sativum, Hoffm.

Alien. First record: Babington, 1839 .

Parsley.

Abundant and thoroughly naturalised on the shingle at Lerée and Perelle. Northern end of Rocquaine Bay. Cobo. Rather plentiful at the Vale Castle, above the moat. Common in stone hedges about Grandes Rocques. Icart, on ruined walls.

In Guernsey, as in Devonshire, there is a rooted belief that it is exceedingly unlucky to transplant Parsley; serious injury, if not death, resulting to the offender himself or to some member of his family within the course of the year. This superstition, which is said to prevail also in parts of South America, may be connected with the custom of the ancient Greeks, who used the plant to bestrew the tombs of the dead.

(Sison Amomum, L., Bastard Stone Parsley, is mentioned in Gosselin's list, but as there is no specimen in his herbarium, and the plant has not been found since, it must be regarded as an uncertain record.)

\section{Ammi majus, L.}

Casual. First found: Miss Dawber, I888.

A single plant was found in 1888 by Miss M. Dawber in a cultivated field near La Turquie, Vale; and I afterwards saw the specimen in her herbarium. This species occurs very rarely in Normandy, and only as an introduced plant.

\section{Aegopodium Podagraria, L.}

Goutweed.

Native. First found: Gosselin, I788.

Rare, but abundant where it occurs. Valley below Casrouge (Iv.). In four or five different places at St. Saviour's. Near King's Mills. In a farmyard at Lower Hubits. West side of St. Andrew's Churchyard. A specimen in Gosselin's herbarium is labelled: "Weed in my garden at Glateney, and in an orchard belonging to the Sieur Hocquard near the Vale Mill, and in a lane behind Mr. Carey's garden-house at the Beauregard.'

Formerly much cultivated for medicinal purposes, but a troublesome weed in gardens, and extremely difficult to eradicate; hence called in Ireland the Farmer's Plague. Gerarde says that 'the roots stamped and laid upon members that are troubled or vexed with the gout, swageth the paine, and taketh away the swelling and inflammation thereof.' 
Carum flexuosum, Fr.

Native. First found: Gosselin, 1788 .

Rare. Occurs in the central and southern districts of the island in many places, chiefly at St. Andrew's and St. Martin's, but, as a rule, only sparingly in each spor. This is the Bunium bulbocastaneum of Gosselin, who preserved specimens from the 'foot of the hedges and along the road between Mr. Brock's grounds and the Vauquiedor.'

In Normandy this plant is known under the name of Gênotte, which in Guernsey is applied to Romulea Columnae. The tuberous roots have somewhat the flavour of hazelnuts or chestnuts, and when boiled or roasted are said to be excellent eating. They are the 'pignuts' mentioned by Caliban in Tempest, ii. 2 .

(Pimpinella Saxifraga, L. Burnet Saxifrage. In Fl. Sarn. this plant is recorded for Guernsey, without specified locality, on the authority of $\mathrm{H}$. O. Carré. It has not been found by any subsequent observer; so that in the absence of specimens, and seeing that the plant does not occur in that part of France which lies nearest to these islands, the record requires confirmation.)

Sium angustifolium, L.

Native (?). First record: Babington, I839.

This species rests on the authority of Babington alone, who describes it in Fl. Sarn. as 'frequent in Guernsey.' I am not aware that it has been found by any one else It is also recorded in the same work for Alderney, but the plant does not occur in that island at the present time.

Bupleurum aristatum, Bart.

Native. First record: Babington, I839.

Rare. On the sandhills in several parts of Lancresse Common. Sandhills at Portinfer. Between Vazon Bay and Albecq. On Vazon Green, plentifully (Miss B. Agnew). The plant of these islands is the small form (var. nanum, Koch.), generally about an inch high or less, seldom two inches. Unless the flowers are expanded (during the first fortnight in June), it is very difficult to detect the plant among the surrounding vegetation. It is much more common in Alderney.

(Bupleurum tenuissimum, L., is marked for Guernsey in the list in Ansted's Channel Islands; but it cannot be admitted without further evidence. It is quite possible that it may have occurred here, as it is generally distributed, though rare, throughout Normandy.)

Bupleurum rotundifolium, L.

Hare's-Ear.

Casual. First found: Miss Agnew, 1900.

A specimen was discovered by Miss B. Agnew in an old, 
neglected garden at Hauteville during the summer of 1900 . This species, like Caucalis daucoides, belongs to calcareous soil, and is foreign to these islands.

Bupleurum protractum, Link.

Casual. First found: Miss Agnew, I900.

One plant was found growing in the same garden as the last species, to which it is closely allied, and for which it might easily be mistaken. It is extremely rare in Normandy.

Oenanthe fistulosa, L.

Common Water Dropitort.

Native. First found: Gosselin, I 788 .

In Gosselin's old herbarium there is a well-preserved specimen labelled 'Moist places at the Grand-Miles,' a locality which is better' known as Grandes Mielles. It was also found at the Vale in 1864 by Mr. E. Dupuy, as proved by a specimen in his collection. This species seems to have been confused with Oen. Lachenalii, for Gosselin adds another station where the latter is plentiful at the present time, viz., 'At foot of a hillock to $\mathrm{E}$. and near the house in Mare de Carteret.'

Oenanthe Lachenalii, Gmel.

Native. First found: Gosselin, I 788.

Local, but usually in good quantity where it occurs. Among rushes between Albecq and Vazon. Field near Grandes Rocques Hotel. Marshy meadow between Mare de Carteret and Cobo. $\mathrm{Mr}$. Andrews found in $\mathrm{I} 900$ one dwarfed plant in a dry field near Les Pelleys (virI.). This species is the Oen. pimpinelloides of Gosselin, and a specimen in his herbarium is labelled 'Wet ditches of the Clôture, and in one of the meadows there.' This locality would be somewhere at the north end of the Vale Road. Also under the name of Oen. pimpinelloides, this species is recorded in Fl. Sarn. as found by Babington near Long Port, and by H. O. Carré at Clos du Vale.

(Oen. Phellandrium, Lam., is given in Gosselin's list under the name Phellandrium aquaticum, Water Hemlock; but as the plant has not been found since, and no specimen exists in his herbarium, it must be regarded as a questionable record.)

Oenanthe crocata, L.

Native. First record: Babington, 1839.

Very common everywhere in the island on sides of streams and ditches.

The patois name of this plant is Pain-faie. Métivier, who spells the word Paim-feis, derives it from a Bas-breton root signifying five-fingers; and in the west of France the local name is Pimpin, which seems connected etymologically. This species is one of the most poisonous of our native plants, and many deaths have occurred 
from eating the roots, which smell and taste like parsnips. Cattle eat them whenever they can, but inevitably with fatal results, unless an antidote be administered immediately. In some parts of England this plant is called Dead Tongue, from its paralysing effects on the organs of the voice.

Aethusa Cynapium, L.

Colonist. First record: Gosselin, I8 I 5 .

Rather rare, but found in all parts of the island as a weed in cultivated ground, especially in gardens. As a rule, single individuals, or at most two or three plants, occur in each locality.

The patois name is Tue-lapin, literally kill-rabbit. It is a very dangerous plant, producing when eaten vomiting, giddiness, and frequently death. It closely resembles Parsley in foliage, but emits a nauseous smell when rubbed; when flowering, the long, pendulous bracts at once distinguish it from every other British umbellate.

Foeniculum officinale, All.

Fennel.

Denizen. First record: Gosselin, I8I5.

Common in the sandy ground of the north and north-west, but much less frequent in the interior and hilly parts, though found here and there in waste corners and near houses all over the island.

The patois name is Fanouć, allied to the modern French Fenouil, and the English Fennel. From time immemorial it has been used as a sauce or garnish for fish, especially salmon and mackerel. There was an old belief mentioned by Pliny, and adopted by many writers of the Shakespearean age, that this plant 'hath a wonderful propertie to take away the film or web that overcasteth and dimmeth our eyes.'

Crithmum maritimum, L.

Native. First found: Gosselin, I 788 .

Samphire.

Common all round the coast, on rocky cliff-sides, as well as sandy shores.

Called in the patois Perchepierre, the local form of its French name Percepierre. Prior says the word Samphire is more correctly written Sampier or Sampire, as it was dedicated to, and takes its name from, the fisherman saint, St. Peter (Saint Pierre). Shakespeare mentions the plant in the well-known passage in King Lear, iv. 6. When properly prepared, Samphire makes a most excellent pickle, as I can personally testify.

Pastinaca sativa, L.

Native. First record: Babington, I839.

Wild Parsnip.

All over the island in arable land may be found strays from cultivation, the Parsnip being extensively grown in Guernsey as food for cattle; and the roots often attain an enormous size. 'This form has glabrous leaves, which are shining on the upper side. The wild 
form, with pubescent leaves, especially beneath, is much less frequent. I have met with it at Les Mourants (viIr.), at Les Annevilles (VIr.), and on Cobo Castle Hill. Probably it is generally distributed.

Heracleum Sphondylium, L. Hogreed. Con Parsinip.

Native. First record: Gosselin, I8 I5.

Very common. Unquestionably the most abundant of all the Umbelliferae in the island.

The patois name is Caisse, a word closely allied to Cashrs, Kecksies, and $K e x$, which in various parts of England designate the dry, hollow stems of this and other umbelliferous plants. Shakespeare speaks of 'hateful docks, rough thistles, kecksies, burs,' in Henry V., v. 2. The French name is Branc-ursine. In the old days of the flint and tinder-box, the country people in Guernsey manufactured their own matches out of the dry stems of Hogweed, slit in narrow slips and dipped in sulphur. In my childhood I have myself seen such matches used.

Daucus Carota, L.

Wild Carrot.

Native. First record: Gosselin, I 8 I5.

Rather common inland; but I am not sure that exactly the typical form occurs: the plant, say, of the Midland counties.

Var. gummifer, Lam. D. maritimus, With. First record (as a species): Babington, 1839 . Very common all round the coast, and distinct enough when growing in rock crevices on the seashore, but away from the sea becoming connected with the type by intermediates, which it is not easy to assign to either. Watson says (Compend. Cyb. Brit., p. 520) that seeds of this form brought by him from Jersey, and sown in a Surrey garden, produced $D$. Carota only. Under the rumes of $D$. intermedius and D. Masclefii, Corbiere describes two forms which on the coast of Normandy connect the present variety with the type. Conf. Lloyd, Fl. de l'Ouest, ed. 3, p. I34; Townsend, Fl. Hants, P. I53; Corbiere, Nouv. Fl. Norm., p. 263.

This is the original stock of our garden Carrot, which was first generally cultivated in England in the reign of Queen Elizabeth. The name seems to have reference to the colour of the root, being derived from the Celtic word car, which means red.

Caucalis daucoides, $L$.

Casual. First found: Miss Agnew, r9oo.

Sinall Bur-parsley.

Several plants were discovered in an old, neglected garden at Hauteville during the summer of 1900 , by Miss B. Agnew.

Caucalis latifolia, L.

Great Bur-parsley.

Casual. First found: Miss Agnew, $\mathrm{x} 898$.

Very rare. One specimen in Rocquaine Bay in 1898 ; several in an old garden at Hauteville in 1900 (Miss B. Agnew). 
Torilis Anthriscus, Gaert.

Native. First record: Gosselin, 18 I 5 .

Upright Hedge Parsley.

Generally distributed throughout the island, and rather common. on hedgebanks and in waste places : seldom occurs in any quantity.

Torilis nodosa, Gaert.

Native. First record: Gosselin, 18 I5.

Rather rare: mostly found near the sea. Here and there all along the coast from Vazon to Lancresse and Fort Doyle. In the south in many places on the cliffs.

\section{Scandix Pecten-Veneris, L.}

Casual. First found: Gosselin, I 788.

Knotted Hedge Parsley.

Very rare. Shore at Grand Havre, two plants in $x 890$. One plant in a garden in the town, in the same year. Shore below the Vale Castle, one specimen in $\mathbf{I} 89 \mathbf{r}$. One or two in an old garden at Hauteville in 1900 (Miss B. Agnew). There is a specimen in Gosselin's herbarium labelled 'Field on a roadside behind the Rohais.' Babington does not record this species for Guernsey. The extreme rarity in these islands of a plant so abundant in southern England and in Normandy is very remarkable.

Chaerophyllum sylvestre, L.

Wild Chervil.

Native (?). First found: Derrick, I895.

Rare. Growing in some quantity in Lord De Sausmarez's grounds at the Catel, where it was found in $\mathbf{1} 895$ by Mr. G. Derrick. Also as a weed in a garden at Mount Durand. This plant is quite common in Alderney.

Chaerophyllum Anthriscus, Lam.

Native. First found: Gosselin, 1788.

Common in the north-west about Lerée and Richmond: less so along the remaining shores of the lowlands. It is the Anthriscus vulgaris of Fl. Sarn. and the Scandix Anthriscus of Gosselin, in whose herbarium there is a specimen from 'near the Long Store.'

Gerarde is loud in his praise of this plant, which 'exceedeth all other sallads by many aegrees ;' while, for old people, 'it rejoiceth and comforteth the heart, and increaseth their strength.'

Chaerophyllum temulum, L.

Native (?). First record: Babington, $\mathbf{r} 839$.

This species is noted for Guernsey, without locality, in the Fl. Sarn, but I have no other evidence of its occurrence. It is a very common plant both in Normandy and the south of England.

Conium maculatum, L.

Hemlock.

Native. First record: Gosselin, I8I 5 .

Rather rare, though generally distributed throughout the island. More frequent in the north than in the south. 
Called in the patois Chue, the same as in Normandy; but its more general French name is Cigrie. The Hemlock is one of the most powerful of our vegetable poisons, and in the words of an old herbalist, 'whosoever taketh it into his body dieth remedilesse.' One of the ingredients of the witches' cauldron, in Macbeth, was 'root of hemlock digged i' the dark.'

Smyrnium Olusatrum, L.

Alexanders.

Denizen. First record: Gosselin, I 8 I5.

Rather common in al! parts of the island. Some botanists have considered this species truly native in the Channel Islands, but, as it is not deemed indigenous in Normandy, I have classed it as a Denizen.

The patois name is Alisandre, clearly the same as Alexanders, whatever that may mean. In French it is called Maceron, and in Normandy it used to be grown under the name of Poivre. Pliny speaks of the plant as Olus atrum, or black potherb, perhaps from the black fruits. When raw, it has somewhat the flavour of celery, and was, in olden times, blanched in the same way, by being earthed up in growing.

Bifora testiculata, Spr.

Casual. First found: Miss Agnew, I900.

One or two specimens were detected, with other curious Casuals, in the summer of 1900 , by Miss B. Agnew in an old, neglected garden at Hauteville. This is a very peculiar Umbellifer, unknown in Normandy, and not found nearer these islands than the Bay of Biscay.

\section{ARALIACEAE.}

Hedera Helix, L.

Native. First record: Gosselin, I 8 I 5.

Very common everywhere. The oldest plant in the island is to be found at Ivy Castle. This venerable specimen, which is still vigorous, and covers a large portion of the ruined Castle, I measured carefully in July 1890 , and found the cylindrical trunk, at one foot above the ground, clear of branches, two feet four inches in circumference. Evidently it is of very great age, and has in later times given the name to the ancient ruin, which is properly called Le Château des Marais, or the Castle of the Marshes.

Called in the patois Yere or Hierre, a slight variation of the French name Lierre: in the northern parts of Normandy known as Gllain. It is generally beliered that Ivy is extremely injurious to the trees it entwines: thus Prospero says of his brother (Tempest, i. 2):-

'He was

The ivy which had hid my princely trunk And suck'd my verdure out on't.' 
But, as a rule, it seldom invests a tree closely until its vigour has from some cause begun to languish. This plant was dedicated to Bacchus, and it was customary in the Middle Ages to hang a bough of ivy over the doors of inns and taverns; whence arose the proverb: Vino bono non est hederâ, Good wine needs no bush.

Gunnera scabra, Ruiz. and Pav.

Locally, Wild Rhubarh. Alien.

Thirty or forty years ago this magnificent plant was entirely confined to private grounds: now it is thoroughly naturalised and has spread rapidly. It is seen at its best in the valley overlooking Moulin Huet Bay, where it expands enormous leaves and bears huge fruiting spikes two or three feet high and six inches thick. It is also to be found, though in less abundance, in several other valleys at St. Martin's, as well as here and there in various parts of the island. This gigantic plant is a native of Chili, and the following extract from Darwin's Voyage of the Beagle, under date Dec. I, I 834 , may be interesting to those who have never seen it growing:- ' On the large island of Tanqui, I one day noticed, growing on the sandstone cliffs, some very fine plants of the Panke (Gunnera scabra), which somewhat resembles the rhubarb on a gigantic scale. The inhabitants eat the stalks, which are subacid; they tan leather with the roots, and prepare a black dye from them. The leaf is nearly circular, but deeply indented on its margin. I measured one which was nearly eight feet in diameter, and therefore no less than twentyfour in circumference! The stalk is rather more than a yard high, and each plant sends out four or five of these enormous leaves, presenting together a very noble appearance.'

(Viscum album, L. Mistletoe. Miss B. Agnew informs me that about twenty years ago mistletoe used to grow on some old appletrees in an orchard behind Les Buttes, St. Saviour's, and she has often seen specimens picked there. There can be no doubt, however, that it was an introduced plant at that station. Five or six years ago I saw several tufts of mistletoe growing in Mr. Dawber's garden at Ruettes Brayes, but the seed had been intentionally sown. The plant is not mentioned in Gosselin's old list, nor in any later one that I know of; and it is significant that it has no patois name, although cartloads of it are brought to the island from France every winter. Viscum album has certainly no title to rank among the indigenous plants of these islands, though its absence is remarkable, seeing how abundant it is on the opposite portion of the French mainland. There it grows usually on apple-trees and poplars; occasionally it is found on a variety of other trees, very irarely on the oak.) 


\section{CAPRIFOLIACEAE.}

Sambucus Ebulus, L.

Dwarf Elder. Danewort.

Denizen. First found: Gosselin, I788.

Rare: plentiful where it occurs. On a hedge and in the field adjoining at $\mathrm{La}$ Tourelle (vi.). Bordering the roadside a little to the south of Le Gélé (viri.). Still flourishes in the old station recorded by $\mathrm{H}$. O. Carré to the north of Paradis. On the cliffs among bracken about half way between Moulin Huet and Saints Bay, covering a space a dozen yards square. In Gosselin's herbarium there is a specimen labelled 'Near La Maison au Comte to the $\mathrm{E}$. at the Clos du Vale. By the side of a hedge on the road between the watch-house at the Catel and Albec.' The former locality may possibly be the Paradis station: but in the second locality the plant is certainly now extinct.

The Dwarf Elder is known in Normandy under the name of Yible. In Norfolk it is believed to have been brought over by the Danes and planted on the battlefields and graves of their countrymen. The Welsh name is Plant of the Blood of Man.

Sambucus nigra, L.

Common Elder.

Native. First record: Gosselin, I 815 .

Common in all parts of the island.

The patois name is Seue as in Normandy: the French name is Sureau. The common belief that lightning never strikes an Eldertree perhaps accounts for its being so frequently found close to houses and cottages. In Wiltshire the people tell you that an elderwood stake will last in the ground longer than an iron bar of the same size.

Lonicera Periclymenum, L.

Honeysuckle.

Native. First record: Gosselin, I8I5.

Common in all districts. In I 894 I found a bush at the Vale still in flower in the month of December.

The patois name Suchets, derived from the verb suchier (French suçer) to suck, is very similar to the Normandy name Sucet, both terms conveying the same idea as the word Honeysuckle. In France the plant is generally called Cherrefeuille. It is the "woodbine' of the poets, especially those later than Shakespeare, and the 'twisted eglantine' of Milton.

\section{RUBIACEAE.}

Sherardia arvensis, L. Field Madder.

Native. First record: Gosselin, I $\delta$ I 5 .

Very common in all parts on dry banks, and as a weed in 
cultivated ground. Abundant on the cliffs. I have occasionally found plants with pure white flowers.

Asperula arvensis, $\mathrm{L}$.

Casual. First found: Miss Agnew, I900.

This plant was discovered among several other strange Casuals. by Miss B. Agnew in the summer of I900 in an old neglected garden. at Hauteville.

(Asperula cynanchica, I., the Squinancy-wort, occurs in Alderney.)

Galium Aparine, L.

Native. First record: Gosselin, 18 r 5 .

Goose-grass. Cleavers.

Generally distributed and rather common in hedgebanks and as a weed in cultivated ground. Often found on the shingle of the sea-beach.

In the patois this plant is called Gratteron, or sometimes La Couce (the tail) from the common amusement of country children to stick wisps, or 'tails,' of the plant on each other's backs on All Fools' Day: a custom also prevalent in the Midlands, where the plant is called Stick-a-back. The seeds have been recommended as a good substitute for coffee.

Galium Mollugo, L.

Native. First record: Gosselin, I8I5.

Common on banks and hedges everywhere.

Called in the patois Pain de Panpan, because the larvae of the Blood-nose Beetle (Timarcha laevis) feed upon it. A child will hold one of these prettv blue beetles in its hand and repeat: 'Panpan, mourte mé ten sang ou bien j'te tuerai' (Beetle, show me your blood or else I'll kill you) until the 'blood' exudes from the insect's mouth, and then it is set free. The patois name Controprinse has. been given me for the present plant, but I suspect it more correctly belongs to G. Aparine. In Normandy the Great Bedstraw is called Caille-lait blanc, and G. verum is Caille lait jaume, owing to their singular property of curdling milk.

Galium verum, L.

Native. First record: Gosselin, I8I 5 .

Yellow Bedstraze.

Common in the sandy pastures and commons of the lowlands, often growing in great profusion. The prevailing form is the var. littorale, Breb. Rare in the interior of the island and on the cliffs.

In some parts of England this plant is called Rennet or Cheeserennet, in allusion to its property of coagulating milk, for which purpose it was actually employed. Gerarde tells us that 'the people in Cheshire, where the best cheese is made, do use it in their rennet, esteeming greatly of that cheese above other made without it." 
Galium saxatile, I.

Heath Bedstran.

Native. First record: Babington, 1839.

Rare. Thinly scattered over the common near Fort Doyle, and also to the westward towards Fort Le Marchant. In Fl. Sarn. it is noted for Paradis, meaning, in all probability, the Fort Doyle locality. A much more common plant in Alderney.

Galium palustre, L.

Native. First record: Gosselin, I8I5.

Generally distributed, but rather rare, growing in marshy places and by ditches and streamlets.

(Galium uliginosum, L., is marked for Guernsey in Ansted's Channel Islands. Probably the last species was mistaken for it.)

*Rubia peregrina, L.

Madder.

Extinct.

Babington found this plant at the Vale, as noted in F\%. Sarn., but it has not been seen anywhere in the island for at least thirty years, and is now certainly extinct. It grows in one spot in Alderney, and has been recorded for Sark.

\section{VALERIANACEAE.}

Centranthus ruber, DC.

Red Valerian.

Alien. First record: Gosselin, I8 I5.

Established on walls in the town, and in other parts of the island : rather rare, but to be found in almost every parish. Gosselin gives it under the name of Valeriana nubra.

Valerianella olitoria, Moench.

Common Lamb's Lettuce.

Native. First record: Babington, 1839.

Generally distributed throughout the island, and rather common, but much less abundant than $V$. carinata, except in the extreme west. Both species often grow together, and are indistinguishable, except by the fruit. The $V$. locusta of Gosselin is the next species.

This plant has long been known in England as a salad herb, and also as a vegetable for the table, usually dressed like spinach. In France it is a favourite salad under the name of Mâche. Lamb's Lettuce is a translation of its old name Lactuca agnina, but it is also commonly called Cornsalad.

Valerianella carinata, Lois.

Keeled Lamb's Lettuce.

Native. First found: Gosselin, I 788 .

Very common on walls and dry banks, and also as a weed in cultivated land. This species has certainly quite as much claim to be considered native in this island as $V$. olitoria. In most parts of Continental Europe it is the commoner species of the two, though 
rare in England. A specimen in Gosselin's herbarium is labelled Valeriana locusta.

Valerianella dentata, Deitr. Narrou-fruited Lamb's Lettuce. Casual. First found: Miss Dawber, I888.

Several plants sprang up as weeds in Mr. W. Dawber's garden at Ruettes Brayes in I888. This plant occurs not uncommonly in Normandy, and I have found it in Alderney.

(Valerianella eriocarpa, Desv., occurs in Alderney.)

\section{DIPSACACEAE.}

Dipsacus sylvestris, L.

Wild Teasel.

Native. First found: Gosselin, 1788.

Rare. Fermain Valley. Petit Port. Saints Bay. Le Graie (vi.). Friquet (vili.). Cobo. Lihou Island. Les Goubais (Ix.). Near Vale Castle. The specimen in Gosselin's herbarium is from Petit Bot Bay.

In Normandy this plant is called Cardère and Peignes, terms which, like Teasel, allude to its use or fitness for dressing wool. One of its oldest names was Labrum Veneris, or Venus's Basin, from the hollows formed by the connate leaves being usually filled with water that was used to cure warts on the hands, and served as a beauty-wash for the face, besides being an efficacious remedy for bleared eyes.

Knautia arvensis, Coult.

Native. First record: Gosselin, I 8 I 5 .

Field Scabious.

Rare. I have seen this plant in about a dozen localities within a radius of a mile and a half from Le Chêne, Forest, but beyond that I have only met with it in a lane near St. George (viri.), where it grew sparingly. Var. integrifolia, C. and G. In a lane to the south of the old Caudré Mill, at St. Peter's.

(Scabiosa succisa, L., the Devil's-bit Scabious, is marked for Guernsey in the list in Ansted's Channel Islands, but it is very doubtful whether this species ever occurred here.)

* Scabiosa Columbaria, L.

Sinall Scabious.

Extinct.

Babington found this plant at St. Martin's sixty years ago, but it must long since have become extinct. It is unknown on the French coast nearest to these islands, and I have no other evidence of its. occurrence within this area. 


\section{COMPOSITAE}

Eupatorium cannabinum, L.

Native. First record: Gosselin, I8 I5.

Hemp Agrimony.

Generally distributed throughout the island, and common on the banks of streamlets, ditches, and other wet places.

An interesting incident connected with this plant is related in Ansted's Channel Islands (1865), p. I 77 : 'The Hempweed or Hemp) Agrimony (Eupatorium cannabinum), a common plant enough, was curiously recognised some time ago by some Bushmen from South Africa, who happened to be in Guernsey, as the material from which they obtain an intoxicating substance for smoking.'

Petasites fragrans, Presl.

Srvect-scented Coltsfoot.

Alien. First record: Babington, 1839.

Rather rare, though found in almost all the southern districts, usually in the vicinity of gardens and shrubberies, where it spreads rapidly, and is a troublesome weed to eradicate.

This is one of the very few plants that only blossom in midwinter; the flowers appear in November and December, and are deliciously fragrant, hence the common name Wild Heliotrope, in France Héliotrope d'hiver. The patois name is Pas d'âne, which properly belongs to Tussilago Farfara, but that species is too rare in the island to have earned for itself a local name. In some parts of Normandy the leaves are dried and smoked by the poor who cannot afford tobacco.

Tussilago Farfara, L.

Native. First found: Gosselin, I 788.

Common Coltsfoot.

Rare. Cobo Bay. Mont Crevelt. Quarry-heap by Vale Castle. Waste place in lane between the Upper Catel Road and Varendes. Specimens in Gosselin's herbarium are labelled 'Field east of Plaisance. Field above Ropewalk at Bouet. Field north-east of Catel Church.' The third of these localities seems to correspond with my last station above noted.

The Coltsfoot, known in France as Pas d'âne, has a very ancient reputation as a remedy for coughs and colds, and even now a decoction of the leaves in milk is used for the purpose in many rural districts in England.

Aster Tripolium, L.

Sea Starwort.

Native. First record: Gosselin, I8I5.

Rare. Marshes close to the Vale pond, in profusion. I saw many scores of plants in flower there in the autumn of 1899 .

Erigeron acre, L.

Bhe Fleabane.

Native. First found: Gosselin, I 788.

Very rare. Near Grandes Rocques, scattered over three or four 
adjoining sandy fields. Specimens in Gosselin's herbarium were found 'on a wall of the garden of the Vrangue, and in the fields east of the house of the Mare de Carteret.'

Erigeron mucronatum, DC.

Alien. First record: Marquand, I89r.

A Mexican plant, which has become thoroughly established on old walls in many parts of the town and suburbs. Abundant in Vauvert, and in the cross-lane between Victoria Road and Queen's Road. Carrefour au Lièvre, and just below on the wall over the boundary stream. Wall-tops at Hauteville and George Road, and below Swissville, Rohais. Wall of farm at Les Mauxmarquis in I 898 (Andrews). I have not been able to discover how or when this plant was introduced into the island, but it has been known here for at least thirty years. It flowers plentifully all through the summer and autumn, and I have seen it in blossom as late as the middle of December. The plant is not conspicuous, and the flowers attract no attention, being very like daisies.

Bellis perennis, L.

Native. First record: Gosselin, I8 I 5.

Very common everywhere.

Called in the patois Berbiette, or phonetically Berbi-yette, the diminutive of berbi (French brebis), possibly from the childish fancy that daisies resemble little sheep in the grass. In Normandy they are called Pâquerettes, or Pâquettes, and in France generally Marguzerites, a name only applied in Guernsey to the Oxeye. In the north of England there is a saying that "Spring has not arrived until you can set your foot on twelve daisies.' Its old English name, daieseyghe, apparently alludes to the opening and closing of the flowers with the daylight. Chaucer calls it-

'The Daisie, or else the Eye of Day,

The Empresse and Flowre of flowres all.'

Inula Helenium, L.

Elecampane.

Alien. First record : Marquand, I89 I.

Very rare. In I 89 I found this plant growing in some quantity and flowering freely at the back of an ancient farmhouse between Les Goubais and Rocque Maingy, at the Vale. The farm people itold me the plant had grown there ever since they could remember. I have seen the plant, without flowers, near St. Peter's Arsenal, and (evidently planted) at Les Marchais (vi.). The medicinal virtues of this plant were celebrated by the monkish herbalists in the line, 'Enula campana reddit praecordia sana,' and the name Elecampane is a corruption of the two first words.

Inula Conyza, DC.

Native. First found: Gosselin, 1788.

Ploughman's Spikenard.

Very rare. On a walltop on the high road at St. Martin's a little 
beyond Carrefour au Lièvre, about six or eight plants in 1892 , and again a few in the same spot the following year. There is a specimen in Gosselin's herbarium labelled, 'Hill above Moulin Huet, to left or north.' Babington found this plant at Fort (ieorge in 1838 .

Inula crithmoides, L.

Native. First record: Gosselin, I8 15.

Golden Samphire.

Rare. Miellette Bay, and in the old quarry close to Fort Doyle. Rocks at Pezeries, Rocquaine. Base of the cliffs at Petit Port, sparingly. Mr. Cecil Andrews has found it growing rather commonly, and in some places in abundance, all along the southern cliffs from Jerbourg to Pleinmont, but low down, and often not easy of access.

*Pulicaria vulgaris, Gaert.

Lesser Fleabane.

Extinct.

This species is mentioned in Gosselin's list, and a specimen in his herbarium bears the following note: 'Grows at the entrance of the Jaonès, near the Cloture wall, and in such places as are plashy or wet in winter.' From this it would appear that the plant was not uncommon a century ago. In Fl. Sarn. it is recorded as found in the Braye du Vale by S. H. Haslam. No trace of it has been seen. for many years, and it is almost certainly now extinct.

Pulicaria dysenterica, Gaert.

Native. First record: Gosselin, I8 5 .

Great Fleabane.

Common all over the island in wet places and moist meadows.

The patois name of this plant is Coummaire, so called because, according to Métivier, 'les sages-femmes (en Espagnol comadres) en faisaient autrefois un remede souverain.' In France it is known as Pulicaire.

Filago germanica, L.

Native. First record: Gosselin, 1815.

Common Cudrueed.

Rather rare, and somewhat local : occurs more frequently in the western parishes. Not uncommon at the Vale. Varies greatly in size. On the cliffs at Jerbourg and elsewhere there is a dwarf form only an inch and a half high: and $I$ once found a specimen near L'Etiennerie (vili.) measuring fourteen inches.

This plant was formerly called Herb Impious, because the younger flowers overtop the older ones. Ray, in r670, writes of this plant: 'Herba impia jumentis ruminantibus utile existimatur ad rumen amissum revocandum, unde nomen Cudzeed apud nostrates indeptum est.' The French name is Cotonniere.

Filago minima, Fr.

Native. First record: Marquand, I89I.

Slender Cudweed.

Frequent on the cliffs at St. Martin's and the Forest, and on several parts of Lancresse Common. 
Gnaphalium luteo-album, L.

Native. First record: Gosselin, 18 I 5 .

Rare, except in the north, where it occurs rather frequently in old quarries and waste places as well as on roadsides : occasionally in cultivated ground. Not uncommon about L'Islet. In I89I I saw this plant in immense profusion (thousands of very fine specimens) in a cultivated field behind the Hermitage, Lancresse : the following year it only occurred there sparingly. On the eastern side of the Vale it is rare, but $I$ have seen it near the Vale Castle and at Spur Point. Mr. Andrews found it in 1899 in a garden at Albecq.

Gnaphalium uliginosum, L.

Marsh Cudzeed.

Native. First record: Gosselin, r815.

Rather common in all parts of the island on roadsides and in damp corners and fields.

Antennaria margaritacea, R.Br.

Casual. First found: Miss Agnew, I898.

Pearly Everlasting.

Very rare. A single specimen, probably a garden escape, was found in 1898 , near Profond Val, St. Peter's, by Miss B. Agnew. In Hooker's Student's Flora (I870) this species is erroneously stated to be naturalised in Guernsey. I have seen specimens from Jersey, but this is the only instance known to me of the occurrence of the plant in Guernsey.

Achillea Millefolium, L.

Yarrow.

Native. First record: Gosselin, 1815.

Very common everywhere.

Called in the patois Querpentiere, the feminine form of the word for carpenter, corresponding with its French appellation Herbe aux Charpentiers, and its old English name Carpenter-grass. Yarrow was highly valued in olden times as a vulnerary; and Gerarde tells us that with this plant Achilles cured the wounds of his soldiers. In Normandy it is called Hure de loup.

Anthemis arvensis, L.

Corn Chamomile.

Colonist. First record: Babington, I839.

I have only met with this species in a few places in the interior of the island, chiefly in cultivated fields: possibly, however, it is really less rare than it would seem.

Anthemis Cotula, L.

Colonist. First record : Gosselin, I8I5.

Stinking Mayzeed.

Rather common in cornfields and other cultivated ground in the south and west: apparently less so in the northern districts.

The patois name is Méroque, evidently another form of Amroque, under which Matricaria Chamomilla is locally known: the names, howeve1, are probably interchangeable, as the two plants would 
certainly not be distinguished by the country people. The French name of the present species is Maroute.

Anthemis nobilis, I.

Native. First record: Gosselin, I8 I 5 .

Common Chamomile.

Rather common in all parts of the island, especially near the sea.

Known in the Guernsey patois by the name of Camiere; in Normandy called Camomille or Camomille romaine. Formerly it used to be planted in garden walks so as to be odoriferous to the tread: and in Henry IV., First Part, ii. 4, Falstaff quotes an old proverb affirming that ' the more it is trodden, the faster it grows.' According to an ancient writer a drooping and apparently dying plant will revive if placed near Chamomile.

\section{Matricaria Parthenium, L.}

Alien. First record: Marquand, I89r.

Feverfew.

Talbots Valley, a few plants in I890, evidently garden outcasts, and without any title to a place in the Flora. But Mr. Andrews has since found the plant fairly well established in the valley below Les Issues (vir.). It used to spring up as a weed all over my garden at Fermain House.

The term Feverfew, or, as it is often called Featherfew, is a corruption of febrifuga, one of the old names of this plant, which, according to the herbalists of the Middle Ages, was 'good to expell feavers and agues.' Its smell is peculiarly offensive to bees.

Matricaria inodora, L.

Native. First record: Babington, I839.

Scentless Mayweed.

Generally distributed and rather common on waysides, borders of fields, and waste spots. Var. maritima, L. Found by $\mathrm{Mr}$. Andrews at two or three places at the Vale. Probably not uncommon.

Matricaria Chamomilla, L.

Colonist. First record: Gosselin, I 8 I 5.

Rather common in cultivated and waste ground, especially in the low-lying districts.

The patois name is Amroque, a contraction of the word Amourôques, by which this species (in common with $M$. inodora and C. Leucanthemum) is known in some parts of Normandy. I am not aware that the meaning or derivation of this name has been traced.

Chrysanthemum Leucanthemum, L.

Native. First record: Gosselin, 18 I 5 .

Common throughout the island, but particularly plentiful on the southern cliffs.

The patois name is Margucerite, which in France belongs to the Daisy, but in Guernsey to the Oxeye. Many Composites with white ray florets, 'a silver shield with boss of gold,' were in olden times 
believed to possess special virtues, and were employed medicinally, 'quod morbis mulierum uterinis medeantur.' The ailments for which they were efficacious were supposed to be under the particular care of St. Margaret of Cortona: hence the name Margaret, or Marguerite.

Chrysanthemum segetum, L.

Colonist. First record : Gosselin, I8 15.

Corn Marigold.

Rather rare, though occasionally found in great abundance. I have seen it in nearly every parish, but often only single plants.

In the patois this plant is called Murlu, the local equivalent of ' as yellow as gold' being 'jaune coumme du murlu.' Métivier traces the word from roots which signify 'l'herbe mélancolique, soucieuse, le souci,' thus connecting it with the Marigold, which in French is called Souci, but in Guernsey Soucique. The very similar name Mullu is used for $C$. segetum by the people in the north of Normandy, C. Leucanthemum being distinguished as Mullu blanc. The Corn Marigold is called in France Chrysanthème.

(Diotis maritima, Cass., the Cotton-weed, has been found in Alderney.)

Artemisia Absinthium, L.

Wormwood.

Denizen. First record: Gosselin, I8I5.

Rare. Frequent along the coast west of Rousse Martello Tower. Coast at Pulias, sparingly. Scattered plants near Rocquaine Bay, near Vale Castle, near the Gouffre, and in the valley below Les Issues (vir.). In these last stations perhaps garden escapes.

Called in the patois Alliene, and in the French Absinthe. This plant is one of the most intense of vegetable bitters, and derives its name Wormwood from having been employed as a vermifuge. Its German name, Wermuth, is applied to a beer made from it, and to a liqueur called in France Vermouth. Wormwood is mentioned by the garrulous old nurse in Romeo and Juliet, i. 3 .

Artemisia vulgaris, L.

Mugwort.

Native. First record: Gosselin, I8I 5.

Rather rare. Found in all districts in waste places and old quarries, but more commonly in the north of the island.

In Guernsey, as in Normandy, this plant is called Herbe St. Jean : the more general French name being Armoise. The term Mugzoort is said to be derived from an old English word signifying a maggot or moth, the plant being supposed to ward off the attacks of insects. An allied species, $A$. Dracunculus, is the Tarragon of our gardens, in French Estragon.

Tanacetum vulgare, $\mathrm{L}$.

Tansy.

Native or Denizen. First record: Babington, I 839.

Rare. Near St. Saviour's Church. Naftiaux Valley, and near 
St. Helena (II.). Les Falaises and near Les Villets (IV.). Paysans Road and Les Marchais (vi.). Near Bordeaux Harbour.

In French Athanasie, now contracted to Tanacée and Tanassie, whence our English name. Three centuries ago this plant used to be sold in England under the name of Athanasia, the Greek word for immortality; and an old writer says it was so called because the oil or juice extracted from it would preserve a dead body from putrefaction. Tansy was formerly much eaten in Lent, as the representative of the bitter herbs; and Tansy pudding used to be a favourite dish.

Senecio vulgaris, $L$.

Common Groundsel.

Native. First record: Gosselin, I8 I5.

Very common everywhere. Var. radiatus, Koch. Western end of Vazon Green. Perelle Bay. Sablons and Lerée. Rocquaine Bay. Mr. Andrews notes this variety as plentiful all along the south cliffs.

The patois name is Sinchon, a corruption of the French Senegon, which, like Senecio, is derived from the Latin senex, an old man. It was thus named, we are told, 'because the flower of this herbe hath white hair, and when the winde bloweth it away, then it appeareth like a bald-headed man.'

Senecio sylvaticus, L.

Mountain Groundsel.

Native. First found: Gosselin, I 788 .

Common throughout the island on dry banks and waste spots, especially near the sea. Abundant on the cliffs. Specimens in Gosselin's herbarium show that he named this species S. viscosus.

Senecio erucifolius, L.

Hoary Ragzort.

Casual. First record: Gosselin, I 8 I5.

Very rare. One plant on the shingle at Lerée Bay in 1890 . One in Rocquaine Bay in 1898 (Miss B. Agnew). The name is in Gosselin's list, but there is no specimen in his herbarium.

Senecio Jacobaea, L.

Common Ragwort.

Native. First record: Gosselin, 1815.

Very common in meadows and pastures, and on waste ground Var. flosculosus, Jord. One plant in Petit Bot Valley in 1898 (Miss B. Agnew).

Called in the patois Meque, a word which also signifies the wick of a lamp or candle (French, mèche). Métivier thinks the plant takes its name from the silky pappus of the fruit, which might serve for wicks: but this explanation is hardly satisfactory. 'The French name of the plant is Jacobée.

Senecio aquaticus, Huds. Marsh Ragwort.

Native. First record: Marquand, r89 I.

Rare. Marshy fields near Ivy Castle. Wet meadows near Les 
Arguillers (IX.). Fields at Pont Vaillant. Babington found in the marshes behind Ivy Castle a plant which in Fl. Sarn. he separates from this under the name of Senecio erraticus, Bert., and remarks. that it "differs from the true S. aquaticus, Sm. Huds., in several particulars. . . . It is found in various parts of England." Hooker says S. erraticus, Bert., is a large state of $S$. aquaticus.

(Senecio paludosus, L., is recorded for Guernsey in Fl. Sarn. on the authority of Prof. La Gasca. Certainly an error. La Gasca published a list of Jersey (not Guernsey) plants in 1839 , and his name is quoted frequently for that island in Fl. Sarn.)

(Calendula arvensis, L. Wild Marigold. In the Report of the Watson Botanical Exchange Club for I890-9 I the following note occurs :- 'Calendula arvensis, L. (?) St. Sampson's, Guernsey, 27 May, I890. M. Dawber. Correct: A. Bennett.' I was botanising with Miss Dawber when this plant was gathered. It grew on a rubbish heap by the Tramway shed between Spur Point and Mont Crevelt: there was plenty, and we each took specimens. But I distinctly remember satisfying myself that we had found, not $C$. arvensis but $C$. officinalis, the common kitchen Marigold, which is abundantly cultivated in the island for culinary purposes. And I also remember expressing my surprise to Miss Dawber when I learnt that it had been passed as arvensis.)

*Bidens tripartita, L.

Trifid-leased Bur Marigold.

Extinct.

The drainage of large tracts of marshy ground during the early part of the century accounts for the loss of this and several other plants, but we have evidence of the former occurrence of this species by the preservation in Gosselin's old herbarium of a specimen labelled 'In a small pond near Abraham Robert's house in the lower part of the Catel.' This plant was perhaps already extinct when the Fl. Sarn. was compiled.

Carlina vulgaris, $\mathrm{L}$.

Native. First record: Gosselin, 1815.

Rare. Lancresse Common, towards Fort Le Marchant, plentiful. Cliffs near Moulin Huet and towards Petit Port, sparingly. Hill by the Trinity signal post at Rocquaine.

This plant was named after the Emperor Charlemagne, whose army, tradition says, was miraculously cured by its agency of a horrible pestilence which broke out during one of his wars.

Arctium minus, Schk.

Lesser Burdock.

Native. First record: Gosselin, 1815.

Generally distributed, and frequent in waste corners throughout the island. 
The patois name of the Burdock, according to Métivier, is Botiillas, and he adds: 'Les enfants se jettent, les uns aux autres, ses glouterons hameçonnés,' which recalls the remark of Pandarus in Troilus and Cressida, iii. 2: 'They are burs, I can tell you: they'll stick where they are thrown.' And again in Measure for Measure, iv. 3: 'I am a kind of bur, I shall stick.' Elsewhere Shakespeare calls the plant Hardock, as in King Lear, iv. 4. In Normandy it is called Gloutonnier, but the more general French name is Bardane.

Arctium intermedium, Lange.

Native. First found: Andrews, 1900.

Rare, or perhaps overlooked as .4 . mimus. A plant identified as belonging to this species was found at Fort George by Mr. C. Andrews during the summer of 1900 .

(Arctium nemorosum, Lej., occurs in Alderney.)

Centaurea nigra, $\mathrm{L}$.

Native. First record: Gosselin, 1815.

Black Knnapreed.

Common throughout the island. The rayed form ( $C$. pratensis, Thuill., not the true var. decipiens, though sometimes mistaken for it) is generally distributed, but much less common than the type. The reverse is the case in Alderney, where the radiant form prevails. With cream-coloured flowers (var. pallens, Koch.) on the cliffs between the Gouffre and the Corbiere (Andrews).

In the patois called Herbe de Flon, the word flon signifying a boil or wen. Under this word, Métivier, in his Dictionnaire FrancoNormand (I 870), says: 'C'est aussi chez nous l'erysipèle: et voilà pourquoi la jacée (Centaurea nigra) est le mate-felon des anglais, mot français qu'ils tiennent de nous.' In Normandy this plant is known as Têtards, a term corresponding to the local English name. Hardheads, and allied to the patois word têtu, obstinate.

Centaurea Cyanus, L. Com-flower. Blue Bottle.

Casual. First record: Gosselin, 1815 .

Very rare. A few plants in 1890 in a cultivated field near the Vale Road. One or two near Rocques Barrées (IX.) in the same year. In I 893 a plant or two in a field near Swansea Villa, Vale.

This beautiful flower, the Kaiser-blume of Germany, is known in Normandy by the name of Bleuts, a word allied to our own Blue Bottle, both doubtless alluding to the fact that the expressed juice of the petals dyes linen a beautiful blue, though the colour is not lasting. In the olden days this plant was called Hurt Sickle, because, says Gerarde, 'it hindereth and annoyeth the reapers by dulling and turning the edges of their sickles in reaping of corne.'

(Centaurea Scabiosa, L., the Great Knapweed, and C. solstitialis, the Yellow Star Thistle, are both given in Gosselin's list, but there is 
no other evidence of their occurrence in this island. The latter may have occurred as a Casual; the former grows plentifully in Alderney.)

Centaurea Calcitrapa, L. Common Star Thistle.

Casual. First found: Miss Dawber, 1894.

Very rare. One specimen was found on the Vale Castle quarryheap in 1894 by Miss M. Dawber, and another in 1899 , at St. Saviour's, by Mr. H. Le Lacheur.

\section{Centaurea aspera, L.}

Denizen. First found: Gosselin, I 788.

Local and rare. Grows in considerable quantity on the Green at the eastern side of Vazon Bay, and in the adjacent fields, spread over two or three acres of ground. It grew here in Gosselin's time, more than a century ago, as a specimen in his herbarium is labelled 'Centaurea Isnardi: field to the east of the house of La Grande Mare.' In Guernsey the plant is confined to this locality; in Alderney it occurs in at least two places, and in Jersey it is more plentiful, but was apparently unknown in Babington's time, as he says in Fl. Sarn. that this species is "not a native of Jersey, although said by Mr. Dickson to have been sent to him from that island.'

\section{* Onopordum Acanthium, L.}

Cotton Thistle. Extinct.

A specimen of this handsome plant is preserved in Gosselin's herbarium, labelled 'Close to and south of the house of the Quartiers, at St. Sampson's.' There is no evidence of its occurrence in this island in later times. In Fl. Sarn. it is only noted for Jersey.

Carduus nutans, L.

Musk Thistle.

Native. First record: Babington, 1839.

Local. Frequent on St. Martin's Cliffs. Also frequent on the Vale coast. Occasional in the lowlands of the north-ivest. Pleinmont.

According to Prior this is the true Scottish Thistle, the national badge of Scotland. But in the opinion of Gardiner, author of the Flora of Forfar, the real Scotch Thistle is Carduus lanceolatus, although Onopordum Acanthium is cultivated as such in Scotland. Bentham says $O$. Acanthium is 'certainly not wild in Scotland, although generally selected to represent the Scotch heraldic Thistle.'

Carduus crispus, L.

Native (?). First found: Gosselin, I788.

Welted Thistle.

A specimen of this plant, preserved in Gosselin's herbarium, is labelled 'Near the Long Store, and at Lancresse and Vazon Bay.' It does not appear to have been noticed in the island by any one 
else; but a thistle which grew in three such widely separated stations ought still to be found.

Carduus tenuiflorus, Curt. Slender-flowered Thistle.

Native. First record : Babington, 1839 .

Common in the low-lying districts, especially near the sea. Less frequent in the south.

Carduus lanceolatus, L.

Spear Thistle.

Native. First record: Babington, I839.

Common throughout the island on dry banks and in waste places and the borders of fields.

The pappus of the fruit, or 'thistledown,' makes an excellent stuffing for pillows and cushions. Withering says the flowers have the property of curdling milk.

Carduus arvensis, Curt. Creeping-rooted Thistle.

Native. First record: Gosselin, I8r5.

Generally distributed and common in cultivated and waste ground, and on roadsides. It is the Serratula arvensis of Gosselin. Var. setosus, Bess. Garden in Grange Road, I897 (Lukis). Roadside near King's Mills, nearly twenty plants in 1899 (Andrews). This variety is so different from the type that it might readily be taken for a distinct species.

Carduus palustris, L.

Marsh Thistle.

Native. First record: Gosselin, 1815 .

Common in all parts of the island in wet meadows and marshy places in general.

(Carduus eriophorus, L., the Woolly-headed Thistle, and C. acaulis, L., the Dwarf Thistle, are included in Gosselin's list, but there is no confirmatory evidence of their occurrence in Guernsey. C. acaulis grows plentifully in Alderney, and, as several other Alderney plants are given in the o?d list, it seems probable that Gosselin intended it as a catalogue of the plants of the entire Bailiwick, so far as he knew them, and not of Guernsey alone).

Silybum Marianum, Gaert.

Milk Thistle.

Casual. First found: Miss Dawber, 1893.

Very rare. Several plants were noticed in waste ground in a garden at Ruettes Brayes by Miss Dawber in $\mathbf{1 8 9 2}$; and in the same year I found a single plant in a cultivated field near Woodlands. In $1890 \mathrm{Mr}$. Andrews found a specimen in a quarry near Le Jardin (viII.).

This handsome plant is also known under the name of Lady's Thistle, or more properly Our Lady's Thistle, from its being dedicated to the Virgin Mary: and an ancient legend accounts in a 
very pretty way for the origin of the milk-white veins which characterise the leaves.

Lapsana communis, L.

Native. First record: Gosselin, I8 5 .

Nipplewort.

Generally distributed throughout the island, and rather common in cultivated and waste ground.

Its French name, Herbe aux mamelles, is the exact equivalent of our Nipplewort. Pliny tells us that Caesar's army lived upon the roots of this plant for a long time at Dyrrhachium, after which lapsana vivere passed into a proverb, signifying to fare hard.

Cichorium Intybus, L.

Native (?). First record: Gosselin, 18 r 5 .

Rare. Scattered plants, mostly single individuals, have been found in a great many places, and in almost all the parishes. The largest number I have seen at once were growing in a sloping field below Ozanne's Mill in 1893 , where I counted more than a dozen.

This plant is extensively cultivated on the Continent for the sake of its roots, which are ground and used to mix with coffee. The young leaves are eaten as salad; and cows fed upon them increase their yield of milk. The Arabic name of the plant is said to be Chikouryeh, whence our word chicory.

Hypochoeris glabra, L.

Smooth Cat's Ear.

Native. First record: Babington, 1839.

Rather common on the cliffs at St. Martin's and the Forest. In dry turfy places at the north of the island. Var. Balbisii, Lois., Pleinmont (Miss B. Agnew).

Hypochoeris radicata, $\mathrm{L}$.

Native. First record: Gosselin, r 8 15.

Very common throughout the island.

Known in the patois by the name of Piat Laitron, literally flat Sowthistle, from the leaves spreading close to the surface of the ground. The French name is Porcelle. We are informed by Gerarde that 'the root and leaves tempered with honey and made into little cakes, with nitre or saltpetre added to them, cleanse away the morphea, sunburnings, and all spots of the face.'

Thrincia hirta, DC.

Native. First record: Babington, 1839.

Hairy Hazkbut.

Very common all round the coast, on the cliffs, and on the sanddunes of the lowlands.

Leontodon hispidum, L.

Native. First record: Gosselin, 18r5.

Rather common, but apparently more frequent in the low-lying districts than in the south. 
Leontodon autumnale, L. Autumnal Hawkbit.

Native. First record: Gosselin, I815.

Generally distributed and rather common in pastures, and on commons and waste ground.

Tragopogon porrifolius, L. Purple Goat's-beard. Salsify. Casual. First found: Marquand, I900.

One plant well in flower in a potato-field on the road from St. Sampson's Bridge to Bordeaux. This species is naturalised in Alderney.

(Tragopogon minor, Fr., Yellow Goat's-beard, occurs in Alderney.)

(Picris hieracioides, L., Hawkweed Oxtongue, is mentioned in Gosselin's list, but that probably refers to its occurrence in Herm, where it is scarce, or else in Alderney, where the plant is locally plentiful. There is no evidence that it ever grew in Guernsey.)

Helminthia echioides, Gaert.

Bristly Ox-tongue.

Native. First record: Gosselin, 18r5.

Local and rare. Coast by the Vale Castle, in plenty. Lane behind Hougue du Pommier (viIr.). Near the Vale Road Nurseries. Grosse Hougue (x.), plentiful in one place.

(Lactuca virosa, L., the Strong-scented Lettuce, is mentioned in Gosselin's list, but a specimen so named in his herbarium is a luxuriant form of Sonchus asper. It is possible, however, that the true plant has occurred in the isl.nd, as I find in an annotated copy of the Filora Sarnica which belonged to Major H. Smith, a botanist residing in Guernsey about the year 1860 , the following note opposite this species: 'Border of a field between Torteval and Pleinmont, and on a bank near Cambray.' On a blank page in the same volume is written: 'Lactuca virosa. I am inclined to think this plant is not indigenous, although Mr. Field has informed me that six years since he saw it growing near the place where I found it at Cambray.')

Taraxacum officinale, Wigg.

Dandelion.

Native. First record: Gosselin, 18I5.

Generally distributed and common. Var. erythrospermum, Andrz. In several places on the Vale coast. Var. palustre, DC. Between King's Mills and Grande Mare. Roadside, Hubits, St. Martin's. Var. laevigatum, DC. Found by Babington at the Vale.

This plant is called in the patois Hôloges, the local form of the French horloges, clocks, from the children's method of telling the hour by blowing away

'What look'd a flight of fairy arrows aim'd

All at one mark, all hitting.' 
The word Dandelion, derived from the French dent de lion, has been deemed inappropriate, inasmuch as the leaf in no way resembles the tooth of a lion or any other animal. But if we suppose the name to have been originally written in the plural, dents de lion, its fitness becomes apparent at once. It is curious that the plant bears a similar name in many European languages.

\section{Sonchus oleraceus, L.}

Common Soze-thistle.

Native. First found: Gosselin, r788.

Common throughout the island in cultivated and waste ground. A specimen in Gosselin's herbarium is labelled Sonchus laevis.

The patois name, like the French, is Laitron, a word which suggests its milkiness, hence its local English name Milk-thistle. An old Latin name of this plant was Lactuca leporina, or Hare's Lettuce; and we are told that 'Yf a hare eat of this herbe in somer when he is mad, he shal be hole.' Sow-thistles were formerly valued for their sprouts, which were eaten as a lettuce.

Sonchus asper, Hoffm.

Native. First found: Gosselin, 1788.

As widely diffused as the last species, but less common. I have noticed the var. glandulosus, C. and G., in Alderney.

Sonchus arvensis, L.

Native. First record: Gosselin, I 8 I5.

Rather common in cornfields and cultivated ground : occasionally found on the seashore, among the shingle.

(Sonchus palustris, Marsh Sow-thistle, is given in Gosselin's list, but as there is no specimen bearing this name in his herbarium it is impossible to say what plant he meant. It was certainly not the true Sonchus palustris, L..)

Crepis virens, L.

Native. First record : Gosselin, I8 I 5.

Common in all parts of the island. A very variable plant. The slender, diffuse, small-flowered form of Lancresse Common and the dry cliffs (var. diffusa, DC.) is quite unlike the type: yet the large erect form has been raised from the seeds of difficsa. Var. agrestis, W. and K. I have seen this variety in Guernsey in several places, but have kept no note of the stations. In 1898 Miss B. Agnew found it near Caudré Mill (vi.) and near Pleinmont Watch-house.

Crepis biennis, L.

Colonist. First record: Marquand, $\mathbf{1} 89 \mathbf{r}$.

Large Rough Hauksbeard.

Very rare. Hedge near the Catel Fairfield, a good many plants in 1890 . Main road towards Vazon, many plants on the roadside in 1894 . 
(Crepis taraxacifolia, Thuil. occurs in Alderney.)

Hieracium Pilosella, L. Mouse-ear Hawkweed.

Native. First record: Gosselin, I 8 I 5.

The commonest form in the island is the var. Peleterianum, Mer., which occurs abundantly on many parts of the cliffs. Babington only records this variety in Fl. Sarn., adding the remark, 'the ordinary form of $H$. pilosalla has not as yet been noticed in these islands.' The type does occur, however, in many parts of Guernsey, though not commonly. It is more plentiful in Alderney.

The French name, Epervicre, like Hawkweed, Hawkbit, and Hieracium (Greek, hierax, a hawk) suggests some sort of connexion between these plants and birds of prey; but I have not been able to discover any satisfactory explanation. The most commonly accepted derivation is the ancient belief that with these herbs hawks were in the habit of clearing their eyesight.

Hieracium umbellatum, L. Narroz-leaved Hazekweed.

Native. First record: Gosselin, I8I5.

Local and rare. Occurs in many lanes and heathy places at the Vale and (sparingly) on Lancresse Common. Also occurs in good quantity on the rocky shores of Cobo, on Cobo Castle hill, and in hedgebanks in the neighbourhood. The station given in Fl. Sam., 'Rocque du Guet,' probably means Cobo Castle. The only locality I know for this plant in the south is in the water-lane behind Le Chêne (Iv.), where I saw a few plants in r893. Mr. Andrews has found it on Lihou Island. A very tall form (four feet high) was found by Miss Dawber in I89I on a heath near Ruettes Brayes. $\mathrm{Mr}$. Andrews has collected specimens belonging to the var. littorale, in a lane near Fort Doyle.

(Under the name of Hieracium laevigatum, Willd. Koch., Babington describes in Fl. Sam., p. 58, a plant which I have not been able to identify with certainty. He records it as being found by him near Grand Havre, Guernsey, and also in Jersey; and remarks that 'the form of the leaves and the outer scales of the involucrum appear to distinguish this plant from both $H$. subaudum and boreale, and the adpressed involucral scales with pale margins separate it from $H$. umbellatum.' I am not aware that any plant answering this description has been found here since. Mr. F. J. Hanbury inclines to the opinion that it was some form of $H$. rigidum, Hartm. In all probability it was merely a Casual.)

Xanthium spinosum, L.

Casual. First found: Derrick, 1890.

A single specimen of this plant was found by Mr. G. Derrick in September 1890 , on the quarry heap by the Vale Castle. 


\section{CAMPANULACEAE.}

Jasione montana, L.

Native. First record: Gosselin, I 8 I 5 .

Sheep's-bit.

Very common on dry banks and sandy waste spots: abundant on the cliffs. Occasionally with nearly white flowers.

(Wahlenbergia hederacea, Reich., the Ivy-leaved Bell-flower, is marked for Guernsey in the list in Ansted's Channel Islands. Certainly an error.)

Trachelium coeruleum, L.

Bhue Throatwort.

Alien. First found: Brown, 1892.

Very rare. A Mediterranean plant first recorded for Guernsey in Journ. Bot., I 892, p. 346, by Mr. J. Cosmo Melvill, who received specimens from Mr. A. Buchanan Brown. The plant was described as 'abundant at the outskirts of St. Peter's-Port, in one or two contiguous places, on old, high, and somewhat ruinous walls.' Mr. Brown counted at least 150 blooms on August 16 th, and had known the plant to exist in the same profusion for quite sixteen years. In 1893 Messrs. Derrick and Royle found the plant growing on the wall of Candie Cemetery Lane, and in 1900 I counted quite a hundred plants upon that wall. I do not know whether this is Mr. Brown's station; if not, I strongly suspect it to be in enclosed private grounds.

\section{ERICACEAE.}

Calluna vulgaris, Salisb.

Native. First record: Gosselin, I8I5.

Heather. Ling.

Rather common on the cliffs: less so on the shore of the lowlands. I have found it still flowering in December.

It is not generally known that briar pipes are manufactured out of the root of a species of Heather which grows in profusion on the rocky slopes of the Tuscan Alps in North Italy, and in Corsica. The word briar (more correctly written brier) is a corruption or rather an anglicised form of the French word bruyere, which signifies heath.

Erica cinerea, L.

Native. First record: Gosselin, I8I5.

Very common on the cliffs, and in suitable places all round the north and north-west coast. Occasionally on banks and hedges in the interior of the island. Pure white flowers have been found at Cobo. In mild seasons this plant continues to blossom all through the winter months. 
Pyrola rotundifolia, $\mathrm{L}$.

Native. First record: Babington, 1839 .

Round-leazed Wintergreen.

Very rare. Confined to Grande Mare, where scattered plants occur all over the marsh. In Bot. Exch. Club Report, i881, p. 83, specimens from this locality queried var. arenaria (?) were passed by Dr. Boswell as in his opinion correctly named. In I893 I sent some fresh plants to Mr. Arthur Bennett, who reported (in lit. 3I July, r 893) that 'they do diverge from the type towards arenaria by the sepals being subparallel for half their length, with the apex broader; by the greater length of the pedicels; and by the 3-4 (I I on the raceme) bracts of the stem.' In Journ. Bot., November I893, Mr. Bennett published a paper on Pyrola rotundifolia and its European forms, and gave a description of the Grande Mare plant, showing that it is "pretty fairly intermediate between rotundifolia and the var. arenaria, perhaps on the whole bearing towards the first.'

\section{AQUIFOLIACEAE.}

\section{Ilex Aquifolium, L.}

Native (?). First record: Marquand, I89r.

Holly.

Common, but nearly always planted. There are very few trees in the island that have the appearance of being really wild, though young plants may frequently be seen on the cliffs springing up from seeds dropped by birds. It is worth noticing that Gosselin does not include the Holly in his list: perhaps he did not consider it indigenous. Babington does not record it for Guernsey.

Called in the patois Housse, the feminine form of Houx, which is the French name of this tree. The custom of decorating houses and churches with holly at Christmas-time was probably first adopted by the early Christians at Rome, where the holly, as an emblem of good wishes, had long been used at the great festival of the Saturnalia, celebrated about that period of the year.

\section{OLEACEAE.}

Ligustrum vulgare, $\mathrm{L}$.

Privet.

Native. First record: Gosselin, 1815 .

Common on the cliffs at St. Martin's and the Forest: frequent in hedges inland, where it has been planted. Babington says in Fl. Sarn. that this species is "indigenous at Lancresse Bay and Jerbourg.'

I do not know whether the Privet has any distinct patois name, but in Normandy it is called Troëne or Bois blanc. The berries are nauseous, and very bitter; when mixed with alum they are said to dye wool a permanent green. 
Fraxinus excelsior, L. Common Ash.

Native. First record: Babington, I839.

A common tree throughout the island.

Called in Guernsey by the ordinary French name Frêne. Gilbert White, of Selborne, records that in his parish, in former times, 'ash-trees; when young and flexible, were severed and held open by wedges, while ruptured children, stripped naked, were pushed through the apertures, under a persuasion that by such a process the poor babes would be cured of their infirmity. As soon as the operation was over, the tree in the suffering part was plastered with loam, and carefully swathed up. If the parts coalesced and soldered together, as usually fell out where the feat was ferformed with any adroitness at all, the party was cured; but, where the cleft continued to gape, the operation, it was supposed, would prove ineffectual.' The same practice was prevalent in some parts of Cornwall down to comparatively recent times.

\section{APOCYNACEAE.}

Vinca major, L.

Alien. First record: Marquand, I89г.

Greater Periwinkle.

Naturalised on the cliffs above Fort Bay, and on the cliffs at Moulin Huet. Also occurs on two banks at Icart Point, at Fermain, and at Calais. This plant is a native of southern Europe, but has. long been cultivated for ornament, and is now found apparently wild in many parts of England. In these latitudes, however, it rarely, if ever, ripens its seed.

The patois name is Pervenche, the same as in French. Chaucer, and other old English poets, call it Pervinke or Pervenke, and this word has become corrupted into Periwinkle.

\section{GENTIANACEAE.}

Erythraea pulchella, Fr.

Native. First record: Babington, I 839.

Slender Centaury.

Rare. Marshy spot on the coast close to Fort Houmet. IVet field adjoining Ivy Castle. Sparingly amongst Glaux on the shore by Grandes Rocques Head. By the Vale pond, one plant, and on Lancresse Common, one plant (Andrews). A slender form, unbranched, an inch or two high (probably var. Szvartziana, Wittr.), occurs plentifully in a sandy hollow at Albecq.

Erythraea Centaurium, Pers.

Native. First found: Gosselin, 1788.

Common Centaury.

Common in all parts of the island in suitable places. I have seen it in blossom on the cliffs as late as the end of December. Mr. Andrews has found it with white flowers at Rocquaine, and a note is 
appended to a specimen in Gosselin's herbarium, stating that 'a white form occurs sparingly.'

According to Métivier, the author of the Dictionnaire FrancoNormand, the patois name of this plant is Déblômâie, a very obscure word, which, in his opinion, signifies stripped of leaves or flowers-a meaning altogether inapplicable to the plant. In Normandy it goes by the name of Petite Centaurée. In ancient times it was known as $\mathrm{Fel}$ terrae, or gall of the earth, owing to its intense bitterness.

(Erythraea linarifolia, Pers, is noted in Fl. Sarn. as having been found at the Vale, but it seems very probable that some form of one or other of the preceding species was mistaken for it. Babington also records Erythraea latifolia, Sm., for Jersey, Guernsey, and Alderney, but it is not the plant now known to English botanists under that name. Hooker says the latifolia of Eng. Bot. is a stunted variety of Centaurium, and in the Flora of Hampshire Mr. Townsend states: "Professor Babington many years ago distributed specimens of $E$. Centaurium, var. capitata, Koch., under the name of E. latifolia, Sm., and it is figured in Eng. Bot. Sup. under that name.')

\section{Erythraea capitata, Willd.}

Native. First found: Mathews, 1876 .

Very rare. In the Journal of Botany, 1884, p. 91, this plant is recorded as having been found on Lancresse Common, in July, r876, by Mr. William Mathews. Like the Isle of Wight plant, it belongs to the var. sphaerocephala, Towns., the type not being found in this country.

Cicendia filiformis, Reich.

Slender Cicendia.

Native. First record: Gosselin, I8 I5.

Abundant all over Fort Doyle headland, and on several parts of Lancresse Common, the plants being usually small. Cobo Castle hill. Plentiful and very fine in one spot on the cliff-side in Saints Bay Valley. It is the Gentiana filiformis of Gosselin.

\section{Cicendia pusilla, Griseb.}

Native. First found: Wolsey, r861 (?).

Very rare. On the sandy common near Fort Doyle, which was supposed to be its only station until Miss B. Agnew discovered it, in 1900 , in considerable plenty in another locality towards Fort Le Marchant. It is a very minute plant, seldom more than an inch high, and flowers in August, though I have seen it as early as July I 6th. The Guernsey form is var. Candollei, Bast., the flowers being pink or pale purple, instead of yellowish-white, as in the type. I do not know who first discovered this little plant in Guernsey, but I possess two specimens labelled, in the hand-writing of the late $\mathrm{H}$. C. 
IVatson, 'Cicendia pusilla, Griseb. Lancresse Common, Guernsey, 186r. Coll. Geo. Wolsey.' This Mr. Wolsey was an acute local botanist, who discovered Ophioglossum lusitanicum in I 854 and Isoetes hystrix in 1860 ; and, as the best-known station for the latter plant is exactly where $C$. pusilla grows, it seems extremely probable that he was the original finder of both species. In Babington's Manual the only locality given is 'Paradis, Guernsey: Capt. Gosselin,' but no date is mentioned. Paradis is the local name for the Fort Doyle end of Lancresse. C. pusilla occurs rather commonly on the coast of the Bay of Biscay, but becomes rare northwards, and in Normandy it is extremely scarce and local.

Menyanthes trifoliata, L.

Native. First found: Gosselin, 1788.

Bogrean or Buckhean.

Very rare, and now nearly extinct; in fact, it was considered so until Miss Naftel rediscovered it, in 1892 , in the marshy corner of a field at Cobo, where it grows in some quantity, but rarely, if ever, flowers. This plant was at one time plentiful at Grande Mare, but an enthusiastic collector succeeded in exterminating it some thirty years ago. It is recorded by H. O. Carré in Fl. Sam. as growing in ditches behind Ivy Castle, a locality known for it in Gosselin's time, as a specimen in his herbarium is labelled 'Wet ditches in a meadow to south of and joining Ivy Castle.'

Known in Normandy under the names of Trèfle d'eau and Patte d'oie. The intense bitter of the leaves has led to their being substituted for hops in brewing, and an infusion is much used in the north of England for dyspeptic complaints.

\section{CONVOLVULACEAE.}

Convolvulus arvensis, $\mathrm{L}$.

Small Bindweed.

Native. First record: Gosselin, I8 I 5 .

Very common everywhere as a weed in cultivated ground and on roadsides.

Called in the patois Vâle or Vaille, a word which Métivier says 'se relie naturellement au latin valgia, contortion, entortillement.' In Normandy the plant goes by the name of Liot. The flowers close before rain, and in dry, warm weather emit an almond-like scent.

Convolvulus sepium, L.

Native. First record: Gosselin, i8 8 .

Common in all districts. A pretty variety, having the flowers banded with pink (var. coloratus, Lge.), occurs abundantly in the valley west of St. Saviour's Church, and in hedges between Ivy Castle and Baubigny. It also grows, though sparingly, in the lane by St. Andrew's Rectory. 
Commonly called in French Liseron, but also known as Manchettes de la Vierge, and Belle d'un jour, because the white blossoms last only a single day. In some parts of England these flowers are termed Hedge Bells, a pretty name exactly corresponding to the German Zaun-glocke.

\section{Convolvulus Soldanella, L.}

Sea Bindweed.

Native. First record: Gosselin, 1815.

Common all over the sandy shores of the north and north-west.

The flowers only expand in fine weather, and during the early part of the day. The plant is known in some places by the name of Sea Bells.

Cuscuta Epithymum, Murr.

Lesser Dodder.

Native. First record: Gosselin, 18 r 5.

Frequent on the cliffs: more rare in other parts of the island. Generally parasitic on Furze, rarely on low plants. In Alderney the reverse is the case, and it is seldom seen on Furze. Gosselin notes this species under the old aggregate Hudsonian name, Cuscuta europaea.

The Guernsey patois name, according to Métivier, is Herbe d'emente: in Normandy it is called Cheveux St. Jean, and in other parts of France Teigne. Prior says the word Dodder signifies bunches of knotted or entangled threads.

(Cuscuta trifolii, Bab. I have found this species in Alderney, growing on Lucerne; and I have also seen there on two occasions a flowerless Cuscuta of a lemon-yellow colour, growing on Thyme. and other low plants. It closely resembled a plant which my old friend, W. Curnow, showed me many years ago on sand banks near Hayle, West Cornwall, and which both Prof. Babington and Mr. H. C. Watson considered to be a form of $C$. trifolii. See note on the Cornish plant in Rep. Bot. Loc. Rec. Club, I875, p. I37.)

\section{BORAGINACEAE.}

Cynoglossum officinale, $\mathrm{L}$.

Denizen. First record: Gosselin, I8I5.

Rare. Here and there on the coast between Grand Havre and Lancresse Bay. Rather plentiful in the neighbourhood of the old Grandes Rocques Barracks. Under a roadside wall near the Hermitage, Vale, in some quantity. Lihou Island. In Fl. Sarn. this plant is noted for the 'central parts of Guernsey,' but no station is known there for it at the present day.

Coles tells us in his Art of Simpling ( $\left(6_{56}\right)$ that this herb "will tye the Tongues of Houndes, so that they shall not bark at you, if it be lard under the bottom of your feet, as Miraldus writeth.' 
Borago officinalis, $\mathrm{L}$.

Alien. First record: Gosselin, I8I5.

Borage.

Rare in the south: more frequent in the low districts. Sometimes occurs in profusion in a field, the seeds having been sown with the crop.

Parkinson declares that all parts of this plant are 'very cordiale and helpe to expell pensivenesse and melancholie.' In the opinion of Dr. Prior, the name Borage, Latin Borago, French Bourrache, is 'probably a Latinized oriental name, brought with the plant from Syria.' Bees are extremely fond of the flowers.

Anchusa sempervirens, L.

Green Alkanet.

Alien. First found : Mrs. Marquand, I 899 .

Very rare. In May, 1899 , a fine flowering specimen of this plant was brought me by my wife, who had gathered it in a hedge in the Hubit Lanes. I do not remember seeing it grown in cottage gardens in this island.

Lycopsis arvensis, L.

Colonist (?). First record: Gosselin, I8I 5 .

Sinall Bugloss.

Rather common in the sandy cultivated fields of the low-lying districts; less frequent in the interior; and almost unknown in the south. Often abundant in a locality.

Symphytum officinale, $\mathrm{L}$.

Denizen. First record: Gosselin, I815.

Rare. Near St. Peter's Arsenal. Les Padins (VIr.). Lane between Hougue Fouque and Les Prevosts. Near Vale Castle. Hedge of a field behind the Forest Church. Miss B. Agnew has found the var. patens, Sibth. in a lane near Les Vinaires (vi.).

Comfrey was formerly regarded as a valuable styptic and vulnerary, and was known as the Great Consound, a name still preserved in Normandy, where the plant is called Grande Consoude. If gathered while tender, the leaves are a substitute for spinach, and the young shoots when blanched are sometimes eaten like asparagus.

Echium vulgare, L.

Native. First record: Gosselin, 1815.

Viper's Bugloss.

Rare. About Lerée, sparingly. Coast near the Vale Church, a few scattered plants. Ville au Roi, one plant in a waste corner. Spur Point, one plant. Portinfer (Andrews). This species is much more common in Herm, and quite plentiful in Alderney.

Called in French Vipérine; the generic name is derived from the Greek echis, a viper. Lyte, in his Niewe Herball, I578, affirms that this plant 'is very good against the bitings of serpents and vipers, and his seede is like the head of an adder or viper.' 


\section{Echium plantagineum, L.}

Casual. First record: Marquand, I89r.

Very rare. The only specimen hitherto known to have occurred in this island is the one $I$ found in r $89 \mathrm{I}$ on the coast west of the Vale Church. It is a plentiful plant in some parts of Jersey.

Lithospermum officinale, I.

Common Gromwell.

Native. First found: Gosselin, 1788.

Rare. Lane near Grandes Rocques, in some quantity. Several plants in the lane on the west side of Grande Mare. Between Mare de Carteret and Cobo, in two or three places, a few plants in each. In Gosselin's herbarium there is a specimen labelled, 'Hedge on roadside bordering on a field called Parc-à-fonaille, near la maison aux Goubés, belonging to ilichel Le Pettevin, at the Grand-Miles.' As far as I can ascertain, this locality is the same as the Grandes Rocques station mentioned above.

This plant is called in French, from its shining seeds, Herbe aux perles, and also Grémil; the latter name being obviously another form of our English Grumzerell, a word said to be derived from the Celtic srann, seed, and mil, stone: alluding to the excessive hardness of the seeds The same meaning, in a Greek form, is expressed in the generic name Lithospermum.

Lithospermum arvense, $L$.

Corn Gromzuell.

Casual. First record: Marquand. I89I.

I found a few plants in 1890 in a cultivated field a little to the west of the Vale Road, near the stream.

Myosotis repens, Don.

Creeping Water Forget-me-not.

Native. First record: Babington, 1839

Common on stream-sides in the south of the island. Marshy fields at Rocquaine (Andrews). Babington notes this species in Fl. Sarn. from his own observation, and also records M. palustris, With., without locality, on the authority of $\mathrm{H}$. O. Carré. As there is no confirmatory evidence of the existence of the latter species in these islands, it is probable that the name was used in its old sense, comprehending $M$. repens.

According to Prior, it is only since the beginning of the nineteenth century that Myosotis has been called Forget-me-not, though it now bears a similar name in nearly every European language. Before that time the name Forget-me-not was applied in France and the Netherlands as well as in Enyland to Ajuga chamaepitys, and ' it is to this plant exclusively,' says Prior, 'that we find it assigned by Lyte, Lobel, Gerarde, Parkinson, and all our herbalists from the middle of the fifteenth century, and by all other botanical writers who mention the plant, inclusive of Gray in his Natural Arrangement, published in $182 \mathrm{r}$, until it was transferred with the pretty story of a drowned lover to that which now bears it.' Myosotis had 
always been called in England Mouse-ear Scorpion Grass, and Lyte tells us that in his day ( 1578 ) it had 'none other knowen name than this.'

Myosotis caespitosa, Sch.

Native. First record: Marquand, I89I.

Tufted Water Forget-me-not.

Local and rather rare. In watery ditches at Grande Mare and neighbourhood; and also in the marshy fields near Ivy Castle and Baubigny.

Myosotis arvensis, Lehm.

Native. First found: Gosselin, 1788.

Field Forget-me-not.

Rather common throughout the island in cultivated and waste ground, and on roadsides. A specimen in Gosselin's herbarium is labelled Myosotis scorpioides.

Myosotis collina, Hoffm.

Native. First record: Marquand, $\mathrm{r} 89 \mathrm{r}$.

Dwarf Forget-me-not.

Very common on dry banks and on the cliffs. A form with pure white flowers (var. Lebelii, Corb.) has been found in one locality on the cliffs near the Gouffre; it also occurs in Alderney. This is one of the earliest of spring flowers, and is at its best before $M$. versicolor begins to blossom.

Myosotis versicolor, Reich.

Native. First record : Babington 1839.

Yeliow Furget-me-not.

Equally common with the last species, and growing in similar situations. Begins flowering when $M$. collina is nearly over. The var. Balbisiana, Jord, distinguished by the flowers remaining always yellow, and not turning blue, was found on the cliffs at Icart in 1894 by Miss Dawber, and in 1899 at Pleinmont by Mr. Andrews. I had previously discovered this rare variety at Jethou in 1890 .

\section{SOLANACEAE.}

Solanum nigrum, L.

Colonist. First record: Gosselin, I 8 I5.

A rather common weed in the low districts in cultivated ground and by waysides: less frequent in the south. Var. luteovirescens, Gmel. Berries yellowish green, semi-transparent. In two spots on the cliffs between Saints Bay and Moulin Huet, in some quantity. In a waste corner near the Vale School, growing with the type, in 1894 . Var. miniatum, Bernh. Berries scarlet. This variety is recorded for Jerbourg in Engl. Bot., ed. 3.

This plant is called in France Morelle noire: like S. Dulcamara it is a narcotic, diuretic, and sudorific, and is reputed to be even more powerful in its effects. 
Solanum Dulcamara, I.

Wioody Nishtshade. Bitrersireet.

Native. First record: Gosselin, 18 I 5 .

Generally distributed throughout the island, and not uncommon. Both the glabrous and the downy forms occur, the latter being the var. tomentosum of Koch. The var., marinum, Bab., with cordate (not hastate, leaves, is the prevailing form on the shores of the lowlands.

All the names of this plant-French liouce-amère, Latin Luliumara, German hittersïss, and English Bittersweet-allude to the rind of the stalk, which, as Turner observes, 'when it is first tasted, is bitter, and afterwards is sweet.' This species is often erroneously called the Deadly Nightshade, instead of the IVoody Nightshade: the former name properly belongs to the following plant.

* Atropa Belladonna, L. .

Deadly Nightshade.

Extinct

There is evidence that this plant occurred here towards the close of the eighteenth century, by the preservation in Gosselin's old herbarium of a specimen labelled 'Near the seashore at foot of Mont Crevel.' And I find it marked 'Paradis, Guernsey,' in an annotated copy of the Flora Samica which formerly belonged to Major H. Smith, a botanist resident in the island about the year r860. Habington records it for Jersey only.

This is perhaps the most dangerous of all British plants: its fruit is tempting in appearance, sweetish, and without any remarkable or repulsive flavour: so that children have often eaten it with fatal results. It uccasions a deep and dendly stupor, and it is said that even half a berry has proved sufficient to cause death.

Hyoscyamus niger, L.

Henbane

Native. First found: Gosselin, 1788.

Very rare: now nearly extinct. Principally at I.ancresse, where a plant or two may be found each year, but I have reason to believe they are intentionally dug out, perhaps by the owners of the sheep that graze un the Common, for fear of poisoning Farmyard at Fontenelles (VI.) one plant in 1899 (Andrews). Two or three in a garden, Burnt Lane, in 1900 (Luff). A specimen in Gosselin's herbarium is marked 'near the Long Store and at Lancresse.' - I am informed that the Henbane was by no means rare on Lancresse Common twenty years ago.

Called in the patois of Guernsey and of the northern parts of Normandy Hannebanne, a word closely allied to our Henbane. The common French name is Jusquiame. Commentators are now pretty well agreed that the liquid poison called hebenon in Hamlet, i. 5, was not Henbane. Most probably, however, it was 'the insane root, that takes the reason prisoner' of Macbeth, i. 3, Henbane having been described as far back as the time of Dioscorides as causing 
madness. Grindon (Shakespeare Flora, r 883) says hebenon 'is a varied form, not of henbane or, as some suppose, of ebony, but of the name by which the Yew is known in at least five of the Gothic languages, the name which appears in Marlowe, Spenser, and other writers of the Elizabethan era as hebon.' Britten and Holland (Dict. Engl. Pl. Names, 1886) assert that 'it is almost certain that the hebenon of Shakespeare was Diospyros Ebenum, L.'

Lycium barbarum, L. Tea Plant.

Barbary Box thorn.

Alien. First record: Marquand, r89r.

Very rare, and always a garden escape in this island. Corner between the Vale Church and Grand Havre. St. Magloire (Ix.) and near Paradis. Near La Moye (IX.). This plant, a native of Africa, is thoroughly naturalised in Alderney, and is quite common, often forming thick hedges at a distance from houses, and growing in large bushes in spots where it could hardly have been intentionally planted.

Datura Stramonium, L.

Casual. First record: Gosselin, I815.

Thorn Apple.

Very rare. Found in cultivated ground near Lancresse Lodge in 1895 by Mr. J. S Hocart, who afterwards traced the plant to the site of the ancient Priory of St. Michael, at the Vale. In $1899 \mathrm{Mr}$. H. Le Lacheur found a specimen at St. Saviour's; and in I900 two or three plants appeared in a waste corner of Mr. Luff's garden at Mount Pleasant, Burnt Lane.

The Guernsey name, according to Mr. Hocart, is Pommier du riable, or Devil's Apple-tree. All parts of the plant are poisonous. but the fruit is considered the most noxious. The leaves and stems, dried and smoked like tobacco, are a well-known remecy for asthma.

\section{OKOBANCHACEAE.}

Orobanche Hederae, Duby.

Native. First record: Babington, 1839.

Ivy Broomrape.

Frequent throughout the island: more common in the northern parts. Often found in great plenty at the foot of ivy-covered walls and stone hedges. In I 889 a fine specimen, with the base of attachment exposed, grew on the ivy on the north wall of St. Martin's Churchyard, at a height of about eight feet from the ground, and the dricd stem remained in situ for two or three years. In the hot, dry summer of 1893 the flowers were often of a peculiar pale yellowish colour, or almost white.

(Orobanche Rapum. Thuill., occurs in Alderney, and O. rubra, Sm., in Sark. The former is mentioned in Gosselin's list, but there is nothing to show that it ever grew in Guernsey.) 
Orobanche minor, Sm.

Lesser Broomrape.

Native. First record: Babington, I839.

Generally distributed, but rather rare: more frequent in the lowlands of the north-west. This species appears to be more plentiful in particular years, though the same may perhaps be said of others of this genus. Although often growing on Trifolizm pratense, I have found it on Plantago Coronopus at Jerbourg; on Lotus corniculatus at Cobo, and St. Martin's Cliffs; and on Medicagu maculata near Grandes Rocques. Var. flavescens, Reut. A plant of this variety (determined in a fresh state by Mr. Arthur Bennett) was found in Fort Bay in 1893 by Messrs. Derrick and Royle. 'A form of Orobanche minor occurs near Grand Havre, Guernsey, on Leontodon autumnale, which has the corolla curved like $O$. amethystea, but a much shorter and denser spike, and the whole plant, including the flowers, is yellow.' (Engl. Bot., 3 ed., vol. vi. p. 200.)

Orobanche amethystea, Thuill.

Native. First record: Marquand, I89r.

Bluish Broomrape.

Rare. Plentiful on the cliffs above Bon Repos. In two or three localities at Pleinmont. North side of Richmond Hill, in good quantity. Field near Les Paysans (VI.) in $x 894$. I have always found this species parasitic on Daucus gummifer, but in Eng\%. Bot., ed. 3 , it is noted as occurring 'on Eryngium maritimum, near Cobo, Guernsey.' In Alderney it grows plentifully on Eryngium, but I have not met with it there on Daucus.

Orobanche caerulea, Vill.

Native. First record: Babington, 1839.

Purple Broomrape.

In Fl. Sarn. this species is noted for St. George on the authority of W. Borrer, jun., and Major H. Smith notes it about twenty years later as found on the 'cliffs westward of St. Martin's and cliffs behind Artillery Barracks ;' but the plant does not appear to have been found again in Guernsey until 1894, when the Rev. G. F. Saxby discovered it in a field near the square tower (known as the Look-out) at the back of St. George (vini.),-probably Borrer's old station. Babington also records it from his own observation from Jersey and Alderney, adding this note: "The present plant, which is parasitical, I believe, upon Achillea Millefolium, does not agree well with $O$. caerulea, but appears to be intermediate between it and $O$. arenaria.' This is perfectly correct, at least as far as it applies to the Alderney plant; but, curiously enough, in the later editions of the Manual Babington emphasises the statement that the Jersey species is $O$. caerulea, while the Alderney one is $O$. arenaria, Bork. In I900 I sent to Mr. Arthur Bennett a set of fresh specimens from Alderney, where the plant is common, and he confirmed my opinion that it is certainly not arenaria, but $O$. Millefolii, Reich. Very probably the Guernsey plant, and perhaps the Jersey one also, 
is the same species. In the Alderney list I employ the name $O$. Millefolii to mark its distinctness from typical caerulea by the rousded lobes of the corolla and the longer floral bracts.

\section{SCROPHULARIACEAE.}

Verbascum Thapsus, I\%

Great Mullein.

Native. First record: Gosselin, 18 r 5 .

Rather rare, but generally distributed throughout the island. Scattered plants are to be found all along the cliffs, but more frequently at St. Martin's.

The patois name is Moleine, the same as our Mullein, or Molayne, as it was spelt by the old writers. The wool of the stem and leaves was formerly used for lamp-wicks. and the seeds of both this species and $V$. nigrum are said to have been used by poachers to poison fish.

Verbascum pulverulentum, Vill.

Hoary Mullein.

Casual. First record: Marquand, 1892.

Very rare. I found a single specimen of this plant in 1892 in an old quarry at La Rochelle, Lancresse; and another in the same quarry the following year.

Verbascum nigrum, L.

Dark Muilein.

Native. First record: Gosselin, I 8 I 5 .

Very rare. Field adjoining St. Andrew's Churchyard, two plants in I 890 (var. tomentosum, Bab.). Paradis, Vale, in $\mathbf{r} 888$ (Mirs M. Dawher). Hedge south of Caudré Mill (vi.), four plants in 1899 (Andrews). In $\delta_{3} 8$ Babington found it in St. Peter's Churchyard. The var. tmmentrsum is not clearly defined in these islands, specimens from Guernsey, Alderney, and Herm showing every gradation between it and the type.

*Verbascum Blattaria, L.

Moth Mullein.

Extinct (?).

Recorded for Guernsey, without locality, in Fl. Sarn. on the authority of $\mathrm{H}$. O Carré. A plant was gathered near Cobo Church in July, I 864, by Mr. Edgar Dupuy, and is preserved in his herbarium. It has not been found in the island for very many years, and is probably extinct.

Lyte, in 1578 , writes that 'the mothes and battes do incontinently come to this herbe, wheresoever it be strowen or layde.'

Verbascum virgatum, With.

Large-flowered Mullein.

Native. First record: Babington, 1839.

Very rare. Hougue des Doreys, between Les Arguillers and Pleinheaume, about twenty plants on the roadside in 1891 : also a 
single plant on the roadside about a quarter of a mile to the eastu ard. Babington found this species at Mont Cuet.

Digitalis purpurea, $\mathrm{L}$.

Native. First record: Gosselin, I815.

Foxglove.

Rather common in the central and southern districts : more rare in the lowlands. Very plentiful and fine on some parts of the cliffs. Gosselin appears to have found the rare white-flowered variety, as he gives in his list, besides the common species, Digitalis alba, Whiteflowered Foxglove.

This plant is known in the patois under the plural name of Claquets, because, says Métivier, 'les enfants s'amusent à faire claquer les fleurs' by bursting them on the palm of the hand; just as the plant is called Blobs in the eastern counties, and Pipdock in Cornwall. The word Foxglove has no association whatever either with the animal of that name or with the covering for the hand, but etymologically simply means Fairies' music: and the idea of a merry peal being rung out from these dappled bells during the stillness of a summer night is exceedingly poetical.

Antirrhinum majus, L.

Alien. First record: Babington, 1839.

Great Snapdragon.

Established on walls in various parts of the town and suburbs. Less frequent in the rural districts. King's Mills. Sohier, Vale.

In Guernsey, where the plant is commonly grown in gardens, it goes by the name of Goule de Lion (in Normandy Gueule de Lion), a name which, like our Snapdragon, would seem to signify the devourer, the flowers being perfect insect-traps.

Antirrhinum Orontium, L.

Colonist. First record: Gosselin, I8 15.

Corn Snapdragon.

Frequent in cultivated fields and gardens in all parts of the island.

The French name of this species is Muftier, from mufle, a muzzle, owing to the fancied resemblance of the ripe capsule to the face or muzzle of an animal.

Linaria Cymbalaria, Mill.

Alien. First record: Marquand, I891.

Iry-leaved Toadflax.

Frequent in almost all districts on old walls, especially in the neighbourhood of the town: occasionally to be found in old quarries.

Often called Mother of Millions, though the appropriateness of the term is by no means obvious. Perhaps Tennyson had this plant in mind when he penned that exquisite little verse beginning:

'Flower in the crannied wall,

I pluck you out of the crannies.' 
Linaria Elatine, Mill.

Colonist. First record: Gosselin; 1815.

Sharp-leaved Toadflax.

Rather common all over the island in gardens, cornfields, and cultivated land in general.

Linaria spuria, Mill.

Colunist First record: Babington, 1839 .

Very rare. Noted in Fl. Sarn. as having been found by Labington at St. Martin's. Nothing has been seen of this plant during recent years, though it has been well searched for. Perhaps it should be classed as a Casual.

Linaria repens, Mill.

Colonist. First record: Marquand, 1891.

Striped Toadflax.

Rare. On the coast by the Vale Castle in 1890 , in profusion over a few square yards of the bank. Near Ozanne's Mill in 1899 (Miss B. Agnew) In a cultivated field at Petit Bot in 1899 (Dr. C. T. Green). Plentiful in Igco near the Cement Mill at St. Saviour's (Miss Le Mesurier). Used to be found near the Gouffre, but has not been seen there lately.

Linaria vulgaris, Mill.

Native. First record: Gosselin, I815.

Yellou Toadflax.

Generally distributed and rather common in the central parts of the island, as well as on the coast. The flowers vary in depth of colour. This plant is often known by the name of Butter and Esgos.

Scrophularia nodosa, L.

Native. First record: Gosselin, 18 I 5 .

Knotted Figzert.

Rather rare, and mostly found in the interior, but $I$ have seen it in nearly every parish.

The leaves are used in rural districts as an application to burns and swellings, and are said to cure cuts and sores. One of the names of this plant is Kernelwort, from its having kernels or tubers attached to the roots, and being therefore supposed, on the doctrine of Signatures (which attributed to any plant bearing some outward resemblance to an organ of the body sovereign virtues in strengthening it or curing its diseases), to cure diseased kernels or scrofulous glands in the neck.

Scrophularia aquatica, L.

Native. First record: Gosselin, 18 I5.

Common in wet places and on the sides of streams and ditches throughout the island.

In old pharmacy this plant had a high repute as a cosmetic, and we are assured that, "if the face be washed with the juice thereof, it taketh away the rednesse and deformity of it.' The flowers produce plenty of honey, but they are never visited by insects with long 
tongues, like humble-bees and hive-bees; whereas wasps, having short, broad tongues, go to the flowers in great numbers.

Scrophularia Scorodonia, L.

Colonist. First record: Gosselin, I8I5.

Balm-leaved Figuort.

Generally distributed throughout the island, but rather rare, and found more frequently in the interior. Grows in hedge-banks and bushy places, and occasionally in old quarries.

*Pedicularis palustris, L.

Marsh Lousezerort.

Extinct.

In Fl. Same this species is noted as having been found by Babington in the 'central parts of Guernsey.' It has been searched for in vain for a great many years, and I have no doubt whatever that it is now extinct.

Pedicularis sylvatica, $\mathrm{L}$.

Common Lousezurt.

Native. First record: Gosselin, I8I5.

Rather common on moist heaths and in damp pastures, especially in the south : plentiful on the cliffs in suitable localities.

Derives its name from pediculus, a louse, the popular belief being that it produces vermin in sheep; whence also its German name, Läuse-kraut. Gerarde says of this plant that 'it filleth sheep) and other cattle that feed in meadows where it groweth full of lice.' But the same is said of some other marsh plants.

Rhinanthus Crista-galli, L.

Yellow Rattle.

Native. First record: Gosselin, I8 15 .

Rare, but usually in abundance when growing in meadows. Grande Mare. Cobo. Albecq. Several parts of the Vale. Talbots Valley. Petit Bot Valley.

This plant takes its English name from the rattling of the ripe seeds within the dry capsule, just as in Normandy it is called Sonnettes, or little bells.

Eufragia viscosa, Benth.

Native. First record: Babington, I 839.

Marsh Eyebright.

Frequent in wet meadows and marshy places in all parts of the island, often very'plentifui in a favourable locality.

Euphrasia officinalis, L.

Native. First record: Gosselin, 1815.

Eyebright.

Very common on dry banks and moors, and on sandy commons. A tall, slender form, with almost simple stems a foot or more high (perhaps var. gracilis, Fr.), occurs plentifully in some parts of Grande Mare. In Mr. Townsend's paper on Euphrasia in Journ. Bot., I 897 
E. nemorosa is recorded as having been found by Mr. IV. S. Miller, in 1892 , near Doyle's Monument in this island. See note under this genus in the Alderney Flora.

This plant was much commended in olden times as a presious medicine for eye diseases and for strengthening the sight. Milton refers to this belief in Paradise Lost:

'Then purged with euphrasy and rue

The visual nerve, for he had much to see.'

In certain parts of Germany the Eyebright is called Milchiieb or milk-thief, from the popular notion that cows yield less milk when the plant is in flower.

\section{Odontites rubra, Pers.}

Native. First found: Gosselin, I 788.

Red Bartsia.

Rather common throughout the island. By far the most frequent form is the var. serotina, Reich. The var. verna, Reich., I have found growing p'entifully in Moulin Huet Valley. On the cliffs above the cottage at Petit Bot there is an intermediate form (O. longifolia, Corb.), which has the habit and leaves of serotina, but the bracts longer than the flowers. In Gosselin's herbarium there is a specimen of var. verna, and another of var. longifolia, in each case without locality.

Sibthorpia europaea, L.

Native. First record: Marquand, r89r.

Cornish Monejiort.

Local and rare: usually plentiful where it occurs. Grows on damp banks by streamlets and springs, and always in sheltered, shady spots. Valley between St. Peter's Arsenal and Rocquaine. On a high bank below Le Becquet (III.). Valley west of St. Saviour's Church. Below the pond at Le Moulin (vi.). Valley below Les Issues (VIr.). Below Les Rebouquets (Iv.) descending towards Petit Bot.

*Veronica scutellata, L.

Marsh Speedwell.

Extinct.

The record of this species in Gosselin's list is confirmed by a specimen preserved in his herbarium marked 'Grows in the marshes,' meaning probably Les Marais, near Ivy Castle. There is no evidence of the occurrence of the plant in Babington's time, or since, so that no doubt it is extinct.

Veronica Anagallis, L.

Native. First found: Gosselin, 1788.

Water Speedreell.

Very rare. A sprinkling of plants in a marshy meadow between Hougue du Pommier and Grandes Rocques. Wet corner of a field at Cobo, in some quantity. In Gosselin's herbarium there is a specimen from Grande Mare. 
Veronica Beccabunga, L.

Native. First record : Gosselin, I8I5.

Brooklime.

Common in watery places in the south, and in all the cliff valleys. I have not noticed this species in the north of the island nor (except at Rocquaine) in the lowlands in general.

This plant was formerly valued as a vulnerary, and was used, together with Scurvy-grass and Seville oranges, in the composition of 'spring juices,' a kind of medicine much in request in ancient days.

\section{Veronica Chamaedrys, L.}

Native. First record: Gosselin, 1815.

Very common throughout the island. I have not noticed here any of the colour-variations of the flower which are to be found in many parts of England.

The patois name of this species is Herbe Terraie, the meaning of which is obscure. In some parts of Devonshire it is known by the pretty name of Angels' Eyes. The corolla falling as soon as the flower is gathered suggests the parting of friends, hence the name Speedwell, a common form of valediction in the olden time.

Veronica officinalis, L.

Native. First found: Gosselin, $\mathbf{1} 788$.

Common Speedwell.

Rare. Occurs in several places at St. Martin's and the Forest, and also in several at the Vale. Les Naftiaux (II.). Fontenelles Valley (vi.). There are specimens in Gosselin's herbarium from a 'dry bank between Rohais and Catel Church.'

At one time this plant was much recommended as a substitute for Chinese tea, but it never became popular, owing to its rather unpleasant bitter flavour.

Veronica serpyllifolia, L.

Native. First record: Gosselin, 1815.

Thyme-leaved Speedwell.

Rather common generally, though less so than some of the other species. More plentiful in the west of the island.

Veronica arvensis, L.

Wall Speedreell.

Very common on dry banks, wall-tops, and roadsides, and as a weed in cultivated ground.

Veronica agrestis, L.

Green Procumbent Speedwell.

Native or Colonist. First record: Gosselin, 18 r 5 .

Common, especially as a field and garden weed. The most frequent form has nearly white flowers, with the three upper petals faintly tinged with pink, the middle one deepest. Plants with pure white flowers also occur, but the pale-blue variety is comparatively rare. 
Veronica polita, Fries.

Grey Procumbent Speedwell.

Native or Colonist. First record: Babington, 1839.

Frequent throughout the island in waste spots and on roadsides, also as a weed in cultivated ground.

Veronica Buxbaumii, Ten.

Colonist. First record: Marquand, I89r.

Very common everywhere in cultivated ground. This plant offers a remarkable instance of the rapid spread throughout the whole country of a weed of cultivation. It was introduced into England about the year 1820 or 1822 , and was first figured and described as a British plant, under the name of Veronica fliformis, Lam., by Johnston, in 1829 , in his Flora of Berwick-upon-Tweed. On p. 226 of that work the author says Borrer 'found it several years ago near Henley [a slip of the pen for Henfield] in Sussex, and communicated specimens to Sir J. E. Smith and others; but it is singular that no notice is taken of it in the English Flora [1824] nor, so far as we know, in any work on the botany of this island.' The plant was still such a rarity in $\mathrm{r} 842$ that about half a dozen localities are specified for it in Hooker's British Flora, ed. 5. By the year I865. however, it had spread so widely as to be described by Bentham (Handb. Brit. Fl.) as occurring 'rather frequently in England, southern Scotland, and southern Ireland.' Twenty years later it was noted in the eighth edition of the London Catalogne as found in no less than eighty out of the I I 2 British counties and vicecounties. At this distance of time it is impossible to ascertain when Veronica Buxbaumii first made its appearance in Guernsey, but it certainly was not known here in $\mathbf{1} 838$, or it would have been detected either by the keen-eyed author of the Flora Samica or by his able coadjutors.

Veronica hederifolia, L.

Native or Colonist. First record: Gosselin, I8I 5 .

A very common weed all over the island in gardens and other cultivated land.

This little plant is known in some parts of England by the name of Hother of Wheat, the prevalent notion being that wherever it grows freely the soil is well suited for the cultivation of corn.

\section{LABIATAE.}

Mentha viridis, $\mathrm{L}$.

Alien or Denizen. First found : Andrews, 1899.

Spear Mint.

Very rare. Waste ground near the Vale Road, plentiful in I 899 (Andrews). Not quite typical, and, in the opinion of Mr. J. G. Baker, coming between viridis and sylvestris. Mr. Andrews has found another form in an old quarry near Le Jardin (viII.), which 
has the appearance of being a hybrid, probably between viridis and rotundifolia.

Mentha rotundifolia, L. Round-leaved Mint.

Native or Denizen. First record: Gosselin, I8I5.

Local. Common in wet places by the cliff streams at St. Martin's and the Forest.

Mentha sylvestris, L.

Horse Mint.

Denizen. First record: Marquand, $189 \mathrm{I}$.

Very rare. One large clump in 1890 on the western side of Mont Cuet, Lancresse. A few plants intermixed with $M$. rotundifolia on the east side of Saints Bay Valley.

Mentha piperita, Sm.

Denizen. First record: Marquand, 1891.

Peppermint.

Very rare. I inserted this species in my list of Guernsey Plants in 1891 on the strength of a few specimens which grew at Les Marchais (vi.), obviously planted there, but, as it seemed to me, very probably brought from somewhere in the neighbourhood. In I 899 Mr. C. Andrews discovered a patch of twenty or thirty plants near a stream in the valley by ILes Vinaires, in the same parish. This form, like the Alderney plant, is var. officinalis, Sole: but Mr. Andrews has found var. vulgaris, Sole, near Saints Bay, together with an intermediate which, in the opinion of some specialists, is really a connecting link between the two varieties.

All parts of this plant abound in a strong-smelling essential oil, of which great quantities are used by confectioners in making peppermint lozenges and sweetmeats. It is also much employed in medicine.

Mentha aquatica, L. Hairy Water Mint.

Native. First record: Gosselin, I8I5.

Very common by streamlets and ditches, and in wet places generally throughout the island.

(Mentha sativa, L., the Marsh Whorled Mint, occurs in Sark.)

Mentha pubescens, Willd.

Native. First found: Andrews, I899.

Very rare. One large clump was found in September i 899 by Mr. C. Andrews on the border of a wet meadow near Ivy Castle. Mr. A. Bennett says the plant 'agrees very well with specimens from Pra Sands, West Cornwall (Curnow), passed by Baker as the pubescens of his monograph.'

Mentha arvensis, L.

Corn Mint.

Native or Colonist. First found: Gosselin, $x_{7} 88$.

Rare. In fields at St. Martin's, in two or three places. Behinct 
St. Peter's Rectory in a corn-field. Field near Les Massis (viI.). Roadside near Hougue Fouque, a few plants in 1893 . Field between Forest Church and Petit Bot in 1900 (Andrews). Specimens in Gosselin's herbarium are labelled 'at lower end of ropewalk at the Bouet, and near Plaisance.'

Mentha Pulegium, L.

Native. First record: Babington, I839.

Pennyroyal.

Very rare. The only locality known for this species is on the western side of Lancresse Common, where it grows plentifully all round a small pool: the plants are dwarf. Sixty years ago, according to Fl. Sam., it grew at the Braye du Vale and at Paradis.

This plant was supposed by the Romans to drive away fieas, whence it was called Pulegium, from the word pulex, under which name we find it mentioned by Pliny.

Lycopus europaeus, L.

Native. First record: Gosselin, I8I 5 .

Rare. Grande Mare. Marshes by Ivy Castle. Marshy meadows at Claire Mare, Lerée. Old millpond near St. Andrew's Church. Wet field at Cobo. Petit Bot Bay, at the mouth of the stream in 1894 .

This plant, which yields a good black dye, is called Gipsywort, according to Lyte, 'bycause the rogues and runagates which call themselves Egyptians do colour themselves black with this herbe.'

Salvia Verbenaca, L.

Native. First record: Gosselin, 1815 .

Wild Sage. Clary.

Frequent in the low sandy districts of the north and north-west : rare in the south. Petit Bot. Moulin Huet. Abundant in Alderney. Var. clandestina, L. Dr. Boswell says in Engl. Bot., ed. 3 , that all the Cornish specimens he has seen, as also a plant from the Vale Church, Guernsey, must be referred to $S$. Verbenaca, but that true clandestina is to be found in Borrer's herbarium at Kew, labelled 'Guernsey' in Borrer's own handwriting. In I 890 I found at Vazon Bay on the sand-hills a sprinkling of plants differing from the type, and agreeing in their extreme forms with the description of clandestina, though connected by intermediates; and on submitting a specimen to Mr. Arthur Bennett he pronounced it clandestina. No locality is specified for it in Fl. Sarn., and both in that work and in the Manual it ranks as a distinct species.

The seeds of this plant when moistened produce a large quantity of mucilage, and this envelopes any particles of dust that may be in the eye; hence its common English name Clary. It is the IVild Clairie of Gerarde, who says: "The seede, put whole into the eies, clenseth and purgeth them exceedingly from waterish humours, rednesse, inflammation, and divers other maladies.' 
Salvia sylvestris, L.

Casual. First found: Andrews, 1898.

Very rare. Two plants of this south-European species were found in July, $\mathrm{x} 898$, by Mr. C. Andrews in the Belvidere Parade Field at Fort George. It is not easy to say how they got there, as the plant is hardly ornamental enough for cultivation as a garden flower.

\section{Origanum vulgare, L.}

Denizen or Alien. First record: Babington, 1839 .

Marjoram.

Very rare, if not extinct. Babington found this plant at the Vale; and Mr. Derrick has told me it used to grow many years ago close to the farm at Les Falaises, overlooking Petit Bot, but has long since disappeared. In $\mathbf{1 8 9 2}$, and for some years afterwards, a few plants were to be seen on the south wall of St. Martin's Church. yard; planted, no doubt, but perhaps brought from one of the old stations in this island.

Called Marjolaine in Normandy. The 'swete margerome,' as the old writers call it, was highly valued before the introduction of various foreign perfumes: and 'swete bags' and 'swete washingwaters' made from this plant were to be found in every druggist's shop.

Thymus Serpyllum, L.

Native. First record: Gosselin, I8I5.

Very common all round the coast. Occasionally found with white flowers.

The French name of this plant is Serpolet. It is recommended by Linnaeus as a cure for headache and the effects of intoxication. Shakespeare only mentions Thyme once, in the familiar passage in Mids. Night's Dream, ii. 2; but his great contemporary, Bacon, praises it highly in his essay on Gardens.

Calamintha Nepeta, Clairv.

Lesser Calamint.

Native (?). First record: Marquand, I89r.

Very rare. Route des Hougues, St. Saviours, in abundance in the hedge on the roadside. A few plants in a waste corner at Bordeaux in $\mathrm{r} 89 \mathrm{I}$.

In France this plant is known by the name of Herbe aux chats, as in England, Catmint, because, says Gerarde, 'cats are very much delighted therewith, for the smell of it is pleasant unto them.'

Calamintha officinalis, Moench.

Common Calamint.

Native. First found: Gosselin, I788.

Very rare. Lane behind Les Pelleys (viII.), sparingly on a hedgebank in 1892 . Plentiful in a field bordering that lane in 1900 (Andrews). Noted in Fl. Sarn. for Grognet, on the authority of H. O. Carré. Specimens in Gosselin's herbarium (labeiled Cila- 
mintha Acinos) were collected ' in a furze field E. of La Maison Sohier, at the Vale.' The plant from Les Pelleys is var. Briggsii, Syme, and Mr. Andrews informs me that it matches very well with Archer Briggs' plants, but is rather more hairy.

(Calamintha Clinopodium, Benth., IVild Basil, occurs in Alderney.)

\section{Melissa officinalis, L.}

Alien. First record: Babington, 1839.

Common Balm.

Very rare. Roadside below Le Tertre (Ix.), a few large plants in 1893 . Field corner below Les Issues (VII.) in good quantity in 1894. Also found by Mr. Andrews in a second locality in this valley, apparently well established. In Fl. Sarn. the station is not specified.

Called in the patois Piment. In Briggs' Flora of Plymouth (1880), we are told that ' an infusion of this herb was formerly much drunk by the country folk, and they still consider its bruised leaves, with salt and honey, necessary for "seasoning the bee-but," or hive, before the young swarm is shaken into it.' A similar custom is prevalent in Guernsey, for Métivier says (Dict. Franc-norm.) that the hives are rubbed with the bruised leaves of this plant in order to attract swarms that have wandered away.

Scutellaria galericulata, L.

Native. First found: Gosselin, I 788 .

Common Skullcap.

Rare. Plentiful in the ditches north of Ivy Castle, where it grew in Gosselin's time, as proved by a specimen in his herbarium. Eastern side of Perelle Bay. Marshy field between Rocque Maingy and Les Goubais. Ditch at Grande Mare, a few plants.

Scutellaria minor, L.

Native. First record: Babington, 1839 .

Lesser Skullcap.

Very rare. On the borders of the cliff stream at Le Jaonnet, near Petit Bot, fairly plentiful. In Fl. Sarn. it is noted by H. O. Carré from furze-brakes near Bessieres; a locality now probably built over.

Prunella vulgaris, L.

Native. First record: Gosselin, I8I5.

Self-heal.

Generally distributed and rather common in pastures, commons, and waste spots. I have occasionally found plants with pure white flowers.

This plant has long enjoyed a high reputation as a vulnerary, and is considered very efficacious in healing cuts; hence its local names, Carpenter's Grass and Carpenter's Herb. An old French proverb affirms that no one needs a surgeon if he has Self-heal at hand. The English name is thought to be a corruption of Slough-heal. 
Nepeta Glechoma, Benth.

Native. First record: Gosselin, 1815.

Ground Iry.

Generally distributed, but not common, and more frequently found in the southern half of the island than in the north. On the cliffs it occurs abundantly in some places.

Formerly called Hedera terrestris, whence comes the common name Ground Ivy. Until superseded by hops about the reign of Henry VIII. this plant was used for clarifying ale and giving it a flavour. It is still often employed as a pectoral medicine.

Lamium amplexicaule, $L$.

Henbit Dead-nettle.

Colonist. First found: Gosselin, I788.

Frequent in all parts of the island in arable land and waste ground; also on roadsides occasionally. More common in the low-lying districts than in the south.

Lamium incisum, IVilld.

Cut-leaved Dead-nettle.

Colonist. First found: Gosselin, I 788.

Rather common throughout the island, growing in the same situations as the last species.

Lamium purpureum, L.

Native or Colonist. First found: Gosselin, I 788.

Frequent in cultivated ground and on roadsides, and often associated with the two preceding species. In Gosselin's herbarium. the three species of Lamium are represented, but the localities in which they were found are not noted.

Leonurus Cardiaca, L.

Alien. First record: Gosselin, r 8 I 5.

Rare. More frequent at the Vale than elsewhere in the island, but noted in many parishes, though often only a plant or two in each place. Sometimes very fine on rubbish heaps.

The common French name of the Motherwort is Agripaume, but in the Guernsey patois it is known as Picot: "à cause des épines, piquots ou piquets de son calice,' says Métivier, though this seems a very improbable derivation. The plant is said to have been originally brought from Asia.

Galeopsis Tetrahit, L.

Native. First found : Gosselin, 1788.

Hemp-nettle.

Very rare, and long supposed to be extinct until it was rediscovered by Mr. G. Derrick in $\mathbf{1} 897$ in a field behind Les Caches (vir.). A specimen in Gosselin's herbarium is labelled 'Orchard behind the house of Mont Plaisir, and near the pond at the Rohais.' No locality is specified in Fl. Sarn. 
*Stachys Betonica, Benth.

Wood Betony.

Extinct.

This generally common plant was probably always rare here, and is now certainly extinct. The only record we have of its occurrence is found in Fl. Sarn., where it is noted for Guernsey, without locality, on the authority of $\mathrm{H}$. O. Carré.

Stachys sylvatica, L.

Native. First record: Gosselin, 1815 .

Hedge. Woundwort.

Rather common in all districts in hedgebanks and in bushy and waste places.

Called in the patois Artie puante, or stinking nettle, owing to its very disagreeable odour when bruised; in Normandy it is known under the same name, and also Epiaire.

Stachys palustris, L.

Native. First record: Gosselin, 1815.

Marsh Woundwort.

Frequent throughout the island generally, but chiefly found towards the interior, or in localities at some distance from the sea. Var. ambigua, Sm. First record: Babington, 1839 . This plant is a hybrid between sylvatica and palustris, and, according to Hooker, never matures fruit. At the Catel I have found plants agreeing fairly well with the ambigua of Smith, but these are far less commonly met with than other intermediates which approach more nearly to palustris. The latter forms occur here and there all over the southern half of the island.

The patois name Coummaire has been given me for this plant, but Métivier says that term belongs to Inula dysenterica. The Woundwort, as its name implies, was formerly renowned as a vulnerary, and old Gerarde affirms that he cured 'many grievous wounds, and some mortale, with the same herbe.'

Stachys arvensis, L.

Native or Colonist. First record: Gosselin, 1815.

Common in all districts in cultivated ground and waste corners.

Ballota foetida, Lam.

Black Horehound.

Native. First record: Gosselin, 1815.

Common in the north of the island, less so westwards, though found in several places at St. Peter's and St. Saviour's; and almost or quite unknown in the extreme south. Occurs very often close to houses and by dusty roadsides.

Marrubium vulgare, L.

White Horehound.

Denizen. First record: Gosselin, I 8 r 5.

Rare. In three or four spots, near buildings, at Lancresse. Roadside at La Moye (Ix.). Top of the cliffs at Petit Bot, by the 
sea wall. Grand Havre. Quarry heap by the Vale Castle. Babington observes in a note in Fl. Sarn. that 'a much more woolly viricty' (M. apulum. Ten.) is not uncommon in the [Channel] islands.'

Called in the neighbourhood of Cherbourg Moriauquemin. The White Horehound was highly prized by the old herbalists, and is still used as a remedy for coughs and other pectoral complaints.

\section{Teucrium Scorodonia, L.}

Native. First record: Gosselin, 18r5.

Wood Sage.

Common throughout the island on bushy and stony hedgebanks, and in heathy places: abundant on the cliffs.

This plant is known in the patois as Lambraise or Ambraise, the local form of the French name Ambroise, under which term it seems to have been known in England at one time, because Lyte, the author of an ancient Herbal, in 1578 says this species is 'called in English Wood Sage. Wild Sage, and Ambros.' The plant is employed in some places in the brewing of ale, to which it communicates a pleasant flavour, but makes it very dark in colour

Teucrium Scordium, L.

Water Germander.

Native. First found: Andrews, I900.

Very rare. In considerable quantity in a sandy field near Grandes Rocques, where it was discovered by Mr. C. Andrews in August, 1900. There can be no doubt that the plant is truly native in this locality.

Ajuga reptans, $L$.

Native. First record: Gosselin, is 15.

Frequent in damp pastures and moist places by roadsides, bitt less common in the north than in the hilly parts of the island: abundant on some parts of the cliffs. Varies in the colour of the flowers.

\section{VERBENACEAE.}

\section{Verbena officinalis, L.}

Vervain.

Native. First record: Gosselin, 1815 .

Rather rare generally, but more frequent in the northern districts. I have noted it at different times in nearly all the parishes.

Vervain was one of the sacred plants of the Druids, and was only gathered by them 'when the Dogstar arose, from unsunned spots.' From time immemorial it has been the floral symbol of enchantment: it was a potent ingredient in love philtres and other magic preparations, and Drayton speaks of it as "gainst witchcraft much avayling.' An allied species, the Lemon-scented Verbena (Aloysia citriodora), more commonly called in Guernsey the Lemon Plant, is an old and general favourite, on account of its fragrant foliage. 


\section{LENTIBULARIACEAE.}

* Utricularia minor, L.

Small Bladderwort.

Extinct.

The preservation of specimens (without flowers) in Gosselin's herbarium, labelled, 'Ditch to S. of Ivy Castle, and in the wet ditches in the Marais,' places beyond doubt the former occurrence in Guernsey of this interesting little plant, which it is to be feared has long since become extinct. Happily the Ivy Castle marshes are not yet drained, and it is possible that a careful search would be repaid by the rediscovery of Utricularia. It may, however, have ceased to exist before Babington's time, as in Fl. Sarn. the plant is recorded for Jersey only.

\section{PRIMULACEAE.}

Primula vulgaris, Huds.

Primrose.

Native. First record: Gosselin, I 8 I 5.

Common throughout the island. White flowers occur occasionally, and plants with liver-coloured flowers have been found. The caulescent form, sometimes mistaken for the Oxlip, has been met with in a few places, perhaps escaped from gardens.

The patois name of this flower is Pâqueralle, i.e., the little rose of Easter; in the north of Normandy it is called Prumerolle or Pruniole, but its proper French name is Primevere, a term unknown among the country people of this island. There is a common local proverb which alludes to the mildness of the average winters here: 'I n'y a poui Noué sans sa pâquerolle ou p'tit agné,' which may be freely translated, There's never a Christmas without its primrose or little lamb. Primroses are said to be more plentiful in England than in any other part of Europe of equal extent.

\section{Primula veris, $\mathrm{L}$.}

Alien. First found: Derrick, 1895.

Very rare. Grows sparingly in a plantation at St. Martin's, where it was discovered by Mr. G. Derrick in I 895 About ten years ago a lady informed me that at one time she used to gather Cowslips in a field near Le Vauriouf (III.), but she had not seen any there for several years. Other persons have spoken of the former occurrence of this plant in St. Martin's parish, but now it appears to be almost extinct. The Cowslip, however, is certainly not indigenous, and the plants found must always have been derived from cultivation.

The German name, Schlüssel-blume, or Key-flower, refers to its resemblance to a bunch of keys, the badge of St. Peter: and that is why the plant is called in some parts of England Herh Peter. 
Shakespeare mentions this flower in many passages, but nowhere more beautifully than in Cymbeline, ii. 2, where the "mole cinquespotted ' is likened to 'the crimson drops i' the bottom of a cowslip.'

Lysimachia Nummularia, L.

Alien. First record: Marquand, I 89 I.

Creeping Lousestrife.

Very rare. Lane behind Friquet Chapel, plentiful in one spot, where it has been known, I am told, for at least twenty years. In a meadow between Grande Mare and Vazon, east of, and adjoining, the stream. Certainly in this island an escape from gardens, where it is often grown. A common name of this plant is IIoneyzert.

(Lysimachia nemorum, L., the Yellow Pimpernel, occurs in Sark, but not elsewhere within this area.)

\section{Glaux maritima, L.}

Native. First record: Gosselin, I 8 r 5 .

Common in brackish marshes on the north and north-west coast from Rocquaine to the Vale; and at Lihou Island. Rarely among rocks at the foot of the cliffs in the south, as at Petit Port.

Anagallis arvensis, L.

Native. First record: Gosselin, 18 15.

Scarlet Pimpernel.

Very common. The form with salmon-coloured flowers is frequent, especially near the sea: plants with pale pink or fleshcoloured flowers (var. carnea, Schrank.) also occur, but less commonly. I have sometimes seen plants having all the flowers sexpartite. Var. caerulea, Sm. Blue Pimpernel. Recorded in Fl. Sam., on the authority of H. O. Carré, as found in a hedge behind Ville au Roi: Mr. Derrick has met with a blue Pimpernel two or three times: Miss Dawber found it at Pleinmont, and Miss Agnew in a garden at Hauteville. But I am not sure that the true plant (having petals destitute of cilia) occurs in Guernsey. In July I 893 I gathered on the roadside at St. Andrews, near the Naftiaux Chapel, two plants of the blue-flowered form, which had the denticulate petals all fringed with cilia, exactly as in the common red form, and the capsules had only five striae; in fact, the plants were in no way distinguishable from the Scarlet Pimpernel, except that the flowers were a deep violet blue. Borrer thought that there might be two species, or sub-species, each varying with blue and red flowers; and Mr. Townsend notes (Fl. Hants, p. 278) that the cultivated plant has been seen 'bearing blue and flesh-coloured -flowers on the same stem.' In the island of Jethou I have seen the blue Pimpernel growing plentifully, in company with the common red form, and among them a sprinkling of the very rare variety having pure white flowers.

Called in the Guernsey patois Pimprenelle, a name which is 
applied in Normandy to Poterium Sanguisorba, whilst the present species shares with Stellaria media the name of Mouron. The extreme sensitiveness of the flowers to a change of weather, which causes them to close their petals on the approach of rain, has earned for this little plant the almost universal name of Poor Man's or Shepherd's Weather-glass.

Anagallis tenella, L.

Native. First record: Gosselin, I 8 I 5 .

Bog Pimpernel.

Common throughout the island on the banks of rivulets and in wet, marshy places.

Centunculus minimus, L.

Native. First record: Babington, 1839.

Small Chaffweed.

Not rare, but extremely liable to be overlooked owing to its minute size. Abundant in hollows all over Fort Doyle headland, towards Fort Le Marchant, and in different parts of Lancresse Common. Also at L'Islet and Mont Cuet. Plentiful in cart-ruts and hollows on Cobo Castle hill. Sparingly on the wet roadside in Petit Bot Valley. Mr. Andrews has found specimens nearly three inches long in an old quarry at $\mathrm{La}$ Rochelle, Lancresse. In the south of England as well as in these islands I have almost invariably found Centunculus associated with Radiola.

Samolus Valerandi, L. Water Pimpernel. Brookweed.

Native. First record: Gosselin, I8 15.

Frequent in wet places in all districts, in the interior as well as on the coast : occurs in all the cliff valleys. Occasionally found on sea rocks just above high-water mark. On the roadside at Hougue du Pommier (viII.). I have seen plants very nearly three feet high, growing among bushes.

The word weed, now commonly restricted to any troublesome or unprofitable plant which gruws where it is not wanted, was formerly applied indiscriminately to all kinds of smaller vegetation. The word also signified wearing apparel, and is so used by the old poets and by Shakespeare in many passages, as in the concluding scene in Truelfth Night. In this sense it has become obsolete, except to designate the mourning apparel of a widow.

\section{PLUMBAGINACEAE.}

* Statice Limonium, L.

Common Sea Lavender.

Extinct.

This species is mentioned in Gosselin's list, and specimens from the Braye du Vale are preserved in his herbarium. Sixty years ago Babington found it in the same locality. No doubt it occurred 
plentifully in former times in the great salt marshes of the Vale and St. Sampson's, but at present no vestige of the plant is to be found.

Statice occidentalis, Lloyd.

Lesser Sea Lavender.

Native. First record: Gosselin, I 8 I 5.

Frequent on the cliffs of the south coast, but mostly in localities difficult of access, so that the plant has hitherto been considered rare. About Fermain and St. Martin's Point it grows in places within easy reach, but further west, where Mr. Andrews has found it plentifully all along the coast as far as Les Thielles, it occurs 'almost invariably in places hardly ever visited, and necessitating a climb to reach them.' This species is noted in Gosselin's list as Statice reticulata, and in Fl. Sarn. as S. spathulata, Desf. (S. binerzosa, G. E. Sm.).

(Statice lychnidifolia, De Gir., a non-British species resembling S. Limonium in general appearance, occurs on seashore rocks in Alderney. Corbiere ( $F l$. Norm.) records it for many places in the Department of La Manche, and for the Chausey Islands.)

Armeria maritima, Willd.

Native. First record: Gosselin, I 8 I5.

Very common all round the coast. Occasionally found with pure white flowers.

Dr. Prior (Pop. Names Brit. Pl.) says the word Thrift is the passive participle of the word threave or thrive, to press close together, and signifies clustered. In Normandy this plant is called by various names, Pas de chat, Pétraux, and Sent à miel.

\section{PLANTAGINACEAE.}

Plantago Coronopus, L.

Buck's-horn Plantain.

Native. First record: Gosselin, I8I5.

Very common, especially on the coast, but also on dry banks and sandy waste spots inland. Extremely variable in size. A dwarf form, identified as var. pygmaea, Lange, was found at Moulin Huet by Mr. Andrews : it is probably not uncommon.

In Normandy this species is called Corne de cerf, i.e., Buck's horn, a name applied in Guernsey to Senebiera Coronopus: in both cases obviously from the resemblance of the leaves to the branching antlers of a stag.

Plantago maritima, L.

Sea Plantain.

Native. First record: Gosselin, 1815 .

Common in the south at the base of the cliffs, and on rocks a 
little above high-water mark. Rare in the low-lying districts. South side of Bordeaux Harbour sparingly.

Plantago lanceolata, L.

Ribwort Plantain.

Native. First record: Gosselin, I8 5 .

Very common, and very variable. In Fl. Sarn. Babington distinguishes three varieties, all of which are more or less common.

Called in the patois Amourettes, about which Métivier remarks: ' Nos amourettes sont les Amorettis, true-love knots, nœuds d'amour, du poëte anglais Chaucer.' In Cheshire it is believed that a large quantity of this plant in the herbage will cause the hay to heat and ultimately ignite the rick. From time immemorial it has been employed as a vulnerary: "plantain ribbed, that heals the reaper's wounds.'

Plantago major, L.

Great Plantain.

Native. First record: Gosselin, I8 I5.

Common throughout the island.

The patois name is Plantain, as in Normandy. Among the old herbalists this species, like the last, was in great repute in the healing of wounds, and Shakespeare alludes to this in Romeo and Juliet, i. 2. Plantain leaves placed inside the stocking are said to relieve the foot when sore from walking. This plant, which now abounds in the Eastern States of North America, was originally introduced from this country, and the Red Indians gave it the very expressive name of White Man's Foot. In Longfellow's poem Hiawatha says, speaking of the early settlers :-

'Wheresoe'er they tread, beneath them Springs a flower unknown among us, Springs the White Man's Foot in blossom.'

(Plantago media, L. Hoary Plantain. By some error Babington notes this species in Fl. Sarn. as occurring commonly in Guernsey. No one else has seen it in the island, and Gosselin makes no mention of it, though he enumerates the other four species of this genus.)

(Amaranthus retroflexus, I., has been found in Sark.)

\section{CHENOPODIACEAE.}

* Suaeda fruticosa, Forsk.

Extinct.

Shrubby Sea Blite.

In Journ. Bot., 1877 , p. 307, Mr. G. C. Druce has reported the fincling of this plant, which was 'growing sparingly by the side of St. Sampson's Saltpans in June last, Polypogon monspeliensis being 
also very abundant there.' Both plants have long since disappeared from that locality, the site being partly covered with greenhouses: and the former species is now almost certainly extinct in the island. But this proves that $S$. fruticosa existed here early in the century, though Prof. Babington doubted it. He remarks in Fl. Sarn., in a note under S. maritima: 'Mr. H. O. Carré gives $S$. fruticosa (Salsola fruticosa, Sm.) as a plentiful inhabitant of the Braye du Vale, but not having been able to discover any plants of it in that place I am inclined to believe that it is recorded in mistake for S. maritima.'

Suaeda maritima, Dum.

Common Sea Blite.

Native. First record: Gosselin, I8 I 5 .

Rare. Brackish pool at Pulias. Lerée Bay. Marshy fields at Claire Mare, near Perelle. On the shore below the causeway leading to Rousse Tower a more robust shrubby form is found, which has much of the aspect of $S$. fruticosa. Mr. Andrews has found at Claire Mare a distinct-looking form with almost simple stems, some of them fifteen inches long.

\section{Salsola Kali, L.}

Native. First record: Gosselin, 1815.

Prickly Saltwert.

Rare. Scattered plants are to be found all along the shores of the lowlands from Rocquaine Bay (and Lihou Island) to Bordeaux, but seldom in any quantity. Occasionally more plentiful in sandy cultivated fields and gardens, especially at the Vale, where this plant is more common than elsewhere.

Called in French Soude épineuse, corresponding to the name Sowdruort (soda plant), by which it is known on some parts of the British coast. It was much valued at one time on account of the quantity of soda it contains. The ashes of this and some other allied maritime plants constitute the barilla of commerce.

Chenopodium Vulvaria, L.

Native. First record: Gosselin, I 8 I 5

Not uncommon in sandy fields under cultivation and on the seashore all along the coast from Cobo to Lancresse, sometimes occurring in plenty. Lerée Bay, and probably elsewhere in the north-west. One plant on the roadside at Havelet in 1892 . The whole plant is invested with a greasy mealiness, which, when touched, exhales a most odious and lasting smell of stale fish.

Chenopodium polyspermum, L.

Allseed Goosefoot.

Colonist. First record : Gosselin, I8 15.

Frequent in cultivated fields and gardens in all parts of the island, but rather more common in the interior and lowlands. Two 
forms of the plant occur here: var. spicatum, Moq., and var. cymosum, Moq.

\section{Chenopodium album, L.}

Native. First record: Gosselin, I8 I5.

Common everywhere: very variable. At least three well-marked forms occur in the island more or less plentifully: var. candicans, Lam., var. paganum, Reich., and var. viride, L.

The patois name, similar to that of the northern parts of Normandy, is Snille or Senille, clearly from the Latin senilis, in allusion to the general hoariness of the plant. It is generally considered a worthless weed, but cattle will eat it; and, when boiled, it is said to be palatable.

Chenopodium ficifolium, Sm.

Colonist. First record: Babington, i 839.

Fig-leaved Goosefoot.

Frequent, and often plentiful, in cultivated ground and fieldcorners, and on rubbish-heaps, especially in the lowlands.

Chenopodium murale, L. Nettle-leaved Goosefoot.

Colonist (?). First record: Gosselin, I8I 5.

Rather common in the north and north-west in cultivated and waste ground, and by roadsides. Less frequent in the south.

Chenopodium rubrum, L.

Native. First record: Marquand, I89r.

Red Goosefoot.

Rare: occurs in marshy places in the low-lying districts. On the shore to the west of Vazon Bay. Marshy spot near Albecq. Dwarf plants in fields by Ivy Castle (Andrews).

Chenopodium botryodes, $\mathrm{Sm}$.

Native. First found: Andrews, r899.

Very rare. Growing plentifully in one part of Lihou Island, where it was discovered by Mr. C. Andrews in 1899. Mr. Arthur Bennett pronounced specimens 'good examples of Smith's plant; more compact than most of those from the marshes of Norfolk, \&c.'

Chenopodium glaucum, L.

Colonist (?). First found: Watson, 1865.

Oak-leaved Goosefoot.

Very rare. In Journ. Bot., 1875, p. 345 , there is a note to the effect that this species was collected at St. Sampson's, Guernsey, by H. C. Watson in I 865 ; but in the opinion of Dr. Boswell it was 'a very different form from the C. glaucum which occurs about London.' I possess a specimen labelled, in Watson's handwriting, 'Garden, I 866 : seeds from the Isle of Guernsey in 1865.'

(Chenopodium hybridum is given in Gosselin's list, but there is no plant bearing that name in his herbarium.) 
Beta maritima, L.

Native. First record: Gosselin, 1815.

Sea Beet.

Very common all round the coast. Sometimes, though rarely, this plant is found on banks inland, as in the lane behind the MIill Cottages, on the Catel Road.

Closely allied to, if not the parent stock of, the Beets and Beetroots of agriculture. The name is supposed to be derived from the resemblance of the seed to the second letter of the Greek alphabet.

Salicornia herbacea, L.

Native. First record: Gosselin, 18r5.

Frequent in muddy salt marshes. Brackish pool at Pulias. Close to the Vale pond. Below the causeway to Rousse Tower. Marshy field by Ivy Castle in r $89 \mathrm{I}$. Most of the plants belong either to the var. procumbens, Sm., or the var. patula, Duv. J.

In former days this plant was collected in large quantities for the production of barilla, and on the shores of the Mediterranean it is still used for the purpose together with some allied maritme species.

Atriplex littoralis, L.

Native. First record: Babington, 1839 .

Grass-leaved Sea Orache.

Frequent in the neighbourhood of Lerée and Perelle. Spur Point, St. Sampson's. Sparingly at Richmond (Andrews). Var. marina, L., still occurs at Lerée Bay, where Babington gathered it sixty years ago.

The name Orache is of obscure origin, and its meaning is uncertain. It was formerly written Arach and Arasches; the French name is Arroche.

Atriplex patula, L.

Narroze-leaved Orache.

Native. First record: Gosselin, I8I 5.

Common throughout the island in cultivated fields and waste ground. Var. angustifolia, Sm., and var. erecta, Huds., are more or less plentiful in all districts, but, like some others belonging to this genus, often present perplexing forms.

Atriplex deltoidea, Bab.

Native. First record: Babington, 1839.

Rather common, especially in the low-lying districts. This species was originally described in the Flora Samica by Prof. Babington from specimens found by him at the Braye du Vale and below Fort George, and his description was copied in the $5^{\text {th }}$ edition (I842) of Hooker's British Flora. Var. salina, Bab. Frequent on the shingle all round the shores of the lowlands. 
Atriplex hastata, L. Halberd-leaved Orache.

Native. First record: Babington, I839.

Common in cultivated and waste ground, in salt marshes, and on the seashore. This species is the A. patula of Fl. Sarn. The saltmarsh form is probably the var. oppositifolia, DC.

Atriplex Babingtonii, Woods.

Native. First record: Babington, I339.

Babington's Orache.

Not uncommon on the seashore, especially on the north and north-west coast. This is another Atriplex which was added to the British Flora from Guernsey specimens, the plant being originally described in Fl. Sarn. by Babington under the name of A. rosea. Corbiere (Nouv. Fl. Norm.) describes three varieties found on the opposite shores of France: it is probable that some or all of them occur in this island also. Mr. Townsend mentions (Fl. Hampshire) that a specimen of this plant was found in Sandown Bay, Isle of Wight, measuring twenty-one feet in circumference.

Atriplex farinosa, Dum.

Frosted Sea Orache.

Native. First record: Babington, I839.

Common on the sandy shores of the low-lying districts, less so in the south. This species is the A. laciniata of Fl. Sarn.

Obione portulacoides, Moq.

Purslane Orache.

Native. First record: Gosselin, I 8 I 5 .

I found this plant at Lerée Bay in I889, and for several years this was the only station known for it in the island. In I 894. Rev. R. H. Tourtel, Rector of Torteval, sent me for identification some specimens he had collected at the base of the cliffs at Les Thielles: and in 1898 and $1899 \mathrm{Mr}$. Cecil Andrews discovered that this plant is generally distributed and locally abundant all along the south coast, from Petit Port westwards, growing on the lower parts of the cliffs where the soil is rubbly, and mostly in places difficult to reach without a good deal of climbing. In Fl. Sarn. it is recorded for Moulin Huet Bay, on the authority of W. Christy.

\section{POLYGONACEAE.}

Rumex conglomeratus, Murr.

Native. First found: Gosselin, 1788 .

Common throughout the island in marshy ground, waste places, and roadsides. Specimens in Gosselin's herbarium show that this is his Rumex paludosus, Marsh Dock; and very probably it is also what he named in his list $R$. acutus, Sharp-pointed Dock.

Rumex rupestris, Le Gall.

Native. First record: Marquand, I89I.

Rare. At the foot of the cliff at Grand Port, on the south side of Rocquaine, in some quantity. 
Rumex sanguineus, L.

Blood-veined Dock.

Native. First record: Gosselin, I815.

Frequent in all districts on roadsides, banks, and waste spots: conspicuous by the blood-red veins of the leaves. Var. viridis, Sibth. Occurs in many places in the interior, but is much less common than the type.

Rumex pulcher, L.

Native. First record: Gosselin, $18 \times 5$.

Fiddle Dock.

Rather common throughout the island. The English name refers to the shape of the lower leaves, which distinguish this species from all others.

Rumex obtusifolius, L.

Native. First record: Gosselin, I8r 5.

Broad-leaved Dock.

Common everywhere in moist corners and waste places, and on the borders of meadows.

Rumex crispus, L.

Native. First record: Gosselin, I8 $_{5} 5$.

Curled Dock.

Common in waste places, cultivated fields, and on roadsides throughout the island.

Rumex Hydrolapathum, Huds.

Native. First record: Gosselin, I8 I $5_{5}$

Great Water Dock.

Rare. Marshes between Rocque Maingy and Les Goubais. Ditches north of Ivy Castle. Field behind the Hermitage, Vale. Wet meadow at Perelle. This is by far the finest of our Docks; the leaves are sometimes two feet long.

Rumex Acetosa, L.

Native. First record: Gosselin, 18 15 .

Common Sorrel.

Common in all districts in hedgebanks and pastures.

Called in the patois Surelle, the French name of the plant. Its reputation as a salad extends back to very ancient times. The Laplanders are said to mix a strong decoction of the leaves with their reindeer milk, which is thus preserved for use from autumn till the ensuing summer.

Rumex Acetosella, L.

Native. First record: Gosselin, I8 15.

Sheep's Sorrel.

Very common everywhere on dry banks, stony places, and barren pastures: abundant on the cliffs.

Polygonum amphibium, L.

Native. First record: Gosselin, I8 15.

Amphibions Persicaria.

Rare. There are two forms of this plant, varying with its habitat, but they are connected by intermediates. Var. natans, Moenc ${ }^{\text {t }}$ 
Growing in the water with submerged stems and floating leaves. Millpond below St. Peter's Church. Pool on the eastern side of Lancresse Common. Stream between Grande Mare and Vazon. Small pool near Albecq. Valley west of St. Saviour's Church (Andrews). Var. terrestre, Moench. Growing in marshy ground: stems more or less erect. Rocques Barrées (Ix.). Moist meadows near Rocque Maingy. Rue d'Enfer, near King's Mills.

Polygonum lapathifolium, L.

Pale-flowered Persicaria.

Native. First record: Babington, 1839.

Rather rare, and mostly in the north and west. Plentiful in a cornfield at Baubigny, and in several cultivated fields at the Vale in I889 and r89o. Here and there in VI., vir., and viII. in fields and on manure heaps. Growing in the sand at Lerée Bay sparingly in I89I, and the following years.

Polygonum maculatum, Dyer. Slender-headed Persicaria.

Native. First record: Babington, I 839.

Very rare. Roadside at Lerée Bay, in considerable quantity in I89 r : a prostrate form with very thick joints. It is noted for the Vale in Fl. Sarn. under the name of P. laxum. T. Archer Briggs observes with regard to this species $(F l . P l y m$.): 'I believe this graduates into lapathifolium, as plants with characters more or less intermediate occur.' He allows it specific rank, however, like the last edition of the Manual and the London Catalogue.

Polygonum Persicaria, L.

Native. First record: Gosselin, I8 15.

Common as a weed in cultivated ground, and on roadsides and waste places.

Polygonum mite, Schrank.

Casual (?). First record : Marquand, I89r.

Very rare. I found a single specimen in I 890 on the roadside at Les Caches, St. Saviour's. This species is rare throughout Normandy in general, and does not occur in the Department of La Manche, the portion nearest to these islands.

Polygonum Hydropiper, $L$.

Native. First record: Gosselin, I8 I 5 .

Rare. In the two valleys at Petit Bot, and in Saints Bay Valley. Below Le Casrouge (Iv.). Roadside behind St. Helena. Streamside in Talbots Valley. Damp hollow on the western side of Lancresse. Mr. Andrews has found it in the valley below Les Issues (VII.), near Les Vinaires (VI.), by the millpond below St. Peter's Church, and in a ditch near Ivy Castle.

The Normandy name for this plant is Poivre d'eau, the equivalent of Water Pepper and Hydropiper, the leaves being so acrid that 
they act as vesicants. It is said that moths will not touch clothes among which the dried stems are laid.

Polygonum aviculare, $\mathrm{L}$.

Native. First record: Gosselin, I8r5.

Common Knotgrass.

Very common and extremely variable. Var. littorale, Link. Frequent all round the sandy shores of the north and north-west. This variety closely resembles $P$. Raii, but is readily distinguished when in good fruit.

Known in Normandy by the name of Trainasse. A curious superstition prevailed at one time in connexion with this plant. It was believed that if a boy drank an infusion of the stems and leaves it would arrest his growth: and it is to this belief that Shakespeare alludes in Mids. Night's Dream, iii. 2 :-

\section{'Get you gone, you dwarf,} You minimus, of hind'ring knotgrass made.'

Polygonum Raii, Bab.

Native. First record: Babington, 5839 .

Ray's Knotgrass.

Occurs not uncommonly all round the sandy coasts of the lowlands, but it must be carefully distinguished from the maritime form of $P$. aviculare, with which it often grows. In some places it is particularly plentiful, as at Rocquaine Bay and on the west side of Lancresse. Grows on the shingle at Lihou Island.

Polygonum maritimum, L.

Native. First record: Babington, 1839 .

Sea Knotgrass.

Very rare. In $1890 \mathrm{I}$ found one fine plant, much buried in the sand, at the north end of Rocquaine Bay. That appears to be the only instance of the occurrence of this species here within the last twenty years. Babington found it at Grand Havre more than sixty years ago: and Mr. Andrews informs me that there is a specimen in the British Museum, collected by H. C. Watson, from 'the sands of Grand Havre, 1852 ;' also a fine specimen of A. G. More's, labelled 'Guernsey, I859.' During the last ten years a diligent search has been made for this plant all along the coast of the lowlands, but without success.

Polygonum Convolvulus, L.

Native or Colonist. First record: Gosselin, I8I 5 .

A very common weed in cultivated ground in all parts of the island. Var. pseudo-dumetorum, Wats. Waste ground at Bordeaux, a few plants in 1899 .

In twining round a support, this plant, like the Hop, turns to the right: whereas the common Scarlet Runner Bean and the White Convolvulus turn to the left. It must be understood that the observer is supposed to stand within the spiral, otherwise the twining appears to take a contrary direction. 
Fagopyrum esculentum, Moench.

Buckwheat.

Casual. First record: Babington, I839.

Occasional plants are to be found on roadsides and near houses, springing up from scattered poultry seed. Buckwheat is very rarely, if at all, grown in Guernsey as a crop.

The word Buckwheat seems to be a corruption of the German Bïche-zueizen, that is, beech-wheat, just as Fagopymum means beechfruit, in allusion to the resemblance of the seeds to beech-mast. Many old writers recommend beehives to be moved to buckwheat fields when the crops are in blossom, as a certain means of increasing the quantity of honey: for bees are extremely fond of the flowers.

(Thesium humifusum, DC., Bastard Toadflax, occurs in Alderney.)

\section{EUPHORBIACEAE.}

\section{*Euphorbia Peplis, L.}

Extinct (?).

From some cause or other which it is difficult to explain this plant seems to have completely disappeared within the last half century. I possess a specimen gathered in Guernsey in 1859 by A. G. More, and that is the most recent evidence I have of its occurrence. During the last dozen years the sandy shores of the north and north-west have been carefully searched, but no trace of the plant has been detected. Gosselin records it in his old list of I 788 , and on August 26th, I837, Babington notes in his Journal that he 'found Euphorbia Peplis in great plenty on the sands of Grand Havre at some distance beyond the Vale Church.' Doubtless these old stations are now covered by deep layers of sand, and some day, when it has been blown back again, and the buried seeds uncovered, the plant will reappear in plenty. In Alderney, where Euphorbia Peplis occurs in several places, I have noticed that the plants do not reappear in exactly the same spot two years in succession, although producing an abundance of seed. On the shell-beach at Herm Mr. Andrews has collected some unusually fine specimens, one measuring thirteen inches by nine inches. The Alderney plants are usually from three to six inches in diameter.

\section{Euphorbia Helioscopia, L.}

Colonist. First record : Gosselin, I8 I 5 .

Sun Spurge.

A rather common weed in gardens and cultivated fields throughout the island.

Called in Normandy Herbe à la biche and Reveil-matin. The acrid milky juice is reputed to cure warts, but it should be used with caution. Fatal results are reported to have followed the eating of the fresh plant. 
Euphorbia amygdaloides, L.

Native. First record: Gosselin, 18r5.

Wood Spurge.

Rare, except on the cliffs at St. Martin's and the Forest, where it is common. Lane behind the Forest School. St. Peter's Road, near Plaisance. Valley west of St. Saviour's Church. Copse at Moulin de Haut, near King's Mills. In an old quarry near Ronceval. Lane between Vale Rectory and Les Marais.

Euphorbia Paralias, L.

Native. First record: Gosselin, 1815.

Sea Spurge.

Rather rare, but occurs here and there all along the sandy shores of the north and north-west as far as Rocquaine Bay. More plentiful on the Vale Coast.

Euphorbia portlandica, L.

Native. First record: Gosselin, 1815.

Portland Spurge.

Very common on the cliffs, and much more frequent than the last species on the shores of the lowlands.

Euphorbia Peplus, L.

Colonist. First record : Gosselin, 1815.

Petty Spurge.

A very common weed in cultivated ground everywhere.

Known in the patois by the name of Lait d'souaris, or mouse's milk. The milky juice of this and other species of Euphorbia is very acrid, and ulcerates the flesh wherever it is applied. The word Spurge comes through the French Espurge, from the Latin expurgare, alluding to the medicinal effects of these plants.

Euphorbia exigua, L.

Colonist. First record: Gosselin, I815.

Dwarf Spurge.

Frequent, especially in the south, in cornfields and arable land, and on banks occasionally. Rare in the north of the island.

Euphorbia Lathyris, L.

Alien or Casual. First found: Gosselin, I788.

Caper Spurge.

Very rare. Not noted in recent times until it was found in 1897 by Mr. H. Le Lacheur in cultivated ground at Les Norgiots (II.). Occurred plentifully as a garden weed at the Rocquettes in I 899 (Andrews). There is a specimen in Gosselin's herbarium labelled, 'My garden at Glateny and in a field at Mont Plaisir.'

This handsome plant, a native of southern Europe, is sometimes cultivated, and often becomes a persistent weed in gardens, as it was years ago in mine at Alphington, near Exeter. The fruits are often pickled as a substitute for capers, which they resemble in size and appearance, but they are inferior in flavour. 
Mercurialis annua, $\mathrm{L}$.

Colonist. First record : Gosselin, I8 15 .

Annual Dog's Mercury.

Very common. One of the most abundant weeds in gardens and cultivated fields in every part of the island.

The patois name of this plant is Foirolle, the same as in Normandy, where the word is sometimes varied to Foiroude. This species offers one of the extremely rare examples of parthenogenesis among phanerogams. Carefully conducted experiments have conclusively proved that the unfertilised ovaries do occasionally produce fertile seed, though less in quantity than that resulting from pollination. See Kerner and Oliver's Nat. Hist. of Plants, 1895 , vol. ii. p. 465. This plant has the reputation of being poisonous.

(Ceratophyllum demersum, L., the Hornwort, is marked for Guernsey in the list given in Ansted's Channel Islands, but there is no satisfactory evidence of its occurrence in these islands.)

\section{CALLITRICHACEAE.}

Callitriche verna, $\mathrm{L}$.

Native (?). First record: Gosselin, 1815.

Common Water Starwort.

In Fl. Sarn. Babington notes this species as common in all the islands, and Gosselin gives it in his list as the only species found by him. Ten years ago I collected in a pool at Baubigny, and in a quarry pool near La Moye, Vale, plants which appeared to me to belong to this species; but unfortunately I kept no specimens, so that it must remain for the present uncertain whether the true Callitriche verna occurs in Guernsey or not.

Callitriche obtusangula, Le Gall.

Native. First record: Marquand, I891.

Rare, but abundant where it occurs. Ditch on the lane side at Grande Mare. Meadow drain at Les Goubais (Ix.). Ditches between Ivy Castle and Baubigny. Quarry pool at L'Islet.

Callitriche stagnalis, Scop. Large-fruited Water Starwort. Native. First record: Marquand, I89r.

Common in shallow pools and ditches; often growing on the mud on wet roadsides.

Callitriche hamulata, Kutz.

Native. First record: Babington, I839.

Rare. Ivy Castle ditches. Quarry pool at L'Islet. A very slender and beautiful form occurs in a large and deep quarry pool at Mont Cuet, Lancresse. Under the name of $C$. pedunculata, DC., this species is noted in Fl. Sarn. from 'near Paradis, and by the roadside near Bordeaux Harbour.' 


\section{Callitriche truncata, Guss.}

\section{Native. First found : Ley, 1885.}

Very rare. Abundant in the running stream at Grande Mare, but barren. In I $892 \mathrm{Mr}$. James Groves and I found it in fine fruit in the pool by Fort Doyle; but not a trace of the plant could be detected there in the dry summer of $\mathbf{1} 899$. The Rev. Augustin Ley discovered this species in the millpond at the King's Mills in July 1885. Five years later I searched the spot, but could see nothing of it. It should be observed, however, that the Grande Mare stream flows out of the King's Mills millpond. It is a characteristic of this plant that it is always entirely submerged, and when the water is high in the stream its presence would never be suspected.

\section{URTICACEAE.}

Parietaria diffusa, Koch.

Native. First record: Gosselin, I 8 I 5 .

Wall Pellitory.

Frequent in all parts of the island on old walls and dry, stony banks. I have noticed occasionally, at the Vale and elsewhere, an erect, unbranched form, approaching var. erecta, M. and K., but graduating towards the type.

This plant is called in the Guernsey patois Paraietole, a slight variant of Pariétaire, the name by which it is known in Normandy.

Urtica urens, L.

Small Nettle.

Native. First record: Gosselin, I 8 I 5 .

Rather common in the north of the island: less so in the lowlands generally, and decidedly rare in the south.

The sting of this species is more venomous than that of the common nettle, hence its name, Ortie brîlante, in France, and Brennende Nessel in Germany. Nettle fibre was used in the manufacture of Scotch cloth as late as the seventeenth century, when flax and hemp were introduced to replace it. According to Prior, the word nettle 'would seem to have meant primarily that with which one sews,' thus connecting it with the word needle.

Urtica dioica, L.

Common Nettle.

Native. First record: Gosselin, 1815.

Very common everywhere. It is very curious that among nearly two hundred wild plants which I found in this island still flowering in the month of December, some years ago, not a single example of this species could be discovered, although $U$. urens was flowering profusely.

Nettles dressed like spinach are excellent eating, and an infusion of the plant is a common spring medicine in many rural districts. In Scotland it is occasionally used in place of rennet to curdle milk, and the young shoots make a favourite dish called 'nettle-brose.' 


\section{CANNABINACEAE.}

Humulus Lupulus, $\mathrm{L}$.

Denizen. First record: Babington, 1839 .

Common Hop.

Occurs in almost every parish in the island, though not com. monly. More often to be met with at the Vale than elsewhere. This plant may be really native, though I have thought it best to class it as a Denizen. Hops are not grown in Guernsey except as ornamental garden plants.

The Hop was well known to the Romans, but was not cultivated in England till the year 1524, when it was introduced from Flanders. Long before this time beer (or, as it was always called, ale) had been brewed in England without hops, other plants being used instead.

\section{ULMACEAE.}

Ulmus campestris, $\mathrm{Sm}$.

Denizen. First record: Gosselin, I815.

Common in all districts both as a tree and a hedgerow bush. The variety suberosa, Sm., the Cork-barked Elm, is also common.

It is worthy of notice that in Guernsey the word Orme (Elm) is feminine, like Ulmuıs, and not masculine, as in modern French. So also the Holly takes the feminine form Housse, not the masçuline Houx, as in France.

Ulmus montana, With.

Alien. First record: Babington, 1839 .

Common Elm.

Rather rare, and chiefly in the central parts of the island. Probably always planted.

The English name Wych Elm (often incorrectly written Witch) comes from the wood having been used to make the chests called in the old writers zeyches.

\section{AMENTIFERAE.}

Salix fragilis, L.

Alien (?). First record: Marquand, r 89 r.

Crack Willow.

Rare, and probably always planted. Roadside near Le Gelé (viIr.). Field corner below Les Rebouquets (Iv.). Roadside west of Petit Bot (Andrews).

Salix alba, L.

Native (?). First record: Gosselin, I8I 5 .

White Willow.

Rare. Lower end of Talbots Valley. Roadside between Forest Church and Petit Bot; and in a wet meadow at Cobo (Andrews). Noted in Fl. Sarn. for Les Landec, but there is no such place: 
possibly a printer's error for Les Landes. Var. vitellina, L. In several places at St. Martin's and the Forest, but apparently always planted.

Salix undulata, Ehrh. Sharp-leaved Willow.

Alien. First found: Andrews, 1900.

Grande Mare (Andrews).

Salix triandra, L.

Native (?). First found: Andrews, 1900.

Grande Mare (Andrews).

(Salix purpurea, L., occurs in Alderney.)

Salix viminalis, $\mathrm{L}$.

Native (?). First record: Gosselin, I815.

Almond-leaved Willow.

Mostly found in the lowlands: often planted but perhaps truly native in some localities, as at Grande Mare.

The word osier, according to Prior, is derived 'from a Celtic word meaning water or ooze, that has given its name to the Oise, in France, and to several rivers in England, e.g., Ouse, Ose, Use, and Ise.'

(Salix stipularis, Sm., occurs in Alderney.)

Salix Smithiana, Willd.

Native. First record: Marquand, I89I.

Silky-leaved Osier.

Between Moulin de Haut and King's Mills. This Willow is really a hybrid between cinerea and viminalis.

Salix cinerea, L.

Native. First record: Babington, r 839 .

Common throughout the island. In Fl. Sarn. the two varieties, aquatica, Sm., and oleifolia, Sm., are recorded for Guernsey.

(Salix aurita, L., occurs in Alderney.)

Salix caprea, L.

Great Sallow.

Native. First found: Rogers, $\mathbf{1} 897$.

Rare apparently: perhaps overlooked. Found in Fermain Bay Valley in 1897 by Rev. W. Moyle Rogers.

Salix repens, L.

Native. First record: Babington, 1839

Dwarf Willow.

Rare. Grande Mare, plentiful in some parts of the marsh. Babington found this species 'near Vazon Bay,' and var. ascendens, Sm., near Les Landes. 
Populus alba, L.

Alien. First record: Babington, 1839.

White Poplar.

Frequent throughout the island: more common in the low-lying districts. Probably always planted.

The ancients regarded the White Poplar as symbolical of Time, partly because the leaves appear always in motion, but also because, being dark above and white beneath, they were supposed to resemblethe alternation of day and night.

Populus canescens, Sm.

Alien. First record: Marquand, I89I.

Grev Poplar.

Several trees close together at the lower part of La Ramée: certainly planted there.

Populus tremula, L.

Native (?). First record: Gosselin, I8 I 5 .

Aspen.

Rare, though found in almost every parish. Mostly planted, but occasionally occurring in situations where it has the appearance of being wild. In Normandy this tree is undoubtedly indigenous, as it is also in the south of England.

The strictly correct name of this tree is simply $A s p e$, and we find it so written by Chaucer and other early poets. Aspen is the adjectival form, like golden, the word tree or timber being understood. So also to speak of a Linden-tree is quite correct, the substantive being properly Lind. Gosselin calls this the Trembling Poplar Asp.

Populus nigra, $\mathrm{L}$.

Alien. First record: Marquand, I89I.

Black Poplar.

Frequent throughout the island, but always planted. Although common enough in England, this tree is only a doubtful native, and it is not indigenous in Normandy. Gosselin includes Populus in his list, but gives no specific name.

(Betula alba, L. Birch. Under this species Babington says, in Fl. Sarn., 'Frequent in hedges. Jersey. Guernsey.' As far as the latter island is concerned this is certainly an error. In Guernsey the Birch is not to be found in hedges at all, and the trees that occur are only to be seen in enclosed grounds, and are no more entitled to a place in the Flora than the Mountain Ash or the Horse Chestnut. It is not mentioned in Gosselin's list.)

Alnus glutinosa, Gaert.

Alder.

Alien. First record: Babington, 1839.

Very rare. A few trees on the edge of the moat at Iry Castle. Several along the stream which crosses the Vale Road. There are some Alders bordering the lane behind Sausmarez (III.), but they have evidently been planted there. We cannot tell whether this. tree was more common formerly, as Gosselin does not mention it, 
and Babington merely says 'In damp hedges, probably planted,' without specifying any locality.

Submerged in water, the wood of this tree is almost indestructible. Bog alder, or wood that has long lain in peat-mosses, is as black as ebony, for which it is often substituted; but it may be detected by its want of lustre.

Fagus sylvatica, L.

Beech.

Denizen or Native. First record: Babington, 1839 .

Occasional in different parts of the island, but by no means common. Fine trees are to be seen in the valley behind Les Vauxbelets (II.) and in a few other places: so, if it is true that beech-mast has been found in the submarine beds at Vazon, this tree may be truly native.

On the Continent the dry dead leaves have long been used for stuffing beds, and the fragrance which the leaves retain is very refreshing and invigorating. The variety called the Purple Beech was discovered in a wood in Germany a century and a half ago, and from it all the purple Beeches in Europe have been propagated.

Castanea vulgaris, Lam. Srveet Chestnut.

Alien. First record: Babington, 1839.

Rare. Hardly entitled to a place in the Flora, as the existing trees have all been planted, and, except in private grounds, few are sufficiently large to bear fruit. Occasionally found in hedges as a small bush.

Quercus Robur, L.

Native. First record: Gosselin, 1815.

$O a k$

A rather common tree in all parts, but seldom or never attaining very large dimensions, though well-grown symmetrical examples are occasionally to be seen. Var. pedunculata, Ehrh., is the common form : var. sessiliffora, Salisb., only occurs as a planted tree.

The Oak is called in the patois Quêne, as it is in Normandy. The Evergreen or Holm Oak (Quercus llex), which grows well in Guernsey, is a native of southern Europe, and was introduced into England about the middle of the sixteenth century. It is a tree of extraordinary duration, continuing to grow for many centuries, and seems to thrive best when planted within the influence of the seabreeze. There are many fine examples in this island.

Corylus Avellana, L.

Hazel.

Native. First record: Babington, 1839 .

Very rare, and now almost extinct. Two large trees in the copse on the hillside between Moulin de Haut and King's Mills. Two or three large trees in a copse in the valley west of St. Saviour's Church. In these two localities the Hazel appears to be perfectly wild. I have seen nuts and branches found in the submerged peat 
in Vazon Bay, so that in ancient times this tree was probably common in the island.

The ancient art of rhabdomancy, or the finding of hidden springs of water by means of a forked twig, is extensively practised in Guernsey, and has been in operation from time immemorial. The Divining Rod, or, as it is termed in Cornwall, the Dowsing Rod, is shaped like a $Y$, and is usually a freshly cut twig of hazel, or, if hazel is not procurable, willow is used, though it is less responsive. That the twig is deflected spontaneously, and in spite of the utmost muscular resistance, I can myself testify from actual experiment : but how this is caused, or why the twig works in the hands of certain persons and not of others, has never yet been satisfactorily explained.

(Carpinus Betulus, L., the Hornbeam, is noted for Guernsey in the list given in Ansted's Channel Islands; but it is very doubtful if any trees occur outside of private grounds.)

(Pinus sylvestris, L., the Scotch Fir, and P. Pinaster, Ait., the Cluster Pine, are to be seen in many parts of the island, but like the Horse Chestnut, the Lime, the Evergreen Oak, and some other trees, have no right whatever to a place in the Flora.)

\section{DIOSCOREACEAE.}

Tamus communis, L.

Native (?). First found: Marquand, I 893.

Black Bryony.

Very rare. On both sides of the path leading down to Fort Bay, in considerable quantity. This plant has quite the appearance of being native in this locality, and it is strange that it had not been noticed until I discovered it in 1893 .

In Townsend's Flora of Hampshire it is stated that the berries of this plant, preserved in gin or brandy, form an excellent remedy for chilblains. The fresh root is very acrid, and when scraped or beaten into a pulp was formerly employed as a stimulating plaster.

\section{ORCHIDACEAE.}

Orchis Morio, L.

Native. First record: Marquand, I89r.

Green-winged Orchis.

Rare, and apparently confined to the extreme south-west of the island. In $1890 \mathrm{I}$ discovered this species growing in considerable quantity in pastures near the Watchhouse at Pleinmont: and in I894 I found it in another locality a little to the south-east and near the cliffs. Some years later Miss B. Agnew found it at Les Pezeries, and also in several fields between Pleinmont and Mont Herault. 
There is no question whatever that it is truly native. Gosselin includes the name Orchis morio in his list, but it seems certain that he really meant $O$. laxiflora, which he does not mention, although it is widely distributed and common. This view is supported by Babington's note under O. laxiflora: 'This plant has been often taken for 0 . morio, which has not been observed in the islands.'

\section{Orchis mascula, L.}

Native. First record: Gosselin, I8I5.

Early Purple Orchis.

Rather rare: generally in very small quantity, often single plants, in each spot. I have noted stations for this species in all the central and southern districts, but I do not remember to have met with it in the extreme north.

Called in parts of Normandy Pain de Coulenvre, or Adder's Bread. These flowers are the Long Purples mentioned in Hamlet, iv. 7 , and the 'grosser name' alluded to in the succeeding line was in very general use in Shakespeare's time. On the famous doctrine of Signatures the old herbalists believed the Orchis to possess powerful properties, the nature of which will be understood by quoting an old author of the early part of the sixteenth century, who asserts that 'mulieres partium Italiae dant eam radicem tritam cum lacte caprino ad incitandam libidinem.' Britten and Holland (Dict. Engl. Plant Names) enumerate no less than eighty English names for this species.

\section{Orchis laxiflora, Lam.}

Native. First record: Babington, 1839 .

Frequent in moist meadows in all parts of the island, but especially about Grande Mare and Vazon, where at the beginning of June the fields are quite purple with these beautiful flowers. This species is certainly the Orchis morio of Gosselin. O. palustris, Jacq, was recorded as having been found in Guernsey in 1872 ; but it was afterwards discovered that the specimen so determined had come, not from this island, but from Hartlepool (see Journ. Bot., 1873, p. 209, and I875, p. 377).

Called in the patois Penneconte, or Whitsuntide. Under this word Métivier, a native of Guernsey, and an erudite student of the Franco-Norman dialects, remarks in his Dictionnaire (1870): 'Comme la primevère est chez nous la pâquerolle, parcequ'elle fleurit au moment où nous célébrons la naissance de l'année et la résurrection du Messie, nos modestes insulaires ont substitué aux noms malhonnêtes, et par conséquent intraduisibles, de l'orchis et du satyrion, celui de l'époque où le panache ravissant de ces belles fleurs printannières embellit nos prairies,- la pentecôte.' It is worth noticing that in the northern parts of Normandy the name Pentecote is applied to the Lady's Smock (Cardamine pratensis). 
Orchis maculata, L.

Native. First record: Gosselin, I815.

Spotted Palmate Orchis.

Common in all districts. This is the latest of the meadow orchids to flower. A form with purple flowers occurs at Grande Mare, though not commonly: it deserves further study, as perhaps it may prove be to a hybrid between the present species and O. latifolia.

In his recently published Flora of Bournemouth the Rev. E. F. Linton describes a new species, allied to this, under the name of Orchis ericetorum. From $O$. maculata it is distinguished by its more slender habit, narrower leaves, even the lowest being more or less acuminate, and by the middle lobe of the lip being much smaller than the broad lateral lobes. It is widely distributed, and occurs as far south as Guernsey. Mr. Linton informs me that as a rule $O$. ericetorum is a plant of heathy, peaty districts, and that the Guernsey specimen in the Boswell herbarium (F. J. Hanbury) was gathered at Lancresse.

Orchis latifolia, L.

Broad-leaved Marsh Orchis.

Native. First record: Babington, I839.

Common in the wet meadows about Grande Mare, and between Mont Saint and Richmond. Also found, but less plentifully, at the lower end of the Talbots Valley, and near Cobo, as well as in several parts of the Vale. This is the earliest of our meadow orchids, coming into flower about the middle of May.

Orchis incarnata, L.

Native. First found: Andrews, 1899.

Common Marsh Orchis.

Rare. This interesting addition to the somewhat scanty list of Guernsey orchids was discovered by Mr. Cecil Andrews, who found it both at Grande Mare and in wet meadows at Rocquaine. In this species the leaves are gradually narrowed from a broad base; whereas in $O$. latifolia, which it much resembles, the leaves are broadest at the middle, and their base narrow.

(Orchis pyramidalis, L., the Pyramidal Orchis, occurs in Alderney.)

Ophrys apifera, Huds.

Native. First found: Gosselin, 1788 .

Bee Orchis.

Very rare, and now almost extinct. I saw a plant or two in flower in 1889 in a sandy field at Portinfer, close to the sea; and the following year a few spikes of bloom in sandy fields on the other side of the coast road, but the plant is now probably lost at this last station, owing to building and cultivation. Fifteen or twenty years ago the Bee Orchis was so plentiful in this neighbourhood that I have heard of a handful or two of flowers being picked in an afternoon; but now most of the ground is covered with cottages and 
gardens. Mr. Andrews was informed by Miss Le Mesurier, of Hauteville, that thirty years ago this plant grew on the cliffs between Mont Hérault and Les Thielles, not abundantly, but in fair quantity. If this is so, it should still be found there. In Fl. Sam. the Bee Orchis is recorded on the authority of $\mathrm{H}$. O. Carré as occurring in 'sandy fields eastward of Cobo Bay,' and there are specimens in Gosselin's old herbarium which were gathered, according to the label, 'in a field called the Parc-à-fouaille,, near the Maison des Goubés, at the Grand-Miles, belonging to Michel Le Pettevin.' 'This field would be somewhere in the Portinfer neighbourhood. Mr. E. Dupuy has in his herbarium some very fine specimens gathered by him in June, I864, near Richmond, St. Saviour's.

Spiranthes autumnalis, Rich. Autumnal Lady's Tresses.

Native. First found : Gosselin, I 788.

Rather common, especially towards the coast of the low-lying districts, but also frequent on the cliffs. Less common in the interior. This is the Oplorys spiralis of Gosselin's list, and specimens still exist in his herbarium.

Almost all flower names beginning with the word Lady date from the early Middle Ages, and are intended to imply some sort of association with Notre Dame, the Virgin Mary.

Spiranthes aestivalis, Rich. Summer Lady's Tresses.

Native. First record: Marquand, I89r.

Very rare, and confined to Grande Mare, where it grows in considerable quantity, but flowers very sparsely in some years. I have observed the same thing in the New Forest, where I once saw half an acre of bog perfectly white with these flowers, but the following year only a few spikes of bloom appeared.

Listera ovata, R. Br.

Native. First record: Babington, I839.

Very rare. Like the last species confined to Grande Mare, where single plants are scattered all over the marsh, but are more numerous on the north side.

Epipactis palustris, Sw.

Marsh Helleborine.

Native. First found : Gosselin, I 788.

Rare. Grows sparingly in two or three spots in the marshy part of Grande Mare, and rather more plentifully in a wet sandy field at Grandes Rocques, where I counted about twenty spikes of blossom in I891. Specimens are still preserved in Gosselin's herbarium, which were gathered both at Grande Mare and 'in moist ground at the bottom of a hillock near and E. of the house of the Mare de Carteret.' This species, like several other orchidaceous plants in this island, is very uncertain in flowering. In some years 
scarcely a blossom can be found; in others it is very fine, as in 1894 at Grande Mare, when some of the spikes had ten or twelve flowers each. The plants are as a rule small, seldom more than six inches high, often less.

\section{IRIDACEAE.}

Iris Pseud-acorus, L.

Native. First record: Gosselin, I8I 5 .

Yellow Flag.

Common throughout the island in marshy field corners and wet places.

The patois name in Guernsey, as in Normandy, is Glajeur or Glajeux, closely allied to the French Glaïeul, and all derived from the Latin gladius, in allusion to the sword-shaped leaves. This plant was formerly held in high repute in medicine ; and we are told that 'it doth mightilie and vehementlie draw forth choler.'

Iris foetidissima, $L$.

Native. First record: Gosselin, I8I 5 .

Stinking Iris. Gladdon.

Generally distributed throughout the island, but rather rare. Babington is certainly wrong in describing it as 'common in Guernsey.' Occurs on many parts of the cliffs, especially at St. Martin's. In autumn the brilliant orange-scarlet seeds in the open capsules are very striking.

Known in Normandy under the name of Gliai, and generally in France as Iris Gigot. The leaves when bruised exhale an extremely disagreeable odour, which has been compared by some imaginative people to the smell of roast meat; hence one of its English names Roast beef plant.

Romulea Columnae, Seb. \& Maur.

Native. First record: Gosselin, I8 8 5.

Common all round the coast in dry exposed spots; abundant on the cliffs. Flowers from the last week in March to the middle of April, but the flowers are more plentiful some seasons than others. It is the Ixia bulbocodium of Gosselin's list.

The patois name, according to Métivier, is Gênotte, which, from his derivation, signifies earthnut; and he says, 'Les oignons de cette plante se mangaient autrefois comme des châtaignes.' One might suspect some confusion between this species and Carum flexuosum (which is called Gênotte in Normandy), but for the fact that the latter plant is too rare in Guernsey to have received a local name.

\section{AMARYLLIDACEAE.}

Narcissus biflorus, Curt. Alien. First record: Marquand, I891.

Very rare. Plentiful in a waste corner above the road at Fort 
George, overlooking Fort Bay. One large clump in a meadow between Grande Mare and Vazon. In both cases certainly escapes from cultivation.

Narcissus Pseudo-narcissus, L.

Daffodil. Lent Lily.

Alien. First found: Derrick, I897.

A few specimens of this plant, certainly escaped from cultivation, were found by Mr. Derrick in 1897 at Le Jardin (viri.). Mr. Derrick informs me that what he believes to be this species used to grow some thirty years ago in two places in the Talbots Valley; but all traces of it have long since disappeared. In I89 I I saw the true English Daffodil growing in a cottage garden near the King's Mills, but the cottagers could not tell me where the plants originally came from. This species is not mentioned either by Gosselin or Babington, and in my opinion has no title whatever to be regarded as indigenous. The double-flowered Lent Lily ( $N$. major) is established in a meadow in the Fauxquets Valley, below Les Videclins, and in pasture fields near the Catel Rectory.

The name Daffodil is a corruption (through Affodilly as this flower is called by the old writers) of the Homeric Asphodel, with the roots of which the spirits of the dead sustained themselves. The plant is also commonly known as the Lent Lily, the word lent signifying primarily the period of the year when the days begin to lengthen. In Normandy it is called Poirions, the name by which the double variety, common in cottage gardens, is known in Guernsey. The root, and to some extent the whole plant, is poisonous.

\section{ALISMACEAE.}

Alisma Plantago, L.

Great Water Plantain.

Native. First record: Gosselin, I8I 5 .

Rare, except in the parishes of the Vale and St. Sampson's, where it occurs in many places. Ditches about Grande Mare. Millpond at King's Mills. Babington found this species at St. Martin's, but it no longer grows there.

This plant is said to possess an established reputation in America as a specific for the bite of the rattlesnake, and in the north of Europe the roots have for ages been a popular remedy for hydrophobia.

Alisma ranunculoides, L.

Lesser Water Plantain.

Native. First record: Gosselin, I8I5.

Rare. In several parts of Grande Mare. Pool by Fort Doyle. Marshy place between Fort Doyle and Fort Le Marchant, and in a pool near there. In Fl. Sarn. the var. repens, Hook. (A. repens, Sm.) is noted as found by Babington on Lancresse Common. 
Triglochin maritimum, L.

Native. First record: Gosselin, I815.

Seaside Arrongrass.

Rare. Brackish pool at Pulias, in good quantity. Abundant in the marshes by the Vale pond.

Triglochin palustre, L.

Native. First found: Gosselin, ${ }_{7788 .}$

Marsh Arrowgrass.

Rare. Grande Mare, in the central part of the main marsh. Sparingly among Juncus acutus near Houmet, and also sparingly near the Vale pond (Andrews). There are specimens in Gosselin's herbarium. This species is stated in Fl. Sarn. to be 'common in Guernsey,' but, had it been so sixty years ago, we ought to find more traces of it at the present day.

\section{ASPARAGACEAE.}

Asparagus officinalis, $\mathrm{L}$.

Native. First found: Gosselin, I788.

Wild Asparagus.

Very rare. Two plants on the sand-hills by Rousse Tower. Two on the sand-hills between Vazon and Albecq in 1893. One in 1894 in a sandy field near Rousse Tower. Near the Fort in Rocquaine Bay in I898 (Miss B. Agnew). All these specimens were taken to belong to the cultivated form. But in the autumn of $1900 \mathrm{I}$ received a fresh specimen of the true wild maritime form, A. prostratus, Dum., gathered near the sea at Pleinmont Point by Mr. H. Le Lacheur, who reported that he had seen about a hundred plants growing in that spot. In Fl.Sarn. $A$. officinalis is recorded as found at Pleinmont by W. C. Trevelyan, but the plant had not been seen there again (the spot being at the foot of the cliffs and difficult of access) until it was rediscovered by Mr. Le Lacheur more than sixty years afterwards. In Gosselin's herbarium there are two very small specimens labelled 'In a field at the Grand-Mills [Grandes-Mielles] called La Rocque-hyvreuse.'

Ruscus aculeatus, $\mathrm{L}$.

Native. First record: Gosselin, I8I 5 .

Butcher's Broom.

Frequent on the cliffs, especially at St. Martin's ; rare elsewhere, though occurring in all parts of the island. The true leaves of this plant are minute and inconspicuous except on the young shoots. The apparent leaves are really flattened branches termed cladodes or phylloclades, bearing on the underside the tiny lilac flowers and he beautiful scarlet berries.

\section{LILIACEAE.}

Ornithogalum umbellatum, L.

Star of Bethlehem.

Alien. First record: Marquand, r89r.

Very rare. One root in the middle of a marshy field at Cobo in 
1892. This field would never be manured, so that it is not easy to guess how the plant got there. A good many plants in an old quarry behind Noirmont House (Ix.) in I892. A few plants on the shore at Grand Havre in 1899 (Andrews). Certainly garden outcasts in the two last stations. Mr. E. Dupuy has in his herbarium a specimen gathered by him in Fort Bay in May 1865 .

Scilla autumnalis, L.

Native. First record: Gosselin, 1815 .

Common on the cliffs, and in the north and north-west: abundant on Lancresse Common. Occasionally found with white flowers.

Allium Ampeloprasum, L.

Native. First record: Babington, 1839.

Wild Leek.

Very rare. At Fort George in three places, growing in plenty and, as far as can be judged, perfectly wild. Babington found the plant 'on a nearly inaccessible cliff beyond the Artillery Barracks,' and remarks: 'This plant appears to be truly indigenous, for I am informed by Messrs. H. O. Carré and F. C. Lukis that it existed in this place before the erection of the Fort, and that at that time the hill had been uninhabited from time immemorial.' It does not appear to have been found truly wild anywhere nearer to Guernsey than the island of Yeu, of the coast of La Vendée, in the Bay of Biscay, where it is known under the name of Carambole.

(Allium Babingtonii, Borr. is noted for Guernsey in the list in Ansted's Channel Islands. Probably the preceding species was mistaken for it.)

Allium vineale, $\mathrm{L}$.

Native (?). First record: Babington, I839.

Crow Garlick.

Very rare. In $1890 \mathrm{I}$ found two plants belonging to the var. compactum, Thuil. on the banks of the stream between Grande Mare and Vazon Bay. Babington found it near Rocquaine Bay.

\section{Allium triquetrum, L.}

Alien. First found: Salwey, I 847 .

Common on roadside hedges and in bushy corners in every part of the island, but less frequent in the north than in the central and southern parishes. This beautiful plant, which flowers in April, is now so thoroughly established and so universally distributed that it has all the appearance of being native: yet it was unknown in the island sixty years ago, when the Flora Sarnica was compiled. From a note in the Biographical Index of British Botanists it appears that it was first discovered as a Guernsey plant in the year 1847 by the Rev. Thomas Salwey, an eminent lichenologist, who was one of the 
earliest to investigate the lichen-flora of this island. I possess a specimen of the plant gathered in June 1853 by Dr. Boswell Syme at Vazon Bay: and in Engl. Bot., ed. 3, he says that Allium triquetrum is 'apparently confined to the island of Guernsey, where it is said to be not uncommon in damp, shady situations in the parishes of Catel, Forest, and St. Martin's ; - the only place where I observed it in the island was in a hedge at the north end of Vazon Bay.' In 1865, when Bentham's Handbook of the British Flora was published, the plant was 'said to be abundant in hedges all over the island of Guernsey.' So that we have here an instance of the remarkably rapid spread of a plant which is not an agrarian weed. How or from whence Allium triquetrum came into the island I do not know: perhaps it was originally a garden outcast. Bentham says it is a Mediterranean species, 'unknown in France, except the extreme south.'

Endymion nutans, Dum.

Native. First record: Gosselin, 18 8 5 .

Very common throughout the island. White flowers occur in several places, and I have seen, though very rarely, pale pink or flesh-coloured ones. A form with very long leafy bracts occurs rather commonly on the islet of Burhou, near Alderney.

Known in the Guernsey patois by the name of Conneilles, a word corresponding to the local terms, Crozebells and Crozuflower, applied to it in different parts of England, the French word comeille signifying a crow. But the precise connexion between the bird and the flower is not at all obvious. Shakespeare calls it Crowflower in Hamlet, iv. 7, and 'azured harebell' in Cymbeline, iv. 2. In Lancashire it is called by the pretty name of Ring o' Bells, from the resemblance of the blossom to an ancient musical instrument, which consisted of a number of tuned bells hung on an arched support, and struck with a hammer. The English Blue Bell is the present species, but the Blue Bell of Scotland is a totally different flower, which we commonly call the Hairbell (Campanula rotundifolia), a plant unknown in these islands, although generally distributed and quite common in Normandy.

\section{JUNCACEAE.}

Juncus maritimus, Sm.

Native. First found: Gosselin, I 788.

Lesser Sea Rusk.

Local and rare. In several places about Cobo and Grandes Rocques. South side of Bordeaux Harbour. Base of cliffs at Petit Port. Shore near $\mathrm{Bec} \mathrm{du} \mathrm{Nez}$, and between there and Fermain Bay. Base of the cliffs west of Petit Bot Bay (Andrews). This species is not mentioned in Gosselin's list, but there are specimens in his herbarium misnamed $J$. squarrosus. 
Juncus acutus, L.

Native. First record: Gosselin, 1815.

Great Sea Rush.

Local and rare. Frequent on the sand-hills and in the neighbouring sandy fields from the eastern end of Vazon Bay to Grandes Rocques and Pulias. Marshy fields near the Vale pond. Several clumps at the foot of the cliffs at Petit Port.

Juncus effusus, L.

Native. First record: Gosselin, 1815.

Soft Rush.

Very common throughout the island in wet and marshy places.

In the olden time it was customary at ceremonial entertainments to strew the floor with rushes: they were also scattered along the way by which processions were to pass on state occasions : hence the call for 'more rushes' in Henry IV., Part II., v. 5.

Juncus conglomeratus, L.

Native. First record: Babington, I839.

Common Rush.

Although termed the Common Rush, this species is much less plentiful than the preceding, and seems more confined to the lowlands. It grows in similar situations.

The pith of the stems was formerly used to make wicks for small candles called rushlights, and White of Selborne gives a full account of the method of making them in his day, showing how 'a poor family will enjoy five and a half hours of comfortable light for a farthing.' See Letter xxvi. (November I, 1775). Gardiner, in his Flora of Forfar, says that in Scotland "the crusey, with its whale oil and rashy-wick, is still [1848] extensively used.' Precisely the same kind of small lamp as the Scotch crusey was employed in farmhouses in Guernsey down to the middle of the century: fish oil was burnt, the wicks were made of rush-pith, and the lamp itself was called in the patois a craucé.

(Juncus glaucus, Sibth., is noted in Fl. Sarn. as being common in Guernsey, but this is an error. The plant does not occur in the island at all at the present time, nor has any one seen it during the last twenty years, and it is not mentioned in Gosselin's list. But it is common in Alderney.)

\section{Juncus capitatus, Weig.}

Native. First record: Symons, I798.

Capitate Rush.

Rare. Occurs in many places on the cliffs at St. Martin's and the Forest, as well as all over Lancresse Common; but the patches are so small that they are easily overlooked. This diminutive Rush was added to the British Flora a century ago on the authority of William Hudson, author of the Flora Anglica, who found it in Guernsey. The original record occurs in Symons' Synopsis Plantarum Insulis Britannicis (1798), and runs as follows: 'Habitat in insulâ 
Sarnia sed rarissime in loco infra pagum Bovet dictum, inter Fort George et Fermain Bay.' 'There is here a slight confusion of localities, but the exact station would probably be the cliffs below La Bouvee, near Doyle's Monument, a locality in which Juncus capitatus is still to be found. So far as $I$ am aware this is the earliest published description of a Guernsey plant.

Juncus acutiflorus, Ehrh.

Native. First record: Gosselin, I8I5.

Sharp-flowered Rush.

Common throughout the island in wet meadows and swampy places.

Juncus lamprocarpus, L.

Native. First record: Marquand, r89r.

Shining-fruited Rush.

Common in all districts. No doubt Babington omitted this species from his Guernsey list by an oversight as he records it for three of the other islands. He incorrectly writes the specific name lampocarpus, as it is frequently found in the old books, owing to a clerical error in the original authority.

Juncus supinus, Moench.

Lesser Jointed Rush.

Native. First found: Gosselin, 1788 .

Rare. Used to grow plentifully at the edge of a deep pool in an old quarry at L'Islet, but the pool has been partly filled in recently, and other alterations made. This was var. subverticillatus, Wulf. A form nearer the the type grows in wet places between Fort Doyle and Fort Le Marchant. This species is noted for Grande Mare in Fl. Sam. It is the Juncus viviparus of Gosselin, and specimens in his herbarium were collected in 'ditches N. of Ivy Castle and at Camp-duré,' the latter locality being probably Camp du Roi.

Juncus compressus, Jacq.

Native. First found: Gosselin, 1788 .

Rare: often growing with $J$. Gerardi. Brackish pool at Pulias. Claire Mare, near Lerée. Mont Cuet. Marshy field at Cobo. Near the Vale pond, and on the eastern side of Lancresse (Andrews). Gosselin gives this species in his list under the name of Juncus bulbosus, Bulbous Rush.

Juncus Gerardi, Lois.

Mud Rush.

Native. First found: Gosselin, 1788.

Rather common in marshy fields and brackish pools all along the coast of the lowlands. Rare in the south, and perhaps only to be found among rocks a little above high-water mark. In Gosselin's herbarium this species and $J$. compressus are included under the name Juncus bulbosus; but no locality is specified. 
Juncus bufonius, L.

Toad Rush.

Native. First record: Gosselin, 18I 5 .

Very common everywhere in muddy places and damp sandy or clayey ground. A very dwarf form occurs on the cliffs in quite dry exposed spots. Var. fasciculatus, Bert. occurs in Alderney.

Luzula sylvatica, Bich.

Great Wood Rush.

Native. First record: Babington, 1839.

Very local, being entirely confined to half a mile of cliffside between Fermain Bay and St. Martin's Point, where it grows in abundance. The occurrence of this plant on the exposed coast, and its complete absence from those parts of the island where woods certainly existed in former times, is somewhat remarkable.

Luzula campestris, Willd.

Field IVood Rush

Native. First record: Gosselin, 1815.

Very common in hedgebanks, pastures and grassy places, and in turfy spots on the cliffs.

Called in the patois $P i d^{\prime}$ 'alouette, or Lark's foot, though the allusion is not apparent. In France the name Pied d'alovette is applied to Delphinium Consolida, one of the wild Larkspurs.

Luzula multiflora, Lej.

Native. First record: Marquand, I89r.

Common in all districts. The two forms or varieties umbellata and congesta occur, the former being, perhaps, the commoner of the two. In Fl. Sarn. var. congesta is made a variety of $L$. campestris.

(Luzula Forsteri, DC. is marked for Guernsey in the list in Ansted's Channel Islands. Certainly an error.)

\section{TYPHACEAE.}

*Typha latifolia, L.

Great Reed Mace. Cat's-tail.

Extinct.

Gosselin mentions this plant in his old list, and there is a specimen preserved in his herbarium collected in the "Milldam below and W. of St. Saviour's Church.' Half a century later it was seen by Babington at Grande Mare. Both this species and the nex. must have been long extinct, as no vestige of either has been detected in the island for at least thirty years.

*Typha angustifolia, $\mathrm{L}$.

Lesser Reed Mace.

Extinct.

This species is recorded in Fl. Sarn. as having been found by Babington in a 'marsh at Caquerau in Perelle Bay.' This place is 
more usually written Catioroc, and the marsh is commonly called Claire Mare. The marsh still exists, but the plant has disappeared from that station.

Sparganium ramosum, Huds. Branched Bur-reea.

Native. First record: Gosselin, I8 15

Rare. Ditches in Grande Mare. Ditches behind Ivy Castle. Streamside between Mont Saint and Richmond. Valley west of St. Saviour's Church. Petit Bot Valley. Meadow drain near Rocque Maingy, Vale (Andrews). It is possible that some of the plants in the last four localities may prove to be $S$. neglectum, as they have not been re-examined since that species was discovered here last summer.

Sparganium neglectum, Beeby.

Native. First found: Andrews, I900.

In the old millpond at the top of the Talbots Valley, not far from St. Andrew's Church. This species very closely resembles S. ramosum, and has often been mistaken for it. In all probability it will be found elsewhere in the island.

\section{ARACEAE.}

Arum maculatum, L. Cuckoopint. Lords and Ladies.

Native. First record: Gosselin, I8I 5 .

Common in the south of the island: less so in the central districts; rare in the north and north-west. The leaves are either entirely green ( $A$. immaculatum, Schott.) or spotted with purplish brown.

With the single exception of Orchis mascula, no other English plant has borne such a variety of common names as this one: Britten and Holland (Dict. Engl. Pl. Names) enumerate more than sixty. A large number of these names, including some in very general use, are nomina impudica, though their etymology is little known. In Queen Elizabeth's reign the finest starch used for the large collars then worn was obtained from the tuberous roots of this plant. In Normandy it is commonly called Pilettes, or Pied de veau, but its more general French name is Gouet.

Arum italicum, Mill.

Native. First record: Marquand, I89I.

Rare. In a hedge near Rue des Bergers (VIII.) one large clump. Plentiful among shrubs on the roadside near Cobo Church. A few plants on the roadside, King's Mills. This is altogether a larger plant than maculatum, and flowers later, though the leaves come up before the winter, and are well developed in December; whereas the leaves of maculatum seldom begin to appear above ground until early in the spring. 


\section{LEMNACEAE.}

Lemna minor, L.

Native. First record: Gosselin, 1815 .

Lesser Duckweed.

Very common everywhere in pools and ditches, and in stagnant water generally.

This minute plant, called in French from the shape of the leaves Lentille d'eau, or Water Lentil, is one of the most simple of all phanerogamous plants. It is but rarely found in flower, though more frequent in that condition than most others of the genus, some of which have hardly ever been seen flowering anywhere.

Lemna gibba, L.

Native. First found: Andrews, 1900.

Very rare. Ditches near Ivy Castle, associated with L. minor and L. polyrrhiza (Andrews).

Lemna polyrrhiza, L.

Native. First record: Babington, 1839.

Great Duckweed.

Very rare. In a quarry pool at Spur Point, in profusion. In ditches behind Ivy Castle, intermixed with $L$. minor, plentiful.

(Lemna trisulca, L. This plant is included in Gosselin's old list, and very possibly existed here a century ago ; but there are no specimens in his herbarium, nor has any one met with it in recent times. Dr. Bull found it in Sark nearly thirty years ago.)

\section{POTAMOGETONACEAE.}

Potamogeton polygonifolius, Pour.

Native. First found: Gosselin, I 788.

Oblong-leaved

[Pondweed.

Rare. In deep pools at Grande Mare, and in some of the ditches in the neighbourhood. Pool on the eastern side of Lancresse. Specimens of this plant from Grande Mare, labelled $P$. natans, are preserved in Gosselin's herbarium.

Potamogeton plantagineus, Ducroz.

Plantain-leaved

Native. First record : Babington, I839.

[Pondweed.

Very rare. In a deep quarry pool at L'Islet; fairly plentiful in 1891 and 1892 ; but had become scarce in 1899 owing to a portion of the pool being drained. Babington found this species 'in peat pits in Grande Mare,' but many of these have been filled up since his time, and I doubt if the plant is still to be found there. 
Potamogeton crispus, L. Curled Pondweed.

Native. First record: Babington, 1839.

Rather common in streams and meadow drains at the Vale and St. Sampson's, from Ivy Castle northwards ; rare elsewhere. Millpond at King's Mills and stream at Grande Mare. Babington found this plant at Paradis, and also 'in the millstream near Park Street, St. Peter's Port.' This millstream was long ago covered in and built over.

Potamogeton pectinatus, $\mathrm{L}$.

Fennel-leaved Pondweed.

Native. First found: Gosselin, $\mathbf{1} 788$.

Rare. Found by Mr. Andrews in a ditch in the Vale Road in 1899, and abundantly in the Vale pond the following year.

'There is a specimen of this plant in Gosselin's herbarium labelled Potamogeton marinum, a name which is not in his list. I am not sure what species he meant by 'Potamogeton compressum or small branched Pondweed with a flat stalk.'

Ruppia rostellata, Koch.

Tassel-grass.

Native. First found: Gosselin, $\mathbf{1} 788$.

Rare. Grows in brackish pools and ditches in the lowlands. Pool at Mare de Carteret. Ditches by the Vale pond. Ditches at Claire Mare, near Perelle. In Fl. Sarn. this plant is given under the old aggregate name $R$. maritima, and a specimen from ' $\mathrm{Mr}$. Lefebvre's Saltpans' in Gosselin's herbarium is so labelled. It is possible, however, that the segregate maritima also occurs here. The Claire Mare plant approaches it in the somewhat inflated sheaths, short fruit-beak, and apparently later fruiting: but the peduncles are nearly straight, not spirally twisted.

Zannichellia palustris, L.

Native. First found: Gosselin, I 788.

Rather rare. Roadside pool near the Hermitage, Vale. Ditches by the Vale pond. Pool by Fort Doyle. Pool towards Fort Le Marchant. Mill-pond below St. Peter's Church. I have not been able to separate clearly the different forms of this very variable species. The var. pedicellata, Fr., seems to be the most frequent, and probably the others may be referred to var. cyclostigma, Clav., and var. repens, Boenn., described by Corbiere (Nouv. Fl. Norm., p. 545), these three forms being, he says, 'presque également répandues dans la région maritime.' In Fl. Sarn. the var. pedunculata, Reich., is recorded as found by Babington 'in brackish water at St. Sampson's near the Saltpans; a larger form occurs in a ditch in the Braye du Vale by the road from St. Peter's Port to Vale.' $\mathrm{Mr}$. Andrews reports having found $Z$. pedunculata, Reich., in a small pool near Grandes Rocques, and also in the pool by Fort Doyle. There is a specimen in Gosselin's herbarium, but without locality. The plants belonging to this genus require further study. 


\section{NAIADACEAE.}

Zostera marina, L.

Native. First record: Gosselin, 1815 .

Very common all along the sandy shores, growing in large beds at low-water mark. The flowers are protected from the salt water under which they grow by the sheathing base of the leaf, which closely enfolds them until they are fertilised.

This plant is called in the patois Plise, an obscure word, possibly connected with the verb plier, to bend, from the pliability of the leaves. In Normandy it goes by the name of Herbé, or Herbet. The dried plant is largely employed for stuffing mattresses and cushions, and for packing glass and chinaware.

\section{CYPERACEAE.}

Cyperus longus, L.

Native. First record: Gosselin, 1815.

Common in moist meadows in all parts of the island, but more plentiful in the lowlands. Small patches of this plant, a few yards square, are often left standing in hayfields when the grass is mown: later on these are cut, and used for binding purposes.

Well known to Guernsey farmers under the name of Han, as the plant is also called near Cherbourg. The origin of this word is unknown, and even Métivier makes no attempt to trace its etymology. though he says that mats and horse-collars are made of the plant in this island. Dr. Prior derives the word Galingale through the Italian and Spanish from the Persian Chalan and the Arabic Khalanjan, so that possibly the word Han may be traced to the same root. The French name of the plant is Souchet.

Schoenus nigricans, L. Black Bog Rush.

Native. First found: Gosselin, I 788.

Rare, though plentiful where it occurs. Grande Mare. On the shore at Cobo, going westward. Marsh between Vazon and Albecq. Field near Grandes Rocques Hotel. The only locality given in $F l$. Sarn. is 'Grande Havre,' which is very likely a clerical error for Grande Mare. There is a specimen in Gosselin's herbarium, but it is not stated where it was found.

Eleocharis palustris, $\mathrm{R}$. Br.

Marsh Club Rush.

Native. First record: Gosselin, 1815. places.

Common throughout the island in wet meadows and marshy 
Eleocharis multicaulis, Sm.

Many-stemmed Club Rush.

Native. First record: Marquand, $\mathbf{1 8 9 x}$.

Rare. Grande Mare and the adjacent meadows. Marsh on the eastern side of Lancresse. Valley below Le Casrouge, Forest.

Scirpus maritimus, L.

Native. First record: Babington, I839.

Sea Club Rush.

Frequent in salt marshes and brackish ditches throughout the low-lying districts: more often met with north of Ivy Castle. This species may perhaps be the Scirpus mucronatus, Pointed Bullrush, of Gosselin's list. In meadows near Ivy Castle Mr. Andrews has found many dwarf plants from three to six inches high, each with a single spikelet, and so unlike the ordinary form as to be hardly recognisable at first sight.

Scirpus Tabernaemontani, Gmel.

Native. First record: Babington, 1839.

Glaucous Bullrush.

Rare. Brackish marsh at Vazon between Grande Mare and the sea: this marsh is almost entirely filled with the plant. At Grande Mare it grows sparingly, and of small size. Marshy spot near Albecq. Wet field corner at Grandes Rocques. Babington records it from Lerée Bay, as well as Grande Mare. Gosselin includes Scirpus lacustris in his list, but, as he does not mention any other belonging to this group, it may be assumed that the present species was the plant he meant.

Scirpus pauciflorus, Light. Chocolate-headed Chib Rush.

Native. First record: Marquand, I89r.

Rare. Plentiful at the upper end of Grande Mare. Marshy spot on the cliffs east of the Corbiere. Gouffre Valley (Andrews).

Scirpus setaceus, L. Bristle-stalked Club Rush.

Native. First record: Gosselin, 18 I 5 .

Rather common in wet places, and at sides of streamlets and springs. Often found in company with $S$. Savii, which it much resembles, but the present species is the commoner of the two, taking the island as a whole.

Scirpus Savii, Seb. \& Maur.

Native. First record: Babington, 1839.

Frequent in the lowlands as well as in the south of the island, where it occurs in nearly every cliff valley. The prevailing form is the var. nonostachys; indeed, I have met with no other in this island, though in Alderney I have seen both the variety and the type. Mr. Andrews, however, has found in the Casrouge Valley (IV.) a fine form of $S$. Savii, growing in large clumps, with stems a foot long, and two spikelets on every stem. Under this species 
Babington remarks in $F$. Sarn., 'Spikes $\mathrm{I}-3$, very variable in length: in some Guernsey specimens they exceed a quarter of an inch, and in that state the plant might easily be taken for a different species.' I have not met with any examples at all answering to this description.

(Blysmus compressus, Panz., is given in Gosselin's list, and it is quite possible that the plant occurred in Guernsey a century ago: but we have no later evidence, and at the present day no trace of it is to be found.)

Eriophorum polystachion, L.

Native. First record: Gosselin, $18 \times 5$.

Cotton Grass.

Local and rare. Grande Mare, still plentiful, but, in common with several other locally rare plants, in danger of being lost ere long through the draining of the marsh. In some quantity in a boggy piece of ground at the eastern end of Lancresse.

Carex pulicaris, L.

Native. First record: Gosselin, $18 \times 5$.

Flea Sedge.

Very rare. Grande Mare, plentiful in some parts of the marsh. One of the most easily recognised of our Carices.

Carex arenaria, L.

Native. First record: Gosselin, 18 5 .

Sea Sedge.

Very common on the sandy shores of the north and north-west : occasionally found in hedges some way inland.

Carex vulpina, $\mathrm{L}$.

Native. First record : Gosselin, 1815.

Great Sedge.

Common in all parts of the island. This is the most frequent and widely distributed of the Guernsey Carices, but it is seldom found in any quantity.

Carex muricata, L.

Native. First found: Gosselin, I 788.

Great Prickly Sedge.

Common throughout the island, being second only to $C$. vulpina in point of frequency and general distribution. Gosselin gives this name in his list, but in his herbarium specimens of the plant are labelled Carex spicata.

Carex divulsa, Good.

Native. First record: Marquand, I $89 \mathrm{r}$.

Grey Sedge.

Very rare. A few plants in a hedge in Foote's Lane, Lower Rohais, during the summer of $189 \mathrm{I}$.

Carex paniculata, L.

Native. First found: Gosselin, I 788.

Great Panicled Sedge.

Rare. Cliff streamlet near Petit Bot. Valley below Les 
Norgiots (II.). Les Bessieres (VIII.) in a waste corner by the stream. This last place is probably a continuation of Babington's old station, 'in fields to the right of Rohais Road.' The other locality mentioned by him 'near Febvre' is unknown to me. There are specimens of this sedge in Gosselin's herbarium from 'side of ditch near the mill in the marshes : also in hedge at Planques des Rohais.' The mill here referred to was, no doubt, the windmill at Baubigny, long ago demolished.

Carex axillaris, Good.

Native. First record : Marquand, r89r.

Axillary Sedge.

Very rare. Foote's Lane, Lower Rohais, very sparingly; and again a few plants at Pont Vaillant, half a mile to the north. The French botanists regard this sedge as an undoubted hybrid between remota and vulpina.

Carex remota, L.

Native. First record: Gosselin, r8 5 .

Distant-spiked Sedge.

Rather rare. Grande Mare and neighbourhood. Meadows between Coutanchez and Baubigny. Les Bessieres and Pont Vaillant. Streamside between Mont Saint and Richmond. Talbots Valley, here and there. Fontenelle Valley, near Rocquaine.

Carex stellulata, Good.

Native. First record: Babington, I839.

Little Prickly Sedoe.

Local and rare. Grande Mare and adjacent meadows, in plenty. Talbots Valley. Cliffs near Fermain Bay, sparingly.

Carex ovalis, Good.

Native. First record: Marquand, r89r.

Oval-spiked Sedge.

Rather rare, and always sparingly in each spot. Occurs in many places in the southern parishes and at the Vale: also in the Talbots Valley, and at Claire Mare, Perelle.

Carex vulgaris, Fries.

Native. First found: Gosselin, I 788.

Common Sedge.

Local and rare, but plentiful where found. Meadows behind the Forest School, on the borders of St. Andrew's. Grande Mare. Marshy meadows at Claire Mare (vi.). There is a specimen, without locality, in Gosselin's herbarium.

Carex panicea, L.

Native. First found: Gosselin, 1788.

Pink-leaved Sedge.

Rare. Cliff valleys at St. Martin's and the Forest. Abundant at Grande Mare. Meadows near Grandes Rocques. There is a specimen, without locality, in Gosselin's herbarium, though the name does not appear in his list. 
Carex pendula, Huds.

Alien. First record: Marquand, $\mathbf{1} 891$.

Great Pendulous Sedge.

Very rare. Several plants at the base of the cliffs in Fort Bay; growing well and fruiting freely. From the situation in which the plant grows I have no doubt whatever that it was originally planted there, and therefore I regard this species as an Alien, as there is no evidence of its existence in the past anywhere in the island, although there are many suitable localities for it.

Carex praecox, Jacq.

Native. First record: Gosselin, I8 5 .

Vernal Sedge.

Rather common in turfy places, and on dry banks and commons in all parts of the island.

Carex pilulifera, L.

Native. First record: Marquand, $189 \mathrm{r}$.

Round-headed Sedge.

Rare, except in the south. Occurs here and there on the cliffs at St. Martin's and the Forest. Sparingly in a furze croft near Ozanne's Mill.

Carex glauca, Scop.

Native. First record: Babington, 1839.

Glaucous Heath Sedge.

Rather common in marshy spots on the southern cliffs and in all the cliff valleys; less frequent in the lowlands. Grande Mare. Cobo. Sandy field at Grandes Rocques.

Carex flava, L.

Native. First record: Gosselin, I8 I 5 .

Yellow Sedge.

Plentiful at Grande Mare and the neighbouring marshes. Rather common in wet places on the cliffs. Marsh on the eastern side of Lancresse. The plant from Claire Mare which I noted in my list of 189 I as var. lepidocarpa was not the true plant, but a tall state of the var. minor, which has often been mistaken for it.

Carex Oederi, Ehrh.

Native. First found: Miller, 1892.

Very rare. Plentiful in a hollow on Lancresse Common west of Lancresse Lodge. It was discovered there in 1892 by Mr. W. F. Miller, who informed me of it; and the following year I found the plant in good quantity in moist places near a roadside pool at the east of Lancresse. Small states of $C$. flava have often been mistaken for $C$. Oederi, but the latter species is so distinct that it could hardly be passed by as a form of C. flava.

Carex extensa, Good.

Native. First found: Gosselin, I 788.

Long-bract Sedge.

Rare. Near the Vale pond, but not plentifully. On rocks above high-water mark at Petit Port. Marshy field between Cobo and 
Mare de Carteret. Base of cliffs west of Petit Bot Bay (Andrews). There is a specimen in Gosselin's herbarium.

Carex punctata, Gaud.

Native. First found: Gosselin, 1788.

Dotted-fruited Sedge.

Rare. Grande Mare, scattered all over the marsh, but thinly. In a cliff stream near Icart, scarce. Upper Moulin Huet Valley, where Gunnera grows, a few roots. Claire Mare, near Perelle. Jaonnet Valley, and on the shore of a bay west of Jaonnet (Andrews). I have a specimen gathered in Guernsey in June I 853 by Dr. Boswell (Syme), and labelled by him 'Vazon Bay ;' but probably the exact locality was Grande Mare. This species is not mentioned in Gosselin's list, but there is a specimen, without locality, preserved in his herbarium.

Carex distans, L.

Native. First found: Gosselin, 788.

Distant-spiked Sedge.

Frequent in marshy places in the low-lying districts, especially near the coast. Base of the cliffs at St. Martin's in a few places, and found by Mr. Andrews in similar localities at the Forest. There is a specimen in Gosselin's herbarium.

Carex laevigata, Sm.

Native. First found: Miss Dawber, $\mathrm{r} 888$.

Smooth-stalked Sedge.

Very rare. Sparingly in a meadow in the Fontenelle Valley, St. Peter's, in I894. Specimens of this plant were gathered in I888 in the Talbots Valley by Miss Dawber, but they remained undetermined in her herbarium for several years.

Carex hirta, L.

Native. First found: Gosselin, I 788.

Hairy Sedge.

Rare. Field corner at Les Bessieres (viII.). Valley below St. Saviour's Church. Rather frequent in the vicinity of Grande Mare. Field near St. Andrew's Church. Lane at Albecq. Marshy meadows at Cobo. Lane near La Moye (Ix.). I do not remember seeing this species on the south coast of Guernsey, but in Alderney it occurs in all the cliff valleys. The name does not figure in Gosselin's list, but there is an unnamed specimen in his herbarium, and also another labelled Carex acuta nigra; no locality is specified for either.

Carex vesicaria, L.

Native. First record: Marquand, I8gr.

Bladder Sedge.

Very rare. On the side of the lane at Grande Mare, rather scantily : but the plant seems hardly typical.

Carex riparia, Curt.

Native. First found: Gosselin, 1788 .

Great Pond Sedge.

Local and rare. Abundant in a meadow at Rue des Bergers, 
close to Grande Mare, and scattered about the adjacent fields. Ditches behind Ivy Castle. Plentiful in a wet meadow between Rocque Maingy and Les Goubais (1x.). A specimen in Gosselin's herbarium is labelled ' on side of ditch near the mill in the marshes,' which I take to mean the windmill which formerly stood at Baubigny, north of Ivy Castle.

\section{GRAMINEAE.}

Echinochloa Crus-galli, Beauv. Loose Panick Grass

Casual. First found: Andrews, 1900.

Very rare. In September 1900 Mr. C. Andrews found this plant growing in fair quantity in a patch of parsnips near Cobo. It is strange that it had not been previously seen in the island, as it is a rather common species throughout Normandy.

Setaria viridis, Beauv. Green Bristle Grass

Casual. First found: Marquand, 1893.

Very rare. Roadside near St. Sampson's Bridge, one plant in 1893. Cordier Hill, one plant on the roadside, September I899. Hubit Lanes, four or five plants in I 899 (Miss B. Agnew). One specimen the same year in a lane near Rocquaine (Andrews).

Setaria glauca, Beauv. Glaucous Bristle Grass.

Casual. First record: Marquand, I892.

Very rare. Field near Rousse Martello Tower, one plant in September I 892. Roadside between Vazon and Cobo, one plant, I 893 (Miss M. Dawber). Richmond, one plant, I 899 (Andrews).

Cynodon Dactylon, Pers. Dog's-tooth Grass.

Native. First record: Babington, 1839.

Very local. On the eastern side of Vazon Bay, near the Martello Tower, growing in abundance on both sides of the road for about a hundred yards. The same locality is given in Fl. Sarn., 'Sandy common, Vazon Bay; Messrs. H. O. Carré and S. H. Haslam.'

\section{Mibora minima, Desv.}

Native. First record: Babington, I839.

Frequent on the cliffs, especially at St. Martin's and the Forest and about Pleinmont. On the low coast it is abundant in many places from Vazon to Grandes Rocques, on the sandhills at the Vale, and on several parts of Lancresse Common. In mild seasons this pretty little grass flowers as early as the beginning of February.

Phalaris canariensis, $\mathrm{L}$.

Canary Grass.

Casual. First found: Gosselin, 1788 .

Rather frequent on rubbish-heaps and in cultivated and waste ground near houses: always springing up from scattered birdseed. In Gosselin's herbarium this species is mixed with $P$. minor. 


\section{Phalaris minor, Retz.}

Native. First found : Gosselin, I 788 .

Locally plentiful in sandy ground on the north-west coast: less common in the north. Early in the summer of 1899 I discovered this grass growing in cultivated fields in Alderney, and when $\mathrm{Mr}$. C. Andrews came over I pointed out to him how it differed from $P$. canariensis. On his return to Guernsey he found that nearly all the plants hitherto assigned to canariensis really belonged to the present species. I had remarked in my little Flora of I89 I that it (i.e., canariensis as I supposed) 'appears native in sandy places about Lerée, Perelle, and Richmond,' and this seems to be the headquarters of the plant, as it has occurred but sparingly about Pulias, Lancresse, and Bordeaux. That $P$. minor is really native in Guernsey there can be little doubt, as shown in Mr. Andrews' paper in Journ. Bot., I900, p. 33, in which he describes and figures it as an addition to the British Flora. That it is not a recent introduction is proved by Gosselin's herbarium, which dates from I 788 or earlier, in which the sheet labelled $P$. canariensis contains one specimen of that and three of $P$. minor. In Alderney I regard $P$. minor as a Colonist as it only grows in cultivated ground.

\section{Phalaris paradoxa, L.}

Casual. First found: Miss Agnew, I 900.

One or two plants were found by Miss B. Agnew during the summer of 1900 in an old neglected garden at Hauteville.

\section{* Phalaris arundinacea, L.}

Ribbon. Grass.

Extinct.

According to Fl. Sarn. Babington found this grass at Grande Mare, together with a few plants of the var. picta, L., 'apparently indigenous.' I am not aware that it has been seen again, and the variety is only to be found now in cottage gardens.

Anthoxanthum odoratum, L.

Sweet-scented Grass.

Native. First record: Gosselin, 1815 .

Very common in all parts of the island.

Called in French Flouve odorante. This is the grass above all others that gives the delightful fragrance to newly-mown meadow hay: but it is the stems which are fragrant, and not the flowers.

Anthoxanthum Puelii, Lec. \& Lam.

Casual. First found: Rogers, I897.

Very rare. Found sparingly by the Rev. W. Moyle Rogers on Lancresse Common, near the Vale Church, in I897. This species is said to be a much commoner plant on the Continent than $A$. odoratum, and is often supplied to English farmers by German seedgrowers as a substitute for the latter, though, being an annual, it is comparatively worthless. It is asserted that $A$. Puelii does not 
readily naturalise itself in this country, and soon disappears from a spot unless renewed from fresh seed.

Phleum arenarium, $\mathrm{L}$.

Native. First found: Gosselin, I 788 .

Sand Timothy Grass.

Frequent on the sandy shores of the north and north-west. Very fine specimens are to be found in some of the sandy fields of the Vale coast. This plant is the Phalaris arenaria of Gosselin, and there is a specimen in his herbarium.

Phleum pratense, $\mathrm{L}$.

Native (?). First record: Babington, 1839.

Very rare: perhaps only a Casual. Roadside near the Vale Church, a few plants in 1889 . Lane at Grosse Hougue (x.), two stunted specimens in 1892. Again a few at St. Sampson's in I894. Plentiful in a garden at Hauteville. and also in a garden near St. Martin's Church in I900 (Andrews). No locality is specified in Fl. Sarn.

This species, called in France Fléole, takes its name Timothy Grass from having been first extensively cultivated in North America by one Timothy Hanson, and introduced into British agriculture on his recommendation.

Alopecurus pratensis, L. Meadow Foxtail Grass.

Native. First record: Marquand, 1891.

Rather rare, though found in almost every parish: often abundant where it occurs. Grows in damp pastures and meadows, and less frequently on roadsides.

According to experts this grass possesses the three great agri cultural requisites of quantity, quality, and earliness in a superio. degree to any other species, besides yielding an abundant aftermath Its French name is Vulpin.

Alopecurus geniculatus, L. Floating Foxtail Gras

Native. First record: Gosselin, 18 I 5 .

Common, often abundant, in marshy meadows and on the grassy sides of streams and ditches in all parts of the island.

Milium scabrum, Merl.

Native First found: Andrews, 1899.

Very rare. For this interesting addition to the British Flora we are indebted to the acute observation of $\mathrm{Mr}$. Cecil Andrews, who discovered a few specimens at the foot of precipitous cliffs near Petit Bot Bay on April I 7 th, I899. It is a rare plant in the northwest of Europe, and is not known to occur nearer here than the Department of La Vendée, on the west coast of France, and in the Netherlands, so that its occurrence in Guernsey is of peculiar interest. From the locality in which it grows there is no doubt 
whatever about its being truly native in this island. Mr. Andrews has given a full description and figure of the plant, together with notes on its Continental distribution, in Journ. Bot., 1 900, p. 33.

Phragmites communis, Trin.

Common Reed.

Native. First record: Gosselin, I8 15.

Generally distributed and common in marshes and swampy corners of meadows: often at the base of the cliffs in the south.

Called in Normandy by the name of Rôs. In the opinion of Dr. Prior this was the plant called Speargrass in Henry IV., Part I., act ii. sc. 4, which was 'to tickle our noses to make them bleed,' but it seems more probable that the species signified was Yarrow (Achillea Millefolium), which, according to Parkinson (in I640) was 'called of some Nosebleed, from making the nose bleede if it be put into it.' It is said that a roof thatched with reeds is much more durable than one of straw, and will last eighty years.

Psamma arenaria, R. \& S. Sea Reed. Marram.

Native. First record: Babington, I839.

Locally abundant on the north-west coast from Cobo to Grandes Rocques and Portinfer. It is remarkable that we have in these islands no trace of Elymus arenarius, a grass which is found plentifully on the opposite shores of France, often growing in company with the present species, which it somewhat resembles.

In Normandy Marram is known by the name of Millegreux, and is much used for making brooms and straw hats. Its far-creeping roots have an amazing power in binding together the loose, drifting sands of our coasts, so that it should always be carefully preserved. At one time it was forbidden by Act of Parliament to gather this grass ; and in Holland its destruction is a penal offence.

Calamagrostis Epigeios, Roth.

Wood Smallreed.

Native. First record: Babington, 1839.

Very rare. In an old quarry at Les Gigands, Baubigny, plentiful in $\mathrm{r} 89 \mathrm{r}$. In plenty at $\mathrm{Bec} \mathrm{du} \mathrm{Ne} z$ in 1899 (Andrews). It is recorded in Fl. Sarn. for the cliffs beyond the Artillery Barracks at Fort George, where very likely it still occurs.

(Apera Spica-venti, Beauv. is noted for Guernsey in the list given in Ansted's Channel Islands, but there is no confirmatory evidence of its occurrence.)

Agrostis canina, L.

Brown Bent Grass.

Native. First record: Marquand, 189r.

Common in meadows at the west of the island, especially near Rocquaine.

Prior says that the name Bent Grass signifies any wiry grass, 
such as usually grows upon a bent, i.e., a common or other neglected broken ground: a word often used in that sense in old English poetry.

Agrostis vulgaris, With.

Common Bent Grass.

Native. First record: Marquand, $189 \mathrm{r}$.

Common throughout the island. The var. pumila, L. is noted in Fl. Sarn. as occurring at Herm. According to Corbiere (Nouv. Fl. Norm.) this variety is merely a dwarf form, having the flowers infested with a micro-fungus (Tilletia sphaerococca).

Agrostis alba, L.

Native. First found: Gosselin, 1788 .

Marsh Bent Grass. Fiorin.

Common in all parts on borders of ditches and grassy pools, and in damp places by roadsides. The var. stolonifera, $\mathrm{L}$. is common on the coast, and the more or less glaucous form occurring on sandy shores is probably the var. maritima, Lam. In Gosselin's herbarium a large form of this species is labelled Agrostis sylvatica, and a small form Aira cristata : in each case without locality.

Lagurus ovatus, $\mathrm{L}$.

Hare's-tail Grass.

Native. First record: Gosselin, 18r5.

Common all along the sandy shores of the north and north-west. Often very small, and as a rule only a few inches high, but in sandy fields, under favourable conditions, attaining the height of a foot or more. Many attempts have been made from time to time to introduce this beautiful grass into Jersey. In Journ. Bot., 1893, p. 22, Mr. G. C. Druce records that he found a good patch of it growing on the sands near St. Ouen's Bay in I 877 , but subsequently ascertained that the seed had been intentionally sown there the previous year. Doubtless in the course of time it will become naturalised in Jersey; and therefore, to prevent confusion in the future, it may be well to state that as an indigenous plant Lagurus ovatus is confined to Guernsey, not only among the Channel Islands, but in the United Kingdom. In Normandy it is found only in the Department of La Manche, where it is very rare.

Polypogon monspeliensis, Desf. Annual Beard Grass. Native. First record: Babington, 1839 .

Very rare. I found two roots on the quarry heap near the Vale Castle in 1889 , but it has not been seen since. Mr. G. C. Druce reported it as very abundant by the side of St. Sampson's saltpans in June 1877 : and Miss M. Dawber gathered it in the saltpans at St. Sampson's in 1886. Probably this grass was not uncommon in former times (Babington found it in the Braye du Vale) when salt marshes abounded from St. Sampson's Harbour to Grand Havre, but at the present day it seems to be almost extinct. 
(Polypogon littoralis, Sm. is marked for Guernsey in the list given in Ansted's Channel Islands : and in Major Smith's annotated copy of the Flora Sarnica both this species and $P$. monspeliensis are noted as found in a meadow east of Ivy Castle.)

Gastridium lendigerum, Gaud.

Nit Grass.

Colonist. First found : Gosselin, I 788.

Rare. Roadside near Torteval Church, one plant in 1889. Lane behind Le Douit (vi.), one in 1890 . Roadside, Etiennerie (vi1i.), a good many roots in 1892 . Lane at Rocquaine, several in 1893. Many plants in 1894 in a field at Les Falaises, above Petit Bot. Field near Caudré Mill (vi.) in fair quantity in 1899, and several plants near Le Moulin (vr.) in 1900 (Andrews). Under the name of Alopecurus ventricosus there is a fine specimen in Gosselin's herbarium from 'fields at Mont Plaisir.'

Holcus lanatus, L.

Native. First record: Gosselin, 18 I5.

Very common in grass fields, lanesides, and on the cliffs.

Holcus mollis, L.

Native. First record: Babington, I839.

Creeping Soft Grass.

Generally distributed throughout the island, but much less common than the last species.

\section{Aira flexuosa, L.}

Native. First record: Babington, 1839.

Heath Hair Grass.

The only record I have for this species is found in Fl. Sarn., where Babington notes it as seen by him in the Braye du Vale. Perhaps it has been overlooked elsewhere.

Aira caryophyllea, L.

Native. First found: Gosselin, I 788.

Silvery Hair Grass.

Common throughout the island. Usually only a few inches high, but at Torteval, near St. Briocq, I have seen plants of remarkable size, as much as two feet in height. There are specimens in Gosselin's herbarium labelled Aira canescens.

Aira praecox, L.

Native. First record : Gosselin, I8I5.

Generally distributed throughout the island, and not uncommon, but much less frequent than $A$. caryophyllea. Usually grows in small, dense patches.

(Trisetum flavescens, Beauv., occurs in Alderney.)

Avena fatua, $\mathrm{L}$.

Wild Oat.

Colonist. First found: Gosselin, 1788.

Rather rare. Occurs in cornfields and waste spots in cultivated 
ground in the central and southern parts of the island. A specimen in Gosselin's herbarium is labelled 'Grows on the hedges,' but no locality is specified.

Avena strigosa, Schreb.

Casual. First record: Marquand, I892.

Black Oat.

Rare. I found a plant near the Vale Road Nurseries in I892, but have not met with it since. But its general resemblance to the cultivated Oat would cause it to escape notice.

(Avena pubescens, L., occurs in Alderney.)

Arrhenatherum elatius, M. \& K.

Native. First found: Gosselin, I 788.

False Oat Grass.

Rather common in all districts. The var. nodosum (A. bulbosum, Presl.) is the prevailing form. In Alderney the type is far more common than the variety. A specimen in Gosselin's herbarium is labelled Avena pratensis, to which a note is added: 'Has a bulbous root and grows on the hedges.'

Triodia decumbens, Beauv.

Native. First found: Gosselin, I 788.

Heath Grass.

Rather common generally. Abundant on the cliffs in some places, and in parts of Lancresse Common; occasionally in hedges and pastures inland. There are specimens in Gosselin's herbarium.

Koeleria cristata, Pers.

Native. First found: Gosselin, 1788 .

Crested Hair Grass.

Local. Occurs here and there on the sandhills and in sandy grassy places all along the coast from Vazon Bay to Lancresse. Most of the Guernsey plant seems to be the var. albescens, DC. It is the Poa cristata of Gosselin, a specimen of which is preserved in his herbarium.

Molinia caerulea, Moench.

Native. First found: Gosselin, I 788.

Rare. Grande Mare, plentiful in places. Scattered clumps between Lower Rohais and Friquet Chapel. Small furze-croft between Capelles and Noirmont. Abundant in a furze-croft near Hougue du Pommier. Cliffs towards Corbiere. Copse near King's Mills (Andrews) There is a specimen in Gosselin's herbarium named Aira distans, but without locality.

This grass is of comparatively no agricultural value: cows seldom eat it, and wherever found in a meadow it indicates want of drainage. The stems are sold by tobacconists for cleaning pipes, and in some places are used as a substitute for bristles in brooms. 
Poa annua, L. Annual Meadow Grass.

Native. First record: Gosselin, 1815 .

Very common: 'creeping silently, creeping everywhere.' Probably no other British plant thrives in such a variety of situations and flowers under such unfavourable conditions as this ubiquitous little grass.

Poa trivialis, L.

Native. First record: Gosselin, 1815 .

Rough Meadow Grass.

Generally distributed and common in damp, shady places, pastures, and roadsides.

(Poa sudetica, Haenke, occurs in Alderney.)

Poa pratensis, L.

Native. First record: Gosselin, I8I5.

Smooth Meadow Grass.

Very common in pastures, and on dry banks, roadsides, and wall-tops. The var. subcaenulea, Sm., occurs in Alderney.

(Poa compressa, L., has been recorded for Sark.)

Glyceria fluitans, R. Br.

Common Flote Grass.

Native. First record: Gosselin, I 8 I 5 .

Common throughout the island on the sides of ditches and slow streams : often growing in and floating on the water.

Gerarde says this and allied species are called 'Flote grasse bicause they swim and flote in the water,' but, according to Prior, it is 'not so much from its floating on the water, as from its abounding n floted or irrigated meadows.'

Glyceria plicata, Fries.

Folded-leaved Flote Grass.

Native. First record: Marquand, I89r.

Not common, or perhaps overlooked. Ditches at Grande Mare. Ditches behind Ivy Castle. In r89 I I found on the wet roadside behind St. Helena the var. declinata, Breb. (Fl. Norm., ed. 5, p. 464).

Sclerochloa maritima, Lindl.

Native. First found: Gosselin, I 788.

Sea Meadow Grass.

Very rare. Banks of a brackish drain on the eastern side of Cobo, plentifully. In Fl. Sarn. it is noted for Braye du Vale. Two forms of this plant are preserved in Gosselin's herbarium: one, without locality, labelled Poa maritima: the other, named Aegilops incurva, from 'Vale Bridge and Mr. Lefebvre's salıpans.'

Sclerochloa procumbens, Beauv.

Native: First record: Babington, I839.

Very rare: perhaps extinct. This plant was found by Babington, 
as recorded in Fl. Sarn, in a 'marsh at the Bouet near St. Peter's Port.' The locality has no doubt been built over long ago, or, at any rate, drained.

Sclerochloa distans, Bab.

Native. First record: Marquand, 1891.

Reflexed Meadou Grass.

Very rare. Plentiful in a small marsh on the north side of Bordeaux in 1889 and for some years after. The plant is now lost at this station owing to the marsh having been filled up with quarry rubble.

Sclerochloa rigida, Link. Hard Meadow Grass.

Native. First record: Marquand, $\mathrm{r} 89 \mathrm{r}$.

Rare. In sandy fields and roadsides here and there at Les Sablons and Lerée; also in similar places at Cobo.

Sclerochloa loliacea, Woods.

Native. First found: Gosselin, I 788.

Rather common, especially near the sea. Occurs in all districts, but is more frequent in the lowlands than in the south. It is the Poa loliacea of Gosselin's list and herbarium.

Briza minor, L. Small Quaking Grass.

Colonist. First record: Gosselin, I8 15 .

Rather rare generally, though found in every parish in arable fields among corn and other crops, on roadsides and waste heaps, and occasionally in old quarries.

(Briza media, L., occurs in Alderney.)

Briza maxima. L.

Alien. First record: Marquand, I89I.

Rare. Thoroughly naturalised in a few places: mostly dwart. Plentiful on a rocky eminence between King's Mills and Mont Saint. Cliffside east of the valley below Le Casrouge (Iv.) in considerable quantity, growing amongst furze. Also growing amongst furze in the Talbots Valley, near the quarry. Sparingly on the rubble above the pool at Pulias: in this spot apparently a garden outcast. Roadside and cliff near the White Tower at Fermain (Andrews).

Catabrosa aquatica, Beauv. Native. First found: Gosselin, 1788.

Rare. Plentiful in one part of the marshes near Ivy Castle. Marshy ground near Les Arguillers (Ix.). This is the Aira aquatica of Gosselin, and the locality given for it in his herbarium is 'Douit de la Vrangue, facing gate of Long-camp.' 
Cynosurus cristatus, $L$.

Native. First record: Gosselin, 1815 .

Common throughout the island in dry pastures and waste turfy places by roadsides and lanes.

Cynosurus echinatus, $\mathrm{L}$. Rough Dog's-tail Grass.

Colonist or Native: First found: Gosselin, 1788.

Rare. On banks and rough waste ground: often in abundance where it occurs. Roadside bank by the big quarry at Paradis, abundant in 1890 , very scarce in 1899 . In profusion in 1890 on the eastern side of the Vale Castle Hill. Portelette, descending to Rocquaine, plentiful on a rough furzy hillside. Mont Cuet, near the first gate, a good sprinkling of plants in 1892 . Roadside by the battery at Les Camps (viII.), plentiful in 1892. Sparingly in I 900 by the zigzag road beyond the Trinity Houses at Rocquaine (Andrews). In Fl. Sarn. this grass is noted for Mont Saint and Portinfer. In Gosselin's herbarium specimens are labelled 'Southeast corner of a cultivated piece of ground behind the house of Mr. Lefebvre's saltpans.' This is a very distinct and beautiful grass, but uncertain in its appearance, being seldom found in the same profusion in one spot two years in succession. It is very rare in Normandy.

Dactylis glomerata, $\mathrm{L}$.

Native. First record: Gosselin, 18 15.

Very common throughout the island.

Festuca uniglumis, Sol.

Native. First found: Gosselin, I 788.

Frequent, and in many parts abundant, all along the sandy coast from Rocquaine to Lancresse. This species is the Festuca cambrica of Gosselin, as proved by a specimen so named in his herbarium.

Festuca sciuroides, Roth.

Barren Fescue Grass.

Native. First found : Gosselin, I 788 .

Common on dry banks, walltops, and roadsides in all parts. Specimens in Gosselin's herbarium show that this is his Festuca myuros. In r 890 I found on a dry bank at Mont Saint, St. Saviour's, a good many strange-looking plants having the uppermost leafsheaths reaching quite up to the panicle; it is possible that they were hybrids between sciuroides and Myurus. The plants were about six inches high or less. In Alderney I have seen remarkably fine specimens of F. sciuroides eighteen inches in height.

Festuca Myurus, L. Mousetail Fescue Grass.

Colonist or Casual. First record: Babington, 1839.

Very rare. A few roots in 1889 in a cultivated field at Grosse Hougue, St. Sampson's. One root on the Vale Castle quarry heap. The plant named $F$. myuros by Gosselin is the preceding species. 
Festuca ovina, L.

Native. First record : Gosselin, I 815.

Sheep's Fescue Grass.

Very common all round the coast. The prevailing form seems to be $F$. tenuifolia, Sibth. ( $F$. capillata, Lam.), but the vars. duriuscula, L., and glauca, Lam., also occur.

\section{Festuca rubra, L.}

Native. First record: Babington, 1839.

Common and very variable. Several of the local forms belonging to this and allied species deserve further study.

\section{Festuca oraria, Dum.}

Native. First found: Gosselin, I788.

Frequent on the sandy shores of the north and north-west coast. It is the F. rubra, var. sabulicola, of Fl. Sarn. There are specimens of this plant in Gosselin's herbarium labelled Poa setacea.

Festuca elatior, L.

Native. First found: Gosselin, I 788 .

Tall Fiescue Grass.

Frequent in moist meadows in the interior of the island; occasionally in wet places on the cliffs. In Fl. Sarn. F. loliacea, Huds., is recorded for Guernsey, and there are specimens in Gosselin's herbarium. According to Hackel it is a hybrid between $F$. elatior and Lolium perenne.

Festuca arundinacea, Schreb.

Native. First found: Gosselin, I 788.

Reed-like Fescue Grass.

Rather common in the wet meadows of the lowlands. In Gosselin's herbarium this species and the last are mixed together under the name of $F$. elatior.

Bromus sterilis, L.

Barren Brome Grass.

Native. First found: Gosselin, I 788.

Very common throughout the island. This species is the Bromus nemoralis of Gosselin's list, as proved by a specimen so named in his herbarium.

As this grass ripens an abundance of seed, its specific name would seem to refer to its uselessness to the agriculturist rather than to its sterility.

Bromus madritensis, $L$.

Colonist (?). First record: Babington, 1839.

Upright Brome Grass.

The type very rare, and only a Casual. A few plants in 1890 on the quarry heap near the Vale Castle. Var. rigidus, Roth. Local and rare. In several places in the neighbourhood of Richmond: occasionally very fine. Lane above Les Rouvets (vir.) in good quantity in 1890 . Roadside, Perelle Bay. This most beautiful grass seems entirely confined to the north-west of the island: Babington found it in the Catel parish. 


\section{Bromus maximus, Desf.}

Colonist or Casual. First record: Babington, I 839.

Very rare. A few plants near the Vale Castle in 1889. Sparingly at Mont Cuet in 1892 . Again found near the Vale Castle in I894. Babington saw it at Cobo, and I possess a specimen gathered at Grand Havre in $185^{2}$ by H. C. Watson. This species, which is so rare in Guernsey, is one of the commonest grasses in Alderney. The very long awns and the comparatively short pedicels readily distinguish this from $R$. sterilts, which it otherwise resembles. Both often grow together.

Serrafalcus racemosus, Parl.

Native. First found: Miss Agnew, 1900.

Very rare. On the cliffs near the Gouffre, where several plants were found in June, 1900, by Miss B. Agnew. This species was recorded for Sark nearly thirty years ago by Dr. Bull, but had not been found elsewhere in these islands.

Serrafalcus commutatus, Bab.

Native. First record: Marquand, I89r.

Local and rather rare, but plentiful where it occurs in grass fields and lanesides in the interior of the island.

Serrafalcus mollis, Parl.

Native. First record: Gosselin, $18 \times 5$.

Confused Brome Grass.

Very common everywhere. The var. glabrescens, which I have found at Cobo and St. Saviour's, is probably not uncommon. A dwarf form (var. compactus, Breb.) occurs on the sandy shores of Lancresse, Vazon, and Lerée. Mr. Andrews has found the var. Lloydianus, Syme, on the Vazon sandhills: and I have gathered plants which 'combine the characters of glabrescens and Lloydianus,' as mentioned by Archer Briggs in his Flora of Plymouth, and which agree exactly with specimens from Briggs himself in my possession. A small glabrous form, with the panicle reduced to one or two spikelets ( $B$. nanus, Weig.) occurs on some parts of the sandy coast.

Serrafalcus arvensis, Godr.

Field Brome Grass.

Casual. First found: Marquand, 1892.

Very rare. Two or three plants on the roadside near Noirmont House, Vale, in 1892.

Brachypodium sylvaticum, R. \& S. False Brome Grass. Native. First found: Gosselin, 1788.

Common in hedgebanks and bushy places throughout the island. This species figures in Gosselin's list as Festuca binnata, and a specimen so named is preserved in his herbarium. 
Triticum repens, L.

Native. First found: Gosselin, I 788.

Very common everywhere. I have seen specimens between five and six feet high growing in hedges in the old 'saltpans' at St. Sampson's. The awned form, var. barbatum, Duv. J., is not uncommon on the coast of the lowlands. The Triticum caninum of Gosselin's list is proved to be the present species by a specimen in his herbarium.

In the north of Normandy this grass is known by the name of Chiendent, though in other parts of France that name is applied to Cynodon. It is one of the most troublesome of weeds to the gardener, owing to the vitality of its creeping underground stems, which break readily and develop into new plants, hence its local names, Quitch, Scutch, Couch, and Quicken Grass, all derived from the Anglo-Saxon word, creic, which signifies alive.

Triticum pungens, Pers.

Native. First found: Gosselin, I 788.

Sea Couch Grass.

Rather common on the sandy shores of the lowlands, but extremely variable, presenting a number of perplexing forms, which at first sight appear to be distinct species. One of the most striking, found by me at Vazon in $189 \mathrm{I}$, and again by Mr. Andrews in I899, is probably var. pycnanthum, G. \& G. There is a form of $T$. pungens preserved in Gosselin's herbarium.

Triticum junceum, L.

Sand Wheat Grass.

Native. First record: Gosselin, 18 I $_{5}$.

Frequent all along the sandy shores of the north and north-west from Rocquaine to Lancresse and Belgrave Bay.

Triticum Spelta, I.

Casual. First found : Andrews, I 899.

Very rare. Two plants of this very distinct species with awns three inches long, were found on the shore at Vazon by Mr. C. Andrews in the summer of 1899 .

(Elymus arenarius, L. is marked for Guernsey in the list given in Ansted's Channel Islands. Certainly an error. I have seen this grass in plenty on the coast of Normandy, but it does not extend to these islands.)

Hordeum murinum, I.

Native. First record: Gosselin, I 8 I 5 .

Common in all parts, but more abundant throughout the lowlying districts, especially near the sea.

Hordeum maritimum, With. Seashore Barley.

Native. First record: Babington, I839.

Very rare. Roadside on the coast near Lerée Bay, extending. 
over some thirty or forty yards, intermixed with $H$. murinum. This is the spot where Babington found the plant sixty years ago, and he also records it from the Braye du Vale. I once found two or three specimens on the quarry heap near the Vale Castle, so that possibly it still occurs somewhere in that neighbourhood.

Lepturus filiformis, Trin.

Native. First found: Gosselin, 1788.

Sea Hard Grass.

Rare. Plentiful in a marshy field at Claire Mare (vi.). Abundant by the Vale pond. Sparingly on the west side of the islet of Homtolle, north of Bordeaux. Pulias (Andrews). Babington records this species for Braye du Vale and Lerée Bay. A specimen of this plant in Gosselin's herbarium is labelled Phoenix acerosaaculeata, but this singular name is not given in his printed list.

Lolium perenne, L.

Rye Grass.

Native. First record: Gosselin, I8 15 .

Common throughout the island. Both the var. tenue, L. and the var. cristatum, Pers. occur. The former is given as a separate species in Gosselin's list, Lolium tenue, Small Darnel Grass

Lolium italicum, Braun.

Alien. First record: Marquand, I89 I.

Italian Rye Grass.

Frequent in waste corners and roadsides, and occasionally in hayfields in all parts.

Lolium temulentum, L.

Casual. First found: Gosselin, I788.

Darnel.

There is a specimen of this grass, without locality, in Gosselin's herbarium, though the name is not mentioned in his list. In Fl. Sarn. it is noted for Guernsey on the authority of H. O. Carré. It has not been found in the island of late years.

The name Darnel, a word of obscure origin, was not always restricted to the present species: for we are told by Newton, in his Herbal to the Bible, 1585, that 'under the name of Cockle and Darnel is comprehended all vicious, noisome, and unprofitable graine, encombring and hindring good corne.' This grass is supposed to be the infelix lolium of Virgil ; the seeds are reputed to be intoxicating to men, beasts, and birds, finally producing convulsions and even death. Its French name Ivraie, or Ivroie, evidently refers to these properties. 


\section{EQUISETACEAE.}

Equisetum arvense, L.

Field Horsetail.

Native. First found: Gosselin, I 788 .

Rather common in all parts of the island in clayey fields, poor land, and on roadsides. There are specimens in Gosselin's herbarium.

This plant is known in the patois under the name of Coue de Rat, or rat's tail. The common French name is Prêle, but in Normandy most of the species are generally known as Queues de cheval.

(Equisetum maximum, Lam. Great Water Horsetail. In Gosselin's printed list four species of Equisetum are noted, including E. fluviatile, River Horsetail. This was the old Hudsonian name for $E$. maximum, but in Gosselin's herbarium the specimens labelled $E$. fluviatile prove to be $E$. limosum. Major H. Smith wrote in his annotated copy of the Flora Sarnica that E. maximum grew near St. Peter's Port (probably about the year 1860); but I am not aware that any Guernsey specimens exist. This beautiful Equisetum grows luxuriantly in one spot in Alderney, the stems attaining a height of four or five feet.)

(Equisetum sylvaticum, L. is mentioned in Gosselin's list, but it is not represented in his herbarium, nor is any other species so named by him. In the absence of confirmation therefore this record is of slight value. Thirty years ago $E$. sylvaticum was recorded for Sark by Dr. Bull, but, as he does not mention two other species which are known to occur there, it is possible that he confounded the names. At present, therefore, we have no satisfactory evidence that this plant ever grew in these islands.)

Equisetum limosum, L.

Smooth Horsetail.

Native. First found: Gosselin, I 788.

Frequent in wet meadows and swampy places, more especially in the low-lying districts. In Gosselin's herbarium there is an unnamed specimen, as' well as one called $E$. fluviatile : but no locality is specified.

Equisetum palustre, L.

Marsh Horsetail.

Native. First found: Gosselin, $\mathbf{I} 788$.

Rather common in moist meadows, marshes, and wet grassy places. Var. polystachyon, Vill. Rare. Scattered plants at Grande Mare and neighbourhood. There is a specimen of this variety in Gosselin's herbarium, but the locality where it was found is not mentioned. 


\section{F E RNS.}

Polypodium vulgare, $\mathrm{L}$.

Native. First record: Gosselin, 1815.

Polypody.

Common in all parts on banks, walls, rocks, and old trees. Often very dwarf on walls. I have occasionally found the form with serrated pinnae (var. serratum, DC.).

Lastrea Filix-mas, Presl.

Male Fern.

Native. First record: Gosselin, I8I5.

Rather common throughout the island, but less abundant than in the south-west of England.

Lastrea dilatata, Presl.

Native. First record: Derrick, I882.

Broad Shield Fern.

Rather rare, and always sparingly in each locality. I have seen this fern in a good number of stations, chiefly in the central districts, but I have no note of it for the north of the island. It occurs at Grande Mare, and on the cliffs here and there between Fermain and St. Martin's Point.

(Lastrea aemula, Brack. On p. I 82 of the second edition (I865) of Ansted's Channel Islands we read: 'The delicate Hay-scented Fern (Lastrea aemula) has been discovered in Guernsey by Mr. James, an accomplished fern-botanist resident in that island.' It has never been found again, and, if the plant was really this, it was probably a specimen or specimens originally planted. Mr. Derrick has searched the island for this fern for thirty years in vain : and I could find no trace of it during my residence in Guernsey, although perfectly familiar with it from residing for several years in a part of Cornwall where Lastrea aemula is quite common. The absence of this species from these islands, however, is remarkable, as although in Normandy it is confined to the Department of La Manche, which lies immediately opposite to the Channel Islands, it is widely distributed there and sufficiently common. Corbiere describes it as a 'plante spéciale à la Grande-Bretagne et au nord-ouest de la France.')

Polystichum angulare, Newm.

Native. First record: Derrick, I882.

Rare. Sparingly on the cliffs above Bec du Nez and Divette Cove, and on the east side of Petit Port. A few roots in the lane behind Les Vauxbelets (1I.). Plentiful in the hedges of a field in the Talbots Valley, where it was shown me by Mr. Derrick. In I 899 MIr. Andrews found in a lane above Les Terres 'scores of 
small plants three or four inches high, which never seem to grow larger;' and at least half a dozen roots in the Moulin Huet Waterlane, where years ago it used to be fairly plentiful.

(Polystichum aculeatum, Roth. In Fl. Sarn. this fern is noted for Guernsey, without specified locality, on the authority of Mr. H. O. Carré. I suspect this is an error, seeing that P. angulare is not recorded. In Normandy the latter species is extremely common, especially in $\mathrm{La}$ Manche, but P. aculeatum is absent.)

Athyrium Filix-foemina, Roth.

Native. First record: Gosselin, 18 5 .

Lady Fern.

Generally distributed and common. Very fine in some of the cliff valleys in the south. In $1882 \mathrm{Mr}$. Derrick exhibited at a meeting of the Guernsey Society of Natural Science 'a tasselled variety called multifidum,' which he had gathered some years previously from a plant growing in Grande Mare.

Asplenium lanceolatum, Huds.

Native. First found: Gosselin, 1788.

Common throughout the island, but less so than the following species, with which it often grows. Very fine plants are occasionally found in rock-crevices on the cliffs, and in some of the hedgebanks at St. Saviour's. In Gosselin's herbarium this species is intermixed with $A$. Adiantum-nigrum. Var. microdon, Moore. This variety, which bears a striking resemblance to $A$. marinum, was found in Guernsey in 1855 by Miss Wilkinson, and subsequently in other stations in the island by Miss Mansell and Mr. C. Jackson. It grew intermixed with the type at some distance from the sea. I possess two fronds taken from a root found at St. Peter's in 1885 : but the locality was kept secret, and the plant has not been seen by others, though often searched for. If this variety grows only inland, it may be extinct, but if it also occurs on the coast it would readily be passed over as $A$. marinum.

Asplenium Adiantum-nigrum, L.

Native. First found: Gosselin, I 788.

Very common in hedgebanks, and on rocks and old walls. In Gosselin's herbarium specimens labelled $A$. adiantum-nignum include both this species and the last.

The Guernsey name of this fern is Capillaire, but the term is also applied to any of the smaller species which cannot be classed under the name of Fouaille.

Asplenium Trichomanes, L.

Maidenhair Spleenwort.

Națive. First record: Gosselin, I815.

Rare. Always in this island on walls, never on hedgebanks. I have seen it in the parishes of St. Peter-Port, St. Martin's, Forest, 
Catel, Vale, and St. Sampson's. In Fl. Sarn. it is noted for St. Peter's. Mr. Derrick states in his paper on the Ferns of Guernsey that he knows 'quite two dozen stations for it, mostly in the town parish.'

Asplenium marinum, L.

Native. First record : Gosselin, I8 I 5 .

Sea Spleenzwort.

Frequent all round the coast, but chiefly in the south, and in inaccessible spots, having been eradicated wherever it could be reached. Beautiful specimens with fronds a couple of feet long are occasionally to be seen high up the walls of some seawashed cavern: but the average size is much less. In Ansted's Channel Islands it is stated respecting this fern: 'Many very beautiful varieties of it have been described, two of them peculiar to the Channel Islands. Fronds measuring three feet in length have been found in Guernsey, but these are rare.'

Asplenium Ruta-muraria, L.

Native. First record: Gosselin, 18 I5. $_{5}$

Rue-leaved Spleenziort.

Rather rare, but found in all parts of the island. I have seen this little fern growing on the churches or churchyard walls of every parish except Torteval. It is more frequent in the north, and on some old walls at the Vale it occurs in great profusion.

Scolopendrium vulgare, Sym.

Native. First record: Gosselin, I8I5.

Hart's Tongue.

Very common. In the shady waterlanes of the south this fern attains an extraordinary size and luxuriance, fronds three feet long being by no means rare. Several varieties are said to have been found in the island.

The patois name of this fern is Langue de boenf.

Ceterach officinarum, Willd.

Scaly Spleenwort.

Native. First record: Gosselin, I8I5.

Rare. Lane near Coutanchez, where in 1890 I counted eighteen roots on about ten feet of wall. Abundant on some of the old walls near Le Caudré (vi.). A few scattered plants in the vicinity of the Catel Church. One very large and fine root which I saw in r 889 near the King's Mills was dug out during the winter of $1890-\mathbf{r}$. Mr. Derrick has found this fern at the Vale, and reports that three roots which he watched for ten years hardly showed any increase in size. He also mentions its occurrence on greenhouse walls in various parts of the island.

Gymnogramme leptophylla, Desv.

Native (?). First found: Derrick, 1877.

Very rare. Only known in the single locality (the hedgebank of a lane) at St. Saviour's, where it was discovered in 1877 by Mr. G. 
Derrick. In his paper on the Ferns of Guernsey (Trans. Guern. Soc. Nat. Sc., 1882-89, p. 51) Mr. Derrick describes it as growing, when first found, 'in every favourable spot throughout the 200 feet of hedgebank,' but he adds that 'the crop becomes less yearly.' In 1890 , when I first saw Gymnogramme here, there was not very much, and it did not appear to increase in subsequent years. Being an annual, however, it may be that the plant is more plentiful in certain favourable seasons. Mr. Derrick expresses the opinion, in the paper above mentioned, that this is the last remnant of a once more common plant, rather than a recent introduction from Jersey: and he supports this view by the fact that all his attempts to spread it in other parts of the island have failed. The nativeness of this little fern in Jersey is, I suppose, not questioned : and so in Guernsey it may be regarded as a very probable native. It was discovered in Jersey in the year 1852 , and the first notice of it was published in the Gardener's Chronicle, January 29, 1853. It was also recorded in the Phytologist for the same year.

Blechnum boreale, Sw.

Native. First record: Gosselin, I8 5 .

Generally distributed, but not common, and seldom occurring in quantity in any station. Much more frequent in the southern half of the island, than in the lowlands. This fern is the Osmunda spicant of Gosselin's list.

Pteris aquilina, $\mathrm{L}$.

Native. First record: Gosselin, 1815 .

Common Brake or Bracken.

Very common in all districts in suitable localities : abundant on the cliffs, and on Lancresse Common. Said to have been sometimes found seven feet high, but specimens of such dimensions are extremely rare in this island.

This fern is known by the patois name of Fouaille or Fouâle; the small cottagers cut and dry it for use as bedding for cattle and pigs. The French name Fougère is not used in this island.

(It is asserted in Ansted's Channel Islands, p. I82, that the Maidenhair Fern (Adiantum Capillus-z'eneris) has been found in Alderney, but no authority is mentioned for the statement. I have no confirmatory evidence of the occurrence of this species anywhere in the islands within this area.)

Osmunda regalis, $\mathrm{L}$.

Native. First found: Gosselin, I 788 .

Very rare: probably now extinct. It is said that at one time this splendid fern was fairly plentiful in Guernsey: but now it is doubtful if a single wild root could be found. In $1882 \mathrm{Mr}$. Derrick stated that he still knew six different stations for it; and in r89 I I 
myself knew it to grow wild in three spots in different parishes, one of them being Grande Mare, where there were two fine roots, but they disappeared shortly afterwards. At St. Peter's the exact locality was kept secret, but the plants were each year dug up and offered for sale until all were gone : and Mr. Andrews informed me in 1900 that not a vestige of the Royal Fern could now be seen in a St. Saviour's valley where I saw four or five large roots ten years ago. Specimens are still preserved in Gosselin's herbarium, and he notes that in his day the Osmunda grew 'in a meadow at the Vauquiédor; in the Baissieres: in the Clôture : and in the Grande Mare.' The Clôture would be somewhere at the north end of the Vale Road, now probably built over or cultivated.

*Botrychium Lunaria, Sw.

Extinct.

In his paper on the Ferns of Guernsey, Mr. Derrick remarked in 1882, with reference to Botrychium: ' $I$ have heard that it used to be found here, but I suggest that unless guaranteed specimens are produced it should be omitted from the lists.' In June, 1900, Mr. L. V. Lester, Principal of Victoria College, Jersey, showed me, in a collection of plants belonging to the College, a specimen of Botrychium Lunaria collected in Guernsey in 1864 by G. Wolsey, and marked 'rare.' It seems almost certain that the plant is now extinct, as no trace of it has been detected in the island during the last thirty years.

Ophioglossum vulgatum, L.

Native. First record: Derrick, 1882.

Common Adder's Tongue.

Local. Occurs plentifully here and there in moist meadows in the low-lying districts of the Vale, Catel, and St. Saviour's : likewise on Lihou Island. I have also seen it in grass fields in several places towards the cliffs between the Corbiere and Creux Mahié. Var. ambiguum, C. \& G. Very rare. Grows in small scattered patches in several parts of Lancresse Common. The Guernsey plant seems to be identical with the one from the Scilly Isles, judging from a comparison of specimens gathered in those islands in 1890 with some which I found near Fort Doyle in the same year. Plants collected on Lancresse Common in July, 1881, and sent to the Bot. Exch. Club, were passed by Dr. Boswell as 'a luxuriant state of ambiguum.' This variety was first described as British by Mr. F. Townsend in a paper entitled, 'Contributions to a Flora of the Scilly Isles,' in Journ. Bot., I864.

Ophioglossum lusitanicum, L. Small Adder's Tongue.

Native. First found: Wolsey, 1854.

The headquarters of this curious little fern are the cliffs between Petit Bot Bay and Jaonnet, where patches of it occur in at least 
eleven different places. Further eastward it becomes more scarce, and the patches are further apart: but it grows in several spots between Jaonnet and Icart. Between Saints Bay and Moulin Huet it occurs sparingly in one place, and again more plentifully on the cliff overlooking Petit Port. IVest of Petit Bot Bay I have only been able to discover one station for the plant all along the south coast, viz., a little beyond the old Sommeilleuse Watchhouse, where it is by no means plentiful. In many of the other stations the plants grow thickly, but the patches are often small. The fronds are generally developed by the beginning of November: the fruit is mature in January or February: and the whole plant disappears in April. In this respect it differs altogether from $O$. ambigunm, which fruits at the end of May or beginning of June, and lasts till midsummer. O. husitanicum was discovered by George Wolsey, an acute Guernsey botanist, who recorded in the Phytologist for 1854 (p. 80) that this little fern grew 'amid short and very level herbage on the summit of rocks not far from Petit Bot Bay; it grows in company with Trichonema Columnae and Scilla autumnalis, and on the I 7 th of January was in full fruit.' 'The Small Adder's Tongue is not found wild elsewhere in the Channel Islands (although several attempts have been made to introduce it in Jersey), nor does it occur nearer to Guernsey than the western shores of the Department of Côtes du Nord, in Brittany.

(In order to prevent future error, it may be well to mention that some twenty years ago an enthusiastic fern botanist, residing in Guernsey, announced in print that. 'wishing to increase the number of our wild plants,' he had repeatedly 'planted out' roots of Cystopteris fragilis and Hymenophyllum tunbridgense, but had 'not met with much encouragement, never having seen a plant the third season.' Should either of these species ever be found in this island, it must be understood that it has no clam at all to be considered indigenous.) 


\section{LYCOPODIACEAE.}

\section{Isoetes Hystrix, Dur.}

Native. First found: Wolsey, 1860.

Rare. In damp sandy ground in various parts of Lancresse Common, particularly near Fort Doyle, and on the western side towards the Great Cromlech. Mr. Derrick has found it sparingly in the neighbourhood of Cobo, and also in a wet place near Petit Port, so that perhaps it is less rare than is commonly supposed. But it is a very inconspicuous plant, and extremely difficult to detect among the surrounding vegetation, until the eye becomes accustomed to it, for, when growing, it bears a striking resemblance to young plants of Armeria maritima or Carex arenaria, though these lack the spinous subterranean bulb which characterises Isoetes. Like Ophioglossum lusitanicum, this interesting plant was added to the British Flora by George IVolsey, who discovered it 'in damp spots on Lancresse Common in June 1860,' as reported by him in the Phylologist, new series, vol. v. p. 45. Iscetes Hystrix is not known to occur in Europe further north than Guernsey, and cutside this island is not found again within fifty miles, its nearest known station being on the coast of the Côtes du Nord, and further south on the shores of the Bay of Biscay. In this respect it resembles Ophioglossum lusitanicum; these two plants being unquestionably the most remarkable in the Sarnian flora. The reader will find an exhaustive paper by my friend, Dr. D. H. Scott, F.R.S. on the structure and affinities of Isoetes Hy'strix, prepared from fresh specimens obtained on Lancresse Common, in Annals of Botany, vol. xiv. (I900), p. 4 I 3 .

(Lycopodium clavatum, L. This species is mentioned in Gosselin's old list with the English name appended, Common Club Moss or Wolf's Claw. It is a plant little likely to be confounded with any other growing in this island, and, as it is widely distributed throughout Normandy and not uncommon in the part nearest these islands, it is quite possible that it existed here in Gosselin's time. But as, unfortunately, there is no specimen of the plant in his herbarium (which, however, is very incomplete), nor any subsequent evidence of its occurrence, I am reluctantly compelled to class this among uncertain records.) 


\section{CHARACEAE.*}

Chara fragilis, Desv.

Native. First record: Marquand, I89 I.

Plentiful in deep pools at Grande Mare. Also in the pool close to Fort Doyle. Var. barbata, Gant. Grande Mare. 'A form with prominent primary cortical cells, and unusually well-developed spine-cells.' (Groves.) Var. capillacea. Coss. \& G. In a quarry pool at the eastern side of Lancresse Common.

Chara aspera, Willd.

Native. First record: Marquand, r $89 \mathrm{r}$. Mare.

In pools at Grande Mare. Var. subinermis, Kuetz. Grande

Chara baltica, Bruz. Var. affinis, H. \& J. Groves.

Native. First record: Marquand, I 89 r.

Plentiful in one of the shallow pools at the south side of Grande Mare. If the draining of the marsh is proceeded with, this rare British Chara, like several other interesting plants, will soon be extinct in this island.

Chara vulgaris, L.

Native. First record: Babington, 1839 .

The most frequent species in Guernsey. Pool by Fort Doyle. Plentiful in an old quarry pool at Portinfer. I have also found it at Herm. No locality is specified for this species in Fl. Sarn. Var. longibracteata, Kuetz. Sparingly in $\mathrm{I} 892$ in a small roadside pool at Cobo. Var. papillata, Wallr. Roadside pool on the eastern side of Lancresse.

\section{Nitella translucens, Ag.}

Native. First record: Marquand, $189 \mathrm{I}$.

Very rare. Ditches behind Ivy Castle in 1890 and 1891 : in small quantity, but extremely fine and fruiting abundantly.

(The only species belonging to this order mentioned in Gosselin's old list is Chara hispida, Prickly Chara. In Fl. Sarn. Babington records two species: $C$. vulgaris, L., and $C$. hispida, L., both as seen by him. It is impossible to say now whether the true C. hispida existed in this island in former times, but it is almost certain that it is not to be found at the present day; and therefore the doubt arises whether some other species was mistaken for it by the old botanists.)

* I am indebted to Messrs. H. and J. Groves for kindly examining and determining all my gatherings of Guernsey Characeae. 


\section{MOSSES.}

In the very interesting catalogue of the wild plants of Guernsey, compiled by Joshua Gosselin in 1788, we find no less than thirtyone mosses enumerated under the following names:-

Bryum pomiforme.
rurale.
murale.
scoparium.
undulatum.
truncatulum.
purpureum.
hornum.
hygrometricum.
serpyllifolium.
curta.

Fontinalis antipyretica.

Hypnum denticulatum. complanatum. sylvaticum. lucens.
Hypnum triquetrum. filiforme. rutabulum. proliferum. parietinum. praelongum. squarrosum. alopecurum. purum. sericeum. myosuroides. clavellatum. cassubicum.

Polytrichum commune. nanum.

This list is well worth preserving as a relic of the days when the entire British moss-flora known to botanists did not number much over a hundred species.

The alphabetical catalogue of Guernsey mosses given in the second edition of Ansted's Channel Islands, p. 185, is unfortunately very inaccurate and misleading. Not only are a great many of the commonest species omitted altogther, but the list includes several alpine and sub-alpine mosses which could not possibly have been gathered in the island within recent times. In the Transactions of the Guernsey Society of Natural Science for 1892 I recorded $I_{42}$ mosses for the island, giving some account of their distribution; and a similar list, in a condensed form, appeared in the Journal of Botany for March 1893. Further study of certain species has necessitated an alteration of name in two or three cases, and a few additions have been made since. I am indebted to Dr. Braithwaite, the Rev. C. H. Binstead, and my lamented friend the late Mr. Henry Boswell, for much assistance in the determination of critical species.

In the following pages the names and arrangement accord with Dixon's Student's Handbook of British Mosses (1896), and the names used in Braithwaite's great work, the British Moss-Flora are, when different, added in brackets. Bryologists visiting the Channel Islands 
may be interested to know that a list of Jersey mosses and hepaticae, comprising I 10 species, collected during a summer excursion by Mons. Auguste Martin, of Cherbourg, was published in the Revue Bryologique for the year 1899 .

The moss-flora of Guernsey, as now recorded, consists of I 45 species.

\section{SPHAGNACEAE.}

Sphagnum acutifolium, Ehrh.

Very rare, and now almost extinct. At Grande Mare a few patches are found in one part, but they will soon disappear if the draining of the marsh is proceeded with.

\section{POLYTRICHACEAE.}

Catharinea undulata, Web. \& Mohr. Frequent in all parts of the island.

Polytrichum nanum, Neck. ( $P$. subrotundum, Braith.) Generally distributed, but less common than the following species.

Polytrichum aloides, Hedw.

Frequent in old quarries, gravelly banks, \&c.

Polytrichum piliferum, Schreb.

Rather common on the cliffs.

Polytrichum juniperinum, Willd.

Common in bare, dry spots and heathy places.

Polytrichum formosum, Hedw. (P. attenuatum, Braith.)

Abundant on Fermain cliffs: not uncommon in other parts of: the island.

\section{DICRANACEAE.}

Pleuridium axillare, Lind.

Upper end of Talbots Valley.

Pleuridium subulatum, Rab.

Frequent on bare, earthy banks, both inland and on the coast.

Ditrichum flexicaule, Hampe.

At the base of rocks at Les Pezeries, Rocquaine.

Ceratodon purpureus, Brid.

Very common on the cliffs, in old quarries, and in bare places. generally.

(Ceratolon conicus, Lindb., has been found in Sark.) 
Dicranella heteromalla, Schp.

Generally distributed and rather common.

Campylopus subulatus, Schp.

Pleinmont Point, sparingly.

Campylopus flexuosus, Brid.

In sandy ground on Lancresse Common.

Campylopus pyriformis, Brid.

On a decaying stump in the copse at Moulin de Haut, near King's Mills.

Campylopus fragilis, B. \& S.

Frequent in heathy places and on turfy banks on the coast and inland.

Campylopus introflexus, Brid.

Not uncommon on some parts of the cliffs, and at Lancresse towards Fort Le Marchant.

Campylopus brevipilus, B. \& S.

Les Pezeries, Rocquaine.

Dicranum scoparium, Hedw.

Common and very variable.

Var. orthophyllum, Brid. Here and there on the cliffs all along the south coast.

Dicranum majus, Turn.

In several places on the cliffs between Fermain and St. Martin's Point. Mont Varouf Valley, St. Saviour's.

Leucobryum glaucum, Schp.

Cliffs above Fermain Bay, in plenty. Eastern end of Lancresse in two or three spots.

\section{FISSIDENTACEAE.}

Fissidens exilis, Hedw.

Found at Moulin Huet in 1885 by Mons. J. Cardot, a French bryologist, who published a list of mosses collected by him in these islands in the Revue Bryologique for I887. Mons. Auguste Martin, of Cherbourg, has kindly sent me specimens gathered by him on a wall at the Forest in May 1898.

Fissidens viridulus, Wahl.

On a shady bank at Jerbourg. 
Fissidens incurvus, Starke.

Found at Moulin Huet in 1885 by Mons. J. Cardot I have gathered this species in Alderney.

Fissidens bryoides, Hedw.

Common in the south of the island.

Fissidens Curnowii, Mitt.

Sparingly on the bank of the stream at the upper end of Talbots Valley. At Variouf, Forest, I have found a form closely approaching this, though not quite typical.

Fissidens rivularis, Spruce.

Plentiful on the sides of a small waterfall on the cliffs between the Gouffre and the Corbiere: fruiting abundantly in October. This is one of the very rarest of British mosses.

Fissidens adiantoides, Hedw.

Frequent in marshy places, fruiting freely. A small form occurs on Lancresse Common.

Fissidens decipiens, De Not. (F. cristatus, Braith.)

Here and there on the cliffs, but not always typical.

Fissidens taxifolius, Hedw.

Not common. At Moulin Huet I have gathered a form with the habit of decipiens and the leaf-structure of taxifolins; and Cardot found at Moulin Huet in 1885 a 'forme à feuilles marginées.'

\section{GRIMMIACEAE.}

Grimmia maritima, Turn.

In rock crevices above high-water mark all round the coast : seldom beyond reach of the salt sea-spray.

Grimmia pulvinata, Sm.

Frequent on rocks and boulders on the coast and inland : sometimes on walls.

Grimmia trichophylla, Grev.

Generally distributed and frequent on rocks, boulders, and (more rarely) walls. Common on the cliffs.

Grimmia subsquarrosa, Wils.

On rocks, Saints Bay, in 1888 , and on the cliffs at Petit Bot in 1891. According to Dixon, this moss has not been found outside of Great Britain, so that its occurrence in the Channel Islands is particularly interesting. 
Grimmia leucophaea, Grev. (G. campestris, Braith.)

Frequent on the southern cliffs, but usually barren. Fruiting. abundantly in $189 \mathrm{r}$ on a rock above Petit Bot Bay.

Rhacomitrium heterostichum, Brid. (Grimmia, Braith.)

Petit Port Cliffs.

Var. alopecurum, Hubn. (Grimmia affinis, Braith.) On several parts of the cliffs at St. Martin's and the Forest, and on Lancresse Common.

Ptychomitrium polyphyllum, Fürnr. (Glyphomitrium, Braith.), On an old wall at Petit Bot, plentiful and fruiting abundantly.

TORTULACEAE.

Phascum cuspidatum, Schreb. ( $P$. acaulon, Braith.)

Generally distributed and not uncommon.

Pottia Heimii, Fürnr.

Base of a wall near the sea at Cobo.

Pottia truncatula, Lindb.

Common in fallow fields, and on bare ground in gardens.

Pottia intermedia, Fürnr.

Generally distributed and frequent.

Pottia littoralis, Mitt.

Bordeaux Harbour. Les Capelles. Braithwaite accords to this moss specific rank; Dixon regards it as a form of intermedia.

(Pottia crinita, Wils., occurs in Alderney.)

Pottia Wilsoni, B. \& S.

Hedgebank near Les Capelles.

Pottia asperula, Mitt.

On the cliffs above Petit Port, sparingly.

(Pottia minutula, Fürnr., occurs on seabanks in Alderney.)

Tortula ambigua, Angstr. ( $T$. ericaefolia, Braith.)

In many places in the south : usually on old walls.

Tortula atrovirens, Lindb.

On the ground near the sea. Saints Bay Valley. Fermain Point. Pezeries, Rocquaine.

Tortu'a muralis, Hedw.

Very common on walls and roadside stones. 
Tortula laevipila, Schwgr.

Generally distributed and not uncommon on tree trunks; occasionally on walls and roadside rocks.

Tortula intermedia, Berk. (T. montana, Braith.)

On walls and rocks. Saints Bay Valley. Old wall near Beaucamps, Catel. Wall in Vale Road.

Tortula ruralis, Ehrh.

On thatched roofs, occasionally on rocks : rare.

Tortula ruraliformis, Dix. ( $T$. ruralis var. arenicola, Braith.)

Abundant on the sandhills of the lowlands.

Barbula lurida, Lindb.

On a wall, Couture Waterlane.

Barbula rubella, Mitt.

Braye Road, near Les Capelles. Near Torteval Church.

Barbula tophacea, Mitt. (B. brevifolia, Braith.)

Occasional at the base of walls by streamsides. On the earth just above high-water mark at Petit Port.

(Barbula fallax, Hedw., and B. rigidula, Mitt., occur in Alderney.)

Barbula cylindrica, Schp. island.

Frequent on roadside walls and banks in the interior of the

Barbula vinealis, Brid.

On walls : generally distributed and rather common.

Barbula Hornschuchiana, Schultz.

On the ground on the cliffs near the Gouffre.

Barbula revoluta, Brid.

Rather common on wall-tops throughout the island.

Barbula convoluta, Hedw.

On a dry bank at Mont Saint. Wall-top near the Trinity Houses at Rocquaine. Old quarry near Fort Le Marchant.

Var. Sardoa, B. \& S. A taller form, growing on the ground in a quarry at Paradis, was referred to this variety by Boswell; and Cardot records it (sub nom. B. commutata, Jur.) for Moulin Huet.

Barbula unguiculata, Hedw.

Frequent in all parts of the island on banks, walls, and bare :ground.

Weisia microstoma, C. M. (Mollia, Braith.)

Gouffre. Vazon. Lancresse Common. 
Weisia viridula, Hedw.

Common on earthy banks and hedges in all parts.

Weisia mucronata, B. \& S. (Mollia rutilans, Braith.) Pleinmont Point.

(Weisia verticillata, Brid., I have found in Alderney at the base of dripping cliffs : and Trichostomum crispulum, Bruch., on banks near the sea.)

Trichostomum mutabile, Bruch. (Mollia brachydontia, Braith.)

Common on banks and old walls, and among rocks on the cliffs: fruiting sparingly in 1892 at Vauxbelets and near Beaucamps.

Var. cophocarpum, Schp. Specimens from Fermain Bay and Petit Bot Waterlane were so named for me by Boswell.

\section{Trichostomum littorale, Mitt. (Mollia, Braith.)}

Rather common throughout the island on old walls and banks, and on the sandhills at Lancresse. Braithwaite allows this moss to rank as a species, but Dixon considers it a variety of mutabile. A curious form growing on rocks above high-water mark at Petit Port which I submitted to Boswell was named by him Trichostomum (Mollia) lutescens, and it was recorded by me under that name in the two papers mentioned above. Dr. Braithwaite, however, has since informed me, after an examination of the plant, that it is not the true Mollia lutescens of Lindberg. The latter is considered by Dixon to be simply a rather marked form of the very variable T. mutabile.

Trichostomum flavo-virens, Bruch.

Frequent all round the coast on sandy banks, and in rock crevices close to the sea.

Pleurochaete squarrosa, Lindb.

Common on the sandhills at Lancresse: frequent on the cliffs. Rare inland: Talbots Valley.

\section{ORTHOTRICHACEAE.}

Zygodon viridissimus, Brown.

Generally distributed and rather common, occurring more often on walls and stones than on trees. Fruiting on walls at the Hermitage, St. Martin's, and at St. Andrew's Churchyard.

Var. rupestris, Lindb. Couture Waterlane. Foote's Lane, Lower Rohais. Wall at Lancresse.

Zygodon Stirtoni, Schp.

On a wall at Portelette, Rocquaine. 
Ulota phyllantha, Brid. (Weissia, Braith.)

Not uncommon throughout the island, growing both on trees. and on rocks.

Orthotrichum affine, Schrad.

On trees here and there, but generally small : rarely on stones.

Orthotrichum tenellum, Bruch.

Sparingly on a roadside tree at La Fosse, St. Martin's.

Orthotrichum pulchellum, Sm.

On a tree in the valley behind Les Vauxbelets.

Orthotrichum diaphanum, Schrad.

Generally distributed, and occurring quite as frequently on walls and boulders as on trees.

\section{FUNARIACEAE.}

Physcomitrium pyriforme, Brid.

Moulin Huet. Fermain Valley. Le Moulin, St. Peter's. Valley below Ozanne's Mill.

Funaria ericetorum, Dix. (F. obtusa, Braith.)

Here and there on the cliffs, and near Fort Doyle.

Funaria hygrometrica, Sibth.

Generally distributed: often abundant on the cliffs where the furze has been burnt.

\section{MEESIACEAE.}

Aulacomnion palustre, Schwgr. (Gymnocybe, Braith.)

Plentiful in some parts of Grande Mare. I have not met with this beautiful moss anywhere else in the island.

\section{BARTRAMIACEAE.}

Bartramia pomiformis, Hedw.

Rather common in hedgebanks between the stones, and on some parts of the cliffs.

(Bartramia stricta, Brid., one of the greatest rarities in the British moss-flora, I have found growing plentifully at the top of the cliffs on the eastern side of Alderney : in early spring its globular goldenyellow or orange capsules are quite conspicuous.)

Philonotis fontana, Brid.

Sparingly in Moulin Huet Valley and at Petit Bot. 


\section{BRYACEAE.}

Leptobryum pyriforme, Wils.

In 1890 this moss appeared in profusion in flower-pots in my greenhouse at Fermain House.

(Webera Tozeri, Schp., occurs in Alderney: a small, inconspicuous species easily overlooked.)

Bryum inclinatum, Bland.

Fruiting abundantly on the sandhills at Albecq in 1892 . The peristome accords with this species, and not with $B$. pendulum.

Bryum bimum, Schreb.

In marshy places. Not uncommon in the cliff valleys, and in a - small boggy spot towards Fort Le Marchant.

Bryum caespiticium, L.

Generally distributed and frequent.

Bryum capillare, L.

Common on walls, rocks, trees, and thatched roofs.

Bryum atropurpureum, W. \& M. (B. bicolor, Braith.)

Generally distributed and rather common : often occurring in old quarries.

Bryum murale, Wils.

On walls. Sausmarez, Catel. Roadside at Vazon. Near Cobo -Church.

Bryum alpinum, Huds.

In small quantity on the rocks at Icart Point. Mons. Auguste Martin, of Cherbourg, has sent me a specimen in nice fruit, gathered iby him at Icart on August 1 5, I 898 .

Bryum Mildeanum, Jur.

Found at the Gouffre in September 1885 by Mons. J. Cardot, as recorded in the Revue Bryologique for 1887 , and in Braithwaite's Moss-Flora, vol. ii. p. 180.

Bryum argenteum, L.

Rather rare, and usually in poor condition.

Mnium rostratum, Schrad.

Sparingly on a bank near Doyle's Monument. This is a curious form, having the leaves apparently entire; but under a high magnifying power the marginal teeth are seen to be rudimentary, taking the form of slightly protruding obtuse cells. 
Mnium undulatum, L.

Petit Bot Waterlane. Le Moulin, St. Peter's, scarce. Field corner in valley west of St. Saviour's Church.

Mnium hornum, L.

Very common.

Mnium punctatum, L.

Le Moulin, St. Peter's, in small quantity.

(Fontinalis antipyretica, L., was recorded by Gosselin as found in Guernsey more than a century ago; and it may still occur. I have a specimen nearly eighteen inches long found in a well in Sark in 1897.$)$

\section{CRYPHAEACEAE.}

Cryphaea heteromalla, Mohr.

On trees, scarce, and not in very good condition, though fruiting. Moulin de Haut and Effards, Catel. Les Prevosts, St. Saviour's.

\section{NECKERACEAE.}

Neckera complanata, Hübn.

Frequent on shaded stones and boulders throughout the island.

Homalia trichomanoides, Brid.

Plentiful on a tree trunk in Moulin Huet Valley.

\section{HOOKERIACEAE.}

Pterygophyllum lucens, Brid.

Not uncommon on streamsides, and at Grande Mare: occasionally with fine fruit.

\section{LEUCODONTACEAE.}

Pterogonium gracile, Sw. (P.ornithopodioides, Braith.)

On rocks, Saints Bay Valley. On the ground at Lancresse, near the Great Cromlech.

Porotrichum alopecurum, Mitt.

Frequent on moist shady banks, and by streamsides.

\section{LESKEACEAE.}

Leptodon Smithii, Mohr.

On a boulder in a shady lane near Les Marais, Vale. It is rather remarkable to find this moss growing on a stone, its usual habitat being the trunks of trees. 
Thuidium tamariscinum, B. \& S.

Common : occasionally in fruit.

\section{HYPNACEAE.}

Pylaisia polyantha, B. \& S.

On stones in the valley below Ozanne's Mill.

Isothecium myurum, Brid. (I. viviparum, Braith.)

Frequent on shady banks and boulders, especially in the hilly parts of the island.

Pleuropus sericeus, Dix. (Hypnum, Braith.)

This species is certainly the most abundant of all the pleurocarpous mosses found in the island: it grows everywhere on walls, rocks, trees, and thatched roofs.

Camptothecium lutescens, B. \& S.

Common on the sandhills of the lowlands.

Brachythecium glareosum, B. \& S. (Hypnum, Braith.)

Frequent on dry stony banks, and on pathways on the cliffs : less common inland. Caudre, St. Peter's. Beaucamps, Catel. Marais, Vale.

Brachythecium albicans, B. \& S.

Not uncommon on the sandhills of the north and west coast: occasionally on the cliffs.

Brachythecium rutabulum, B. \& S.

Very common everywhere.

Brachythecium rivulare, B. \& S.

Valley descending to Petit Bot from the west. Spring at Le Variouf, Forest.

Brachythecium plumosum, B. \& S.

Frequent on stones in streamlets.

Brachythecium illecebrum, De Not. (Hypnum, Braith.)

Rather common throughout the island on exposed banks, and on the ground, especially in old quarries. In I89I I found this species very sparingly in fruit near Doyle's Monument.

Brachythecium purum, Dix. (Hypnum, Braith.)

Very common.

Eurhynchium piliferum, B. \& S.

In various parts of the island, but not common. 
Eurhynchium crassinervium, B. \& S. (Hypnum, Braith.) Moulin Huet Waterlane.

Eurhynchium speciosum, Schp.

On the sides of small waterfalls at the Gouffre and near the Corbiere : in the latter station fruiting.

Eurhynchium praelongum, B. \& S.

Very common everywhere. Var. Stokesii, Brid. Waterlane below Le Chêne, Forest. Moulin Huet Valley. Streamside at the Gouffre.

Eurhynchium Swartzii, Hobk.

Moulin Huet Waterlane. Saints Bay Valley.

Eurhynchium pumilum, Schp. (Hypnum pallidirostre, Braith.)

Not rare in moist shady places and on streamsides in the south : often fruiting, but not abundantly.

Eurhynchium curvisetum, Husn.

On dripping perpendicular rocks in a cave at Petit Port, fruiting plentifully in April r892. Further study of this little moss shows it to belong to this species, and not to $E$. Teesdalii, as recorded in my papers above mentioned.

Eurhynchium tenellum, Milde. (Hypnum Algirianum, Braith.)

On the old sea wall above Fermain Bay. On stones in the valley below Ozanne's Mill, sparingly.

Eurhynchium myosuroides, Schp. (Isothecium, Braith.)

Common on rocks, boulders, and trees.

Eurhynchium circinatum, B. \& S.

On walls and rocks, not uncommon. Also on the sandhills of the north coast. It is extremely rare to find this moss growing on wood: at St. Martin's I once found a patch on a tree-trunk, and I have also seen it growing on an ash-tree in Alderney.

Eurhynchium striatum, B. \& S. (Hypnum, Braith.)

Common in hedgebanks.

Eurhynchium rusciforme, Milde.

Common on streamsides: occasionally in wells and cattletroughs. Var. atlanticum, Brid. Waterfall at the Gouffre. Echelle Mill, Talbots Valley.

Eurhynchium confertum, Milde.

Common throughout the island. 
Eurhynchium megapolitanum, Milde.

On a bank in Talbots Valley: fruiting freely.

Plagiothecium Borrerianum, Spruce.

Near Moulin de Haut, Catel, in several places. Valley west of St. Saviour's Church. Cliffs near Doyle's Monument.

Plagiothecium denticulatum, B. \& S.

Not uncommon on shady, earthy banks.

Plagiothecium sylvaticum, B. \& S.

In similar situations as the last, but less frequent.

Amblystegium serpens, B. \& S.

Generally distributed and not uncommon.

Amblystegium irriguum, B. \& S.

On stones under the drip of watermills. Petit Bot Mill. Echelle Mill, Talbots Valley.

Amblystegium filicinum, De Not.

Frequent in cliff rivulets, and near springs.

Hypnum riparium, L. (Amblystegium, Braith.)

Wet grassy places behind Ivy Castle. Waterlane, Mont Saint. Var. longifolium, Schp. Grande Mare, plentiful in one part of the marsh.

Hypnum stellatum, Schreb. (Amblystegium, Braith.)

Grande Mare, plentiful. Marshy spot on the cliffs between Icart and Petit Bot. Boggy spot at Lancresse towards Fort Le Marchant.

(Hypnum fluitans, L. has probably been overlooked in Guernsey, as it occurs in several places in Alderney.)

Hypnum commutatum, Hedw. (Amblystegium glaucum, Braith.)

Valley between Forest Church and Petit Bot.

Hypnum cupressiforme, L.

Very common and extremely variable.

Hypnum resupinatum, Wils.

Common on trees, rocks, and boulders. This moss in its typical form is so different in appearance from the last species that it was long considered distinct: but it has been shown to be merely a well-marked variety of $H$. cupressiforme, connected with the type by intermediate gradations.

Hypnum molluscum, Hedw.

Found at Moulin Huet in 1885 by Mons. J. Cardot. 
Hypnum cuspidatum, L.

Very common in marshy places and wet corners of fields. Fruits plentifully at Grande Mare, and occasionally elsewhere.

Hylocomium splendens, B. \& S.

Furze croft near Moulin de Haut, Catel.

Hylocomium brevirostre, B. \& S.

Sparingly on the cliffs in several places between Fermain and Doyle's Monument. In 1892 I found a single fruiting specimen on the hillside above Fermain Bay.

Hylocomium loreum, B. \& S.

Furze croft near Moulin de Haut. Fermain cliffs and Jerbourg cliffs. Near Le Moulin, St. Peter's.

Hylocomium squarrosum, B. \& S.

Common in damp grassy places, furze crofts, and field corners.

Hylocomium triquetrum, B. \& S.

Frequent in bushy places on St. Martin's cliffs : fruiting between Fermain and Bec du Nez. Mont Varouf Valley, St. Saviour's. Moulin de Haut, Catel. Pezeries, Rocquaine. 


\section{HEPATICAE.}

PRIOR to the year 1892 the only plants belonging to this family recorded for Guernsey were the six species included in Gosselin's old list under the following names: Jungermannia albicans, dilatata, tamariscifolia, platyphylla, marchantia conica, androgyna. In the Transactions of the Guernsey Society of Natural Science for 1892 I enumerated thirty-eight Hepaticae collected by me in the island, and since then I have received two additional species found here by a French botanist, Mons. Auguste Martin, of Cherbourg.

\section{MARCHANTIACEAE.}

Conocephalus conicus, L.

Common on streamsides and moist banks throughout the island.

Asterella hemisphaerica, L.

Frequent on earthy banks in the south.

Lunularia vulgaris, Mich.

Generally distributed and common.

Riccia glauca, L.

Frequent on the cliffs, and on hedgebanks in the south.

\section{JUNGERMANNIACEAE.}

Frullania dilatata, Dum.

Very common on trees, rocks, and boulders.

Frullania fragilifolia, Tayl.

On rocks on the cliffs. Jerbourg. Petit Bot. Corbiere.

Frullania Tamarisci, Dum.

Common on rocks and mossy banks : abundant on the cliffs. A variety with apiculate leaves occurs on the cliffs between the Gouffre and the Corbiere.

Lejeunia minutissima, Sm.

Frequent in all parts of the island, but more common in the south. Grows on stones and boulders as well as on trees.

Lejeunia serpyllifolia, Mich.

Not uncommon on shaded stones and tree-trunks. 
Radula complanata, L.

On old walls and earthy banks; frequent in the south, the prevailing form being the var. propagulifera.

Porella laevigata, Schrad.

On a bank near Le Casrouge, Forest.

Porella platyphylla, L.

On banks and boulders in all parts of the island, but not common.

Porella Thuja, Dicks.

Near Doyle's Monument. Le Moulin, St. Peter's.

Bazzania trilobata, L.

This beautiful species grows in several spots on the cliffs between Fermain Bay and Bec du Nez.

Cephalozia divaricata, Sm.

Frequent on dry banks in the hilly parts.

Cephalozia bicuspidata, Dum.

Generally distributed, but not very common.

Cephalozia Turneri, Lindb.

Fermain cliffs, sparingly on a gravel bank, intermixed with small mosses. This is one of the very rarest as well as one of the most minute of British scale-mosses.

\section{Lophocolea bidentata, L.}

Common throughout the island.

\section{Lophocolea Hookeriana, Nees.}

In old wells at La Bouvée, St. Martin's, and Saints Bay Valley. Very different from the last species, being of a deep green colour and much branched. It is also much more fragrant than the other species of this genus, so that it attracts attention by that character alone.

Lophocolea heterophylla, Schrad.

Generally distributed and not uncommon.

Lophocolea spicata, Tayl.

Abundant in a hollow lane at Les Messuriers, Forest: also found, but less plentifully, in several other parts of the island. This is one of the most interesting of Guernsey hepaticae, as it is essentially an Irish species. 
Chiloscyphus polyanthos, L.

Rather common in streamlets in all parts.

Saccogyna viticulosa, Mich.

Frequent on banks in the south. Talbots Valley.

Kantia Trichomanis, L.

Generally distributed and common.

Kantia arguta, Nees.

Moulin Huet Valley. A delicate species which I have often seen growing in Cornwall on the roofs of caves, or recesses in gravelly banks : it occurs in a similar habitat in Guernsey.

Scapania compacta, Dum.

Common among rocks on the cliffs: occasionally to be found in all parts of the island.

Scapania nemorosa, L.

On shaded rocks below Doyle's Monument.

Scapania resupinata, Dum.

I have a specimen kindly sent me by Mons. Aug. Martin, who gathered it at the Gouffre in August 1899.

Diplophyllum albicans, L.

Rather common on shady banks.

Plagiochila asplenioides, $\mathrm{L}$.

Occurs in many parts of the island, varying much in size. A small tufted form, with entire leaves, growing on hedgebanks near Les Hèches, St. Peter's, and also between Torteval Church and Pleinmont, is probably the var. Iumilis, Lind.

Plagiochila spinulosa, Dicks.

Frequent on the cliffs and on banks in the south.

Jungermannia crenulata, Sm.

On the cliffs at Saints Bay and at Petit Bot I have found a small form with the leaves very indistinctly bordered, resembling those of Jung. Genthiana, Hübn.

(Jungermannia ventricosa, Dicks., occurs in Alderney.)

Nardia Funckii, Nees.

Mons. Aug. Martin has sent me a specimen of this hepatic collected by him in May 1898 on the cliffs between the Gouffre and Corbiere Point.

Nardia scalaris, Schrad.

Occasional on the cliffs. 
Fossombronia pusilla, Nees.

Generally distributed and not uncommon.

Pellia epiphylla, L.

Common on shady streamlet banks.

Pellia calycina, Tayl.

Frequent by streamlets and springs.

Aneura multifida, Gray.

Rather common in marshes and boggy places.

Metzgeria furcata, Dum.

Common on trees and shady stones.

\section{ANTHOCEROTACEAE.}

Anthoceros laevis, Dill.

Occurs in nearly all the valleys in the south, and on the streamside in Talbots Valley. 


\section{FUNGI.}

THE present list of Guernsey fungi was compiled under exceptionally favourable circumstances. Three or four years ago I was engaged on special cryptogamic work at the Kew Herbarium, and Mr. George Massee, F.L.S., the Chief of the Department, one of the most experienced of living mycologists, having kindly offered to name for me any fungi from Guernsey, I wrote to some of my friends in that island requesting them to send me all the fresh specimens they could possibly procure. This appeal was responded to so promptly, and with such hearty goodwill, that within twelve months the list had attained its present dimensions.

To Mr. Massee I am deeply grateful for his never-failing readiness to examine the large parcels of fresh fungi which I submitted to him several times a week; and, as a voucher for the accuracy of this list, it is sufficient to state that not only every species, but specimens from each locality noted in these pages (several thousands in the aggregate), were individually examined and identified by Mr. Massee.

It gives me pleasure to record that the whole of the fungi now enumerated were collected and forwarded to me by Mrs. Marquand, Mrs. Boley, Miss Boley, Miss Bowman, Miss Dawber (now Mrs. Lewis), Miss Domaille, Miss Royle, and Messrs. W. Cameron, S. Chutter, A. Collenette, G. Derrick, T. Domaille, J. S. Hocart, H. Le Lacheur, W. A. Luff, A. Quick, J. B. Randell, and T. C. Royle. To all these ladies and gentlemen I desire to return my sincere thanks.

Many agarics are so extremely uncertain in their appearance that I have thought it best to specify all the localities in which a species has occurred. But the rule of priority has been strictly adhered to. The person's name first given indicates the discoverer of the species in this island, and the first locality mentioned is always the one where the earliest specimen was found.

The fungi of Guernsey now recorded comprise 612 species.

\section{HYMENOMYCETES.}

\section{I.-AGARICINEAE.}

Amanita phalloides, Fr.

Very poisonous, causing a large percentage of the deaths due to fungus-poisoning. Moulin de Haut, Catel (Le Lacheur).

Amanita rubescens, Fr.

Edible. Anneville, St. Saviour's (Le Lacheur). 
Amanitopsis vaginata, Fr.

Edible. Fir plantation near Bec du Nez (Luff).

Lepiota procera, Scop.

An edible, excellent, and safe species. Varclin, St. Martin's (Miss Boley); Grandes Rocques, Burnt Lane, Grande Mare, and Grand Havre (Luff); Lancresse Common, Woodlands, Calais, and Cobo (Derrick); Vieille Rue, St. Saviour's, and Pleinmont (Le Lacheur); Lancresse (Hocart).

Lepiota rachodes, Vitt.

Edible. Garden, Burnt Lane, and Ivy Castle (Luff); greenhouse, King's Road (Miss Royle); Saints' Bay (Miss Boley); l'Islet (Collenette).

Lepiota permixta, Fr.

Very rare in Britain. 'A critical species, but truly distinct from $L$. procera and L. rachodes' (Massee). Lancresse Common (Hocart); in a greenhouse near St. Martin's Church (Collenette).

Lepiota excoriata, Schaef.

Near Woodlands, and in a garden at Mount Durand (Derrick); Lancresse (Hocart); Ronceval and Pulias (Luff).

Lepiota gracilenta, Kromb.

Near Woodlands (Derrick); Lancresse, Bordeaux, and Fort Doyle (Luff); Norgiots and Cambridge Park (Le Lacheur); Icart Point (Miss Boley).

Lepiota Friesii, Lasch.

Fauxconnaires (Collenette).

Lepiota clypeolaria, Bull.

Fermain Bay (Luff).

Lepiota cristata, A. \& S.

Norgiots, St. Andrew's (Le Lacheur).

Lepiota erminea, Fr.

Vazon (Luff).

Lepiota holosericea, Fr.

Lancresse Common (Hocart).

Lepiota granulosa, Batsch.

Calais, St. Martin's (Derrick).

Lepiota sistrata, Fr.

Grand Havre (Luff). 
Lepiota prominens, Barla.

Only a single specimen has been found in Britain, and that many years ago. Near Richmond Barracks and near Ivy Castle (Luff); Prevosts, St. Saviour's (Le Lacheur).

Lepiota delicatula, Fr.

Near St. Martin's Church (Cameron).

Lepiota carneifolia, Gill.

A French species, new to Britain. Sausmarez Lodge grounds, Queen's Road (Derrick).

Armillaria mellea, Vahl.

Edible, but lacking flavour. Moulin Huet (Mrs. Boley); near St. Martin's Church (Miss Boley); Fermain, Bec du Nez, Saints Bay, Petit Bot, and Lancresse Common (Luff); Norgiots and Prevosts (Le Lacheur); Ville au Roi (Derrick).

Armillaria mucida, Schrad.

Norgiots (Le Lacheur); Vazon (Luff).

Tricholoma spermaticum, Fr.

Fetid. Coast near Grand Havre (Luff).

Tricholoma stans, Fr.

Rare in Britain. Norgiots, St. Andrew's (Le Lacheur).

Tricholoma rutilans, Schaef.

Les Terres (Miss Dawber); Norgiots (Le Lacheur).

Tricholoma atrocinereum, Pers.

Rare in Britain. Lancresse Common (Hocart).

Tricholoma cuneifolium, Fr.

Norgiots (Le Lacheur); Jerbourg (Mrs. Boley); Icart Point (Miss Boley); Lower Havelet, Moulin Huet, and Ivy Castle (Luff). Var. cinereo-rimosus, Batsch. Perelle (Luff).

Tricholoma sulphureum, Fr.

Fetid. Norgiots (Le Lacheur).

Tricholoma personatum, Fr.

Edible. One of the few fungi besides the common mushroom offered for sale in English markets. Known as 'Blue Caps' or 'Blewits.' Lancresse Common (Hocart); Grandes Rocques, Pulias, Vazon, and Burnt Lane (Luff); Buttes, St. Saviour's (Le Lacheur); Naftiaux, Hougue du Pommier, and Cobo (Derrick). 
Tricholoma nudum, Bull.

Edible. Coast near Grand Havre, and Burnt Lane (Luff); Sausmarez, Catel, Vazon Bay, and in a greenhouse in Valnord Road, (Derrick); Colombier, Ruettes Brayes (Miss Domaille).

Tricholoma panaeolum, Fr.

Norgiots, St. Andrew's (Le Lacheur).

Tricholoma melaleucum, Pers.

Var. polioleucum. Edible. Cliffs near Saints Bay (Luff); Norgiots (Le Lacheur).

Tricholoma brevipes, Bull.

Lancresse Common (Hocart).

Tricholoma humile, Pers.

Lancresse Common (Hocart); Grand Havre (Uerrick).

Tricholoma sordidum, Fr.

Vazon (Luff).

Tricholoma exscissum, Fr.

Grand Havre (Derrick).

Tricholoma militare, Lasch.

Garden, Indiana, St. Martin's (Mrs. Boley).

Tricholoma gambosum, Fr.

The St. George's Mushroom; edible; by some considered the most delicious of all agarics. Norgiots (Le Lacheur).

Tricholoma ionides, Bull.

A French species, very rare in Britain. Moulin Huet Water Lane (Luff).

Tricholoma terreum, Schreft.

Saints Bay cliffs (Luff).

Tricholoma scalpturatum, Fr.

Rare in Britain. Lancresse Common (Hocart).

Marasmius peronatus, Fr. (Luff).

Poisonous. Terres Plantation (Miss Royle); Talbots Valley

Marasmius oreades, Fr.

The Fairy Ring Mushroom. Edible; best dried for winter use. Saints Bay (Miss Boley); Paradis (Royle); Doyle's Monument, Petit Bot, Lihou Island, Vazon, Cobo, Grandes Rocques, Pulias, Ronceval, Grand Havre, and Fort Doyle (Luff); Moulin Huet 
and Fermain (Derrick); Lancresse Common (Hocart); Jerbourg and Icart Point (Mrs. Boley); Norgiots (Le Lacheur); l'Islet (Collenette).

Marasmius erythropus, Fr.

Lancresse (Luff).

Marasmius amadelphus, Fr.

Indiana, St. Martin's, in a fern-pot (Mrs. Boley).

Marasmius ramealis, Fr.

Lancresse (Hocart); Saints Bay (Luff).

Marasmius rotula, Fr.

Moulin Huet (Miss Boley).

Marasmius androsaceus, Fr.

Indiana, St. Martin's, in a fern-pot (Mrs. Boley); on dead wood, Norgiots (Le Lacheur).

Marasmius insititus, Fr.

In greenhouse, Indiana (Mrs. Boley).

Marasmius globularis, Fr.

Not British. Fermain Hill (Derrick).

Marasmius archyropus, Fr.

Mielles, Vale (Hocart).

Marasmius Wynnei, B. \& Br.

Rare in Britain. Talbots Valley (Luff).

Marasmius prasiosmus, Fr.

Grand Havre (Derrick).

Marasmius urens, Fr.

Near Ozanne's Mill (Luff).

Collybia radicata, Relh.

Lancresse Common (Hocart); Norgiots (Le Lacheur).

Collybia fusipes, Bull.

Catel (Derrick) ; near St. Martin's Church (Miss Boley); garden, Lower Havelet (Luff).

Collybia velutipes, Fr.

Grand Havre, Pulias, Cobo, Pleinmont, Petit Bot Bay, Icart, Saints Bay, and Jerbourg (Luff); Massys, St. Pèter's (Le Lacheur): Lancresse Common (Derrick). 
Collybia confluens, Pers.

Lancresse Common (Hocart); Grand Havre, Moulin Huet, and Jerbourg (Luff).

Collybia tuberosa, Bull.

Quarry by Ozanne's Tower, Catel (Derrick).

Collybia collina, Scop.

Rare in Britain. Cobo (Luff).

Collybia xanthopoda, Fr.

Lancresse Common (Hocart); garden, Burnt Lane (Luff).

Collybia nitellina, Fr.

Lancresse (Luff).

Collybia esculenta, Wuif.

Vazon Bay, towards Richmond (Derrick).

Collybia acervata, Fr.

Lancresse Common (Derrick).

Collybia dryophila, Bull.

Moulin Huet and Touillets (Derrick) ; Lancresse (Luff); Norgiots (Le Lacheur).

Collybia atrata, Fr.

Petit Bot cliffs (Luff).

Collybia exsculpta, Fr.

In a greenhouse near Catel Church (Collenette).

Collybia nummularia, Bull.

Lancresse Common (Hocart).

Mycena corticola, Fr.

Norgiots (Le Lacheur).

Mycena capillaris, Fr.

Ville au Roi (Miss Boley).

Mycena tenerrima, Berk.

Norgiots (Le Lacheur); Saints Bay and Petit Bot (Luff);

Galliennes, St. Andrew's (Quick).

Mycena leucogala, Cooke.

Lancresse Common (Hocart).

Mycena sanguinolenta, A. \& S.

Icart Point (Mrs. Boley). 
Mycena filopes, Bull.

Norgiots (Le Lacheur).

Mycena alcalina, Fr.

Coast near Grand Havre and Saints Bay (Luff); Parade Field, Fort George (Derrick).

Mycena ammoniaca, Fr.

Rabbit Warren, near Ivy Castle (Luff).

Mycena metata, Fr.

Coast near Pulias (Luff).

Mycena aetites, Fr.

Jerbourg (Miss Boley); Rabbit Warren (Luff).

Mycena stannea, Fr.

Saints Bay and Corbiere (Luff); Jerbourg (Mrs. Boley).

Mycena psammicola, B. \& Br.

Sous l'Eglise, St. Saviour's (Le Lacheur).

Mycena rugosa, Fr.

Lancresse Common (Hocart).

Mycena galericulata, Scop.

Jerbourg (Miss Boley); fir plantation near Bec du Nez, Rabbit Warren, Fort Bay, and Jerbourg (Luff).

Mycena polygramma, Bull.

Norgiots (Le Lacheur).

Mycena gypsea, Fr.

Norgiots (Le Lacheur).

Mycena flavo-alba, Fr.

Gouffre (Luff); Grand Havre (Derrick).

Mycena adonis, Bull.

Norgiots (Le Lacheur).

Mycena flavipes, Quel.

Grandes Rocques (Luff).

Mycena pura, Pers.

Lancresse Common (Hocart); Pulias (Luff).

Mycena stylobates, Pers.

Saints Bay (Luff). 
Russula alutacea, Fr.

Hubits (Miss Boley); Bec du Nez (Luff).

Russula lutea, Fr.

Varclin Lane (Miss Boley).

Russula nitida, Fr.

Havilland Hall (Royle); Bec du Nez and Jerbourg (Luff).

Russula Linnaei, Fr.

Fir plantation near Bec du Nez (Luff).

Russula puellaris, Fr.

Varclin Lane (Miss Boley).

Russula nigricans, Fr.

Norgiots (Le Lacheur).

Russula adusta, Fr.

Saints Bay (Miss Boley).

Russula furcata, Fr.

Norgiots (Le Lacheur).

Russula vesca, Fr.

Edible. Varclin Lane (Miss Boley).

Russula cyanoxantha, Schaef.

Varclin Lane (Miss Boley); Norgiots (Le Lacheur).

Russula rubra, Fr.

Hubits (Miss Boley).

Russula drimeia, Cooke.

Near Doyle's Monument (Luff).

Russula Queletii, Fr.

Fir plantation near Bec du Nez (Luff).

Russula xerampelina, Fr.

Oberland, St. Andrew's (Le Lacheur).

Lactarius vellereus, Fr.

Mont Vaurouf, St. Saviour's, in a furze-brake (Le Lacheur). A very fine specimen, nine inches in diameter. Mr. Le Lacheur says he has also seen this species at Moulin de Haut, Catel.

Lactarius pallidus, Fr.

Near Doyle's Monument (Derrick). 


\section{Lactarius rufus, Scop.}

Cliffs near Doyle's Monument (Luff).

Lactarius thejogalus, Fr.

Norgiots, St. Andrew's (Le Lacheur).

Laccaria laccata, Scop.

Varclin Lane (Miss Boley); Norgiots and Moulin de Haut (Le Lacheur); Lancresse (Hocart); near St. Andrew's Church and Jerbourg (Luff); Vallon grounds (Derrick).

Laccaria bella, Pers.

Norgiots, St. Andrew's (Le Lacheur).

Clitocybe nebularis, Batsch.

Edible. Norgiots and Talbots Valley (Le Lacheur).

Clitocybe phyllophila, Fr.

Sages, St. Peter's (Le Lacheur).

Clitocybe senilis, Fr.

Near Corbiere (Luff).

Clitocybe fragrans, Sow.

Lower Havelet, Bec du Nez, Icart Point, Saints Bay, Cobo, and Pulias (Luff); St. Sampson's (Derrick); Vinaires, St. Peter's (Le Lacheur).

Clitocybe obsoletus, Batsch.

Coast near Pulias (Luff).

Clitocybe augustissima, Fr.

Fir plantation near Jerbourg (Luff).

Clitocybe flaccidus, Sow.

Hubit Lanes (Luff).

Clitocybe Trogii, Fr.

Cobo (Luff).

Omphalia pyxidata, Bull.

Vazon Bay, towards Richmond (Derrick).

Omphalia philonotis, Lasch.

Ivy Castle (Luff).

Omphalia oniscus, Fr.

Cobo (Luff).

Omphalia glaucophylla, Lasch.

Cobo (Luff). 
Omphalia rustica, Fr.

Bec du Nez (Luff); Ivy Castle (Derrick); Lancresse Common (Hocart).

Omphalia demissa, Fr.

Rare in Britain. Lancresse Common (Hocart).

Omphalia campanella, Batsch.

Fermain (Luff).

Omphalia fibula, Bull.

Petit Bot (Luff); Sausmarez, Catel (Derrick).

Omphalia integrella, Pers.

Grand Havre (Derrick).

Omphalia belliae, Johnst.

Rare in Britain. Ivy Castle (Derrick).

Omphalia umbellifera, Linn.

Lancresse Common (Luff).

Omphalia striaepileus, Fr.

Norgiots, St. Andrew's (Le Lacheur).

Omphalia Luffii, Mass.

Cliffs at Icart, Jan. 3,1898 (Luff). Cliffs on the western side of Moulin Huet (Derrick). A remarkably fragrant species with a spicy smell like Clitocybe fragrans, which it somewhat resembles. Described by Mr. Massee in the Transactions of the British Mycological Society for 1897 ; the description copied in my second paper on the Fungi of Guernsey (Trans. Guernsey Soc. Nat. Sc., 1898, p. 279).

Pleurotus Ruthae, B. \& Br.

Very rare in Britain; has not been found for many years. Near St. Martin's Church (Miss Boley).

Pleurotus algidus, Fr.

Rabbit Warren, near Ivy Castle (Luff); Valnord Road (Derrick).

Pleurotus septicus, Fr.

On a bramble stem, Fort George (Derrick).

Hygrophorus sciophanus, Fr.

Talbots Valley (Luff).

Hygrophorus laetus, Fr.

Cobo, Moulin Huet, and Saints Bay (Luff.). 
Hygrophorus ceraceus, Wulf.

Petit Bot (Luff); Lancresse Common (Hocart); Fort George and near Doyle's Monument (Derrick); Jerbourg (Miss Boley).

Hygrophorus coccineus, Schaef.

Lancresse Common (Hocart). Much modified in form, size, and colour by growing in sand. Vale Castle Hill, Pulias, Icart Point, and Saints Bay (Luff); Moulin, St. Peter's (Le Lacheur); Petit Bot Bay and Moulin Huet cliffs (Derrick).

Hygrophorus miniatus, Fr.

Lancresse, Saints Bay, and Moulin Huet (Luff).

Hygrophorus turundus, Fr.

Fields near Saints Bay (Luff); Moulin Huet cliffs (Derrick).

Hygrophorus mucronellus, Fr.

Rare in Britain. Fermain Bay (Luff).

Hygrophorus puniceus, Fr.

Edible. Near Doyle's Monument and St. Martin's cliffs (Derrick); Corbiere, Perelle, Vazon, Cobo, Grand Havre, Pulias, and Fort Doyle (Luff); Jerbourg (Miss Boley); Norgiots (Le Lacheur); Icart Point (Mrs. Boley); Lancresse Common (Hocart). Var. castaneus, Mass. Var. nov. A new variety, distinguished by its ruddy chestnut colour. Moulin Huet, Saints Bay, and Grand Havre (Luff); Pleinmont (Le Lacheur).

Hygrophorus obrusseus, Fr.

Jerbourg (Miss Dawber); Norgiots (Le Lacheur); Moulin Huet, Saints Bay, Icart Point, Corbiere, Perelle, Pulias, Cobo, and Belvidere (Luff).

Hygrophorus intermedius, Pass.

Bec du Nez and Saints Bay (Luff).

Hygrophorus conicus, Fr.

Moulin Huet (Derrick); Saints Bay, Petit Bot, Corbiere, Lihou Island, Perelle, Grande Mare, Cobo, Fort Le Marchant, Fort Doyle, and Lower Havelet (Luff); Lancresse Common (Hocart); Prevosts and Houguette, St. Peter's (Le Lacheur).

Hygrophorus calyptraeformis, Berk.

Rare in Britain. Edible. Ronceval (Luff).

Hygrophorus chlorophanus, Fr.

Norgiots (Le Lacheur); Belvidere, Jerbourg, Saints Bay, Icart, and Pulias (Luff): Moulin Huet (Derrick). 
Hygrophorus psittacinus, Schaef.

Lancresse Common (Hocart); Saints Bay, Moulin Huet, Petit Bot, Pulias, Rabbit Warren, Havelet, Belvidere, and Pleinmont (Luff); Norgiots (Le Lacheur); Ivy Castle and Vallon Grounds (Derrick).

Hygrophorus unguinosus, Fr. Ivy Castle (Luff).

Hygrophorus pratensis, Fr.

Edible. Lancresse Common (Hocart); Jerbourg and Fermain Hill (Miss Boley); Norgiots, Pleinmont, Vallées, Moulin de Haut, and near St. Peter's Church (Le Lacheur); Perelle. Moulin Huet, Petit Bot, and Fort Doyle (Luff); St. Saviour's (Chutter); Naftiaux and Fort George (Derrick).

Hygrophorus virgineus, Wulf.

Edible. Saints Bay, Moulin Huet, Petit Bot, Perelle, Grandes Rocques, Pulias, Fort Doyle, and Havelet (Luff); Norgiots (Le Lacheur); Lancresse Common (Hocart); Ivy Castle and St. Sampson's (Derrick); St. Saviour's (Chutter). Growing specimens are frequently coloured on the under side bright lilac-purple, caused by the parasitic mould Verticillium Marquandii, Mass.

Hygrophorus niveus, Fr.

Norgiots (Le Lacheur); Fermain cliffs, Moulin Huet, Saints Bay, Corbiere, Lihou Island, Cobo, Grandes Rocques, Grand Havre, and Fort Doyle (Luff); Jerbourg (Miss Boley); Lancresse Common (Hocart); Fort George (Derrick).

Hygrophorus russo-coriaceus, B. \& Br.

Very rare in Britain. Smells like Russia leather. Ville au Roi and St. Martin's cliffs (Derrick); Icart Point (Mrs. Boley); Lancresse Common (Hocart); Pulias, Talbots Valley, and Jerbourg (Luff).

Hygrophorus ventricosus, B. \& Br.

Extremely rare in Britain; has not been found for a great many years. Moulin Huet, in fields overlooking the bay (Luff).

Hygrophorus ovinus, Bull.

Cobo (Luff).

Hygrophorus subradiatus, Fr. Var. lacmus.

Saints Bay (Luff).

Hygrophorus aureus, Arrh.

Vallon grounds, St. Martin's (Derrick).

Hygrophorus nemoreus, Fr.

Belvidere (Luff). 
Cantharellus cibarius, Fr.

Edible. Smell resembling apricots, especially the day after being gathered. Mont Vaurouf, St. Saviour's, and Oberland, St. Andrew's (Le Lacheur).

Cantharellus Friesii, Quel.

Queux, Catel (Derrick); Rabbit Warren (Luff).

Cantharellus aurantiacus, Fr.

Poisonous. Vieille rue, St. Saviour's (Le Lacheur); Lancresse Common (Hocart). Mr. Le Lacheur says he has also seen this species at Norgiots, St. Andrew's.

Cantharellus carbonarius, Fr.

Moulin Huet (Derrick); Cobo (Luff).

Lentinus tigrinus, $\mathrm{Fr}$.

Grandes Rocques (Miss Boley).

Panus stypticus, Fr.

Norgiots and Moulin de Haut (Le Lacheur).

Lenzites betulina, Fr.

Norgiots, on an oak stump (Le Lacheur).

Pluteus cervinus, Schaef.

Norgiots (Le Lacheur).

(Volvaria gloiocephala, Fr., occurs in Alderney.)

Entoloma sinuatum, Fr.

Poisonous. Moulin Huet (Luff); Lancresse Common (Hocart).

Entoloma jubatum, Fr.

Rocquaine (Le Lacheur).

Entoloma sericellum, Fr.

Lihou Island (Luff).

Entoloma costatum, Fr.

Cobo, Lancresse, Saints Bay, and Pleinmont Point (Luff).

Entoloma sericeum, Fr.

Saints Bay (Miss Boley); Vazon, Pulias, Fort Doyle, Jerbourg, Petit Bot, and Pleinmont (Luff); Lancresse Common (Hocart).

Entoloma speculum, Fr.

Cliffs at Pleinmont Point (Luff).

Entoloma clypeatum, Linn.

Garden, Burnt Lane (Luff). 
Entoloma prunuloides, Fr.

Jaonnet cliffs (Miss Dawber). Pleinmont Point (Luff).

Entoloma porphyrophaeum, Fr.

Cliffs at Pleinmont Point (Luff).

Nolanea pascua, Pers.

Corbiere and Rabbit Warren (Luff).

Nolanea mammosa, Fr.

Rare in Britain. Gouffre (Luff).

Nolanea nigripes, Trog.

Vazon Bay, towards Richmond (Derrick).

Leptonia lampropoda, Fr.

Paradis, Vale (Royle); Norgiots (Le Lacheur); Corbiere, Lihou Island, Moulin Huet, Saints Bay, and Lancresse (Luff); Vazon Bay, and Grand Havre (Derrick).

Leptonia solstitialis, Fr.

Saints Bay, Rabbit Warren, Pulias, and Vale Castle Hill (Luff); Jerbourg and Icart Point (Miss Boley); Galliennes (Derrick).

Leptonia serrulata, Fr.

Lancresse Common (Hocart) ; near Calais (Derrick) ; Jerbourg (Luff).

Leptonia euchroa, Pers.

Lancressie Common (Luff).

Leptonia chalybea, Pers.

Rare in Britain. Corbiere (Luff).

Leptonia anatina, Lasch.

Saints Bay cliffs (Luff).

Leptonia placida, Fr.

Oberland Lane (Le Lacheur).

Clitopilus cretatus, B. \& Br.

Talbots Valley (Luff).

Clitopilus sarnicus, Mass.

Talbots Valley (Luff). Apparently very uncommon, as only the specimens (about half a dozen) originally found have been seen. Described by Mr. Massee in the Transactions of the British Mycological Society for 1897 ; the description copied in my second paper on the Fungi of Guernsey (Trans. Gucrnsey Soc. Nat. Sc., I898, p. 278). This species is allied to Clitopilus undatus. 
Clitopilus prunulus, Scop.

Saints Bay cliffs (Luff).

Eccilia carneo-grisea, B. \& Br.

Lancresse Common (Hocart).

Eccilia atropuncta, Pers.

Cobo (Luff).

Pholiota squarrosa, Mull.

Norgiots (Le Lacheur). Var. Mulleri. Reines, St. Peter's (Le Lacheur).

Pholiota adiposa, Fr.

St. Martin's (Miss Boley); Fermain Lane (Luff).

Pholiota Junonia, Fr.

Cobo (Luff).

Pholiota aegerita, Fr.

Garden, Indiana (Mrs. Boley).

Pholiota molliscoria, Cke. and Mass.

Rare in Britain. Near Catel Church (Collenette).

Pholiota praecox, Pers.

Lancresse Common (Derrick).

Pholiota mutabilis, Schaef.

Norgiots, St. Andrews (Le Lacheur).

Bolbitius vitellinus, Fr.

Rabbit Warren (Luff).

Bolbitius titubans, Fr.

Cobo (Luff).

Bolbitius tener, Berk.

Indiana, St. Martin's, in a fern pot (Mrs. Boley); near Calais (Derrick).

Bolbitius Boltoni, Fr.

Norgiots (Le Lacheur).

Bolbitius grandiusculus, Cke. and Mass.

Petit Bot (Derrick).

Inocybe scaber, Fr.

Garden, Lower Havelet (Luff).

Inocybe Bongardii, Weinm.

Petit Bot (Luff). 
Inocybe hiulca, Fr.

Garden, Lower Havelet (Luff).

Inocybe rimosa, Bull.

St. Martin's, in a lane near the Church (Miss Boley); Pleinmont (Luff); Norgiots (Le Lacheur).

Inocybe sindonia, Fr.

Cobo (Luff).

Inocybe asterospora, Quel.

Lancresse Common (Hocart).

Naucoria cerodes, Fr.

Rocquettes Lane (Royle).

Naucoria sideroides, Bull.

Moulin de Haut, Catel (Le Lacheur).

Naucoria semi-orbicularis, Bull.

Lancresse Common (Hocart).

Naucoria tabacina, DC.

Havilland Hall (Royle).

Naucoria tenax, Fr.

Rabbit Warren (Luff).

Naucoria temulenta, Fr.

Field near Saints Bay and Belvedere (Luff); Norgiots (Le Lacheur).

Naucoria scorpioides, Fr.

Norgiots (Le Lacheur).

Naucoria conspersa, Pers.

Norgiots (Le Lacheur).

Naucoria pediades, Fr.

Norgiots (Le Lacheur).

Naucoria melinoides, Fr.

Petit Bot (Derrick).

Hebeloma glutinosum, Lindg.

Talbots Valley (Luff).

Hebeloma mesophaeum, Fr.

Cobo (Luff).

Galera tenera, Schaef.

Indiana, in a fern pot; Icart Point (Mrs. Boley); Norgiots (Le Lacheur); Pulias, Cobo, Belvidere, Saints Bay, and Petit Bot (Luff). 
Galera siliginea, Fr.

Fermain Hill (Miss Boley).

Galera campanulata, Mass.

I cart Point (Luff).

Galera antipoda, Lasch.

Garden, Rue Poudreuse (Domaille).

Galera spartea, Fr.

Gouffre and Pleinmont cliffs (Luff); Indiana, St. Martin's, in a fern pot (Mrs. Boley); Petit Bot cliffs (Derrick).

Galera hypnorum, Batsch.

Norgiots (Le Lacheur); Pulias (Luff).

Galera rubiginosa, Pers.

Saints Bay cliffs (Luff).

Galera ovalis, Fr.

Cliffs at Icart (Luff).

Flammula carbonaria, Fr.

Bec du Nez and Cobo (Luff).

Flammula flavida, Schaef.

Sous l'Eglise, St. Saviour's (Le Lacheur).

Flammula apicrea, Fr.

Vazon (Luff).

Flammula hybrida, Fr.

Norgiots (Le Lacheur).

Flammula sapinea, Fr.

Cobo (Luff).

Flammula ochrochlora, Fr.

Rare in Britain. Norgiots (Le Lacheur).

Tubaria furfuracea, Pers.

Cliffs, Petit Bot and Jerbourg (Luff); Lancresse Common . (Hocart); Galliennes (Derrick).

Tubaria inquilina, Fr.

Petit Bot (Luff). Grand Havre (Derrick).

Crepidotus mollis, Fr.

Norgiots (Le Lacheur).

Crepidotus calolepis, Fr.

Norgiots (Le Lacheur). 
Cortinarius saturninus, Fr.

Varclin Lane (Miss Boley).

Cortinarius dolabratus, Fr.

Cobo (Luff).

Cortinarius leucopus, Bull.

Varclin Lane (Miss Boley): Moulin Huet (Mrs. Boley).

Cortinarius rigidus, Fr.

Varclin Lane (Miss Boley).

Cortinarius ochroleucus, Fr.

Icart cliffs (Luff).

Paxillus lividus, Cooke.

Lihou Island (Luff).

Agaricus campestris, Linn.

The common edible Mushroom, apparently rare in Guernsey. Var. hortensis. The cultivated form. Fauxconnaires (Collenette); Lancresse Common (Luff, Hocart). Var. sylzicola. Norgiots (Le Lacheur): Ronceval and Grand Havre (Luff).

Agaricus arvensis, Schaef.

The Horse Nushroom; edible. Near Icart Point (Miss Boley); Pleinmont (Le Lacheur); Grand Havre (Luff).

Agaricus xanthodermus, Pat.

Edible. Lancresse Common (Hocart).

Agaricus sylvaticus, Schaef.

Lihou Island and Pulias (Luff).

Agaricus cretaceus, Fr.

Jerbourg (Miss Boley).

Agaricus sagatus, Fr.

Lihou Island (Luff); greenhouse, Valnord Road (Derrick).

Agaricus comptulus, Fr.

Lihou Island (Luff).

Agaricus rubellus, Gill.

Not British. Closely allied to A. campestris. Edible. Lan. cresse Common (Derrick).

Agaricus pratensis, Schaef.

Rare in Britain; common in France; edible. Garden, Mount Durand (Derrick). 
Agaricus augustus, Fr.

Very rare in Britain. One of the best edible Mushrooms. In: a hedgebank on the Forest Road (Luff).

Pilosace algeriensis, Fr.

Extremely rare in Britain, only a solitary specimen having: hitherto been found. 'Difficult to distinguish in the field from. Agaricus campestris, except in the absence of a ring.' (Massee, Brit. Fung. Fl.). Paradis, Vale (Royle).

Stropharia albo-cyanea, Desm.

Cobo (Luff).

Stropharia coronilla, Bull.

Poisonous. Saints Bay (Miss Boley); Petit Bot and Jerbourg: (Luff); Norgiots (Le Lacheur); Cobo (Derrick).

Stropharia merdaria, Fr.

Norgiots (Le Lacheur); near Fort Doyle and Petit Bot Bay (Luff).

Stropharia semiglobata, Batsch.

Poisonous. Saints Bay (Miss Boley); Lower Havelet, Gouffre, Corbiere, Grand Havre, and Cobo (Luff); Lancresse Common (Hocart); Ivy Castle and Petit Bot (Derrick); St. Saviour's. (Chutter).

Stropharia stercoraria, Fr.

Jerbourg (Luff).

Stropharia melasperma, Bull.

Jerbourg Point, and garden, Burnt Lane (Luff).

Stropharia inuncta, Fr.

Petit Bot cliffs (Luff).

Stropharia aeruginosa, Curt.

Le Colombier, Ruettes Brayes (Miss Domaille).

Hypholoma sublateritius, Schaef.

Lancresse Common (Hocart); Rabbit Warren (Luff).

Hypholoma capnoides, Fr.

Near Doyle's Monument (Derrick); Petit Bot cliffs (Luff).

Hypholoma fasciculare, Huds.

Poisonous. Lancresse Common (Hocart); Queux, Fermain, Calais, Hubits, St. Julian's Avenue, and Moulin Huet (Derrick); Vinaires and Norgiots (I.e Lacheur); Cobo (Luff): Mauxmarquis, St. Andrew's (Quick). 
Hypholoma elaeodes, Fr.

Norgiots (Le Lacheur); Moulin Huet Waterlane (Luff).

Hypholoma dispersum, Fr.

Near Doyle's Monument (Derrick).

Hypholoma velutinum, Pers.

Near Doyle's Monument (Derrick).

Hypholoma hydrophilus, Bull.

Petit Bot cliffs (Luff).

Hypholoma catarius, Fr.

Norgiots, St. Andrew's (Le Lacheur).

Hypholoma cascus, Fr.

Cliffs at Pleinmont Point (Luff).

Psilocybe sarcocephala, Fr.

Coast near Pulias, Petit Bot Bay, and Moulin Huet (Luff);

Norgiots (Le Lacheur).

Psilocybe semilanceata, Fr.

Poisonous. Saints Bay (Miss Boley); Icart Point, Pulias, Belvidere, and Jerbourg (Luff).

Psilocybe spadicea, Fr.

Norgiots (Le Lacheur); Galliennes (Derrick).

Psilocybe foenisecii, Pers.

Lancresse Common (Hocart); Belvidere, Bec du Nez, Jerbourg, Moulin Huet, Saints Bay, Icart, Petit Bot, and Gouffre (Luff); Grandes Rocques (Miss Dawber).

Psilocybe udus, Pers.

Moulin Huet (Luff).

Psilocybe subericaeus, Fr.

Saints Bay (Luff).

Psilocybe squalens, Fr.

A rare species everywhere. Saints Bay (Luff).

Psilocybe bullacea, Bull.

Moulin Huet (Luff).

Psathyra corrugis, Pers.

Lancresse Common (Hocart).

Psathyra frustulenta, Fr.

Cobo (Luff). 
Psathyra bifrons, Berk.

Hubits, St. Martin's (Derrick).

Psathyra semivestita, B. \& Br.

Norgiots (Le Lacheur).

Psathyra elata, Mass.

Catioroc, near Perelle (Luff).

Psathyrella atomata, Fr.

Moulin Huet (Mrs. Boley); Icart Point (Luff); Rocquaine (Le Lacheur).

Psathyrella disseminata, Pers.

Norgiots (Le Lacheur); Vauquiédor (Derrick).

Panaeolus leucophanes, B. \& Br.

Norgiots (Le Lacheur).

Panaeolus retirugis, Fr.

Corbiere (Luff).

Panaeolus sphinctrinus, Fr.

Norgiots (Le Lacheur); Jerbourg (Luff).

Panaeolus papilionaceus, Fr.

Vazon, Cobo, Grandes Rocques, Pulias, Ronceval, Rabbit Warren, Couture, Saints Bay, and Moulin Huet (Luff) ; Icart Point (Mrs. Boley) ; Ivy Castle and Delancey Hill (Derrick); St. Saviour's (Chutter).

Panaeolus campanulatus, Linn.

Saints Bay, Corbiere, Pulias, Cobo, Vazon, and Petit Bot (Luff); Icart Point (Miss Boley); Norgiots (Le Lacheur); Homtolle, Vale (Collenette); Mielles, Vale (Hocart).

Panaeolus fimicola, Fr.

Petit Bot cliffs and Cobo (Luff).

Anellaria separata, Karst.

Cobo and Lihou Island (Luff).

Anellaria fimiputris, Karst.

Talbots Valley (Luff).

Coprinus comatus, Fr.

Sausmarez, Catel (Derrick).

(Coprinus atramentarius, Fr,, occurs in Alderney.)

Coprinus niveus, Fr.

Vauquiédor Lane and Grand Havre (Luff). 
Coprinus micaceus, Fr.

Robergerie, St. Sampson's (Derrick); Mielles, Vale (Hocart); Saints Bay cliffs and near Doyle's Monument (Luff).

Coprinus deliquescens, Fr.

Cobo and Vazon (Luff); Norgiots (Le Lacheur).

Coprinus tardus, Karst.

Corbiere (Luff).

Coprinus lagopus, Fr.

Sous l'Eglise, St. Saviour's (Le Lacheur).

Coprinus radiatus, Fr.

Lihou Island and Vazon (Luff); Norgiots (Le Lacheur); Petit Bot (Derrick).

Coprinus plicatilis, Fr.

Near Doyle's Monument (Derrick); Norgiots (Le Iacheur); Saints Bay, Fermain, and Rabbit Warren (Luff).

Coprinus ephemerus, Fr.

Moulin Huet cliffs, on dung (Derrick).

Coprinus Spraguei, B. \& C.

Norgiots (Le Lacheur).

Coprinus aratus, B. \& Br.

Hubit Lanes (Mrs. Marquand).

Coprinus ovatus, Schaef.

Edible, with a very delicate aroma and flavour. Lancresse Common (Hocart).

\section{II.-POLYPOREAE.}

Boletus chrysenteron, Fr.

Poisonous. Moulin Huet and Varclin Lane (Miss Boley).

Boletus fulvidus, Fr.

Rare in Britain. Norgiots and Oberland, St. Andrew's (Le Lacheur): Varclin Lane (Miss Boley).

Boletus castaneus, Bull.

Varclin Lane (Miss Boley).

Boletus edulis, Bull.

Edible. Havilland Hall (Royle).

Boletus luridus, Schaef.

Poisonous. Havilland Hall (Royle). 
Boletus duriusculus, Schulz.

Norgiots (Le Lacheur).

Polyporus lentus, Berk.

Rare in Britain. Havilland Hall (Royle).

Polyporus squamosus, Fr.

St. Peter's (Luff); Norgiots and Fauxquets (Le Lacheur); Lancresse (Hocart); Rocques Barrées and Sausmarez Lodge (Derrick).

Polyporus Rostkovii, Fr.

Rare in Britain. Delancey Hill (Derrick); Norgiots (Le Lacheur).

Polyporus picipes, Fr.

Lancresse Common (Derrick); Norgiots (Le Lacheur).

Polyporus hispidus, Fr.

Norgiots (Le Lachẹur); King's Mills, Cobo, and Ramée (Luff); Catel (Miss Boley).

Polyporus adustus, Fr.

Ville au Roi (Derrick; Miss Dawber); Forest Road and Petit Bot (Luff); Lancresse Common (Hocart); Isabel Road, Foulon (Derrick).

Polyporus fragilis, Fr.

Norgiots (Le Lacheur).

Polyporus armeniacus, Berk.

Norgiots (Le Lacheur).

Polyporus chioneus, Fr.

On old wood in a well near St. Martin's Church (Cameron).

Fomes ulmarius, Fr. (Luff).

Norgiots (Le Lacheur); near Cobo Church, in a hollow elm-tree

Fomes fomentarius, Fr.

A very destructive parasite, especially to beech-trees. Norgiots (Le Lacheur) ; Hermitage, St. Martin's (Mrs. Boley) ; garden, Burnt Lane, and Fermain Lane (Luff); Haute Lande, Vale (Hocart); St. Jacques (Derrick).

Fomes salicinus, Fr.

Jaonnets, St. Saviour's, on Whitethorn (Le Lacheur).

Fomes ferruginosus, Mass.

Rare in Britain. Near St. Martin's Schools (Luff); Norgiots (Le Lacheur). 
Fomes igniarius, Fr.

Foulon Cemetery (Derrick).

Fomes conchatus, Fr.

On a furze hedge, Norgiots (Le Lacheur).

Fomes ribis, Fr.

Saints Bay and Jerbourg (Luff).

Fomes annosus, Fr.

A very destructive parasite to conifers, attacking the roots and soon killing the tree. Vallon grounds (Derrick).

Polystictus versicolor, Fr.

Bon Air (Miss Boley); Norgiots (Le Lacheur); near Ozanne's Mill (Royle); Queux, Catel, and Foulon (Derrick); Gouffre and Petit Bot cliffs (Luff).

Polystictus radiatus, Fr.

Water Lane, Petit Bot (Luff); Norgiots (Le Lacheur); Lancresse Common (Hocart).

Polystictus hirsutus, Fr.

Norgiots (Le Lacheur); Catel (Miss Boley): near Delancey Hill (Derrick) ; Icart, Petit Bot cliffs, and Mansell Street (Luff); St. Jacques (Collenette).

Polystictus tomentosus, Fr.

Not previously recorded for Britain. Fort Doyle and Pulias (Luff); Lancresse Common (Hocart).

Poria vaporaria, Fr.

Norgiots (Le Lacheur); Sausmarez Lodge, Queen's Road (Derrick); Haute Lande, Vale (Hocart).

Poria mucida, Fr.

Mielles, Vale (Hocart); Fir plantation, Jerbourg (Luff).

Poria terrestris, Fr.

The most primitive form met with in this large genus. Havilland Hall (Royle).

Poria bombycina, Fr.

Sausmarez Lodge, Queen's Road (Derrick).

Poria hibernica, B. \& Br.

Sausmarez Lodge (Derrick).

Poria vitrea, Pers.

On a chestnut tree, Norgiots (Le Lacheur). 
Trametes gibbosa, Fr.

Foulon, on an old Beech-tree (Derrick).

Daedalea quercina, Pers.

Moulin de Haut, Catel, on dead Oak (Le Lacheur).

Daedalea unicolor, Fr.

Saints Bay (Luff).

Daedalea cinerea, Fr.

Fort Bay (Luff).

Merulius lacrymans, Fr.

This fungus is familiar under the name of 'dry rot,' and is generally common in consort with man. Not known in a wild state. Wine stores, Truchot (Royle).

Merulius laeticolor, B. \& Br.

Rare in Britain. On the ceiling of an outhouse in Mansell Street (Luff).

\section{III.-HydNEAE.}

Caldesiella ferruginosa, Sacc.

Sausmarez Lodge, Queen's Road, on decaying wood (Derrick).

Irpex pendulus, Fr.

On old wood in garden, Indiana, St. Martin's (Miss Boley).

Hydnum repandum, Linn.

In a furze-brake, Neuf Chemin, St. Saviour's (Le Lacheur).

Hydnum niveum, Pers.

Robergerie, St. Sampson's (Derrick); garden, Burnt Lane (Luff).

\section{IV.-THELEPHOREAE.}

Cyphella alboviolascens, Karst.

Near Pulias (Luff).

Cyphella Curreyi, B. \& Br.

On Elm bark, Norgiots (Le Lacheur).

Cyphella capula, Fr.

On White Currant, Norgiots (Le Lacheur).

Stereum hirsutum, Fr.

A destructive timber parasite. Norgiots (Le Lacheur); Queux, Catel, and Foulon (Derrick); Villette, Jerbourg, Talbots Valley, and Rabbit Warren (Luff); Haute Lande and Mielles, Vale (Hocart); Garden, Allez Street (Randell). 
Stereum ochroleucum, Fr.

Norgiots (Le Lacheur).

Stereum purpureum, Pers.

Norgiots (Le Lacheur); Talbots Road (Luff).

Stereum involutum, Schwein.

Norgiots and Moulin de Haut (Le Lacheur).

Stereum rugosum, Fr.

Near Vale Mill (Derrick); Norgiots (Le Lacheur).

Stereum spadiceum, Fr.

Queux, Catel, and Vallon grounds (Derrick); Talbots Valley and Moulin Huet (Luff); Norgiots (Le Lacheur); Haute Lande, Vale (Hocart).

Corticium sebaceum, Mass.

Grande Mare, Talbots Valley, and Pleinmont cliffs (Luff); Robergerie, St. Sampson's (Derrick).

Corticium lacteum, Fr.

Moulin Huet, in a hollow tree-trunk (Derrick).

Corticium nudum, Fr.

Fermain Bay (Luff).

Corticium arachnoideum, Berk.

Norgiots (Le Lacheur); Foulon (Derrick).

Corticium sảmbuci, Fr.

Norgiots (Le Lacheur); Fermain Bay (Luff).

Corticium flaveolum, Mass.

Haute Lande, Vale (Hocart).

Corticium comedens, Fr.

Norgiots, St. Andrew's (Le Lacheur).

(Corticium caeruleum, Fr, occurs in Alderney.)

Corticium calceum, Fr.

Saints Bay, Jerbourg, and Lancresse Common (Luff).

Hymenochaete tabacina, Lev.

Saints Bay (Luff).

Hymenochaete leonina, B. \& C.

Lancresse Common (Luff). 


\section{Peniophora rosea, Mass.}

Near St. Martin's Schools, Fermain Bay, Talbots Valley, Pleinmont cliffs, and Burnt Lane (Luff); Norgiots (Le Lacheur).

Peniophora ochracea, Mass.

Sausmarez Lodge, Queen's Road (Derrick); Norgiots (Le Lacheur).

Peniophora cinerea, Cke.

Saints Bay cliffs (Luff); Norgiots (Le Lacheur).

Peniophora incarnata, Mass.

Poidevins, St. Andrew's (Quick).

Peniophora gigantea, Mass.

Ivy Castle (Derrick).

Soppittiella sebacea, Mass.

Fir plantation near Bec du Nez (Luff).

Coniophora arida, Karst.

Norgiots (Le Lacheur).

Coniophora incrustans, Mass.

Garden, Burnt Lane (Luff).

\section{V.-Clavarieae.}

Clavaria fastigiata, Linn.

Lancresse Common (Hocart); Lihou Island (Luff).

Clavaria muscoides, Linn.

Lancresse Common (Hocart); Norgiots and Eclet, St. Peter's (Le Lacheur); Ville au Roi and Fermain Hill (Miss Boley); Fort Doyle and Saints Bay (Luff).

Clavaria coralloides, Linn.

Saints Bay (Miss Boley).

Clavaria cinerea, Bull.

Norgiots (Le Lacheur).

Clavaria cristata, Holmsk.

Varclin Lane (Miss Boley); Lancresse Common (Hocart).

Clavaria rugosa, Bull.

Edible. Norgiots (Le Lacheur).

Clavaria flaccida, Fr.

Norgiots (Le Lacheur). 
Clavaria fusiformis, Sow.

Lancresse Common (Hocart); Rabbit Warren and Icart Point (Luff).

Clavaria vermicularis, Scop.

Edible; Norgiots (Le Lacheur); Saints Bay and Fort Doyle (Luff).

Clavaria fragilis, Holmsk.

Lancresse Common (Hocart); Icart Point (Miss Boley); Pulias, Vazon, and Vale Castle Hill (Luff).

Clavaria dissipabilis, Britz.

Lancresse Common (Hocart); Cobo (Luff).

Clavaria inaequalis, Berk.

Jerbourg (Luff).

\section{VI.-DACRYOMYCETEAE.}

Dacryomyces deliquescens, Duby.

Petit Bot (Luff); Ivy Castle, and Sausmarez Lodge, Queen's Road (Derrick).

Dacryomyces stillatus, Nees.

Norgiots (Le Lacheur).

Dacryomyces macrosporus, B. \& Br.

Garden, Burnt Lane (Luff).

Naematelia encephala, Fr.

On Gooseberry, Norgiots (Le Lacheur).

\section{VII.-TREMELLINEAE.}

Tremella mesenterica, Retz.

Norgiots (Le Lacheur); Petit Bot (Luff).

Tremella foliacea, Pers.

Norgiots (Le Lacheur).

Tremella atrovirens, Fr.

Fermain Bay (Luff).

Tremella lutescens, Pers.

Cliffs at Pleinmont Point (Luff).

Exidia albida, Bref.

Petit Bot (Luff). 


\section{VIII.-AURICULARIEAE.}

Auricularia mesenterica, Fr.

Norgiots (Le Lacheur); Queux, Catel (Derrick); Garden, Allez Street (Randell); Saints Bay cliffs and Cobo (Luff).

Auricularia lobata, Sommerf.

Very rare in Britain. St. George and Les Queux (Derrick); Hubits (Miss Boley).

Hirneola Auricula-judae, Berk.

Fermain Bay (Luff).

\section{GASTROMYCETES.}

Clathrus cancellatus, Tournef.

A very beautiful but extremely offensive fungus. (Garden, Orchard Hill, Rozel Road, where specimens sprang up several years in succession. A specimen from another locality also seen (Marquand).

Tulostoma mammosum, Fr.

Rare in Britain, representing an ancient retiring groul). Vazon Bay, towards Richmond, in sandy ground (Derrick).

Geaster striatus, DC.

Lancresse Common (Hocart); Grand Havre (Luff).

Lycoperdon gemmatum, Batsch.

Grandes Rocques, Cobo, and Lihou Island (Luff); Les Terres (Miss Dawber).

Lycoperdon pyriforme, Schaef.

Moulin Huet (Miss Boley); Sausmarez, St. Martin's (Mrs. Boley); Rocquettes Lane (Derrick); Cobo, Pulias, Grand Havre, Pleinmont, and South Esplanade (Luff); Norgiots (Le Lacheur).

Lycoperdon perlatum, Pers.

Lancresse Common (Derrick); Fauxconnaires (Collenette); Lower Havelet and Vazon (Luff).

Lycoperdon coelatum, Bull.

Lancresse Common (Royle); Fermain Hill (Miss Boley); Icart Point (Luff).

Lycoperdon Bovista, Linn.

Edible. Garden, Burnt Lane (Luff); Calais (Mrs. Marquand). 
Lycoperdon plumbeum, Pers.

Gouffre (Miss Boley); Lancresse, Ronceval, Moulin Huet, and Saints Bay (Luff); Icart Point (Mrs. Boley).

Lycoperdon nigrescens, Vitt.

Paradis, Vale (Royle); St. Martin's cliffs (Derrick).

Lycoperdon pusillum, Fr.

Hubit Lanes and Pleinmont Point (Luff).

Lycoperdon ovalisporum, Mass.

Grande Mare (Luff); l'Islet (Collenette).

Scleroderma verrucosum, Pers.

Sometimes used instead of truffles, but a very poor substitute. Saints Bay and Varclin Lane (Miss Boley); Norgiots and Moulin de Haut (Le Lacheur); Moulin Huet and Bailiff's Cross (Derrick); Rocquettes Lane (Royle); Jerbourg (Mrs. Boley); Les Terres (Miss Dawber); Lower Havelet (Luff).

Scleroderma Geaster, Fr.

Varclin Lane (Miss Boley).

Hysterangium nephriticum, Berk.

Foot of a wall, Bailiff's Cross (Derrick).

Cyathus vernicosus, DC.

The Bird's Nest Fungus. In greenhouse, Bellieuse Vineries, St. Martin's (Cameron).

\section{ASCOMYCETES.}

I. -PYRENOMYCETES.

Sphaerotheca pannosa, Lev.

A destructive parasite to wild and cultivated roses, covering the leaves with a white frost-like bloom. Garden, Burnt Lane (Luff).

Sphaerotheca Castagnei, Lev.

Indiana, St. Martin's (Miss Boley); Burnt Lane (Luff); Rue Poudreuse (Miss Dawber); Fauxconnaires (Collenette).

Erysiphe Martii, Link.

Garden, Rue Poudreuse (Miss Dawber).

Erysiphe umbelliferarum, De By.

Church Lane, St. Martin's (Miss Boley); Havilland Hall (Royle).

(Erysiphe communis, Fr., occurs in Alderney.) 
Eurotium herbariorum, Link.

Grande Mare (Luff).

Anixia Wallrothii, Fckl.

Norgiots (Le Lacheur); Friquet, Catel (Derrick).

Cordyceps militaris, Fr.

Norgiots and Rocquaine (Le Lacheur); Icart cliffs and Pleinmont Point (Luff).

Hypocrea rufa, Fr.

Norgiots (Le Lacheur).

Nectria cinnabarina, Tode.

Garden, Burnt Lane (Luff); Sausmarez Lodge, Queen's Road (Derrick); Norgiots (Le Lacheur); Garden, Doyle Road (Randell).

Nectria coccinea, Fr.

Norgiots, on a Walnut-tree (Le Lacheur); Indiana, St. Martin's (Mrs. Boley).

Nectria cucurbitula, Fr.

A dangerous parasite to conifers. Norgiots (Le Lacheur).

Nectria aquifolii, Berk.

Norgiots, on a dead Pear-tree (Le Lacheur).

Nectria sanguinea, Fr.

Norgiots, on Holly (Le Lacheur); Lancresse (Luff).

Nectria umbrina, Fr.

Norgiots (Le Lacheur).

Nectria ribis, Rabenh.

Norgiots (Le Lacheur); garden, Burnt Lane (Luff); Valnord Road (Derrick).

Nectria mammosa, Phil. \& Plow.

On an Apple-tree, Norgiots (Le Lacheur).

Nectriella aurea, Sac.

La Croix, St. Peter's, on Sycamore (Le Lacheur).

Hypomyces chrysospermus, Tul.

Havilland Hall (Royle), parasitic on Boletus luridus and B. edulis, giving them the appearance of having been copiously sprinkled with mustard powder.

Hypomyces rosellus, A. \& S.

Near St. Martin's Church (Miss Boley); Gouffre (Luff). 
Xylaria Hypoxylon, Fr.

Norgiots (Le Lacheur); Lancresse Common (Hocart); Pulias, Talbots Valley, and Jerbourg (Luff); Galliennes (Royle); Bellieuse

Vineries (Cameron).

Nummularia Bulliardii, Fr.

Norgiots (Le Lacheur).

Hypoxylon rubiginosum, Fr.

Hubits (Miss Boley); Moulin Huet Waterlane (Luff).

Hypoxylon fuscum, Fr.

Norgiots (Le Lacheur).

Hypoxylon atropurpureum, Fr.

Rare in Britain. Norgiots (Le Lacheur); Talbots Valley (Luff).

Hypoxylon marginatum, Berk.

On a Willow stump, Norgiots (Le Lacheur).

(Poronia punctata, Fr., occurs in Alderney.)

Daldinia concentrica, Bolt.

St. Martin's (Luff); Norgiots and Vauxbelets (Le Lacheur); Talbots Road and Catel (Miss Boley); Rozel Farm (Miss Bowman).

Phyllachora graminis, Pers.

Vale Castle Hill, and Saints Bay (Luff).

Phyllachora heraclei, Fckl.

Rabbit Warren (Luff).

Phyllachora ulmi, Fckl.

Talbots Valley (Luff); garden, Indiana, St. Martin's (Mrs.

Marquand).

Rhytisma salicinum, Fr.

Plantation, South Esplanade (Luff).

(Rhytisma acerinum, Pers., occurs in Alderney.)

Plowrightia ribesia, Sac.

Norgiots, on Red Currant (Le Lacheur).

Valsa salicina, Fr.

Fermain Bay, on Willow twigs (Luff).

Valsa leiphemia, Fr.

Moulin Huet Waterlane (Luff). 
Valsa ceratophora, Tul.

On Elm, Norgiots (Le Lacheur).

Valsa stilbostoma, Fr.

Fir plantation near Jerbourg (Luff).

Bertia collapsa, Rom

Not British. Only recorded from Sweden, where it grows on Sorbus aucuparia (Mountain Ash). Norgiots, growing on Gooseberry and Red Currant wood (Le Lacheur).

Diatrype disciformis, Fr.

Cobo (Luff).

Byssosphaeria aquila, Fr.

On an Apple-tree, Norgiots (Le Lacheur).

Byssosphaeria phaeostroma, Mont.

Galliennes, St. Andrew's (Royle).

Chaetomium elatum, Kze.

Norgiots (Le Lacheur).

Sordaria coprophila, Ces.

On dung, Friquet, Catel (Derrick).

Leptosphaeria acuta, Karst.

Cliffs near Gouffre and Moulin Huet Waterlane (Luff).

Sphaeria glis, Berk. \& Curr.

On Sycamore, Norgiots (Le Lacheur).

Sphaeria callicarpa, Curr.

Norgiots (Le Lacheur).

Sphaeria rubella, Pers.

Fir plantation near Jerbourg (Luff).

Sphaeria pulveracea, Ehr.

On EIm, Catioroc, near Perelle (Royle).

\section{II.-DisCOMYCETES.}

Geoglossum glabrum, Pers.

Cobo (Luff). Growing amongst the grass where wrack is spread out to dry. The fungus so closely resenibles the dried seed-vessels and stems of the seaweed that it is difficult to distinguish it. Norgiots (Le Lacheur); Ronceval (Luff). 
Geoglossum difforme, Fr.

Grais, St. Peter's (Le Lacheur).

Geoglossum hirsutum, Pers.

Norgiots (Le Lacheur). Var. amerianum, Cooke. Moulin Huet Valley (Derrick).

Otidea aurantia, Mass.

St. Martin's Churchyard (Miss Boley).

Otidea luteonitens, Mass.

In patches of moss; Icart Point (Luff).

Peziza ampliata, Pers.

In greenhouse, Bellieuse Vineries, St. Martin's (Cameron).

Peziza ochracea, Boud.

In greenhouse, Bellieuse Vineries (Cameron).

Humaria rutilans, Sac.

Petit Bot Valley, Ronceval, and garden, Burnt Lane (Luff); Mount Row (Derrick).

Humaria granulata, Sac.

Moulin Huet (Luff); Norgiots (Le Lacheur); Haute Lande, Vale (Hocart); Friquet, Hougue du Pommier, and Moulin Huet (Derrick).

Neottiella polytrichi, Mass.

Vauquiédor, St. Andrew's, and Sausmarez, Catel (Derrick).

Neottiella nivea, Sacc.

Norgiots (Le Lacheur).

Sphaerospora asperior, Sacc.

Norgiots (Le Lacheur).

Dasyscypha crucifera, Phil.

Havilland Hall (Royle).

Lachnea scutellata, Gill.

Moulin Huet (Miss Boley).

Lachnea pulcherrima, Crouan.

Not British. On dung, Lower Rohais (Derrick).

Lachnea ascoboloides, Mass.

Lancresse Common (Luff); Moulin Huet cliffs (Derrick). 
Lachnea hirta, Gill.

Near St. Martin's Church (Cameron).

Helotium herbarum, Fr.

Lancresse Common (Luff).

Helotium claroflavum, Berk.

Norgiots (Le Lacheur); Moulin Huet Waterlane (Luff).

Helotium virgultorum, Karst.

Lancresse, on old wood (Hocart).

Belonidium pruinosum, Mass.

Norgiots, St. Andrew's, on bark of Lime-tree, and on Black Currant wood (Le Lacheur).

Mollisia cinerea, Karst.

On Furze stems, Norgiots (Le Lacheur).

Mollisia atrata, Karst.

Norgiots (Le Lacheur).

Cenangium pulveraceum, Fr.

Fir plantation near Jerbourg (Luff).

Ascobolus furfuraceus, Pers.

Lower Røhais and Friquet (Derrick).

Ascobolus aeruginosus, Fr.

Bellieuse Vineries (Cameron).

Ascobolus immersus, Pers.

Petit Bot (Derrick).

Ryparobius Cookei, Boud.

Haute Lande, Vale (Hocart); Petit Bot (Derrick)

Ryparobius Crouani, Phil.

Lancresse Common (Luff).

Propolis faginea, Karst.

Talbots Valley (Luff).

Ascophanus microsporus, Phil.

Haute Lande (Hocart).

Ascophanus granuliformis, Boud.

Haute Lande (Hocart). 
Ascophanus equinus, Mass.

Haute Lande (Hocart).

Orbilia coccinella, Karst.

Norgiots (Le Lacheur).

Orbilia inflatula, Karst.

Norgiots (Le Lacheur).

Phaeangella ulicis, Mass.

Saints Bay, on a dead furze stem (Mrs. Boley).

Ascomyces aureus, Magn.

Rare in Britain. Bon Air, on Poplar leaves (Miss Boley).

Zasmidium cellare, Fr.

The cellar fungus. Wine-cellar, Pollet, and wine stores, Truchot (Royle); cellar, Hospital Lane (Collenette).

Hysterium pulicare, Pers.

Fermain Bay (Luff).

Rhopographus filicinus, Fckl.

Fir plantion near Jerbourg (Luff).

Hysterographium fraxini, Denot.

Petit Bot (Luff).

Hypoderma virgultorum, DC.

Saints Bay (Luff).

\section{III.-Phycomycetes.}

Pilobolus crystallinus, Tode.

Haute Lande, Vale (Hocart).

Pilobolus longipes, Van Tieg.

A rare species in Britain. On dung, Lower Rohais and Petit Bot (Derrick).

Pilobolus roridus, Fr.

Hougue du Pommier (Derrick).

Mucor delicatulus, Berk.

Indiana, St. Martin's, on rotten apples (Miss Boley).

Rhizopus nigricans, Ehr.

Moulin Huet (Mrs. Boley). 
Syzygites megalocarpus, Ehr.

In a flower-pot in a shed, Valnord Road (Derrick); on decaying Boletus, Oberland, St. Andrew's (Le Lacheur).

Cystopus cubicus, Grev.

Mielles, Vale (Hocart).

Cystopus candidus, Lev.

Saints Bay (Miss Boley); Moulin Huet (Mrs. Boley).

Phytophthora infestans, De By.

The cause of the destructive scourge known as the potato disease. Only too common.

Pythium Baryanum, Hesse.

Causes the so-called 'damping off' of seedling plants. Very common.

Empusa muscae, Cohn.

On dead house-flies in autumn. Common.

\section{HYPHOMYCETES.}

Oospora microsperma, Sacc.

Garden, Burnt Lane (Luff); Bellieuse Vineries (Cameron).

Oidium Chrysanthemi, Rab.

On Chrysanthemum leaves in a greenhouse at l'Islet (Collenette).

Monilia fructigena, Pers.

A very destructive parasite causing the disease called 'bitter rot' on apples and pears. Norgiots (Le Lacheur).

Fusidium viride, Grove.

Varclin Lane (Miss Boley).

Trichoderma lignorum, Harz.

Norgiots (Le Lacheur).

Aspergillus glaucus, Link.

Very common on all kinds of decaying vegetable matter.

Penicillium glaucum, Link.

Indiana, St. Martin's, on melon-rind and on grapes (Mrs. Boley); Sausmarez Lodge and Valnord Road, on fungi (Derrick); Burnt Lane, on cheese (Luff).

Rhinotrichum repens, Reuss.

Talbots Valley (Luff). 
Sporotrichum sulphureum, Grev.

Rare in Britain. On the skin of a mummified cat found under the floor of an old house in the town (Luff).

Botrytis cinerea, Pers.

Indiana, St. Martin's (Miss Boley); Norgiots (Le Lacheur).

Botrytis vulgaris, Fr.

Coast near Pulias (Luff).

Ovularia obliqua, Oudem.

On Dock leaves, Fermain Lane (Mrs. Marquand).

Sepedonium chrysospermum, Fr.

Said to be the conidial form of Hypomyces chrysospermum. Garden, Norgiots, on immature Boleti, attacking them before they appear above the ground (Le Lacheur).

Ramularia pruinosa, Speg.

Gardens by the Bathing Places (Derrick); Moulin Huet, on Gunnera (Mrs. Marquand).

Verticillium lateritium, Berk.

Vauxbelets and Norgiots (Le Lacheur).

Verticillium Marquandii, Mass.

Parasitic on living specimens of Hysrophonus virgineus, forming bright lilac-purple patches on the gills and stem. Norgiots (Le Lacheur); Grandes Rocques, Perelle, and Moulin Huet (Luff); Fermain Hill (Miss Boley); Ivy Castle (Derrick); St. Saviour's (Chutter). A very beautiful mould, apparently confined to $H$. virgineus, as no trace of it has been detected on any other species. Very conspicuous on account of its deep lilac or amethyst colour. Described by Mr. Massee in the Transactions of the British Mycological Society for 1897 , the description copied in my second paper on the Fungi of Guernsey (Trans. Guernsey Soc. Nat. Sc., I898, p. 278).

Acrostalagmus cinnabarinus, Corda.

Norgiots (Le Lacheur).

Trichothecium roseum, Link.

On melon and tomato-plants in greenhouses at Fauxconnaires (Collenette); garden, Indiana (Mrrs. Boley); Norgiots (Le Lacheur).

Mycogone rosea, Link.

Isabel Road (Collenette).

Coniosporium olivaceum, Link.

Norgiots (Le Lacheur). 
Torula pulveracea, Corda.

Norgiots (Le Lacheur).

Torula antennata, Pers.

Norgiots (Le Lacheur).

Torula herbarum, Link.

Moulin Huet (Miss Boley); Norgiots (Le Lacheur); Pulias (Luff); Les Terres and Fort George (Derrick).

Torula asperula, Sac.

Not British. Fermain Bay (Luff).

Tetraploa aristata, B. \& Br.

Haute Lande, Vale (Hocart).

Polythrincium Trifolii, Kze. \& Schm.

Moulin Huet, on Clover (Miss Boley); Richmond, on Vetch (Luff).

Cladosporium epiphyllum, Mart.

Couture (Royle); Saints Bay (Luff).

Cladosporium fulvum, Cooke.

On Tomato plants, causing the 'sleepy disease.' Common.

Helminthosporium macrocarpum, Grev.

Saints Bay, on a dead furze stem (Mrs. Boley).

Helminthosporium Smithii, B. \& Br.

Lancresse Common (Luff); Norgiots (Le Lacheur).

Helminthosporium scolecoides, Cord.

On holly, Norgiots (Le Lacheur).

Heterosporium epimyces, C. \& M

Parasitic on various Agarics. Grandes Rocques (Miss Boley);

Perelle Bay, Grand Havre, Fort Doyle, Ivy Castle, and Moulin Huet (Luff).

Heterosporium echinatum, Cooke.

Ivy Castle (Luff).

Macrosporium tomato, Cooke.

A serious tomato disease; forms dark patches on the ripening fruit. Common.

Macrosporium heteronemum, Sacc

On leaves of Fragrant Butterbur, Varclin, St. Martin's (Mrs. Marquand). 
Fumago vagans, Pers.

Fauxconnaires (Collenette); forming sooty patches on the fruit and leaves of melons. Moulin Huet, on Willow leaves (Miss Boley); Foulon, on Lime leaves (Derrick).

Isaria felina, Fr.

Norgiots (Le Lacheur).

Stilbum erythrocephalum, Ditm.

Petit Bot cliffs (Luff).

Ceratium hydnoides, A. \& S.

Rare in Britain Norgiots, on old wood (Le Lacheur).

Tubercularia herbarum, Fr.

Indiana, St. Martin's (Miss Boley); Lancresse Common (Luff).

Aegerita candida, Pers.

Church Lane, St. Martin's (Miss Boley).

Volutella vitis, Sac.

Not British. Norgiots (Le Lacheur).

Fusarium heterosporum, Nees.

Havilland Hall (Royle).

Fusarium solani, Sac.

Norgiots, on a potato (Le Lacheur).

Fusarium epimyces, Cooke.

Bailiff's Cross, growing on Hysterangium nephriticum (Derrick).

Fusarium argillaceum, Sac.

Not British. Norgiots, on red Beet (Le Lacheur).

Fusarium lateritium, Nees.

On a broccoli stump, Norgiots (Le Lacheur).

SPHAEROPSIDEAE.

Actinonema Rosae, Lib.

Garden, Indiana, St. Martin's (Miss Boley). An injurious parasite on rose-leaves.

Phoma nebulosa, Berk.

Moulin Huet (Miss Boley); Talbots Valley (Luff).

Phoma ampelina, De By.

The cause of the grape disease known as 'shank.' Very common. 
Cytospora nivea, Fckl.

On a bramble stem, Catioroc, near Perelle (Royle).

Darluca filum, Fr.

Near Catel Church (Collenette).

Septoria Hederae, Desm.

Catioroc, near Perelle (Royle).

Septoria Virgaureae, Desm.

On Chrysanthemum leaves in a greenhouse at l'Islet (Collenette).

Phyllosticta hedericola, Dur. \& Mont.

Not British. On Ivy leaves. Moulin Huet (Mrs. Boley); Church Lane, Lower Hubits, and several other places at St. Martin's (Miss Boley).

Ceuthospora Lauri, Grev.

Fermain Bay, on Holly leaves (Luff).

Vermicularia dematium, Fr.

Norgiots (Le Lacheur).

\section{HYPODERMII.}

Uromyces Trifolii, Lev.

Near Perelle Bay and Rabbit Warren, on living Clover leaves (Luff); Lower Rohais, on Medick (Derrick). The uredo stage.

(Uromyces Polygoni, Wint. and U. concentrica, Lev. occur in Alderney.)

Uromyces Pisi, Wint.

Garden, rue Poudreuse, on leaves of edible Pea (Miss Dawber). The uredo-spore and teleuto-spore stages both present.

\section{Uromyces Fabae, Cke.} Boley).

On leaves of broad Beans, garden, Indiana, St. Martin's (Miss

Uromyces Poae, Rab.

Petit Bot (Luff).

Uromyces Betae, Wint.

On Beetroot leaves, Lower Rohais (Derrick).

Uromyces Rumicis, Wint.

Thielles, St. Peter's, on Dock leaves (Derrick). 
Puccinia Primulae, DC.

Talbots Road, on Primrose leaves (Luff).

Puccinia Graminis, Pers.

Rocques Barrées, Vale, the uredo stage on Oat leaves (Derrick)

Saints Bay, the aecidium stage on Pilewort leaves (Luff).

(Puccinia Violae, Wint. occurs in Alderney.)

Puccinia coronata, Corda.

An injurious parasite to cereals, as is also P. graminis. Garden, Hauteville, on Rye grass (Collenette); Caudré, St. Peter's (I.uff).

Puccinia obscura, Schrot.

Rare in Britain. The aecidial stage, formerly called Aecidium Bellidis, on Daisy leaves. Lancresse Common, Rocques Barrées, and Damouettes Lanes (Derrick); Talbots Road and Vale Castle Hill (Luff); Norgiots (Le Lacheur).

(Puccinia Menthae, Pers. and P. suaveolens, Wint. occur in Alderney.)

Puccinia Hieracii, Mart.

On Hypochoeris leaves. Thielles, St. Peter's (Derrick); Rabbit Warren (Luff).

Puccinia Polygoni, Pers.

Near the coast at Richmond, on leaves of Polygonum (Luff).

Puccinia Smyrnii, Corda.

On leaves of Alexanders; the aecidium stage. Delancey Hill, Fort George, and Damouettes Lanes (Derrick).

Puccinia Umbilici, Guep.

On Navelwort leaves. Moulin Huet (Mrs. Boley); Valnord (Collenette); near Catel Hospital (Derrick); Saints Bay (Luff).

Puccinia malvacearum, Mont.

Causes the 'Hollyhock disease.' St. Martin's, on Hollyhock leaves (Miss Boley); Upper and Lower Catel and Delancey Hill, on Mallow; Fort George, on Tree Mallow (Derrick); Perelle Bay (Mrs. Marquand); Mielles (Hocart); Richmond (Royle); Moulin Huet (Luff).

Puccinia lychnidearum, Link.

On Red Campion leaves, Fermain Lane (Mrs. Marquand).

Puccinia Aegopodii, Wint.

Near Fort George (Luff).

Puccinia prenanthis, Fckl.

Petit Bot (Luff). 
Phragmidium violaceum, Schultz.

Very local in Britain. On Bramble leaves. St. George (Derrick); Ramée (Royle); Vale Castle Hill, Rabbit Warren, Talbots Valley, and Petit Bot cliffs (Luff).

Phragmidium Rubi, Schrot.

On Bramble leaves. Thielles, St. Peter's (Derrick); Saints Bay (Miss Boley); Havilland Hall (Royle).

Phragmidium gracile, Berk.

On Raspberry leaves. Indiana, St. Martin's (Miss Boley); aecidiospore, uredospore, and teleutospore stages all present on the leaf at same time. Rue Poudreuse (Miss Dawber).

Phragmidium Fragariae, Wint.

On leaves of Barren Strawberry, Petit Bot (Luff).

Melampsora farinosa, Schrot.

Talbots Road, on the under side of living IVillow leaves (Luff).

Melampsora Helioscopiae, Pers.

Rue Poudreuse, on Sun Spurge (Miss Dawber).

Coleosporium Senecionis, Wint,

On Groundsel. St. George (Derrick); Indiana (Miss Boley); Rabbit Warren (Luff).

Coleosporium Sonchi, Schrot.

L'Erée, on Sow-thistle leaves, and Moulin Huet, on Fragrant Butterbur (Derrick).

(Coleosporium Euphrasiae, Wint. occurs in Alderney.)

Ustilago Avenae, Pers.

Gouffre, on ears of Oats (Miss Boley).

Ustilago violacea, Pers.

On the anthers of Sea Campion in many places on the coast (Marquand); on Bladder Campion, Grand Havre (Luff).

Ustilago longissima, Tul.

On Reed leaves, Grande Mare (Luff).

Ustilago Salweii, B. \& Br.

On Meadow Soft Grass (Holcus mollis). The type specimen of this fungus is in the Kew Herbarium; and the label shows that it was collected at St. Martin's, Guernsey, by the Rev. Thomas Salwey as far back as the year 1847. It does not appear to have been found since. 


\section{MYXOGASTRES.}

Dictydium cernuum, Nees.

Rare in Britain. Norgiots (Le Lacheur).

Stemonitis typhina, Mass.

Norgiots (Le Lacheur).

Reticularia Lycoperdon, Rost.

Sous l'Eglise, St. Saviour's (Le Lacheur); cliffs at Pleinmont Point (Luff).

Lycogala epidendrum, Rost.

On an old door-post, Vale (Luff); Norgiots (Le Lacheur).

Arcyria punicea, Rost.

Norgiots (Le Lacheur).

Trichia varia, Rost.

Norgiots (Le Lacheur).

Didymium farinaceum Schrad.

Garden, Indiana, St. Martin's, parasitic on Irpex pendulus (Miss Boley).

Didymium clavus, Rost.

Lane leading down to Divette Bay, St. Martin's (Mrs. Boley).

Spumaria alba, DC.

Norgiots (Le Lacheur); Grandes Rocques (Luff).

Diachaea quercina, Fr.

On Elm bark, Norgiots (Le Lacheur).

Craterium confusum, Mass.

Galliennes, St. Andrew's (Royle).

Tilmådoche nutans, Rost.

Norgiots (Le Lacheur). 


\section{LICHENS.}

NineteEN lichens are included in Gosselin's list of Guernsey plants, dated 1788 , and the quaint old names are interesting, all the species being included in one comprehensive genus, Lichen. They are as follows:-Lichen verrucosus parietinus, stellaris, perlatus, nigrescens, farinascens, calicaris, fraxineus, prunastri, caninus, pyxidatus, fimbriatus, rangiferinus, furcatus, fuciformis, roccella, crocatus, corniculatus, and tinctorus. Fifty years later a catalogue of about I 40 Guernsey lichens, prepared by Mr. F. C. Lukis, the well-known local antiquary and naturalist, was given as an appendix to Babington's Flora Sarnica. The great bulk of these species are known to occur in the island at the present time, but there are some which cannot be admitted as natives without further evidence; and as the list includes, without comment, such lichens as Cetraria nivalis and Parmelia stygia, it should only be accepted as furnishing the earliest published record of species which have been subsequently confirmed.

In Ansted's Channel Islands, second edition (1865), p. I87, we have a carefully prepared and reliable list drawn up by a lady who had devoted much study to the lichens, Mrs. Collings, the wife of the then Seigneur of Sark. About I 50 species are enumerated, besides many named varieties, the nomenclature of Mudd's Manual of British Lichens being followed throughout. Further records are found in Leighton's Lichen Flora of Great Britain, Ireland, and the Channel Islands, third edition (1879), where nearly r8o species are noted for Guernsey, chiefly on the authority of two distinguished lichenologists, the Rev. Thomas Salwey, of Oswestry, who died in I 878 , and Mr. Charles Larbalestier, of Jersey.

None of these lists furnish any information as to the comparative frequency or rarity of the different species: and it was with the object of supplying this deficiency that I contributed to the Transactions of the Guernsey Society of Natural Science for 1892 a paper summarising my own work at the lichens, and recording 243 species with localities and notes on distribution. Some further additions are taken from the records given in Crombie's Monograph of British Lichens (1894), only one volume of which has yet been published. Specimens of these are in the herbarium of the British Museum.

In the following pages the names and arrangement accord with Leighton's Lichen Flora, and I am responsible for all particulars of distribution and locality, except where otherwise stated. The number of lichens now recorded for Guernsey amounts to 309 species, without counting named varieties and forms. 


\section{COLLEMACEI.}

Lichina pygmaea, Light.

On many parts of the coast, but less common than the next species. In spite of its name it is the larger plant of the two.

Lichina confinis, Ach.

On rocks at high-water mark all round the coast.

Collema pulposum, Bernh.

Descent to Saints Bay. Base of Doyle's Monument. Wall at Beaucamps, Catel.

Collema ceranoides, Borr.

In sandy hollows at Albecq. Guernsey (Salwey).

Collema limosum, Ach.

Guernsey (Mrs. Collings).

Collema crispum, Huds.

Guernsey (Salwey). Var. cristatulum, Nyl., occurs in Herm.

Collema cheileum, Ach.

Frequent on old walls, but most often barren.

Collema flaccidum, Ach.

Saints Bay, on rocks.

Collema nigrescens, Huds.

On old roadside trees. Moulin Huet Valley. Road to Icart. Calais Valley. Near St. Saviour's Church.

(Leptogium biatorinum, Nyl, occurs in Alderney, and Lept. humosum, Nyl., in Sark. According to Crombie, the latter 'has externally the appearance of Lecidea uliginosa.')

Leptogium pusillum, Nyl.

St. Peter's Port (Crombie).

Leptogium lacerum, Ach.

Cliffs between Fermain and Bec du Nez. Petit Bot Cliffs. The var. pulvinatum, Hffm., occurs in Herm.

Leptogium subtile, Schrad.

Guernsey (Salwey).

Leptogium plicatile, Ach.

Rocquaine Castle. Near Grantez Mill.

Leptogium palmatum, Huds.

Guernsey (Mrs. Collings). 
Leptogium tremelloides, L.

On mossy rocks in Moulin Huet Valley.

Leptogium Schraderi, Bernh.

Moulin Huet (Crombie).

Leptogium muscicolum, Sw.

Guernsey (Salwey).

(Myriangium Duriaei, Mnt. and Berk., was found in Sark more than fifty years ago. In Cornwall I have many times gathered this curious lichen, but never met with it in this island. It should be looked for on the branches of young ash-trees.)

\section{LICHENACEI.}

\section{I.-EpiconiodeI.}

Sphinctrina turbinata, Pers.

Guernsey (Crombie).

(Sphinctrina Kylemoriensis, Cromb. (Calicium, Leight), a very rare species parasitical on the thallus of Lecanora nitens, occurs in Sark.)

Calicium curtum, Borr.

Guernsey (Crombie).

Sphaerophoron compressum, Ach.

Guernsey (Salwey). Also noted by Crombie.

Sphaerophoron coralloides, Pers.

Rare in this island. Jerbourg Head. Corbiere

$$
\text { II.-Cladodei. }
$$

Baeomyces rufus, DC.

Here and there on earthy banks on St. Martin's cliffs.

Baeomyces icmadophilus, Ehrh.

Guernsey (Mrs. Collings).

Cladonia endiviaefolia, Fr.

Western side of Lancresse Common.

Cladonia pungens, Flk.

Guernsey (Mrs. Collings). 
Cladonia cervicornis, Schaer.

On the cliffs at Petit Bot. Pleinmont (Crombie).

Cladonia delicata, Flk. Var. subsquamosa, Nyl.

Guernsey (Mrs. Collings).

Cladonia alcicornis, Flk.

Jerbourg, Icart Point, and Lancresse Bay (Crombie).

Cladonia firma, Nyl.

Jerbourg (Crombie)

Cladonia pyxidata, Fr.

Common and extremely variable. Var. pocillum, Fr. The Vale (Crombie). Var. chlorophaea, Flk. Guernsey (Crombie).

Cladonia fimbriata, Hffm.

Guernsey (Mrs. Collings).

Cladonia caespititia, Flk.

Guernsey (Crombie).

Cladonia gracilis, Hffm.

Guernsey (Crombie). Var, chordalis, Ach. Guernsey (Rev.

T. Salwey).

Cladonia degenerans, Flk.

Guernsey (Mrs. Collings).

Cladonia furcata, Hffm

Guernsey (Salwey). Var. recurva, Hffm. Guemsey (Mrs. Collings).

Cladonia squamosa, Hffm.

Cliffs near Fermain Bay.

Cladonia cornucopioides, Fr.

On the cliffs at Fermain and Jerbourg. Gouffe (Crombie).

Cladonia deformis, Hffm.

Guernsey (Mrs. Collings).

Cladonia digitata, Hffm. Var. macilenta, Hffm.

Guernsey (Mrs. Collings).

Cladonia rangiferina, Hffm.

Common in dry heathy places.

Cladonia uncialis, Hffm.

Guernsey (Mrs. Collings).

f. turgescens, Fr. 
Stereocaulon condensatum, Hffm.

Torteval, Guernsey (Larbalestier).

Stereocaulon nanum, Ach.

On the earth in crumbly banks and fissures of rocks: not uncommon.

\section{III.-Ramalodet.}

Roccella tinctoria, DC.

Both Mudd (Man. Brit. Lich.) and Leighton (Brit. Lich. Fl.) record this species as having been found in Guernsey by Mr. G. Gosselin; but Crombie (Mon. Brit. Lich.) says Roccella tinctoria does not extend so far north as the British Isles.

Roccella phycopsis, Ach.

Frequent on the southern cliffs, and about Lerée and Rocquaine. Occasionally fuund on walls in the north of the island.

Roccella fuciformis, Ach.

On rocks all round the coast: more plentiful than the last species. At Petit Port I have gathered a specimen fourteen inches long, the finest I ever saw.

Usnea barbata, L.

Rare. On trees at Les Bordages, St. Saviour's. On rocks at Jerbourg and St. Martin's Point. Var. plicata, L. On mossy rocks below Doyle's Monument, sparingly. Var. florida, L. and var. hirta, L. Guernsey (Crombie).

Evernia furfuracea, Mann.

Guernsey (Mrs. Collings).

Evernia prunastri, L.

Rare. Les Prevosts, St. Saviour's, and Moulin de Haut, Catel, on Apple-trees. Var. stictocera, Ach. Guernsey (Mrs. Collings).

Ramalina calicaris, Hffm.

On trees above Le Jaonnet, St. Martin's.

Ramalina farinacea, L.

Frequent on trees and bushes.

Ramalina fraxinea, L.

On old thorns, Jerbourg.

Ramalina fastigiata, Pers.

Rather common, especially on old thorns: occasionally on boulders. 
Ramalina polymorpha, Ach. f. depressa, Cromb.

Guernsey (Salwey). Coast of Guernsey (Crombie). f. gracilescens, Cromb. occurs in Sark.

Ramalina pollinaria, Ach.

Rather common on trees in many parts of the island: occasionally on rocks and stones.

(Ramalina evernioides, Nyl, occurs in Sark.)

Ramalina scopulorum, Dicks.

Common all round the coast, but extremely variable in form: sometimes very large and fine. Var. incrassata, Nyl. Frequent on rocks on the cliffs.

\section{Ramalina subfarinacea, Nyl.}

Jerbourg Head. This species closely resembles $R$. farinacea, but is readily distinguished by the medulla turning red on the application of hydrate of potash.

Ramalina cuspidata, Ach.

Common on rocks on the coast, growing in company with $R$. scopulorum, which it much resembles; but the different chemical reaction at once separates them. Var. crassa, Del. Frequent in the north and north-west. f. minor, Nyl. The Vale, Guernsey (Crombie).

(Ramalina intermedia, Del. occurs in Sark.)

Ramalina Curnowii, Cromb.

On rocks on the coast: rare. Cliffs at Jerbourg and Petit Port. Rocks near Fort Houmet.

Cetraria aculeata, Fr.

Guernsey (Mrs. Collings).

Platysma saepincola, Ehrh.

Guernsey (Salwey)

Platysma diffusum, Web.

Guernsey (Mrs. Collings).

\section{IV.-Phyllodei.}

Nephromium laevigatum, Ach.

Leighton records this species on Larbalestier's authority as being 'common on all the islands,' but I suspect there has been some confusion of names, as $N$. lusitanicum is not reported for the Channel Islands at all. Both species were well known to me in 
Cornwall twenty years ago, but I have searched in vain for $N$. laevigatum, both in Guernsey and in Alderney.

Nephromium lusitanicum, Schaer.

Frequent in the south of the island on rocks and hedgestones. Guernsey (Crombie).

Peltigera canina, L.

Generally distributed, but not common, and usually in poor condition.

Peltigera rufescens, Hffm.

Guernsey (Crombie).

Peltigera spuria, Ach.

In several places at St. Martin's, and near St. Peter's Rectory.

Peltigera polydactyla, Hffm.

On the cliffs here and there between Fermain Bay and St. Martin's Point. Petit Bot Valley.

Peltigera scutata, Dicks.

Guernsey (Mrs. Collings).

Stictina limbata, Sm.

In several places on St. Martin's cliffs, but always sparingly. Very fine on mossy rocks below Doyle's Monument.

Stictina fuliginosa, Dicks.

Frequent on rocks between Fermain and $\mathrm{Bec}$ du Nez; also at Jerbourg.

Stictina scrobiculata, Scop

Rare. On mossy rocks south of Fermain Bay, very fine. Jerbourg (Crombie).

Sticta pulmonaria, Ach.

Rare On old trees in the road opposite Sausmarez, St Martin's: rather poor, and in small quantity.

Sticta aurata, Ach.

Jerbourg: Mrs. Collings and Mr. Lukis (Leighton). Also noted by Crombie for the same locality.

Ricasolia amplissima, Scop.

Jerbourg (Salwey). Also noted by Crombie.

Ricasolia laetevirens, Lightf.

On rocks between Fermain and St. Martin's Point. Sparingly on the cliffs near Saints Bay. 
Parmelia caperata, L.

Common on trees, rocks, and boulders.

Parmelia olivacea, L.

Frequent on rocks all round the coast.

Parmelia physodes, L.

Rare. On rocks, Jerbourg. Var. labrosa, Ach. Guernsey (Crombie).

Parmelia reddenda, Stirt.

On tree trunks: generally distributed. It is quite impossible to distinguish this lichen from $P$. Borreri by external characters; but, if the white medulla be wetted with hypochlorite of lime, it will turn red in $P$. Borreri, and will remain unchanged in the present species.

Parmelia perlata, L.

Common on rocks and trees throughout the island.

Parmelia ciliata, Nyl.

On the cliffs at Fermain. f. dissectula, Nyl. On rocks at the Corbiere.

Parmelia tiliacea, Ach.

Guernsey (Salwey).

Parmelia scortea, Ach.

Jerbourg, on rocks.

Parmelia carporhizans, Cromb.

Near Jerbourg (Crombie).

Parmelia Borreri, Turn.

Less common than $P$. reddenda. On rocks at Jerbourg. On trees, Effards, Catel.

Parmelia fuliginosa, Dub.

Rather common on seaside rocks all round the coast.

Parmelia perforata, Wulf.

Occasionally on trees and stones in all parts of the island.

Parmelia conspersa, Ehrh.

Common on rocks near the sea; also on hedgestones inland. f. stenophylla, Ach. On the southern cliffs. f. isidiata, Anzi. Mont Cuet. Jerbourg.

Parmelia sinuosa, Sm.

Guernsey (Crombie). 
Parmelia saxatilis, L.

Common on rocks and tree-trunks. Var. furfuracea, Schaer. Guernsey (Mrs. Collings).

Parmelia sulcata, Tayl.

Guernsey (Salwey).

Parmelia omphalodes, Ach.

Common on the cliffs and on the coast of the lowlands.

Parmelia laevigata, Sm.

Generally distributed and not uncommon. Var. rugosa, Tayl. Guernsey (Salwey).

Parmelia Delisei, Dub.

On rocks near Petit Bot. Near Fort Le Marchant. Near Les Camps, Catel. (Var. isidiascens, Nyl., occurs in Sark.)

Physcia flavicans, Sw.

Rare: always on rocks, never on trees in these islands. Thinly scattered all along the southern cliffs from Jerbourg to Pleinmont.

Physcia chrysophthalma, L.

Guernsey (Crombie).

Physcia parietina, L.

Very common. Var. cinerascens, Leight. Near Lerée. Near the Hermitage, Lancresse. Les Capelles. Var. ectanea, Nyl. Guernsey (Crombiel. I have found a terricolous form on a bank at Plaisance, St. Peter's.

Physcia ciliaris, L.

Rare. On an old roadside tree at Saumarez, St. Martin's; and on another on the road to Doyle's Monument.

Physcia pulverulenta, Schreb.

Vauxbelets Valley, on elms. On trees near Les Mourants, Catel.

On a wall towards Rousse Martello Tower. f. deminuta, Cromb. Guernsey (Crombie').

Physcia pityrea, Nyl.

Guernsey (Crombie).

Physcia obscura, Ehrh.

On trees near Les Videclins, Catel; and in the valley at Calais, St. Martin's. Var. ulothrix, Ach. Guernsey (Salwey).

Physcia adglutinata, Flk. f. sorediata, Nyl.

Between Lès Blanches and Doyle's Monument. 
Physcia leucomela, L.

Jerbourg, and the south-western point of Rocquaine Bay; Mr. Lukis (Leighton).

Physcia speciosa, Wulf. Castle.

Frequent on St. Martin's cliffs and near Petit Bot. Rocquaine

Physcia erosa, Borr.

Not uncommon on trees, rocks, and walls in many parts.

Physcia astroidea, Clem.

On a tree at Les Falaises, St. Martin's. In fructification on young trees in the Fontenelle Valley, St. Peter's.

Physcia stellaris, L.

Frequent in all parts. Var. leptalea, Ach. On trees above $\mathrm{Bec} \mathrm{du} \mathrm{Nez}$, and in several places at the Forest.

Physcia tenella, Nyl.

Frequent on trees, rocks, and stones.

Physcia caesia, Nyl.

On rocks. Jerbourg. Lancresse Common. Les Camps, Catel.

Physcia aquila, Ach.

Common on the cliffs, and on rocks and stone hedges all round the coast.

\section{Umbilicaria pustulata, Hffm.}

Rare On the cliffs between Jaonnet and Petit Bot.

Psoroma hypnorum, Vahl.

Guernsey (Crombie).

Pannaria rubiginosa, Thunb.

Jerbourg (Larbalestier). Guernsey (Crombie). Var. caeruleobadia, Schleich. Guernsey (Crombie).

Pannaria pezizoides, Web.

Guernsey (Salwey).

Pannaria coronata, Ach.

At Plaisance, and near Le Graie, St. Peter's. Bordages, St. Saviour's.

Pannaria microphylla, Sw.

Jerbourg (Larbalestier).

Pannaria nebulosa, Hffm.

Guernsey (Crombie). 
Pannaria plumbea, Lightf.

Guernsey (Salwey). Mr. Larbalestier says this species is 'very rare in the Channel Islands.'

Pannaria nigra, Huds.

On old wall tops. Les Fauxquets and Les Camps, Catel.

Pannaria psotina, Ach.

On a wall in the Vale Road. Crombie notes this species from the Vale, Guernsey.

Amphiloma lanuginosum, Ach.

In several places between Fermain Bay and St. Martin's Point, on shaded mossy rocks.

Squamaria crassa, Huds.

Guernsey (Salwey).

Squamaria cartilaginea, West.

Guernsey (Mrs. Collings).

Squamaria saxicola, Poll.

Plentiful on the eastern side of the Vale Castle.

\section{V.-PlacodeI.}

Placodium murorum, Hffm.

Frequent on old walls and on rocks.

Placodium lobulata, Smrft.

Rather common on the shore of the lowlands.

Placodium miniatum, Hffm.

Fort Doyle Richmond, f. obliteratum, Pers. Divette Cove.

Placodium callopismum, Ach.

On a ruined brick wall near the rifle-butts at Houmet, scarce. Var. plicatum, Wedd. Vale Castle (Crombie).

Placodium citrinum, Ach.

Frequent throughout the island on old walls and posts, and on the earth at the base of hedgebanks. (f. depauperata, Cromb., occurs in Alderney.)

Placodium fulgens, Sw.

Grandes Rocques (Larbalestier). North side of Guernsey; Miss Lukis (Leighton). I have found this species in Alderney.

Placodium candicans, Dicks.

Guernsey (Mrs. Collings). 
Lecanora vitellina, Ach.

Common on rocks and stones. Var. coruscans, Ach. On a roadside wall at Calais, and on an old gate near St. Martin's Church. (Var. aurella, Ach., occurs in Sark.)

Lecanora candelaria, Ach.

On an old apple-tree in my garden at Fermain House. On rocks at Mont Cuet. Vale Castle, on stone (Iarbalestier's Lich. Rar., No. 95, in my copy).

Lecanora glaucocarpa, Whlnb. f. eucarpa, Nyl.

Cobo (Larbalestier). IVest Coast of Guernsey (Crombie).

Lecanora squamulosa, Schrad.

Vale Castle Hill. Albecq. Near Fort Le Marchant. f. sinopica, Whlnb. Guernsey (Larbalestier).

Lecanora smaragdula, Nyl.

Guernsey (Crombie).

(Lecanora privigna, Nyl. occurs in Alderney, and L. simplex, Nyl. in Sark.)

Lecanora fuscata, Schrad.

On a wall near Les Vauxbelets, St. Andrew's.

Lecanora cinerea, L.

Vale Castle Hill. Cliff wall at Icart. Jaonnet cliffs.

Lecanora tartarea, L.

Grandes Rocques Head. Near Fort Houmet. Jerbourg.

Lecanora varia, Ehrh.

On wooden gates and gateposts. Les Naftiaux. Corbiere. Rocquaine Bay.

Lecanora atra, Huds.

Common on rocks and boulders : rarely on trees. Les Vinaires, St. Peter's, on trees.

Lecanora circinata, Pers.

Guernsey (Salwey; Crombie).

Lecanora frustulosa, Dicks.

Guernsey (Mrs. Collings).

Lecanora polytropa, Ehrh.

Frequent on rocks on the cliffs and on the lowland coast. 
Lecanora sulphurea, Hffm.

Common on the coast and occasionally inland. Easily known by its peculiar dull yellow-green colour.

Lecanora symmicta, Ach.

On an old shed near Fort Le Marchant.

Lecanora expallens, Ach.

On old wooden gateposts. Grande Mare. Jerbourg. Les Falaises, St. Martin's.

Lecanora chlorophaeodes, Nyl.

Vale Castle (Larbalestier, Lich. Rariss., No. I 8 in my copy). This is the only British station given by Crombie for this lichen, and he remarks that it was "erroneously recorded by Leighton from the north-west of Ireland.'

Lecanora subfusca, L.

Very common throughout the island. f. allophana, Ach. and f. chlarona, Ach. on trees at Les Naftiaux. f. argentata, Leight. The Vale (Crombie). f. gangalea, Ach. Bordeaux Harbour (Mrs. Collings).

Lecanora coilocarpa, Nyl.

Frequent on the cliffs.

Lecanora galactina, Ach.

On stones in hedges, and on the earth in crumbly, gravelly banks: not uncommon in all parts of the island.

Lecanora prosechoides, Nyl.

On rocks on the shore. Moulin Huet. Richmond. Lerée Point. Grandes Rocques.

Lecanora zosterae, Nyl.

Moulin Huet Bay (Crombie).

Lecanora Hageni, Ach.

On gateposts near Paradis, Vale, and at Frie Baton, St. Saviour's.

Lecanora gibbosa, Ach.

Not uncommon on the cliffs. Mont Cuet.

Lecanora badia, Ach.

Guernsey (Larbalestier).

(Lecanora nitens, Ach., a species intimately related to L. badia, occurs in Sark.)

Lecanora poliophaea, Whln.

Grandes Rocques Head, scarce. Icart cliffs. 
(Lecanora torquata, Fr. occurs in Alderney. According to Leighton it is doubtfully distinguishable from Lecitea rivulosa, but Crombie regards it as a true and distinct Lecanora.)

Lecanora parella, L.

Very common on trees, rocks, and stones. Var. pallescens, L. Mourants, Catel. Mrs. Collings records the forms tumidula, Pers. and Turneri, Sm.

Lecanora rupestris, Scop.

Guernsey (Mrs. Collings).

Lecanora glaucoma, Hffm.

Common on rocks and hedgestones throughout the island. (f. decussata, Cromb. occurs in Sark.)

(Lecanora subcarnea, Ach, occurs in Alderney.)

Lecanora albella, Pers.

Bec du Nez cliffs, on a willow. Fermain Valley, on an old ash-tree.

Lecanora aurantiaca, Lightf.

Mont Cuet, Vale, on a stone in a hedge.

Lecanora ferruginea, Huds.

Common on rocks and hedgestones. f. saxicola, Ach. Petit Port. f. festiva, Ach. Frequent on the south coast.

(Lecanora caesiorufa, Nyl. occurs in Sark. Crombie describes it as ' well separated from $L$. ferruginea, with which until recently it has usually been confounded.')

Lecanora cerina, Ehrh.

Rather common throughout the island on elder-trees; less frequent on other trees, and on old ivy stems.

Lecanora pyracea, Ach.

Mont Saint, on hedgestones.

Lecanora ulmicola, DC.

On old elms : Les Buttes, St. Saviour's, and near Mont Saint.

Lecanora arenaria, Pers.

Guernsey (Mrs. Collings).

Lecanora epixantha, Ach.

Vale Castle (Larbalestier's Lich. Rariss., No. $9^{2}$ in my copy).

Lecanora phlogina, Ach.

Etiennerie, Catel, on a gate bar. 
Lecanora sophodes, Ach.

Frequent in all parts on elm-trees. On stones at Icart.

Lecanora exigua, Nyl.

The Vale (Crombie).

(Lecanora roboris, Nyl, occurs in Sark.)

Lecanora milvina, Whlnb.

Vale Castle (Larbalestier).

Lecanora atrocinerea, Dicks.

Fermain. Jerbourg. Icart cliffs.

(Lecanora coniopta, Nyl. occurs in Alderney.)

Lecanora Hutchinsiae, Nyl.

Moulin Huet Bay (Crombie).

Lecanora holophaea, Mnt.

In crevices of rocks. In several places on St. Martin's cliffs. Albecq, and coast near Fort Houmet. Var. glaucopsora, Nyl. Saints Bay (Larbalestier).

Lecanora erysibe, Ach.

Rocquaine Castle. Fort Houmet. Mount Saint. Richmond. f. sarniense, Larbal. Ruins of Vale Castle (Larbalestier, Lich. Rariss., No. 132). f. sincerior, Nyl. Guernsey (Larbalestier).

Lecanora aipopsila, Ach.

Jerbourg (Crombie). f. maritima, Smrft. Jerbourg (Larbalestier, Lich. Rariss., No. $\mathrm{IO}_{3}$ in my copy).

(Lecanora albariella, Nyl. occurs in Sark.)

Lecanora Ralfsii, Salw.

On sea rocks in Moulin Huet Bay.

Lecanora confragosa, Ach.

Jerbourg, Petit Port. Jaonnet cliffs.

(Lecanora pyreniospora, Nyl. occurs in Alderney, Sark, and Jethou, and L. diplinthia, Nyl. in Sark.)

Lecanora fuscella, Schaer.

Guernsey (Mrs. Collings).

Lecanora prosecha, Ach.

Rocquaine Castle. Extremely like the much commoner $L$. prosechoides, but at once distinguished by the septate spores. 
Lecanora haematomma, Ehrh.

On the vertical sides of rocks at Jerbourg.

Lecanora ventosa, $L$.

Guernsey (Mrs. Collings).

Pertusaria concreta, Nyl. f. Westringii, Nyl.

Guernsey (Crombie).

Pertusaria ceuthocarpa, Sm.

On rocks, Lerée Point.

Pertusaria dealbata, Ach.

Jerbourg, on rocks.

Pertusaria communis, DC.

On trees near the Catel Church, and near Les Effards.

Pertusaria fallax, Pers.

Saints Bay.

Pertusaria faginea, L.

Guernsey (Mrs. Collings).

(Pertusaria lactea, Nyl. occurs in Sark.)

Pertusaria pustulata, Ach.

Fauxquets Valley, Catel.

Pertusaria leioplaca, Ach.

Guernsey (Mrs. Collings).

Phlyctis agelaea, Ach.

Guernsey (Larbalestier).

\section{Urceolaria scruposa, L.}

St. Martin's Point. Lerée. Rocquaine Castle. Vale Castle.

(Urceolaria actinostoma, Pers., var. caesioplumbea, Nyl. occurs in Sark. Crombie describes it as 'a singular species with much the aspect of a Vernucaria.')

Lecidea Salweii, Borr.

On the earth among rocks. Jaonnet and Petit Port cliffs. Saints Bay (Salwey).

Lecidea atro-rufa, Dicks.

Guernsey (Salwey).

Lecidea lurida, Swartz.

The lichen so named from Saints Bay, Guernsey, and numbered 
340 in my copy of Larbalestier's Lichen Herbarium (Fasc. Ix.), is not that species, but Lecanora holophaea, Mnt. But L. hurida is noted for Rocquaine Hill, Guernsey, on Mr. Larbalestier's authority in Leighton's Lichen Flora, ed. 3, addenda, p. 547.

Lecidea sylvicola, Flot.

Below Doyle's Monument.

Lecidea lucida, Ach.

On perpendicular shady rocks and quarry-sides. Petit Bot Valley. Moulin Huet Valley. Near Les Fauxquets.

Lecidea decolorans, Flk.

On the earth among rocks. Cliffs at Jaonnet and Saints Bay.

Lecidea vernalis, $\mathrm{L}$.

Guernsey (Larbalestier).

Lecidea quernea, Dicks.

Guernsey (Salwey).

Lecidea enteroleuca, Ach.

St. Martin's cliffs, here and there.

Lecidea parasema, Ach.

Common. Var. elaeochroma, Ach. Common on hawthorns and young trees. Var. latypea, Ach. On rocks. Southern cliffs. Valley below St. Briocq, St. Peter's.

Lecidea protrusa, Fr.

On rocks at the Corbiere.

Lecidea enterochlora, Tayl.

Fermain Bay.

Lecidea uliginosa, Schrad.

Guernsey (Larbalestier).

Lecidea coarctata, Sm.

Generally distributed. f. elacista, Ach. Near Grantez Mill, Catel. f. involuta, Tayl. St. Saviour's fo terrestris, Leight. On a gravelly roadside bank at Villiaze, St. Andrew's.

(Lecidea caligans, Nyl. occurs in Alderney. In Leighton's Lichen Flora this species is described under two different sections of the genus; first, as No. I 66 on page $28_{3}$, and again as No. 347 on page $37 \mathrm{I}$.)

Lecidea lapicida, Fr.

Jerbourg, on rocks. 
Lecidea rivulosa, Ach.

Common on the cliffs, and more or less all round the coast.

Lecidea fusco-atra, Ach. f. fumosa, Ach.

Jerbourg.

Lecidea Taylori, Salw.

In several places on the cliffs between Fermain and Jerbourg.

Lecidea contigua, Fr.

Common generally. f. limitata, Leight. Frequent on the cliffs.

f. steriza, Ach. Divette Cove, below Doyle's Monument.

Lecidea albo-caerulescens, Wulf.

Forest cliffs at Portelet.

Lecidea confluens, Web.

Lerée Point.

Lecidea diducens, Nyl.

Cliffs between Jaonnet and l'etit Bot. Wall at Icart. On Lancresse Common I have found a form with polari-locular spores: possibly a distinct species.

Lecidea canescens, Dicks.

Very common on trees, walls, and rocks : fruiting freely.

Lecidea stellulata, Tayl.

Generally distributed and common.

Lecidea atro-alba, Ach.

Moulin Huet cliffs. Jerbourg, Grandes Rocques Head.

Lecidea myriocarpa, DC.

Rather common. f. chloropolia, Fr. Frie Baton. Paradis. Mont Saint. f. areolata, Leight. Saints Bay. f. pinicola, Ach. Guernsey (Mrs. Collings).

Lecidea subdisciformis, Leight.

Common all round the coast. At once distinguished by the chemical reaction $\mathrm{K}$. yellow, then red. Var. meiosperma, Nyl. Corbiere. Jerbourg Point.

Lecidea chalybeia, Borr.

On rocks at Petit Port, Fermain, and Portelet Cove, Forest. On a brick wall in the Villiaze Road.

Lecidea applanata, Fr.

St. Martin's cliffs in several places. Albecq. 
Lecidea candida, Web.

Guernsey (Mrs. Collings).

Lecidea caeruleo-nigricans; Lightf.

Cobo (Larbalestier).

Lecidea biformigera, Leight.

Lerée Point. Cliffs between Moulin Huet and Petit Port.

Lecidea lenticularis, Ach.

Occasional on rocks on the cliffs. Rocquaine Castle. On walls at Vauxbelets, Villiaze Road, and Lerée.

Lecidea lutea, Dicks.

On an old oak in the valley below Mont Varouf, St. Saviour's; and on an elm at Les Prevosts.

Lecidea cyrtella, Ach.

On elder-trees. Fermain Valley. Cliffs above Bec du Nez and at Petit Port.

Lecidea subviridescens, Nyl.

Saints Bay Valley. Jerbourg, in the interstices of an old wall.

Lecidea incompta, Borr.

On an aged elm at Calais, St. Martin's.

Lecidea albo-atra, Hffm.

Frequent. f. epipolia, Ach. Not uncommon on walls in all parts of the island. f. ambigua, Ach. Lerée Point.

Lecidea chlorophaea, Hepp.

On rocks, Lerée Point.

Lecidea Oederi, Web.

Guernsey (Mrs. Collings).

Lecidea mesoidea, Nyl.

Jerbourg, on rocks.

Lecidea aromatica, Sm.

Common on old walls throughout the island.

(Lecidea squamulosa, Deak., occurs in Herm.)

Lecidea abietina, Ach.

Guernsey (Larbalestier).

Lecidea exanthematica, Sm.

Guernsey (Mrs. Collings). 
Lecidea sphaeroides, Dicks.

Guernsey (Mrs. Collings).

Lecidea carneo-lutea, Turn.

Generally distributed: occurring on old elms and occasionally on other trees: rarely on ivy stems.

Lecidea umbrina, Ach.

On rocks, old walls, and gate-bars: generally distributed and not uncommon. This species is readily recognised by the curious spirally-contorted spores.

Lecidea milliaria, Fr. f. terrestris, Fr.

Guernsey (Larbalestier).

Lecidea phacodes, Korb. f. chlorotica, Ach.

On old elms. Prevosts and Bordages, St. Saviour's. Vinaires, St. Peter's. Calais Valley.

Lecidea sabuletorum, Flk.

Frequent on old walls among small mosses.

Lecidea premnea, Ach.

Guernsey (Larbalestier).

Lecidea carneola, Ach.

On trees on the cliffs above Bec du Nez, scarce.

Lecidea endoleuca, Nyl.

Common on tree-trunks, old ivy, and furze stems.

Lecidea rubella, Erhr.

Not uncommon on elms in the interior of the island.

(Lecidea bacillifera, Nyl, occurs in Herm.)

Lecidea effusa, Sm.

Valley below La Fosse, St. Martin's, on a young elm-tree. Var. fuscella, Fr. Guernsey (Larbalestier).

(Lecidea herbarum, Hepp. occurs in Sark.)

Lecidea geographica, L.

Rather common all round the coast. One of the prettiest of crustaceous lichens, conspicuous by its bright greenish-yellow colour and map-like markings.

Lecidea petraea, Wulf.

Common on rocks and stones. 
Lecidea concentrica, Dav.

Fermain Bay. Le Moulin, St. Peter's. Frequent about Petit Bot, on walls and hedgestones.

\section{Lecidea cupularis, Ehrh.}

Fermain, Jerbourg. Grandes Rocques. Usually grows at the base of boulders and rocks, almost concealed by the vegetation.

Lecidea ochrophora, Nyl.

On an old elder-tree on the cliffs above Bec du Nez.

Lecidea Parmeliarum, Smrft.

Jerbourg cliffs (Larbalestier).

Opegrapha herpetica, Ach.

Guernsey (Mrs. Collings).

Opegrapha atra, Pers.

Very common. f. parallela, Leight. Frequent at St. Martin's. f. denigrata, Ach. Guernsey (Larbalestier). f. nigrita, Leight. Guernsey (Mrs. Collings). f. ochrocheila, Nyl. Lancresse Common (Larbalestier).

Opegrapha Turneri, Leight.

On a young oak-tree between Fermain and Bec du Nez.

Opegrapha saxicola, Ach.

Very common on stones in roadside hedges, and on rocks.

Opegrapha Chevallieri, Leight.

Spur Point Albecq. Grantez, Catel.

Opegrapha saxigena, Tayl.

On the perpendicular face of a rock in Moulin Huet Bay.

Opegrapha grumulosa, Duf.

On rocks between Fermain and Bec du Nez, scarce.

Opegrapha varia, Pers.

Common, and very variable. f. diaphora, Ach. Fermain. Saints Bay. Mrs. Collings records f. pulicaris, Lightf, f notha, Ach., f. tigrina, Ach., and f. rimalis, Fr.; and Mr. Larbalestier f. tridens, Ach.

Opegrapha caesariensis, Nyl.

Moulin Huet Bay.

Opegrapha vulgata, Ach.

Frequent on various trees: generally distributed. (f. steriza, Ach., occurs in Alderney and Sark.) 
Opegrapha lyncea, $\mathrm{Sm}$. Guernsey (Larbalestier).

Opegrapha prosodea, Ach.

On an old ash-tree in Moulin Huet Valley.

Stigmatidium crassum, Dub.

Common throughout the island on the trunks of large trees.

Stigmatidium circumscriptum, Tayl.

In several places at Jerbourg, and on the cliffs between Petit Port and Moulin Huet; also between Fermain and Bec du Nez. Eastern side of Lancresse. Forms small snow-white patches usually on the under side of overhanging rocks.

Stigmatidium Hutchinsiae, Leight.

Roadside wall, Saints Bay Valley. Old well, Moulin Huet.

Arthonia punctiformis, Ach.

Guernsey (Larbalestier):

Arthonia astroidea, Ach.

Frequent in all parts : usually on young trees.

Arthonia epipasta, Ach.

Petit Port cliffs, on a crab apple-tree.

Arthonia Swartziana, Ach.

Guernsey (Mrs. Collings).

Arthonia cinnabarina, Wallr.

Not common. On trees near St. Andrew's Church. Cliffs at Bec du Nez, on old willows. Mrs. Collings notes f. dubia, T. \& B., and f. detrita, T. \& B. (Var. pruinata, Del. occurs in Alderney.)

Arthonia anastomosans, Ach.

Guernsey (Mrs. Collings).

Arthonia varians, Dav.

Parasitic on the apothecia of Lecanora glaucoma. Not uncommon.

Graphis scripta, Ach.

The forms f. flexuosa, Leight., and f. tremulans, Leight., are recorded by Mr. Larbalestier; and f. radiata, Leight. by Mrs. Collings.

Graphis pulverulenta, Ach

Guernsey (Larbalestier).

Graphis dendritica, Ach.

Fermain Valley. Near King's Mills. Mont Varouf, St. Saviour's.

f. obtusa, Leight. Near Sausmarez Manor, Catel. 
Graphis inusta, Ach.

Near Bec du Nez, on trees. Moulin de Haut, Catel. f. simpliciuscula, Leight. On trees at Fermain. f. vera, Leight. Guernsey (Larbalestier). f. elongata, Leight., and f. macularis, Leight. Guernsey (Mrs. Collings).

Graphis Lyellii, Sm.

Guernsey (Mrs. Collings).

Graphis sophistica, Nyl.

Bec du Nez cliffs on willow and chestnut, sparingly. On oak in the valley below Les Issues, St. Saviour's. Var. pulverulenta, Sm. Guernsey (Mrs. Collings).

Chiodecton sarniense, Salw.

On rocks at Jerbourg Head, very scarce. This lichen was first described by the Rev. T. Salwey from specimens collected by him at Jerbourg, Guernsey, in 1847 .

\section{VI.-PYRENODEI.}

Normandina pulchella, Borr.

Rare. On a tree at Les Effards, Catel, sparingly. This pretty little lichen, which usually grows on trees among Frullania dilatata, is excessively rare in fruit. Many years ago it was my good fortune to find an elder-tree covered with fruiting specimens, on Madron Moor, West Cornwall.

(Normandina laetevirens, T. \& B. occurs in Alderney.)

Endocarpon miniatum, I.

On rocks. Petit Bot Bay. Cliffs at Petit Port and Jerbourg. Pezeries Point, Rocquaine.

Endocarpon fluviatile, DC.

Moulin Huet Bay. Saints Bay. A specimen from the latter station is No $35^{8}$ in my copy of Larbalestier's Lichen Herbarium.

Verrucaria mucosa, Whlnb.

Petit Port. Forms smooth patches of a dark olive-green colour on hard rocks helow high-water mark.

Verrucaria halophila, Nyl.

Jerbourg (Larbalestier).

(Verrucaria striatula, Whlnb. and V. microsporoides, Nyl. occur in Alderney.)

Verrucaria margacea, Whlnb.

On rocks over which water trickles. Saints Bay Valley. Petit Port. Lerée Point. 


\section{Verrucaria aethiobola, Whlnb.}

Portelet Cove. Petit Port, on a rock below high-water mark.

Verrucaria mutabilis, Borr.

Guernsey (Mrs. Collings).

Verrucaria maura, Whlnb.

Common at high-water mark all round the coast. Forms dull black patches on the rocks.

Verrucaria aractina, Whlnb.

Cascade, Jerbourg (Larbalestier's Lich. Rariss., No. 78 in my copy).

Verrucaria mauroides, Schaer.

Common on stones in hedges, and on smooth-grained rocks.

Verrucaria nigrescens, Pers.

On rocks near Portelet Cove, Forest.

(Verrucaria polysticta, Borr. occurs in Alderney.)

Verrucaria macrostoma, Duf.

Walls of the Vale Castle.

Verrucaria viridula, Schrad.

On an old ruined wall at Mont Saint; and at MIoulin Huet.

Verrucaria murina, Leight.

Jerbourg.

Verrucaria rupestris, Schrad.

Fermain. Jerbourg.

Verrucaria gemmata, Ach.

Not uncommon on old trees throughout the island.

Verrucaria epidermidis, Ach.

On trees near St. Helena. Upper end of Talbots Valley.

Verrucaria analepta, Ach.

Rather common.

Verrucaria cinerea, Pers.

Guernsey (Mrs. Collings).

Verrucaria biformis, Borr.

Frequent in all parts on many kinds of trees.

Verrucaria Salweii, Leight.

On the old battery at Saints Bay. 
Verrucaria chlorotica. Ach.

In several places at St. Martin's; usually on shaded stones in hedges. f. trachona, Tayl. Fermain cliffs. f. carpinea, Schaer. On trees near the Gouffre.

Verrucaria nitida, Weig.

Common on trees, especially Ash. One of the largest and most elegant species of the genus, often growing in company with the var. nitidella, Flk, but the latter is less common in this island. 


\section{SEAWEEDS.}

THE earliest list we have of the marine Algae of Guernsey is the one given on p. 125 of the Flora Sarnica, for which the author says he is indebted to Mr. H. O. Carré, one of the Judges of the Royal Court, and afterwards Lieutenant-Bailiff of the island. This small but accurate list, which must have been compiled before the year I839, comprises 37 species, excluding Lichina pysmaea, a lichen. A more lengthy catalogue is to be found in the Phytologist, firsi series, vol. i. p. I 72, where Dr. R. K. Greville, the eminent algologist, communicates the names of 83 seaweeds collected in Guernsey in I $\mathrm{S}_{4} \mathrm{I}$ by Mr. D. Ross, of Lasswade. Some twenty years later another list was published in the second edition of Ansted's Channel Islands, p. I9I. It was contributed by Miss L.e Lievre, and consists of 123 marine algae-not 223 , as misprinted in the summary of the flora on p. 198.

Yet another list, this time with localities and distribution, appeared in the Transactions of the Guernsey Society of Natural Science for 1894 : it comprised 236 seaweeds collected in the island by my wife and myself during the summer and autumn months of the two previous years. For the identification of four species which were then new to Britain, as well as for the determination of a great many critical and puzzling forms, I am indebted to Mr. E. M. Holmes, F.L S.

In the following pages I have followed the order and the names used in Holmes and Batters' Revised List of British Marine Algae (1892), inserting in brackets, whenever necessary, the older and perhaps more familiar names of Harvey's Phycologia Britannica

The seaweed flora of Guernsey, as now recorded, consists of 252 species.

\section{CYANOPHYCEAE.}

Pleurocapsa amethystea, Rosen.

Parasitic on Cladophora mpestris. Petit Port.

Oscillaria corallinae, Gom. (O. litoralis, Phyc. Brit.partim.) Bordeaux.

Lyngbya semiplena, J. Ag. (Calothrix caespitula.)

Petit Port. Cobo. St. Martin's Point. Fermain.

Lyngbya majuscula, Harv.

Cobo: common in some of the pools at high-water mark. 
Symploca hydnoides, Kutz. (Calothrix semiplena.)

Fermain : common on corallines near high-water mark. Grandes Rocques: Cobo, frequent.

Calothrix confervicola, C. Ag.

Parasitic on filamentous algae. Common in autumn on all parts of the coast.

Calothrix scopulorum, C. Ag.

Lihou Island. Cobo. Bec du Nez.

Isactis plana, Thur. (Rivularia, Harv.)

Vazon Bay.

Rivularia Biasolettiana, Meneg. (Schizosiphon Warreniae.)

Rock pools at high-water mark, Fermain Point. Dripping cliff, Petit Port.

Rivularia atra, Roth.

Common on rocks : resembling black pellets of shot.

Rivularia nitida, C. Ag. ( $R$. plicata.)

On wet rocks in a cave, Petit Port.

Rivularia bullata, Berk. ( $R$. nitida.)

Common all round the coast.

Anabaena torulosa, Lag. (Sphaerosyga Carmichaelii.)

Cobo: frequent in pools at half-tide level.

\section{CHLOROPHYCEAE.}

Enteromorpha clathrata, J. Ag.

Belgrave Bay. Bordeaux. St. Martin's Point. Grandes Rocques.

Enteromorpha percursa, C. Ag.

In a brackish pool at Pulias.

Enteromorpha ramulosa, Harv.

Bordeaux, scarce.

Enteromorpha compressa, Grev.

Very cominon everywhere near high-water mark.

Enteromorpha Linza, J. Ag. (Ulva.)

Found all round the coast: often abundant where it occurs, as at Belgrave Bay. 
Enteromorpha intestinalis, Link.

Common, especially in brackish ditches.

Ulva latissima, J. Ag.

Very common everywhere.

(Ulva rigida, J. Ag. occurs in Alderney.)

Chaetomorpha tortuosa, Kutz. (Conferra.)

Petit Port. Bec du Nez. La Vallette.

Chaetomorpha crassa, Kutz. (Conferva limum.)

Rockpools near Bec du Nez.

Chaetomorpha aerea, Kutz.

Common.

Chaetomorpha baltica, Kutz.

Bordeaux. A recent addition to the British flora.

Rhizoclonium tortuosum, Kutz. (Conferra implexa.)

Petit Bot. Moulin Huet.

Cladophora pellucida, Kutz.

On the sides of deep rockpools. Cobo. Petit Port. Vazon Bay.

Cladophora diffusa, Phyc. Brit.

Frequent all round the coast.

Cladophora laetevirens, Phyc. Brit.

Not uncommon.

Cladophora rupestris, Kutz.

Very common near high-water mark.

Cladophora flexuosa, Griff.

Fermain Point. Rocquaine Bay.

Cladophora repens. J. Ag.

Noted in Miss Le Lievre's list.

Cladophora fracta, Kutz.

Brackish pool at Pulias; a curious state of the plant.

Cladophora flavescens, Kutz.

In the brackish pool at Pulias.

Cladophora albida, Kutz.

In pools at Bec du Nez. 
Cladophora refracta, Phyc. Brit.

All round the coast.

Cladophora arcta, Kutz.

Bec du Nez. Cobo.

(Cladophora lanosa, Kutz., occurs in Alderney.)

Bryopsis hypnoides, Lam.

Occurs all round the coast, but not very commonly.

Bryopsis plumosa, C. Ag.

Moulin Huet. Bordeaux. Spur Point.

Codium adhaerens, C. Ag.

Saints Bay, spreading over the vertical face of a rock at lowwater mark.

Codium tomentosum Stack.

Very common.

\section{PHAEOPHYCEAE。}

\section{I.-ECTOCARPINAE.}

Desmarestia aculeata, Lam.

Specimens washed up all round the coast.

Desmarestia ligulata, Lam.

Rather common. Grows luxuriantly at Cobo and Petit Bot

Desmarestia viridis, Lam.

Noted in Greville's list.

Dictyosiphon foeniculaceus, Grev.

Noted in Greville's list.

Litosiphon pusillus, Harv.

Parasitic on Chorda filum. Fermain. Belgrave Bay. Bordeaux.

(Stictyosiphon Griffithsianus, Holm. \& Batt. (Ectocarpus bracliatus), occurs in Alderney.)

Punctaria plantaginea, Grev.

Cobo.

Punctaria latifolia, Grev.

Petit Bot.

Myriotrichia filiformis, Phyc. Brit.

Parasitic on Scytosiphon lomentarius; rather common. 
Asperococcus echinatus, Grev.

Belgrave Bay, plentiful.

Asperococcus bullosus, Lam. (A. Turneri.)

Rocquaine Bay, in pools near the Trinity Houses.

Streblonema fasciculatum, Thur.

Parasitic on Castagnea virescens, Fermain Point.

Streblonema velutinum, Thur. (Elachista.)

Cobo.

Streblonema Zanardinii, Crn.

Parasitic on Chylocladia kaliformis. Belgrave Bay, not uncommon Fermain, one specimen. When I discovered this species in 1894 it was new to Britain.

Ectocarpus pusillus, Harv.

Petit Port.

Ectocarpus virescens, Thur.

In several places between Fermain Point and Jerbourg.

Ectocarpus secundus, Kutz.

Cobo.

Ectocarpus confervoides, Le Jol. (E. siliculosus.)

Common on all parts of the coast.

Ectocarpus fasciculatus, Harv.

Cobo. Fermain. Bordeaux. Petit Bot.

Ectocarpus granulosus, C. Ag.

Petit Port.

Ectocarpus tomentosus, Lyng.

Not uncommon all round the coast.

Pylaiella litoralis, Kjell. (Ectocarpus.)

Common on Fuci between tide-marks.

Myriactıs pulvinata, Kutz. (Elachista attenuata.) Bordeaux. Fermain Point. Lihou Island.

Elachista stellulata, Aresch.

Fermain, growing on Dictyota.

Elachista scutulata, Duby.

Fermain. Grandes Rocques. Bordeaux.

Elachista flaccida, Aresch.

Grandes Rocques. Petit Port. 
Elachista fucicola, Fries.

Common on Fucus vesiculosu's.

Sphacelaria radicans, Harv.

Vazon Bay.

(Sphacelaria olivacea, Prings. occurs in Alderney.)

Sphacelaria cirrhosa, C. Ag.

Very common.

(Sphacelaria fusca, Phyc. Brit. occurs in Alderney.)

Cladostephus spongiosus, C. Ag.

Here and there on the south coast.

Cladostephus verticillatus, C. Ag.

Common.

Halopteris filicina; Kutz. (Sphacelaria.)

Moulin Huet Petit Bot. Vazon Pay. Petit Port. Lancresse Bay, washed up.

Halopteris patens, Harv. (Sphacelaria sertularia.)

Noted in Miss Le Lievre's list.

Siypocaulon scoparium, Kutz. (Sphacelaria.)

Common in pools between tide-marks.

(Chilionema ocellatım, Sauv. occurs in Alderney.)

Myrionema strangulans, Grev.

Cominon on Ulva and Enteromorpha.

Myrionema punctiforme, Harr.

Parasitic on Ceramium ruhrum. Belgrave Bay. Rocquaine Bay.

Ascocyclus Leclancherii, Magn. (Myrionema.)

Frequent on Rhodymenia palmata.

Ralfsia clavata, Crn.

Fermain, on limpets. Bordeaux. Lancresse Bay. Vazon.

Ralfsia verrucosa, Aresch. ( $R$. deusta.)

Moulin Huet Bay. Cobo. Grandes Rocques. Petit Bot, with plurilucular sporangia.

Stilophora rhizodes, J. Ag

Cobo. Grandes Rocques.

Chordaria flagelliformis, C. Ag.

Cobo. Lihou Island. 
Mesogloea vermiculata, Le Jol.

Petit Bot. Cobo. Fermain. Bordeaux.

Liebmannia Leveillei, J. Ag.

I gathered a specimen in a rockpool off Bordeaux in the autumn of $\mathbf{1} 894$, mistaking it for a large form of Mesogloea rermiculata. On learning that this was its first discovery in British waters, I searched carefully on several occasions, but failed to find any more of it.

Castagnea virescens, Thur. (Mesogloia.)

Fermain. Cobo. Rocquaine. Near Rousse Martello Tower.

Petrospongium Berkeleyi, Nag. (Leathesia.)

All round the coast at extreme low-water mark.

Leathesia difformis, Aresch. (L. tuberiformis.)

Common. Resembling hollow, distorted potatoes.

\section{II.-LAMINARINaE.}

Phyllitis Fascia, Kutz. (Laminaria.)

Lancresse Bay, in shallow pools at mid-tide level.

Scytosiphon lomentarius, J.Ag. (Chorda.)

Generally distributed, but not common.

Chorda Filum, Stack.

Common. Said to have been found forty feet in length.

Laminaria saccharina, Lam.

Common.

Laminaria digitata, Edm.

Common.

Saccorhiza bulbosa, De la Pyl.

Common.

(Alaria esculenta, Grev. occurs in Alderney.)

\section{III.-SPOROCHNINAE:}

Sporochnus pedunculatus, C.Ag.

Noted in Miss Le Lievre's list.

\section{IV.-Cutlerinae.}

Aglaozonia reptans, Kutz. (Zonaria parnula.)

Bordeaux. Vazon Bay. 
Zanardinia collaris, Crn. (Zonaria.)

Vazon Bay.

Cutleria multifida, Grev.

Noted in Miss Le Lievre's list.

$$
\text { V.-Fucinae. }
$$

Fucus ceranoides, Linn.

Noted in Miss Lievre's list.

Fucus vesiculosus, Linn.

Common. A well-preserved specimen in the Kew Herbarium is labelled: 'Alga marina. Gather'd on the Isle of Guernesey.-T. Know. I726.'

Fucus serratus, Linn.

Common.

Ascophyllum nodosum, Le Jol. (Fucus.)

Generally distributed and common.

Pelvetia canaliculata, Dcne. (Fucus.)

Common.

Bifurcaria tuberculata, Stack. (Pycnophycus.)

Frequent all round the coast

Himanthalia lorea, Lyng.

Common.

Halidrys siliquosa, Lyng.

Common: sometimes cast up in abundance.

Cystoseira ericoides, C. Ag.

Occurs all round the coast in rock pools, and is easily recognised by its beautiful iridescence when under water.

Cystoseira granulata, C. Ag.

Cobo. Lancresse Bay.

Cystoseira barbata, Ag.

Noted in the lists of H. O. Carré and Miss Le Lievre. This species is described and figured in the Phycologia Britannica, but is now excluded from the British flora, as only cast-up specimers have been found on the coast, and the plant has not been seen growing.

Cystoseira discors, C. Ag. (C. foeniculacea.)

Fermain. Bordeaux. Lihou Island. Lerée. Cobo.

Cystoseira fibrosa, C. Ag.

Common. 


\section{VI. - TILOPTERIDINAF.}

Tilopteris Mertensii, Kutz. (Ectocarpus.)

Noted in Miss Le Lievre's list.

\section{VII.-DictyotinaE.}

Dictyota dichotoma, Lam.

Common. Var. implexa, J. Ag. (intricata, Phy'c. Brit.) Bordeaux. Moulin Huet Bay. Petit Port.

Padina pavonia, Gail.

In shallow pools. Cobo. Grandes Rocques. Rocquaine Bay. A singular and strikingly beautiful seaweed, appropriately called the Peacock's Feather.

Dictyopteris polypodioides, Lam. (Haliseris.)

Fermain Point. Coast by Rousse Martello Tower.

\section{RHODOPHYCEAE.}

\section{I.-PORPHYRINAE.}

Erythrotrichia carnea, J. Ag. (Bangia ceramicola.)

Near Bec du Nez on a plant of Ceramium ciliatum, growing at extreme low-water mark.

Porphyra linearis, Grev. (P. vulgaris.) Common.

Porphyra laciniata, C.Ag.

Common. Both species of Porphyra, under the name of Laver or Sloke, are said to be very wholesome when boiled into a pulp and eaten with pepper and vinegar or lemon-juice.

\section{II.-NeMalioninae.}

Chantransia Daviesii, 'Thur. (Callithamnion.) Saints Bay. Petit Bot. Fermain. Bec du Nez. Lihou Island.

Chantransia luxurians, Thur.

On limpets in mid-tide pools, St. Martin's Point.

Helminthocladia purpurea, J. Ag. (Nemaleon.).

Petit Bot. Moulin Huet.

Helminthora divaricata, J. Ag. (Dudresnaia.)

Saints Bay. Petit Port. Spur Point. 
Scinaia furcellata, Biv. (Ginnania.)

Moulin Huet in rock pools. Very fine specimens, of unusually large size, washed up in Lancresse Bay.

Naccaria Wigghii, Endl.

Rare. Rocquaine Bay.

Pterocladia capillacea, Born. (Gelidium.)

Spur Point.

Gelidium corneum, Lam.

Common. Var. pulchella, Grev. Common. Var. plumula, Grev. Bordeaux. Var. latifolia, Grev. Bordeaux. Var, setacea, Grev. Fermain Point.

\section{III.-Gigartininae.}

Chondrus crispus, Stack.

Very common.

Gigartina acicularis, Lam.

Rather common all round the coast.

Gigartina pistillata, Stack.

Petit Bot. Moulin Huet. Petit Port.

Gigartina mamillosa, J. Ag.

Generally distributed, but not common.

Phyllophora rubens, Grev.

Frequent on the south coast. Cobo.

Phyllophora palmettoides, J. Ag. Petit Bot.

Phyllophora membranifolia, J. Ag.

Petit Port.

Gymnogongrus Griffithsiae, Mart.

Petit Bot.

Gymnogongrus norvegicus, J. Ag. (Chondrus.)

Fermain. Bec du Nez. Moulin Huet. Petit Bot.

Ahnfeltia plicata, Fries. (Gymnogongrus.)

Frequent all round the coast.

Callophyllis laciniata, Kutz. (Rhodymenia.)

Rather common: often washed ashore. 
Callymenia reniformis, J. Ag. (Kallymenia.)

Petit Bot. Moulin Huet. Lancresse Bay.

Cystoclonium purpurascens, Kutz. (Hypner.)

Rather common.

Catenella Opuntia, Grev.

Entrance to a cave at Bec du Nez, abundant. Causeway to Lihou Island

Rhodophyllis bifida, Kutz. (Rhodymenia.)

Rather common all round the coast.

Rhodophyllis appendiculata, J. Ag. (R. bifidu, var. ciliata.) Fermain Point. Cobo. Bordeaux. Bec du Nez.

\section{IV.-RHODYMENINAE.}

Sphaerococcus coronopifolius, Grev.

Fragmentary specimens washed up at Petit Bot Bay and Bec du Nez. Much finer in Alderney.

Gracilaria confervoides, Grev.

Frequent in all parts.

Calliblepharis ciliata, Kutz. (Rhodymenia.)

Fermain. Bordeaux. Lancresse Bay.

Calliblepharis jubata, Kutz.

Here and there all round the coast.

Rhodymenia palmetta, Grev.

Petit Bot. Fermain. Lancresse Bay.

Rhodymenia palmata, Grev.

Very common. Var. sarniensis, Grev. In several places on the Vale coast. Var. sobolifera, J. Ag. Fermain Point. Bec du Nez. The var. sarniensis was originally described by Mertens in I 806 under the name of Fucus samiensi, and was the first indigenous plant named after the island of Guernsey (Sarnia).

Lomentaria articulata, Lyng. (Chylocladia.)

Common.

Lomentaria clavellosa, Gail. (Chrysymenia.)

Cobo. Bordeaux. Rocquaine Bay.

Champia parvula, Harv.

Fermain. Petit Bot. Bordeaux. Cobo. 
Chylocladia kaliformis, Grev.

Rather common.

Chylocladia ovalis, Hook.

Frequent all round the coast.

Chylocladia reflexa, Lenorm. Cobo.

Plocamium coccineum, Lyng.

Generally distributed, but not very common.

Nitophyllum uncinatum, J. Ag.

Bordeaux.

Nitophyllum Gmelini, Harv.

Noted in Miss Le Lievre's list.

Nitophyllum laceratum. Grev.

Generally distributed and rather common.

Nitophyllum reptans, Crn.

Petit Port, growing on Lithothamnion polymorphum.

Nitophyllum punctatum, Grev.

Rare. Cobo. Var, ocellata, J. Ag. Petit Bot. Cobo. Moulin Huet.

Nitophyllum Hilliae, Grev.

Rare. Fermain Point, at extreme low-water mark.

Delesseria alata, Lam.

Frequent all round the coast.

Delesseria Hypoglossum, Lam.

Here and there, but not common. Usually a pale narrow form.

Delesseria ruscifolia, Lam.

Rather common.

Delesseria sinuosa, Lam.

Petit Bot. Vazon Bay. Lancresse Bay. Cast up at Moulin Huet in great abundance in 1894 .

Delesseria sanguinea, Lam.

Frequently washed up) : growing specimens mostly small.

Bonnemaisonia asparagoides, C. Ag.

One small specimen washed up in Petit Bot Bay.

Rhodomela subfusca, C. Ag.

Fermain. Bordeaux. Grandes Rocques. 
Laurencia obtusa, Lam.

Cobo. Rocquaine. Bordeaux. Fermain.

Laurencia hybrida, Lenorm. (L. caespitosa.)

Common.

Laurencia pinnatifida, Lam.

Very common.

Halopithys pinastroides, Kutz. (Rvtiphloca.)

Noted in Greville's list.

Chondria tenuissima, C. Ag. (Laurencia.)

Belgrave Bay, plentiful. Cobo.

Chondria dasyphylla, C. Ag.

Fermain. Petit Bot. Vale Coast. Cobo.

Polysiphonia sertularioides, J. Ag. ( $P$. pullinata.)

Petit Port. Spur Point.

Polysiphonia fibrata, Harv.

Common.

Polysiphonia urceolata, Grev.

Petit Bot.

Polysiphonia violacea, Wyatt.

Rather common.

(Polysiphonia fibrillosa, Grev., occurs in Alderney).

Polysiphonia opaca, Zan.

Petit Port, in sand at mid-tide level (f. simplicior). This plant is an addition to the British flora.

Polysiphonia fastigiata, Grev.

Common : parasitic on Fucus nodosus.

Polysiphonia simulans, Harv.

Fermain. Moulin Huet. Spur Point.

Polysiphonia atro-rubescens, Grev.

Petit Port. Vazon.

Polysiphonia subulifera, Harv.

Belgrave Bay, in considerable quantity. Petit Bot.

Polysiphonia obscura, J. Ag.

Vazon Bay, in crevices of rocks at low-water mark. 
Polysiphonia nigrescens, Grev.

Cobo. Petit Bot. Fermain.

Polysiphonia byssoides, Grev.

Frequent all round the coast.

Polysiphonia Brodiaei, Grev.

Petit Bot. Cobo. Fermain.

Polysiphonia thuyoides, Harv. (Rytiphloea.)

Moulin Huet. Fermain. Petit Port. Vazon.

Polysiphonia fruticulosa, Spreng. (Rytipliloea.)

Common.

Dasya venusta, Harv.

Noted in Miss Le Lievre's list.

Dasya arbuscula, C. Ag.

Fermain. Bec du Nez. Cobo.

Dasya coccinea, C. Ag.

Rather common.

Sphondylothamnion multifidum, Nag. (Wrangelia.)

Here and there all round the coast.

Spermothamnion Turneri, Aresch. (Callithamnion.)

Rocquaine. Bordeaux. Fermain. Grandes Rocques.

Ptilothamnion pluma, Thur. (Callithamnion.)

Petit Bot Bay, on washed-up Laminaria stems.

Griffithsia corallina, C. Ag.

Rather common.

Griffithsia setacea, C. Ag.

Common.

Halurus equisetifolius, Kutz. (Grifithsia.)

Cobo. Bordeaux. Lancresse Bay. Frequent on the south coast.

Bornetia secundiflora, Thur. (Griffithsia.)

Cobo. Moulin Huet. Rocquaine. Bec du Nez. Fermain.

Monospora pedicellata, Solier. (Callithannion.)

Freyuent all round the coast.

Pleonosporium Borreri, Nag. (Callithamnion.)

Fermain. Petit Port. Bec du Nez. Petit Bot. 
Rhodochorton Rothii, Nag. (Callithamnion.)

Common.

Rhodochorton floridulum, Nag.

Petit Port. Lancresse Bay.

Callithamnion roseum, Harv.

Noted in Miss Le Lievre's list.

Callithamnion Hookeri, C. Ag.

Belgrave Bay. Grandes Rocques. Bordeaux. Lancresse Bay.

Callithamnion arbuscula, Lyng.

Noted in Miss Le Lievre's list.

Callithamnion tetragonum, C. Ag.

Frequent in the south.

(Callithamnion brachiatum, Phyc. Brit. occurs in Alderney.)

Callithamnion tetricum, C. Ag.

Occasional all round the coast.

Callithamnion corymbosum, Lyng.

Common.

Callithamnion granulatum, C. Ag. (C spongiosum.)

Fermain. Petit Bot. Moulin Huet. Petit Port.

Callithamnion byssoides, Arn.

Moulin Huet. Cobo. Bordeaux.

Compsothamnion thuyoides, Schm. (Callithannion.)

Fermain Point.

Plumaria elegans, Bon. (Ptilota.)

Rather common. Grows on the vertical faces of rocks.

(Ptilota plumosa, C. Ag., occurs in Sark.)

Antithamnion plumula. Thur. (Callithannion.)

Vazon Bay: one specimen washed up.

Crouania attenuata, J. Ag.

Common generally: in some places abundant.

Ceramium tenuissimum, J. Ag. (C. nodosum.)

Rocquaine Bay. Cobo.

Ceramium Deslongchampsii, Chauv.

Bordeaux. 
Ceramium strictum, Harv.

Grandes Rocques, on Zostera.

Ceramium diaphanum, Roth.

Cobo. Bordeaux. Grandes Rocques.

(Ceramium circinatum, J. Ag. (C. decurrens), occurs in Alderney.)

Ceramium rubrum, C. Ag.

Very common. Var. proliferum, J. Ag. (C. botryocarpum). Fermain. Saints Bay. Cobo. Bordeaux.

Ceramium echionotum, J. Ag.

Common.

Ceramium acanthonotum, Carm.

Vazon Bay.

Ceramium ciliatum, Ducl.

Rather common all round the coast.

Ceramium flabelligerum, J. Ag.

Noted in Miss Le Lievre's list.

Microcladia glandulosa, Grev.

Moulin Huet. Bec du Nez.

\section{V.-CRYPTONEMinaE.}

Gloeosiphonia capillaris, Carm.

Rare. Cobo.

Halymenia ligulata, C. Ag.

Lancresse Bay, washed up.

Grateloupia filicina, C. Ag .

Bordeaux. Petit Bot. Var. intermedia, Holm. \& Batt. Moulin Huet.

Dumontia filiformis, Grev.

Moulin Huet. Fermain.

Dudresnaya coccinea, Bon.

Rocquaine Bay, rare.

Dilsea edulis, Stack.. (Iridaea.)

Moulin Huet. Fermain. Bordeaux.

Schizymenia Dubyi, J. Ag. (Kallymenia.)

Noted in Miss Le Lievre's list. 
Furcellaria fastigiata, Lam.

Rather common.

Polyides rotundus, Grev.

Bec du Nez. Petit Bot.

Petrocelis cruenta, J. Ag. (Cruoria pellita.)

Fermain.

Peyssonnelia Dubyi, Dcne.

Bordeaux. Petit Bot. Fermain.

Hildenbrandtia prototypus, Nard. (H. rubra.)

Common.

Schmitziella endophloea, Born \& Batt.

Parasitic on Cladophora pellucida. Petit Port. Vazon.

Melobesia corticiformis, Kutz.

On Rhodymenia palmata and Cladophora pellucida. Fermain.

Cobo. Petit Bot. Lancresse Bay.

Melobesia membranacea, Lam.

Fermain Point, on Rhodymenia palmata.

Melobesia verrucata, Lam.

Fermain. Cobo. Vazon.

Melobesia Lejolisii, Rosan.

On Zostera leaves. Vazon Bay. Petit Port.

Melobesia pustulata, Lam.

Cobo. Petit Port. Fermain.

Melobesia Laminariae, Crn.

Fermain. Bordeaux.

Melobesia Corallinae, Crn

Petit Bot Bay.

Melobesia sp.

I have found at Petit Bot Bay, and also at Vazon Bay, a species approaching $M$. Cystoseirae, Hauck, but it has not yet been satisfactorily determined.

Lithophyllum lichenoides, Phil. (Melobesia.)

Common.

Lithophyllum Lenormandi, Rosan.

Conmon. 
Lithophyllum expansum, Phil.

Fermain. Bordeaux. Lancresse Bay. Vazon. An addition to the British flora.

Lithothamnion polymorphum, Aresch. (Melohesia.) Common.

Lithothamnion intermedium, Kjellm.

Bordeaux. Petit Bot. Vazon Bay.

(Lithothamnion incrustans, Fosl., occurs in Alderney.)

Corallina officinalis, Linn.

Common.

Corallina squamata, Ellis.

Common.

(Corallina mediterranea, Aresch., occurs in Alderney.)

Corallina rubens, Ellis. (Jania.)

Rather common

Corallina corniculata, Ellis. ( /ania.)

Cobo. Petit Bot. Rocquaine Bay. 


\section{FRESH-WATER ALGAE.}

THE plants belonging to this section are but meagrely represented in Guernsey, and the only list of species hitherto published is the one I made out in 1894. Many unrecorded forms have occurred in my gatherings, but not in a condition to be identified with certainty. Only nine Desmids have been observed, although repeated gatherings were made in many likely spots, including Grande Mare, the most promising locality in the island. Further research will undoubtedly add to the number, but the Fresh-water Algae will always remain relatively the weakest section of the Guernsey cryptogamic flora.

Besides the 9 Desmids, 44 species are now recorded.

\section{CHLOROPHYLLOPHYCEAE.}

Pleurococcus vulgaris, Meneg.

Common on tree-trunks, wooden fences, and shaded walls.

Gloeocystis rupestris, Rab.

On moist rocks at foot of the cliffs, Petit Port.

Porphyridium cruentum, Nag.

Common on damp ground and at the base of walls, forming patches resembling blood-stains.

Rhaphidium falcatum, Rab.

Abundant in a gathering from one of the pools at Grande Mare.

Protococcus viridis, Ag.

Common on damp walls, trees, and fences. Probably an undeveloped state of some of the higher algae.

Chlorococcum Gigas, Grun.

In some of the Grande Mare gatherings.

Scenedesmus obtusus, Meyen.

Grande Mare, in pools, but only sparingly.

Scenedesmus quadricauda, Breb.

Abundant in a water-tank in my greenhouse.

Pediastrum ellipticum, Ralfs.

Grande Mare : not common. 
Pediastrum Boryanum, Turp.

Saints Bay Valley, abundant. Pool by Fort Doyle

Coelastrum sphaericum, Nag.

Grande Mare, in some of the ditches.

Characium ornithocephalum, Br.

Saints Bay Valley, attached to filamentous algae.

Zygnema cruciatum, Ag.

Grande Mare.

Zygnema anomalum, Hass.

Grande Mare. The Tyndaridca anomala of Ralfs. See remarks on this species in Cooke's Brit. Fr. W. Alg., i. p. 8x.

Spirogyra bellis, Cleve.

Grande Mare. The plant described by Petit, Spirogyra des environs de Paris, p $3 \mathrm{I}$.

Spirogyra porticalis, Cleve.

Roadside ditch near Vazon, and in pools at Grande Mare.

Mesocarpus nummuloides, Hass.

Grande Mare; in good fruit in some gatherings.

Vaucheria sessilis, DC.

Moulin Huet Valley, in a well, fruiting

Conferva bombycina Ag.

Streamside, Moulin Huet.

Cladophora glomerata, Linn.

In streamlets near Iry Castle-and near Hougue du Pommier.

Bulbochaete setigera, Ag.

On submerged reed-stems in deep pools at Grande Mare.

Bulbochaete pygmaea, Wittr.

Grande Mare. A very minute species.

Ulothrix radicans, Kutz.

Base of walls and damp ground.

Chroolepus aureus, Linn.

Common on old walls and tree-trunks. Conspicuous by its bright orange-red colour

Stigeoclonium tenue, Ag.

Moulin Huet Cascade. Stream behind Ivy Castle, on stones

Chaetophora tuberculosa, $\mathrm{Ag}$.

Plentiful in a water-trough towards the Corbiere. 
Chaetophora endiviaefolia, Ag.

In pools at Grande Mare, scarce.

\section{PHYCOCHROMOPHYCEAE.}

Chroococcus turgidus, Nag.

Grande Mare, common in one of my gatherings.

Merismopedia glauca, Nag.

In a ditch in Saints Bay Valley, plentiful.

Nostoc commune, Vauch.

Apparently not common in this island; I have seldom seen it.

Nostoc verrucosum, Vauch.

Plentiful in a streamlet flowing into Saints Bay Valley from the east side; less common lower down the valley.

Cylindrospermum macrospermum, Kutz.

In a water-trough at Casrouge, Forest.

Oscillaria tenerrima, Kutz.

Petit Port, at base of the cliffs, among other algae.

Oscillaria tenuis, Ag.

In a water-trough in Saints Bay Valley, and also in one near

St. Peter's Church

Oscillaria limosa. Ag.

Roadside ditch near St. Sampson's Bridge.

Oscillaria nigra, Vauch.

In a water-trough at Casrouge, Forest.

Oscillaria Frohlichii, Kutz.

In some of the pools at Grande Mare.

Lyngbya vulgaris, Kirch.

Common on damp earth and shady walls in the autumn.

Tolvpothrix coactilis, Kutz.

Grande Mare, in pools.

Rivularia granulifera, Carm.

Base of the cliffs at Petit Port.

Gloiotrichia natans, Thur.

In pools, Grande Mare.

Gloiotrichia pisum, Thur.

Adhering to submerged plants in deep pools at Grande Mare. 


\section{RHODOPHYCEAE.}

Chantransia chalybea, Fr.

On stones in a rivulet behind Les Vauxbelets, St. Andrews.

Batrachospermum moniliforme, Roth.

Sparingly in pools at Grande Mare.

\section{DESMIDIACEAE.}

Leptocystinema Kinahani, Arch.

I once found this singular Desmid in considerable abundance in a trickling streamlet in Saints Bay Valley.

Cosmarium tetrophthalmum, Breb.

Grande Mare, in pools.

Cosmarium margaritiferum, Meneg.

Grande Mare, not uncommon in some gatherings.

Cosmarium Botrytis, Meneg.

In a water-trough near the Corbiere, scarce.

Docidium truncatum, Breb.

Grande Mare.

Closterium Lunula, Ehr. ditches.

Frequent in gatherings from Grande Mare. Saints Bay Valley in

Closterium acerosum, Ehr.

Not uncommon in water-troughs and wells.

Closterium Ehrenbergii, Meneg.

With the last : rather common in many places.

Closterium Dianae, Ehr.

Grande Mare. Water-trough at King's Mills. 


\section{DIATOMACEAE.}

IVE are indebted to a well-known Diatomist, Mr. Thomas G. Rylands, of Warrington, for the excellent catalogue of Diatoms, comprising nearly 250 species, which is given in Ansted's Channel Islands, ed. 2 (1865), p. I 93. Mr. Rylands states that this catalogue was prepared 'from the valuable series of gatherings made at Guernsey in $1858-59$ by Dr. Wallich. . . . All the species observed, about the names of which there could be no reasonable doubt, have been included: but there remain others which, in the present state of our knowledge, can be referred with safety to no recorded character, and several which, there can be little doubt, are entirely new.'

In the course of some rather desultory researches among these microscopic plants (chiefly, it must be confessed, with the object of adding to my collection) I discovered a good many additions to this list, besides ascertaining something about the comparative frequency of many species: and this afforded material for my paper in the Transactions of the Guernsey society of Natural Science for I 893. But a large number of Wallich s species did not occur in my gatherings; so that only the bare fact of their occurrence in the island (teste Rylands) can at present be recorded.

The classification here followed is that of Rabenhorst's Filora Euspaea Algarum (1864-68); but it has been thought advisable not to alter the nomenclature, especially as Mr. Rylands expressly states that 'Professor Gregory's species are named separately, simply to show which forms occur.'

The number of Diatoms now recorded for Guernsey amounts to 323 specics.

\section{MELOSIREAE.}

Cyclotella Dallasiana, Sm.

Hyalodiscus cervinus, Grev.

This species is marked with a query in Mr. Rylands' list.

Coscinodiscus centralis, Ehr.

Coscinodiscus Oculus-Iridis, Ehr.

Coscinodiscus concinnus, $\mathrm{Sm}$.

Cobo: frequent in rock scrapings from low-water mark. Moulin Huet, a few scattered valves. 
Coscinodiscus radiatus, Ehr.

Not uncommon in shore gatherings all round the coast.

Coscinodiscus lineatus, Ehr.

Coscinodiscus eccentricus, Ehr.

Two valves at Moulin Huet, and one at Petit Bot. Frequent in a mixed gathering from the Salerie.

Coscinodiscus minor, Kutz.

Common in some of the gatherings from Cobo. Moulin Huet and Bordeaux, occasional. In Mr. Rylands' list two species are given under this name: Cosc. minor, of Kutzing, and Cosc. minnr, of Ehrenberg. The litter species, according to Rabenhorst, is Orthosira angulata, Greg. Cosc. minor, of Smith (Brit. Diat), is Meiosira nivalis, Sm.

Coscinodiscus nitidus, Greg.

Rather frequent in a gathering from Perelle Bay. A few specimens at Cobo and Petit Bot Bay.

Actinocyclus quinarius, Ehr.

' This was the only form seen of the A. moniliformis, Ralfs. It was very scarce.' (Rylands.)

Asterolampra flabellata, Grev.

'This species has occurred two or three times in different gatherings.' (Rylands.)

Actinoptychus undulatus, Ehr.

More or less common in all shore gatherings: varying greatly in size, and often very small.

Actinoptychus senarius, Ehr.

Podosira Montagnei, Ehr.

'A form occurs not uncommonly, which is probably a peculiar variety of this species.' (Rylands.)

Podosira hormoides, Kutz.

Podosira maculata, Sm.

Frequent, occasionally abundant, in all gatherings from lowwater mark.

Melosira nummuloides, Ag.

Common on all parts of the coast.

Melosira Westii, Sm.

Melosira Borreri, Grev. 
Melosira varians, Ag.

Common in pools, marshes, and water-troughs.

Orthosira orichalcea, Sm.

Orthosira marina, Sm.

Cobo, plentiful in rock scrapings.

\section{SURIRELLE.AE.}

Campylodiscus limbatus, Breb.

Campylodiscus costatus, Sm.

Common in bogpools at Grande Mare. Saints Bay Valley, scarce. A few valves in the submarine peaty deposit at Cobo.

Campylodiscus clypeus, Ehr.

Campylodiscus parvulus, Sm.

Campylodiscus simulans, Greg.

Common at Cobo. Frequent in shore gatherings from other parts of the coast.

Campylodiscus Hodgsoni, Sm.

Campylodiscus eximius, Greg.

Campylodiscus Ralfsii, Sn.

Moulin Huet, in rock scrapings, sparingly.

Campylodiscus spiralis, Sm.

Saints Bay Valley, plentiful. In bog pools at Grande Mare, scarce.

Campylodiscus decorus, Breb.

Not uncornmon at extreme low-water mark all round the coast.

Surirella linearis, $\mathrm{Sm}$.

Marsh at the eastern end of Lancresse, plentiful. Mostly the linear acuminate form.

Surirella biseriata, Breb.

Abundant at a spring in the valley below Casrouge, Forest.

Surirella angusta, Kutz.

Surirella splendida, Kutz.

Saints Bay Valley, plentiful in some gatherings.

Surirella striatula, Turp.

Abundant in the brackish pool at Pulias. Common and fine in the submerged peaty deposit at Cobo. 
Surirella ovalis, Breb.

Grande Mare bog pools, common. Abundant in a roadside rivulet near Lilyvale, Catel. Pool near Fort Doyle, occasional.

Surirella ovata, Kutz.

Plentiful in the brackish pool at Pulias, also in a quarry marsh at Bordeaux, and in Saints Bay Valley.

Surirella fastuosa, Ehr.

More or less common in all shore gatherings.

Surirella lata, Sm.

Common. The unconstricted form plentiful at Moulin Huet.

Podocystis americana, Bail.

'Two valves only, seen in different slides. Locality: Cobo' rocks, at extreme low water, on corallines attached to the rock. The gathering was a very mixed one.' (Rylands.)

Cymatopleura Solea, Sm.

Frequent in Saints Bay Valley, and in a marsh at Vazon. Sparingly in a rivulet near Lilyvale, Catel. Usually the short, broad form.

\section{EUNOTIEAE.}

Epithemia turgida, Kutz.

Common in the Grande Mare pools. Saints Bay and Moulin Huet streams, scarce. Two specimens in the Cobo peat deposit.

Epithemia Westermanni, Kutz.

Common at Grande Mare and in the marsh at the eastern side of Lancresse. Frequent in gelatinous drippings at the foot of the cliffs at Petit Port.

Epithemia granulata, Kutz.

Epithemia gibba, Kutz.

Abundant in some of the pools at Grande Mare.

Epithemia ventricosa, Kutz.

Epithemia marina, Donk.

Cobo, rock scrapings at extreme low-water mark, two specimens.

Epithemia musculus, Kutz.

Brackish pool at Pulias, sparingly. Cobo peat deposit, frequent.

Epithemia constricta, Sm. 
Epithemia Argus, Kutz.

Plentiful in the Grande Mare pools, and in the gelatinous drippings from the base of the cliffs at Petit Port.

Himantidium gracile, Grun.

Valley below Casrouge, in a spring, plentiful.

Himantidium pectinale, Kutz.

Scattered valves in the submarine peat deposit at Cobo.

Himantidium undulatum, Sm.

Common in the marsh between Grande Mare and Vazon Bay.

\section{CYMBELLEAE.}

Cymbella cuspidata, Kutz.

Grande Mare pools; not conmon.

Cymbella maculata, Kutz.

Marsh on the eastern side of Lancresse, sparingly.

Cymbella affinis, Kutz.

Cymbella ventricosa, Ag.

Cocconema lanceolatum, Ehr.

Plentiful in the pools at Grande Mare and Lancresse. Rather common in the Cobo peat.

Cocconema cymbiforme, Ehr.

Common in gelatinous drippings from rocks at Petit Port

Cocconema Cistula, Hemp.

Amphora binodis, Greg.

Perelle Bay, sparingly, among rock scrapings.

Amphora laevissima, Greg.

Amphora minutissima, Sm.

Amphora acuta, Greg.

Amphora lineata, Greg.

Frequent in gatherings from Cobo at extreme low-water mark.

Amphora salina, Sm.

Salerie, scarce; only a few frustules seen.

Amphora costata, Sm.

Cobo, common in rock scrapings. 
Amphora ovalis, Kutz.

Rather common in fresh-water gatherings.

Amphora incurva, Greg.

Abundant at Cobo and at Bordeaux.

Amphora Grevilleana, Greg.

In the same localities as the last species, but less common.

Amphora robusta, Greg.

Amphora hyalina, Kutz.

Brackish pool at Pulias, frequent.

Amphora affinis, Kutz.

With the last, but less common.

Amphora marina, Sm.

Frequent in shore gatherings all round the coast.

Amphora crassa, Greg.

Petit Bot Bay, a few good characteristic specimens.

Amphora spectabilis, Greg.

Amphora biseriata, Greg.

Moulin Huet, at low-water mark : often unsymmetrical.

Amphora fascinata, Ehr.

Amphora sarniensis, Greg.

\section{ACHNANTHEAE.}

Cocconeis Pediculus, Ehr.

Pool near Fort Doyle, frequent in one of my gatherings.

Cocconeis Placentula, Ehr.

Saints Bay Valley, rare. Rivulet near Lilyvale, rare.

Cocconeis diaphana, $\mathrm{Sm}$.

Rather common: mostly the var. $\beta$. of Smith.

Cocconeis dirupta, Greg.

Rather common in shore gatherings.

Cocconeis Scutellum, Ehr.

Common generally. The var. $\gamma$ of Roper occurred plentifully in rock scrapings from low tide at Perelle Bay.

Cocconeis lamprosticta, Greg.

Petit Bot Bay, one valve. Perelle Bay, a few. 
Cocconeis splendida, Greg.

Two specimens in rock scrapings from Cobo. Perelle Bay, one.

Cocconeis Grevillei, Sm.

Occasional specimens have occurred in nearly all my shore gatherings.

Cocconeis ornata, Greg.

Cocconeis Morrisii, Sm.

Cocconeis pinnata, Greg.

Cocconeis nitida, Greg.

A few valves in rock-gatherings from extreme low-water mark at Cobo, on the eastern side of the bay.

Cocconeis transversalis, Greg.

Cocconeis distans, Greg.

Perelle Bay, one characteristic specimen. Cobo peat deposit, one imperfect valve.

Cocconeis pseudo-marginata, Greg.

Very sparingly in a gathering from the Pulias pool.

Cocconeis punctatissima, Grev.

Cocconeis excentrica, Donk.

Three specimens in rock scrapings at Cobo. These agree exactly with Donkin's description and figures, except that the median line is central, instead of being on one side.

Coccone1s sparsa, Greg.

Achnanthidium lanceolatum, Breb.

Achnanthidium lineare, Sm.

Achnanthidium coarctatum, Breb.

Achnanthes exilis, Kutz.

Achnanthes subsessilis, Kutz.

Achnanthes brevipes, Ag.

Abundant at Petit Bot Bay, and in the brackish pool at Pulias.

Achnanthes longipes, Ag.

Salerie, plentiful on algae in rock-pools: also at Cobo. 
FRAGILARIEAE.

Denticula tenuis, Kutz.

Denticula obtusa, Sm.

Denticula decipiens, Rylands' MS.

'IVas found originally by Prof. Walker Arnott. It appears to be very generally distributed. Character and description will be published in due course.' (Rylands.)

Odontidium mesodon, Kutz.

Saints Bay Valley, common in one gathering.

Plagiogramma Gregorianum, Grev.

Plagiogramma interruptum, Greg.

Plagiogramma inaequale, Grev.

Plagiogramma laevis, Greg.

Fragilaria capucina, Desm.

Abundant in a marsh at the eastern side of Lancresse Common.

Fragilaria virescens, Ralfs.

Diatoma hyalinum, Kutz.

Dimeregramma minor, Ralfs.

Dimeregramma nanum, Ralfs.

Dimeregramma distans, Ralfs.

Dimeregramma fulvum, Ralfs.

Dimeregramma marinum, Ralfs.

Dimeregramma mutabile, Ralfs.

Doryphora amphiceros, Sm.

Synedra lunaris, Ehr.

Saints Bay Valley, common in one of my gatherings.

Synedra longissima, Sm.

'Curiously intermediate between S. longissima and S. radians' (Rylands).

Synedra undulata, Sm.

Several fine and perfect specimens, as well as some broken ones, in a gathering from rocks and corallines at extreme low-water mark, on the coast near Bordeaux. 
Synedra pulchella, Kutz.

Saints Bay Valley, frequent. Fort Doyle pool, common. Cobo, peat deposit, rare.

Synedra acicularis, Sm.

Synedra gracilis, Sm.

Synedra minutissima, Sm.

Pool by Fort Doyle, rather plentiful.

Synedra tenera, Sm.

Synedra Ulna, Ehr., and var. $\beta$.

Synedra deformis, Sm.

Synedra investiens, Sm.

Synedra radians, Kutz.

Common generally in fresh-water gatherings in the south.

Synedra Gallioni, Bory.

More or less common all round the coast.

Synedra fasciculata, Kutz.

Synedra tabulata, Kutz.

Synedra affinis, Kutz.

Synedra Arcus, Kutz.

Synedra superba, Kutz.

Frequent, sometimes abundant, on all parts of the coast.

Synedra fulgens, Sm.

Generally distributed and common.

\section{AMPHIPLEUREAE.}

Amphipleura sigmoidea, Sm.

\section{NITZSCHIEAE.}

Tryblionella marginata, Sm.

Quarry marsh at Bordeaux, scarce. Cobo peat, two specimens.

Tryblionella punctata, Sm.

Tryblionella acuminata, Sm.

Sparingly in the brackish pool at Pulias. 
Tryblionella angustata, $\mathrm{Sm}$.

Tryblionella apiculata, Greg.

Tryblionella constricta, Greg.

Rather frequent in shore gatherings from various parts.

Tryblionella gracilis, Sm.

Pool by Fort Doyle, frequent. Mr. Rylands notes the var. B. minor in his list.

Nitzschia Amphioxys, Sm.

Ioulin Huet cascade, sparingly. Roadside rivulet near Lilyvale, frequent. Fort Doyle Pool, scarce.

Nitzschia vivax, Sm.

Marsh between Grande Mare and Vazon, frequent.

Nitzschia dubia, Sm.

Common in the Pulias pool. Mr. Rylands notes both the type and the var. $\beta$.

Nitzschia plana, Sm.

Nitzschia parvula, Sm.

Common in a roadside streamlet near Lilyvale, Catel.

Nitzschia panduriformis, Greg.

Nitzschia sigmoidea, Sm.

Pool by Fort Doyle, plentiful.

Nitzschia Brebissonii, Sm.

Occasional in the pools at Grande Mare.

Nitzschia obtusa, Sm.

In the submerged peaty deposit at Cobo, sparingly.

Nitzschia Sigma, Sm.

Common in brackish pools, and on the shore.

Nitzschia linearis, Sm.

Generally common in fresh-water gatherings.

Nitzschia minutissima, Sm.

Nitzschia Palea, Sm.

Valley below Casrouge, common in a water-trough.

Nitzschia spathulata, Breb. 
Nitzschia scalaris, Sm.

Frequent in a reedy marsh between Crande Mare and Vazon. Perelle, two broken valves. Cobo peat deposit, not uncommon, but mostly broken specimens. In Wallich's gatherings 'a single, muchhidden valve only occurred.'

Nitzschia insignis, Greg.

Nitzschia virgata, Roper.

Nitzschia spectabilis, Sm.

Nitzschia Closterium, Sm.

Nitzschia birostrata, Sm. (Ceratoneis longissima, Breb.)

Salerie, one very fine specimen. Two or three at extreme lowwater mark at Cobo.

Nitzschia socialis, Greg.

Bacillaria paradoxa, Gmel.

Homoeocladia filiformis, Sm., var. $\beta$.

\section{NAVICULACEAE.}

Navicula cuspidata, Kutz.

Rivulet near Lilyvale, frequent. Fort Doyle pool, rather scarce.

Navicula angulosa, Greg.

Perelle Bay, at extreme low-water mark, three specimens.

Navicula Lyra, Ehr.

In nearly all the coast gatherings, but sparingly. Varies much in size, and to some extent in shape also.

Navicula forcipata, Greg.

Navicula Hennedyi, Greg.

Cobo rock gatherings, scarce. Salerie, one valve. Perelle Bay, two or three.

Navicula clavata, Greg.

Occasional in the Cobo gatherings. Two or three specimens at Perelle Bay.

Navicula Smithii, Breb.

Moulin Huet and Cobo, scarce.

Navicula fusca, Greg. 
Navicula nebulosa, Greg.

A few specimens from extreme low water at Cobo.

Navicula sp.

In the same gathering as the last species I found two valves of a very beautiful, broadly elliptic form allied to it, but having a narrow crescent of striae interposed between the median line and the uniformly narrow marginal band, so that there are two granular blank spaces and three bands of striae between the median line and the edge of the valve.

Navicula elliptica, Kutz. (N. ovalis, Sm.)

Common, often abundant, in fresh-water gatherings.

Navicula lineata, Donk.

Three or four specimens from extreme low tide, Cobo.

Navicula Liber, Sm.

On Corallines at Moulin Huet and Cobo, frequent. Also frequent at Petit Bot Bay, but mostly a small form.

Navicula rhombica, Greg.

N'avicula elegans. Sm.

Abundant in the peaty deposit under the sand at Cobo.

Navicula palpebralis, Breb.

Very sparingly in gatherings from Cobo and the Salerie.

Navicula praetexta, Ehr.

Three specimens in rock scrapings from low-water mark at Perelle Bay; two from Cobo.

Navicula pygmaea, Kutz.

Streamlet near Lilyvale, Catel, scarce.

Navicula aestiva, Donk.

More or less frequent in all shore gatherings. Easily recognised by the dry valve being bright blue.

Navicula Allmaniana, Ralfs. (Pinnularia, Greg.)

Navicula pectinalis, Breb.

Navicula mesotyla, Ehr.

Navicula laevissima, Kutz.

Navicula gibberula, Sm.

Saints Bay Valley, scarce. 
Navicula inflata, Kutz.

Navicula Amphisbaena, Bory.

Generally distributed and common. Var. $\beta, S m$. Pool near Fort Doyle, frequent. Pulias pool, less common.

Navicula pusilla, Sm.

Navicula cryptocephala, Kutz.

Common, often abundant, on stones over which water trickles.

Navicula dicephala, Ehr.

Navicula lacustris, Greg.

Navicula humerosa, Breb.

This species has occurred in most of my coast gatherings, but very sparingly: seldom more than two or three specimens in each.

Navicula granulata, Breb.

One valve in a mixed gathering from the Salerie.

Navicula latissima, Greg.

Navicula punctulata, Sm.

Common in the brackish pool at Pulias.

Navicula crassinervia, Breb.

Saints Bay Valley, common.

Navicula didyma, Ehr.

More or less common in all the coast gatherings. Var. $\beta$ (sporangial, of Smith). Single valves at Saints Bay, Cobo, and Perelle. Var. $\gamma$, Greg. On several parts of the coast, but sparingly. Plentiful in the Cobo peat deposit.

Navicula incurvata, Greg.

Navicula Musca, Greg.

Navicula Bombus, Kutz.

A few specimens in the Cobo gatherings, and a few at Perelle Bay.

Navicula Pandura, Breb.

Rather common and generally distributed.

Pinnularia nobilis, Ehr.

Grande Mare bog-pools, not uncommon. Marsh on the east side of Lancresse, fragments only. Broken specimens occur in the Cobo peat. 
Pinnularia major, Rab.

Common at Grande Mare and in the Cobo peat.

Pinnularia Tabellaria, Ehr.

Pinnularia acrosphaeria, Rab.

Saints Bay Valley and Casrouge Valley, frequent.

Pinnularia viridis, Rab.

Generally distributed and common.

Pinnularia hemiptera, Rab.

Pinnularia oblonga, Rab.

Grande Mare pools, common.

Pinnularia peregrina, Ehr.

Abundant in the marsh near Vazon Bay. Pulias pool, common. Salerie, frequent.

Pinnularia radiosa, Rab.

Frequent in the Cobo peat deposit.

Pinnularia viridula, Rab.

Generally distributed and common.

Pinnularia gracilis, Sm.

Marsh between Grande Mare and Vazon Bay, in abundance.

Pinnularia borealis, Ehr.

Pinnularia acuminata, Sm.

Pinnularia distans, Sm.

More or less common all round the coast.

Pinnularia Cyprinus, Sm. (P. Normani, Rab.)

Brackish pool at Pulias, abundant.

Pinnularia acuta, Sm.

Grande Mare, common.

Pinnularia longa, Greg.

Two specimens in a Cobo gathering from low water.

Pinnularia acutiuscula, Greg.

Pinnularia Entomon, Ehr.

One fine and perfect valve in a mixed gathering from Petit Bot Bay.

Pinnularia interrupta, Sm.

Abundant in a spring in the valley below Casrouge, Forest. 
Pinnularia divergens, Sm.

Marsh at the eastern side of Lancresse : a rather small form resembling Smith's $P$. stauroneiformis, var. $\beta$.

Pleurosigma arcuatum, Donk.

A sprinkling of specimens occurred in a gathering I made in I889 from a small roadside marsh at Bordeaux which has since been filled with quarry rubbish. Dr. Donkin aptly compares the curved rostrate apices of this diatom to the bill of a curlew.

Pleurosigma macrum, Sm.

One fine specimen in a rock gathering from Cobo.

Pleurosigma prolongatum, Sm.

Pleurosigma formosum, Sm.

Cobo peat deposit, one imperfect specimen. The colour of the dry valve is described by Smith, Ralfs, Rabenhorst, and others as pale chestnut brown: but in scores of gatherings containing this beautiful diatom which $I$ have made at various times in Hampshire, Devonshire, and Cornwall, the dry valve has invariably been of a deep blue colour.

Pleurosigma decorum, Sm.

Petit Bot Bay, abundant. Perelle Bay and Bordeaux, rather common. Salerie, a few.

Pleurosigma rigidum, $\mathrm{Sm}$.

More or less common in low-water gatherings from all parts of the coast. Petit Bot Bay, occasional and rather small.

Pleurosigma validum, Shadb. (?).

Frequent at Cobo and Petit Bot Bay at extreme low water: more rarely at Saints Bay, Moulin Huet, Bordeaux, and Perelle. A large and nearly straight species with broad apices, very slightly flexed median line, and delicate striation. It agrees exactly with the species described under this name by Ralfs ('in Pritchard's Infusoria, I86I), but I have seen no figure.

Pleurosigma strigosum, Sm.

Common in a mixed scraping of rocks and corallines from low water at Cobo.

Pleurosigma naviculaceum, Breb. ( $P$. transversale, Sm.)

Rather common in low-water gatherings from all parts.

Pleurosigma elongatum, Sm.

Frequent in a gathering from a small marsh at Bordeaux.

Pleurosigma intermedium, Sm. 
Pleurosigma angulatum, Sm.

Abundant in the brackish pool at Pulias, and in the (now filled up) marsh at Bordeaux. Sparingly at Moulin Huet.

Pleurosigma quadratum, Sm.

Pulias pool, and at low-water mark, Bordeaux : in each case only a single specimen.

Pleurosigma Normani, Ralfs.

Rather common at Cobo, Bordeaux, and Perelle Bay.

Pleurosigma Hippocampus, Sm.

Marsh between Grande Mare and Vazon: rather scarce.

Pleurosigma acuminatum, Sm.

Pleurosigma Wansbeckii, Donk.

Perelle Bay, one specimen.

Pleurosigma attenuatum, Sm.

Fort Doyle pool, abundant. Saints Bay Valley, common.

Pleurosigma Spencerii, Sm.

Roadside streamlet near Lilyvale, common. A few specimens in the Cobo peat deposit.

Donkinia compacta, Ralfs.

Perelle Bay, one specimen.

Toxonidea insignis, Donk.

Cobo, at extreme low-water mark, three specimens. Perelle Bay, one. All the specimens were short and broad, resembling a cocked hat rather than a strung bow, to borrow Donkin's apt comparison.

Stauroneis Phoenicenteron, Ehr.

Casrouge Valley and Grande Mare, rather common.

Stauroneis gracilis, Ehr.

Generally distributed and not uncommon.

Stauroneis linearis, Sm.

Stauroneis anceps, Ehr.

Plentiful in a water-trough near Casrouge, Forest.

Stauroneis pulchella, Sm.

Common in all marine gatherings, varying much in size. 
Stauroneis australis, Grev. (?).

One fine specimen in a gathering from low water at Cobo. A large species, agreeing well with Greville's figure and description of the Queensland form, except that the stauros is longer and broader. Dry valve nearly colourless.

Amphiprora vitrea, Sm.

Amphiprora elegans, Sm.

Amphiprora lepidoptera, Greg.

Rather common in some of the Cobo gatherings. A few at Bordeaux and at Petit Bot Bay.

Amphiprora maxima, Greg.

Amphiprora complexa, Greg.

Amphiprora alata, Kutz.

Abundant in a small roadside marsh at Bordeaux, now filled up Sparingly at Petit Bot Bay and Perelle.

Diadesmis Williamsoni, Greg.

Mastogloia Smithii, Thw.

Common in some of the gatherings from Grande Mare.

Mastogloia Dansei, Thw.

Plentiful among gelatinous drippings on rocks at Petit Port.

Mastogloia apiculata, Sm.

Sparingly in a gathering from Cobo.

Berkeleya fragilis, Grev.

Colletonema vulgare, Sm.

Schizonema crucigerum, Sm.

Schizonema Grevillei, Ag.

GOMPHONEMEAE.

Gomphonema tenellum, Kutz.

Gomphonema dichotomum, Kutz.

Frequent in the marsh at the eastern side of Lancresse.

Gomphonema Vibrio, Ehr. 
Gomphonema acuminatum, Ehr.

Generally distributed and rather common.

Gomphonema olivaceum, Kutz.

Valley below Casrouge, and Saints Bay Valley, sparingly.

Gomphonema curvatum, Kutz.

Streamlet near Lilyvale, Catel.

Gomphonema marinum, Sm.

\section{MERIDIONEAE.}

Meri lion constrictum, Ralfs.

Meridion marinum, Greg.

Podosphenia Ehrenbergii, Sm.

Rhipidophord Dalmatica, Kutz.

Rhipidophora Lyngbyei, Kutz.

Rhipidophora paradoxa, Lyng.

Rhipidophora elongata, Sm.

Abundant on algae at Bordeaux and Cobo.

Licmophora splendida, Grev.

Licmophora flabellata. Ag.

Generally distributed and in some localities abundant in rockpools. By a curious oversight the names of the only two species of Licmophora are reversed in Smith's monograph of the British Diatomaceae. The L. splendida of that work is the L. flabellata of Agardh, and Smith's L. flabellata is the true L. splendida of Greville. This singular error was pointed out by Mr. Roper in 1863 . Both species were gathered in Guernsey by Wallich (teste Rylands).

\section{TABELLARIEAE.}

Grammatophora marina, Kutz.

Common all round the coast.

Grammatophora macilenta, Sm.

Sparingly in a gathering from Perelle Bay. 
Grammatophora hamulifera, Kutz.

Cobo, at low-water mark, a few specimens.

Grammatophora serpentina, Ralfs.

Very common.

Rhabdonema arcuatum, Kutz.

Common generally.

Rhabdonema minutum, Kutz.

Rhabdonema adriaticum, Kutz.

Common in low-water gatherings.

Striatella unipunctata, Ag.

Common on algae in rockpools at Bordeaux, Cobo, and Salerie.

\section{BIDDULPHIEAE.}

Isthmia enervis, Ehr.

Plentiful and fine at Cobo and Petit Bot. Less common in gatherings from several other parts of the coast.

Biddulphia pulchella, Gray.

More or less common at low-water mark.

Biddulphia Regina, Sm.

'Occurs in three of the gatherings: ought to be sought for growing.' (Rylands.)

Biddulphia aurita, Breb.

Biddulphia Rhombus, Sm.

Biddulphia Baileyi, Sm.

Scattered specimens have occurred in nearly all my low-water gatherings, but they would not amount to very many in the aggregate. Mr. Rylands quotes a note on this species by Dr. Wallich: "Taken with the skimming-net : evidently a floating species.'

Biddulphia granulata, Roper.

Biddulphia turgida, Sm.

I have only met with a single specimen of this species, in a gathering from Cobo: but Mr. Rylands gives 'Pond and beach at the Vale : plentiful in the slides.'

Triceratium Favus, Ehr.

Triceratium alternans, Bail.

Triceratium striolatum, Ehr. 
Triceratium armatum, Roper. (T. spinosum, Bail.)

\section{Triceratium Brightwellii, West.}

Amphitetras antediluviana, Ehr.

Generally distributed, but especially common on the south coast. The var. $\beta$, with deeply concave sides, occurs at Moulin Huet, sparingly intermixed with the type. In my early diatom-collecting days, some five-and-twenty years ago, I used to find this var. $\beta$ in profusion on the shores of the Solent, near Lymington. Intermixed with it, though always sparsely, was the splendid pentagonal var. $\gamma$, an excessively rare form, and one of the most brilliant and beautiful of British diatoms, resembling a star composed of small diamonds.

Eupodiscus Ralfsii, Sm.

Frequent in low-water gatherings all round the coast.

Eupodiscus crassus, Sm.

Eupodiscus subtilis, Greg.

A few specimens from Petit Bot Bay, at extreme low water.

Eupodiscus tessellatus, Roper.

Eupodiscus fulvus, Sm.

Bordeaux, one specimen.

Auliscus sculptus, Ralfs.

Petit Bot Bay, one small specimen.

Chaetoceros Wighami, Brightw.

'Taken by the skimming-net. Found in myriads at or near the surface: day quite calm. These are evidently floating species: all contained bright yellow endochrome: could be seen by the naked eye.' (Rylands.)

Rhizosolenia styliformis, Brightw.

'A second species occurs in one of the sea-surface skimmings-a very fine form, but not in a condition to be identified.' (Rylands.) 


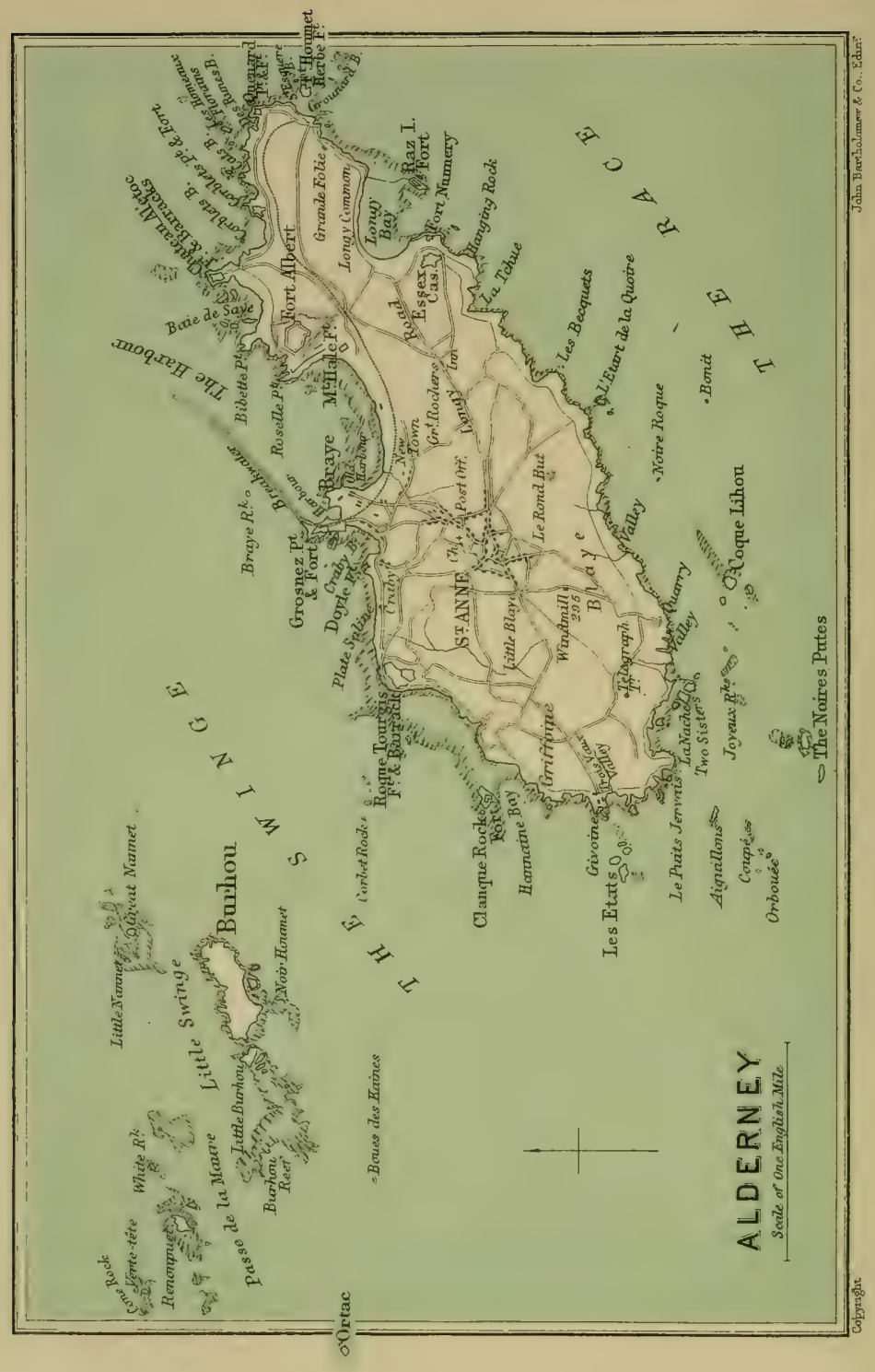




\section{ALDERNEY.}

$\mathrm{O}^{\mathrm{r}}$ $\mathrm{F}$ all the Channel Islands the one least known to the outside world is Alderney. It is customary to speak of it as a bleak and desolate spot, devoid of any single object of interest, and surrounded by an exceptionally tempestuous sea. Scarcely five per cent. of the people who annually visit Jersey, Guernsey, and Sark ever set foot in Alderney, and to thousands of the permanent residents of the larger islands it remains literally a terra incognita. No doubt the average tourist, bent on sight-seeing, would find it a dull and unattractive sort of place : but to a dweller in cities, or to the tired brain-worker seeking rest, Alderney is in several respects. without a rival, even in this favoured archipelago. The coast scenery is extremely picturesque, and in many places hardly to be surpassed for wildness and beauty: the air is delightfully pure and bracing: there is plenty of sunshine and comparatively little rain: whilst, above all, there is an indescribable sense of liberty and freedom, which is altogether lacking in the other islands. Nature has provided the place with all the requirements of a splendid health resort: and it may be that some day in the remote future Alderney will flourish as a fashionable watering-place. At present, however, there are but few indications of any immediate development in that direction.

It is curious that, although situated so close to the mainland of France that the houses may be distinguished by the naked eye in clear weather, Alderney is the least French of all the Channel Islands. The local patois, which differs considerably from the vernacular of the other islands, is rarely heard nowadays : and the English spoken by the common people is purer than that of the corresponding class in either Jersey or Guernsey. There is regular communication with Guernsey by steamer three times a week, and once a week with Cherbourg.

Alderney is shaped like an elongated oval, its extreme length being three and a half miles from north-east to south-west, and its greatest width a little over a mile. The central portion consists of a level plateau about $25^{\circ}$ or 300 feet above sea-level, bordered on the south and west by precipitous cliffs, and sloping gradually towards the north and east, where there are some fine sandy bays. The 
town of St. Anne's, situated almost in the centre of the island, is unpretentious, clean, and healthy, and comprises a greater number and variety of shops than the visitor would expect to find. It is built on the upper slopes of the hill overlooking the harbour, the most conspicuous building being the handsome church, erected about fifty years ago to replace a very ancient one, which dated from the early part of the twelfth century.

At the present day the population of the island is much less than it was during the middle of the century, when the Government works were constructed. It varies according to the strength of the garrison; but the civil population amounts to about 1500 , and as a general rule from 300 to 400 suldiers are quartered here.

Owing to its situation at the entrance of the English Channel, Alderney has always been regarded as an outpost of great military importance, and enormous sums of money have been expended by our Government in constructing a long chain of forts and batteries all round the low-lying coast, as well as in erecting a breakwater, which, through some blundering in the design, is unfortunately less useful than was originally intended.

Westward from Alderney several groups of islets and rocks stretch out for many miles, and. when viewed from the heights of Butes Hill, compose a picture of rare beauty. The uninhabited island of Burhou (a description of which will be found elsewhere in these pages) is par excellence the seabirds' home, and is seldom invaded by man, except during the nesting season. This desolate islet lies on the other side of the passage called the Swinge, one of the most dangerous pieces of water in the Enylish Channel. To the right are the Nannel Rocks, to the left Ortach, rising out of the sea like a colossal haystack. Further away, seven or eight miles from Alderney, glitters the "hite tower of the Casquets Lighthouse, marking the most perilous reef on the British coast, where, as Shakesperre says of the Goodwins, "the carcases of many a tall ship lie buried '-and a spot memorable for many a long year to come by the dreadful wreck of the steamship Stella, on the eve of Good Friday, 1899.

The Casquet Rocks lie almost exactly midway between Weymouth and St. Malo, and are the outposts of a gigantic natural breakwater partly submerged, forming the northern arm of the great bay in which the Channel Islands are situated. 'If the sea-bottom were elevated a hundred and twenty feet,' says Ansted, 'the island of Alderney, the Burhou and Ortach group, and the Casquets would be connected by low land, and form a narrow island about twelve miles long. The eastern extremity of this island would approach within a few miles of the coast of France, and it would range nearly parallel to the south coast of England between Weymouth and the Isle of 'Wight.'

The geology of Alderney in the main resembles that of the sister 
islands, the chief peculiarity being the occurrence of sandstone or gritstone, which replaces the more usual diorite in the north-eastern end, and presents on that coast a type of rock scenery not found elsewhere in the Channel group. A remarkable natural curiosity is a magnificent block of this stone, forty feet high, which juts out from the cliff and leans seawards-whence its name, La Roche Pendante, or the Hanging Rock.

The soil in some parts of the island is deep and of excellent quality, but in others it is poor, and produces but thin crops. Except in the valleys that open out towards the north, there are few trees, and they do not attain any large size. Springs of excellent water abound, but streamlets are few in number and very small. The air is very much drier and more bracing than in Guernsey, as well as colder, so that even in summer the evenings are often chilly; but the winters are mild, and the rainfall is below the average for these islands.

In an old book, which has now become somewhat scarceJacob's Annals of the British Norman Isles, published in 18.30-it is asserted that 'the botanist will be disappointed if his sole object in visiting Alderney is to collect rare plants'-a statement which loses some of its force, however, when the writer candidly confesses, a few lines further on, that he does not possess 'the microscopic eye of those who make botany their peculiar study.' A more intimate acquaintance with the subject would have convinced the old author that not only does. Alderney possess an exceedingly interesting flora, but also that a visitor will find here in a single day's botanising a larger variety of really rare plants than in either of the other Channel Islands. There are certainly not many places in England where, within an area of four square miles, a dozen plants may be found equal in rarity to the following :-

Sinapis incana.

Helianthemum guttatum.

Polycarpon tetraphyllum.

Hypericum linarifolium.

Unonis reclinata.

Arthrolobium ebracteatum.
Herniaria glabra.

Bupleurum aristatum.

Centaurea aspera.

Orobanche Millefolii.

Romulea Columnae.

Bromus maximus.

Little, if anything, was known about the wild plants of this outof-the-way spot until the publication in 1839 of the first Flora of the Channel Islands-Professor C. Cardale Babington's little book, entitled Primitiae Florae Sarnicae. Babington spent a week in Alderney in 1838 , from the 12 th to the 19 th of July, and notes in his Journal that he then gathered 330 plants, 'exclusive of several as yet undetermined.' This estimate, however, proved to be a little too large, for the number of Flowering Plants and Ferns he records for the island is 313 species, as stated in the Preface of his book. 
During the sixty years that have since elapsed, many English and French botanists have visited Alderney, but I am not aware that any additional information has been published on the subject. Fecling certain that there was yet much to be learnt about the botany of that little island, I spent the summer there in I899, and compiled a list of 426 phanerogams and ferns, one-third of them being unrecorded by Babington. This list was published in the Trunsactions of the Guernsey Society of Natural Science for 1899 . Another year's work has enabled me to fill up several gaps and add a good many species to the list, so that the phanerogamic flora of Alderney may now be considered fairly well worked up.

Any one sufficiently acquainted with the flora of Guernsey and Sark will find Alderney exceedingly interesting, not only on account of the striking difference in the distribution of many of the species, but also because the number of plants which do not occur elsewhere in the area now dealt with is relatively large. Alderney is one-sixth of the size of Guernsey, and yields, in roun 1 numbers, two-thirds of the phanerogams : but no less than thirty-seven of these, or seven per cent. of the total, have not been found in the larger island. The following is a complete list so far as known at present :-

Cochlearia officinalis.

Helianthemum guttatum.

Dianthus Armeria.

Silene nutans.

Geranium sanguineum.

Vicia varia.

Onobrychis sativa.

Agrimonia Eupatoria.

Rubus Idaeus.

Rosa involuta.

tomentosa. stylosa.

Sedum Telephium.

Asperula cynanchica.

Valerianella eriocarpa.

Diotis maritima.

Arctium nemorosum.

Centaurea Scabiosa.

Carduus acaulis.
Tragopogon minor.

Picris hieracioides.

Crepis taraxacifolius.

Cuscuta trifolii.

Orobanche Rapum.

Calamintha Clinopodium.

Statice lychnidifolia.

Thesium humifusum.

Salix purpurea. stipularis. aurita

Orchis pyramidalis.

Juncus glaucus.

Trisetum flavescens.

Avena pubescens.

Poa sudetica.

Briza media.

Equisetum maximum.

With the exception of some lichens, no cryptogamic plants have hitherto been recorded for Alderney; and the present lists simply give the result of my own researches during the year 1900 . They must be regarded as suggestive rather than exhaustive.

The air is so dry here that the moss-vegetation is far less luxuriant than in Guernsey. The occurrence, however, of such an excessively rare British moss as Bartramia stricta (a species confined 
in this country to a single locality in Wales, being extinct in Sussex) shows that the bryologist will find something to reward his researches even in so circumscribed a field. With regard to the lichens, I have added to my own imperfect list such species as are recorded for Alderney by Mr. C. Larbalestier in the last edition of Leighton's Lichen Flora of Great Britain (1879) and in Crombie's Monograph of British Lichens (1894). The list of Fungi shows that, although deficient in woodland and warm sheltered nooks and valleys, this island is, from a mycological point of view, more productive than might be supposed ; and the number of species would most certainly be largely increased by prolonged and critical study.

As a collecting ground for seaweeds Alderney is inferior to the two larger islands by its greater exposure, and also by the want of outlying ledges of rocks, which are only to be reached at the very lowest tides. 'The south side is practically inaccessible: but several productive localities occur on the north coast, and at Longy. All the seaweeds now enumerated were collected by my wife and myself during the summer of 1900 : and I wish to acknowledge my indebtedness to Mr. E. M. Holmes for kindly determining many critical and microscopical species.

The following list shows the forty-five species of Alderney cryptogams which have not hitherto been detected in Guernsey. Doubtless many of them will be found if searched for.

Pottia crinita. minutula.

Barbula fallax. rigidula.

Weisia verticillata.

Trichostomum crispulum.

Bartramia stricta.

Webera Tozeri.

Hypnum fluitans.

Jungermannia ventricosa.

Volvaria gloiocephala.

Coprinus atramentarius.

Corticium caeruleum.

Erysiphe communis.

Poronia punctata.

Rhytisma acerinum.

Uromyces Polygoni. concentrica.

Puccinia Menthae. Violae. suaveolens.

Coleosporium Euphrasiae. Leptogium biatorinum.
Lecanora privigna. torquata. subcarnea. coniopta. pyreniospora.

Lecidea caligans.

Normandina laetevirens.

Verrucaria striatula. microsporoides.

Ulva rigida. polysticta.

Cladophora lanosa.

Stictyosiphon Griffithsianum.

Sphacelaria fusca. olivacea.

Chilionema ocellatum.

Alaria esculenta.

Polysiphonia fibrillosa.

Callithamnion brachiatum.

Ceramium circinatum.

Lithothamnion incrustans.

Corallina mediterranea. 
In every section of the flora Alderney differs from the mother island by the possession of plants peculiar to itself, and in many respects approximates more closely to the continental mainland, as would be expected from its geographical position.

The flora of Alderney, as recorded in the following pages, consists of 503 Flowering Plants, 3 Equisetaceae, 13 Ferns, 93 Mosses, 2 I Hepaticae, 109 Fungi, I 5 Lichens, and 156 Seaweeds.

\section{RANUNCULACEAE.}

Ranunculus trichophyllus, Chaix. Rare. In the pond on Longy Common, and in marshy places at Mauney.

R. hederaceus, L. Very rare. Occurs sparingly in a ditch on the hillside at Clanque. Babington found this plant in the valley below Rose Farm.

R. Flammula, L. Rather common in wet places. Var. radicans, Nolt. Clanque cliffs.

R. Lingua, L. In the pond on Longy Common, plentiful and fine, growing six feet high or more. This is the only station for the plant in these islands. Sixty years ago it grew in the valley below Rose Farm, but it has disappeared from that locality.

R. Ficaria, L. Common generally: abundant in grassy fields. in some parts of the island.

R. acris, L. Common in wet places and moist fields.

R. repens, L. Generally distributed but not common.

R. bulbosus, L. Very common. In May igoo, on the north: s'ope of Fort Tourgis, amongst multitudes of the ordinary form, I found a root bearing very double flowers, resembling the garden. variety called Bachelor's Buttons. 
R. parvifiorus, L. Plentiful on the western side of Longy Common; and in two places on the cliffs west of La Quoire. Undoubtedly native in these localities.

Dephinium Ajacis, Reich. About a dozen plants in 1900 on the embankment of the road between New Town and the large quarry. Certainly of garden origin, and only to be regarded as a casual in this island. Another foreign plant, Vicia varia, grew close by in the same year.

\section{PAPAVERACEAE.}

Papaver hybridum, L. Frequent in cultivated ground in all parts, but more common in the eastern half of the island.

P. Rhoeas, L. Very common.

P. dubium, L. Generally distributed and rather common, but less so than the last species.

P. somniferum, L. Scattered plants in cultivated ground and on roadsides.

Glaucium luteum, Scop. More or less common all along the sandy shores; abundant in some places, as at Platte Saline, and in the vicinity of the Harbour.

\section{FUMARIACEAE.}

Fumaria pallidiflora, Jord. On the cliffs opposite Coque Lihou, in good quantity. Sparingly on the cliffs near La Quoire. Reuters Valley, a few plants.

F. Boraei, Jord. Generally distributed and rather common.

F. confusa, Jord. Quite as widely diffused as the last, but rather less common.

F. officinalis, L. Plentiful in cultivated ground, especially on the Blaye. In two different parts of the Blaye I have found var. media, Loisel., a form closely resembling $F$. confusa in its habit of growth, but having the flowers and fruic of $F$. officinalis. 


\section{CRUCIFERAE.}

Nasturtium officinale, R. Br. Common on streamsides and in wet places generally.

Barbarea praecox, R. Br. Half a dozen fine plants in an old quarry at Rochers.

Arabis hirsuta, R. Br. Common on the moorlands and in dry, sandy places : often on tops of walls.

Cardamine flexuosa, With. Slopes of Essex Castle Hill. Marshy place towards Corbelets. Rose Farm Valley.

C. hirsuta, I. Common.

Sisymbrium officinale, Scop. Very common.

Alliaria officinalis, Andrz. Rare. Reuters Valley, plentifully. In Fl. Sarn. it is noted for Platte Saline, but it does not grow there now.

Brassica campestris, L. The var. napus, L., is frequent on the Blaye; occasional elsewhere in cultivated ground and on roadsides.

B. Cheiranthus, Vill. Recorded for Braye Bay in Fl. Sarn. I have searched for this plant all over the island, but in vain: perhaps it is now extinct.

Sinapis arvensis, L. Abundant in cultivated ground, especially on the Blaye, where it sometimes grows so thickly as to form the principal crop of the field. On the shore at Longy Bay I have noticed the var. villosa, Merat, growing with the type.

S. alba, L. Rare. One large clump at Platte Saline, on the sea bank below Fort Tourgis.

S. incana, L. Abundant in the neighbourhood of Braye Bay: and more or less frequent all over the eastern half of the island. Both the forms mentioned in Fl. Sarn. grow here.

Diplotaxis tenuifolia, DC. An abundant and pestilent weed in dry pastures and on hillsides, especially on the east side of the island. I have been assured that this plant was introduced into Alderney at the time of the Government works: but it certainly existed here before the year 1838 , as it is mentioned in Fl. Sarn. as occurring at Platte Saline and Braye Sands. 
D. muralis, DC. Rather common in cultivated ground, particularly when sandy. Var. Babingtonii, Syme. Roadside above Platte Saline, one plant.

Alyssum maritimum, L. Plentiful on the walls and roadside below the Wesleyan Chapel, and in and about an old quarry lower down the valley. Walls above Government House, and near the Church.

Draba verna, L. Common on banks and sandhills all over the east side. On a wall-top in Rose Farm Valley. I have seen this little plant in full flower here in February.

Cochlearia officinalis, L. . Plentiful along about fifty sards of the sea-cliff between Fort Tourgis and Clanque: also in good quantity on the north side of Fort Albert, and on the shore east of Corbelets This species does not occur in Guernsey or the smaller islands.

C. danica, L. One of the most widely distributed anu abundant of spring flowers.

Armoracia rusticana, Rupp. Occasional in all parts, flowering freely in several places, especially by the old millpond in Rose Farm Valley.

Teesdalia nudicaulis, R. Br. Not uncommon on the cliffs: local, but usually abundant where it occurs.

Lepidium Draba, I. Rare. On the Railway embankment between White Gates and Baie de Saye, plentiful in one spot.

L. Smithii, Hook. Very rare. Roadside by Fort Tourgis, one plant.

L. ruderale, L. Rare. Roadside above Crabbie Bay, about twenty plants in 1899 and 1900.

Capsella Bursa-pastoris, DC. Common. In a cultivated field below the Terrace I noticed in I899 some very large plants two and a half to three feet high.

Senebiera Coronopus, Poiret. Frequent throughout the island : often plentiful where it occurs.

S. didyma, Pers. Generally distributed, but rather rare. Sometimes grows intermixed with the last species, although much less common. 
Cakile maritima, Scop. More or less common in all the sandy bays.

Crambe maritima, L. Rare. On the shingle by Fort Houmet, in good quantity. Western side of Platte Saline, one plant.

Raphanus Raphanistrum, L. Scattered plants on the Railway embankment, and in the neighbourhood of Longy.

R. maritimus, Sm. Plentiful on the cliffs and more or less. all along the sandy coast. Plants with white flowers occasionally occur.

\section{RESEDACEAE.}

Reseda lutea, L. It is doubtful if this plant still occurs in the island. Sixty years ago it was found by Babington 'between Braye Bay and Mauney Barracks,' but it is not there now.

R. Luteola, L. Rare generally : occasionally plentiful in old quarries, and on the Railway line. A few scattered plants near Essex Castle.

\section{CISTACEAE.}

Helianthemum guttatum, Mill. This is perhaps the most interesting of Alderney plants, as it occurs nowhere else in the British Isles, except in Jersey. It grows in the greatest profusion along a quarter of a mile of cliff on the south coast, not far from Val du Sud. At the beginning of June it is in full flower: I have seen it as early as May r8th, and as late as June 23 rd. It is curious that, although the flowers (which expand only in bright weather) are not injured by a violent wind, the most careful handling will not prevent the petals dropping as soon as the plant is gathered. The dead and dry plants retain their leaves and remain conspicuous. throughout the summer. Occasionally the flowers are unspotted.

\section{VIOLACEAE.}

Viola Riviniana, Reich. Common throughout the island.

V. arvensis, Murr. In cultivated ground: rather rare, but generally distributed. 
POLYGALACEAE.

Polygala vulgaris, L. Not common. The var. oxyptera, Reich., is occasionally found in furze-brakes and on the cliffs.

\section{CARYOPHYLLACEAE.}

Dianthus Armeria, L. Very rare. One clump on the cliffs to the west of Val du Sud. This species occurs in Sark, but not in Guernsey.

Silene anglica, L. Frequent in cornfields and other cultivated ground : also in several places on the cliffs. Near La Chue there is a form with pale rosy-pink flowers, which in Guernsey would be set down as a hybrid between this species and S. quinquevulnera: but the latter does not grow in Alderney.

S. nutans, L. Rare. Two good patches in a furze-brake to the south of Fort Tourgis: sparingly on the cliffs near Chaise à l'Emauve. This species occurs plentifully in Herm, but is unknown in Guernsey.

S. inflata, Sm. Rather common all over the eastern half of the island : rare in the west.

S. maritima, With. Very common on the coast.

S. conica, L. Rare. Plentiful on one part of the hillside at the lower end of the Braye Road. This is the dwarf form, which occurs in Guernsey: but at the western side of Longy Common there is an unusually large form of this plant, the stems varying from a foot to as much as sixteen inches in height. This tall form grows in profusion over a quarter of an acre of ground.

Lychnis Flos-cuculi, L. Common in wet places. With pure white flowers in Rose Farm Valley.

L. vespertina, Sibth. Generally distributed and rather common throughout the island. With pale pink flowers at Platte Saline.

L. diurna, Sibth. This species, so abundant in Guernsey, is quite rare in Alderney: and, though the flowers are occasionally of a deep rose colour, they are more often of a sickly, washed-out pink. The plant occurs in several places, but sparingly. 
L. Githago, Scop. Rare. A plant or two in cornfields here and there on the Blaye. A few specimens in 1900 in the yuarry by Crabbie Bay.

Sagina procumbens, L. Common.

S. apetala, L. Common.

S. ciliata, Fr. Rather common, especially on the cliffs. Two varieties occur, var. ambigua, Lloyd, which is the prevailing form : and var. patula, Jord., on the cliffs east of Val du Sud. On the coast between Corbelets and Quenard I have seen plants of var. ambigua seven inches high.

S. maritima, Don. Common on the low-lying coast.

S. subulata, Wimm. Frequent on the cliffs.

S. nodosa, Meyer. Recorded for Alderney in Fl. Sarn., but no locality is specified. 'I'here are many suitable places for this plant, and it is hardly likely to have become extinct even in sixty years: but, though well searched for, I have not been able to find it.

Honkeneja peploides, Ehrh. Occurs in all the sandy bays: occasionally also on the sandhills.

Arenaria serpyllifolia, L. Generally distributed and common. Both the type and var. leptoclados, Guss., occur : and I have found the var. Lloydii, Jord., at Longy Bay.

Stellaria media, Vill. Common.

Cerastium glomeratum, Thuill. Common both in the lowlands and on the cliffs.

C. triviale, Link. Common.

C. semidecandrum, L. Plentiful on the sandhills all round the north and east coast, and on parts of Butes Hill.

C. tetrandrum, Curt. Very common.

Moenchia erecta, Sm. Very rare. Cliffs at La Chue.

Polycarpon tetraphyllum, L. Rather common throughout the island.

Lepigonum rubrum, Fr. Rather rare: generally found on roadsides. 
L. rupestre, Kindb. Very common on the coast : occasionally on walls and banks inland.

Spergula arvensis, L. Rare. In cultivated ground in several parts of the Blaye.

Scleranthus annuus, L. Very rare. A small dwarf form occurs on the cliffs below the old mill, but very scantily. I have never found it in cultivated ground here: in fact, it looks like a plant that is dying out. In Guernsey it seems to be now extinct, or nearly so.

\section{MALVACEAE.}

Malva moschata, L. Very rare. One clump on the top of Rochers Hill, towards the farmhouse.

M. sylvestris, L. Common everywhere.

M. rotundifolia, L. Very rare. Two plants in 1899 on the roadside near the Church : none seen since. It is noted in Fl. Sarn., but no locality is specified.

Lavatera arborea, L. Scattered plants all along the north and east coast from Platte Saline to Longy: plentiful near Fort Quenard, and on Rat Island.

\section{HYPERICACEAE.}

Hypericum tetrapterum, Fr. Common in wet places. This is by far the most frequent species of the genus.

H. humifusum, L. Rather rare. On the cliffs in several parts, and in old quarries at Mauney: also on the Blaye.

H. linarifolium, Vahl. Very rare. On a headland east of Chaise à l'Emauve, in small quantity. Quite the typical plant.

H. pulchrum, L. Very rare. A few plants in one of the Clanque valleys, and on the hillside between Clanque and Tourgis.

H. elodes, L. Very rare. Streamside at Trois Vaux, in small quantity.

ACERACEAE.

Acer Pseudo-platanus, L. One of the commonest trees in Alderney. 


\section{GERANIACEAE.}

Geranium sanguineum, L. One patch about a yard square at the lower end of the Longy Road. May possibly be of garden origin, though there is no garden anywhere near. 'This is the only locality for the plant in these islands.

G. molle, L. Very common everywhere.

G. rotundifolium, L. Very rare. Several roots at the foot of a wall along the path beyond White Gates.

G. dissectum, L. Common.

G. columbinum, L. Rare. Only found on the Railway banks, where it occurs in plenty and extends for half a mile or more, growing luxuriantly.

G. Robertianum, L. Rare generally, though found in many parts of the island, principally on the cliffs.

Erodium cicutarium, Sm Very common. With pure white flowers at Braye Bay and Grounard Bay. Var. pimpinellifolium, on the Blaye, and also on the cliffs

E. moschatum, Sm. Generally distributed, and not uncommon.

E. maritimum, L'Her. Rare. On wall-tops at the higher part of St. Anne's : and in Rose Farm Valley. On the cliffs near the Hanging Rock. Plentiful on the islet of Burhou.

\section{LINACEAE.}

Linum angustifolium, Huds. Rather common generally : in some parts abundant.

L. catharticum, L. Occurs in many places in the eastern half of the island, but nowhere commonly.

Radiola millegrana, Sm. Plentiful in one of the valleys descending to Clanque, growing in company with Centunculus.

\section{LEGUMINOSAE.}

Ulex europaeus, L. Very common.

U. nanus, Forst. Plentiful on the moors and cliffs of the south-west, often growing with the dwarf form of $U$. Gallii. 
U. Gallii, Planch. Common.

Sarothamnus scoparius, Koch. Here and there on the cliffs, and on Mauney Hill. Var. prostratus, Bail. Plentiful on the cliffs at Chaise à l'Emauve, and round the coast to Clanque.

Ononis arvensis, L. Very common throughout the island, frequently with white flowers.

O. reclinata, I. Abundant at Corbelets, Mauney, Houmet, and all round the eastern coast to Longy Bay. Begins flowering at the end of May, and is mostly over when $O$. ariensis comes into blossom.

Medicago sativa, L. Very common: much grown for fodder M. lupulina, L. Common.

M. maculata, Sibth. Common.

M. denticulata, Willd. Rare. Butes Hill. Lıngy Road. Cliffs near La Chue. Var. apiculata, Willd. Cultivated fields on the Blaye. Babington notes this variety in Fl. Sarn. for the Blaye and the sands of Braye Bay.

Melilotus parviflora, Desf. Very rare. One plant near Fort Quenard in 1899 , and one on Longy Common the following year.

Trifolium pratense, L. Common.

T. incarnatum, L. East side of Fort Albert Hill, and here and there on the Blaye: the remains of cultivation.

T. arvense, L. Rather common on the cliffs: more rare elsewhere.

T. striatum, L. Frequent on many parts of the coast, but less common than $T$. scabrum. Var. erectum, Leight. Old quarry at Mauney. Cliffs near La Quoire. Near Fort Tourgis.

T. scabrum, L. Common on the sand-hills and on the cliffs.

T. subterraneum, L. Frequent throughout the island.

T. glomeratum, L. Rare. Dry bank on the Blaye. In two old quarries near La Quoire.

T. suffocatum, L. Rare. Cliffs above the Hanging Rock. In an old cliff quarry near La Quoire, and in another below the old windmill. 
T. repens, L. Very common.

T. fragiferum, L. Not uncommon in marshy places. Trois. Vaux. Rose Farm Valley. Val du Sud. Longy Pond.

T. procumbens, L. Common.

T. minus, Sm. Very common.

T. filiforme, L. Here and there on the cliffs.

Falcatula ornithopodioides, Bab. Rare In two old quarries on the cliffs below the mill.

Lotus corniculatus, L. Very common. Var. crassifolius, Pers. On all parts of the coast.

L. major, Scop. Frequent in all the cliff valleys, and in wet places generally.

L. angustissimus, L. Occurs here and there on the cliffs, but is a far rarer plant than the following species.

L. hispidus, Desf. Rather common on the cliffs, and on many parts of the low coast.

Anthyllis vulneraria, L. Common, especially in the eastern half of the island. In Guernsey it is extremely rare.

Vicia hirsuta, Koch. Frequent in all parts.

V. tetrasperma, Moench. Rare. In the large quarry at Mauney. Hillside at Val du Sud. Cliffs at La Quoire.

V. Cracca, L. Very rare. Furzebrake above Essex Castle, and on the north side of the hill, sparingly.

V. sativa, L. Generally distributed, but not common.

V. angustifolia, Roth. Common. Var. uncinata, Desv. On the Railway banks, sparingly.

V. varia, Host. Grass field opposite Braye Bay, one large plant in 1900. This is a very beautiful purple-flowered species, native of centrai Europe, and of course only a Casual here.

Lathyrus pratensis, L. Very rare. Sea cliff on the western side of Longy Bay, plentiful.

Ornithopus perpusillus, L. Common.

Arthrolobium ebracteatum, DC. Locally plentiful on some parts of the southern cliffs, especially in the old quarries 
there. Also in the quarries at Mauney. Flowers from the middle of May until August. Babington found it 'on the sea slope of Essex Castle Hill, and on the south coast near Chaise à l'Emauve.'

Onobrychis sativa, Lam. One plant on the upper side of Longy Common. Field near IVatermill Farm, many scattered plants. Perhaps in the latter station the remains of a former crop.

\section{ROSACEAE.}

Prunus spinosa, [. Common on the cliffs and in hedges inland.

Agrimonia Eupatoria, I. Very rare. A good many plants on the roadside a little below L.ongy Villas. Quite typical, and very distinct in the furrowing of the fruit from $A$. odorata, which replaces this species in Guernsey.

\section{Alchemilla arvensis, I. Common.}

Potentilla anserina, L. Frequent in all parts. The var. concolor, DC., with the leaves densely silky on both sides, is the prevailing form: the type is much less common.

P. reptans, L. Very common.

P. Tormentilla, Nesl. Common, especially on the cliffs.

P. fragariastrum, Ehrh. Rare. Banks behind the Terrace, and on the hillside below, in a few places. Reuters Valley.

Rubus Idaeus, L. A large patch, ten yards square, on the north side of Essex Castle Hill, growing among furze and brambles, in a spot that has certainly never been cultivated. This species, which, as far as one can judge, is truly indigenous here, is not known anywhere else in these islands.

R. argenteus, W. \& N. Recorded by Babington in Fl. Sarn. for Alderney, but not for any other of the Channel Islands. $\mathrm{He}$ remarks that 'on our plant the thorns are straight, not bent back as in Weihe's plate.'

R. caesius, I. Generally distributed and not uncommon.

(Several other species of Rubus occur in Alderney, but the genus has not been studied critically.)

Geum urbanum, L. Rare. Occurs in the Terrace, and in a few places in the immediate neighbourhood. Rose Farm Valley, sparingly: 
Rosa spinosissima, L. Grows sparingly and in small patches here and there all over the south and west cliffs : never on sandy commons, as in Guernsey.

R. involuta, Sm. One bush in the valley below Essex House. Apparently belonging to the var. Moorei, Baker: but it was not possible to decide with certainty from the specimens collected.

R. tomentosa, Sm. Rose Farm Valley (the var. sulglobosa, Sm.), two or three bushes.

R. rubiginosa, L. Cliffs near Val du Sud, one bush. In several places near Essex Castle. Another plant found near Val du Sud was considered by Mr. Arthur Bennett to be 'perhaps near $R$. umbellata, Leers.'

R. micrantha, Sm. One bush on the cliffs near Val du Sud. In this plant the glands are more pronounced than usual.

R. canina, L. A form from the valley at Chaise à l'Emauve, and another from Essex Castle Hill, in both cases without flowers or fruit, were named 'probably lutefiana, Lem.', by Mr. Bennett. Var. sphaerica, Gren. Cliffs near Val du Sud 'Apparently so, but fruit scarcelv globose enough.' Var. dumalis, Bechst. On the southern cliffs, scarce. Var. z'erticillacantha, Merat. Hedge at top of Trois Vaux. Var. dumetomm, Thuil. Under the walls of Essex Castle A plant from Rose Farm Valley seems to belong to this variety, but it has aciculate peduncles and calyx tube. Var. decipiens, Dum. In two places on the cliffs near Val du Sud.

R. stylosa, Desv. One fine bush in the cliff valley next to Val du Sud. A plant from Rose Farm Valley, Mr. Bennett says, is 'apparently a sy'styla form with aciculate peduncles; otherwise .agreeing with var. ofaca, Baker.'

Crataegus Oxyacantha, L. Generally distributed and common. Babington is quite wrong in describing the Hawthorn as rare in Alderney.

Pyrus Malus, L. Very rare. One small bush on the shore at Baie de Saye. A larger one in the old quarry near Corbelets.

\section{TAMARISCACEAE.}

Tamarix anglica, Webb. In hedges on the Longy Road and near Watermill Farm. 
ONAGRACEAE:

Epilobium parviflorum, Schreb. Common in wet places and marshy spots : occasionally at the outlet of streamlets on the seashore.

E. lanceolatum, Seb. \& Maur. Very rare. In the large quarry at Mauney, in one spot, many plants.

E. tetragonum, L. Recorded for Alderney in Fl. Sarn., but without any specified locality. I have not met with it.

Oenothera odorata, Jacq. Very rare. Lower end of Butes Hill, near Braye Road, in some quantity. This is one of the very few plants recorded for Alderney in Corbiere's Nouvelle Flore de Normandie. It has quite the appearance of being native.

Circaea lutetiana, L. In the Terrace, and in a narrow lane above Picaterre Brewery. In some of the gardens in the town this plant is a noxious weed difficult to extirpate.

\section{HALORAGACEAE.}

Hippuris vulgaris, L. Abundant in the pond on Longy Common. This is the only locality for the plant in these islancis.

\section{PORTULACEAE.}

Montia fontana, I. Frequent in moist turfy places. Var. rivularis, Gm. Trois Vaux. Near Val du Sud.

\section{PARONYCHIACEAE.}

Herniaria glabra, L. Rare. Bibette Point, sparingly. Coast between Corbelets and Fort Quenard. Cliffs at La Quoire, scarce.

H. ciliata, Bab. Very rare. In an old quarry towards the Hanging Rock, in small quantity.

\section{CRASSULACEAE.}

Sedum Telephium, L. In 1900 I found a single plant on the Railway embankment beyond the White Gates.

S. anglicum, Huds. Very common. 
S. acre, L. Common on the sandy shores, and also plentiful on many parts of the cliffs.

Cotyledon Umbilicus, L. Common.

\section{SAXIFRAGACEAE.}

Saxifraga tridactylites, L. Rather common in the eastern. halt of the island, especially on sandy ground.

\section{- UMBELLIFERAE.}

Hydrocotyle vulgaris, L. Common in wet places.

Eryngium maritimum, L. Plentiful on all the sandy shores from Fort Tourgis to Longy Bay.

Apium nodiflorum, Reich. Common on streamsides and in wet places.

Petroselinum sativum, Hffm. Occurs in many parts of the island, but almost always near ruins or old houses. In every case remains of cultivation.

Sium angustifolium, L. Recorded for Alderney in Fl. Sarn. without specified locality. I very much doubt if this plant occurs at all in Alderney at the present time.

Bupleurum aristatum, Bartl. Plentiful on the sandhills at Longy Bay and Braye Bay, and on the western slopes of Fort Albert Hill: also occurs here and there on the cliffs. This little plant flowers during the month of June, chiefly during the first half, but when out of flower it is very difficult to detect.

Oenanthe crocata, L. Babington found this species in Alderney sixty years ago: it is now extinct, having probably been exterminated by the farmers on account of its danger to cattle.

Foeniculum officinale, All. Abundant between St. Anne's and Braye Bay: less frequent in other parts of the island.

Crithmum maritimum, L. Common on the coast.

Pastinaca sativa, L. Frequent in cultivated ground.

Heracleum Sphondylium, L. Very common.

Daucus Carota, L. Generally distributed and not uncommon. Var. gummifer, Lam. Very common near the sea. 
Torilis Anthriscus, Gaert. Recorded for Alderney in Fl. Sarn., but not found recently.

T. nodosa, Gaert. Rather common in all parts.

Scandix Pecten-Veneris, L. Very rare. On the Railway banks beyond White Gates, and in a cultivated field off the Longy Road: only a few plants in each case.

Chaerophyllum sylvestre, L. Generally distributed and common.

C. Anthriscus, Lam. In many places on the eastern side of the island, and on the Blaye.

C. temulum, L. Recorded for Alderney in Fl. Sarn., but not seen recently.

Conium maculatum, L. Rather common generally: in some parts abundant.

Smyrnium Olusatrum, L. Rare. In a hedge near the Presbyterian Church, and in another hedge on the south side of St. Anne's.

\section{ARALIACEAE.}

Hedera Helix, L. Common throughout the island.

\section{CAPRIFOLIACEAE.}

Sambucus nigra, L. Frequent in all parts.

Lonicera Periclymenum, L. All along the cliffs here and there, but less common than in Guernsey. Rarely found away from the coast.

\section{RUBIACEAE.}

Sherardia arvensis, L. Rather common on dry banks and on the cliffs : occasionally with pure white flowers.

Asperula cynanchica, L. Very rare. On the hillside facing Braye Bay, one patch, which at a little distance might have been passed by as Galium saxatile. This plant is not known to occur elsewhere in these islands.

Galium Aparine, L. Very common in all parts. 
G. Mollugo, L. Very rare. Sparingly in the valley east of Val du Sud. The extreme rarity of this plant is remarkable.

G. verum, L. Plentiful everywhere, but especially abundant in the sandy ground of the low-lying districts.

G. saxatile, L. Frequent on the heaths and cliffs of the south-west.

G. palustre, L. Plentiful at Longy Pond, and in two valleys descending to Clanque.

Rubia peregrina, L. Very rare. At Corbelets Bay this plant covers about twenty yards of the seacliff, but is now in danger of being lost owing to the deposit of quarry rubbish. Sixty years ago Babington found it in the 'eastern part of Alderney,' which would probably be the same locality. The plarst is now extinct in Guernsey, and this is the only known locality for it in these islands.

\section{VALERIANACEAE.}

Centranthus ruber, DC. On walls in various places on the outskirts of St. Anne's.

Valerianella olitoria, Moench. Very rare. After much searching I discovered a few plants growing intermixed with $V$. carinata on the roadside near Watermill Farm, but I have not seen it again. This species is so common in Guernsey that its rarity in Alderney is rather remarkable.

V. carinata, Loisel. Very common everywhere.

V. dentata, Deitr. In a cultivated field at Rochers, fairly plentiful in 1900.

V. eriocarpa, Desv. Generally distributed and frequent in the eastern half of the island, and plentiful in the spots where it occurs. Closely resembles $V$. carinata, but the flowers are brighter coloured, and the fruit at once distinguishes it from all others of the genus. I consider this plant undoubtedly native in Alderney, judging from its distribution and the various kinds of localities in which it grows. It has not been found in any of the other islands.

\section{DIPSACACEAE.}

Knautia arvensis, Coult. Rare. Scattered plants in many places on Rochers Hill. 


\section{COMPOSITAE.}

Petasites fragrans, Presl. In an old garden at the upper part of St. Anne's.

Erigeron acre, L. Very rare. Hillside above Reuters Valley, two or three plants in 1899 : none seen anywhere the following year. In Fl. Sarn. this plant is noted for La Chue.

Bellis perennis, L. Very common.

Inula crithmoides, L. Corbelets Point, in abundance. Chateau l'Etoc. Base of the cliffs below Fort Essex, and near the Hanging Rock. Cliffs below Trois Vaux. In Fl. Sarn. it is recorded for cliffs near Clanque and Rozelle Point.

Pulicaria dysenterica, Gaert. Common in wet places.

Filago germanica, L. Recorded for Alderney in Fl. Sarn. I have not met with this plant in the island.

F. minima, Fr. Rather common on some parts of the cliffs, sometimes occurring in profusion.

Gnaphalium uliginosum, L. Very rare. One plant on the Blaye in 1900; a rather starved specimen.

Achillea Millefolium, L. Very common everywhere.

Anthemis arvensis, L. Recorded for Alderney in Fl. Sarn. I have searched for two successive summers without finding a single plant belonging to this species.

A. Cotula, L. Very rare. One plant in 1899 close to the gateway of Essex Castle.

A. nobilis, L. Rather common on the cliffs.

Matricaria inodora, L. Common in cultivated ground and waste places.

Chrysanthemum Leucanthemum, L. Common on the cliffs, and on Mauney Hill.

C. segetum, L. Frequent in cultivated ground, sometimes abundant in fields on the Blaye.

Diotis maritima, Cass. Babington found this plant sixty years ago at Braye Bay. It seems to be extinct in the island now. 
Artemisia Absinthium, L. Abundant at the eastern end of Platte Saline, and about Crabbie and New Town. Scattered plants on the Blaye, and in some quantity by the cottages near Fort Corbelets.

A. vulgaris, L. Very rare. Two or three plants on Braye sands near the houses.

Senecio vulgaris, L. Very common. Var, radiatus, Koch. On the sandhills by Fort Corbelets. An apparent hybrid between this species and $S$. sylvaticus found on the shore beyorid Longy Bay.

S. sylvaticus, L. Very common on the cliffs : often in dry places inland.

S. Jacobaea, L. Very common everywhere.

Carlina vulgaris, L. Frequent in the eastern half of the island.

Arctium nemorosum, Lej. Not uncommon, especially in the vicinity of the Harbour. This is one of the few plants recorded for Alderney in Corbiere's Nouvelle Flore de Normandie.

A. minus, Schk. Rather more common than the last species, and equally distributed.

Centaurea nigra, L. Common. With cream-white flowers (var. pallens, Koch.) on Rochers hillside. The radiant form of this plant (C. pratensis, 'Thuil.) is the prevailing one, but the type occurs in various parts of the island.

C. Cyanus, L. Very rare. One plant in a cornfield on the Blaye. One on a rubbish heap, Butes Hill. Noted for the Blaye in Fl. Sarn.

C. Scabiosa, L. Frequent in that part of the island which lies between St. Anne's, Fort Albert, and Longy Bay; also occasionally elsewhere With white flowers at Rochers. This plant is not found in the other islands.

C. aspera, L. Rare. A large patch in a sandy pasture on the eastern side of Braye Bay, and another about a quarter of a mile off, on the hillside overlooking the Bay.

Carduus nutans, L. Rather common.

C. tenuiflorus, Curt. Frequent throughout the island.

C. lanceolatus, L. Common. With white flowers at Val du Sud, on the south coast. 
Carduus arvensis, Curt. Very common.

C. palustris, L. Common in wet places.

C. acaulis, L. Abundant on the eastern slope of Fort Albert Hill, and also towards Corbelets. Hill above Longy Common, scarce. Some of the plants on Fort Albert Hill with pale lilac or almost white flowers: and some with flower stalks four or five inches long (var. caulescens, Willd. ?). The caulescent form also occurs sparingly on the hillside at the lower end of Longy Road. This thistle has not been recorded for any of the other islands.

Lapsana communis, L. Very rare. Lane above Picaterre Brewery, one plant only.

Cichorium Intybus, L. Very rare. In a garden, Butes Hill, a few scattered specimens.

Hy pochoeris glabra, L. Rather common on the cliffs. Var. Balbisii, Lois. Occasionally found with the type.

H. radicata, L. Very common everywhere.

Thrincia hirta, DC. Common all round the coast.

Leontodon hispidum, L. Generally distributed and common.

L. autumnale, L. Frequent in all parts.

Tragopogon minor, Fr. Rare. Longy Road, and hillside near Longy Bay. Slopes of Fort Albert Hill. Valley behind Essex House, in a grass field. This plant is not known to occur in the other islands within the area.

T. porrifolius, L. Naturalised on an isolated rocky mound near the Harbour, where there are a good many plants which fruit freely.

Picris hieracioides, L. Iocal, but plentiful where it occurs. Found in several places between Braye, Corbelets, and Longy. This plant occurs in Herm, but not in Guernsey.

Helminthia echioides, Gaert. Rare. On the Railway banks, and at the lower end of the Longy Road. Hillside, Rochers, and in the great quarry below. Several plants on the rocky mound by the Harbour.

Taraxacum officinale, Wigg. Very common Var, erythrospermum, DC. Plentiful at Baie de Saye, Longy Common, and elsewhere in the low districts. 
Sonchus oleraceus, L. Common. I measured a tall plant which grew among brambles on Rochers hillside, and found it very nearly six feet in height.

S. asper, Hffm. Rather common. Var. glandulosus, C. \& G. Platte Saline.

S. arvensis, L. Frequent in cornfields and other cultivated ground. Grows among brambles in some places on Rochers Hill.

Crepis taraxacifolia, Thuil. Very common in hayfields and pastures: occasionally on roadsides. Flowers earlier than $C$. virens.

C. virens, L. Common everywhere. Var. diffusa, DC. is abundant in dry places, and in Reuters Valley I have seen var. agrestis, W. \& K.

C. biennis, L. Recorded for Alderney in Fl. Sarn., but no locality is specified. I have not met with this plant, and rather suspect that $C$. taraxacifolia (which Babington does not mention) was the species intended.

Hieracium Pilosella, L. Rather common throughout the island. Var. Peleterianum, Mer. Valley below the Church, and in several other places; but much less frequent than the type.

H. umbellatum, L. Here and there all along the cliffs from the Hanging Rock to Clanque and Fort Tourgis.

\section{CAMPANULACEAE.}

Jasione montana, L. Common on dry, rocky, and stony banks and cliffsides; and in sandy places.

\section{ERICACEAE.}

Calluna vulgaris, Salisb. Rather common on the cliffs.

Erica cinerea, L. Very common. Continuing in flower on the cliffs throughout the winter.

\section{OLEACEAE.}

Ligustrum vulgare, L. Very rare. A few bushes on the cliffs to the east of Val du Sud.

Fraxinus excelsior, L. Scattered trees in Longy Valley, Reuters Valley, below the Church, and near Rose Farm. 
APOCYNACEAE.

Vinca major, L. On a bank in the Braye Road: a garden escape, and hardly entitled to a place in this list.

\section{GENTIANACEAE.}

Erythraea Centaurium, Pers. Generally distributed and rather common. The Erythraea latifolia recorded for this island in Fl. Sarm. is only a stunted form of this species. See remarks on some of the plants belonging to this genus, ante, p. I29.

\section{CONVOLVULACEAE.}

Convolvulus arvensis, L. Very common on roadsides and in cultivated ground. White flowers rather frequent.

C. sepium, L. Rather common.

C. Soldanella, L. Plentiful in all the sandy bays.

Cuscuta Epithymum, Murr. Common in all parts : usually grows on low plants, seldom on furze.

C. Trifolii, Bab. Rare. One patch on Lucerne on the hilltop at Rochers. I have twice seen a lemon-yellow Cuscuta spreading over low plants, but there were no flowers in either case, so that I am not sure that it belongs to this species. See page I3I.

\section{BORAGINACEAE。}

Cynoglossum officinale, L. Recorded for Alderney in $\mathrm{Fl}$. Sarn. I have not seen any vestige of this plant, and very much fear it is now extinct in this island.

Borago officinalis, L. Rare. Scattered plants occur in many places, especially in the west.

Lycopsis arvensis, L. Generally distributed and rather common: more plentiful on the east side of the island.

Symphytum officinale, L. Rare. Plentiful in a field near Watermill Farm; also on the north side of the Blaye, overlooking Platte Saline.

Echium vulgare, L. Common on the cliffs, and generally in the eastern half of the island: a strikingly beautiful plant. 
Lithospermum arvense, L. Very rare. One large plant in I 900 in the quarry by Crabbie Bay.

Myosotis repens, Don. Common in wet places generally.

M. arvensis, Lehm. Frequent in cultivated ground and on roadsides.

M. collina, Hoffm. Rather common. Var. Lebelii, Corb. Flowers pure white, with a yellow throat. Growing plentifully with the type in two places on the cliffs towards Val du Sud.

M. versicolor, Reich. Rather common.

\section{SOLANACEAE.}

Solanum nigrum, L. Rare. I have seen this species in several places, but only a single plant at a time.

S. Dulcamara, L. Rather rare, but occurs on many parts of the cliffs and east coast, as well as at Mauney.

Hyoscyamus niger, L. Very rare. On the shore by Fort Doyle, in the quarry by Crabbie Bay, and in the plantation at Tolval, one plant in each case.

Lycium barbarum, L. An African shrub thoroughly naturalised in Alderney, growing luxuriantly in all parts of the island, frequently at a distance from houses, and in places where it could not have been intentionally planted. It flowers freely.

\section{OROBANCHACEAE.}

Orobanche Rapum, Thuill. Plentiful on the cliffs in the vicinity of Chaise à l'Emauve (Lover's Chair), and also east and west of Trois Vaux. More sparingly to the east of Val du Sud. In Alderney this plant appears to be parasitic chiefly on the prostrate Broom. It is not known in any of the other islands.

O. Hederae, Duby. Parasitic on Ivy. On the lawn of Moriaux House, plentiful at the foot of an ivy-covered wall.

O. minor, Sutt. Generally distributed and rather common.

O. amethystea, Thuill. Parasitic on Erynginm. Plentiful on Braye Sands. Château l'Etoc, more sparingly. 
O. Millefolii, Reich. Parasitic on Achillea Millefolinn. Frequent in all parts of the island, sometimes abundant, as on Butes Hill. A very beautiful species with violet-blue flowers: at its best during the latter half of June. See remarks on this Orobanche in the Guernsey Flora, under $O$. caerulea, page 137.

\section{SCROPHULARIACEAE.}

Verbascum nigrum, L. Local. In several places on the top of Rochers Hill. Longy Road, below Balmoral, about twenty plants in a field in 1899 . Field near the old Brick Kilns. Two plants in $\mathbf{1 9 0 0}$ in the field adjoining the Church. Most of the Alderney plants seem to belong to the var. tomentosum, Bab.

Digitalis purpurea, L. Rather rare. Here and there all along the cliffs, but much less common than in Guernsey.

Antirrhinum majus, L. On several walls on the outskirts of the town: occasionally with white flowers.

Linaria Cymbalaria, Mill. Rare. On walls below the Church, and above Moriaux House.

L. Elatine, Mill. Rare. Cultivated field in the eastern part of the Blaye. Not seen elsewhere, though looked for.

L. vulgaris, Mill. Very rare. Sparingly on the top of Rochers Hill towards the farmhouse.

Scrophularia aquatica, I. Rare. Lower end of Rose Farm Valley, a few plants. One or two on the streamside behind the Terrace.

Pedicularis sylvatica, L. Common in moist places on the cliffs, and in the south-west generally.

Eufragia viscosa, Benth. Frequent in wet places.

Euphrasia officinalis, L. Common.*

* After the notes on Euphrasia on page I4I were in type, Mr. F. Townsend kindly sent me the following particulars showing the distribution in these islands of the various forms of which he has seen specimens:

E. stricta. Guernsey, 1892, W. S. Miller. (This is the plant previously recorded as E. nemorosa.) Alderney, 1900, E. D. Marquand.

E. nemorosa. Longy Common, Alderney, rgoo, E. D. Marquand.

E. curta. Cobo Bay, Guernsey, 1897, W. Moyle Rogers. Possibly the form glabrescens.

E. occidentalis. Longy Common, Alderney, I900, E. D. Marquand. Or may be a hybrid with this as one of the parents. Moie du Mouton, Sark, I892, W. S. Miller. 
Odontites rubra, Pers. Frequent in sandy ground and in cultivated fields on the Blaye. I have not seen in this island any other form but the var, verna.

Veronica Anagallis, L. Plentiful and fine at the mouth of the streamlet at Longy. Noted in Fl. Sarn. for Platte Saline and Trois Vaux, but apparently extinct there now.

V. Beccabunga, L. Not common. Rose Farm Valley. Near Essex House. Marshy spot at Tolval.

V. Chamaedrys, L. Common. With lilac flowers, at Val du Sud, and in one or two other places.

V. officinalis, L. Very rare. Grows sparingly at Trois Vaux, in a grassy spot half way down the valley.

V. arvensis, L. Generally distributed, but not very common.

V. agrestis, L. Common in cultivated ground.

V. polita, Fr. More or less common in cultivated land.

V. Buxbaumii, Ten. Here and there throughout the island in cultivated ground and on roadsides : but not common.

V. hederifolia, L. Common in all parts.

\section{LABIATAE.}

Mentha viridis, L. Laneside near Essex House. Field corner east of New Town. Under the elm-trees in the Moriaux road. South side of St. Anne's, bordering the Blaye. A form approaching very near to var. crispa, Hook. occurs at Longy Bay on the shore near the Nunnery.

M. piperita, Sm. Valley below Essex House, and lower down, near the Nunnery, in considerable quantity. This is var. officinalis, Sole.

M. aquatica, L. Common in wet places.

Salvia Verbenaca, L. Common generally; in some parts of the island growing in great profusion.

Thymus Serpyllum, L. Very common.

Calamintha Clinopodium, Benth. Very rare. A good many plants in an old gravel pit at the east side of Rochers : found by Mr. C. Andrews. This is the only locality at present known for this plant in these islands. 


\section{Prunella vulgaris, L. Common.}

Nepeta Glechoma, Benth. Not common. Essex Castle Hill, plentiful on the east side, and at the bottom below the old quarry. Also in Rose Farm Valley.

\section{Lamium amplexicaule, L. Common.}

L. incisum, Willd. Here and there in fields on the Blaye, but less common than the last species.

L. purpureum, L. Common in cultivated ground.

Stachys sylvatica, L. Frequent in all parts.

S. palustris, L. In many parts of the Blaye, and in cultivated ground near the Quoire cliffs.

S. arvensis, L. Frequent on the Blaye.

Ballota foetida, Lam. Generally distributed, but not common.

Marrubium vulgare, L. Rare, and always sparingly. Occurs in several spots between New Town, Fort Albert, and Longy. It is noted in Fl. Sarn. for Baie de Saye and Platte Saline.

Teucrium Scorodonia, L. Common on the cliffs and also at Corbelets and Mauney.

\section{VERBENACEAE.}

Verbena officinalis, L. Very rare. I have seen solitary plants in a few places, but all within a mile of the town.

\section{PRIMULACEAE.}

Primula vulgaris, Huds. Rather common generally: in profusion in some of the valleys.

Glaux maritima, L. Among rocks on the shore near Fort Houmet. Very much finer on the island of Burhou.

Anagallis arvensis, L. Common. Salmon-coloured flowers are frequent: flesh-coloured ones are rare. Var. caerulea, Sm. One plant in cultivated ground on the Blaye.

A. tenella, L. Common on streamsides and in wet places.

Centunculus minimus, L. Plentiful in the valley descending to Clanque from the Blaye. Grows in company with Radiola. 
Samolus Valerandi, L. Frequent in the cliff valleys; sometimes at the foot of wet sea-cliffs, as at Clanque and Corbelets.

\section{PLUMBAGINACEAE.}

Statice occidentalis, Lloyd. On sea-shore rocks near Fort Houmet, but not in any great quantity. On the cliffs below the Hanging Rock.

S. lychnidifolia, De Gir. Among rocks on the seacoast near Fort Houmet, growing in company with the last species: about a dozen plants discovered by Mr. C. Andrews in 1900. This species, which does not occur in the British Isles, is very like $S$. Limonium in general appearance, and might easily be passed over as that species. Corbiere notes it for many places in the Department of La Manche, and also for the Chausey Islands, so that its occurrence in Alderney is not very surprising. But at present it is not known to occur anywhere else in the Channel Islands.

Armeria maritima, Willd. Very common on the coast. Flowers sometimes pure white.

\section{PLAN'TAGINACEAE.}

Plantago Coronopus, L. Very common in dry places.

P. lanceolata, L. Abundant and very variable. I have noticed the three forms mentioned by Babington in Fl. Sarn., but they pass insensibly into each other, being chiefly dependent on soil and situation.

P. major, L. Common in all parts.

\section{CHENOPODIACEAE.}

Salsola Kali, L. Frequent in the sandy bays.

Chenopodium album, L. Very common.

C. murale, L. Common in waste places and on rubbish heaps in all parts of the island.

Beta maritima, L. Very common on the coast.

Atriplex littoralis, L. Rare. Platte Saline.

A. patula, L. Common. Var. angustifolia, Sm. Plentiful in cultivated ground.

A. deltoidea, Bab. Common in cultivated and sandy ground. Var. salina, Bab. On the shore at Clanque Bay. 


\section{A. hastata, L. Common.}

A. Babingtonii, Woods. On the seashore near Clanque, and at Crabbie Bay and Corbelets.

A. farinosa, Dum. Common in all the sandy bays.

Obione portulacoides, Moq. Recorded for Alderney in Fl. Sam. Probably the plant still occurs here, but I have not met with it. It should be looked for at the lower part of the cliffs.

\section{POLYGONACEAE.}

Rumex conglomeratus, Murr. Frequent in moist places.

R. sanguineus, L. A good many plants in the Terrace, belonging to the var viridis.

R. pulcher, L. Very common.

R. obtusifolius, L. Rather common throughout the island.

R. crispus, L. Common.

R. Acetosa, L. Generally distributed and frequent.

R. Acetosella, L. Very common.

Polygonum amphibium, L. Abundant in the pond on Longy Common: much of it floating, and passing into the land form.

P. lapathifolium, L. Occurs in many parts of the island in waste corners and on heaps, but seldom in any quantity.

P. maculatum, Dyer. Recorded in Fl. Sarn. as found by Babington on the Blaye. I have not seen the plant here.

P. Persicaria, L. Frequent in all parts: common on the Blaye.

P. Hydropiper, L. Very rare. Sparingly at the lower end of Rose Farm Valley.

P. aviculare, L. Very common and very variable.

P. Raii, Bab. Found by Babington sixty years ago at Corbelets Bay, as noted in Fl. Sarn. I have searched for it in vain both there and elsewhere on the sandy coast.

P. Convolvulus, L. Very common in cultivated ground. 
Fagopyrum esculentum, Moench. A few plants at Rochers and in Reuters Valley.

\section{SANTALACEAE.}

Thesium humifusum, DC. Local. In two or three "spots on Butes Hill, where it grew in Babington's time. Rochers Hill in a few places. Longy Common, towards the Nunnery, and eastward. beyond the Rifle Butts. Baie de Saye. Sandy field, Platte Saline. This plant is not known elsewhere in these islands.

\section{EUPHORBIACEAE.}

Euphorbia Peplis, L. Rare, though plentiful where] it occurs. Platte Saline. Crabbie Bay. Although producing an abundance of seed, the plants do not reappear in the same spot two years in succession.

E. Helioscopia, L. Common in cultivated ground.

E. Paralias, L. Rather common on the sandy shores.

E. portlandica, L. Common all round the coast: often on roadside banks and in old quarries.

E. Peplus, L. Very common.

Mercurialis annua, L. Very common in cultivated and waste ground everywhere. Babington records the var. ambigua, $\mathrm{L}$. as found by him at St. Anne's.

\section{CALLITRICHACEAE.}

Callitriche verna, L. Very rare. A few plants in the old millpond in Rose Farm Valley. I am not sure that they belonged to this species, as there was no fruit, but I assigned them to $C$. verna as Babington had noted it for Alderney in Fl. Sarn. Possibly the plant is $C$. stagnalis.

\section{URTICACEAE.}

Parietaria diffusa, Koch. Plentiful on some of the walls on the outskirts of the town. Also at Longy, Crabbie, Platte Saline, and on some parts of the cliffs.

Urtica urens, L. Frequent in cultivated ground and on waste heaps.

U. dioica, L. Common everywhere. 


\section{CANNABINACEAE.}

Humulus Lupulus, L. In the old quarry on the road down. to Platte Saline: perhaps a garden outcast.

\section{ULMACEAE.}

Ulmus campestris, Sm. Frequent in the larger valleys.

U. montana, With. Reuters Valley.

\section{A.MENTIFERAE.}

Salix fragilis, L. New Town. Clanque. Rose Farm Valley. Planted in all these localities.

S. purpurea, L. Upper part of Longy Road; planted.

S. viminalis, L. St. Martin's : a broad-leaved form.

S. stipularis, Sm. Recorded for Alderney in Fl. Sarn.

S. Smithiana, Willd. Rose Farm Valley.

S. aurita, L. Growing with S. cinerea on the cliffs to the west of the Lover's Chair.

S. cinerea, L. In nearly all the valleys, and often in hedges.

S. caprea, L. In hedges off the Moriaux Road. Reuters Valley. A large tree Willow (one of the very few in Alderney). growing among other trees in the Moriaux Road is a hybrid, caprea $\times$ viminalis, as determined by Rev. E. F. Linton.

Populus alba, L. Evidently planted in some places near St. Anne's : more wild at Val du Sud.

P. nigra, L. Several trees in the field adjoining the Churchyard, and one or two in the Terrace.

Betula alba, L. A few trees in the Terrace: planted.

Castanea vulgaris, Lam. Two or three trees in the Terrace.

Quercus Robur, L. Several trees in the Terrace: probably planted. Sixty years ago Babington noted in the Flora Sarnica that the oak was 'rare in Alderney.' 


\section{ORCHIDACEAE.}

Orchis maculata, L. Very rare. A few plants in Rose Farm Valley, by the old millpond.

O. latifolia, L. In two valleys descending to Clanque, where I counted quite a hundred flowering spikes in Igoo. Also grows sparingly between there and Fort Tourgis.

O. pyramidalis, L. Plentiful in several spots between the Braye Road and Corbelets. Sparingly on the top of Rochers, and on Butes Hill. This species does not occur in the other islands.

Spiranthes autumnalis, Rich. Rather common all over the island, and in many places abundant.

\section{IRIDACEAE.}

Iris Pseud-acorus, L. Pond on Longy Common, plentiful. Valley between St. Anne's and Platte Saline.

I. foetidissima L. On the cliffs close to the Hanging Rock, and also along the coast westwards.

Romulea Columnae, Seb. \& Maur. Very common on the cliffs, and also on the low-lying coast.

\section{ALISMACEAE}

Triglochin palustre, L. Rather common in marshy spots, and on the sides of cliff streamlets.

\section{ASPARAGACEAE.}

Ruscus aculeatus, I. Frequent on the cliffs of the eastern half of the island. More rare towards Fort Albert and Mauney.

\section{LILIACEAE.}

Scilla autumnalis, L. Rather common all round the coast, and on Mauney Hill : in some places abundant. Occasionally the flowers are pure white.

Allium triquetrum, L. Rare. A patch about five yards square on the north-west side of Fort Tourgis. Also grows in grassy 
places in Victoria Street, at Government House, and in St. Anne's Churchyard. In these last stations perhaps planted.

Endymion nutans, Dum. Frequent on the cliffs and about Corbelets. On the island of Burhou this species is abundant and exceptionally fine: some of the plants have unusually long floral bracts, and occasionally the flowers are white.

\section{JUNCACEAE.}

Juncus maritimus, Sm. Frequent among rocks on the shore all round the east coast from Fort Quenard to Longy. One patch on Longy Common near the pond. Plentiful half way down the valley at Trois Vaux.

J. acutus, L. Rare. Sparingly on the shore beyond Longy Bay. Foot of the cliffs below Essex Castle on the east side, and also below the Hanging Rock.

J. effusus, L. Common in some of the cliff valleys. Rose Farm Valley, in plenty.

J. conglomeratus, L. Much less frequent than the last species. Marshy spot at Trois Vaux, scarce.

J. glaucus, Sibth. Very common in most of the cliff valleys, and in marshy places at Mauney. This Rush is not known to occur in the other islands.

J. acutiflorus, Ehrh. Frequent in wet places.

J. lamprocarpus, Ehrh. Rather common in marshy spots.

$\mathrm{J}$. supinus, Moench. Wet places near Clanque, and on the cliffs here and there.

J. bufonius, L. Common. Var. fasciculatus, Bert. On the shore at Longy Bay.

Luzula campestris, Willd. Common.

L. multiflora, Lej. Rather common in all parts.

TYPHACEAE.

Sparganium ramosum, Huds. (?). At Longy Pond a Sparganium occurs in some quantity, but, as it has not flowered during my stay in Alderney, I am uncertain to which species it belongs. It is most probably either $S$. ramosum or $S$. neglectum. 


\section{LEMNACEAE.}

Lemna minor, L. Very common in ditches and pools.

\section{NAIADACEAE.}

Zostera marina, L. On various parts of the coast, growing in the sand at low-water mark.

\section{CYPERACEAE.}

Cyperus longus, L. Rare. Valley below Tolval, in one place. Rose Farm Valley. Wet meadow below the Terrace.

Schoenus nigricans, L. Abundant at Trois Vaux, and in the valleys descending to Clanque.

Eleocharis palustris, R. Br. Common in wet places throughout the island.

E. multicaulis, Sm. Frequent in the cliff valleys.

Scirpus maritimus, L. Grows luxuriantly above high-water mark on the west side of the islet of Burhou. This plant does not appear to have ever been found on the main island of Alderney.

S. Tabernaemontani, Gm. Abundant in the pond on Longy Common.

S. setaceus, L. Rather common on streamsides, and in marshy spots.

S. Savii, S. \& M. Less common than the last species: found in several of the cliff valleys. The usual form is the solitary-spiked var. monostachys (Isolepis pygmaea, Kunth.), but I have found the type, with two spikelets, on the wet sea-cliff in Clanque Bay.

Carex pulicaris, L. Plentiful in the cliff streams at Clanque. Marshy places at Trois Vaux.

C. arenaria, L. Very common on the sandy shores.

C. muricata, L. Clanque Cliffs. Near La Quoire. Cliffs near Val du Sud. Noted for Mauney in Fl. Sarn.

C. divulsa, Good. Rare. In good quantity in a narrow lane above Picaterre Brewery.

C. paniculata, L. Rare. Several large clumps in one of the valleys at Clanque. 
C. stellulata, Good. Very rare. Clanque cliffs.

C. panicea, L. Frequent in some of the cliff valleys.

C. praecox, Jacq. Very rare. On the slopes of Essex Castle Hill, sparingly.

C. glauca, Scop. Generally distributed and rather common.

C. flava, L. Common on stream-sides in the cliff valleys.

C. extensa, Good. Rare. In good quantity among the rocks on the shore by Fort Houmet, associated with Glaux and Juncus maritimus.

C. hirta, L. Generally distributed: one of the commonest Carices in Alderney: occasionally very fine in the cliff valleys.

\section{GRAMINEAE.}

Echinochloa Crus-galli, Beauv. One plant by the old millpond in Rose Farm Valley in 1900.

Phalaris canariensis, L. Here and there on rubbish heaps and roadsides: sometimes on the seashore. Much less common than $P$. minor, and nearly always single plants.

P. minor, Retz. Frequent in cultivated ground throughout the island: sometimes with heads two or three inches long, and then very distinct from $P$. canariensis. In this island I regard this grass as a Colonist : not a native, as it is in Guernsey.

Anthoxanthum odoratum, L. Very common.

Phleum arenarium, L. Common in sandy places on the coast. Occasionally found on the cliffs.

P. pratense, L. Rare. In a grassy field above Essex House.

Alopecurus pratensis, L. Rare. Meadow near Rose Farm, plentiful. St. Anne's churchyard.

A. geniculatus, L. Frequent in wet places in all parts.

Phragmites communis, Trin. Abundant in the pond on Longy Common.

Psamma arenaria, R. \& S. Common on the sandy shores, and on Rat Island.

Agrostis canina, L. Marshy field at Platte Saline. 
A vulgaris, With. Generally distributed and common.

A. alba, L. Rather common: sometimes very dwarf and scarcely recognisable when growing among sea-rocks.

Holcus lanatus, L. Very common.

H. mollis, L. Rare. Lower end of Rose Farm Valley.

Aira caryophyllea, L. Common on the cliffs, and on the coast generally.

A. praecox, L. Rather common on banks and heaths, and on the cliffs.

Trisetum flavescens, Beauv. Very common on the hillsides at Rochers and Butes Hill. Noted in Fl. Sarn. for St. Anne's and Longy Road.

Avena fatua, L. Frequent in cornfields and cultivated ground on the Blaye.

A. strigosa, Schreb. Scattered plants found all over the island in arable land and borders of fields.

A. pubescens, L. Rare. Hillside off the Longy Road. South side of Mauney Hill.

Arrhenatherum elatius, M. \& K. Rather common. Var. bulbosum, Lindl. Generally distributed but less frequent than the type, whereas in Guernsey the variety is the common form.

Triodia decumbens, Beauv. Frequent on heaths and cliffs.

Koeleria cristata, Pers. Frequent in the eastern half of the island in sandy places.

Poa annua, L. Very common.

P. trivialis, L. Common.

P. sudetica, Haenke. Rare. Sparingly in a wet grassy spot near the Nunnery, at Longy. There are no introduced plants here, and this grass looks quite as native as the other species amongst which it grows. It has not been found elsewhere in these islands.

P. pratensis, L. Very common. Var. subcaerulea, Sm. On wall-tops in the Longy Road.

Glyceria fluitans, R. Br. Rather common in streamlets.

G. plicata, Fr. Streamside near Essex House. Valley below Tolval, between Moriaux and Platte Saline. 
Sclerochloa rigida, Link. Rare. Waste place on Rochers Hill. On the shore, Longy Bay.

S. loliacea, Woods. Very common on old walls, and in dry, sandy places.

Briza media, L. Local. Plentiful in the two valleys descending to Clanque; and in one place on the north side of Little Rochers. This grass is peculiar to Alderney among these islands.

Cynosurus cristatus, L. Common.

Dactylis glomerata, L. Very common.

Festuca uniglumis, Sol. Common in all the sandy parts of the island.

F. sciuroides, Roth. Rather common. I found at the lower end of Reuters Valley in I899 an unusually large form of this grass, eighteen inches high, and much resembling $F$. Myurus. There was but one root, and the plant did not reappear there the following year, nor have I met with it since.

F. Myurus, L. Recorded for Alderney in Fl. Sarn. The nearest approach to it that I have seen here is the form mentioned under the last species.

F. ovina, L. Common.

F. rubra, L. Rather common.

F. oraria, Dum. Common on the sandy coasts.

F. arundinacea, Schreb. Trois Vaux, plentiful in one part. Field corner, Le Val.

Bromus sterilis, L. Very common.

B. maximus, Desf. Abundant in all parts of the island.

Serrafalcus mollis, Parl. Very common. A small glabrous form, two inches high, with the panicle reduced to a single spikelet (B. namus, Weig.), occurs near Fort Corbelets and in other parts of the east coast.

Brachypodium sylvaticum, R. \& S. Rare. Here and there on the cliffs. Banks in the Terrace.

Triticum repens, L. Very common. Tall and fine on the shore at Longy Bay. 
T. pungens, Pers. Rather common all along the sandy coast. A fine Triticum, which has not yet been satisfactorily determined, grows on the shore at Fort Doyle and Baie de Saye. It has much the appearance of $T$. acutum, DC., and may possibly prove to be that species.

T. junceum, L. Frequent in sandy bays.

Hordeum murinum, I، Very common everywhere.

Lolium perenne, L. Very common.

L. italicum, A. Br. Here and there in all parts, sparingly.

L. temulentum, L. Recorded by Babington as found by him at St. Anne's.

\section{EQUISETACEAE.}

Equisetum arvense, L. Generally distributed, and usually plentiful where it occurs.

E. maximum, Lam. Field corner not far from Rose Farm, plentiful : some of the stems five feet high. This fine Horsetail is not known to occur in any other locality in these islands.

E. palustre, L. Pond on Longy Common. Reuters Valley. Valley behind Essex House.

\section{FE RNS.}

Polypodium vulgare, L. Generally distributed, but rather rare, and often stunted. Fairly fine specimens occasionally occur in old quarries, and on the cliffs.

Lastrea Filix-mas, Presl. Rare. Sparingly about Clanque, in Rose Farm Valley, and in the old quarries at Mauney. More plentiful in one place on the hillside above Clanque Bay.

L. dilatata, Presl. Very rare. Scattered roots in Rose Farm Valley, and on the hillside at Clanque.

Athyrium Filix-foemina, Roth. Very rare. Rose Farm Valley, a few clumps in different spots.

Asplenium lanceolatum, Huds. Rare. In several places on the cliffs, but as a rule scantily. 
A. Adiantum-nigrum, L. The most frequent fern in Alderney with the exception of the common Bracken: but by no means common, and often small.

A. Trichomanes, L. Very rare. One root in an old wall near the Presbyterian Church.

A. marinum, L. Rare. Sparingly in several places on the coast near Corbelets. Plentiful on the inner walls of Fort Houmet. Scattered roots here and there among rocks on the cliffs.

A. Ruta-muraria, L. Very rare. On one of the walls of Fort Essex, in good quantity.

Scolopendrium vulgare, Sym. Rare. A few scattered roots in the larger valleys, and in the old quarries at Mauney. Stunter plants on walls on the outskirts of the town.

Ceterach officinarum, Willd. Very rare. Three plants on a wall on the west side of St. Anne's.

Blechnum boreale, Sw. Rare. A few roots in one of the Clanque Valleys. . Rose Farm Valley, scarce.

Pteris aquilina, L. Very common. This is the only fern at all plentiful in Alderney.

\section{MOSSES.}

Catharinea undulata, Web. \& Mohr. In an old quarry at Clanque. Banks behind the Terrace. Reuters Valley.

Polytrichum piliferum, Schreb. Near Chaise à l'Emauve. Great quarry at Mauney.

P. juniperinum, Willd. Common on the cliffs, as well as in old quarries and heathy places.

Pleuridium subulatum, Rab. On a moist bank on the cliffs above Clanque.

Ceratodon purpureus, Brid. Very common.

Dicranella heteromalla, Schp. On banks in Rose Farm Valley. Cliffs near Val du Sud, in a rabbit hole.

Campylopus fragilis, B. \& S. Frequent on the cliffs. 
C. introflexus, Brid. Rather common on the cliffs.

C. brevipilus, B. \& S. Cliffs near La Chue, and below Essex Castle.

Dicranum scoparium, Hedw. Rather common on the cliffs, and at Mauney. Var. orthophyllum, Brid. Clanque cliffs.

D. majus, Turn. Plentiful in one place on the cliffs at Clanque.

Fissidens viridulus, Wahl. On a shady bank in Reuters Valley.

F. incurvus, Starke. On banks behind the Terrace.

F. bryoides, Hedw. Rather common on moist, shady banks.

F. decipiens, De Not. Frequent on dry grassy hillsides in all parts of the island.

F. taxifolius, Hedw. Mauney Hill.

Grimmia maritima, Turn. On sea rocks at Bibette Point and Château l'Etoc.

G. pulvinata, Smith. Frequent on rocks and boulders.

G. trichophylla, Grev. Cliffs near Val du Sud. Near Chaise à l'Emauve.

G. leucophaea, Grev. Common on the cliffs: atso on Mauney Hill and at Corbelets.

Phascum cuspidatum, Schreb. Fallow field by the brickkilns off the Longy Road. Bare spots on Clanque cliffs.

Pottia truncatula, Lind. Banks by Essex Castle. Old quarry at Mauney. Field off the Longy Road.

P. intermedia, Fuern. Rather common in all parts.

P. crinita, Wils. Cliffs near the Hanging Rock.

P. minutula, Fuern. Sea bank below Fort Tourgis.

Tortula ambigua, Angst. Common on the earthy tops of ruined walls, and in old quarries.

T. atrovirens, Lind. Banks by Fort Corbelets.

T. muralis, Hedw. Common on walls and rocks.

T. laevipila, Schwgr. On old ash-trees, Essex House Valley. On trees below the Terrace and in Reuters Valley. 
T. ruralis, Ehrh. On rocks, La Chue cliffs.

T. ruraliformis, Dix. Abundant on the sandhills and commons of the low-lying coast.

Barbula rubella, Mitt. In a hedgebank at Clanque.

B. tophacea, Mitt. On streamsides in Reuters Valley, and in Essex House Valley. Mauney.

B. fallax, Hedw. On the ground in the great quarry at

B. rigidula, Mitt. Walls of Fort Tourgis.

B. cylindrica, Schp. Rose Farm Valley. Saline.

B. Hornschuchiana, Schultz. On the sandhills at Platte

B. revoluta, Brid. Ruined wall by the Longy Rifle Butts. Farm.

B. convoluta, Hedw. Wall-top on the roadside near Rose

B. unguiculata, Hedw. On banks, Braye Road. Wall-top in the Moriaux Road. Among ruins between Fort Albert and Longy.

Weısia viridula, Hedw. Common.

W. verticillata, Brid. On dripping rocks on the shore below Fort Albert. Albert.

Trichostomum crispulum, Bruch. North slopes of Fort

T. mutabile, Bruch. Rather common in all parts.

T. littorale, Mitt. Wall near White Gates. Bibette Point. Here and there on the cliffs.

T. flavovirens, Bruch. Common on the sandhills, and on Mauney Hill.

Pleurochaete squarrosa, Lindb. Plentiful on the south slopes of Mauney Hill, and on the common beyond the Rifle Butts.

Zygodon viridissimus, Brown. Frequent on trees, walls, and boulders.

Ulota phyllantha, Brid. On treetrunks in the Terrace. On both trees and stones in Essex House Valley. 
Orthotrichum affine, Schrad. On stones, Mauney Hill, Essex House Valley, and Rochers Hill : in each case very sparingly.

O. diaphanum, Schrad. On trees and stones in many parts of the island.

Funaria ericetorum, Dix. Streamsides below Chaise à l'Emauve and at Trois Vaux.

F. hygrometrica, Sibth. Common on the cliffs.

Bartramia stricta, Brid. Plentiful on the cliffs between La Chue and the Hanging Rock: fruiting freely in March. Grows on the ground and in crevices of rocks : capsules bright orange yellow. This is the only locality in the Channel Islands for this rare moss, and the second station in the kingdom: the other being the Stanner Rocks, in Radnorshire, where it was discovered a year or two ago. It used to grow in one locality in Sussex, but it is believed to be extinct there now.

Webera Tozeri, Schp. On a moist roadside bank below Essex Castle : barren.

Bryum bimum, Schreb. Marshy place in the great quarry at Mauney.

B. capillare, L. Frequent on the cliffs.

B. atropurpureum, W. \& M. In old quarries and on banks in several places.

B. murale, Wils. On a wall in Rose Farm Valley.

B. argenteum, L. Here and there throughout the island, but not common.

Mnium hornum, L. Frequent.

Thuidium tamariscinum, B. \& S. Cliffs near Essex Castle. In fruit sparingly on the Clanque cliffs.

Isothecium myurum, Brid. Railway banks at Mauney.

Pleuropus sericeus, Dix. Rather common.

Camptothecium lutescens, B. \& S. Common on the lowlying coast. Fruiting plentifully at Corbelets.

Brachythecium glareosum, B. \& S. In a hedgebank on the Longy Road.

B. albicans, B. \& S. Frequent on the sandhills.

B. rutabulum, B. \& $\mathrm{S}$. Rather common in all parts. 
B. plumosum, B. \& S. On stones in the stream in Rose Farm Valley.

B. illecebrum, De Not. Rather common in old quarries and on dry banks throughout the island.

B. purum, Dix. Common.

Eurhynchium piliferum, B. \& S. Essex House Valley.

E. speciosum, Schp. On stones in the streamlet at Clanque.

E. praelongum, B. \& S. Very common.

E. Swartzii, Hobk. Rose Farm Valley.

E. pumilum, Schp. On a bank, Essex House Valley.

E. tenellum, Milde. Sparingly, but fruiting, at the base of the Terrace wall.

E. myosuroides, Schp. Rather common on the cliffs.

E. circinatum, B. \& S. Frequent on rocks and walls. On the trunk of an old ash-tree in Essex House Valley.

E. striatum, B. \& S. Railway banks near White Gates. Valley below the Terrace.

E. rusciforme, Milde. In the streamlet at Val du Sud.

E. confertum, Milde. Common.

Amblystegium serpens, B. \& S. Rather common.

A. filicinum, De Not. Frequent on streamsides and in wet places.

Hypnum stellatum, Schreb. Marshy spot near Clanque.

H. fluitans, L. Marsh on Clanque cliffs. Streamside at Trois Vaux.

H. commutatum, Hedw. In a small waterfall at the end of the valley at Trois Vaux.

H. cupressiforme, L. Very common.

H. resupinatum, Wils. Frequent on shaded trees, rocks, and stones.

H. molluscum, Hedw. Marshy place on the cliffs at Clanque.

H. cuspidatum, L. Common in wet places. 
Hylocomium squarrosum, B. \& S. In damp grassy spots near Clanque; in the valley below the Terrace; and in Rose Farm Valley. cliffs.

H. triquetrum, B. \& S. On mossy banks on the Clanque

\section{HEPATICAE.}

Conocephalus conicus, L. Streamside in Reuters Valley.

Lunularia vulgaris, Mich. Rose Farm Valley.

Riccia glauca, L. Several places on the cliffs, and in Rose Farm Valley.

Frullania dilatata, Dum. Common on the cliffs on rocks: occasionally on walls and stones.

F. Tamarisci, Dum. Cliffs near Essex Castle, and about Clanque. Rocks under Fort Albert.

Lejeunia minutissima, Sm. On tree-trunks in Essex House Valley, and below the Terrace. On stones in Reuters Valley.

Radula complanata, L. Reuters Valley, on stones.

Cephalozia divaricata, Sm. Moor above Clanque. Near the old Telegraph Station. Cliffs near Val du Sud.

C. bicuspidata, Dum. Cliffs near Essex Castle, Val du Sud, and Clanque.

Lophocolea bidentata, L. Rather common.

L. heterophylla, Schrad. Among rocks on Mauney Hill. On earthy banks in the Terrace.

Chiloscyphus polyanthos, L. Streamlets at Trois Vaux and Val du Sud.

Kantia Trichomanis, L. Cliffs at Clanque and near Essex Castle. Var. propagulifera, Husn. Rose Farm Valley. Trois Vaux.

Scapania compacta, Dum. Old quarry at Mauney. Hillside at Clanque. Cliffs near Val du Sud.

Plagiochila spinulosa, Dicks. On a bank at Clanque. 
Jungermannia ventricosa, Dicks. Cliffs near the Hanging Rock.

Fossombronia pusilla, Nees. Streamside at Clanque.

Pellia epiphylla, L. On streamsides in Reuters Valley and Rose Farm Valley.

P. calycina, Tayl. Marshy place on the Clanque cliffs.

Aneura multifida, Gray. Sides of the cliff streamlet at Clanque.

Metzgeria furcata, Dum. Frequent in all parts of the island on trees, rocks, and boulders.

\section{FUNGI.}

Lepiota procera, Scop. On many parts of the cliffs and the Blaye. Valley below Essex House.

L. excoriata, Schaef. On the Blaye, towards Telegraph Bay.

L. gracilenta, Kromb. Near the Explosive Factory west of St. Anne's.

Tricholoma personatum, Fr. Essex House Valley. West side of the Blaye.

T. nudum, Bull. Rochers Hill. Longy Common. Clanque.

T. humile, Pers. Hillside, Rochers.

T. gambosum, Fr. Western side of the Blaye.

Marasmius oreades, Fr. Many parts of the Blaye. Mauney Hill. A rather common species.

M. rotula, Fr. On dead twigs, Reuters Valley.

M. androsaceus, Fr. Cliffs at Clanque.

Collybia radicata, Relh. Hillside near Essex Castle.

C. velutipes, Fr. Reuters Valley. Hillside, Rochers. Near Essex Castle.

Mycena tenerrima, Berk. On decayed stems. Reuters Valley. The Terrace. Rose Farm Valley.

M. pura, Pers. On the cliffs at Clanque. 
Russula alutacea, Fr. Among furze on the cliffs above Clanque, two specimens.

Laccaria laccata, Scop. Rose Farm Valley. Near Fort Tourgis.

Clitocybe nebularis, Batsch. Hillside at Rochers.

C. fragrans, Sow. Near Fort Tourgis. Rochers.

Omphalia pyxidata, Bull. Near Fort Tourgis.

Pleurotus septicus, Fr. On decaying cabbage stumps, east side of the Blaye.

Hygrophorus puniceus, Fr. Little Rochers.

H. obrusseus, Fr. Clanque cliffs. Rochers Hill.

H. conicus, Fr. Rochers Hill. Clanque cliffs. West side of the Blaye.

H. virgineus, Wulf. Slopes of Fort Tourgis. Baie de Saye.

H. niveus, Fr. Little Rochers.

Cantharellus cibarius, Fr. Hillside close to Fort Tourgis.

Volvaria gloiocephala, Fr. Fort Albert Hill, near White Gates, several fine specimens.

Entoloma sericeum, Fr. On the Blaye. Hillside above Clanque.

Nolanea pascua, Pers. Near Fort Tourgis.

Clitopilus prunulus, Scop. Baie de Saye. Rochers. Blaye.

Bolbitius titubans, Fr. Pastures on the Blaye.

B. Boltoni, Fr. Baie de Saye.

Naucoria semi-orbicularis, Bull. Rose Farm Valley. Longy Common. Clanque.

N. melinoides, Fr. On the Blaye towards Clanque.

Galera tenera, Schaef. Rochers Hill.

Agaricus campestris, Linn. On many parts of the Blaye, and at Mauney.

A. arvensis, Schaef. Blaye towards Rose Farm, and near Fort Tourgis. 
Stropharia semiglobata, Batsch. Near Essex Castle. Blaye. Rose Farm Valley.

S. aeruginosa, Curt. Essex House Valley.

Hypholoma sublateritius, Schaef. On stumps in the Terrace.

H. fasciculare, Huds. On furze stumps, Fort Tourgis. Rose Farm Valley.

Psilocybe semilanceata, Fr. Blaye near Telegraph Bay.

P. spadicea, Fr. Butes Hill.

P. foenisecii, Pers. Hillside at Rochers.

Psathyrella atomata, Fr. Rose Farm Valley.

Panaeolus papilionaceus, Fr. Rochers Hill.

Coprinus atramentarius, Fr. On stumps in the Tcrrace.

C. niveus, Fr. Fort Tourgis. Blaye. Little Rochers. Clanque.

C. micaceus, Fr. Hillside above Clanque Bay.

C. radiatus, Fr. Clanque cliffs.

C. plicatilis, Fr. Essex House Valley.

Polyporus squamosus, Fr. On a tree in the Terrace.

Merulius lacrymans, Fr. In an outhouse, Belle Vue.

Stereum hirsutum, Fr. The Terrace. Rose Farm Valley.

S. spadiceum, Fr. The Terrace.

Corticium caeruleum, Fr. On a stump, Rose Farm Valley.

Peniophora incarnata, Mass. On stumps in the Terrace.

Clavaria fastigiata, Linn. Clanque. Fort Tourgis.

C. muscoides, Linn. On the Blaye towards Clanque. Clanque.

C. fusiformis, Sow. Grassy slope by Essex Castle. Cliffs at

Tremella mesenterica, Retz. Rose Farm Valley.

Exidia albida, Bref. On decaying twigs in the Terrace.

Hirneola Auricula-judae, Berk. On Elder-trees. Longy Road. West side of the Blaye. Essex House Valley. 
Tulostoma mammosum, Fr. In sandy ground at Baie de Saye, in several spots. North end of Butes Hill. Blaye.

Lycoperdon gemmatum, Batsch. Rose Farm Valley. The

L. pyriforme, Schaef. Near Fort Houmet.

L. Bovista, Linn. Cliffs at Clanque. Pasture field near Trois Vaux. Sud.

L. plumbeum, Pers. Rochers Hill. Cliffs towards Val du

Erysiphe umbelliferarum, De By. On leaves of Heracleum, Rochers.

E. communis, Fr. On Polygonum aviculare, Rochers. Rose Farm Valley, on Ranunculus acris.

Nectria cinnabarina, Tode. The Terrace. Essex House Valley.

Xylaria Hypoxylon, Fr. Essex House Valley. The Terrace. Clanque Cliffs. Rose Farm Valley. dung.

Poronia punctata, Fr. Coast near Fort Houmet, on horse-

Rhytisma acerinum, Pers. On Sycamore leaves in the 'Terrace. Valley.

Geoglossum glabrum. Pers. Grassy place, Essex House

G. difforme, Fr. Braye Bay.

Humaria rutilans, Sacc. Cliffs near the Hanging Rock. stump.

Helotium claroflavum, Berk. Rose Farm Valley, on a

H. virgultorum, Karst. On a stump on the Blaye.

Mollisia cinerea, Karst. On furze stumps, Reuters Valley. Near Essex Castle.

Ascobolus furfuraceus, Pers. Clanque Cliffs. Road.

Hysterium pulicare, Pers. On dead bramble, Moriaux

Cystopus candidus, Lev. In several places at Longy on Diplotaxis. Near the Church on Capsella. 
Phyllosticta hedericola, Dur. \& Mont. On Ivy leaves near Essex Castle.

Vermicularia dematium, Fr. East side of the Blaye, on dead stems.

Uromyces Trifolii, Lev. Longy. Blaye. Rose Farm Valley.

U. Polygoni, Wint. On Polygonum amphibium, Longy Pond.

U. concentrica, Lev. On leaves of Endymion nutans at Burhou.

U. Fabae, Cke. On the Blaye.

U. Poae, Rab. Lane above Picnterre Brewery : the Aecidium stage on Pilewort leaves. Teleutospores on grass leaves in Rose Farm Valley.

U. Rumicis, Wint. On the Blaye.

Puccinia Graminis, Pers. On grass leaves on the Railway banks.

P. Violae, Wint. On leaves of Dog Violet, Rose Farm Valley.

P. obscura, Schrot. The Aecidium stage on Daisy leaves. Rochers Hill. Rose Farm Valley. Clanque.

P. Menthae, Pers. On Water Mint, Longy Bay. Rose Farm Valley.

P. suaveolens, Wint. On Thistle leaves on the Blaye, and on the Railway banks.

P. Smyrnii, Corda. On leaves of Smyrnium, the Aecidium stage. Near the Presbyterian Church.

P. Umbilici, Guep. On leaves of Cotyledon, frequent.

P. malvacearum, Mont. Moriaux Road. Butes Hill. The Blaye. Mauney.

Phragmidium violaceum, Schultz. On the cliffs.

P. Rubi, Schrot. Corbelets. Platte Saline. Mauney.

Melampsora farinosa, Schrot. Rose Farm Valley.

Coleosporium Senecionis, Wint. In several places on the cliffs. Braye Bay.

C. Sonchi, Schrot. Rose Farm Valley. 
C. Euphrasiae, Wint. On Eyebright, Longy Common.

Ustilago Avenae, Pers. On the Blaye. Longy Road.

U. violacea, Pers. In flowers of Silene maritima on the cliffs, and at Corbelets.

Lycogala epidendrum, Rost. Cliffs near Val du Sud, on a decaying stump.

Spumaria alba, DC. Little Rochers. Baie de Saye.

\section{LICHENS.}

Lichina pygmaea, Lightf. Clanque. Château l'Etoc. Fort Houmet.

L. confinis, Ach. On rocks at high-water mark, frequent.

Collema pulposum, Bernh. On a wall above Platte Saline.

C. cheileum, Ach. Walls in the Longy Road.

Leptogium biatorinum, Nyl. Under Fort Essex (Larbalestier).

Sphaerophoron coralloides, Pers. On rocks at Clanque.

Baeomyces rufus, DC. Roadside bank on the Blaye Road. Cliffs near Val du Sud.

Cladonia endiviaefolia, Fr. Near Château l'Etoc, and on the eastern side of Mauney.

C. pyxidata, Fr. Rather common.

C. squamosa, Hffm. Near Essex Castle.

C. rangiferina, Hffm. Common on the cliffs and moors: occasionally on sandy shores.

Roccella phycopsis, Ach. On the cliffs at Clanque, and near the Hanging Rock. Rocks Lelow Fort Albert. Plentiful on a roadside wall above Platte Salin`.

R. fuciformis, Ach. On rocks on the cliffs, and on the coast generally. More common than the last species.

Usnea barbata, L. Rare. Clanque cliffs, on rocks. 
Ramalina farinacea, L. Rose Farm Valley.

R. fraxinea, L. On trees off the Longy Road.

R. fastigiata, Pers. Growing in company with the last species.

R. pollinaria, Ach. On Hawthorns, Longy Road.

R. scopulorum, Dicks. More or less common all round the coast.

R. subfarinacea, Nyl. Alderney (Crombie). Larbalestier's Lichenes Rarissimi, No. I 30 in my copy.

$R$. cuspidata, Ach. Intermixed with $R$. scopulorum on rocks on the coast.

Peltigera canina, Hffm. On the cliffs in many places, and on the western side of the Blaye. Mauney Hill and quarries.

P. rufescens, Hffm. Cliffs east of Essex Castle.

Parmelia caperata, L. Rather common. In fruit near the Hanging Rock.

P. olivacea, L. Château l'Etoc.

P. physodes, L. Near the Hanging Rock.

P. reddenda, Stirt. Tree-trunks in Essex House Valley, sparingly.

P. perlata, L. Rather common on rocks.

P. fuliginosa, Dub. Cliffs near the Hanging Rock.

P. perforata, Wulf. On the cliffs near the Hanging Rock. Near Fort Essex (Labalestier).

P. conspersa, Ehrh. On rocks at the eastern end of the island.

P. saxatilis, L. Common on the cliffs. In fruit below the Hanging Rock. f. furfuracea, Schaer. Alderney (Crombie).

P. omphalodes, Ach. Frequent on rocks.

Physcia flavicans, Sw. On rocks. Clanque. Hanging Rock. Chaise à l'Emauve.

P. parietina, L. Very common. Var. ectanea, Nyl. On a wall near the White Gates. 
P. obscura, Ehrh. On trees, Essex House Valley. Var. virella, Ach. On Black Poplars below the Church.

P. leucomela, L. Alderney (Crombie).

P. speciosa, Wulf. Alderney (Crombie).

P. erosa, Borr. Cliffs near Val du Sud.

P. stellaris, L. On trees, Longy Road. Var. leptalea, Ach. Near the Hanging Rock.

P. tenella, Nyl. Cliffs near Val du Sud.

P. aquila, Ach. Rather common on the coast.

Pannaria nebulosa, Nyl. Alderney (Crombie).

P. plumbea, Lightf. Alderney (Larbalestier: Crombie).

Placodium murorum, Hffm. On several walls on the outskirts of the town.

P. lobulatum, Smrft. On sea-rocks at the east of the island.

P. miniatum, Hffm. Rocks at Clanque.

P. callopismum, Ach. Var. plicatum, Wedd. Coast of Alderney (Crombie).

P. citrinum, Ach. On old walls at Clanque, and on the Blaye. f. depauperata, Cromb. Alderney (Crombie). This is perhaps the same form as No. I 77 in Larbal. Lich. Rar., which is labelled, 'Lecanora citrina, Hffm. var. - - (A_very singular form, C. L.) coast of Alderney, r873.'

P. fulgens, Sw. On sandy ground on the coast north of Longy Bay.

Lecanora vitellina, Ach. Frequent on rocks and boulders.

L. candelaria, Ach. On Poplars below the Church.

L. privigna, Nyl. Alderney (Crombie).

L. fuscata, Schrad. Wall near Trois Vaux. Stony bank on the Blaye.

L. cinerea, L. Cliffs near La Chue.

L. tartarea, Ach. Rocks near Chaise à l'Emauve.

L. atra, Huds. Frequent on rocks. 
L. sulphurea, Hffm. Rather common on the coast.

L. subfusca, L. On walls, common. Longy Road, on trees.

L. galactina, Ach. Old wall in Reuters Valley.

L. sp. In my copy of Larbalestier's Lichenes Rarissini, the specimen numbered 125 is a fragment labelled in Mr. Larbalestier's handwriting 'Lecanora . . . . affinis L. badiae, Ach. nova species ut videtur. Apothecia non visa. Ad saxa in insulâ Alderney, sterilis, I873. C. L.'

L. torquata, Fr. Alderney (Crombie). This is No. I 12 of Larbal. Lich. Rariss. in my copy.

L. parella, L. Common on rocks and stones: occasionally on trees.

L. glaucoma, Hffm. Walls near Essex Castle.

L. subcarnea, Ach. Alderney (Crombie). Larbal. Lich. Rariss., No. Iog.

L. ferruginea, Huds. Frequent on rocks and hedgestones.

L. cerina, Ehrh. On an Elm-tree near Petit Val. On Sycamores in Essex House Valley.

L. ulmicola, DC. Essex House Valley, on an Elm-tree.

L. coniopta, Nyl. Near Fort Essex (Larbalestier). No. I I I of Larbal. Lich. Rariss. in my copy.

L. holophaea, Nyl. Var. glaucopsora,, Nyl. Alderney (Larbalestier: Crombie).

L. pyreniospora, Nyl. Alderney, 1873, Mr. Larbalestier (Lich. Rariss., No. I59).

L. haematomma, Ehrh. Clanque Cliffs. Hanging Rock.

Pertusaria dealbata, Ach. On rocks in Clanque Bay. Cliffs near La Chue.

Lecidea lucida, Ach. Below the Hanging Rock.

L. enteroleuca, Ach. Cliffs near La Chue.

L. parasema, Ach. On trees, common. Var. latypaea, Ach. On rocks near La Chue. 
L. protrusa, Fr. Cliffs at Clanque. Near Fort Essex (Larbalestier).

L. coarctata, Sm. Slopes of Fort Tourgis.

L. caligans, Nyl. On a single block of stone near Fort Essex (Larbalestier). My specimen (Larbal. Lich. Rariss., No. I I9) is labelled 'L. caligans, Nyl. nov. spec. (c. fr.) Alderney, 1873 . Only three or four specimens found.'

L. rivulosa, Ach. Frequent on the cliffs.

L. contigua, Fr. Rather common on rocks and stones.

L. canescens, Dicks. One of the commonest lichens in Alderney. Occasionally in fruit.

L. stellulata, Tayl. Cliffs near La Chue. Walls on the Blaye.

L. myriocarpa, DC Cliffs at Clanque.

L. subdisciformis, Leight. Near Val du Sud, and at Clanque.

L. biformigera, Leight. Coast of Alderney (Larbalestier).

L. albo-atra, Hffm. Roadside wall near Trois Vaux.

L. aromatica, Sm. Frequent on old walls.

L. phacodes, Korb. On an Elm-tree in Reuters Valley (f. chlorotica, Ach.).

L. sabuletorum, Flk. Old wall below Essex Castle. Wall near White Gates.

L. endoleuca, Nyl. Essex House Valley, on trees. Chaise dे l'Emauve, on furze stems.

L. rubella, Ehrh. On an Elm, Essex House Valley.

L. geographica, L. Frequent on the coast.

L. petraea, Wulf. Rather common on rocks and stones.

L. concentrica, Dav. On a wall near Trois Vaux.

Opegrapha atra, Pers. On trees, common.

O. saxicola, Ach. Common on walls and boulders. 
O. Chevallieri, Leight. Wall on the Blaye.

O. grumulosa, Duf. Walls of the old Nunnery, Alderney (Larbalestier). This is No. 161 of Larbal. Lich. Rariss. in my copy.

O. varia, Pers. On trees, frequent.

O. vulgata, Ach. On rocks at Clanque (f. steriza, Ach.).

Stigmatidium crassum, Dub. On an old hawthorn near Rose Farm.

Arthonia cinnabarina, Wallr. Rare. Near Rose Farm, on an old hawthorn (var. pruinata, Del.).

A. varians, Dav. Parasitic on the apothecia of Lecanora glaucoma, on a wall near Essex Castle.

Normandina laetevirens, Turn. \& Borr. On the earth among rocks. North side of Fort Albert. Near Corbelets.

Verrucaria striatula, Whlnb. Under Fort Essex (Larbalestier). No. 84 of Larbal. Lich. Rariss. in my copy.

V. microsporoides, Nyl. Coast of Alderney (Larbalestier). No. 77 of Larbal. Lich. Rariss.

V. maura, Whlnb. Rather common on the coast.

V. mauroides, Schaer. Common on hedgestones.

V. polysticta, Borr. Hill above Fort Essex (Larbalestier).

V. viridula, Schrad. Wall above Moriaux House.

V. analepta, Ach. On hawthorns near Trois Vaux. Road.

V. biformis, Borr. Essex House Valley. Trees in Moriaux

V. chlorotica, Ach. Wall on the Blaye.

V. nitida, Weig. The Terrace. Near Rose Farm. Var. nitidella, Flk. Essex House Valley. 


\section{SEAWEEDS.}

Lyngbya majuscula, Harv. In a rockpool close to Fort Houmet.

Calothrix confervicola, C. Ag. Platte Saline. Longy.

C. scopulorum, C. Ag. Clanque. Fort Houmet.

Rivularia atra, Roth. Fort Houmet. Braye Bay. Longy.

R. bullata, Berk. Clanque. Braye Bay. Corbelets.

Enteromorpha compressa, Grev. Longy. Clanque.

E. Linza, J. Ag. Longy. Corbelets. Braye.

E. intestinalis, Link. Braye Bay.

Ulva latissima, J. Ag. Common.

U. rigida, J. Ag. Clanque.

Chaetomorpha aerea, Kutz. Corbelets. Longy.

Cladophora diffusa, Phyc. Brit. Longy. Clanque.

C. Laetevirens, Phyc. Brit. Clanque. Longy.

C. rupestris, Kutz. Clanque. Corbelets. Longy.

C. flexuosa, Griff. Longy.

C. refracta, Phyc. Brit. Clanque.

C. arcta, Kutz. Clanque.

C. lanosa, Kutz. Longy. Clanque, in fruit.

Bryopsis hypnoides, Lam. Corbelets. Fort Houmet.

B. plumosa, C. Ag. Fort Houmet. Platte Saline.

Codium tomentosum, Stack. Clanque. Corbelets. Longy.

Desmarestia aculeata, Lam. Clanque Bay, washed up.

D. ligulata, Lam. Clanque Bay, washed up. 
Litosiphon pusillus, Harv. Braye Bay, on Chorda filum. Platte Saline, on Alaria esculenta.

Stictyosiphon Griffithsianum, Holm. \& Batt. Longy Bay, on Rhodymenia palmata.

Punctaria plantaginea, Grev. Clanque, in fruit. Longy.

Asperococcus echinatus, Grev. Longy.

Ectocarpus fasciculatus, Harv. Clanque.

E. granulosus, C. Ag. Clanque.

E. tomentosus, Lyng. Longy. Clanque. Braye.

Pylaiella litoralis, Kjell. Corbelets.

Myriactis pulvinata. Kutz. Clanque, on Cystoseira ericoides.

Elachista scutulata, Duby. Fort Houmet.

E. flaccida, Aresch. Clanque. Longy. Braye.

E. fucicola, Fries. Clanque. Braye. Longy.

Sphacelaria radicans, Harv. Longy.

S. olivacea, Prings. Longy.

S. cirrhosa, C. Ag. Braye Bay. Clanque. Longy.

S. fusca, Phyc. Brit. Longy.

Cladostephus spongiosus, C. Ag. Corbelets. Clanque.

C. verticillatus, C. Ag. Clanque. Longy.

Stypocaulon scoparium, Kutz. Clanque. Longy.

Chilionema ocellatum, Sauv. On Laminaria saccharina, Clanque

Myrionema strangulans, Grev. Clanque. Longy.

Ralfsia clavata, Crn. Clanque.

R. verrucosa, Aresch. Clanque. Longy.

Castagnea virescens, Thur. Clanque. Longy. Braye. 
Leathesia difformis, Aresch. Longy. Clanque. Braye.

Scytosiphon lomentarius, J. Ag. Corbelets. Braye Bay. Fort Houmet. Longy.

Chorda Filum, Stack. Longy.

Laminaria saccharina, Lam. Clanque. Longy., Braye.

L. digitata, Edm. Corbelets.

Saccorhiza bulbosa, De la Pyl. Clanque. Corbelets.

Alaria esculenta, Grev. Platte Saline, growing on the rocks in the middle of the bay.

Fucus vesiculosus, Linn. Clanque. Corbelets. Braye.

F. serratus, Linn. Longy. Clanque. Braye.

Ascophyllum nodosum, Le Jol. Clanque. Corbelets.

Pelvetia canaliculata, Dcne. Corbelets. Clanque.

Bifurcaria tuberculata, Stack. Corbelets.

Himanthalia lorea, Lyng. Corbelets. Longy. Clanque.

Halidrys siliquosa, Lyng. Clanque. Corbelets.

Cystoseira ericoides, C. Ag. Longy. Corbelets. Clanque.

C. discors, Clanque. Longy.

C. fibrosa, C. Ag. Corbelets. Clanque. Longy.

Dictyota dichotoma, Lam. Longy. Clanque. Var. intricata, Phyc. Brit. Longy.

Padina pavonia, Gail. In a pool near Fort Houmet.

Porphyra linearis, Grev. Clanque. Longy.

P. laciniata, Grev. Braye Road. Fort Houmet. Clanque.

Chantransia Daviesii, Thur. Corbelets.

Helminthora divaricata, J. Ag. Clanque.

Scinaia furcellata, Biv. Rockpool by Fort Houmet. 
Gelideum corneum, Lam. Clanque (vars. pinnatum and confertum).

Chondrus crispus, Stack. Corbelets. Clanque. Longy.

Gigartina acicularis, Lam. Platte Saline.

G. pistillata, Stack. Fort Houmet.

G. mamillosa, J. Ag. Platte Saline. Longy. Braye.

Phyllophora rubens, Grev. Corbelets. Clanque.

Gymnogongrus Griffithsiae, Mart. Corbelets.

Ahnfeltia plicata, Fries. Platte Saline. Corbelets. Clanque.

Callophyllis laciniata, Kutz. Platte Saline.

Callymenia reniformis, J. Ag. Longy.

Cystoclonium purpurascens, Kutz. Clanque. Longy.

Rhodophyllis bifida, Kutz. Platte Saline. Clanque.

Sphaerococcus coronopifolius, Grev. Corbelets Bay, washed up.

Gracilaria confervoides, Grev. Corbelets.

Calliblepharis jubata, Kutz. Longy. Clanque.

Rhodymenia palmetta, Grev. Corbelets.

R. palmata, Grev. Longy. Clanque. Corbelets.

Lomentaria articulata, Lyng. Platte Saline. Longy. Clanque. Braye.

Champia parvula, Harv. Clanque.

Chylocladia kaliformis, Grev. Corbelets. Longy. Clanque.

C. ovalis, Hook. Clanque. Corbelets.

Plocamium coccineum, Lyng. Clanque. Longy. Corbelets. Nitophyllum uncinatum, J. Ag. Longy. Clanque.

N. laceratum, Grev. Platte Saline. Longy.

N. punctatum, Grev. Fort Houmet. 
N. Hilliae, Grev. Longy. Braye Bay.

Delesseria alata, Lam. Corbelets. Longy.

D. Hypoglossum, Lam. Longy.

D. ruscifolia, Lam. Longy.

D. sinuosa, Lam. Clanque.

D. sanguinea, Lam. Corbelets. Clanque. Longy.

Bonnemaisonia asparagoides, C. Ag. Longy. Braye.

Laurencia obtusa, Lam. Fort Houmet.

L. pinnatifida, Lam. Clanque. Corbelets. Longy.

Chondria dasyphylla, C. Ag. Longy.

Polysiphonia fibrata, Harv. Braye Bay. Corbelets.

P. urceolata, Grev. Longy.

P. violacea, Wyatt. Platte Saline. Longy.

P. fibrillosa, Grev. Clanque.

P. fastigiata, Grev. Longy. Platte Saline.

P. simulans, Harv. Clanque.

P. atro-rubescens, Grev. Braye Bay.

P. nigrescens, Grev. Corbelets. Clanque. Longy.

P. byssoides, Grev. Longy. Clanque. Braye.

P. Brodiaei, Grev. Longy.

P. fruticulosa, Spreng. Clanque. Longy. Platte Saline. Braye Bay.

Dasya arbuscula, C. Ag. Longy. Braye.

D. coccinea, C. Ag. Clanque. Corbelets. Longy.

Sphondylothamnion multifidum, Nag. Longy.

Griffithsia corallina, C. Ag. Longy.

G. setacea, C. Ag. Clanque. Longy. 
Halurus equisetifolius, Kutz. Corbelets. Fort Houmet.

Bornetia secundiflora, Thur. Corbelets.

Monospora pedicellata, Solier. Clanque. Longy.

Rhodochorton Rothii, Nag. Longy.

R. floridulum, Nag. Clanque.

Callithamnion Hookeri, C. Ag. Longy. Braye.

C. brachiatum, Phyc. Brit. Platte Saline.

C. tetricum, C. Ag. Longy.

C. corymbosum, Lyng. Corbelets. Braye.

Plumaria elegans, Bon. Platte Saline. Longy.

Crouania attenuata, J. Ag. Fort Houmet. Longy.

Ceramium diaphanum, Roth. Clanque.

C. circinatum, J. Ag. Longy. Clanque.

C. rubrum, C. Ag. Clanque. Corbelets. Longy. Braye.

C. echionotum, J. Ag. Longy. Clanque. Braye.

C. acanthonotum, Carm. Longy.

C. ciliatum, Ducl. Clanque. Longy.

Gloeosiphonia capillaris, Carm. Clanque.

Dumontia filiformis, Grev. Longy. Clanque.

Dilsea edulis, Stack. Platte Saline.

Furcellaria fastigiata, Lam. Clanque Longy. Corbelets.

Polyides rotundus, Grev. Longy.

Peyssonnelia Dubyi, Dcne. Clanque.

Hildenbrandtia prototypus, Nard. Corbelets. Clanque.

Melobesia corticiformis, Kutz. Clanque. Fort Houmet.

M. verrucata, Lam. Clanque. 
M. Lejolisii, Rosan. On Zostera leaves, Platte Saline.

Lithophyllum lichenoides, Phil. Clanque.

L. Lenormandi, Rosan. Clanque.

L. polymorphum, Aresch. Longy.

Lithothamnion incrustans, Fosl. Clanque.

Corallina officinalis, Linn. Corbelets. Clanque. Longy.

C. mediterranea, Aresch. Longy.

C. corniculata, Ellis. Platte Saline. Clanque. 



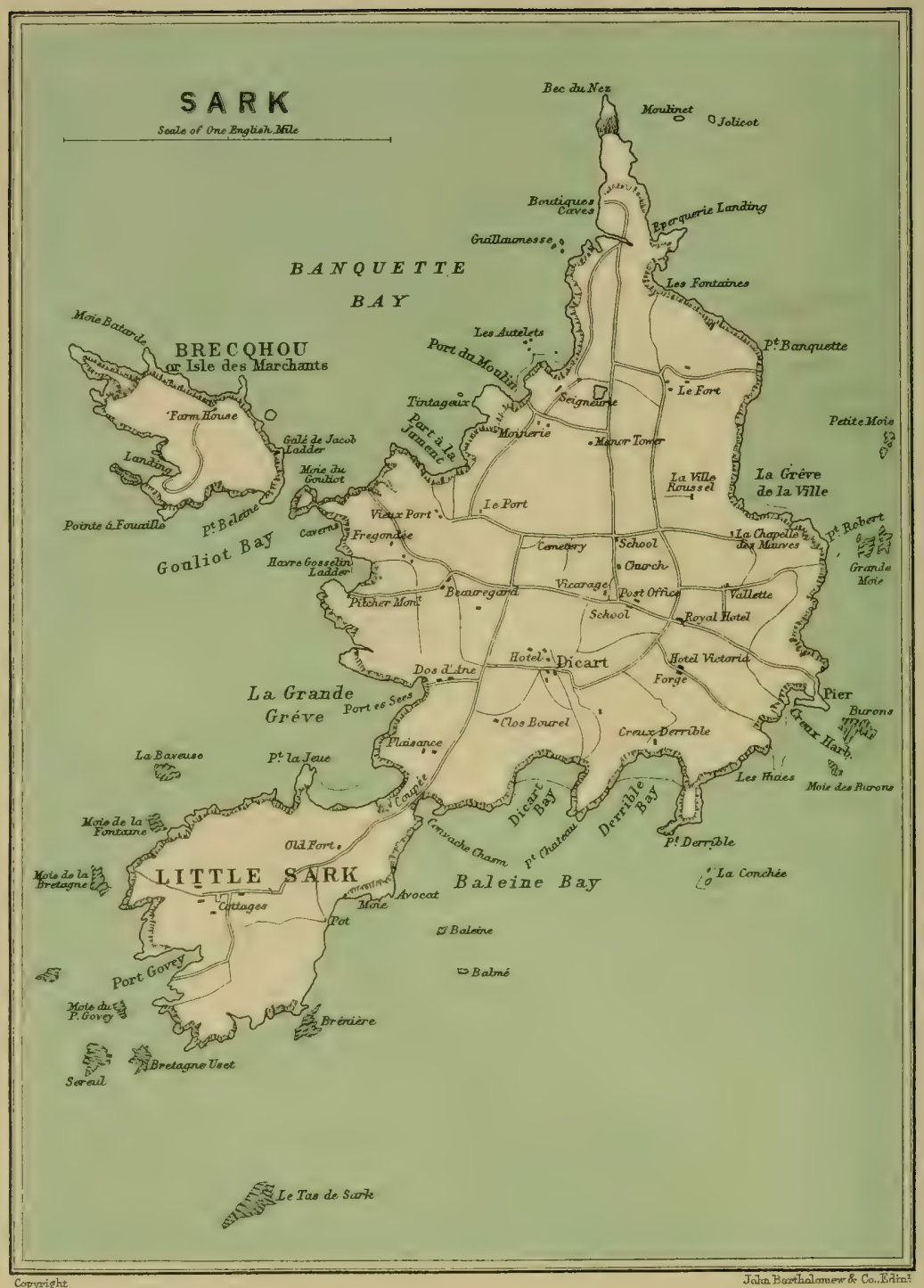




\section{SARK.}

EEW persons who spend a holiday in the Channel Islands fail to visit Sark, if only for the sake of its magnificent coast scenery. Throughout the summer months there are daily excursions by steamer from Guernsey, and the passage only occupies an hour: but it must not be imagined that a hurried scamper over the island will suffice to see what is worth seeing. On the contrary, there is quite enough to interest a lover of nature for a week, and still leave much to be explored.

Like all the other members of this small archipelago, the main island is surrounded by a multitude of smaller islands and rocks, some of them wave-washed and bare, some covered with vegetation and peopled by seabirds which resort there to breed. "Nowhere can the destroying power of the sea be better studied,' says Ansted, 'than in the grand scenes presented at every point round this remarkable island. Detached portions of the main island-others nearly detached and only connected by natural bridges or narrow necks of land-huge vaults through which the sea dashes at all times, or into which it penetrates only at high water-fragments of rock of all dimensions, some jagged and recently broken, some rounded and smooth-vast piles of smaller rocks heaped round : all these offer abundant illustrations of nature's course when the elements meet on the battlefield of an exposed coast, the tidal wave undermining and tearing asunder even the hardest porphyries and granites, however they may seem to present a bold front, and beur the reputation of being indestructible.'

Unlike the island of Guernsey, which is wedge shaped, and has the high part lying on the south, sloping gradually northwards, Sark is an almost level tableland, elevated 350 feet above the sea, with but few valleys, and surrounded at nearly all points by lofty and almost perpendicular cliffs. In outline the island may be roughly compared to an hour-glass, or an elongated figure 8 ; or perhaps more correctly, to a double loop, the two portions being of unequal size, and connected by a short line. This connecting line is the famous Coupée-' 'the glory of the Channel Islands,' as it has been termed-a narrow isthmus 200 yards long, 300 feet high, and only a few feet wide at the top, so that from the pathway along the ridge 
you can almost drop a stone into the sea below. The two divisions of the island on opposite sides of this isthmus are called respectively Great and Little Sark : the former being rather more than two miles long from north to south, the latter barely a mile. The greatest width of the larger peninsula is a little over a mile and a half.

On the western side of Sark, the side which faces Guernsey, a narrow passage of deep and dangerous water separates the main island from the islet of Brechou, or Ile aux Marchands, which rises nearly 200 feet above the sea. This detached fragment is about two-thirds of a mile long, and is surrounded by vertical walls of cliff.

The entire coast-line of Sark is broken into numerous small coves, with sandy, shingly, or rocky beaches, but only a few of these are accessible from the land: in fact, the only way to explore the island properly is to make free use of a boat: but of course this can only be done during calm weather. The caves and caverns which abound on all parts of the coast are of remarkable size and beauty. The most renowned are the Gouliot Caves, concerning which zoologists say that nowhere else in Europe can be found such a wealth and variety of marine life in so small a space. These caves, however, can only be thoroughly investigated a few times in the year, viz., at the very lowest spring tides.

There is no town in Sark, and paved streets are unknown. The beautiful gardens and grounds belonging to the Seigneur, or lord of the island, the Creux du Derrible, and the Coupée, are the principal points of attraction with holiday excursionists. During the summer and autumn thousands of people visit the island: but the resident population does not much exceed six hundred.

The rocks of Sark correspond in their main features with those of Guernsey, though the geologist will find an ample field for study in the local modifications presented by the two islands. There is a plentiful supply of good spring water, but hardly any streamlets, so that little marshy ground and wet meadow-land is to be seen; there is also an entire lack of sand-hills and sandy commons, such as we find in Herm, Alderney, and on the north and west of Guernsey. The climate in general resembles that of the last-named island, except that the air is more bracing, though less so than in Alderney.

For our knowledge of the phanerogamic flora of Sark we are indebted to the researches of four botanists who have investigated the island at different periods. The first of these, and perhaps the first person who systematically studied the botany of Sark, was Professor Charles Cardale Babington, who spent five days here at the end of July and beginning of August in the year 1838 . On that occasion. he noted 247 flowering plants and ferns, as recorded in the pages of his little book, Primitiae Florae Sarnicae, published in 1839 . After an interval of some thirty odd years 1)r. Martin M. Bull, of Jersey, published in the Journal of Botany for 1872 (p. r 99) and for 1874 (p. 83) two lists of plants observed by him in Sark, including six 
species noted by the Rev. W. W. Newbould in 1841 and 1842 . In these two papers 89 new species were added to Professor Babington's record. Twenty years later Mr. W. F. Miller, of Sidcot, North Somerset, spent a fortnight in the island (August I7 to $3 \mathrm{I}$, I 892 ), and during that time was successful in adding 26 phanerogams to the then known flora. These additions formed the subject of a paper in Journ. Bot., November, I892 (p. 347), but Mr. Miller very kindly handed over to me a complete catalogue of all the plants observed by him in Sark, with localities noted for the less common species. This was a valuable acquisition, because in the previous lists of Babington and Bull localities were almost entirely wanting.

The most recent, and by far the most complete enumeration of Sark plants yet printed is the one drawn up by Mr. G. T. Derrick, of Guernsey. In his three papers published in the Transactions of the Guernsey Society of Natural Science for the years I 896 , r 897 , and $x 898$, Mr. Derrick recordis and localises from personal observation 345 flowering plants and ferns, of which upwards of fifty had not previously been noted by any observer.

In the following pages such localities and notes as are given in the above lists are followed by the observer's name in brackets : in other cases the person's name signifies that the plant is mentioned in his list, but without any particulars as to distribution: the dates of observation being, as already stated: Babington, $18_{3} 8$; Bull, I 872 and 1874; Miller, I892; and Derrick, 1896 to 1898 . A few additional notes have been furnished during the last two or three years by my friend Mr. Cecil Andrews, M.A.

An interesting and valuable paper by the Rev. W. Moyle Rogers on 'The Rubi and Rosae of the Channel Islands' will be found in the Journal of Botany for March r 898 (p. 85). Out of about thirty distinct brambles observed in the islands by Mr. Rogers, seven were found in Sark, all of them being, with one exception, "practically identical with our British forms.'

It is clear that the Sark flora resembles in a general way that of the southern or elevated portion of Guernsey, and yet there are some differences that deserve notice. Certain species which are generally diffused throughout the south of Guernsey, and may be described as common, are quite rare in the smaller island, and some appear to be absent altogether, like Medicago lupulina and Geranium Robertianum. So that, although the component parts of the flora are in a great measure the same, they are arranged, so to speak, in a different pattern. Further, it would seem that Sark is by no means so closely related to the Continental mainland as Guernsey is, notwithstanding its position in a direct line between the latter and the nearest part of France : for, out of the seventeen non-British plants indigenous to, or more or less established in Guernsey, only one species (Brassica Cheiranthus) is included in the Sark flora, and even this solitary exception must be either very 
rare or extinct, as it has not been found of late years. Mr. Derrick evidently expected to meet with some of these Continental plants, as he alludes to their absence in his second paper.

Among the Sark phanerogams there are fourteen species which are not known to occur in Guernsey : they are as follows :-

Ranunculus floribundus.

Dianthus Armeria.

Saponaria officinalis.

Trifolium agrarium.

Agrimonia Eupatoria.

Rubus Balfourianus.

Rosa stylosa.
Pyrus communis.

Orobanche rubra.

Mentha sativa.

Lysimachia nemorum.

Amaranthus retroflexus.

Lemna trisulca.

Poa compressa:

With the exception of a few lichens, no plants of any kind have been recorded from the adjacent islet of Brechou. It is not a very attractive botanising ground, perhaps, and is somewhat difficult of access: but it would be worth investigating, because, even if it failed to produce anything distinctive, some information would be gained on the subject of plant-distribution.

The cryptogamic flora of Sark has been very imperfectly studied. A short list of 38 seaweeds, contributed by Miss Le Lièvre, is given in the second edition (1865) of Ansted's Channel Islands, p. I9I. In a paper on the mosses collected in the Channel Islands, in September 1885 , by the eminent French bryologist, Mons. J. Cardot, and published in the Revue Bryologique for $\mathrm{I} 887$, seven species are recorded for Sark. To this meagre list I am able to add one species, Fontinalis antipyretica, a fine specimen of which, nearly eighteen inches long, was found in a well at Dosdâne, by Mr. G. Derrick, in June I897. Mons. Cardot records one hepatic for the island. The list of lichens has been compiled from the following sources: Leighton's Lichen Flora, third edition (1879); Larbalestier's Lichen Herbarium (1881); Larbalestier's Lichenes Rarissimi; Crombie's British Lichens (1894). In Leighton's book nearly all the species noted for Sark are recorded on the authority either of Mr. C. Larbalestier or of the Rev. Thomas Salwey, a well-known lichenologist, who spent some time in the Channel Islands about the year 1847 .

The following Sark cryptogams have not been recorded for Guernsey up to the present time:-

Ceratodon conicus.

Fontinalis antipyretica.

Leptogium humosum.

Myriangium Duriaei.

Sphinctrina Kylemoriensis.

Ramalina evernioides. intermedia.

Lecanora nitens.
Lecanora caesio-rufa.

albariella. pyreniospora. diplinthia.

Pertusaria lactea.

Urceolaria actinostoma.

Lecidea herbarum.

Ptilota plumosa. 
The flora of Sark, as recorded in the following pages, consists of 410 Flowering Plants, 3 Equisetaceae, I2 Ferns, 8 Mosses, I Hepatic, 89 Lichens, and 38 Seaweeds.

\section{RANUNCULACEAE.}

Ranunculus trichophyllus, Chaix. Pond between Dixcart Hotel and Clos Buret (Derrick).

R. floribundus, Bab. Bull. (This is the only record for this species within the area dealt with in this volume.)

R. hederaceus, L. Wet places (Babington). Bull. Miller. Marshy places, frequent (Derrick).

R. Flammula, L. Babington. Bull. Miller. Pond between Dixcart Hotel and Clos Buret; and also in the Seigneurie grounds (Derrick).

R. Ficaria, L. Bull. Common (Derrick).

R. acris, L. Babington. Bull. Miller. Frequent (Derrick).

R. repens, L. Babington. Bull. Miller. Derrick.

R. bulbosus, L. Derrick.

R. hirsutus, Curt. Bull. La Collenette (Derrick).

R. parviflorus, L. Bull. Clos Buret (Derrick).

\section{PAPAVERACEAE.}

Papaver Rhoeas, L. Newbould (184I). One plant on waste ground (Miller). Little Sark (Derrick).

P. dubium, L. Common (Derrick).

\section{FUMARIACEAE.}

Fumaria Boraei, Jord. Derrick.

F. confusa, Jord. Babington. Derrick.

F. muralis, Sond. Bull. Miller. Derrick.

\section{CRUCIFERAE.}

Cheiranthus Cheiri, L. On waste ground (Miller).

Nasturtium officinale, R. Br. Babington. Bull. Miller. Baker's Valley and Dosdâne (Derrick). 
Cardamine flexuosa, With. Streamside at La Moinerie (Derrick).

C. hirsuta, L. Miller. Common (Derrick).

C. pratensis, L. Baker's Valley: Seigneurie grounds, double variety (Derrick).

Sisymbrium officinale, Scop. Babington. Bull. Miller. Derrick.

S. thalianum, Gaud. Plentiful (Derrick).

Alliaria officinalis, Andrz. Bull. Miller. Baker's Valley (Derrick).

Brassica Cheiranthus, Vill. Bull.

Sinapis arvensis, L. Babington.

Cochlearia danica, L. Babington. Bull. Miller. Very common (Derrick).

Thlaspi arvense, L. Cultivated field in Little Sark (Derrick).

Teesdalia nudicaulis, R. Br. Common on the cliffs (Derrick).

Lepidium Smithii, Hook. Bull. Miller. Abundant (Derrick).

Capsella Bursa-pastoris, DC. Babington. Bull. Miller. Near the Vicarage (Derrick).

Senebiera Coronopus, Poir. Babington. Bull. Miller.

Cakile maritima, Scop. Babington.

Raphanus Raphanistrum, L. One plant, Little Sark (Miller). La Forge, rare (Derrick).

R. maritimus, Sm. Newbould (I84I).

\section{RESEDACEAE.}

Reseda Luteola, L. Babington. Bull. Miller. In several localities (Derrick).

VIOLACEAE.

Viola Riviniana, Reich. Babington. Bull. Miller. Comman (Derrick). 
V. tricolor, L Babington. Bull. Derrick. Var. arvensis, Murr. Newbould (184I). Miller. Field near Clos Buret (Derrick).

\section{POLYGALACEAE.}

Polygala vulgaris, L. Babington. Bull. lirequent on the cliffs (Derrick). Var. oxyptera, Reich. Babington.

P. depressa, Wend. Several plants (Miller).

\section{CARYOPHYLLACEAE.}

Dianthus Armeria, L. Bull. Several plants in a shady lane towards Port à la Jument (Miller). Dixcart Valley (Derrick). Sparingly in Baker's Valley in 1895 (Collens). Abundant on north side of lane leading from the old cemetery to Le Port (Andrews).

Saponaria officinalis, L. On banks in several places, but always near houses (Miller).

Silene anglica, L. Babington. Bull. A cornfield weed (Miller). Near Clos Buret (Derrick).

S. maritima, With. Babington. Bull. Miller. Common on the cliffs (Derrick).

Lychnis vespertina, Sibth. Bull. One plant (Miller). Little Sark (Derrick).

L. diurna, Sibth. Babington. Bull. Miller. Common in all the hedges (Derrick).

L. Githago, Scop. Babington. Miller.

Sagina procumbens, L. Babington. Bull. Miller. Frequent (Derrick).

S. apetala, L. Babington. Bull. Miller. Common (Derrick).

S. maritima, Don. Babington.

S. subulata, Wimm. Babington. Bull. Miller. Cliffs in Great and Little Sark (Derrick).

Honkeneja peploides, Ehr. Babington. Bull.

Stellaria media, Vill. Babington. Bull. Miller. Abundant (Derrick).

S. graminea, L. Bull (on the authority of Rev. J. J. Muir). 
S. uliginosa, Murr. Bull. Miller. In various parts: roadside to Creux (Derrick).

Cerastium glomeratum, Thuill. Babington. Bull. Miller. Common (Derrick).

C. triviale, Link. Babington. Bull. Miller. Frequent (Derrick).

C. tetrandrum, Curt. Babington.

Moenchia erecta, Sm. Common on the cliffs (Derrick).

Polycarpon tetraphyllum, L. Babington. Very common (Miller). Fields in various parts (Derrick).

Lepigonum rubrum, Fr. Bull. Miller.

L. rupestre, Kindb. Babington. Bull. Miller. Coupée (Derrick).

Spergula arvensis, L. Babington. Bull. Miller. Cliffs and fields : very common (Derrick).

Scleranthus annuus, L. Babington. Bull. Common in cultivated fields, La Tour (Miller). A common weed in cultivated ground, and also on the cliffs (Derrick).

\section{MALVACEAE.}

Malva moschata, L. Very common in Sark (Babington). Bull. One plant only, near the Seigneurie (Miller).

M. sylvestris, L. Babington. Bull. Miller. Near Beauregard (Derrick).

M. rotundifolia, L. Babington. Bull. Miller. Common (Derrick).

Lavatera arborea, L. Babington. Bull. On the cliffs (Derrick).

\section{HYPERICACEAE.}

Hypericum Anđrosaemum, L. Bull. Cliffs, Grève de la Ville (Miller). Same locality, and Dixcart Valley (Derrick). 
H. tetrapterum, Fr. Valley on the north-east of Sark (Babington). Bull. Miller. Marsh north of Le Fort (Derrick).

H. humifusum, L. Babington. Bull A form of decumbens, Peterman, one or two plants (Miller). Frequent (Derrick).

H. pulchrum, L. Babington. Bull. Miller. Common (Derrick).

\section{ACERACEAE.}

Acer Pseudo-platanus, L. Miller. Copse at Port du Moulin (Derrick).

\section{GERANIACEAE.}

Geranium striatum, L. Copse, Dixcart Lane (Derrick).

G. molle, L. Bull. Miller. Frequent (Derrick).

G. dissectum, L. Babington. Bull. Miller. Frequent (Derrick).

Erodium cicutarium, Sm. Babington. Bull. Miller. Common on the cliffs (Derrick).

E. moschatum, Sm. Babington. Near the Coupée, and in Little Sark (Derrick).

E. maritimum, L'Herit. Bull. Abundant round the mines in Little Sark (Derrick).

OXALIDACEAE.

Oxalis corniculata, L. Bull. A common weed in the Seigneurie grounds (Miller). Baker's Valley, rare (Derrick).

\section{LINACEAE.}

Linum angustifolium, Huds. Babington. Bull. Miller. In furze brakes (Derrick).

Radiola millegrana, Sm. Babington. Bull, Miller. On the cliffs, Coupée to Pilcher Monument (Derrick).

\section{LEGUMINOSAE.}

Ulex europaeus, L. Babington. Bull. Miller. Very common (Derrick).

Sarothamnus scoparius, Koch. Babington. Bull. Miller, Frequent on the cliffs (Derrick). 
Ononis arvensis, L. Bull. Plentiful near Creux du Derrible (Miller). Coupée (Derrick).

Medicago denticulata, Willd. Mr Derrick says he found seed-pods of this plant in the wool of a dead sheep fallen from the cliffs, but he had not seen the plant growing

Trifolium pratense, L. Babington. Bull. Miller. Derrick.

$T$. incarnatum, L. Little Sark, towards the mines: an escape from cultivation (Derrick).

T: arvense, L. Babington. Bull. Miller. On the cliffs (Derrick).

T. striatum, L. Babington. Bull. On the clifts (Derrick).

T. scabrum, L. Babington. Bull. Rare: Port du MIoulin (Derrick).

T. subterraneum, L. Babington. Bull. Abundant on the cliffs (Derrick).

T. glomeratum, L. On the cliffs (Derrick).

T. suffocatum, L. Bull. Port du Moulin (Derrick).

T. repens, L. Babington. Bull. Miller. Derrick.

T. agrarium, L. Miller.

T. procumbens, L. Babington. Bull. Miller. Derrick.

T. minus, Sm. Babington. Bull. Miller. Derrick.

T. filiforme, L. Babington. Bull.

Falcatula ornithopodioides, Bab. Babington. Bull. On the cliffs (Derrick).

Lotus corniculatus, L. Babington. Bull. Miller. Var. crassifolius, Pers. Not unfrequent on the cliffs (Miller). Common (Derrick). Mr. Derrick also notes the var. villosus, Ser.

L. major, Scop. Babington. Bull. Miller. Creux roadside and above Petit Dixcart (Derrick).

L. angustissimus, L. Between La Coupée and Dixcart Bay (Babington): In furze-brakes (Derrick).

L. hispidus, Desf. Babington. Bull. Derrick.

Anthyllis vulneraria, L. Sark, Mr. H. O. Carré (Babington). Bull. Miller. Dixcart Bay; Coupée (Derrick). 
Vicia hirsuta, Koch. Babington. Bull. Derrick.

V. tetrasperma, Moench. Babington. Bull. Derrick.

V. Cracca, L. Babington. Bull. Miller. Derrick.

V. sativa, L. Babington. Derrick.

V. angustifolia, Roth. Babington. Bull. Field near Dixcart (Derrick). Var. uncinata, Desv. Lane between the mill and Gouliot caves (Miller).

Ornithopus perpusillus, L. Babington. Bull. Abundant on the cliffs (Derrick).

ROSACEAE.

Prunus spinosa, L. Babington. Bull. Miller. Common on the cliffs, and in hedges (Derrick).

Agrimonia Eupatoria, L. Bull. Miller.

Alchemilla arvensis, Scop. Bull. Common on the cliffs (Derrick).

Potentilla anserina, L. Miller.

P. reptans, L. Babington. Bull. Miller. Derrick.

P. Tormentilla, Nesl. Babington. Bull. Miller. Derrick.

P. fragariastrum, Ehr. Bull. Not common (Derrick).

Rubus dumnoniensis, Bab. Near Dixcart Hotel in plenty (Rev. W. Moyle Rogers). Mr. Rogers says of this species, "usually identical with our luxuriant British form : but a second form occurs in Sark (unknown thus far in Britain) with terminal leaflet subrotund and strongly cordate.'

R. rusticanus, Merc. Sark (Rev. W. Moyle Rogers).

R. macrophyllus, Wh. \& N. Var. macrophylloides, Genev. Very fine and remarkably abundant, apparently more so than all the other brambles in the island put together (Moyle Rogers).

R. leucostachys, Schleich. In a furze-brake near Dixcart Lane (Moyle Rogers).

R. dumetorum, Wh. \& N. Var. diversifolius, Lindl. Banks near Dixcart Hotel : a weak form (Moyle Rogers).

R. corylifolius, Sm. Genetière (Moyle Rogers). 
R. Balfourianus, Blox. Very characteristic, though weaker than the average plant (Moyle Rogers).

(In the Flora Samica, Rubus rhamnifolius, IV. \& N., is recorded for Sark: and Dr. Bull notes Rubus discolor, the only species mentioned by him).

Geum urbanum, L. Bull. Miller. Dixcart: rare in Sark (Derrick).

Rosa spinosissima, L. Babington. Bull. Miller. Cliffs overlooking the Harbour : frequent in furze brakes (Derrick).

R. rubiginosa, L. Road north of Seigneurie (Moyle Rogers and Derrick).

R. micrantha, Sm. Near the Druid's Altar in Little Sark (Babington). Bull. Dixcart Valley (Moyle Rogers and Derrick).

R. canina, L. Bull. One bush (var. dumalis) on the cliffs, Moie du Mouton (Miller). Coupée, var. dumalis (Derrick).

R. stylosa, Desv. Var. systyla, Bast. Dixcart Bay, several fine bushes (Moyle Rogers).

Crataegus Oxyacantha, L. Babington. All the fruit examined had solitary carpels (var. monogyna, Jacq.), but the plants varied much as to pubescence of peduncles, \&c., and shape of leaves (Miller). Common (Derrick).

Pyrus Malus, L. Plentiful on the edge of the cliffs north of the Harbour: one tree in valley from the old mill to Little Dixcart (Derrick).

P. communis, L. One tree in a hedge in Baker's Valley' on the cliffs (Derrick).

LYTHRACEAE.

Peplis Portula, L. Bull. Pond at Dixcart (Derrick).

TAMARISCACEAE.

Tamarix anglica, Webb. Miller. Port du Moulin (Derrick).

ONAGRACEAE.

Epilobium hirsutum, L. Bull. 
E. parviflorum, Schreb. Marsh near La Ville (Miller). Field north of Beau Séjour (Derrick).

E. montanum, L. Bull. Roadside to Bel Air (Derrick).

E. tetragonum, L. Babington. Bull. Creux roadside (Derrick).

E. obscurum, Schreb. Bull. Creux Harbour, in great plenty (Miller).

$$
\text { PORTULACEAE. }
$$

Montia fontana, L. Frequent on the cliffs (Derrick).

\section{CRASSULACEAE.}

Tillaea muscosa, L. Port du Moulin (Derrick).

Sedum anglicum, Huds. Babington. Bull. Miller. Common (Derrick).

Cotyledon Umbilicus, L. Babington. Miller. Common on walls and banks (Derrick).

\section{UMBELLIFERAE.}

Hydrocotyle vulgaris, L. Babington. Bull. Miller. Marsh near Clos Buret (Derrick).

Eryngium maritimum, L. Babington.

Apium nodiflorum, Reich. Babington. Miller. Frequent in streams (Derrick). Var, repens, Koch. Babington. Bull.

A. inundatum, Reich. Babington.

Petroselinum sativum, Hoffm. Babington.

Oenanthe crocata, L. Babington. Bull. Miller. Frequent in streams (Derrick).

Aethusa Cynapium, L. Bull. Miller. Near La Forge and Le Fort (Derrick).

Foeniculum officinale, All. Bull. Miller. Dixcart Valley and south coast (Derrick). 
Crithmum maritimum, L. Babington. Bull. Miller. Common on the cliffs (Derrick).

Pastinaca sativa, L. Babington.

Heracleum Sphondylium, L. Bull. Miller. Abuntant in cultivated fields (Derrick).

Daucus Carota, L. Babington. Miller. Frequent (Derrick). Var. gummifer, Lam. Babington.

Torilis Anthriscus, Gaert. Common in Sark (Babington). Miller. Near the Coupée (Derrick).

Conium maculatum, L. Babington. Bull. Miller. Little Sark Village, and in Great Sark (Derrick).

Smyrnium Olusatrum, L. Babington. Miller. Common (Derrick).

\section{ARALIACEAE.}

Hedera Helix, L. Babington. Bull. Miller. Very common (Derrick).

Gunnera scabra, Ruiz \& Pav. By the pond in the Seigneurie grounds (Miller). Baker's Valley; Seigneurie (Derrick).

\section{CAPRIFOLIACEAE.}

Sambucus nigra, L. Babington. Bull. Miiler. In several parts, Beauregard, \&c. (Derrick).

Lonicera Periclymenum, $\mathrm{L}$. Very common in Sark (Babington). Bull. Very plentiful on cliffs and in hedgerows (Miller). Frequent in hedges (Derrick).

\section{RUBIACEAE.}

Sherardia arvensis, L. Babington. Bull. Miller. Common on the cliffs (Derrick).

Galium Aparine, L. Babington. Bull. Miller. Abundant (Derrick).

G. Mollugo, L. Babington. Bull. Miller. Abundant (Derrick). 
G. verum, L. Babington. Bull. Miller. Derrick.

G. saxatile, L. Little Sark (Derrick).

Rubia peregrina, L. Babington.

\section{VALERIANACEAE.}

Valerianella carinata, Lois. One or two plants by the roadside (Miller). Frequent : road from Mill to Vicarage (I)errick).

\section{DIPSACACEAE.}

Dipsacus sylvestris, L. Babington. Cliffs by Coupée (Miller). Field south of Dixcart (Derrick). Cliffs above Le Pot in Little Sark (Andrews).

\section{COMPOSITAE.}

Eupatorium cannabinum, L. Tiabington. IBull. Miller. Streamsides generally (Derrick).

Petasites fragrans, Presl. Bull. Dixcart Valley, spreading (Derrick).

Bellis perennis, L. Babington. Bull. Miller. Very abundant (Derrick).

Inula Conyza, DC. Babington. Bull. Cliffs near Creux Harbour (Miller). Les Laches Common (Derrick).

I. crithmoides, L. Babington. Bull. Cliffs near the Creux Harbour (Miller). Near Derrible Point, and side of a bay facing the Sept Moires (W. C. Crofts). Cliffs at Les Laches (Andrews).

Pulicaria vulgaris, Gaert. Bull.

P. dysenterica, Gaert. Babington. Bull. Miller. 1)errick.

Filago germanica, L. Babington. Bull. Miller. On the cliffs (Derrick). Abundant in 1898 in a cornfield near Creux du Derrible (Andrews).

F. minima, Fr. Cliffs, Dixcart Bay (Derrick).

Gnaphalium uliginosum, L. Babington. Bull. Miller. Fairly common (Derrick). 
Achillea Millefolium, L. Babington. Bull. Miller. Frequent (Derrick).

Anthemis arvensis, L. Babington. Bull. Miller. Great and Little Sark (Derrick).

A. Cotula, L. Babington. Bull. In Capt. Henry's furzèbrake (Derrick). Derrick.

A. nobilis, L. Babington. Bull. Very common (Miller).

Matricaria Parthenium, L. Babington. Bull. La Vallette, a good many plants (Derrick).

M. inodora, L. Bull. Miller. Field south of Dixcart (Derrick).

M. Chamomilla, L. Bull. Frequent (Derrick).

Chrysanthemum Leucanthemum, L. Babington. Bull. Miller. Common (Derrick).

C. segetum, L. Babington. Buil. Miller. Very common (Derrick).

Artemisia Absinthium, L. Very common in Sark (Babington). Bull. Much more common than A. vulgaris (Miller). Creux Tunnel (Derrick). Near the Church (Andrews).

A. vulgaris, L. Bull. Several scattered plants (Miller).

Tanacetum vulgare, L. Orchard, La Tour, and other places (Miller). Little Sark, rare (Derrick).

Senecio vulgaris, L. Babington Bull. Miller. Very common (Derrick).

S. sylvaticus, L. Babington. Bull. Miller. Frequent on the cliffs (Derrick).

S. Jacobaea, L. Babington. Bull. Miller. Common (Derrick).

Carlina vulgaris, L. Babington. Bull. Miller. Derrick.

Arctium minus, Schk. Babington. Bull. Approach to Creux Harbour (Miller). Dixcart Valley (Derrick).

A. intermedium, Lange. Several plants at side of stream, Baker's Valley (Miller).

Centaurea nigra, L. Babington. Bull. Typical nigra is very 
much the commoner plant in Sark: several plants with rayed flowers in an orchard, La Tour (Miller). Frequent on banks (Derrick).

Carduus nutans, L. Bull.

C. tenuiflorus, Curt. Babington. Bull.

C. lanceolatus, L. Babington. Bull. Miller. Common (Derrick).

C. arvensis, Curt. Babington. Bull. Miller. Near Collenette (Derrick).

C. palustris, L. Babington. Bull. Miller. Common (Derrick).

Lapsana communis, L. Babington. Bull. Miller. Frequent (Derrick).

Cichorium Intybus, L. Bull. One plant (Miller). Letween Dixcart and Clos Buret (Derrick). Meadow near the Church, and field near farm in Little Sark, one plant each (Andrews).

Hypochoeris glabra, L. Babington.

H. radicata, L. Babington. Bull. Miller. Derrick.

Thrincia hirta, DC. Babington. Bull. Miller. In various parts (Derrick).

Leontodon hispidum, L. Babington. On the cliffs (I)errick).

L. autumnale, L. Babington.

Helminthia echioides, Gaert. Bull.

Taraxacum officinale, Wigg. Babington. Bull. Miller. Common (Derrick).

Sonchus oleraceus, L. Babington. Bull. Miiler. A common weed (Derrick).

S. asper, Hoffm. Bull. Miller. Common (Derrick).

S. arvensis, L. Babington. Bull. Miller. Common (Derrick).

Crepis virens, L. Babington. Bull. Miller. Field near Collenette (Derrick).

Hieracium Pilosella, L. Bull. Common on banks, \&c., inland (Miller). Cliffs in many places (Derrick). Var. Peleterianum, Mer. Babington. Plentiful on the cliffs, Creux Harbour, 
Dixcart Bay, \&c., and less fine and characteristic amongst grass at top of cliffs (Miller).

H. umbellatum, L. Bull. Mr. Miller notes from 'cliffs, Grève de la Ville, a broad-leaved form very different from the typical umbellatum which grows in many parts of Guernsey.' [This is probably var. littorale.] Cliff near Creux Harbour (Derrick). Dr. Bull appends the following note to his first paper: 'Mr. C. Bailey is inclined to refer some specimens he collected on the rocks in the northern part of Sark to Hieracium strictum, Fries (Proc. Manch. Lit. and Phil. Soc. 1868, p. 197).'

\section{CAMPANULACEAE.}

Jasione montana, L. Babington. Bull. Exceedingly common (Miller). Frequent (Derrick).

\section{ERICACEAE.}

Calluna vulgaris, Salisb. Babington. Bull. Miller. Common (Derrick).

Erica cinerea, L. Babington. Bull. Miller Abundant (Derrick).

\section{AQUIFOLIACEAE.}

Ilex Aquifolium, L. Miller. Copse above Port du Moulin (Derrick).

\section{OLEACEAE.}

Ligustrum vulgare, L. Babington. Bull. Miller. Frequent : roadside to Bel Air (Derrick).

Fraxinus excelsior, L. Babington. Miller. Derrick.

\section{APOCYNACEAE.}

Vinca major, L. Eperquerie: Saignie Cliffs (Derrick).

GENTIANACEAE.

Erythraea Centaurium, Pers. Babington. Bull. Miller. Frequent (Derrick). 


\section{CONVOLVULACEAE.}

Convolvulus arvensis, L. Babington. Bull. Miller. Com mon (Derrick).

C. sepium, L. Bull. Not very common : Collenette; Dixcart; Little Dixcart (Derrick).

Cuscuta Epithymum, Murr. One good-sized patch near the Coupée, on Anthemis nolitiss, Lotus, \&c. (Miller). A small patch on low herbage near La Moinerie (Capt. Carré). On young furze near Clos Buret (Derrick).

\section{BORAGINACEAE.}

Borago officinalis, L. In several places on waste ground (Miller). Near the Vicarage (Derrick).

Lycopsis arvensis, L. Babington. Bull. Little Sark (Derrick).

Echium vulgare, L. Babington. One plant in stubble-field, Little Sark (Miller). Cliff-field east of Clos Buret (Derrick).

Myosotis repens, Don. Babington. Bull. Stream in Dixcart Valley (Derrick).

M. arvensis, Lehm. Babington. Bull.

M. collina, Hoffm. Common in Sark (Babington). Frequent on the cliffs (Derrick).

M. versicolor, Reich. Fields near Beauregard (Derrick).

\section{SOLANACEAE.}

Solanum nigrum, L. Babington. Bull. Niller. Common (Derrick).

S. Dulcamara, L. Babington. Bull. Miller. In various parts (Derrick). Var. marinum, Bab Miller.

\section{OROBANCHACEAE.}

Orobanche rubra, Sm. Grassy slopes on the east cliffs (Miller).

O. Hederae, Duby. Creux Derrible (Derrick). 
O. minor, Sutt. Near Le Creux (Babington). Miller. Fields above Little Dixcart (Derrick). A tall stout plant (identified by Mr. Arthur Bennett as O. minor), was gathered in Sark in June I 893 by Miss M. Dawber.

O. amethystea, Thuill. Creux Harbour (Derrick). In the Journ. Bot., loc. cit., Mr. Miller says he 'gathered two other Orobanches in Sark which seem very probably new to Britain, but the plants were too far gone for Mr. Bennett to determine them with certainty.'

\section{SCROPHULARIACEAE.}

Verbascum Thapsus, L. Babington. Cliffs by the Coupée (Miller). La Moinerie (Derrick).

V. nigrum, L. By the pond below the Manor House (Babington). Bull. One plant near La Forge (Derrick).

V. Blattaria, L. Bull.

Digitalis purpurea, L. Babington. Bull. Miller. Common in furze-brakes (Derrick).

Antirrhinum Orontium, L. Babington. Bull. Common in cornfields (Miller). Frequent in cultivated fields (Derrick).

Linaria Cymbalaria, Mill. Bank near the Post Office (Derrick)

L. Elatine, Mill. Babington. Bull. Miller. Abundant (Derrick).

L. spuria, Mill. One plant in a stubble-field (Miller).

L. repens, Ait. Newbould (I84I).

L. vulgaris, Mill. Babington. Bull. Miller. Beauregard (Derrick).

Scrophularia aquatica, L. Babington. Bull. Miller. In various parts (Derrick).

Pedicularis sylvatica, L. Babington. Bull. Miller. Common in wet places on the cliffs (Derrick).

Eufragia viscosa, Benth. Babington. Bull. Very common in marshes and by streams (Miller). Field south of Dixcart (Derrick).

Euphrasia officinalis, L. Babington. Bull. Miller. Common on the cliffs (Derrick). Mr. Miller's plant from Moie du Mouton is $E$. occidentalis. See page 373 , footnote. 
Sibthorpia europaea, L. Bull. Sides of streams, Grève de la Ville and Baker's Valley (Miller). Dixcart Valley (Derrick).

Veronica Beccabunga, L. Babington.

V. Chamaedrys, L. Babington. Bull. Miller. Frequent in Great and Little Sark (Derrick).

V. officinalis, L. Babington. Bull. Derrick.

V. serpyllifolia, L. Babington. Bull. Common in cultivated fields (Derrick).

V. arvensis, L. Babington. Bull. Miller. Common(Derrick).

V. agrestis, L. Babington. Bull. Miller. Common (I)errick).

V. Buxbaumii, Ten. Plentiful in the Churchyard (Miller).

\section{LABIATAE.}

Mentha rotundifolia, L. Newbould (184I).

M. aquatica, L. Babington. Bull. Roadside from Harbour to Bel Air Hotel (Derrick). Mr. Miller notes the form sulspicata.

M. sativa, L. Miller.

M. arvensis, L. Bull. Miller. Common (Derrick). Abundant in 1898 in a cornfield near Creux Derrible (Andrews).

Thymus Serpyllum, L. Babington. Bull. Miller. Com. mon on the cliffs (Derrick).

Prunella vulgaris, L. Babington. Miller. Frequent: La Collenette (Derrick).

Nepeta Glechoma, Benth. Babington. Bull. Miller. Fairly frequent: Dixcart Valley : Little Sark (Derrick).

Lamium amplexicaule, L. Bull. A few plants in cultivated fields (Miller). Field south of Dixcart (Derrick).

L. incisum, Willd. Bull. A few plants by Bel Air Hotel, and in garden, La Tour (Miller).

L. purpureum, L. Bull. Common in cultivated fields (Derrick).

Leonurus Cardiaca, L. Bull. Plentiful in farmyard by the Mill, and in garden, La Tour (Miller). Aval du Creux (Derrick). 
Stachys sylvatica, L. Babington. Bull. Miller. Dixcart (Derrick).

S. palustris, L. Babington. Bull. Miller. Derrick.

S. arvensis, L. Babington. Bull. Miller. Common in cornfields (Derrick).

Marrubium vulgare, L. Formerly very common in Sark, according to Mr. Le Pelley, the lord of the island; now rare (Babington). Bull. One plant (Miller). Aval du Creux (Derrick).

Teucrium Scorodonia, L. Babington. Bull. Niller. Common (Derrick).

\section{VERBENACEAE.}

Verbena officinalis, L. Bull. Miller. Mr. Derrick says he found this plant years agi) near La Forge, but has not met with it lately.

\section{PRIMULACEAE.}

Primula vulgaris, Huds. Babington. Bull. Very common and large : occasionally with five or six flowers on a common stem (Derrick).

Lysimachia nemorum, L. Bull. In considerable quantity in Dixcart Valley (Derrick).

Anagallis arvensis, L. Babington. Bull. Miller. Common in cultivated ground (Derrick). Var. caerulea, Sm. Near Dixcart Hotel, one plant (Derrick).

A. ter:ella, L. Babington. Bull. Miller Eperquerie Common (Derrick).

Samolus Valerandi, L. Babington. Bull. Miller. Dixcart Valley; Dosdane; Trois Fontaines (Derrick).

\section{PLUMBAGINACEAE.}

Statice occidentalis, Lloyd. Near the Creux (Babington). Bull. Cliffs, Venus' Bath, Port Gorey (Derrick). Cliffs in Derrible Bay, and abundant on the cliffs in Little Sark above Venus' Bath (Andrews). Mr. Miller notes a Statice (undetermined) from the cliffs between Les Cagnons and Creux Harbour.

Armeria maritima, Willd. Babington. Bull. Miller. On the cliffs in all parts (Derrick). 
PLANTAGINACEAE.

Plantago Coronopus, L. Babington. Bull. Miller. On the cliffs (Derrick).

P. maritima, L. Babington. Bull. Miller. Frequent on the coast (Derrick)

P. lanceolata, L. Babington. Bull. Miller. Common Derrick).

P. major, L. Babington. Bull. Miller. Frequent in fields (Derrick).

\section{AMARAN'THACEAE.}

Amaranthus retroflexus, L. One sjecimen in cultivated ground attached to Dixcart Hotel (Derrick).

\section{CHENOPODIACEAE.}

Salsola Kali, L. Babington.

Chenopodium polyspermum, L. Bull. Rather frequent (Derrick). Var. acutifolium, Sm. Babington. Miller.

C. album, L. Babington. Bull. Miller. Frequent (Derrick).

C. murale, L. Babington. Bull. Miller. Rather frequent (Derrick).

C. rubrum, L. Bull.

Beta maritima, L. Babington. Bull. Miller. Frequent (Derrick).

Atriplex angustifolia, Sm. Babington. Bull. Miller. Roadside between the Mill and La Varèque (T. C. Royle). Dixcart (Derrick). Var, erecta, Huds. Miller.

A. deltoidea, Bab. Babington. Bull. Rather frequent (Derrick). Mr. Miller notes the var. salina.

A. hastata, L. Babington. Miller. Roadside, Bel Air to Harbour (T. C. Royle). La Ville : Seigneurie (Derrick).

A. Babingtonii, Woods. Bel Air to Harbour (Derrick).

A. farinosa, Dum. Babington. Bull. Miller: 


\section{POLYGONACEAE}

Rumex conglomeratus, Murr. Babington.

R. sanguineus, L. Bull (on the authority of Rev. J. J Muir). Var. viridis, Sibth. Bull. Miller. Derrick.

R. pulcher, L. Babington. Bull. Miller. Common (Derrick)

R. obtusifolius, L. Babington. Bull. Miller. Frequent (Derrick). Mr. Miller notes the var. syliestris, Wallr. and also the var. Friesii, G. \& G.

R. crispus, L. Babington. Bull. Miller. Frequent (Derrick).

R. Acetosa, L. Babington. Bull. Miller. In fields (Derrick).

R. Acetosella, L. Babington. Bull. Hog's Back, and fields generally (Derrick).

Polygonum lapathifolium, L. Bull.

P. Persicaria, L. Bull. Miller. In several localities (Derrick).

P. Hydropiper, L. Bull. Miller. Rather common in marshy places (Derrick). Abundant on roadside between Creux Harbour and Bel Air Hotel : also in Dixcart Valley (Andrews).

P. aviculare, L. Babington. Bull. Miller. Roadsides, frequent (Derrick). Babington notes var. erectum.

P. Raii, Bab. Dixcart Bay (Babington).

P. Convolvulus, L. Babington. Bull. Miller. Field near Clos Buret (Derrick).

\section{EUPHORBIACEAE.}

Euphorbia Peplis, L. Babington.

E. Helioscopia, L. Babington. Bull. Miller. Frequent in cultivated fields (Derrick).

E. amygdaloides, L. Babington.

E. Paralias, L. Babington. Bull.

E. portlandica, L. Babington. Bull. Miller. Frequent on the cliffs (Derrick).

E. Peplus, L. Babington. Bull. Miller. Common (Derrick). 
E. exigua, L. A few plants in stubble fields (Miller). Field near Dixcart (Derrick).

Mercurialis annua, L. Babington. Bull. Miller. Derrick.

\section{CALLITRICHACEAE.}

Callitriche verna, L. Babington. In ponds, Dixcart, Clos Buret (Derrick).

C. stagnalis, Scop. Bull. In several damp spots (Miller). Dixcart Valley and near Seigneurie (Derrick).

\section{URTICACEAE.}

Urtica urens, L. Little Sark (Derrick).

U. dioica, L. Babington. Bull, Miller. Common (Derrick).

\section{CANNABINACEAE.}

Humulus Lupulus, L. Bull. Sea cliffs, Grève de la Ville (Miller). Same locality (Derrick).

\section{ULMACEAE.}

Ulmus campestris, Sm. Babington. Many avenues as well as single trees (Miller)

U. montana, With. Babington. Bull.

\section{AMENTIFERAE.}

Salix cinerea, L. A common tree in hedgebanks in several places (Derrick). Babington notes the var. oleifolia.

Populus alba, L. Copse in Dixcart Lane (Derrick).

Castanea vulgaris, Lam. Miller.

Quercus Robur, L. Babington. Miller. Copse at Port du Moulin (Derrick).

ORCHIDACEAE.

Orchis mascula, L. Saignie Bay; Dixcart (Derrick).

O. maculata, L. Bull. A few plants near Dixcart (Derrıck). 
Spiranthes autumnalis, Rich. Bull. Very common (Miller). Common on the cliffs (Derrick).

\section{IRIDACEAE}

Iris Pseud-acorus, L. Babington. Bull. Miller. Com mon by streams (Derrick).

I. foetidissima, L. Babington. Miller. Common (Derrick).

Romulea Columnae, Seb. \& Maur. Babington. Bull. Common on the cliffs and in furze-brakes (Derrick).

ASPARAGACEAE.

Ruscus aculeatus, L. Miller. Dixcart Bay (Derrick).

\section{LILIACEAE.}

Scilla autumnalis, L. Near the Creux (Babington). Bull. In great plenty (Miller). On the cliffs and in furze-brakes (Derrick).

Allium triquetrum, L. Baker's Valley: Bel Air to Creux (Derrick).

Endymion nutans, Dum. Babington Bull. Miller. Very common (Derrick).

\section{JUNCACEAE.}

Juncus effusus, L. Babington. Bull. Pond near Clos Buret (Derrick).

J. conglomeratus, L. Babington. Miller. Pond near Clos Buret (Derrick).

J. capitatus, Weig. On the cliffs (Derrick).

J. acutiflorus, Ehr. Babington. Bull. Miller.

J. lamprocarpus, Ehr. Newbould (I84I). Pond near Clos Buret (Derrick).

J. supinus, Moench. Babington. Bull. Marsh north of Le Fort, with a viviparous form (Derrick).

J. bufonius, L. Babington. Bull. Miller. Frequent (Derrick).

Luzula campestris, Willd. Bull. Abundant (Derrick). 
ARACEAE.

Arum maculatum, L. Bull. Not uncommon (Miller). On the cliffs, Creux to Dixcart (Derrick).

A. italicum, Mill. Only seen in fruit (Bull)

LEMNACEAE.

Lemna trisulca, L. Bull.

L. minor, L. Bull. Common (Miller). Pond near Clos Buret (Derrick).

NAIADACEAE.

Zostera marina, L. Bull.

CYPERACEAE.

Cyperus longus, L. Baker's Talley (Babington). Bull.

Eleocharis palustris, R. Br. Bull. Pond near Clos Buret (Derrick).

Scirpus setaceus, L. Babington. Bull. Miller. Marsh north of Le Fort (Derrick).

S. Savii, S. \& M. Babington. Miller. Trois Fontaines in Little Sark (Derrick).

Carex muricata, L. Babington. Bull. A small form (Miller). The Avenue (Derrick).

C. divulsa, Good. Bull. Frequent (Derrick). Roadside above Creux Harbour (Andrews).

C. ovalis, Good. Pond near Clos Buret (Derrick).

C. praecox, Jacq. Bull.

C. pilulifera, L. Bull. Rather frequent (Derrick). 

Bull.

C. flava, L. Valley in the north-east part of Sark (Babington). GRAMINEAE.

Anthoxanthum odoratum, L. Babington. Frequent (Derrick).

Alopecurus pratensis, L. Derrick.

A. geniculatus, L. Bull. Derrick.

Phragmites communis, Trin. Bull. Miller. Grève de la Ville (Derrick).

Agrostis vulgaris, With. Bull. Near Cliff-house (Derrick).

A. alba, L. Babington. Miller. Bel Air to Harbour (Derrick).

Gastridium lendigerum, Gaud. Bull.

Holcus lanatus, L. Babington. Miller. Frequent (Derrick).

H. mollis, L. Rather common (Derrick).

Aira flexuosa, L. Babington.

A. caryophyllea, L. Babington. Bull. Miller. Common (Derrick). Mr. Miller also notes the var, aggregata, Tim.

A. praecox, L. Babington. Near Cliff-house (Derrick).

Arrhenatherum elatius, M. \& K. Babington. Common (Derrick).

Triodia decumbens, Beauv. Babington. Bull. Frequent (Derrick).

Poa annua, L. Babington. Bull. Miller. Very common (Derrick).

P. trivialis, L. Bull. Frequent (Derrick).

P. pratensis, L. Bull. Common (Derrick).

P. compressa, L. Bull.

Glyceria fluitans, R. Br. Bull. Miller. 
Sclerochloa maritima, Lindl. Noted by Mr. Derrick on the authority of Rev. W. Moyle Rogers.

S. 1oliacea, Woods. Babington. Frequent (Derrick).

Briza minor, L. Bull. Lane near Le Port (Andrews).

B. maxima, L. Two or three plants on waste ground (Miller).

Cynosurus cristatus, L. Babington. Bull. Common (Derrick).

Dactylis glomerata, L. Babington. Bull. Miller. Common (Derrick).

Festuca uniglumis, Sol. Rather common; Creux Harbour, \&c. (Derrick).

F. sciuroides, Roth. Babington. Bull. Derrick.

F. ovina, L. Babington. Var. glauca. Near Cliff-house (Derrick).

F. rubra, L. Babington. Miller. Var. arenaria. Roadside to Bel Air (Derrick).

F. oraria, Dum. Babington.

Bromus sterilis, L. Babington. Bull. Frequent (Derrick).

B. rigidus, Roth. The Creux and Coupée (Babington). 'Very fine specimens' were collected in Sark in June, 189.4 , by Mr. J. W. White, and distributed through the Botan. Exch. Club.

Serrafalcus racemosus, Parl. Bull.

S. mollis, Parl. Babington. Bull. Miller. Roadside to Bel Air (Derrick).

Brachypodium sylvaticum, R. \& S. Babington. Miller. Copse in Dixcart Valley (Derrick).

Triticum repens, L. Babington. Bull. Derrick.

Hordeum murinum, L. Babington. Miller. Common (Derrick).

Lolium perenne, L. Babington. Bull. Miller. Frequent (Derrick).

L. temulentum, L. Bull. 


\section{EQUISETACEAE.}

Equisetum arvense, I. Path down to Grère de la Ville (Derrick).

E. sylvaticum, L. Bull. [Confirmation desirable.]

E. palustre, L. Babington. Fairly common (Derrick).

\section{FERNS.}

Polypodium vulgare, L. Babington. Miller. On walls both in Great and Little Sark (Derrick).

Lastrea Filix-mas, Presl. Bull. Grève de la Ville (Miiler). Fairly common (Derrick).

L. dilatata, Presl. Bull. A few plants, Grève de la Ville (Miller). Dixcart : Port du Moulin (Derrick).

Polystichum angulare, Newm. Bull. Rare: Dixcart (Derrick).

Athyrium Filix-foemina, Roth. Babington. Bull. Miller. Fairly common (Derrick).

Asplenium lanceolatum, Huds. Babington. Miller. A few places in Great and Little Sark (Derrick).

A. Adiantum-nigrum, L. Babington.' Bull. Miller. I)ixcart (Derrick).

A. marinum, L. Babington. Bull. Miller. In caves in Great and Little Sark (Derrick).

A. Ruta-muraria, L. La Collenette (Derrick).

Scolopendrium vulgare, Sym. Babington. Bull. Common (Derrick).

Pteris aquilina, L. Babington. Bull. Miller. Very common (Derrick).

Osmunda regalis, L. Bull. NIr. Derrick says he has not found this fern growing in Sark, but he has seen many fresh roots brought over from the island. 


\section{MOSSES.}

Polytrichum piliferum, Schreb.

P. juniperinum, Willd.

Ceratodon purpureus, Brid.

C. conicus, Lindb.

Trichostomum mutabile, Bruch.

Bryum sp.

Fontinalis antipyretica, $\mathrm{L}$.

Hypnum resupinatum, Wils.

\section{HEPATICAE.}

Cephalozia divaricata, Sm. (Jungermannia Starkii, Nees.)

\section{LICHENS.}

Lichina pygmaea, Lightf. Larbalestier. Crombie.

Collema cheileum, Ach. Crombie.

C. nigrescens, Huds. Seigneurie (Larbalestier).

Leptogium humosum, Ny! On the mortar of walls, Port Gorey (Crombie). Resembles externally Lecidea uliginosa.

Myriangium Duriaei, M. \& B. Salwey.

Sphinctrina Kylemoriensis, Cromb. Crombie. Parasitical on Lecanora nitens.

Sphaerophoron compressum, Ach. Salwey.

S. coralloides, Pers. Larbalestier.

Baeomyces rufus, DC. Crombie.

Cladonia pungens, Flk. Crombie. 
C. cervicornis, Schaer. Larbalestier.

C. alcicornis, Flk. Larbalestier. Crombie.

C. pyxidata, Fr. Larbalestier.

C. gracilis, Hffm. Crombie. Var. chordalis, Ach. Larbalestier.

C. furcata, Hffm. Larbalestier.

C. squamosa, Hffm. Larbalestier.

C. rangiferina, Hffm. Larbalestier.

Roccella phycopsis, Ach. Larbalestier.

Ramalina fastigiata, Pers. Larbalestier.

R. polymorpha, Ach. f. depressa, Cromb. Crombie. f. gracilescens, Cromb. Crombie.

R. pollinaria, Ach. Crombie.

R. evernioides, Nyl. Dixcart (Crombie).

R. scopulorum, Dicks. Crombie.

R. subfarinacea, Nyl. Crombie.

R. intermedia, Del. Moulin Bay (Crombie).

Nephromium lusitanicum, Schaer. Brechou (Crombie).

Peltigera canina, L. Larbalastier.

Stictina fulliginosa, Dicks. Larbalastier.

Sticta aurata, Ach. On rocks north of the Eperquerie (Salwey: Crombie). Brechou (Larbalestier).

Ricasolia amplissima, Scop. Larbalestier. Chateau Point (Crombie).

R. laetevirens, Lightf. Island of Brechou, Larbal. Lich. Herb., No. 326 in my copy.

Parmelia caperata, L. Larbalastier.

P. physodes, L. Larbalestier.

P. perlata, L. Larbalestier. Crombie.

P. scortea, Ach. Crombie.

P. conspersa, Ach. Larbalestier. Crombie. 
P. saxatilis, L. Larbalestier.

P. omphalodes, L. Larbalestier.

P. Delisei, Dub. f. isidiuscens, Nyl. Chateau Point (Crombie).

Physcia flavicans, Sw. Crombie Island of Brechou (Larbalestier).

P. chrysophthalma, L. Larbalestier. Crombie. Orchard at Sark (Salwey).

P. parietina, L. Larbalestier. Var. ectanea, Ach. Crombie.

P. ciliaris, L. Larbalestier. Crombie.

P. leucomela, L. Crombie.

P. aquila, Ach. Larbalestier.

Psoroma hypnorum, Vahl. Eperquerie (Larbalestier). No. I55 of Larbal. Lich. Rariss, in my copy.

Pannaria microphylla, Sw. Crombie. Eperquerie (Larbalestier).

P. nebulosa, Hffm. Crombie.

Squamaria saxicola, Poll. Crombie.

Placodium murorum, Hffm. Larbalestier.

P. lobulatum, Smrft. Larbalestier.

P. citrinum, Ach. Larbalestier. Crombie.

Lecanora vitellina, Ach. Crombie. Var. aurella, Ach. Chateau Point (Crombie).

L. squamulosa, Schrad. f. simplex, Dav. Chateau Point (Crombie).

L. atra, Ach. Crombie.

L. sulphurea, Hffm. Crombie.

L. subfusca, L. Larbalestier.

L. coilocarpa, Ach. Eperquerie (Larbalestier). Chateau Point (Crombie).

L. galactina, Ach. Crombie.

L. zosterae, Ach. Eperquerie (Crombie).

L. gibbosa, Ach. Var. lusca, Nyl. Chateau Point (Crombie). 
L. nitens, Ach. On schistose rocks at Chateau Point (Crombie). 'Intimately related to Lecanora badis.'

L. parella, L. Chateau Point (Crombie).

L. glaucoma, Hfm. Crombie f. decussata. Chateau Point (Crombie).

L. ferruginea, Huds. f. corticola, Leight. Larbalestier. f. festiva, Ach. Larbalestier.

L. caesio-rufa, Nyl. Chateau Point (Crombie). 'Well separated from $L$. fermsinea, with which until recently it has usually been confounded.

L. cerina, Ehrh. Crombie.

L. sophodes Ach. f. roboris, Duf. Dixcart (Crombie).

L. exigua, Nyl. Chateau Point (Crombie).

L. holophaea, Mnt. Var. glaucopsora, Nyl. Larbalestier.

L. albariella, Nyl. In precipitous cliffs, r perfuerie (Larbal. Lich. Herb. No. 336). Island of Brechou, Mr. Larbalestier (Leighton).

L. pyreniospora, Nyl. Crombie.

L. diplinthia, Nyl. Slopes of Eperpuerie (Mrs. Collings) Eperquerie and Dixcart Bay (Crombie).

L. haematomma, Ehrh. Island of Brechou (Crombie).

Pertusaria dealbata, Ach. Crombie.

P. communis, DC. Larbalestier. Crombie.

P. lactea, Nyl. Chateau Point (Crombie).

Urceolaria scruposa, L. Larbalestier.

U. actinostoma, Pers. Var. caesioplumbea, Nyl. Chateau Point (Crombie). 'A singular species with much the aspect of a Verrucaria.'

Lecidea lucida, Ach. Larbalestier.

L. canescens, Dicks. Larbalestier.

L. subdisciformis, Leight. Var. meiosperma, Nyl. Coast of Sark (Larbalestier). Larb. Lich. Rariss. No. 55 in my copy.

L. mesoidea, Nyl. Larbalestier. 
L. rubella, Ehrh. Salwey.

L. herbarum, Hepp. On rocks and decayed mosses, Eperquerie (No. ${ }_{4}$ Larb. Lich. Rar. and No. 350 Larb. Lich. Herb.).

L. geographica, L. Larbalestier.

Opegrapha vulgata, Ach. f. steriza, Ach. Eperquerie (Larbalestier)

Chiodecton sarniense, Salw. Sark (Mrs. Collings). Island of Brechou (Larbal. Lich. Herb. No. 356).

Verrucaria nitida, Weig. Iarbalestier. Var, nitidella, Flk. Larbalestier.

\section{SEAWEEDS.}

Enteromorpha compressa, Grev.

Bryopsis hypnoides, Lam.

B. plumosa, C. Ag.

Ectocarpus granulosus, C. Ag.

Scytosiphon lomentarius, J. Ag.

Chorda filum, Stack.

Saccorhiza bulbosa, De La Pyl.

Halidrys siliquosa, Lyng.

Porphyra laciniata, C. Ag.

Gelideum corneum, Lam.

Chondrus crispus, Stack.

Gigartina mamillosa, J. Ag.

Callophyllis laciniata, Kutz.

Gracilaria confervoides, Grev.

Chylocladia kaliformis, Grev.

Plocamium coccineum, Lyng.

Nitophyllum laceratum, Grev.

N. punctatum, Grev. 
Bonnemaisonia asparagoides, C. Ag.

Laurencia obtusa, Lam.

L. pinnatifida, Lam.

Polysiphonia fruticulosa, Spreng.

Griffithsia corallina, C. Ag.

G. setacea, C. Ag.

Halurus equisetifolius, Kutz.

Bornetia secundiflora, Thur.

Callithamnion arbuscula, Lyng.

Ptilota plumosa, C. Ag.

Antithamnion plumula, Thur.

Ceramium strictum, Harv.

C. rubrum, C. Ag.

C. echionotum, J. Ag.

C. acanthonotum, Carm.

C. ciliatum, Ducl.

C. flabelligerum, J. Ag.

Dumontia filiformis, Grev.

Furcellaria fastigiata, Lam.

Corallina corniculata, Ellis. 



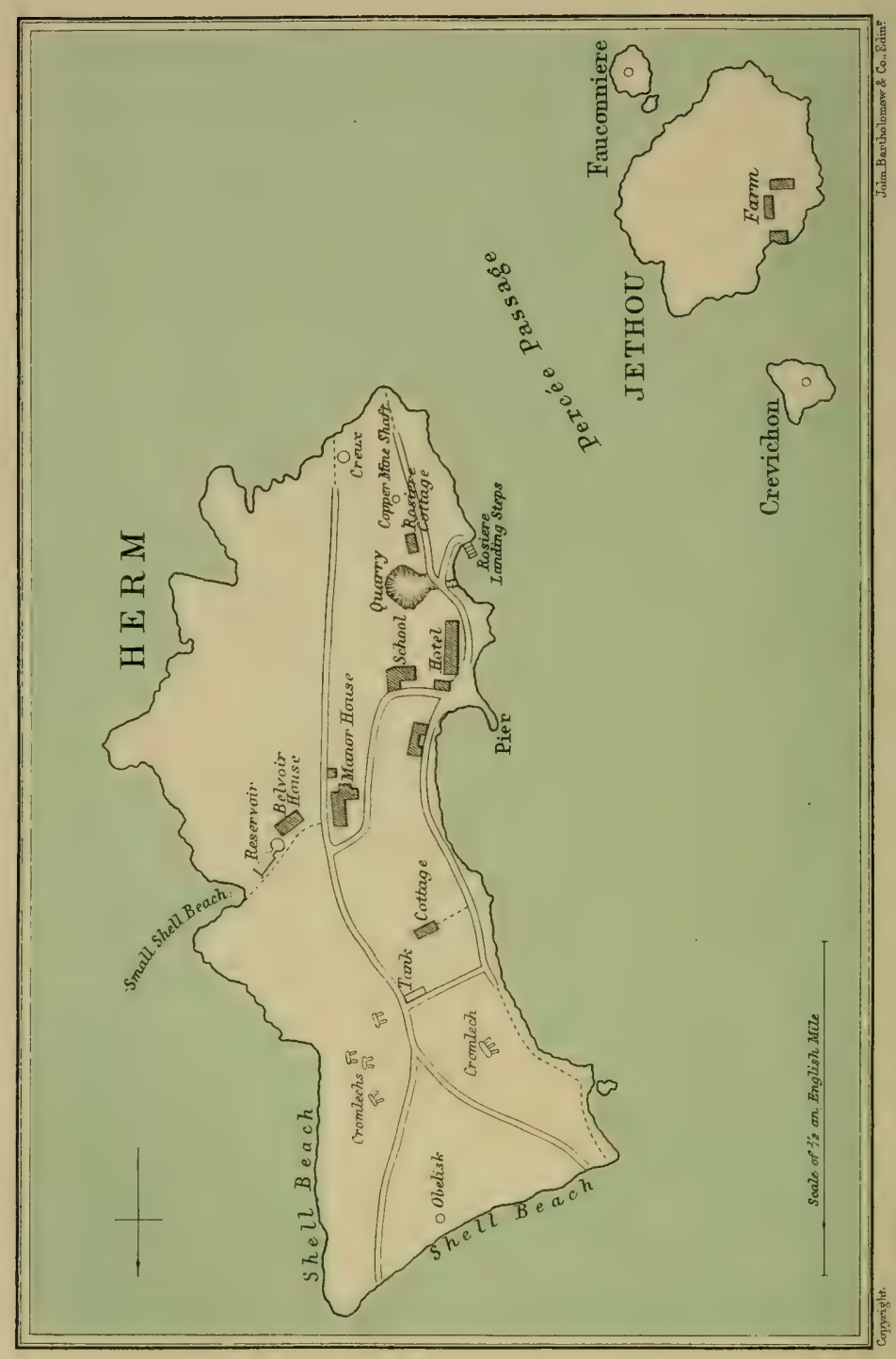




\section{HERM.}

$\triangle$ CCORDING to the guide-books Jersey is unrivalled in its valleys, Guernsey in its bays and waterlanes, Sark in its caves, and Herm in its shell-beach. Whatever difference of opinion may exist with respect to the others, there can be none about Herm, for the shell-beach is not only unique in the Channel Islands, but, as conchologists well know, it is without equal on the British coasts for the profusion, variety, and rarity of the shells to be found there; in fact, to a collector it is absolutely inexhaustible. There is a second shell-beach further eastward round the coast-a little cove at the bottom of a rather deep valley; it is very small, but extremely rich in shells, and is reputed to be even more productive in the way of rarities than the larger and better-known one

Fringed as it is, especially to the northward, with irregular masses of rock and jagged reefs, which at low water form an almost unbroken stretch two miles long, the aspect of Herm and its surroundings is very different at high and low tide: but, like all the other islands, it rises high above the sea, though less so than its twir-sister Jethou. Irregularly oval in shape, it measures about a mile and a half in length from north to south, and half as much in width; and like Guernsey, its southern and eastern portions are high and precipitous, bounded by rocky cliffs, while towards the north and west the land slopes down gradually to a low, flat, sandy shore.

The central portion of the island is a nearly level tableland, mostly under cultivation, and producing good crops, as the soil is fertile: but the cliffs and slopes near the sea are too rugged to be utilised for agricultural purposes, and remain as nature formed them. There are very few places on the higher portion where a descent to the sea can be made with safety: and in scrambling among the rocks at the foot of the cliffs there is often considerable danger of being shut in by the rising tide. Deep ravines have been cut by the sea in various places, terminating in caverns, mostly of small dimensions as compared with those of Sark, but singularly beautiful in their brilliant drapery of sea-ferns. A narrow channel, less than a quarter of a mile across, divides Herm from Jethou; it is extremely dangerous to navigation, partly on account of submerged rocks, and also owing to the force of the tide, which flows through with great rapidity. Springs of fresh water occur in different parts of the island, and there are two running streams of insignificant size: trees are scarce, but vegetation in general is so 
luxuriant that there is no appearance of barrenness. The population consisted of thirty-eight persons when the last census was taken in isgr. During the summer months excursions are made from Guernsey every few days by steamer, the passage occupying about half an hour.

Mention is made of Herm in early times. There is a document still extant recording that the island, together with Sark, Alderney, and one half of Guernsey, were presented to the great Benedictine Abbey of Mont St. Michel, by Robert, Duke of Normandy, the father of William the Conqueror. In the thirteenth century, and for two hundred years afterwards, there was a church in Herm, the traces of which have long since disappeared, unless the remains of it are to be found in an ancient building which is now used as a barn.

From the old historians we learn that Herm and Jethou were formerly preserved as a deer park or chase for the use of the Governors of Guernsey, who long enjoyed the privilege of hunting and shooting there. In $7 \mathrm{r} 6$ an inquiry was held 'for the discovery of certain persons who had killed stags, roebucks, and pheasants on the island, contrary to the ordinance;' and it is said that the last two deer were killed about the year I 773 .

The rocks of Herm consist chiefly of hornblendic granite. Traces of copper ore are reported to have been found, and mining operations were at one time commenced: but the chief mineral product of the place is granite, which many years ago was rather largely exported, though quarrying has long since ceased. It may be mentioned, in passing, that the steps of the Duke of York's Column, in London, are made of the stone from this island

Small as it is, there is plenty in Herm to occupy the attention of the botanist, as distinguished from the mere plant-collector, and he will soon discover that there is more ground to be gone over than he anticipated. The vegetation of a diminutive island like this is in some respects more interesting and more suggestive than that of a large tract of country, because its character is less likely to have altered through human agency, and consequently the question of accounting for the existence or absence of certain plants, "the fact that some are there and others are not there, a problem which involves all the migrations of these species and their ancestral forms,' as Alfred Russel Wallace says in a passage already quoted in these pages, can be studied in all its bearings.

In Babington's Flora Sarnica, I 74 wild plants, viz., I 72 phanerogams, I equisetum, and I fern, are recorded for Herm, as observed by the author, who paid a visit to the island on the 2 Ist of August, I $\$_{37}$ At that time of the year many spring flowers would have entirely disappeared, which accounts for their omission from his list. Fifty-two years later, on June I $5^{\text {th }}$, ISS9, I accompanied a party of excursionists, who were mostly bent on investigating the marine 
zoology of Herm, and during a few hours' ramble across the island I noted i 8 I flowering plants, 6 ferns, and, what was far more unexpected, a fine form of Chara vulgaris. Besides these, four species were brought to me, which were not among my own gatherings. A complete list of the plants detected on this occasion, of which 57 were unrecorded in the Flora Sarnica, was afterwards printed in the Transactions of the Guernsty Society of Natural Science for I889. Further additions to the list were made during subsequent visits by $\mathrm{Mr}$. Derrick and myself in $\mathrm{I} 893$, and by $\mathrm{Mr}$. C. Andrews in $\mathrm{I} \$ 98$ and 1899.

I much regret that it did not occur to me at the time to note the comparative frequency of the various species that came under my notice : an easy matter to an observer on the spot, who can mark on his list as he goes along whether a plant ii scarce, common, or local, and notes of this kind are sure to be useful afterwards. Of course, taking the Channel Islands as a group, this omission is of slight importance; but it is a serious drawback when comparing closely the vegetation of one island with that of another Such notes on distribution as have been supplied are now given, but in most cases only the name of the observer can be recorded. The list of lichens is compiled from the works which were enumerated in treating of the lichens of Sark.

There are four Herm plant;, two phanerogams and two lichens, which have not as yet been discovered in Guernsey, viz., Silene mutans, Picris hieracioides, Lecidea squamulosa, and Lecidea bacillifera.

The flora of Herm as recorded in these pages, consists of 248 Flowering Plants, 6 Fern;, I Equisetum, I Chara, and +3 Lichens.

Ranunculus Flammula, L. Marquand.

R. Ficaria, L. Marquand.

R. repens, L. Babington. Marquand.

R. bulbosus, L. Marquand.

R. parviflorus, L. Derrick.

Papaver Rhoeas, L. Babington. Marquand.

P. dubium, L. Marquand.

Glaucium luteum, Scop. Babington. Marquand.

Fumaria officinalis, L. Babington. Marquand. 
Cardamine hirsuta, L. Marquand.

Sisymbrium thalianum, Gaud. Marquand.

Sinapis nigra, L. Babington.

S. arvensis, L. Babington. Marquand.

S. alba, L. Babington.

Draba verna, L. Derrick.

Cochlearia danica, L. Marquand.

Thlaspi arvense, L. Frequent in 1889 (Marquand).

Capsella Bursa-pastoris, DC. Babington. Marquand.

Cakile maritima, Scop. Babington. Marquand.

Raphanus maritimus, Sm. Babington.

Reseda Luteola, L. Babington. Marquand.

Viola Riviniana, Reich. Babington. Marquand.

V. tricolor, L. Var. ariensis, Murr. Babington. Derrick.

Polygala vulgaris, I. Babington. Marquand.

Silene anglica, L. Babmgton.

S. nutans, L. Babington. Abundant on the slopes towards the south (Marquand). Specimens of this plant, probably I 20 years old, are preserved in Gosselin's herbarium, and are labelled 'Island of Erm.?

S. maritima, With. Babington. Marquand.

Lychnis vespertina, Sibth. Not uncommon (Marquand). Plentiful, but rather stunted, on the way to the shell-beach (Andrews).

L. diurna, Sibth. Babington. Marquand. More than a century ago Joshua Gosselin noted that 'a white and a red sort, rather different in the leaf, grows at Erm.'

Sagina procumbens, L. Babington. Marquand.

S. apetala, L. Marquand.

S. subulata, Wimm. Marquand.

Honkeneja peploides, Ehr. Babington. South end of shellbeach, very sparingly in 1899 (Andrews). 
Arenaria serpyllifolia, L. Marquand.

Stellaria media, Vill. Babington. Marquand.

Cerastium glomeratum, Thuill. Babington. Marquand.

C. triviale, Link. Babington. Marquand.

C. tetrandrum, Curt. Babington. Marquand.

Moenchia erecta, Sm. Babington. Derrick.

Polycarpon tetraphyllum, L. Babington. Marquand.

Lepigonum rupestre, Kindb. Babington. Marquand.

Spergula arvensis, L. Mabington. Marquand.

Scleranthus annuus, L. Babington. Noted by Gosselin as growing at Herm more than a century ago.

Malva sylvestris, L. Babington. Marquand.

M. rotundifolia, L. Babington. Marquand.

Hypericum tetrapterum, Fr. Babington.

H. humifusum, L. Marquand.

Geranium molle, L. Babington. Marquand.

G. dissectum, L. Babington. Marquand.

Erodium cicutarium, Sm. Babington. Narquand.

E. moschatum, Sm. Babington. Marquand.

E. maritimum, L'Herit. Babington. In several parts of the island (Marquand).

Linum catharticum, L. Babington. Marquand.

Ulex europaeus, L. Babington. Marquand.

Ononis arvensis, L. Marquand.

Medicago lupulina, L. Babington.

M. maculata, Sibth. Babington. Marquand.

Trifolium glomeratum, L. Marquand.

T. repens, L. Babington. Marquand.

T. procumbens, L. Marquand:

T. minus, Sm. Babington. Marquand. 
Lotus corniculatus, L. Babington. Marquand.

L. major, Scop. Marquand.

L. angustissimus, L. Babington. Marquand.

L. hispidus, Desf. Marquand.

Vicia sativa, L. Marquand.

Ornithopus perpusillus, L. Babington. Marquand.

Arthrolobium ebracteatum, DC. Mr. Andrews informed me that this plant was found in Herm in 1899 by Dr. C. Theodore Green.

Prunus spinosa, L. Babington. Marquand.

Poterium Sanguisorba, L. Marquand.

Alchemilla arvensis, L. Marquand.

Potentilla reptans, L. Babington. Marquand.

P. Tirmentilla, Nesl. Babington. Marquand.

Rubus sp. Several species occur in Herm, but none have been identified.

Rosa spinosissima, L. Babington. Marquand.

R. rubiginosa, L. Several plants on the Common, in fruit in 1899 (Andrews).

Epilobium tetragonum, L. Marquand.

Sedum anglicum, Huds. Babington. Marquand.

S. acre, L. Babington. Marquand.

Cotyledon Umbilicus, L. Babington. Marquand.

Saxifraga tridactylites, L. Derrick.

Hydrocotyle vulgaris, I. Babington. Damp places on the Common (Andrews).

Eryngium maritimum, L. Babington. MIarquand.

Apium nodiflorum, Reich Var. repens, Koch. Marquand.

Bupleurum aristatum, Bartl. Derrick.

Oenanthe crocata, L. Marquand.

Crithmum maritimum, I. Babington. Marquand. 
Heracleum Sphondylium, L Babington Marquand.

Daucus Carota, var, gummifer, Lam. Marquand

Chaerophyllum Anthriscus, Lam. Marquand

Conium maculatum, L. liabington. Marquand

Smyrnium Olusatrum, L. Marquand.

Hedera Helix, L Babington. Marquand

Sambucus nigra, L. Babington. Marquand

Lonicera Periclymenum, L. Babington. ILarquand.

Sherardia arvensis, L. Marquand.

Galium Aparine, L. Babington. Marquand

G. Mollugo, L. Babington.

G. verum, L. Babington. Marquand.

Dipsacus sylvestris, I. Rather common in 1889 (Marquand) Abundant in I 898 (Andrews)

Bellis perennis, L. Babington. Marquand.

Inula Conyza, DC. Marquand.

Pulicaria dysenterica, Gaert. Babington. Marquand

Filago germanica, L. Babington. Marquand.

Achillea Millefolium, L. Babington. Marquand.

Anthemis nobilis, L. Babington.

Matricaria Chamomilla, L. Babington Marquand.

Chrysanthemum Leucanthemum, L. Babington. Marquand.

C. segetum, L. Babington.

Artemisia vulgaris, L. Marquand.

Senecio vulgaris, L. Babington. Marquand.

S. sylvaticus, L. Babington.

S. Jacobaea, L. Babington. Marquand.

Carlina vulgaris, L. Babington. Marquand.

Arctium minus, Schk. Marquand. 
Carduus nutans, L. Marquand.

C. tenuiflorus, Curt. Babington. Marquand.

C. lanceolatus, L. Babington. Marquand

C. arvensis, Curt. Marquand.

C. palustris, L. Babington. Marquand.

Hypochoeris radicata, L. Babington. Marquand.

Thrincia hirta, DC. Babington. Marquand.

Picris hieracioides, L. Sereral plants on the east side of the island (Andrews).

Taraxacum officinale, Wigg. Babington. Marquand.

Sonchus oleraceus, L. Marquand.

S. asper, Hoffm. Marquand.

Crepis virens, L. Babington.

Hieracium Pilosella, L. Var. Peleterianum, DC. Babington.

Jasione montana, L. Babington. Marquand.

Erica cinerea, L. Babington. Marquand.

Erythraea Centaurium, Pers. Babington. Marquand.

Convolvulus arvensis, L. Babington Marquand.

C. sepium, L. Marquand.

C. Soldanella, L. Babington. Marquand.

Cuscuta Epithymum, Murr. Marquand.

Cynoglossum officinale, L. Babington. Marquand.

Lycopsis arvensis, L. Babington. Marquand

Echium vulgare, L. Babington. Rather common in 1889 (Marquand).

Myosotis arvensis, Lehm. Derrick.

M. versicolor, Reich. Marquand.

Solanum nigrum, L. Babington. Marquand.

S. Dulcamara, L. Marquand.

Hyoscyamus niger, L. Babington. Randell. 
Orobanche amethystea, Thuill. Marquand.

Verbascum nigrum, L. Two plants on the eastern side of the island in 1899 (Andrews).

Digitalis purpurea, L. Babington. Marquand.

Linariaa Elatine, Mill. Babington.

L. vulgaris, Mill. Babington. Marquand.

Scrophularia Scorodonia, L. Babington. Marcquand.

Eufragia viscosa, Benth. Marquand.

Euphrasia officinalis, L. Babington. Marquand.

Veronica Chamaedrys, L. Marquand.

V. officinalis, L. Frequent in the island (Marquand).

V. 'serpyllifolia, L. Marquand.

V. arvensis, L. Babington. Cumber (1900).

V. agrestis, L. Marquand.

V. polita, Fr. Babington. Marquand.

Mentha aquatica, L. Babington. In one spot on the Common (Andrews).

Thymus Serpyllum, L. Babington. Marquand.

Calamintha Nepeta, Clairv. Babington. I have a specimen gathered by Mr. Charles Bailey, of Manchester, on rocks on the western side of Herm, August 14th, 1867.

C. officinalis, Moench. Herm, W. C. Trevelyan (Babington). Marquand.

Prunella vulgaris, L. Babington. Marquand.

Nepeta Glechoma, Benth. Babington. Marquand.

Lamium amplexicaule, L. Marquand.

L. purpureum, L. Babington.

Stachys arvensis, L. Babington.

Ballota foetida, Lam. Marquand.

Teucrium Scorodonia, L. Babington. Marquand.

Primula vulgaris, Huds. Babington. Marquand. 
Anagallis arvensis, L. Babington. Marquand.

Samolus Valerandi, L. Babington. Marquand.

Armeria maritima, Willd. Babington. Marquand.

Plantago Coronopus, L. Babington. Marquand.

P. lanceolata, L. Babington. Marquand.

P. major, L. Babington. Marquand.

Salsola Kali, L. Babington.

Chenopodium Vulvaria, L. Babington. In good quantity on the sandy road on the east side (Andrews).

C. album, L. Babington. Marquand.

C. murale, L. Marquand.

Beta maritima, L. Babington. Marquand.

Atriplex patula, L. Babington (var. erecta, Huds.).

A. hastata, L. Babington. Marquand.

A. Babingtonii, Woods. Babington.

A. farinosa, Dum. Babington. Marquand.

Rumex pulcher, L. Babington. Marquand.

R. obtusifolius, L Babington. Marquand.

R. crispus, L. Bäbington. Marquand.

R. Acetosa, L. Babington. Marquand.

R. Acetosella, L. Babington. Marquand.

Polygonum Persicaria, L. Babington.

P. aviculare, L. Marquand.

P. maritimum, L. Northern part of Herm (Babington).

P. Convolvulus, L. Babington.

Euphorbia Peplis, L. North end of Herm (Babington). On the shell-beach in 1897 (Mrs. Randell). Abundant there in I 898 : some of the specimens unusually fine, one measuring thirteen inches by nine (Andrews).

E. Helioscopia, L. Babington. Derrick. 
E. Paralias, L. Babington. South end of shell-beach (Andrews).

E. portlandica, L. Babington. Marquand.

Mercurialis annua, l. Babington. Marquand.

Callitriche verna, L. Babington.

Parietaria diffusa, Koch. Babington. Marquand.

Urtica urens, L. Babington. Marquand.

U. dioica, L. Babington. Marquand.

Ulmus campestris, Sm. Marquand.

Quercus Robur, L. Marquand.

I ris foetidissima, L. Babington. Marquand.

Romulea Columnae, Seb. \& Maur. liabington.

Ruscus aculeatus, L. Babington.

Endymion nutans, Dum. liabington. Marquand.

Juncus acutus, L. Babington. Marquand.

J. effusus, L. Marquand.

J. acutiflorus, Ehr. Babington.

J. lamprocarpus, Ehr. Babington.

J. bufonius, L. Babington.

Luzula campestris, Willd. Marquand.

Lemna minor, L. Marquand.

Cyperus longus, L. Marquand.

Scirpus Savii, S. \& M. Babington.

Carex arenaria, L. Babington. Marquand.

C. muricata, L. Marquand.

Anthoxanthum odoratum, L. Narquand

Phleum arenarium, L. Marquand.

P. pratense, L. Marquand.

Phragmites communis, Trin. Babington. Marquand. 
Psamma arenaria, R. \& S. Babington. Marquand.

Agrostis vulgaris, With. Var, pumila, L. Babington.

A. alba, L. Babington. Marquand.

Holcus lanatus, L. Babington. Marquand.

Aira caryophyllea, L. Babington. Marquand.

A. praecox, L. Babington.

Arrhenatherum elatius, M. \& K. Marquand.

Triodia decumbens, Beauv. Babington.

Poa annua, L. Babington. Marquand.

P. trivialis, L. Babington. Marquand.

P. pratensis, L. Babington. Marquand.

Sclerochloa loliacea, Woods. Babington.

Cynosurus cristatus, L. Marquand.

Dactylis glomerata, L. Babington. Marquand.

Festuca sciuroides, Roth. Babington. Marquand.

F. ovina, L. Babington. Marquand.

F. rubra, L. Babington. Marquand.

Bromus sterilis, L. Babington. Marquand.

Serrafalcus mollis, Parl. Babington. Marquand.

Brachypodium sylvaticum, R. \& S. Babington. Marquand.

Triticum repens, L. Babington. Marquand.

T. junceum, L. Babington.

Hordeum murinum, L. Marquand.

H. maritimum, With. Babington.

Lolium perenne, L. Babington. Marquand.

Equisetum palustre, L. Babington.

Athyrium Filix-foemina, Roth. Marquand. 
Asplenium lanceolatum, Huds. Marquand.

A. Adiantum-nigrum, L. Marquand.

A. marinum, L. Marquand.

Scolopendrium vulgare, Sym. Marquand.

Pteris aquilina, L. -Babington. Marquand.

Chara vulgaris, L. Plentiful in June $\tau \$ 89$ in a drinkingtrough for cattle on the north side of the island (Marquand).

\section{LICHENS.}

Lichina pygmaea, Lightf. Larbalestier.

Collema pulposum, Bernh. Larbalestier.

C. ceranoides, Borr. Salwey. Crombie.

C. crispum, Huds. Larbalestier. Shores of the island of Herm (Crombie). Var. cristatuium, Nyl. Larbalestier. Crombie. A specimen of this variety from Herm, collected in I866, is No. 140 in my copy of Larbal. Lich. Rariss.

C. cheileum, Ach. Larbalestier. Crombie. lestier.

Leptogium lacerum, Ach. Var. puliinatum, Hffm. Larba-

L. palmatum, Huds. Larbalestier. Crombie.

L. Schraderi, Bernh. Larbalestier. Crombie.

Cladonia pyxidata, Fr. Larbalestier.

C. rangiferina, Hffm. Larbalestier.

Peltigera canina, L. Larbalestier.

Parmelia caperata, L. Larbalestier.

P. olivacea, L. Larbalestier.

P. perlata, L. Larbalestier.

P. conspersa, Ehr. Larbalestier.

P. saxatilis, L. Larbalestier.

P. omphalodes, L. Larbalestier. 
Physcia parietina, L. Larbalestier.

P. aquila, Ach. Larbalestier.

Pannaria nigra, Huds. Larbalestier.

Squamaria crassa, Huds. Larbalestier. Crombie. A specimen from the shell-beach, Herm, is No. 333 in my copy of Larbal. Lich. Herb.

Placodium murorum, Hffm. Larbalestier.

P. lobulatum, Smrft. Larbalestier.

Lecanora vitellina, Ach. Larbalestier.

L. tartarea, L. Larbalestier.

L. varia, L. Larbalestier.

L. atra, L. Larbalestier

L. subfusca, L. Larbalestier.

L. coilocarpa, Ach Larbalestier.

L. parella, L. Larbalestier (and f. pallescens, L.).

L. glaucoma, Hffm. Larbalestier.

Lecidea enteroleuca, Ach. Larbalestier.

L. parasema, Ach. Larbalestier.

L. contigua, Fr. Larbalestier.

L. aromatica, Sm. Larbalestier.

L. squamulosa, Deak. Larbalestier.

L. bacillifera, Nyl. Var. alpina, Hepp. Larbalestier.

L. geographica, L. Larbalestier.

L. petraea, Wulf. Larbalestier.

Verrucaria maura, Whlnb. Larbalestier.

V. nigrescens, Pers. Larbalestier.

V. macrostoma, Duf. Larbalestier.

V. viridula, Schrad. Larbalestier. 


\section{JETHOU.}

SEPARATED from the south-western extremity of Herm by a $S$ narrow channel only a few hundred yards wide - the navigable passage called La Percée-the small island of Jethou, or, to write it phonetically, Jetto, rises like a miniature mountain, flanked on each side at nearly equal distances by two symmetrical rocky islets called respectively Crevichon and Fauconnière. Away to the southward for two or three miles the sea is sprinkled with rocks of various shapes and sizes, so that the whole group as seen from Herm, or from a boat at sea, is exceedingly picturesque.

Jethou itself is a round hummock of granite, conical in shape, but almost flat on the summit, which is a small plateau of cultivated land. The island is hardly more than half a mile across at its widest part, and is said to measure a mile and a quarter around the base : it rises abruptly, so that everywhere the sides are steep and precipitous, except towards the north, where the land slopes more gradually down to a rough pebbly beach. At this end of the island there is a small cluster of trees. some of them, especially Spanish chestnuts and sycamores, of considerable size, and of finer growth than would be looked for in such an exposed situation. In this comparatively sheltered corner are to be found the only three habitations, - two cottages and a larger house, the residence of an English gentleman who rents the island, and from whom permission to visit it must be obtained. 'There are about fifty acres of arable land, and the soil is good, yielding fair crops of corn, potatoes, \&c.

The predominant rock is syenite, sometimes in a state of disintegration, elsewhere solid and compact, often heaped up in tabular masses, which bear a striking resemblance to the so-called Druids' Altars. Rivulets and pools are entirely absent: low-lying commons and sandy shores are also wanting: and in these respects Jethou differs from the sister-island of Herm, which otherwise it closely resembles.

When Professor C. C. Babington visited the Channel Islanós in the year $\mathrm{I}_{3} 38$, he devoted a day to Jethou (July $2 \mathrm{rst}$ ), and gathered the 113 flowering plants and 2 ferns which he afterwards recorded in his Flora Sarnica. On the 25 th of June, 1890 , during an excursion made to Jethou by the members of the Guernsey Society of Natural Science, I catalogued I 35 flowering plants and seven ferns, of which fifty-six species were not noted in the Flora Sarnica. These were 
enumerated in my paper on the Flora of Jethou, published in the Transactions of the Society for I890. A second excursion was made by the Society on the 26 th of June, I 894 , when several additional species were discovered, and particular attention was directed to the distribution of species, and their comparative frequency. By a curious coincidence, however, these three visits to Jethou were made at exactly the same time of the year, viz., midsummer. A further investigation in the autumn and early spring might be repaid by the finding of a few novelties, though probably not very much remains to be added in the way of wild flowers and ferns.

The only indigenous plants deserving special mention are ( $\mathrm{I}$ ) the very rare Myosotis Balbisiana, which I discovered in IS9o growing under the trees: and (2) a variety of Anagallis arcensis, with pure white flowers. of which many specimens were found in I 894 at the upper part of the island. The former was at the time new to the Channel Islands, but has since been detected in Guernsey: the latter is an excessively rare plant, apparently unknown in Normandy : in our own country it has occurred in the Isle of Wight. The blue-flowered Pimpernel ( 4 . caerulea) was also found plentifully in 1894 , besides, of course, the common red form.

Although this little island possesses a fairly good phanerogamic flora, the most interesting feature about it consists rather in what it has not than in what it has. Comparing it with that portion of Herm which lies almost within earshot, and which closely resembles Jethou in general character, the absence, or at any rate the apparent absence, of many common plants in the latter island is sufficiently remarkable. It is unnecessary to specify instances, as a comparison of the two lists will make the point clear. And then there are plants like Geranium molle, Bellis perennis, Achillea Millefolium, Plantago lanceolata, and several others ranking among the very commonest in the neighbouring islands, which in Jethou are extremely rare, indeed so scantily represented as to convey the impression that they are dying out. 'Hence it would seem,' as I remarked in my paper above mentioned, 'that in the grim struggle for life many plants which still occur in profusion on the cliff-sides of Guernsey are being slowly but surely crowded out of existence in Jethou by their stronger and more numerous neighbours. In this little island we can perceive the gradual change which is taking place in the vegetation of all countries, great and small, and the slow extinction of species by purely natural means, apart altogether from human agency. It is quite likely that in a couple of centuries many of the wild plants now rare in Jethou will have vanished altogether, and their place will be taken, not by new colonists, but by the oldestablished and firmly rooted denizens of the soil.'

Strictly speaking, the little islet of Crevichon forms an outlying part of Jethou, as the passage between them is uncovered at low 
water; and yet its vegetation differs, since two phanerogams (Hedera Helix and Euphorbia amlyrdaloides) and four ferns, which have been found upon it, are not known to grow at all on the main island. It seems better, therefore, to treat this curious little pyramidal rock as a distinct area, for its flora certainly deserves to be described separately. By comparison, Crevichon is rich in ferns, which are all exceedingly rare in Jethou proper, with the sole exception of the common Bracken.

The few lichens recorded by Leighton and Crombie probably do not represent a tenth part of the number that could easily be found, but the island has never been properly searched for cryptogams.

The flora of Jethou as recorded in the following pages consists of I 79 Flowering Plants, 7 Ferns, and io Lichens.

Ranunculus acris, I. Recorded by Babington.

R. repens, L. Rare.

R: bulbosus, L. Very rare.

R. hirsutus, Curt. A few dwarf plants were found: they were only an inch or two in height, but in full flower.

R. parviflorus, L. Two plants gathered in 1894 in different localities at the top of the island.

Papaver somniferum, L. Plentiful but small at the northern end, mostly in the cultivated plots.

Fumaria confusa, Jord. In the cultivated plots, scarce.

F. officinalis, L. Recorded by Babington.

Cardamine hirsuta, L. Local.

Sisymbrium officinale, Scop. Frequent. end.

S. thalianum, Gaud. Frequent in the plots at the northern

Sinapis arvensis, L. Frequent: usually dwarf.

Cochlearia danica, L. Occasional throughout the island.

Lepidium Smithii, Hook. Rare.

Capsella Bursa-pastoris, DC. Not common.

Cakile maritima, Scop. Very rare. 


\section{Reseda Luteola, L. Common.}

Viola Riviniana, Reich. Not common.

V. tricolor, L. One plant in good flower in 1894 at the top of the island. Var. arvensis, Murr. Two plants in different placesin 1894 .

Polygala oxyptera, Reich. Recorded by Babington.

Silene maritima, With. Abundant in the southern part.

Lychnis vespertina, Sibth. Two plants seen in 1894 .

L. diurna, Sibth. Recorded by Babington.

Sagina procumbens, L. Common.

S. apetala, L. Rather common.

S. ciliata, Fr. Rather common.

S. subulata, Wimm. Locally common.

Stellaria media, Vill Frequent.

Cerastium glomeratum, Thuill. Rare.

C. triviale, Link. Common.

C. tetrandrum, Curt. Locally common.

Polycarpon tetraphyllum, L. Frequent.

Lepigonum rupestre, Kindb. Common.

Spergula arvensis, L. Abundant in the cultivated fields at the top of the island.

Malva sylvestris, L. Rare.

M. rotundifolia, L. Locally common.

Lavatera arborea, L. Recorded by Babington.

Hypericum humifusum, L. Common.

H. pulchrum, L. Recorded by Babington.

Acer Pseudo-platanus, I. A good many large and wellgrown trees near the houses.

Geranium molle, L. Rare.

G. dissectum, L. Very rare.

Erodium cicutarium, Sm. Not common. 
E. moschatum, Sm. Sparingly on the cliffs near the Creux.

E. maritimum, L'Herit. Abundant on the higher part by the fields, and also low down the north slope.

Linum angustifolium, Huds. Recorded by Babington.

Ulex europaeus, L. Frequent.

Medicago lupulina, L. Recorded by Babington.

M. maculata. Sibth. Not common.

Trifolium pratense, L. Recorded by Babington.

T. glomeratum, L. Rare.

T. repens, L. Rare.

T. minus, Sm. Common.

Lotus corniculatus, L. Common.

L. major, Scop. Plentiful in some parts.

L. angustissimus, L. Not uncommon.

L. hispidus, Desf. Common.

Vicia angustifolia, Roth. Common.

V. 1athyroides, L. Seen in many parts of the island.

Ornithopus perpusillus, L. Common.

Prunus spinosa, L. Recorded by Babington.

Alchemilla arvensis, L. Frequent.

Potentilla Tormentilla, Nesl. Common.

Rubus discolor, W. \& N. Recorded by Babington.

R. villicaulis, W. \& N. Recorded by Babington,

Crataegus Oxyacantha, L. Rare.

Sedum anglicum, Huds. Common.

Cotyledon Umbilicus, L. Common.

Crithmum maritimum, L. Rare.

Heracleum Sphondylium, L. Common.

Daucus Carota, L. Very rare. Var. gummifer, Lam. Much less common than in the other islands. 
Conium maculatum, L. A few plants near the houses.

Hedera Helix, L. I have seen no trace of this plant on Jethou proper, nor did Babington find it there, but it grows on Crevichon.

Sambucus nigra, L. Frequent.

Lonicera Periclymenum, L. Rather common.

Sherardia arvensis, L. Frequent.

Galium Aparine, L. Not common.

G. saxatile, I. Plentiful on the north side of the island.

Bellis perennis, L. Not common.

Filago germanica, L. Recorded by Babington.

Achillea Millefolium, L. Extremely rare: one flowerless plant found in 1894 .

Senecio vulgaris, L. Recorded by Babington.

S. sylvaticus, L. Rare.

S. Jacobaea, L. Common.

Carlina vulgaris, L. Common in some parts of the island.

Arctium minus, Schk. Frequent near the houses.

Carduus tenuiflorus, Curt. Common.

C. lanceolatus, L. Frequent.

C. arvensis, Curt. Common.

C. palustris, L. Rare.

Lapsana communis, L. Recorded by Babington.

Hypochoeris glabra, L. Recorded by Babington.

H. radicata, L. Not common.

Thrincia hirta, DC. Common.

Leontodon hispidum, L. Common.

Taraxacum officinale, IVigg. Recorded by Babington.

Sonchus oleraceus, L. Common.

S. asper, Hoffm. Frequent. 
Crepis virens, L. Recorded by Babington.

Jasione montana, L. Not common.

Erica cinerea, L. Common.

Fraxinus excelsior, L. Near the houses.

Erythraea Centaurium, Pers. Common.

Lycopsis arvensis, L. Common.

Symphytum officinale, L. Plentiful on the slope towards Crevichon.

Echium vulgare, L. One fine plant in $r 894$ at the top of the island.

Myosotis collina, Hoffm. Freguent : plentiful on the north side, attaining a length of six or eight inches.

M. versicolor, Reich. Frequent. Var. Balbisiana, Jord. Near the houses, rare.

Solanum Dulcamara, L. Not uncommon.

Digitalis purpurea, L. Rare.

Linaria Elatine, Mill. Recorded by Babington.

Eufragia viscosa, Benth. Occasional at the northern end.

Euphrasia officinalis, L. Locally common.

Veronica Chamaedrys, L. Rare.

V. officinalis, L. Common.

V. serpyllifolia, L. Under the trees: rare.

V. arvensis, L. Frequent.

V. polita, Fr., Occasional.

Prunella vulgaris, L. Common.

Nepeta Glechoma, Benth. In profusion all over the island.

Lamium purpureum, L. Frequent.

Stachys arvensis, L. Plentiful in one of the cultivated plots.

Teucrium Scorodonia, L. Very common.

Primula vulgaris, Huds. Common. 
Anagalis arvensis, L. Common. Unusually fine in a small potato field on the western side. In the fields at the top of the island a number of plants were found in 1894 with pure white flowers. Var. caerulea, Sm. Very beautiful specimens occurred in 1894 mixed with the red form in a potato field at the west.

Centunculus minimus, L. A considerable patch in the corner of one of the larger enclosures at the top of the island.

Armeria maritima, Willd. Not very common.

Plantago Coronopus, L. Frequent.

P. lanceolata, I. Very rare.

P. major, L. Rare.

Chenopodium album, L. Not common.

C. murale, L. Rare.

Atriplex hastata, L. Rare.

Rumex conglomeratus, Murr. Not common.

R. pulcher, L. Occasional.

R. obtusifolius, L. Rare.

R. crispus, I. Rather rare.

R. Acetosa, L. Not common.

R. Acetosella, L. Common.

Polygonum aviculare, L. Rare.

Euphorbia amygdaloides, L. Crevichon: not seen on the main island.

E. portlandica, L. Occurs on the eastern side.

E. Peplus, L. Near the houses: scarce.

Mercurialis annua, L. A few plants in the cultivated plots.

Urtica urens, L. Rare.

U. dioica, L. Common.

Ulmus campestris, Sm. Var. suberose, Sm. Near the houses.

Salix cinerea, L. Near the houses.

Populus nigra, L. Planted: like most of the other trees. 
Castanea vulgaris, Lam. A few well.grown trees near the houses.

Quercus Robur, L. A few among the other trees.

Iris foetidissima, L. Rather common.

Ruscus aculeatus, L. Rare.

Endymion nutans, Dum. Local.

Juncus acutus, $L$. Not uncommon at the base of the cliffs on the western side; also on a rock midway along the passage to Crevichon.

J. capitatus, Weig. In several places, but in small quantity. places.

J. bufonius, I. Very dwarf specimens were found in two

Luzula campestris, Willd. Very rare.

Arum maculatum, L. Several plants were growirg in the garden of the house in 1894: no doubt planted: but perhaps brought from some part of the island.

Zostera marina, L. Plants washed up on the beach.

Carex arenaria, L. Rare.

Phalaris canariensis, L. Near the houses, from scattered birdseed.

Anthoxanthum odoratum, L. Very rare.

Agrostis vulgaris, With. Recorded by Babington.

A. alba, L. Frequent.

Holcus lanatus, L. Rare.

Aira caryophyllea, L. Frequent.

A. praecox, L. Recorded by Babington.

Poa annua, L. Not common.

P. trivialis, L. Rare.

P. pratensis, L. Rare.

Cynosurus cristatus, L. Recorded by Babington.

Dactylis glomerata, L. Not common.

Festuca sciuroides, Roth. Frequent. 
F. ovina, L. Rather common.

F. rubra, L. Frequent.

Serrafalcus mollis, Parl. One small tuft on the western side : very dwarf.

Brachypodium sylvaticum, R. \& S. Frequent.

Lolium perenne, L. Not common.

Polypodium vulgare, L. Crevichon.

Lastrea Filix-mas, Presl. Crevichon.

Athyrium Filix-foemina, Roth. Recorded by Babington. I have seen this fern on Crevichon, but not on the main island.

Asplenium lanceolatum, Huds. In many places, sparingly.

A. Adiantum-nigrum, L. Crevichon.

A. marinum, L. Sparingly all round the coast.

Pteris aquilina, L. Abundant. The only common fern in the island.

\section{LICHENS.}

Lichina pygmaea, Lightf. Larbalestier.

Cladonia rangiferina, $\mathrm{Hfm}$. Larbalestier.

Parmelia caperata, L. Larbalestier.

Physcia parietina, L. Larbalestier.

P. aquila, Ach. Crevichon (Babington, Fl. Sarn.).

Pannaria plumbea, Lightf. Crevichon (Iarbalestier).

Placodium lobulatum, Smrft. Larbalestier.

Lecanora coilocarpa, Ach. Larbalestier.

L. pyreniospora, Nyl. Larbalestier. Crombie.

Graphis pulverulenta, Ach. Larbalestier. 


\section{LIHOU.}

THE islet of Lihou is situated off Lerée Point, on the west coast of Guernsey, with which it is connected by a rough, winding causeway nearly half a mile in length. This causeway is covered by the sea, except at low water, so that the crossing is not practicable at all hours, or in every kind of weather: during heavy gales no communication with the outer world is possible. The island is about a third of a mile long, and somewhat rectangular in shape, with projecting angles on the side nearest Guernsey. Most of it consists of grass-land or sandy banks covered with fine turf, interspersed here and there with large masses or clusters of rock: on the western side these rocks rise to a height of a hundred feet above sea level, and from certain points present picturesque bits of scenery.

There is a substantially built farmhouse and out-buildings on the island, and several plots of cultivated ground : but farming operations are carried on under difficulties, and are probably not very remunerative. Some years ago this building was used as an iodine manufactory, and the machinery and fixtures are said to be still in good working order. A profitable trade used to be carried on in Guernsev half a century ago in the manufacture of iodine, the seaweed of the Channel Islands being, in the opinion of experts, exceptionally rich in that product; but this branch of industry has for some reason not been extensively developed, although there is little danger of exhausting the supply of raw material. This little islet is still, however, the chief station in Guernsey for collecting and burning seaweed locally called v'arerh or vraic, from the soluble ash of which iodine is obtained.

In spite of its loneliness and exposure there is much that is interesting about Lihou from an antiquarian standpoint. It is the only spot in the Channel Islands where there are ruins of monastic buildings having some architectural pretensions, and the remains are still visible of a chapel dating as far back as the beginning of the twelfth century. But the hand of the spoiler has been at work even in this desolate spot. Much of what remained of the ancient chapel at the early part of the century was utilised for the construction of the farmhouse or the outbuildings behind it. Flint arrowheads, and other relics of a prehistoric age, have been found here from time to time; and it was in searching for some of these a few years ago 
that my wife unearthed a small silver coin in excellent preservation, a half-groat of the reign of Queen Elizabeth.

The vegetation consists almost entirely of low plants. There are no trees or shrubs of any kind : heath and heather are absent : gorse is only to be seen at the south-eastern corner of the island, and there is very little bracken. Rabbits abound, but they find very little cover above ground.

A catalogue of the plants growing on Lihou was drawn up some years ago during an excursion made by the members of the Guernsey Society of Natural Science, and an account of this visit and the list of species will be found in the Transactions of the Society for 1895 . It was interesting to find that the Seakale (Crambe maritima), a very rare plant in these islands, still grows in the same spot where it occurred sixty or seventy years ago, as recorded in the Flora Sarnica. Ferns are scarce, and the discovery of the Adder's Tongue was a pleasing surprise. Some of the very commonest plants, like the Daisy, seem to be absent, which is strange, bearing in mind that the shores of Guernsey are only a few hundred yards distant. so that seeds may easily be blown across. Mr. C. Andrews has added several species to the list during the last year or two, the most interesting being Chenopodium botryodes, which he found growing abundantly in one spot. This is the only known locality for this rare plant in these islands.

Thirteen species of fungi, nearly all agarics, were collected by Mr. W. A. Luff during the winter of $1897-98$. Three of them have not been found elsewhere within the area, and their occurrence on this most westerly point of land is of some interest.

The flora of Lihou, so far as at present known, consists of 95 Flowering Plants, 4 Ferns, and $\mathrm{I}_{3}$ Fungi.

Ranunculus Ficaria, L.

R. repens, $L$.

Cochlearia danica, L.

Thlaspi arvense, $\mathrm{L}$.

Crambe maritima, L.

Viola Riviniana, Reich.

Polygala oxyptera, Reich.

Silene maritima, With.

Sagina maritima, Don.

Honkeneja peploides, Ehr.
Stellaria media, Vill.

Cerastium triviale, Link.

C. tetrandrum, Curt.

Polycarpon tetraphyllum, L.

Lepigonum rupestre, Kindb.

Malva sylvestris, L.

Geranium molle, L.

Erodium cicutarium, Sm.

E. moschatum, Sm.

E. maritimum, L'Herit. 
Radiola millegrana, Sm.

Ulex europaeus, L.

Trifolium repens, L.

T. fragiferum, L.

Lotus corniculatus, L.

L. hispidus, Desf.

Vicia angustifolı, Roth.

Potentilla Tormentilla, Nesl.

Rubus sp.

Sedum anglicum, Huds.

S. acre, L.

Cotyledon Umbilicus, L. Crithmum maritimum, L Daucus gummifer, Lam.

Galium Aparine, L

G. verum, $L$.

Dipsacus sylvestris, L.

Matricaria Chamomilla, L.

Senecio vulgaris, $L$.

S. Jacobaea, L.

Arctium minus, Schk.

Carduus tenuiflorus, Curt.

C. lanceolatus, L.

Hypochoeris radicata, $\mathrm{L}$.

Thrincia hirta, DC.

Leontodon hispidum, L.

Sonchus oleraceus, L.

Crepis virens, $L$

Hieracium umbellatum, L.

Erythraea Centaurium, Pers.

Convolvulus arvensis, $\mathrm{L}$.

Cynoglossum officinale, L.

Lycopsis arvensis, L.

Myosotis collina, Hoffm.

Solanum Dulcamara, L.
Digitalis purpurea, L.

Glaux maritima, L.

Anagallis arvensis, L.

Armeria maritima, Willd.

Plantago Coronopus, L.

P. lanceolata, L.

P. major, L.

Salsola Kali, L.

Chenopodium murale, L.

C. botryodes, Sm.

Beta maritima, L.

Atriplex patula, L.

A deltoidea, Bab.

A. Babingtonii, Woods.

Rumex pulcher, L.

R. crispus, $L$.

R. Acetosa, L.

R. Acetosella, L.

Polygonum Raii, Bab.

Urtica urens, L.

U. dioica, L.

Romulea Columnae, S. \& M.

Scilla autumnalis, L.

Endymion nutans, Dum.

Juncus Gerardi, Lois.

Luzula campestris, Willd.

Carex arenaria, L.

C. muricata, $\mathrm{L}$.

Agrostis alba, L.

Holcus lanatus, $\mathrm{L}$.

Aira caryophyllea, L.

Poa annua, L.

Sclerochloa loliacea, Woods.

Dactylis glomerata, L.

Festuca sciuroides, Roth.

F. rubra, L. 
Bromus sterilis, L.

Serrafalcus mollis, Parl.
Hordeum murinum, L.

Lolium perenne, L.
Asplenium lanceolatum, Huds.

A. marinum, $\mathrm{L}$.
Pteris aquilina, $\mathrm{L}$.

Ophioglossum vulgatum, L.

\section{FUNGI.}

Marasmius oreades, Fr.

Hygrophorus conicus, Fr.

H. niveus, Fr.

Entoloma sericellum, Fr.

Leptonia lampropoda, Fr.

Paxillus lividus, Cooke.

Agaricus sylvaticus, Schaef.
A. sagatus, Fr.

A. comptulus, Fr.

Anellaria separata, Karst.

Coprinus radiatus, Fr.

Clavaria fastigiata, L.

Lycoperdon gemmatum, Batsch. 


\section{CREVICHON.}

$\mathrm{I}^{\mathrm{r}}$

$\mathrm{F}$ it were possible, without too grent danger and inconrenience, to get at all the islets in the Channel Islands which are corered with verdure, it would be an interesting study to compare their vegetation one with another, having regard to area, elevation. exposure, and so on. It is possible that these green islets would be found to differ more widely than might at first sight be supposed. But it is practically impossible to land on many of them, because either the base is a vertical wall of smooth rock, or else the current is too strong to permit the approach of a boat, except on rare occasions.

Much may be learnt, however, from those semi-detached fragments which have been severed from their mother-islands within geologically recent times, but are still connected with them at extreme low tide. The finest example within the area dealt with in this book is Lihou, on the west coast of Guernsey, of which an account has already been given. On the opposite side of Guernsey, off the Vale coast, there are three small islets, accessible at low water : the northernmost of these, called Houmet Homptolle, is about eighty yards long by sixty wide, the area above high-water mark being roughly about an acre: the surface is fairly even, and is covered with grass and low plants. A careful examination of this islet some years ago shows that the vegetation consists of fifteen phanerogams, one of which, Lepturus fliformis, I certainly never expected to find in such a locality. It may be interesting to give here a list of the Homptolle plants for the purpose of comparison: Cochlearia danica, Lepigonum rupestre, Silene maritima, Trifolium repens, Lotus corniculatus, Daucus gummifer, Thrincia hirta, Sonchus oleraceus, Armeria maritima, Plantago Coronopus, Beta maritima, Agrostis alba, Sclerochloa loliacea, Festuca ovina, Lepturus filiformis.

Intermediate in size between Lihou and Homptolle, but differing in character from both, is the pyramidal rock called Crevichon, which lies off the north-western end of Jethou. It is a little more than three acres in extent, and from certain points of view makes an extremely pretty picture. There is an old quarry on one side, from which a large quantity of granite was taken many years ago, but the carting away of the stone must have been an achievement of some difficulty. This little islet is of additional interest to a botanist from the circumstance that it was visited by Professor C. C. Babington 
during his stay in the Channel Islands in 1838 . In the preface to the Flora Sarnica he gives a list of the twenty flowering plants and two ferns which he found growing on 'a conical rocky mound called Crevichon, which is connected with Jethou at low water.' The author evidently considered this a rather remarkable list for so diminutive an islet, but it was certainly not a full and complete one, as on my visit to Crevichon in I 890 I noted thirty-two flowering plants and six ferns, of which more than half were additions to the catalogue in the Flora Sarnira: so that at present we have a record of thirty-nine phanerogams and six ferns for this curious little beaconcrowned rock. The number of ferns is particularly noteworthy, considering their rarity on the main island of Jethou, and it should be mentioned that two or three Crevichon plants were not met with on Jethou proper when the latest list was drawn up.

Four lichens have been recorded for Crevichon: two by Babingtor in the Flora Sarnica, I'armelia caperata and Plyssia aquila; and two by Leighton on the authority of Larbalestier: Physcia parietina and Pannaria plumliea. The latter species is No. I 8 of Larbalestier's Lichenes Rarissimi, and is labelled in my copy 'on rocks, Crevichon : very rare in the Channel Islands.'

Cakile maritima, Scop. Mariuand.

Viola Riviniana, Reich. Marquand.

Silene maritima, With. Babington. Marquand.

Sagina procumbens, L. Marquand.

Ulex europaeus, L. Marquand.

Lotus corniculatus, L. Marquand.

L. hispidus, Desf. Marquand.

Vicia angustifolia, Roth. Marquand.

Rubus sp. Marquand.

Sedum anglicum, Huds. Babington. Marquand.

Cotyledon Umbilicus, L. Babington. Marquand.

Conium maculatum, L." Babington.

Hedera Helix, L. Babington.

Sambucus nigra, L. Babington. 
Lonicera Periclymenum, L. Babington. Marquand.

Carlina vulgaris, L. Marquand.

Arctium minus, Schk. Marquand.

Carduus lanceolatus, I. Babington. Marquand.

Thrincia hirta, DC. Babington. Marquand.

Leontodon hispidum, L. Marquand.

Sonchus asper, Hffm. Marquand.

Erythraea Centaurium, Pers. Marquand.

Myosotis versicolor, Reich. Marquand.

Solanum Dulcamara, L. Marquand.

Nepeta Glechoma, Benth. Babington. Marquand.

Teucrium Scorodonia, I. Babington. Marquand.

Anagallis arvensis, L. Babington. Marquand.

Armeria maritima, Willd. Babington. Marquand.

Rumex crispus, L. Marquand.

Atriplex patula, L. Babington.

Euphorbia amygdaloides, L. Babington.

E. portlandica, L. Babington. Marquand.

Urtica dioica, L. Babington.

Iris foetidissima, L. Marquand.

Ruscus aculeatus, L. Marquand.

Endymion nutans, Dum. Babington. Marquand.

Juncus acutus, L. Marquand.

Holcus lanatus, L. Babington.

Dactylis glomerata, L. Babington. Marquand.

Polypodium vulgare, L. Babington. Marquand.

Lastrea Filix-mas, Presl. Marquand. 
Asplenium lanceolatum, Huds. Marquand.

A. Adiantum-nigrum, L. Marquand.

A. marinum, L. Marquand.

Pteris aquilina, L. Babington. Marquand.

\section{LICHENS.}

Parmelia caperata, L. Babington.

Physcia parietina, L. Larbalestier.

P. aquila, Ach. Babington.

Pannaria plumbea, Lightf. Larbalestier. 


\section{BURHOU.}

I N crossing from Southampton to Jersey or Guernsey, the first of the Channel Islands to come in sight is Alderney, which lies on the horizon to the left like a little grey cloud. Between Alderney and the ship's course there may be distinguished in clear weather a low bank of land, very little elevated above the level of the sea. This is Burhou, the most lonely and exposed island in the English Channel. It is uninhabited, except by sea birds and rabbits, but a small cottage provides shelter for shipwrecked sailors, or fishermen who may be driven to land there by stress of weather.

In form the island is oblong, its total length from east to west being nearly three-quarters of a mile, including a small detached fragment, called Little Burhou, at the western end, which is separated from the main island by a narrow gully laid bare at low water. The surface of the land slopes upwards to a slightly elevated central ridge, but the highest ground is hardly, if at all, more than thirty-five feet above high-tide level. Huge masses of rock, shaggy with lichens and weather-worn, are piled up in picturesque groups in many parts: here and there are shingly beaches filled with large, rounded pebbles, but the shore is nowhere precipitous, though extremely dangerous to approach by boat, owing to the multitude of surrounding rocks, and the force of the current. Everything about the ssland is wild, rugged, and storm-beaten, like the relic of a prehistoric age.

Sea birds in countless thousands resort there to breed-mostly Puffins and Lesser Black-backed Gulls: and they are so unaccustomed to the sight of man that during the nesting season they may often be captured by hand. The Puffins burrow in the soft, sandy earth, and lay their solitary eggs in rabbit burrows or other deep holes : but the Gulls make their nests on the ground, and at the height of the breeding time, at the end of May and beginning of June, the nests are scattered about in such profusion that one must keep a sharp look-out in walking in order to avoid trampling upon the eggs. In spite of the IVild Birds' Preservation Act, thousands of eggs are taken every year and eaten : and I can testify from personal experience that, when properly prepared, gulls' eggs make a most savoury and appetising omelette.

The island of Burhou (pronounced Burrov, with the accent on 
the second syllable) is one of the few spots in the United Kingdom where Stormy Petrels breed, and they do so here in great numbers, but their nests are very difficult to get at. These curious little birds, the 'Mother Carey's chickens' of sailors, are never seen on land in the daytime, but after dark they fly about like bats, as I discovered when I was forced to pass a night on the island, owing to the sudden appearance of a dense fog. The ceaseless kerek-oo, kerek-oo of the Petrels as they sat on their nests-a peculiar wailing cry, seemingly far distant, though really close by--varied with the plaintive scream of a sea-gull and the shrill pipe of an oyster-catcher; all these voices, mingled with the dull roar of the sea, formed a singularly impressive concert in the calm stillness of a summer's night.

The distance between Burhou and Alderney is two or three miles, but the sea passage is comparatively narrow, owing to the outlying rocks. This passage, called La Passe au Singe, anglicised into its more familiar name, the Swinge, is reputed to be one of the very worst bits of sea in all the English Channel. To the southwest another dangerous passage separates Burhou from Ortach, a curious isolated rock, which rises out of the sea like a colossal hayrick sixty-five feet high. Still further westward, some three miles or so, is the perilous group called the Casquets, on which the illfated steamship Stella was wrecked with an appalling loss of life on the afternoon before Good Friday, I 899. The Casquet rocks, the largest of which bears the well-known lighthouse, cover a mile and a half of sea, and are particularly dangerous to navigation, as they lie almost exactly midway between England and France, in the direct line of a ship's course advancing up the Channel from the Atlantic or the Bay of Biscay.

When seen from the heights of Alderney, the greater part of Burhou appears clothed with verdure, and this appearance is not deceptive, but nowhere else have I seen so large an extent of greenery composed of so few different wild plants. The great bulk of the vegetation is made up of four species only, the other plants hardly forming a conspicuous portion of the general mass. The common Bracken (Pteris aquilina) is the principal constituent, the greater part of the island being thickly covered with this fern, which grows about two feet high. Towards the north and east the Blue Bell, or Wild Hyacinth (Endymion nutans) grows literally by the acre, and much finer than $I$ ever saw it, except in a garden. The flowers are larger and more fragrant than usual, and of an intense purple blue. The sandy soil, enriched for centuries by multitudes of sea birds, no doubt accounts for the luxuriance of this plant. But the most abundant species of all is the Sea Spurrey (Lepigonum mpestre), which forms a thick carpet wherever the grourd is not occupied by fern and Blue Bells; and, like the latter, it is very luxuriant. And, lastly, there is the pretty white-flowered Sea 
Campion (Silene maritima), which occurs in abundance along the coast, especially on Little Burhou.

I paid two visits to the island during the summer of 1899 , viz., on May 3 oth and on July 5 th. and it was on the latter occasion that I was detained there by fog. My principal object was to study the nesting habits of certain sea birds, but I also wished to ascertain what plants were to be found on such a bare, wind-swept islet. The season was an exceptionally dry one, it is true, but, making every allowance for drought, I certainly expected to find a greater variety of plant-life. During both visits only a meagre list of fifteen flowering plants and two ferns could be compiled after a pretty careful search: and even of this small number two or three are certainly not indigenous, but must have been introduced, probably during the building of the house.

On the I I th of May, I900, I again spent a few hours on Burhou, but the only new plant I could discover was Cerastium tetrand $1 \mathrm{~m}$, which grew very sparingly on the western slopes. A Frenchman and his wife were living in the cottage, and had brought over a few pigs, goats, and fowls. This will, in the course of a few years, materially affect the native vegetation of the island, and introduce new species. It may be as well to note therefore, as a rather curious fact, that, in my three visits to Burhou, though looking closely for plants, I was unable to detect a single blade of grass anywhere, or a Composite of any kind. The most remarkable phanerogam found here is the Sea Club Rush (Scirpus maritimus), because it has never been known to occur in Alderney, and the nearest station for it is eighteen miles away, in Guernsey.

It is interesting to compare the scanty flora of Burhou with that of Lihou, on the west coast of Guernsey, the two islands being, roughly speaking, about the same size. As many as ninety-five flowering plants are known to occur on Lihou, or six times as many as on Burhou. But, then, the former islet has been inhabited from early times, and is, moreover, so close to the main island that the seeds of plants would be blown over continually during the prevalence of high winds.

Cochlearia danica, L. Fairly common all over the island.

Silene maritima, With. Abundant on many parts of the coast, especially on Little Burhou.

Sagina maritima, Don. Plentiful in all parts. side.

Cerastium tetrandrum, Curt. Sparingly on the western 
Lepigonum rupestre, Kindb. Abundant: in many places covering the ground like a thick green mat.

Erodium maritimum, L'Herit. Plentiful in some places, as on the side towards Little Burhou.

Cotyledon Umbilicus, L. Very common among rocks, especially on the eastern side.

Crithmum maritimum, I. Scattered among the rocks just above high-water mark on some parts of the coast, but not very plentiful

Lycopsis arvensis, L. A few plants near the house.

Myosotis arvensis, Lehm. Like the last, a few specimens near the house: both species probably introduced.

Glaux maritima, L. In two or three places on the west side, growing among rocks just above high-water mark. Extremely fine, and flowering ahundantly.

Anagallis arvensis, L. Rather common in the central parts.

Atriplex deltoidea, Bab. Only a few plants seen; ponr specimens.

Rumex crispus, L. A few rather poor and stunted plants seen in different places.

Endymion nutans, Dum. Abundant in some parts of the island, and very luxuriant. Many of the plants had exceedingly long floral bracts, and some of the flowers were white

Scirpus maritimus, L. Growing vigorously and flowering well in a rock-pool just above high-water mark on the western side.

Lastrea Filix-mas, Presl. 'Two or three small roots in crevices of rocks on the north side.

Pteris aquilina, L. Abundant : growing in large patches. 


\section{LIST OF JERSEY PLANTS}

not found elsewhere in the Channel Islands.

T Mr. J. Piquet's paper on 'The Phanerogamous Plants and Ferns of Jersey,' published in 1896 , the number of species enumerated amounts to 721 . Mr. Piquet has lately sent me a list of forty-five additional species discorered by him since the publication of that paper, making a total, up to June 1900 , of 766 Flowering Plants and Ferns which he has himself seen growing in Jersey. A large number of these, viz., rog species, or one-seventh of the total, have not been found elsewhere in the Channel Islands, and the names are given below as likely to interest botanists who may not have seen MIr. Pi juet's paper. For details of distribution and other information the reader is referred to the original publication, which appeared in the Bulletin de la Socicte' Jersiaise. 'The plants mentioned in the supplementary (unpublished) list are distinguished by an asterisk.

Ranunculus tripartitus, DC. chaerophyllus, L. auricomus, L.*

Delphinium Consolida, L.

Berberis vulgaris, $\mathrm{L}$.

Glaucium corniculatum, L.*

Corydalis claviculata, DC.*

Nasturtium palustre, $\mathrm{DC}$. *

Sisymbrium Sophia, L.*

Erysimum orientale, $\mathrm{R} . \mathrm{Br}$.

Bunias Erucago, L.*

Hutchinsia petraea, R. Br.

Viola odorata, L.

Drosera rotundifolia, L

Elatine hexandra, DC.

Dianthus prolifer, L. caesius, L. * deltoides, $\mathrm{L}$

Silene Armeria, L。*
Cucubalus baccifer, L. Stellaria Holostea, L. Arenaria trinervis, L. Malva parviflora, L. * Geranium lucidum, L. pyrenaicum, $\mathrm{L}$. pusillum, L.*

Oxalis Acetosella, L. Acer campestre, L. Genista tinctoria, L. Medicago minima, Lam. Trifolium strictum, L. Molinerii, Balb.

Hippocrepis comosa, L. Lathyrus hirsutus, L.* Spiraea Ulmaria, L. Potentilla argentea, L. Sanguisorba officinalıs, L. Poterium muricatum, Spach. 
Portulaca oleracea, L.*

Sedum rupestre, L.

Myriophyllum verticillatum, $L$.

Isnardia palustris, L.

Carum verticillatum, Koch.

Falcaria Rivini, Host.*

Oenanthe Phellandrium, Lam.

Angelica sylvestris, L.

Cornus sanguinea, L.

Galium erectum, Huds.

Asperula odorata, L.

Scabiosa succisa, L. maritima, L.

Erigeron canadense, L.

Gnaphalium undulatum, L.

Bidens cernua, L.

Petasites vulgaris, Desf.

Solidago Virgaurea, L.

Serratula tinctoria, L.

Carduus pratensis, Willd.

Centaurea solstitialis, L.

paniculata, L.

Hypochoeris maculata, L

Lapsana pusilla, Willd.

Xanthium strumarium, L. ${ }^{*}$

Erica Tetralix, L.

Armeria plantaginea, Willd.

Vinca minor, L.

Symphytum tuberosum, L.*

Echinospernum Lappula, Lehm.*

Linaria Pelisseriana, Mill. minor, Desf.

Veronica peregrina, L。*

Lamium album, $\mathrm{L}$.

Galeobdolon, Crantz.

Littorella lacustris, L.

Amaranthus Blitum, L.*
Chenopodium Bonus-Henricus, L.

Polygonum minus, Huds.

Rumex maritimus, L.

Daphne Laureola, L.

Mercurialis perennis, $\mathrm{L}$.

Cannabis sativa, $\mathrm{L}$.

Betula alba, L.

Carpinus Betulus, L.

Elodea canadensis, Mich.*

Galanthus nivalis, L.

Allium sphaerocephalum, L.

Juncus obtusiflorus, Ehr.

Sparganium simplex, Huds.

Acorus Calamus, L

Scirpus lacustris, L. pungens, Vahl.

Cladium Mariscus, R. Br.

Isolepis fluitans, $\mathrm{R}, \mathrm{Br}$.

Carex binervis, Sm.

Alopecurus agrestis, $\mathrm{L}$

Aira canescens, L.

Avena pratensis, L.

Digitaria sanguinalis, Scop.

Setaria verticillata, Beauv.

Poa nemorosa, L.

Sclerochloa Borreri, Bab.

Milium effusum, L.

Bromus erectus, Huds. tectorum, L.** secalinus, L.

Lolium multiflorum, Lam.

Nardus stricta, L.

Adiantum Capillus-Veneris, L. Pilularia globulifera, L

'All that we can do is to throw our pebbles upon the heap, which shall hereafter when they have sufficiently accumulated, become the landnark of Systematical Botany.' 


\section{INDEX OF NAMES.}

\section{GUERNSEY.}

ABsinthe, II 6

Acer, 70

Aceraceae, 70

Ache, 98

Achillea, II 4

Achnanthere, 330

Achnanthes, 33I

Achnanthidium, 33 I

Acrostalagmus, 27 I

Actinocyclus, 326

Actinonema, 273

Actinoptychus, 326

Adder's Tongue, 212

Adiantum, 2 I I

Adonis, 42

Aegerita, 273

Aegopoaium, 99

Aethusa, 102

Affo tilly, I 77

Agaricineac, 234

Agaricus, 25 I

Aglaozonia, 309

Ayrimonia, 84

Agrimony, 84

Agripaume, 149

Agrostis, I96

Ahnfeltia, 312

Aira, 198

Ajonc, 73

Ajuga, 151

Alaria, 309

Alchemilla, 84

Alder, 170

Alexanders, 105

Alisandre, 105

Alisma, 177

Alismaceae, 177

Alkanet, I32

All-heal, 68

Alliaria, 5 I

Alliène, I1 6

Allium, 179

Allseed, 65, 73

Alnus, 170
Alopecurus, 195

Althaea, 68

Alyssum, 53

Amanita, 234

Amanitopsis, 235

Amaranthus, 156

Amaryllidaceae, 176

Amblystegium, 228

Ambraise, I5I

Ambroise, 151

Amentiferae, 168

Ammi, 99

Amourettes, 156

Amourôques, II 5

Amphiloma, 288

Amphipleura, 333

Amphipleureae, 333

Amphiprora, 34I

Amphitetras, 344

Ainphora, 329

Amroque, IT 5

Anabaena, 304

Anagallis, 153

Anchusa, I 32

Anellaria, 254

Aneura, 233

Angels' Eyes, 143

Anixia, 264

Antennaria, I 14

Anthemis, II4

Anthoceros, 233

Anthocerotaceac, 233

Anthoxanthum, 194

Anthyllis, 8o

Antirrhinum, I39

Antithamnion, 317

Apera, 196

Apium, 98

Apocynaceae, 128

Apple, 91

Apple-pie, 92

Aquifoliaceae, 127

Aquilegia, 45

Arabis, 50
Arach, I 59

Araceae, I84

Araliaceae, 105

Arasches, 159

Arctium, II 8

Arcyria, 277

Arenaria, 64

Argentine, 84

Armeria, 155

Armillaria, 236

Armoise, 116

Armoracia, 54

Arresta bovis, 74

Arrête boeu, 79

Arrhenatherum, 199

Arroche, I 59

Arrow-grass, 178

Artemisia, I I6

Arthonia, 299

Arthrolobium, 82

Arum, I84

Ascobolus, 268

Ascocyclus, 308

Ascomyces, 269

Ascomycetes, 263

Ascophanus, 268

Ascophyllum, 310

Ash, 128

Asparagaceae, 178

Asparagus, 178

Aspen, 170

Aspergillus, 270

Asperococcus, 307

Asperula, 108

Asplenium, 209

Aster, II I

Asterella, 230

Asterolampra, 326

Athanasie, I I 7

Athyrium, 209

Atriplex, I 59

Atropa, I35

Aubépine, 90

Aulacomnion, 223 
Auliscus, 344

Auricularia, 262

Auricularieae, 262

Avena, I98

BACILLARIA, 335

Baeomyces, 280

Ballota, I 50

Balm, 148

Balm of Warrior's Wound, 68

Bangia, 3 I I

Barbarea, 49

Barbula, 221

Bardane, 119

Barley, 205

Bartramia, 223

Bartramiaceae, 223

Bartsia, I42

Basil, I48

Bastard Toadflax, I64

Batrachospermum, 324

Bazzania, 23I

Beard Grass, 197

Bedstraw, Io8

Beech, 17 I

Beet, 159

Bêle, 98

Bell-flower, I 26

Belle d'un jour, I3 I

Bellis, II 2

Belonidiunı, 268

Benoîte, 88

Bent Grass, 196

Berbiette, I 12

Berkeleya, 34I

Berle, 98

Bertia. 266

Beta, 159

Betony, 150

Betula, I 70

Bianche Epeine, 90

Biddulphia, 343

Biddulphieae, 343

Bidens, 118

Bifora, 105

Bifurcaria, 310

Bindweed, 130

Birch, 170

Bird's-foot, 82

Bird's-foot Trefoil, 79

Bistort, I 163

Bitter Cress, 50

Bittersuiss, I 35

Bittersweet, I 35

Blackthorn, 83

Bladderwort, 152

Blechnum, 2 I I
Bleuets, I 19

Blinks, 94

Blobs, 139

Blue Bell, I8o

Blue Buttle. I 19

Blysmus, 189

Bigbean, I30

Bog Rush, 187

Bois blanc, 127

Boisjan, 73

Bolbitius, 248

Boletus, 255

Bonnemaisonia, 314

Borage, I32

Boraginaceae, I3I

Borago, 132

Bornetia, 3 I 6

Botrychium, 212

Botrylis, 27 I

Boûillas, I 19

Bourrache, 132

Boxthorn, 136

Brachypodium, 204

Brachyihecium, 226

Bracken, 2 I I

Brake, 2 II

Bramble, 86

Branc-ursine, I03

Brassica, 52

Brennende Nessel, I67

Bristle Grass, 193

Briza, 201

Brome Grass, 203

Bromus, 203

Brooklime, 143

Brookweed, 154

Broom, 74

Broomrape, 136

Bryaceae, 224

Bryony, 172

Bryopsis, 306

Bryum. 224

Buche-weizen, I64

Buckbean, I30

Buckwheat, 164

Bugle, I5 I

Bugloss, 132

Bugrane, 74

Bulbochaete, 322

Bullace, 83

Bullrush, I 88

Bunias, 56

Bupleurum, 100

Burdock, i 8

Bur-marigold, 118

Bur-parsley, 103

Bur-reed, 184

Burnet Saxifrage, 100
Butcher's Broom, 178

Butter and Eggs, I 40

Buttercup', 44

Byssosphaeria, 266

CABBAGE, 52

Caille-lait, I08

Caisse, $\mathrm{IO}_{3}$

Cakile, 56

Calamagrostis, 196

Calamint, 147

Calamintha, 147

Caldesiella, 258

Calendula, 1 i 8

Calic ium, 280

Calliblepharis, $3 I_{3}$

Callithamnion, 3 I 7

Callitrichaceae, I 66

Callitriche, 166

Callophyllis. 312

Calluna, 126

Callymenia, 313

Calothrix, 304

Camière, Ir 5

Camomille, I 5

Campanulaceae, 126

Campion, 61

Camptothecium, 226

Campylodiscus, 327

Campylopus, 2 I 8

Canary Grass, 193

Cannabinaceae, I68

Cantharellus, 246

Capillaire, 209

Caprifoliaceae, 107

Capsella, 56

Cardamine, 50

Cardère, I 10

Cardon d'banque, 98

Carduus, 120

Carex, 189

Carlina, II 8

Carline Thistle, I 18

Carpenter-grass, I I 4, I 48

Carpenter's Herb, I 48

Carpinus, 172

Carrot, $\mathrm{IO}_{3}$

Carum, 100

Caryophyllaceae, 6r

Cashes, 103

Castagnea, 309

Castanea, I 7 I

Catabrnsa, 20r

Catchfly, 6I

Catenella, 3 I $3_{3}$

Catharinea, 217

Catmint, I 47

Cat's-ear, I 22 
Cat's-tail, 183

Caucalis, $\mathrm{IO}_{3}$

Celandine, 44, 47

Celastraceae, 73

Celer!, 98

Cenangium, 208

Centaurea, II9

Centaurée, I 29

Centaurr, 128

Centranihus, 109

Centunculus, I 54

Cephalozia, 231

Ceramium, 317

Cerastium, 65

Ceratium, 273

Ceratodon, 217

Ceratophyllum, I 66

Ceteracn, 2 I0

Cetraria, 283

Ceuthospora, 274

Chaernphyllum, 104

Chaetocerss, 344

Chaetomiun, 266

Chaetomorpha, 305

Chaetophora, 322

Chaffweed, 154

Chamumile, I14

Champia, 3!3

Chandelles, 97

Chantransia, 3I I, 324

Chara, 215

Characeae, 215

Characium, 322

Charlock, 52

Cheese-rennet; 108

Cheiranthus, 49

Chelidonium, 47

Chenopodiaceae, 156

Chenoporium, 157

Cherry, 83

Chervil, 104

Chestnut, I 7 I

Cheveux St. Jean, I 3 I

Chèvrefeuille, 107

Chickweed, 64

Chicorv, 122

Chiendent, 205

Chilionema, 308

Chiloscyphus, 232

Chiodecton, 300

Chloroc ccum, 32 I

Chlorophyceae, 304

Chlorophyllophyceae, 32 I

Chontria, 315

Chondıus, 312

Chorda. 309

Chordaria, 308

Chroococcus, 323
Chroolepus, 322

Chrysanthème, I 16

Chrysanthemum, II 5

Chrysosplenium, 97

Chrysymenia, 313

Chue. 105

Chyclocladia, 3 I4

Cicendia, 129

Cichorium, 122

Ciguë, 105

Cinquefoil, 84

Circaea, 93

Cladodei, 280

Cladonia, 280

Clarinphnra, 305, 322

Cladosporium, 272

Cladostephus, 308

Claquets, I 39

Clary. 146

Clathrus, 262

Clavaria, 260

Clavarieat, 260

Cleavers, 108

Clematis, 42

Clitocybe, 242

Clitopilus, 247

Closterium, 324

Clover, 76

Club Moss, $2 I_{4}$

Club Rush, I 87

Cluster Pine, 172

Cocconeis, 330

Cocco.iema, 329

Cochlearia, 54

Cock's-foot Grass, 202

Codsum, 306

Codlins and Cream, 92

Coelastrum, 322

Coleosporium, 276

Collema, 279

Colleı acei, 279

Coller onema, 34 I

Collybia, $23^{\gamma}$

Colt's-foot, III

Columbine, 45

Comarum, 85

Comtrey, 132

Compositae, I I I

Compsothamnion, 317

Côneilles, I80

Conferva, 305, 322

Coniophora, 260

Coniosporium, 27 I

Conium, 104

Conocephalus, 230

Contreprinse, 108

Convolvulaceae, I 30

Convolvulus, 130
Coprinus, 254

Coquelicot, 46

Cor 1 lina, 320

I ordyceps, 264

Corn Cnckle, 63

Corn Flower, I 19

Corn Marigold, I 16

Corne de crrf, I 55

Cornish Moneywort, 142

Cornsalad, 109

Corticium, 259

Cortinarius, 251

Cirydalis, 47

Corylus, I 7 I

Coscinodiscus, 325

Cosmarium, 324

Cotonnière, II 3

Cottun Grass, 189

Cotton Thistle, I 20

Cutton-weed, 116

Cotyledon, 97

Concou, 58

Couch Grass, 205

Coue de Rat, 207

Counmaïre, I 13 , I 50

Cow Parsnip, IO3

Cowslip, $15^{2}$

Crab, 91

Crambe. 57

Cranesbill, 70

Crassulaceae, 95

Crataegus, 90

Craterium, 277

Crepidotus, 250

Crepis, 124

Cress, 55

Cresson, 49

Crithmum, 102

Crouania, 317

Crou bells, I80

Crow-flower, 180

Crowfoot, 43

Cruciferae, 49

Cruoria, 319

Cryphaea, 225

Cryphaeaceae, 225

Cryptoneminae, 318

Cuckoo-buds, 44

Cuckoo Flower, 50

Cuckoopint, I84

Cudweed, I 13

Cuscuta, I3I

Cutleria, 3 Io

Cutlerinae, 309

Cyanophyceae, 303

Cyathus, 263

Cyclotella, 325

Cylindrospermum, 323 
Cymaıopleura, 328

Cymbella. 329

Cymbellede, 329

Cyrodon. 193

Cynoglossum, I31

Cynnsurus, 202

Cyperaceae, 187

Cyperus. 187

Cyphellit, 258

Cystoclonium, 313

Cystopus, 270

Cystoseira, 310

Cystospora, 274

DACRYOMYCES, 261

Dacryom) cetere, 26 I

Dactylis, 202

Daedalea, 258

Daffodil, 177

Daisy, II 2

Daldinia, 265

Dandelion, I23

Danewort, 107

Darluca, 274

Darnel, 206

Dasja, 316

Dasyscypha, 267

Datura, 136

Daucus, 103

Dead-nettle, 149

Dead Tongue, 102

Deadly Nightshade, I 35

Déblômâie, 129

Delesseria, 314

Delphinium, 45

Denticula, 332

Desmarestia, 306

Desmidiaceae, 324

Dewberry, 88

Diachaea, 277

Diadesmis, 341

Dianthus, 6 I

Diatoma, 332

Diatomaceae. 325

Diatrype, 266

Dicranaceae, 217

Dicranella, 218

Dicrasum, 2 I 8

Dictydium, 277

Dictyopteris, 3 I I

Dictyosiphon. 306

Dictyota, $3^{\text {II }}$

Dictyotinae, 3 I I

Didymium, 277

Digitalis, I 39

Dilsea, 318

Dimeregramma, 332

Dioscoreaceae, 172
Diotis, I 6

Diplophyllum, 232

Diplotaxis 53

Uip:acaceae, I Io

Dipsacus, 110

Discomycetes, 266

Ditrichum, 2 I 7

Dittander, 55

Docidiunı, 324

Dock, 160

Dodder, 13I

Dog's Mercury, I66

Dog's-tail Grass, 202

Dog's-tooth Grass, 193

Donkinia, 340

Donnerbart, 96

Doryphora, 332

Druce-amère, 135

Douve, 43

Draba, 53

Drosera, 59

Duckweed, r85

Dudresnaya, 3I I, 318

Dunnontia, 3 is

Dyer's Rocket, 57

EARTHNUT, 100

Eccilia, 248

Echinochloa, I93

Echium, 132

Eclaire, 47

Ectocarpinae, 306

Ectocarpus, 307

Ecuelle "'eau, 98

Eglantine, 89

Eillet d'banque, 62

Elachista, 307

Elatine, 60

Elder, 107

Elecampane, II 2

Eleocharis, 187

Elm, 168

Elym is, 205

Empusa, 270

Enchar,ter's Nightshade, 93

Endocarpon, 300

Endymion, I80

Enteromorpha, 304

Entoloma, 246

Epervière, I25

Epiaire, I50

Epiconiodei, 280

Epilobium, 92

Epine noire, 83

Epingles à la Vierge, $7 \mathbf{I}$

Epipactis, I75

Epithemia, 328
Equisetaceae, 207

Equisetum, 207

Erica, 126

Ericaceae, I26

Erigeron, II I

Eri uhorum, I 89

Erodium, 7 I

Eryngium. 98

Erysimum, 5I

Ery siphe. 2 ? 3

Eiythraea, 128

Erythrotrichia, 3I I

Espurge, 165

Estragon, I 16

Etricoeur, 97

Etriqueur, 97

Eufragia, I4 I

Eunotieae, 328

Euonymus, 73

Eupatorium, I I I

Euphorbia, 164

Euphorbiaceae, I64

Euphrasia, I4I

Eupodiscus, 344

Eurhynchium, 226

Furotium, 205

Evening Primrose, 93

Evening Star, 93

Evergrcen Oak, I7I

Everlasting, II 4

Evernia, 282

Exidia, 26 I

Eyebright, I4I

FAGOPYRUM, I6 4

Fagus, I 7

Falcatula 79

Fanoué, IO2

Farmer's Plague, 99

Featherfew, I 15

Fel terrae, 129

Fennel, IO2

Fenouil, IO2

Fenugreek, 79

Ferns, 208

Fescue Grass, 202

Festuca, 202

Feumeterre, 48

Feverfew, I 5

Ficus infernalis, 47

Field Madder, I07

Figwort, I40

Filago, I $_{3}$

Fioıin, 197

Fir, 172

Fissidens, 218

Fissidentaceae, 218

Flag, 176 
Flammula, 250

Flax, 72

Fleabane, III II3

Fléole, I95

Fleur de Cuucou, 62

Flote Grass, 200

Flouve odorante, 194

Foeniculum, 102

Foirolle, 166

Foiroude, 166

Fomes, 256

Fontinalis, 225

Fool's Parsley, I02

Forget-me-not, 133

Fossombronia, 233

Fouaille, 2 I I

Fougère, 2 I I

Foxglove, I 39

Fox-tail Grass, 195

Fragaria, 85

Fragilaria, 332

Fragilarieae, 332

Frankenia, 59

Frankeniaceae, 59

Fraxinus, 128

Frêne, 128

Frullania, 230

Fucinae, 3 IO

Fucus, 3 ro

Fuga daemonum, 69

Fumago, 273

Fumaria, 47

Fumariaceae, 47

Fumeterre, 48

Fumiter, $4^{5}$

Fumitory, 48

Fumus terrae, 48

Funaria, 223

Funariaceae, 223

Furcellaria, 319

Furze, 73

Fusarium, 273

Fusidium, 270

Galeopsis, I 49

Galera, 249

Galingale, I87

Galium, 108

Garlick, 179

Garlic Mustard, 5 I

Gastridium, I98

Gastromycetes, 262

Gaude, 57

Geaster, 262

Gelidium, 312

Genêt, 74

Genoillière, 67

Gênotte, 100, 176
Gentianaceae, $12 S$

Geoglossum, 266

Geraniaceae, 70

Geranium, 70

Germander, I5I

Geuın, 88

Gigartina, 312

Gigartininae, 3I2

Ginnania, 312

Gipsywort, I46

Gladdon, 176

Glaïeul, 176

Glajeur, 176

Glasswort, I 59

Glaucium, 47

Glaux, 153

Gliai, 176

Gllairu, 105

Gloeocystis, 321

Gloeosiphonia, 318

Gloiotrichia, 323

Gloutonnier, I I9

Glyceria, 200

Glyphomitrium, 220

Gnaphalium; II4

Goat's-beard, 123

Godets, 97

Goldcups, 44

Golden Samphire, 113

Golden Saxifrage, 97

Gomphonema, 34I

Gomphonemeae, 34I

Goosefout, 157

Goosegrass, 108

Gorse, 73

Gouet, I84

Goule de Lion, I39

Goutweed, 99

Gracilaria, 313

Graminede, 193

Grammatophnra, 342

Grande Consoude, 132

Graphis, 299

Grasswrack, 187

Grasse Herbe, 97

Grateloupia, 310

Gratieron, IoS

Great Consound, $\mathbf{I 3 2}^{2}$

Gremil, I 33

Griffitısia, 316

Grimmia, 219

Grimmiaceae, 219

Gromwell, I 33

Ground Ivy, 149

Groundsel, I I 7

Guernsey Lily, 3I

Gueule de Lion, I39

Gunnera, 106
Gymnocybe, 223

Gymnogongrus, 312

Gymnogramme, 2ro

Hair Grass, 198

Halidrys, 310

Haliseris, $31 \mathrm{I}$

Halopithys, 315

Halopteris, 308

Haloragaceae, 94

Halurus, 316

Halymenia, 318

Han, 187

Hannebanne, I 35

Hard Grass, 206

Hardheads, I I 9

Hardock, I I 9

Harebell, I80

Hare's Ear, 100

Hare's-tail Grass, 197

Hart's-tongue, 210

Hawkbit, 122

IIawksbeard, 124

Hawkweed, 125

Hawkweed Oxtongue, 123

Hawthorn, 90

Hazel, 17 I

II leart's ease, 58

Heath, 126

Heath Grass, 199

Heather, 126

Hebelc ma, 249

Hebenon, I35

Hedera, 105

Hedera terrestris, I 49

Hedge Bells, I 3 I

Hedge Mustard, 5 I

Hedge Parsley, 104

Helianthemum, 58

Héliotrope d'hiver, I I I

Helleborine, 175

Helminthia, 123

Helminthocladia, 3 II

Helminthora, 3 I I

Helminthosporium, 272

Helotium, 268

Hemlock, I04

Hemp Agrimony, I I I

Hemp-nettle, I49

Henbane, I35

Hepaticae, 230

Heracleum, $\mathrm{IO}_{3}$

Herb Bennet, 88

Herb Impious, I I3

Herb Peter, I 52

Herb Robert, 71

Herba benedicta,. 88 
Herba coxendica, 97

Herbé, 187

Herbe à jaunir, 57

Herbe à la biche, 164

Herbe à l'esquinancie. 60

Herhe à mille pestus, 69

Herbe à raralysie, 85

Herbe aux chantres, 51

IIerbe aux charpent,ers, I I 4

Herbe aux chats, 147

Herbe aux $n$ agiciennes, 94

Herhe aux mamelles, 122

Herbe aux perles, I33

Herbe aux verrues, 47

Herbe d emeute, I3I

Herbe de flon, I 19

Herhe St. Jean, II6

Herbe tersaie, I 43

Herbet, I 87

Herniaria. 95

Heterosporium, 272

Hieracium, I25

Hierre, IO $_{5}$

Hildenhrand, ia, 319

Himanthalia, 3 Io

Hir antidium, 329

Hippuris, 94

Hirneola, 262

Hogweed, I03

Holcus, I9S

Holly. I 27

Holm Oak, 17:

Hôloges, 123

Homalia. 225

Homoeocladia, 335

Honersuckle, 107

Honkereja, 64

Hookeriaceae, 225

Hop, I68

Hordeum, 205

Horehound, I 50

Horn Poppy, 47

Hornbeam, 172

Horned Pnndweed, I86

Hornwort, 166

Horse Ches'rilt, 172

Horse Radish, 54

Horsetail, 207

Hound's tongue, I3I

Houseleek. 96

Housse, 127

Houx, 127

Humaria, 267

Humulus, 168

Hure de loup, II 4

Hurt Sickle, IIg
Hyacinth, I8o

Hyalodiscus, 325

Hydneae. 258

Hydnum, $25^{8}$

Hydrocotyle, 98

Hygrophorus, 24.3

Hylocnmium, 229

Hymenochaete, 259

Hymenonycetes, 234

Hyoscyamus, I35

Hypericaceae, 68

Hypericum, 68

Hypholoma. 252

Hy phomycctes. 270

Hypnaceae, 226

Hypnea, 313

Hypnum, 228

Hypochoeris, I 22

Hypocrea, 26

H) porerma, 269

Hypodermii. 274

Hypomyces, 264

Hypoxylon, 265

Hyste angium, 263

Hysterium, 269

Hysterographium, 269

ILEX, 127

Inocybe, 248

Inula, 112

Iridaceae, 176

Iridaea, 318

Iris, 176

Ir s gigot. 176

Irpex. 258

Isacris, 304

Isaria. $27 ?$

Isoetes, 2 I4

Isotheciun. 226

Isthmia, 343

Ivraie. 206

Ivy, 105

JACOBÉE, II 7

Jan. 73

Jania. 320

Jasione, 126

Jaune barbe, 96

Jaunet, 44

Jombarbe, 96

Joubarbe, 96

Jovis barba. 96

Juncaceae, I80

I uncus, 180

Jungermannia, 232

Jungermanniaceae, 230

Jusquiame, I35
Kaiser-Blume, II 9

Kallymenia, 313, 318

Kantia, 232

Käsepappel, 67

Kecksies, IO3

Kernelwort, I40

Kerson, 49

Kex, Io 3

Kidney Vetch, 8o

Knapweed II9

Knautia I IO

Knawel. 67

Knotgrass, 163

Koeleria, 199

Kresse 50

LA Coue. IO 8

Labiatae. 144

Labrum Veneris, I 10

Laccaria 242

Lachnea, 267

Lactarius, 24 I

Lactuca, I 23

Lactuca agnina. I09

Lactuca leporina, I 24

Lady's Smuck. 50

Lady's Thistle, I 2 I

Lady's Tresses, I75

Lagurus. 197

Lait d'souaris, 165

Laitron, 124

Lambraise, 15 I

Lamb's Lettuce, 109

Laminaria. 309

Laminarinae, 309

Lamium, 149

Landes, 73

Langue de boeuf, 2 I0

Lapsana, 122

Larkspur, 45

Lastrea, 208

Lathyrus, 82

Laurencia, 3 I 5

Läusekraut, I41

Lavatera, 68

Leathesia, 309

I.ecanora, 289

Lecidea, 293

Leek, 179

Leguminosae, 73

Lejeunia, 230

Lemna, I85

Lemnaceae, 185

Lemon Plant, I5I

Lent Lily, I77

Lentibulariaceae, 152

Lentille d'eau, I85

Lentinus, 246 
Lenzites, 246

Leontodon, 122

Leonurus, 149

Lepidium, 54

Lepigonuw, 66

Lepiota, 235

Leptobryum, 224

Leptocystinema, 324

Leptodon, 225

Leptogium, 279

Leptonia, 247

Leptosphamria, 266

Lepturus, 206

Leskeaceap, 225

Lettuce, 123

Leucohy yum, 2 I8

Leucodontaceae, 225

Lichenacei, 280

Lichina, 279

Licmophora, 342

Liebmannia, 309

Lierre, 105

Ligustrum, 127

Liliaceae, 178

Lime Trer, 172

Linacear, 72

Linaria, I 39

Ling, 126

Linum, 72

Liot, 130

Liseron, I $\mathbf{I}$

Listera, 175

Lithophyllum, 319

Lithospermum, I33

Lithothamion, 320

Litosiphon, 306

Lolium, 206

Lomentaria, 313

London Pritie, 97

Lorg Purples, I73

Lonicera, 107

Loosestrife, 15.3

Lophocolea, $23 \mathbf{I}$

Lords and Ladies, 184

Lotus, 79

Lousewort, I4I

Love-in-Idleness, 58

Lucerne, 74

Lunularia, 230

Luzula, I $\mathbf{\gamma}_{3}$

Lychnis, 62

Lyciun, I 36

Lycogala, 277

Lycoperdon, 262

Lycopodiaceae, 214

Lycopodium, 214

Lycopsis, I 32

Lycopus, I 45
Lyngbya, 303, 323

Lysimachia, 153

Lythraceae, 91

Lythrum, 9I

MACERON, 105

Mâche, 109

Macrosporium, 272

Madder, I09

Mallow, 67

Malva, 67

Malvaceae, 67

Manchettes de la Vierge, I3I

Maple, 70

Marasmius, 237

Marchantiaceae, 230

Mare's-tail, 94

Marguerite, II2, II 5

Marigold, I 16, I I 8

Marjolaine, 147

Marioram. 147

Marou'e, II 5

Narram, 196

Marrubium, 150

Narsh Eyebright, I4I

Marsh Mallow, 68

Marsh Pennywort, 98

Marsh Samphire, I 59

Marshwort, 98

Martınets, 58

Mastoglnia, 34 I

Matricaria, I 15

Matthiola, 49

Mauve, 67

Mayweed, I I4

Meadow Grass, 200

Medicago, 74

Medick. 75

Medlar, 90

Meesiaceae, 223

Melampsora, 276

Nelic Grass, 199

Mêlier, 90

Melilot, 75

Melilotus, 75

Melissa, 148

Melobesia. 319

Melosira, 326

Melosireae, 325

Mentha, 144

Menyanthes, I30

Mèque, II 7

Mercurialis, 166

Meridion, 342

Meridionese, 342

Merismopedia, 323

Méroque, 114
Merulius, 258

Mesocarpus, 322

Mesogloea, 309

Mespilus, 90

Metzgeria, 233

Mibora, 193

Microcladia, $3 \mathbf{J} 8$

Mignonette, 57

Milchdieb, I42

Milium, 195

Milk Thistle, I2I, I24

Milkwort, 60

Millegreux, 196

Mint, I44

Mistletoe, 106

Nnium, 244

Moenchia, 65

Moleine, 138

Molinia, I 99

Mollia. 221

Molisia, 268

Moneywort, I 53

Monilia. 27u

Monnoyere, 54

Monospora, 316

Mnntia, 94

Moonwoit, 2 I 2

Morelle noire, 134

Moriauquemin, I5I

Mossy Redshanks, 95

Yother of Millions, I 39

Morher of wheat, I44

Motherwort, I49

Moudron, 64

Mountain Ash, 9 I

Mourdron, 64

Mouron, 64

Mouse-ear Chickweed, 65

Mouse-ear Scorpion

Grass, 134

Mousetail, 42

Nucor, 269

Mutlier, 139

Nugwort, I 6

Mullein, 138

Mullu, I 6

Murlu, I 6

Mustard, 52

Mycena, 239

Mycogone, 27 I

Myosotis, I33

Myosurus, 42

Myriactis, 307

Myriangium, 280

Myrionema, 308

Myriophyllum, 94

Myriotrichia, 306

Myxogastres, 277 
Naccaria, 312

Naematelia, 26I

Naiadaceae, 187

Narcissus, 176

Nardia, 232

Nasturtium, 49

Naucoria, 249

Navelwort, 97

Navicula, 335

Naviculaceae, 335

Neckera, 225

Neckeraceae, 225

Nectria, 264

Nectriella, $2 \kappa_{4}$

Néflier, 90

Nêle, 63

Nemaleon, 3 I I

Nemalioninae, 3I I

Neottiella, 267

Nepeta, I49

Nephromium, 283

Nère Epeine, 83

Nettle, 167

Nielle des blés, 63

Nightshade, Deadly, I35

Nightshade, Enchanter's, 93

Nightshade, Woody, I35

Nipplewort, 122

Nit Grass, 198

Nitella, 215

Nitophyllum. 3I4

Nitzschia, 334

Nitzschieae, 333

Nolanea, 247

Nombril de Vénus, 97

None-so-pretty, 97

Normandina, 300

Nose-bleed, 196

Nostoc, 323

Nummularia, 265

OAK, I7I

Oat, 198

Oat Grass, 199

Obiune, I6

Odontidium, 332

Odontites, 142

Oenanthe, IOI

Oenothera, 93

Oidium, 270

Old man's beard, 42

Oleaceae, 127

Olus atrum, 105

Omphalia, 242

Onagraceae, 92

Onobrychis, 82

Ononis, 74
Onopordum, 120

Oospora, 270

Opegrapha, 298

Ophioglossum, 2 I 2

Ophrys, 174

Orache, I 59

Orbilia, 269

Orchidaceae, 172

Orchis, 172

Origanum, 147

Orme, 168

Ornithogalum, 178

Ornithopus, 82

Orobanchaceae, 136

Orobanche, 136

Orpine, 95

Orthosira, 327

Orthotrichaceae, 222

Orthotrichum, 223

Ortie brûlante, 167

Ortie puante, 150

Oscillaria, 303, 323

Osier, 169

Osmunda, 2 I I

Otidea, 267

Ovularia, 27 I

Oxalidaceae, 72

Oxalis, 72

Ox-eye, 115

Ox-tongue, 123

PADINA, 3II

Paim-feis, 101

Pain d'coucou, 58

Pain de couleuvre, 173

Pain de panpan, 108

Pain-faie, 101

Panaeolus, 254

Panicaut, 98

Panick Grass 193

Pannaria. 287

Pansy, 58

Panus, 246

Papaver, 46

Papaveraceae, 46

Páquerette, I1 12

Pâquerolle, I52

Pâquette, II 2

Paraietole, I67

Pariét dire, 167

Parietaria, I67

Parmaceti, 56

Parmelia, 285

I'aronychiactae, 95

Parsley, 99

Parsley Piert, 84

Parsnip, I02

Pas d’âne, I I I
Pas de chat, 155

Pastinaca, 102

Patte a'oie, 130

Paxillus, 25 I

Pea, 82

Pear. 9I

Pearlwort, 63

Pediastrum, 32 I

Pedicularis, I4I

Peignes, 110

Pellia, 233

Pellitory, 167

Peltigera, 284

Pelvetia, 3 IO

Penicillium, 270

Peniophora, 260

Pennecoûte, 173

Penny Cress, 54

Pennyroyal, 146

Pennywort, Marsh, 98 .

Pennywort, Wall, 97

Pentecôte, 5 I

Peplis, 91

Peppermint, 145

Pepperwort, 54

Percepier, 84

Percepierre, 102

Perchepierre, 102

Periwinkle, 128

Persicaria, I6I

Pertusaria, 293

Pervenche, I28

Pervinke, I2S

Petasites, I II

Pétraux. I 55

Petrocelis, 319

Petroselinum, 99

Petrospongium, 309

Peyssonnelia, 319

Peziza, 267

Pfennigkraut, 54

Phaeangella, 269

Hhaeophyceae, 306

Phalaris, 193

Phascum, 220

Pheasant's Eye, 42

Philonotis, 223

Phleum, 195

Phlyctis, 293

Pholiota, 248

Phoma, 273

Phragmidium, 276

Phragmites, 196

Phycochromophyceae, 323

Phycomycetes, 269

Phyllachora, 265

Phyllitis, 309 
Phyllodei, $28_{3}$

Phyllophora, 3 I 2

Phyllosticta, 274

Phy'scia, 286

Physcomitrium, 223

Phytophthora, 270

Pi d'alonette, I 83

Pial Laitron, I 22

Picot, 149

Picris, 123

Pied de veau, 184

Piedbot. 44

Piépot, 44

Pignut, I00

Pilettes. I84

Pilewort, 44

Pilobolus, 269

Pilosace, $2 ; 2$

Piment, 148

Pimpernel, I 53

Pimpin, IOI

Pimpinella, ioo

Pimprenelle, 153

Pinaster, 172

Pink, 61

Pinnularia, 337

Pinus, 172

Piquets, 73

Pissenliette, 44

Piss $\leq n l i t, 44$

Placodei, 288

Placodium, 288

Plagiochila, 232

rlagiogramma, 332

Plagiothecium, 228

Plant of the Blood of Man, 107

Plantaginaceae, I 55

Plantago, I 55

Plantain, 155

Platysma, 283

Pleonosporium, 316

Pleuridium, 217

Pleurocapsa, 303

Pleurochaete, 222

Pleurococcus, 321

Pleuropus, 226

Pleurosigma, 339

Heurotus, 243

Plise, 187

Plocamium, 314

Ploughman's Spikenard, I 12

Plowrightia, 265

Plum, 83

Plumaria, 317

Plumbaginaceae, I 54

Pluteus, 246
Poa, 200

Podocystis, 328

Podosira, 326

Podosphenia, 342

Poirions, 177

Poivre. 105

Poivre d'eau, I62

Polycarpon, 65

Polyrala, 60

Polygalaceae, 60

Polygonaceae. 160

Polygonum, I6I

Polyides, 319

Polyportium, 208

Polypody. $20 \mathrm{~S}$

Polypogon 197

Polyporeae, 255

Polyporus, 256

Polysiphonia, 315

Polystichum, 208

Polystictus, 257

Polythrincium, 272

Pulytrichaceae, 217

Polytrichum, 217

Pommier du diable, I36

Pondweed, 185

Poor man's Parmaceti, 56

Poor rnan's I'epoer, 56

Poor man's Weatherglass, 154

Popdock, I 39

Poplar, I7o

Poppy, 46

I'opulus, 170

Porcelle, I 22

Purella, 23 I

Poria, 257

Poronia, 265

Porotrichum, 225

Porphyra, 3 II

Porphyridium, 32 I

Porphyrinae, 3 I I

Portulaceae, 94

Potamogeton, I85

Potamogetonaceae, 185

Potentilla, 84

Poterium, $8_{3}$

Pottia, 220

Prêle, 207

Primevère. 152

Primrose, 152

Primula, 152

Primulaceae, I52

Privet. 127

Propolis, 268

Protococcus, 32 I

Prumerolle, 152

Prunella, I48
Pruniole, 152

Prunus, 83

Psamina, 196

Psathyra. 253

Psathyrella, 254

Psilocybe, 253

Psoroma, 287

Pteris, 2II

Pterocladia, 3I2

Pterogonium, 225

Pterygophyllum, 225

Ptilota, 317

Ptilothamnion, 316

Pty chomitrium, 220

Puccinia, 275

Pulicaire, II 3

Pulicaria, II 3

Punctaria, 306

Purple Loosestrife, 9I

Purslane, Sea, 64

Purslane, IVater, 9I

Pursley-piert, 84

Pycnophycus, 3 Io

Pylaiella, 307

Pylaisia, 226

Pyrenodei, 300

Pyrenomycetes, 263

Pyrola. I 27

P'yrus, 9 I

Pythium, 270

QUAKING Grass, 20I

Quêne, I7I

Quercus, I7 I

Querpentière, II 4

Queue de cheval, 207

Quicken Grass, 205

Quitch Gra:s, 205

RADIOL', 73

Radish; 57

Radula, 23I

Ragged Robin, 62

Ragwort, I I 7

Ralfsia, 308

Ramalina, 282

Ramalodei, 282

Ramularia, 27 I

Ranunculaceae, 42

Ranunculus, 42

Raphanus, 57

Raspberry, 86

Redshanks, 7 I

Reed, 196

Reed Mace, 183

Réglisse, 74

Remora aratri, 74

Rennet, 108 
Reseda, 57

Resedaceae, 57

Rest Harrow, 74

Rest Plough. 74

Reticularia, 277

Reveil-matin, 164

Khabdonema, 343

Rhacomitrium, 220

Rhaphidium, 32 I

Rhinanthus, I4I

Rhinotrichum, 270

Rhipidophora, 342

Rhizoclonium, 305

Rhizopus, 269

Rhizosolenia, 344

Rhodochorton, 3 I 7

Rhodomela, 3 I 4

Rhorlophyceae, 3II, 324

Rhodophyllis, 3 I 3

Rhoulymenia. 313

Rhodymeninae, 313

Rhopographus, 269

Rhytisma, 265

Ribbon Grass, 194

Ricasolia, 284

Riccia, 230

Ring $0^{\circ}$ bells, 180

Rivularia, 304, 323

Roast-beef Plant, I 76

Roccella. 282

Rock Rose, 58

Rocket, 49

Romulea, 176

Rôs, I96

Rosa, 89

Rosacear, $8_{3}$

Rose. 89

Rose de Tchen, 46

livuâge Gambe, 7 I

Rubia, I09

Rubiucede, 107

Rubus, 86

Rumex, 100

Ruppia, I 86

Rupiurew st 95

Ruscus, 178

Rush, 180

Russula, 24I

Rye Gras-, 206

Ryparobius, 268

Rytiphluea, 315, 316

SACCOGYNA, 232

Saccurhiza, 309

Sage, 146

Sagina. 63

Sainfoin, 82

St. John's IVort. 69
Salad Burnet, 83

Salicornia, I 59

Salix, 168

Sallow, 169

Salsify, I 23

Salsola, 157

Saltwort, 153, 157

Salvia, 146

Sambucus, 107

Samolus, I 54

Samphire, 102

Sand Rocket, 53

Sandwort, 64

Sandwort-spurrey, 66

Saponaria, 6I

Sarothamnus, 74

Sauce alone, 51

Saxılraga, 97

Saxifragaceae, a7

Saxifraye, 97

Scabiosa, 1 ro

Scabious, I IO

Scandix, 104

Scspania, 232

Scenedesmu*, 32I

sichizonema, 34I

Schizosiphon, 304

Schizymenia, 318

Schlitisel-blume, 152

Schmitziella, 319

Schoenus, I 87

Scilla, $\mathbf{1} 79$

Scinaia, 312

-cirpus, I88

Scleranihus, 67

Sclerochloa, 200

Scleroderma, 263

Scolopendrium, 210

Scorpion-grass, 134

Scrophularia, I40

Scrophulariaceae, 138

scurvy-grass, 54

Scutch Grass, 205

scutellaria, I 48

Scytosiphon, 309

Sea Bells, I3I

Sea Blite, 156

Sea Heath, 59

Sea Holly, 98

Sea Kale, 57

Sea Lavender, 154

Sea Pink, I 55

Sea Purslane, 64

Sea Reed, 196

Sea Rocket, 56

Sea Sitarwort, I I I

Sea Stuck, 49

Sedge, 189
Sedum, 95

Self-heal, 148

Sempervivum, 96

Senebiera, 56

Senecio, I 17

Seneçolı, I I7

Senille, I 58

Sent-à miel, 155

Sepedonium, 27 I

Septoria, 274

Serpolet, 147

Serrafalcus, 204

Setaria, 193

Seue, 107

Shamrock, 79

Sheep's-bane, 98

Sheep's-bit, I 26

Shepherd's Cress, 54

Shepherd's Needle, I04

Shepherd's Purse, 56

Shepherd's IVeatherglass, I 54

Sherardia, 107

Sibthorpia, 142

Silene, 6I

Silverweed, $8+$

Silybum, 121

Sinapis, 52

Sison, 99

Sisymbrium, 5 $\mathbf{I}$

Sium, 100

Skullcap, I 4 S

Sloe, $8_{3}$

Snlalireed, 196.

Smyrnium, 105

snapdragon, I39

Snichon, II 7

snille, 158

Soapwort, 61

Soft Grass, 198

Solanaceae, 134

Solanum, I34

Sonchus, I 24

Sonnettes, I4I

Suppittiella, 260

Sordaria, 266

Sorrel, I6I

Souchet, I87

Souci, I I 6

Soucique, I 16

Soude épineusr, I 57

Sowdwort, 157

Sowthistle, 124

Sparganium, I84

Spargoutte, 67

Speargrass, 196

spearwort, 43

Speedwell, 142 
Spergula, 66

Spermothamnion, 316

Sphacelaria, ' 308

Sphaeria, 266

Sphaerococcus, 313

Sphaerophoron, 280

Sphaeropsideae, 273

Sphaerospora, 267

Sphaerotheca, 263

Sphaerozyga, 304

Sphagnaceae, 217

Sphagnum, 217

Sphinctrina, 23o

Sphondylothamnion, 316

Spindle Tree, 73

Suiranthes, 175

Spirugyra 322

Spleenuort, 209

Sporozhninae, j09

Sprirochnus. 309

Spororrichum, 27 I

Spuniria, 277

Spurge, 164

Spurrey, 66

Squamaria, 288

Squill, I79

Squinancie, 60

Squinancy-wort, 108

Stachys, I 50

Star of Bethlehem, I78

Star Thistle, 120

Statice, 154

Staurone s. 340

Stellaria, 64

Stemonit is, 277

Stereocaulın, 282

Stereum, $25^{8}$

Stick-a-back, 108

Sticta, 284

Stictina, 284

Stictyosiphon, 306

Stigeoclonium, 322

Stigmatidium, 299

Stilbum, 273

Stilophora, 308

Stitchwort, 64

Stock, 49

Stone Parsley, 99

Stunecrop, 95

Stork s-hill, 7 I

Strawberry, 85

Streblonema, 307

Siriatella, 343

Stropharia, 252

Sturrions, 49

Stypocaulon, 308

Suaeda, 156

succory, 122
Sucet, I07

Suchets, 107

Sundew, 59

Sureau, 107

Surelle, I6I

Surirella, 327

Surirelleae, 327

Swallow-hero, 47

Sweet briar, 89

Sweet-scented Grass, 194

Sycamore, 70

Symphytum, 132

Symploca, 304

Synedra, 332

Syzygites, 270

TABELLARIEAE, 342

Tamariscaceae, 92

Tamarisk, 92

Tamarix, 92

Tamus, 172

Tanacée, 117

Tanacetum, II6

Tanaisie, 117

Tansy, I 6

Taraxacum, 123

Tare, so

Tarragon, I 16

Tassel-grass, I 86

Tea Planr, I 36

Teasel, I 10

Teesdalia, 54

Teigne, I3I

Têtards, I I 9

Tetraploa, 272

Teucrium, I5I

Thale Cress, 51

Thelephoreae, 258

Tnesium, 164

Thistle, 120

Thlaspi, 54

Thorn Apple, I36

Thrift, I 55

Thrincia, 122

Throatwort, 126

Thuidium, 226

Thym de crapaud, 96

Thyme, 147

Thymus, 147

Tillaea, 95

Tilmadoche, 277

Tilupteridinae, 3 II

Tilopteris, 3 I I

Tinothy Grass, 195

Toadflax, i 39

Tolypothrix, 323

Torilis, IO4

Tormentil, 85
Tortula, 220

Tortulaceae, 220

Torula, 272

Toute saine, 68

Toxonidea, 340

Trachelium, I 26

Tragopogon, 123

Trainasse, 163

Trametes, 258

Traveller's Joy, 42

Treacle Mustard, 5I

Tree Mallow, 6s

Trèfle, 76

Trèfle d eau, 130

Trefoil. 77

Tremaine, 76

Tremella, 261

Tremellineae, 261

Triceratium, 343

Trichia, 277

Trichnilerma, 270

Trich loma, 236

Trichostomun, 222

Trich'shecium, 271

Trifolium, 76

Triglochin. $17 \mathrm{~S}$

Trioaia 199

Trisetum, I9S

Triticum, 205

Troëne, 127

Tropaenlum, 49

Tryblionella, 333

Tubaria, 250

Tubercularia. 273

Tue.lapin, 102

Tulostoma, 262

Tussilago, I I I

Tutsan. 68

Twayblade, 175

Typha, i83

Typhaceat, 183

ULEX, 73

Ulmaceae, 168

Ulmus, 168

Ulota, 223

Ulothrix, 322

Ulva, 305

Umbelliferae, 98

Umbilicaria, 287

Umbilicus Veneris, 97

Urceolaria, 293

Uromyces, 274

Urtica, I67

Urticacfae, 167

Usnea, 282

Ustilago 276

Utricularia, 152 
VAILLE, I 30

Vâle, 130

Valerian, 109

Valerianaceae, 109

Valerianella, 109

Valsa, 265

Vaucheria, 322

Vaudre, 57

Verbascum, $\mathrm{I}_{3} 8$

Verhena, I5I

Verbenaceae, I 5 I

Vermicularia, 274

Veronica, 142

Verrucaria, 300

Verticillium, 27 I

Vervain. I 5I

Vetch, 8I

Vetchling, 82

Vicia, 80

Vinca 128

Viola, 58

Violaceae, 58

Violet, $5^{8}$

Violette, 63

Vipérine, I32

Viper's Bugloss, 132

Viscum, I06

Volutella, 273

I olvaria, 246

Vulpin, I95

WAHLENBERGIA, 126
Wall Cress, 50

Wallflower, 49

Wall Pennywort, 97

Wall Pepper, 96

Wall Rocket, 53

Wart Crrss, 56

Water Cress, 49

Water Crowfoot, 43

Water Dropwort, IOI

Water Fennel, 42

Water Milfoil, 94

Water Parsnip, I00

Water Pepper, I62

Water Pimpernel, 154

Water Plantain, 177

Water Purslane, 9I

Water Starwort, I66

Webera, 224

Weisia, 22I

IVeissia, 223

Weld, 57

Wermuth, I 6

Wheat Grass, 205

White Man's Foot, 156

White-rot, 98

Whitethorn, 90

Whitlow Grass, 53

Whorl Grass, 20I

Wild Heliotrope, I II

Wild Liquorice, 74

Wild Rhuharh, Io6

Willow, 168
Willow-herb, 92

Winter Creșs, 50

Wintergreen, 127

Wolf's-claw, 214

Woodbine, 42

Wood Rush, 183

Wood Sage, 151

Wood Sorrel, 72

Wormwood, 116

Woundwort, I 50

Wrangelia, 316

Wych Elm, I68

XANTHIUM, 125

Xylaria, 265

YARROW, I I4

Yèble, 107

Yellow Cress, 49

Yellow Rattle, I4 I

Yerre, 105

ZANARUINIA, 3 IO

Zannichellia, I86

Zasmidism, 269

Zaun-glocke, I31

Zonaria, 309

Zostera, I87

Zygnema, 322

Zygodon, 222

\section{ALDERNEY.}

ACER, 357

Achillea, 367

Agaricus, 394

Agrimonia, 36I

Agrostis, 383

Ahnfeltia, 407

Aira, 384

Alaria, 406

Alchemilla, $36 \mathrm{I}$

Alliaria, $35^{2}$

Allium, 380

Alopecurus, 383

Alyssum, 353

Amblystegium, 39I

Anagallis, 375

Aneura, 393

Anthemis. 367

Anthoxanthum, 383

Anthyllis, 360

Antirrhinum, 373

Apium, 364

Arabis, 352

Arctium, 368

Arenaria, 356

Armeria, 376

Armoracia, 353

Arrhenatherum, 384

Artemisia, 368

Arthonia, 403

Arthrolobiam. 360

Ascololus, 396

Ascophyllum, 406

Asperococcus, 405

Asperula, 365

Asplenium, 386

Athyrium, 386
Atriplex, 376

Avena, 384

BaEOMYCES, 398

Ballota, 375

Barbarea, $35^{2}$

Barbula, 389

Bartramia, 390

Bellis, 367

Beta, 376

Betula, 379

Bifurcaria, 406

Blechnum, 387

Bolbitius, 394

Bonnemaisonia, 408

Borago, 37 I

Bornetia, 409

Brachypodium, 385 
Brachythecium, 390

Brassica, 352

Briza, 385

Bromus, 385

Bryopsis, 404

Bryum, 390

Bupleurum, 364

CAKILE, 354

Calamintha, 374

Calliblepharis, 407

Callithamnion. 409

Callitric «e, 378

Callophyllis, 407

Calluna, 370

Callymenia, 407

Calothrix, 404

Camptothecium, 390

Campylopus. 38 ;

Cantharellus, 394

Capsella, 353

Cardamine, 352

Carduus, 368

Carr $x, 382$

Carlina, 368

Castagnea, 405

Castanea. 379

Catharinea, 387

Centaurea, 368

Centranthus 366

Centunculus, 375

Cephalozia, 392

Cerarium, 409

Cerastium, 356

Ceratodnn, 387

Ceterach, 387

Chaerophyllum, 365

Chaetomorpha, 404

Champia, 407

Chantransia, 406

Chenopodium, 376

Chilionema 405

Chiloscyphus, 392

Chondria, 408

Chondrus, 407

Chorda, 406

Chrysanthenumi, 367

Chylocladia, 407

Cichorium, 69

Circaea. 363

Cladonia, 398

Cladıphora, 404

Cladostephu: 405

Clavaria, 395

Clitocyhe, 394

Clitopilus, 394

Cochlearia, 353

Codium, 404
Coleosporium, 397

Collema, 398

Collybia, 393

Conium, 365

Conocephalus, 392

Convolvulus, 37 I

Coprinus, 395

Corallina, 410

Corticium, 395

Cotyledon, 364

Crambe, 354

Crataegus, 362

Crepis, 370

Crithmum, 364

Crouania 409

Cuscuta, 371

Cynoglossum, 37 I

Cynosurus, 385

Cyperus, 382

Cystoclonium. 407

Cystopus, 396

Cystoseira, 406

DACTYLIS, 385

Dasya. 408

Daucus, 364

Delesseria. 408

Delphinium, 351

Desmarestia, 404

Dianthus, 355

Dicranella, 387

Dicranum, 385

Dictyota, 406

Digitalis, 373

Dilsea, 409

Diotis, 367

Dıplotaxis, 352

Draba, 353

Dumontia, 409

ECHINOCHLOA, $3^{8} 3$

Echium, 37 I

Ectocarpus, 405

Elachista, 405

Eleocharis, 382

Endymion, $38 \mathrm{I}$

Enteromorpha, 404

Entoloma. 394

Epilobium, 3631

Equisetum, 386

H.rica, 370

Erigeron, 367

Erodiun, 358

Eryngium, 364

Erysiphe. 396

Erythraea, 37 I

Eutragıa, 373

Euphorb a, 378
Euphrasia, 373

Eurhynchium, 391

Exidia, 395

Fagopyrum, 378

Falcatula, 360

Festuca, 385

Filago, 367

Fissidens, 388

Foeniculum, 364

Fossombronia, 393

Fraxinus, 370

Frullania, 392

Fucus, 406

Fumaria, 35I

Funaria, 390

Furcellaria, 409

GALERA, 394

Galium. 365

Gelidium, 407

Geoglossum, 396

Geranium, 358

Geum, 36I

Gigartina, 407

Glaucium, 35I

Glaux, 375

Gloeosiphonia, 409.

Glyceria, $3 \mathrm{~S}_{4}$

Gnaphalium, 367

Gracilaria, 407

Griffithsia, 408

Grimmia, 388

G) mnogongrus. 407

HALIDRYS, 406

Halurus, 409

Hedera, 365

Helianthemuin, 354

Helminthia, 369

Helminthora. 406

Helotium, 396

Heracleum. 364

Herniaria, 363

Hieracium, 370

Hildenbrandtıa, 409

Himanthalia, 406

Hippuris, 363

Hirneola, 395

Holcus, 384

Honkeneja, 356

Hordeum, 386

Humarıa, 396

Humulus, 379

- Hydrocotyle, 364

IIygrophorus, 394

Hyloconium, 392

Hyoscyamus, 372 
Hypericum, 357

Hypholoma, 395

Hypnum, 39I

Hypochoeris, 369

Hysterium, 396

INULA, 367

Iris, 380

Isothecium, 390

JASIONE, 370

Juncus, $38 \mathrm{I}$

Jungermannia, 393

KANTIA, 392

Knautia, 366

Koeleria, 38 t

LACCARIA, 394

Laminaria, 406

Lamium. 375

Lapsana, 369

Lastrea, 386

Lathyrus, 360

Laurencia, 408

Lavatera, 357

Leathesia, 406

Lecanora, 400

Lecidea, 401

Lejeunia, 392

Lemna, 382

Leontodon, 369

Lepidium, 353

Lepigonum, 356

Lepiota, 393

Leptogium, 398

Lichina, 398

Ligustrum, 370

Linaria, 373

Linum, 358

Lithophyllum, 410

Lithospermum, 372

Lithothamnion, 410

Litosiphon, 405

Lolium, 386

Lomentaria, 407

Lonicera, 365

Lophocolea, 392

Lotus, 360

Lunularia, 392

Luzula, 381

Lychnis, 355

Lycium, 372

Lycogala, 398

Lycoperdon, 396

Lycopsis, 37 I

Lyngbya, 404
MALVA, 357

Marasmius, 393

Marrubium, 375

Matricaria, 367

Medicago, 359

Melampsora, 397

Melilotus, 359

Melobesia, 409

Mentha, 374

Mercurialis, 378

Merulius, 395

Metzgeria, 393

Mnium, 390

Moenchia, $35^{6}$

Mollisia, 396

Monospora, 409

Montia, 363

Mycena, 393

Myosotis, 372

Myriactis, 405

Myrionema, 405

NASTURTIUM, 352

Naucoria, 394

Nectria, 396

Nepeta, 375

Nitophyllum, 407

Nolanea, 394

Normandina, 403

OBIONE. 377

Odontites, 374

Oenanthe, 364

Oenothera, 363

Omphalia, $j 94$

Onobrychis, 36 I

Ononis, 359

Opegrapha, 402

Orchis, 380

Ornithopus, 360

Orobanche, 372

Orthotrichum, 390

Padina, 406

Panaeolu-, 395

Pannaria, 400

Papaver, 35I

Parietaria, 378

Parmelia, 399

Pastinaca, 364

Pedicularis, 373

Pellia, 393

Peltigera, 399

Pelvetia, 406

Peniophora, 395

Pertusaria, 401

Petasites, 367

Petroselinum, 364
Peyssonnelia, 409

Phalaris, 383

Phascum, 388

Phleum, 383

Phragmidium, 397

Phragmites, 383

Phyllophora, 407

Phyllosticta, 397

Physcia, 399

Picris, 369

Placodium, 400

Plagiochila, 392

Plantago, 376

Pleuridium, 387

Pleurochaete, 389

Pleuropus, 390

Pleurotus, 394

Plocamium, 407

Plumaria, 409

Poa, 384

Polycarpon, 356

Polygala, 355

Polygonum, 377

Polyides, 409

Polypodium, 386

Polyporus, 395

Polysiphonia, 408

Polytrichum, 387

Populus, 379

Poronia, 396

Porphyra, 406

Potentilla, 36r

Pottia, 388

Primula, 375

Prunella, 375

Prunus, 36 I

Psamma, 383

Psathyrella. 395

Psilocybe, 395

Pteris, 387

Puccinia, 397

Pulicaria. 367

Punctaria, 405

Pylaiella, 405

Pyrus, 362

Quercus, 379

RADIOLA. 358

Radula, 392

Ralfsia, 405

Ramalina 39 ?

Ranunculus, $35^{\circ}$

Raphanus, 354

Reseda, 354

Rhrdochorion, 409

Rhodophyllis, 107

Rhodymenia, 407 
Rhytisma, 396

Riccia, 392

Rivularia, 404

Roccella, 398

Romulea, 380

Rosa, 362

Rubia, 366

Rubus, 36I

Rumex, 377

Ruscus, 380

Russula, 394

SACCORHIZA, 406

Sagina, 356

Salix, 379

Salsola, 376

Salvia, 374

Sambucus, 365

Samolus, 376

Sarothamnus, 359

Saxifraga, 364

Scandix, 365

Scapania, 392

Schoenus, 382

Scilla, 380

Sc naia, 406

Scirpus, 382

Scleranthus, 357

Sclerochloa, 385

Scolopendrium, 387

Scrophularia, 373

Scytosiphon, 406

Serium, 363

Senebiera, 353

Senecio, 368

Serrafalcus, 385

Sherardia, 365
Silene, 355

Sinapis, 352

Sisymbrum, 352

Sium, 364

Smyrnium, 365

Solanum, 372

Sonchus, 370

Sparganium, 381

Spergula, 357

Sphacelaria, 405

Sphaerococcus, 407

Sphaerophoron, 398

Sphondylothamnion, 408

Spiranthes, 380

Spumaria, 398

Stachys, 375

Statice, 376

Stellaria, 356

Stereum, 395

Stictyosiphon, 405

Stigmatidiurn, 403

Stropharia, 395

Siypocaulon, 405

Symphytum, 37 I

TAMARIX, 362

Taraxacum, 369

Teesdalia, 353

Teucrium, 375

Thesium, 378

Thrincia, 369

Thuidium, 390

Thymus, 374

Torilis, 365

Tortula, 388

Tragopogon, 369

Tremella, 395

\section{SARK.}

ACER, 4I9

Achillea, 426

Aethusa, 423

Agrimonia, 421

Agrostis, 438

Aira, 438

Alchemilla, 42 I

Alliaria, 416

Allium, 436

Alopecurus, 438

Amaranthus, 430

Anagallis, 432

Anthemis, 426
Anthoxanthum, 438

Anthyllis, 420

Antirrhinum, 430

Antithamnion, 446

Apium, 423

Arctium, 426

Armeria, 432

Arrhenatherum, 438

Artemisia, 426

Arum, 437

Asplenium, 440

Athyrium, 440

Atriplex, 433
Tricholoma, 393

Trichostomum, 389

Trifolium. 359

Triglochin, 380

Triodia, 384

Trisetum, 384

Triticum, 385

Tulostoma, 396

ULEX, $35^{8}$

Ulmus, 379

Ulota, 389

Ulva, 404

Uromyces, 397

Urtica, 378

Usnea, 398

Ustilago, 398

VALERIANELLA, 366

Verbascum, 373

Verbena, 375

Vermicularia, 397

Veronica, 374

Verrucaria, 403

Vicia, 360

Vinca, 371

Viola, 354

Volvaria, 394

WEBERA, 390

Weisia, 389

XYLARIA, 396

ZOSTERA, 382

Zygodon, 389
BAEOMYCES, 44I

Bellis, 425

Beta, 433

Bonnemaisonia, 446

Borago, 429

Bornetia, 446

Brachypodium, 439

Brassica, 416

Briza, 439

Bromus, 439

Bryopsis, 445

Bryum, 44I 
CAKILE, 416

Callithamnion, 446

Callitriche, 435

Callophyllis, 445

Calluna, 428

Capsella, 4I 6

Cardamine, 416

Carduus, 427

Carex, 437

Carlina, 426

Castanea, 435

Centaurea, 426

Cephalozia, 441

Ceramium, 446

Cerastium, 4I 8

Ceratodon, 44I

Cheiranthus, 415

Chenopodium, 433

Chiodecton, 445

Chondrus, 445

Chorda, 445

Chrysanthemum, 426

Chylocladia, 445

Cichorium, 427

Cladonia, 44I

Cochlearia, 4I 6

Collema, 44I

Conium, 424

Convolvulus, 429

Cornllina, 446

Cotyledon, 423

Crataegus, 422

Crepis, 427

Crithmum, 424

Cuscuta, 429

Cynosurus, 439

Cyperus. 437

DACTYLIS, 439

Daucus, 424

Dianthus, 417

Digitalis, 430

Dipsacus. 425

Dumontia, 446

EсHIUM, 429

Ectocarpus, 445

Eleocharis, 437

Endymion, 436

Enteromorpha, 445

Epilobium, 422

Equisetum, 440

Erica, 428

Erodium, 4I9

Eryngium, 423

Erythraea, 428

Eufragia, 430

Eupatorium, 425
Euphorbia, 434

Euphrasia, 430

Falcatula, 420

Festuca, 439

Filago, 425

Foeniculum, 423

Fontinalis, $44 \mathrm{I}$

Fraxinus, 428

Fumaria, 4I 5

Furcellaria, 446

Galium, 424

Gastridium. 438

Gelideum, 445

Geranium, 419

Geum, 422

Gigartina, 445

Glyceria 438

Gnaphalium, 425

Gracilaria, 445

Griffithsia, 446

Gunnera, 424

HALIDRYS, 445

Halurus, 446

Hedera 424

Helminthia, 427

Heracleum, 424

Hieracium, 427

Holcus, 438

Honkeneja 4I7

Hordeum, 439.

Humulus 435

Hydrocotyle 423

Hypericum. 418

Hypnum, 44I

Hypochoeris, 427

ILEX, 428

Inula, 425

Iris, 436

JASIONE, 428

Juncus, 436

LAMIUM, 43I

Lapsana, 427

Lastrea, $44^{\circ}$

Laurencia, 446

Lavatera, 4 I8

Lecanora, 443

Lecidea, 444

Lemna, 437

Leontodon, 427

Leonurus, 43I

Lepidium, 416

Lepigonum, 4I8
Leptogium, 44I

Lichina, 44I

Ligustrum, 428

Linaria, 430

Linum, 419

Lolium, 439

Lonicera, 424

Lotus, 420

Luzula, 436

Lychnis, 4I7

Lycopsis, 429

Lysimachia, 432

Malva. 4 I 8

Marrubium, 432

Matricaria, 426

Medicago 420

Mentha, 43I

Mercurialis, 435

Moenchia, 418

Montia, 423

Myosolis, 429

Myriangium, 44I

Nasturtium, 4I 5

Nepeta, 43 I

Nephromium, 442

Nitophyllum, 445

OENANTHE, 423

Unonis, 420

Opegrapha 445

Orchis, 435

Ornithopus, 42I

Orobanche, 429

Osmunda, 440

Oxalis, 419

PANNARIA, 443

Papaver, 415

Parmelia 442

Pastinaca, 424

Pedicularis, $43^{\circ}$

Peltigera, 442

Peplis, 422

Pertusaria, 444

Petasites, 425

Petroselinum, 423

Phragmites, $43^{8}$

Physcia, 443

Placodium. 443

Plantago. 433

Plocamium, 445

Poa, 438

Polycarpon. 418

Polygala, 417

Polygonum, 434

Polypodium, 440 
Polysiphonia, 446

Polystichum, 440

Polytrichum, 44I

Populus, 435

Porphyra, 445

Potentilla, 421

Primula, 432

Prunella, 43I

Prunus, 421

Psoroma, 443

Pteris, 440

Ptilota, 446

Pulicaria, 425

Pyrus, 422

\section{Quercus, 435}

RADIOLA. 4 I9

Ramalina, 442

Ranunculus, 4I 5

Raphanus, 4 I 6

Reseda, 416

Ricasolia, 442

Roccella, 442

Romulea, 436

Rosa, 422

Rubia, 425

Rubus, 421

Rumex, 434

Ruscus, 436

SACCORHIZA, 445

Sagina, 4I 7
Salix, 435

Salsola, 433

Sambucus, 424

Samolus, 432

Saponaria, 417

Sarothamnus, 4 I9

Scilla, 436

Scirpus, 437

Scleranthus, 418

Sclerochloa, 439

Scolopendrium, 440

Scrophularia, 430

Scytosiphon, 445

Sedum, 423

Senebiera, 416

Senecio, 426

Serrafalcus, 439

Sherardia, 424

Sibthorpia, 43 I

Silene, 417

Sinapis, 416

Sisymbrium, 416

Smyrnium, 424

Solanum, 429

Sonchus, 427

Spergula, 418

Sphaerophoron, 44 I

Sphinctrina, 44I

Spiranthes, 436

Squamaria, 443

Stachys, 432

Statice, 432

Stellaria, 417
Sticta, 442

Stictina, 442

TAMARIX, 422

Tanacetum, 426

Taraxacum, 427

Teesdalia, 416

Teucrium, 432

Thlaspi, 416

Thrincia, 427

Thymus, 43I

Tillaea, 423

Torilis, 424

Trichostomum, 44I

Trifolium, 420

Triodia, 438

Triticum, 439

ULEX, 419

Ulmus. 435

Urceolaria, 444

Urtica, 435

VALERIANELLA, 425

Verbascum, 430

Verbena, 432

Veronica, 43I

Verrucaria, 445

Vicia, 421

Vinca, 428

Viola, 416

ZOSTERA, 437

'All faults I make, when I shall come to know them, I do repent.'

Winter's Tale, iii. 2. 







\section{QK306. M291 \\ Marquand. Ernest $\mathrm{Da} /$ Flora of Guernsey an \\ (1) \\ |||||||||||||||||||||||||||||||||||||||||||||||||||||||||||||||||||| \\ 3 5185001226339}


